\title{
Mechanism of the Bis(imino)pyridine-Iron-Catalyzed Hydromagnesiation of Styrene Derivatives
}

Peter G. N. Neate $,{ }^{\ddagger},{ }^{\dagger}$ Mark D. Greenhalgh, ${ }^{\dagger}$ William W. Brennessel,,${ }^{\ddagger}$ Stephen P. Thomas $*, \dagger$ and Michael L. Neidig*,*

$\dagger$ EaStCHEM School of Chemistry, University of Edinburgh, David Brewster Road, Edinburgh EH9 3FJ, U.K. *Department of Chemistry, University of Rochester, Rochester, New York 14627, United States

\section{TABLE OF CONTENTS}

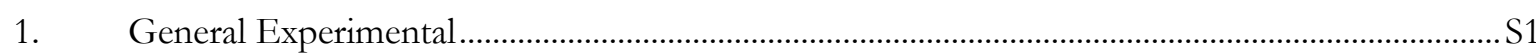

2. Preparation of Compounds ....................................................................................................... 2

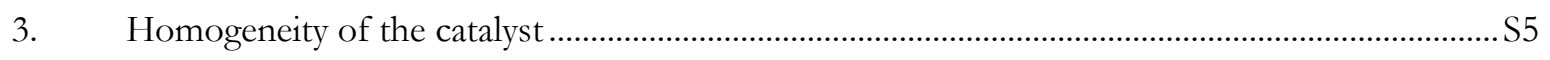

4. Influence of Grignard Reagent on Selectivity ................................................................................

5. Hydride Transfer: Reversibility and Selectivity .............................................................................. 13

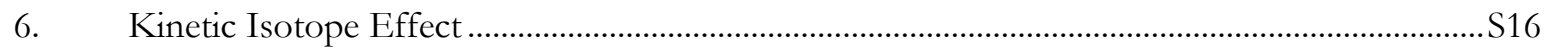

7. Hydride Transfer Mechanism: Isomerisation of phenethylmagnesium bromide.........................S20

8. $\quad{ }^{57} \mathrm{Fe}$ Mössbauer Spectroscopic Studies........................................................................................ S23

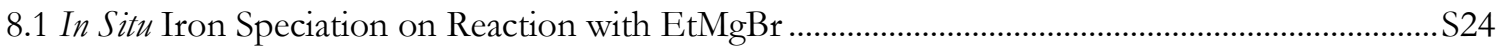

8.2 In Situ Iron Speciation on Reaction with Phenethylmagnesium bromide/chloride .......................S28

8.3 Iron Speciation During Catalysis ................................................................................................... 29

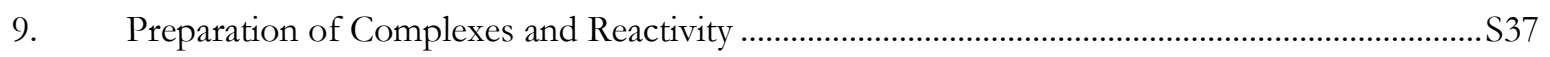

9.1 Preparation of Complex 1, $\left[\mathrm{MgBr}_{0.67} \mathrm{Cl}_{0.33}(\mathrm{THF})_{5}\right]\left[\left({ }^{\mathrm{Pr}} \mathrm{BIP}\right) \mathrm{Fe}(\mathrm{Et})\left(\mathrm{H}_{2} \mathrm{C}=\mathrm{CH}_{2}\right)\right]$...........................S37

9.2 Preparation of Complex 3, $\left[\mathrm{MgBr}_{0.6} \mathrm{Cl}_{0.4}(\mathrm{THF})_{5}\right]\left[\left({ }^{\mathrm{Pr} B I P}\right) \mathrm{Fe}\left(\mathrm{N}_{2}\right)\left(\mathrm{CH}_{2} \mathrm{CH}_{2} \mathrm{Ph}\right)\right]$............................S42

9.3 Preparation of Complex 4, $\left[\mathrm{MgBr}_{0.69} \mathrm{Cl}_{0.31}(\mathrm{THF})_{5}\right]\left[\mathrm{Fe}\left(\eta^{2} \text {-styrene }\right)_{3}\left(\kappa^{1}-\mathrm{CH}\left(\mathrm{CH}_{3}\right) \mathrm{Ph}\right)\right]$...................S47

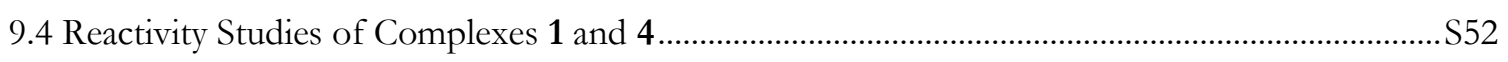

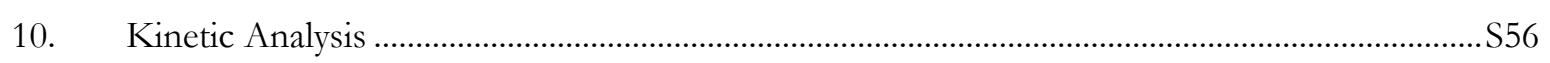

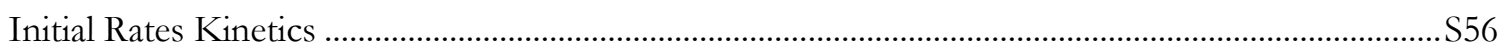

Inhibition/Deactivation Studies: Same Excess Rate Profile Analysis....................................................S73

11. 4-tert-butylstyrene vs 3-methoxystyrene competition experiment ………….................................. 78

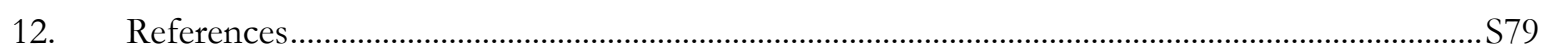

Appendix A. Structure Report for Complex 1, $\left[\mathrm{MgBr}_{0.67} \mathrm{Cl}_{0.33}(\mathrm{THF})_{5}\right]\left[\left({ }^{\mathrm{PP} B I P}\right) \mathrm{Fe}(\mathrm{Et})\left(\mathrm{H}_{2} \mathrm{C}=\mathrm{CH}_{2}\right)\right] \ldots \mathrm{S} 82$

Appendix B. Structure Report for Complex 3, $\left[\mathrm{MgBr}_{0.6} \mathrm{Cl}_{0.4}(\mathrm{THF})_{5}\right]\left[\left({ }^{\mathrm{Pr} B I P}\right) \mathrm{Fe}\left(\mathrm{N}_{2}\right)\left(\mathrm{CH}_{2} \mathrm{CH}_{2} \mathrm{Ph}\right)\right] \ldots \ldots \ldots$

Appendix C. Structure Report for Complex 4, $\left.\mathrm{MgBr}_{0.69} \mathrm{Cl}_{0.31}(\mathrm{THF})_{5}\right]\left[\mathrm{Fe}\left(\eta^{2} \text {-styrene }\right)_{3}\left(\kappa^{1}-\mathrm{CH}\left(\mathrm{CH}_{3}\right) \mathrm{Ph}\right)\right]$.. 


\section{General Experimental}

All air- and moisture sensitive reactions were carried out using standard vacuum line and Schlenk techniques, or in a glovebox with a purified nitrogen or argon atmosphere (Innovative Technology or MBraun). All glassware was cleaned using base $(\mathrm{KOH}, \mathrm{iPrOH})$ and acid ( $\mathrm{HClaq}_{\text {aq }}$ baths.

Iron(II) chloride was purchased from Strem Chemicals Inc. (UK); anhydrous iron chloride, 98\% (product number 93-2631. Lot $19226800,44.00000 \% \mathrm{Fe}$, expect $44.059 \%$ ). Iron(II) chloride $99.99 \%$ was purchased from Sigma Aldrich (UK); anhydrous beads, 10 mesh, 99.99\% (product number 450936). All reagents were purchased from Sigma Aldrich, Alfa Aesar, Acros organics, Tokyo Chemical Industries UK, and Apollo Scientific or synthesised within the laboratory.

All anhydrous solvents used for reactions sensitive to air and or moisture were obtained from an anhydrous solvent system (Innovative Technology). When anhydrous solvent is not specified, these were of ACS grade and used without further purification.

Thin layer chromatography (TLC) was carried out using aluminium backed silica plates (Merck $60 \mathrm{~F}_{254}$ ) and spots were visualised using UV light at $254 \mathrm{~nm}$. Flash chromatography was performed on silica gel (Merck Geduran Si 60, 40-63 $\mu \mathrm{m}$ )

All ${ }^{1} \mathrm{H},{ }^{2} \mathrm{H},{ }^{13} \mathrm{C}$ spectra were recorded on Bruker Avance III 400, 500 and $600 \mathrm{MHz}$ spectrometers or a Bruker Avance I $600 \mathrm{MHz}$ spectrometer. All spectra were obtained at ambient temperature. The chemical shifts $(\delta)$ are recorded in parts per million (ppm). Coupling constants $(J)$ are recorded in hertz $(\mathrm{Hz})$. Multiplicities (reported using the standard nomenclature $\mathrm{s}=$ singlet, $\mathrm{d}=$ doublet, $\mathrm{t}=$ triplet, $\mathrm{q}=$ quartet, quint. $=$ quintet, sex. $=$ sextet, sep. $=$ septet, non. $=$ nonet, $\mathrm{m}=$ multiplet, br. $\mathrm{s}=$ broad singlet $)$ and coupling constants are reported where applicable. ${ }^{1} \mathrm{H}$ and ${ }^{13} \mathrm{C}\left\{{ }^{1} \mathrm{H}\right\}$ NMR spectra were referenced relative to the residual solvent and solvent peaks, respectively: $\mathrm{CDCl}_{3} 7.27 \mathrm{ppm}, 77.2 \mathrm{ppm} ; \mathrm{CD}_{2} \mathrm{Cl}_{2} 5.32 \mathrm{ppm}, 53.8 \mathrm{ppm}$, respectively.

Gas Chromatography was carried out using a Shimadzu GC-2010 Plus with an RTX-1, 60 m, 0.25mm internal diameter. Data workup carried out on Lab Solutions Lite. Details of the method used were: injection volume $1 \mathrm{uL}$; injection temperature $300{ }^{\circ} \mathrm{C}, 100{ }^{\circ} \mathrm{C}$ (hold $2 \mathrm{~min}$ ); ramp rate $15^{\circ} \mathrm{C} / \mathrm{min}$ ending and holding at $300{ }^{\circ} \mathrm{C}$ for $3 \mathrm{~min}$.

High resolution mass spectra were collected by the University of Edinburgh, School of Chemistry, Mass Spectrometry Laboratory. Electron Ionisation (EI) mass spectra were obtained using a Thermo/Finngan MAT 900 Sector instrument. Data are reported in the form of $\mathrm{m} / \mathrm{z}$ of parent (molecular) ions $\left([\mathrm{M}]^{-+}\right.$or $\left.[\mathrm{M}+\mathrm{H} / \mathrm{Na}]^{+}\right)$.

Infra-red (IR) spectra were measured using a Shimadzu IRAffinity-1 spectrometer (serial no. A213747). Peaks are reported in $\mathrm{cm}^{-1}$.

For X-Ray crystallography: data collection, structure solution, and structure refinement were conducted at the X-ray Crystallographic Facility, B51 Hutchison Hall, Department of Chemistry, by William W. Brennessel. See Appendices for full details within crystallographic reports. 


\section{Preparation of Compounds}

2-Methoxystyrene ${ }^{1,2}$

$$
\overbrace{\mathrm{OMe}}^{\mathrm{N}}
$$

2-methoxybenzaldehyde $(1.21 \mathrm{~g} ; 8.89 \mathrm{mmol})$ was added to a suspension of potassium carbonate $(2.2 \mathrm{~g} ; 16$ $\mathrm{mmol}$ ) and methyltriphenylphosphonium bromide (4.33 g; $12.1 \mathrm{mmol})$ in anhydrous tetrahydrofuran (10 $\mathrm{mL})$. The reaction mixture was heated at reflux for 16 hours after which time it was cooled to room temperature. The resulting suspension was filtered and the solids washed with additional tetrahydrofuran $(10 \mathrm{~mL})$. The solution was concentrated in vacuo and the residues dissolved in boiling $n$-pentane $(20 \mathrm{~mL})$, cooled in an ice/water bath, filtered and the solids washed with additional cold $n$-pentane $(10 \mathrm{~mL})$. After removal of solvent in vacuo the resulting yellow oil was purified by flash column chromatography (conditions: silica, $44 \mathrm{~g} ; 30 \mathrm{~mm} \varnothing$; pentane/diethyl ether, 99:1 v/v; $\mathrm{R}_{\mathrm{f}}=0.55$ ) to give 2-methoxystyrene as a colourless oil ( $0.75 \mathrm{~g} ; 5.6 \mathrm{mmol} ; 63 \%)$.

1'H NMR: $\quad\left(600 \mathrm{MHz}, \mathrm{CDCl}_{3}\right)$

$$
\begin{aligned}
& 7.50(\mathrm{dd}, J=7.6,1.7 \mathrm{~Hz}, 1 \mathrm{H}), 7.28-7.25(\mathrm{~m}, 1 \mathrm{H}), 7.08(\mathrm{dd}, J=17.8,11.2 \mathrm{~Hz}, 1 \mathrm{H}), 6.98 \\
& -6.94(\mathrm{~m}, 1 \mathrm{H}), 6.92-6.88(\mathrm{~m}, 1 \mathrm{H}), 5.76(\mathrm{dd}, J=17.8,1.5 \mathrm{~Hz}, 1 \mathrm{H}), 5.29(\mathrm{dd}, J=11.2,1.5 \\
& \mathrm{Hz}, 1 \mathrm{H}), 3.88(\mathrm{~s}, 3 \mathrm{H}) .
\end{aligned}
$$

${ }^{13} \mathbf{C}\left\{{ }^{1} \mathbf{H}\right\}$ NMR: $\left(150 \mathrm{MHz}, \mathrm{CDCl}_{3}\right)$

$156.8,131.7,128.8,126.8,126.6,120.6,114.5,110.9,55.5$.

Data in accordance with those previously reported. ${ }^{3}$

\section{3-Methoxystyrene ${ }^{1,2}$}<smiles>C=Cc1cccc(OC)c1</smiles>

3-methoxybenzaldehyde $(4.5 \mathrm{~mL} ; 36.9 \mathrm{mmol})$ was added to a suspension of potassium carbonate $(8.16 \mathrm{~g}$; $59 \mathrm{mmol})$ and methyltriphenylphosphonium bromide $(15.8 \mathrm{~g} ; 44.2 \mathrm{mmol})$ in anhydrous tetrahydrofuran $(50 \mathrm{~mL})$. The reaction mixture was heated at reflux for 16 hours after which time it was cooled to room temperature. The resulting suspension was filtered, and the solids washed with additional tetrahydrofuran $(30 \mathrm{~mL})$. The solution was concentrated in vacuo and the residues dissolved in boiling $n$-pentane $(50 \mathrm{~mL})$, cooled in an ice/water bath, filtered and the solids washed with additional cold $n$-pentane $(20 \mathrm{~mL})$. After removal of solvent in vacuo the resulting yellow oil was purified by flash column chromatography (conditions: silica, $100 \mathrm{~g}$; $30 \mathrm{~mm}$ Ø; pentane/diethyl ether, 9:1 v/v; $\mathrm{R}_{\mathrm{f}}=0.76$ ) to give 3-methoxystyrene as a colourless oil (2.3 g; $17.1 \mathrm{mmol} ; 47 \%)$.

1H NMR: $\quad\left(600 \mathrm{MHz}, \mathrm{CDCl}_{3}\right)$

$7.28-7.25(\mathrm{~m}, 1 \mathrm{H}), 7.06-7.02(\mathrm{~m}, 1 \mathrm{H}), 6.99-6.97(\mathrm{~m}, 1 \mathrm{H}), 6.86-6.82(\mathrm{~m}, 1 \mathrm{H}), 6.72$ $(\mathrm{dd}, J=17.6,10.8 \mathrm{~Hz}, 1 \mathrm{H}), 5.77(\mathrm{dd}, J=17.6,0.9 \mathrm{~Hz}, 1 \mathrm{H}), 5.28(\mathrm{dd}, J=10.9,0.9 \mathrm{~Hz}, 1 \mathrm{H})$, $3.85(\mathrm{~s}, 2 \mathrm{H})$.

${ }^{13} \mathbf{C}\left\{{ }^{1} \mathbf{H}\right\}$ NMR: $\left(150 \mathrm{MHz}, \mathrm{CDCl}_{3}\right)$

$159.8,139.1,136.8,129.5,118.9,114.1,113.5,111.5,55.2$.

Data in accordance with those previously reported. ${ }^{4}$ 


\section{5,6,11,12-Tetrahydrodibenzo[a,e] cyclooctene ${ }^{5}$}

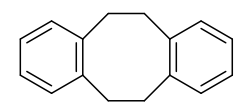

A solution of $\alpha, \alpha^{\prime}$-dibromo- - -xylene $(10.6 \mathrm{~g}$; $40.2 \mathrm{mmol})$ in anhydrous tetrahydrofuran $(16 \mathrm{~mL})$ was added dropwise to a stirring suspension of lithium metal $(705 \mathrm{mg} ; 101.6 \mathrm{mmol})$ in anhydrous tetrahydrofuran (25 $\mathrm{mL}$ ). The cloudy grey solution was heated at reflux for 2 hours and then room temperature for 12 hours. On filtration of the dark red/brown solution it decolourised to a pale yellow. The filter was washed with additional tetrahydrofuran $(10 \mathrm{~mL})$ and the solvent removed in vacuo. The residual viscous pale yellow oil was suspended in dichloromethane $(70 \mathrm{~mL})$ and filtered through a plug of silica, which was washed repeatedly with additional dichloromethane $(140 \mathrm{~mL}$ total). The filtrates were dried over magnesium sulphate and the solvent removed in vacuo. The off-white residue was purified by flash column chromatography (conditions: silica, $100 \mathrm{~g} ; 30 \mathrm{~mm} \varnothing$; petroleum ether 40-60; $\mathrm{R}_{\mathrm{f}}=0.18$ ) to give 5,6,11,12tetrahydrodibenzo[a,e]cyclooctene as colourless plates $(1.74 \mathrm{~g} ; 8.36 \mathrm{mmol} ; 42 \%)$. Note: solubility very poor in petroleum ether 40-60 and streaks on column coming off column very slowly but all fractions are clean and no other compounds are observed to come off the column.

1H NMR: $\quad\left(500 \mathrm{MHz}, \mathrm{CDCl}_{3}\right)$

$$
7.04-6.93(\mathrm{~m}, 8 \mathrm{H}), 3.07(\mathrm{~s}, 8 \mathrm{H}) \text {. }
$$

${ }^{13} \mathbf{C}\left\{{ }^{1} \mathbf{H}\right\}$ NMR: $\left(125 \mathrm{MHz}, \mathrm{CDCl}_{3}\right)$

$$
140.6,129.7,126.1,35.2 \text {. }
$$

Data in accordance with those previously reported. ${ }^{5}$

\section{5,11-Dibromo-5,6,11,12-tetrahydrodibenzo[a,e]cyclooctene ${ }^{5}$}

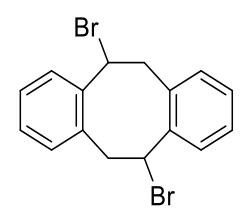

A suspension of 5,6,11,12-tetrahydrodibenzo[a,e]cyclooctene $(1.73 \mathrm{~g} ; 8.3 \mathrm{mmol})$ and $\mathrm{N}$-bromosuccinimide $(3.18 \mathrm{~g} ; 17.9 \mathrm{mmol})$ in carbon tetrachloride $(18 \mathrm{~mL})$ was heated at reflux for 2 hours 15 minutes. After this time the suspension was filtered, whilst still hot, and solvent removed in vacuo. The resulting solids were washed with deionised water $(2 \times 25 \mathrm{~mL})$ and dried under high vacuum for 5 hours to give 5,11-Dibromo5,11-Dibromo-5,6,11,12-tetrahydrodibenzo[a,e]cyclooctene $(2.57 \mathrm{~g} ; \sim 7.0 \mathrm{mmol} ; \sim 85 \%)$ as a pale yellow solid which was used immediately without further purification.

1H NMR: $\quad\left(500 \mathrm{MHz}, \mathrm{CDCl}_{3}\right)$

$$
\begin{aligned}
& 7.17-6.92(\mathrm{~m}, 8 \mathrm{H}), 5.33(\mathrm{dd}, J=11.2,8.4 \mathrm{~Hz}, 2 \mathrm{H}), 4.29(\mathrm{dd}, J=14.4,11.3 \mathrm{~Hz}, 2 \mathrm{H}), 3.66 \\
& (\mathrm{dd}, J=14.3,8.5 \mathrm{~Hz}, 2 \mathrm{H}) .
\end{aligned}
$$

Data in accordance with those previously reported. ${ }^{5}$ 


\section{Dibenzo[a,e]cyclooctene ${ }^{5}$}

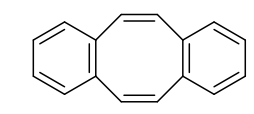

A solution of 5,11-Dibromo-5,6,11,12-tetrahydrodibenzo[a,e]cyclooctene $(2.57 \mathrm{~g} ; \sim 7.0 \mathrm{mmol})$ in anhydrous tetrahydrofuran $(11 \mathrm{~mL})$ was added dropwise over 40 minutes to a stirred slurry of potassium tert-butoxide $(3.15 \mathrm{~g} ; 28.1 \mathrm{mmol})$ in anhydrous tetrahydrofuran $(12 \mathrm{~mL})$ at $0{ }^{\circ} \mathrm{C}$. The suspension rapidly turned brown during dropwise addition and darkened throughout. The slurry was left to stir at room temperature for 2 hours after which time water $(1.1 \mathrm{~mL})$ was added and stirred for a further 5 minutes. The dark slurry was filtered through a silica plug (silica: $30 \mathrm{~mm} \varnothing ; \sim 4 \mathrm{~cm}$ diameter, $\sim 2.5 \mathrm{~cm}$ deep) and the filter washed with diethyl ether $(2 \times 40 \mathrm{~mL})$. The brown/red filtrates were dried over magnesium sulphate, filtered and solvent removed in vacuo. The brown residues were purified by flash column chromatography (conditions: silica, $100 \mathrm{~g} ; 30 \mathrm{~mm} \varnothing$; petroleum ether 40-60; $\left.\mathrm{R}_{\mathrm{f}}=0.20\right)$ to give dibenzo[a,e]cyclooctene $131(400 \mathrm{mg} ; 28 \%)$ as colourless plates.

1H NMR: $\quad\left(500 \mathrm{MHz}, \mathrm{CDCl}_{3}\right)$

$$
7.20-7.10(\mathrm{~m}, 4 \mathrm{H}), 7.10-7.00(\mathrm{~m}, 4 \mathrm{H}), 6.76(\mathrm{~s}, 4 \mathrm{H}) .
$$

${ }^{13} \mathbf{C}\left\{{ }^{1} \mathbf{H}\right\}$ NMR: $\left(125 \mathrm{MHz}, \mathrm{CDCl}_{3}\right)$

$$
137.1,133.3,129.1,126.8 .
$$

Data in accordance with those previously reported. ${ }^{5}$

\section{2,6-bis-[1-(2,6-diisopropylphenylimino)ethyl]pyridine ${ }^{6,7}$}<smiles></smiles>

2,6-Diisopropylaniline 127 (7.5 mL; $39.8 \mathrm{mmol}$ ) was added to a solution of 2,6-diacetylpyridine (2.87 g; 17.6 $\mathrm{mmol})$ and para-toluenesulfonic acid mono-hydrate $(203 \mathrm{mg} ; 1.1 \mathrm{mmol})$ in toluene $(100 \mathrm{~mL})$. The resulting solution was heated at reflux under Dean-Stark conditions for 18 hours after which it was cooled to room temperature. Solvent was removed in vacuo and the remaining solids recrystallised from dichloromethane by slow evaporation to give 2,6-bis-[1-(2,6-diisopropylphenylimino)ethyl]pyridine $\mathbf{9 6}$ as yellow needles (4.82 g, $10 \mathrm{mmol}, 57 \%)$.

${ }^{1} \mathrm{H}$ NMR: $\quad\left(500 \mathrm{MHz}, \mathrm{CD}_{2} \mathrm{Cl}_{2}\right)$

$8.51(\mathrm{~d}, J=7.9 \mathrm{~Hz}, 2 \mathrm{H}), 7.95(\mathrm{t}, J=7.8 \mathrm{~Hz}, 1 \mathrm{H}), 7.24-7.17(\mathrm{~m}, 4 \mathrm{H}), 7.17-7.10(\mathrm{~m}, 2 \mathrm{H})$, 2.80 (hept, $J=7.0 \mathrm{~Hz}, 4 \mathrm{H}), 2.30$ (s, 6H), 1.19 (d, $J=7.0 \mathrm{~Hz}, 24 \mathrm{H})$.

${ }^{13} \mathbf{C}\left\{{ }^{1} \mathrm{H}\right\}$ NMR: $\left(125 \mathrm{MHz}, \mathrm{CD}_{2} \mathrm{Cl}_{2}\right)$

166.9, 155.1, 146.5, 136.8, 135.8, 123.6, 123.0, 122.2, 28.3, 23.2, 22.9.

Data in accordance with those previously reported. ${ }^{6}$ 


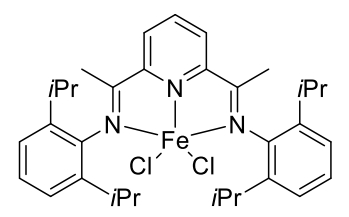

2,6-bis-[1-(2,6-diisopropylphenylimino)ethyl]pyridine (1.01 g; $2.1 \mathrm{mmol})$ and anhydrous iron(II) chloride (265 mg; $2.1 \mathrm{mmol})$ were stirred in anhydrous tetrahydrofuran $(40 \mathrm{~mL})$ at room temperature for 24 hours. After this time the volume was reduced to $\sim 30 \mathrm{~mL}$ in vacuo followed by the addition of anhydrous diethyl ether $(60 \mathrm{~mL})$. The resulting precipitate was collected by filtration and washed with additional anhydrous diethyl ether $(20 \mathrm{~mL})$ before being dissolved in anhydrous dichloromethane $(30 \mathrm{~mL})$. The dichloromethane solution was then filtered, washing the filter with additional anhydrous dichloromethane $(10 \mathrm{~mL})$, and the solvent removed in vacuo. The solids were further dried under high vacuum for 2 hours at $120{ }^{\circ} \mathrm{C}$ to give 2,6-bis-[1-(2,6-diisopropylphenylimino)ethyl]pyridine iron(II) chloride as a dark blue solid (1.15 g; 1.89 mmol; $90 \%)$.

1H NMR: $\quad\left(500 \mathrm{MHz}, \mathrm{CD}_{2} \mathrm{Cl}_{2}\right)$

82.08 (br. s), 15.14 (br. s), -4.91 (br. s), -5.91 (br. s), -11.13 (br. s), -21.69 (br. s), -36.73 (br. s).

Data in accordance with those previously reported. ${ }^{6}$

\section{Homogeneity OF THE CATALYST}

3-Phase test using a polymer-supported styrene substrate

\section{Substrate synthesis}
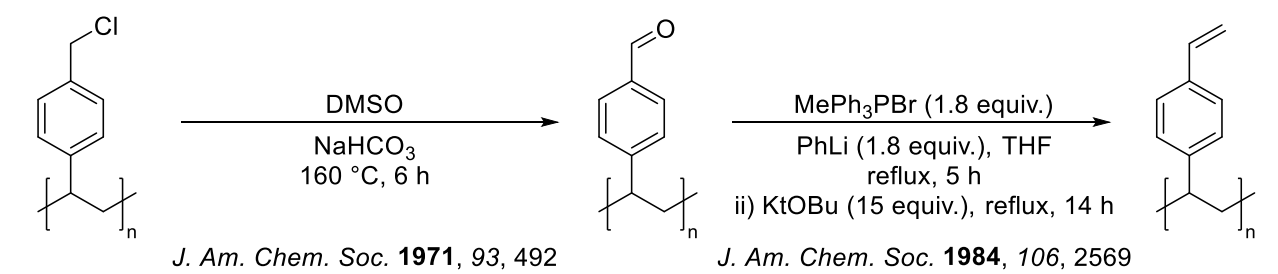

Merrifield Resin

100-200 mesh

approx. $2 \mathrm{mmol} / \mathrm{g}$

The polymer-supported substrate was synthesised according to literature procedures. ${ }^{23,24}$

\section{Hydromagnesiation procedure}




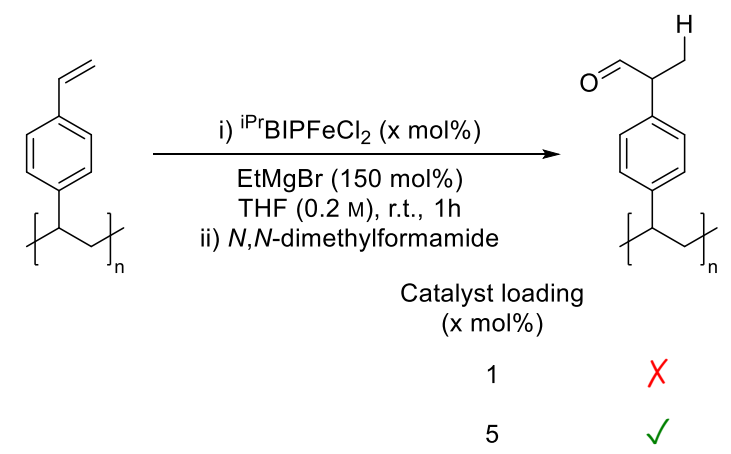

Anhydrous tetrahydrofuran $(1 \mathrm{~mL})$ was added to a mixture of the polymer-supported styrene substrate (100 $\mathrm{mg}$, potentially $0.2 \mathrm{mmol}$ of functional group) and 2,6-bis-[1-(2,6-diisopropylphenylimino)ethyl]pyridine iron(II) chloride (1.2-6.1 mg, 0.002-0.01 mmol, 1-5 mol\%) under a nitrogen atmosphere. Ethylmagnesium bromide $(0.1 \mathrm{~mL}, 3 \mathrm{M}$ in Et $2 \mathrm{O}, 0.3 \mathrm{mmol}, 150 \mathrm{~mol} \%)$ was added in one portion, and the reaction was stirred for 60 minutes. Anhydrous N,N-dimethylformamide $(77 \mu \mathrm{L}, 500 \mathrm{~mol} \%)$ was added and the reaction was stirred for 1 hour. Aqueous $\mathrm{HCl}(1 \mathrm{M}, 10 \mathrm{~mL})$ was added and the suspension was stirred for 1 minute. The suspension was filtered using a glass sinter frit, and the polymer was washed sequentially with aqueous $\mathrm{HCl}$ $(1 \mathrm{M}, 20 \mathrm{~mL}), 2 \times$ distilled water $(20 \mathrm{~mL}), 2 \times$ tetrahydrofuran $(20 \mathrm{~mL}), 2 \times$ diethyl ether $(20 \mathrm{~mL})$, and then dried under high vacuum for 8 hours.

The product was analysed using IR spectroscopy. Using $1 \mathrm{~mol} \%$ iron pre-catalyst, only starting material was recovered, however using $5 \mathrm{~mol} \%$ pre-catalyst gave the aldehyde product. IR (neat) $v_{\max } \mathrm{cm}^{-1} 3024$, 2920, 1721, 1600, 1493, 1450.

\section{Control reaction with solution-phase styrene substrate}

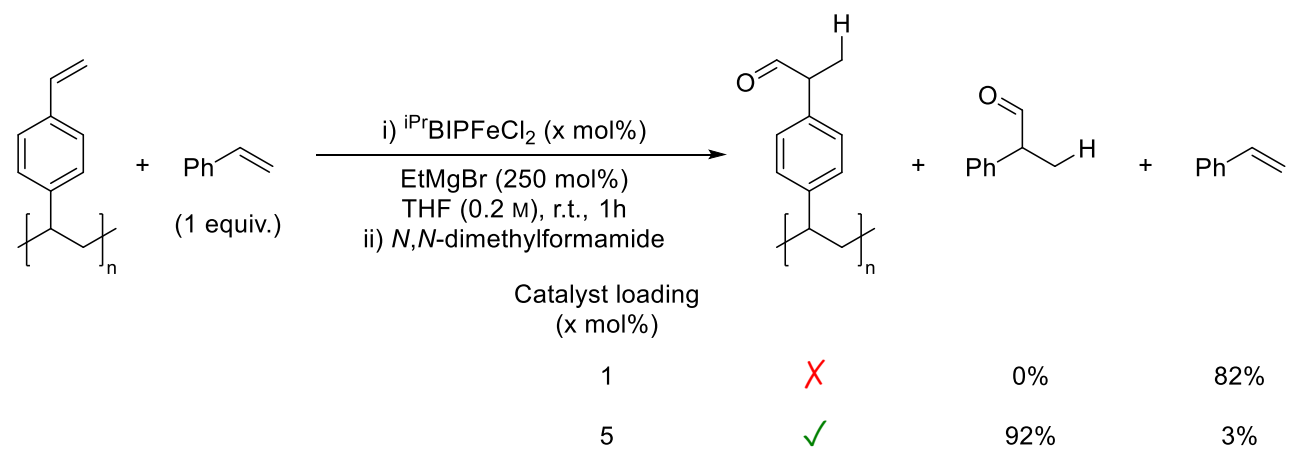

Procedure as above, but with the addition of styrene $(23 \mu \mathrm{L}, 0.2 \mathrm{mmol})$, and using an extra equivalent of ethylmagnesium bromide $\left(1.7 \mathrm{~mL}, 3 \mathrm{M}\right.$ in $\left.\mathrm{Et}_{2} \mathrm{O}, 0.5 \mathrm{mmol}, 250 \mathrm{~mol} \%\right)$. For reaction work-up, 1,3,5trimethoxybenzene [(6.7 $\mathrm{mg}, 0.04 \mathrm{mmol}, 20 \mathrm{~mol} \%)$ in diethyl ether $(5 \mathrm{~mL})]$ added following addition of aqueous $\mathrm{HCl}$. The suspension was stirred for 1 minute and then allowed to settle. A portion of diethyl ether layer was removed (approx. $1 \mathrm{~mL}$ ) and added to a glass vial. The diethyl ether was allowed to evaporate at room temperature (approx. 20 minutes) and the residue dissolved in $\mathrm{CDCl}_{3}$. The percentage yield of each product was determined by quantitative ${ }^{1} \mathrm{H}$ NMR spectroscopy, using 1,3,5-trimethoxybenzene $(20 \mathrm{~mol} \%)$ as an internal standard.

\section{Selective catalyst poisoning using dibenzo[a,e]cyclooctatetraene (DCT)}




\section{Hydromagnesiation reaction in the presence of DCT}

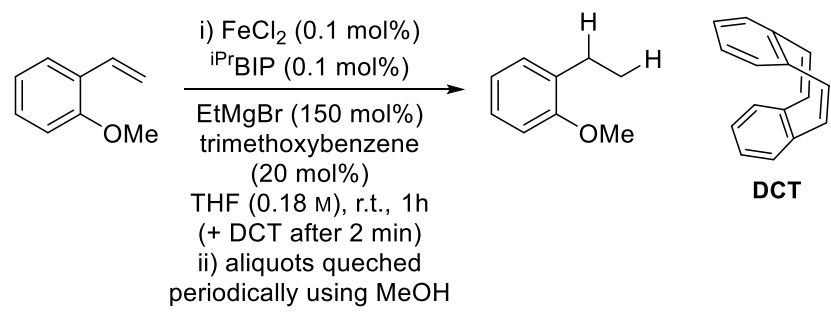

2-Methoxystyrene (94 $\mu \mathrm{L}, \quad 0.7 \mathrm{mmol})$ was added to a solution of 2,6-bis-[1-(2,6diisopropylphenylimino)ethyl]pyridine iron(II) chloride ( $0.5 \mathrm{~mL}, 0.0014 \mathrm{M}$ in THF, $0.0007 \mathrm{mmol}, 0.1 \mathrm{~mol} \%$ ) and 1,3,5-trimethoxybenzene ( $23.5 \mathrm{mg}, 0.14 \mathrm{mmol}, 20 \mathrm{~mol} \%$ ) in anhydrous tetrahydrofuran (total volume $3.65 \mathrm{~mL})$. Ethylmagnesium bromide $\left(0.35 \mathrm{~mL}, 3 \mathrm{M}\right.$ in $\left.\mathrm{Et}_{2} \mathrm{O}, 1.05 \mathrm{mmol}, 150 \mathrm{~mol} \%\right)$ was added in one portion, and the reaction was stirred at room temperature $\left(20-22^{\circ} \mathrm{C}\right)$. Aliquots $(<100 \mu \mathrm{L})$ were periodically removed and added to HPLC vials containing anhydrous methanol (approx. 10-15 $\mu \mathrm{L}, 0.25-0.37 \mathrm{mmol}$ ). After all samples were taken, aqueous sulfate buffer (approx. $0.3 \mathrm{~mL}$ ) was added to each vial followed by diethyl ether (approx. $0.7 \mathrm{~mL}$ ). The vial was shaken and the layers were allowed to settle. The diethyl ether layer was removed and added to a $7 \mathrm{~mL}$ glass vial, from which the diethyl ether was allowed to evaporate at room temperature (approx. 10-15 min) until the majority of the solvent had evaporated (but wasn't thoroughly dry). The residue was dissolved in $\mathrm{CDCl}_{3}$ and added to an NMR tube for analysis by ${ }^{1} \mathrm{H}$ NMR spectroscopy.

The percentage yield of each product was determined by quantitative ${ }^{1} \mathrm{H}$ NMR spectroscopy, using 1,3,5trimethoxybenzene $(20 \mathrm{~mol} \%)$ as an internal standard.

Reactions in the presence of DCT:

The above standard procedure was followed, with DCT (0.05-0.2 mL, $0.007 \mathrm{M}$ in THF, $0.05-0.2 \mathrm{~mol} \%)$ added after 2 minutes. 


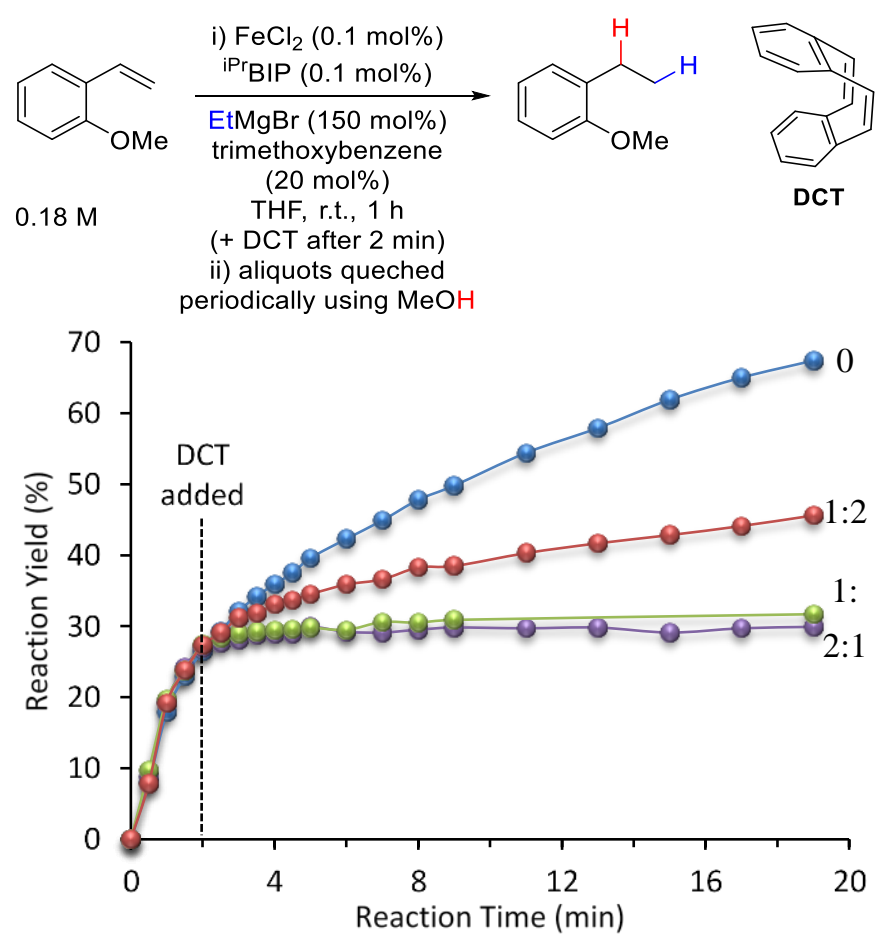

DCT $:$ Fe ratio $\bullet=0 ; \bullet=1: 2 ; \bigcirc=1: 1 ; \bigcirc=2: 1$

\section{Influence of GrignaRd ReAGent on SELECtivity}

Hydromagnesiation of 2-methoxystyrene using different Grignard reagents

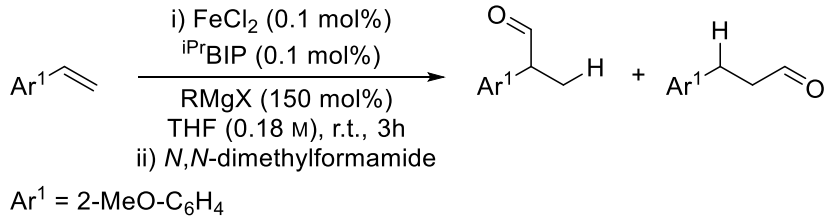

2-Methoxystyrene (47 $\mu \mathrm{L}, \quad 0.35 \mathrm{mmol})$ was added to a solution of 2,6-bis-[1-(2,6diisopropylphenylimino)ethyl]pyridine iron(II) chloride $(0.25 \mathrm{~mL}, 0.0014 \mathrm{M}$ in THF, $0.00035 \mathrm{mmol}, 0.1$ $\mathrm{mol} \%$ ) and 1,3,5-trimethoxybenzene $(11.8 \mathrm{mg}, 0.07 \mathrm{mmol}, 20 \mathrm{~mol} \%$ ) in anhydrous tetrahydrofuran (total volume $2 \mathrm{~mL}$ after addition of Grignard reagent). A Grignard reagent ( $0.52 \mathrm{mmol}, 150 \mathrm{~mol} \%)$ was added in one portion, and the reaction was stirred at room temperature $\left(20-22^{\circ} \mathrm{C}\right)$. Aliquots $(<100 \mu \mathrm{L})$ were periodically removed and added to HPLC vials containing anhydrous $N, N$-dimethylformamide (approx. 10 $\mu \mathrm{L}, 0.13 \mathrm{mmol}$ ). The samples were shaken for 30 minutes, after which aqueous sulfate buffer (approx. 0.3 $\mathrm{mL}$ ) was added to each vial followed by diethyl ether (approx. $0.7 \mathrm{~mL}$ ). The vial was shaken and the layers were allowed to settle. The diethyl ether layer was removed and added to a $7 \mathrm{~mL}$ glass vial, from which the diethyl ether was allowed to evaporate at room temperature (approx. 10-15 min) until the majority of the solvent had evaporated (but wasn't thoroughly dry). The residue was dissolved in $\mathrm{CDCl}_{3}$ and added to an NMR tube for analysis by ${ }^{1} \mathrm{H}$ NMR spectroscopy.

The percentage yield of each product was determined by quantitative ${ }^{1} \mathrm{H}$ NMR spectroscopy, using 1,3,5trimethoxybenzene $(20 \mathrm{~mol} \%)$ as an internal standard. All products were identified by comparison to their literature values: 2-(2-methoxyphenyl)-propanal, ${ }^{8} 3$-(2-Methoxyphenyl)-propanal. ${ }^{9}$ 


\begin{tabular}{|c|c|c|c|c|c|}
\hline \multirow{2}{*}{ entry } & \multirow{2}{*}{ RMgX } & \multirow{2}{*}{$\begin{array}{l}\text { initial } \\
\text { rate } \\
(\% / m i n)\end{array}$} & \multirow{2}{*}{$\begin{array}{c}\text { Yield } \\
(\%) \\
(\alpha+\beta)\end{array}$} & \multicolumn{2}{|c|}{$\alpha: \beta$ ratio $^{a}$} \\
\hline & & & & Start & End \\
\hline 1 & $\mathrm{MgBr}$ & 40 & $99^{b}$ & $80: 1$ & 100:1 \\
\hline 2 & $\mathrm{MgBr}$ & 7 & 78 & $35: 1$ & $60: 1$ \\
\hline $3^{c}$ & & $0.5^{d}$ & 23 & $15: 1$ & $21: 1$ \\
\hline 4 & & 5 & 85 & $10: 1$ & $16: 1$ \\
\hline 5 & & 1 & 62 & $11: 1$ & $22: 1$ \\
\hline 6 & $\mathrm{MgH}_{2}$ & 0 & $0(8)^{e}$ & \multicolumn{2}{|c|}{$N / A^{f}$} \\
\hline 7 & $\mathrm{Ph} \leftrightharpoons{ }_{\mathrm{MgBr}}$ & 15 & 82 & $4: 1$ & $10: 1$ \\
\hline
\end{tabular}

Empty cells indicate that data was not collected.

\begin{tabular}{|c|c|c|c|c|c|c|}
\hline & \multicolumn{3}{|c|}{ EtMgBr } & \multicolumn{3}{|c|}{$\mathrm{DecMgBr}$} \\
\hline Time & $\begin{array}{c}\text { 2-(2-Methoxy } \\
\text { phenyl)-propanal }\end{array}$ & $\begin{array}{c}\text { 3-(2-Methoxy } \\
\text { phenyl)-propanal }\end{array}$ & $\begin{array}{l}\alpha: \beta \\
\text { ratio }\end{array}$ & $\begin{array}{c}\text { 2-(2-Methoxy } \\
\text { phenyl)-propanal }\end{array}$ & $\begin{array}{c}\text { 3-(2-Methoxy } \\
\text { phenyl)-propanal }\end{array}$ & $\begin{array}{l}\alpha: \beta \\
\text { ratio }\end{array}$ \\
\hline 0.5 & 0.3 & & & 0.1 & & \\
\hline 1 & 7.1 & & & 3.2 & & \\
\hline 1.33 & 19.9 & & & & & \\
\hline 1.5 & & & & 6.8 & & \\
\hline 1.66 & 27.1 & & & & & \\
\hline 2 & 32.6 & 0.4 & $82: 1$ & 10.1 & & \\
\hline 2.5 & 39 & 0.5 & $78: 1$ & 11.6 & & \\
\hline 3.5 & 46.9 & 0.5 & $94: 1$ & 15.7 & 0.5 & $31: 1$ \\
\hline 5 & 54.6 & 0.6 & $91: 1$ & 19.2 & 0.5 & $38: 1$ \\
\hline 6 & 59.8 & 0.7 & $85: 1$ & & & \\
\hline 7 & & & & 24.6 & 0.6 & $41: 1$ \\
\hline 10 & 70 & 0.8 & $88: 1$ & 30.1 & 0.8 & $38: 1$ \\
\hline 15 & 81.2 & 0.8 & 102:1 & & & \\
\hline 20 & & & & 42.3 & 1.1 & $38: 1$ \\
\hline 30 & 92.9 & 1 & 93:1 & 47.8 & 1.1 & $43: 1$ \\
\hline 60 & 98 & 1 & $98: 1$ & 60.3 & 1.3 & $46: 1$ \\
\hline 90 & 98.9 & 1 & 99:1 & 69.3 & 1.3 & $53: 1$ \\
\hline 120 & & & & 74.1 & 1.3 & $57: 1$ \\
\hline 150 & & & & & & \\
\hline 180 & 98.6 & 1 & 99:1 & 78.1 & 1.3 & $60: 1$ \\
\hline
\end{tabular}

\begin{tabular}{|c|c|c|c|c|c|c|}
\hline & \multicolumn{3}{|c|}{ 3-(4-Methoxyphenyl)propylmagnesium bromide } & \multicolumn{3}{|c|}{ iBuMgBr (1 mol\% $\left.{ }^{\mathrm{iPr}} \mathrm{BIPFeCl}_{2}\right)$} \\
\hline Time & $\begin{array}{l}\text { 2-(2-Methoxy } \\
\text { phenyl)-propanal }\end{array}$ & $\begin{array}{c}\text { 3-(2-Methoxy } \\
\text { phenyl)-propanal }\end{array}$ & $\begin{array}{c}\alpha: \beta \\
\text { ratio }\end{array}$ & $\begin{array}{c}\text { 2-(2-Methoxy } \\
\text { phenyl)-propanal }\end{array}$ & $\begin{array}{l}\text { 3-(2-Methoxy } \\
\text { phenyl)-propanal }\end{array}$ & $\begin{array}{l}\alpha: \beta \\
\text { ratio }\end{array}$ \\
\hline 0.5 & & & & & & \\
\hline 1 & 5.3 & & & & & \\
\hline 1.33 & & & & & & \\
\hline
\end{tabular}




\begin{tabular}{|c|c|c|c|c|c|c|}
\hline 1.5 & 8.6 & & & & & \\
\hline 1.66 & & & & & & \\
\hline 2 & 10.9 & 0.3 & $36: 1$ & & & \\
\hline 2.5 & 12.9 & 0.3 & $43: 1$ & 0.7 & & \\
\hline 3.5 & 16.7 & 0.4 & $42: 1$ & & & \\
\hline 5 & 20.5 & 0.45 & $46: 1$ & 1.9 & & \\
\hline 6 & & & & & & \\
\hline 7 & 24 & 0.45 & $53: 1$ & & & \\
\hline 10 & 27.2 & 0.5 & $54: 1$ & 3.4 & & \\
\hline 15 & 34.3 & 0.6 & $57: 1$ & & & \\
\hline 20 & 38.1 & 0.7 & $56: 1$ & & & \\
\hline 30 & 45.9 & 0.9 & $51: 1$ & 7.5 & & \\
\hline 60 & & & & & & \\
\hline 90 & 69.7 & 1 & $70: 1$ & 14.5 & & \\
\hline 120 & & & & & & \\
\hline 150 & & & & & & \\
\hline 180 & 75.1 & 0.92 & $82: 1$ & 23.4 & 1.9 & \\
\hline
\end{tabular}

\begin{tabular}{|c|c|c|c|c|c|c|}
\hline & \multicolumn{3}{|c|}{ CyclopentylMgBr } & \multicolumn{3}{|c|}{ iPrMgBr } \\
\hline Time & $\begin{array}{c}\text { 2-(2-Methoxy } \\
\text { phenyl)-propanal }\end{array}$ & $\begin{array}{c}\text { 3-(2-Methoxy } \\
\text { phenyl)-propanal }\end{array}$ & $\begin{array}{c}\alpha: \beta \\
\text { ratio }\end{array}$ & $\begin{array}{c}\text { 2-(2-Methoxy } \\
\text { phenyl)-propanal }\end{array}$ & $\begin{array}{c}\text { 3-(2-Methoxy } \\
\text { phenyl)-propanal }\end{array}$ & $\begin{array}{l}\alpha: \beta \\
\text { ratio }\end{array}$ \\
\hline 0.5 & 2.4 & & & & & \\
\hline 1 & 4.8 & 0.5 & $10: 1$ & & & \\
\hline 1.33 & & & & & & \\
\hline 1.5 & 6.6 & 0.6 & $11: 1$ & 1.8 & & \\
\hline 1.66 & & & & & & \\
\hline 2 & 8.8 & 0.8 & $11: 1$ & & & \\
\hline 2.5 & 10.2 & 0.9 & $11: 1$ & 2.7 & & \\
\hline 3.5 & 12.2 & 1.1 & $11: 1$ & 3.7 & & \\
\hline 5 & 14.8 & 1.3 & $11: 1$ & 4.9 & & \\
\hline 6 & & & & & & \\
\hline 7 & 18.4 & 1.5 & $12: 1$ & 6.8 & 0.7 & $10: 1$ \\
\hline 10 & 22.9 & 2 & $11: 1$ & 8.2 & 0.7 & 12:1 \\
\hline 15 & & & & & & \\
\hline 20 & 32.9 & 2.6 & $13: 1$ & 13.6 & 1.2 & $11: 1$ \\
\hline 30 & 39.8 & 3.2 & $12: 1$ & 19.5 & 1.2 & $16: 1$ \\
\hline 60 & 57.2 & 4.8 & $12: 1$ & 32 & 2.1 & $15: 1$ \\
\hline 90 & 70.2 & 4.9 & $14: 1$ & 42.8 & 2.4 & 18:1 \\
\hline 120 & 78.3 & 5.4 & $15: 1$ & 52.6 & 2.5 & 21:1 \\
\hline 150 & & & & 58.4 & 2.8 & 21:1 \\
\hline 180 & 84.7 & 5.3 & $16: 1$ & 62.1 & 2.8 & $22: 1$ \\
\hline
\end{tabular}

\begin{tabular}{|c|c|c|c|}
\cline { 2 - 4 } \multicolumn{1}{c|}{} & \multicolumn{3}{c|}{ phenethylmagnesium bromide } \\
\hline Time & $\begin{array}{c}\text { 2-(2-Methoxy } \\
\text { phenyl)-propanal }\end{array}$ & $\begin{array}{c}3-(2-\text { Methoxy } \\
\text { phenyl)-propanal }\end{array}$ & $\begin{array}{c}\alpha: \beta \\
\text { ratio }\end{array}$ \\
\hline
\end{tabular}




\begin{tabular}{|c|c|c|c|}
\hline 0.5 & & & \\
\hline 1 & & & \\
\hline 1.33 & & & \\
\hline 1.5 & 0.3 & & \\
\hline 1.66 & & & $4: 1$ \\
\hline 2 & 2.8 & 0.7 & $3: 1$ \\
\hline 2.5 & 11.2 & 3.6 & $5: 1$ \\
\hline 3.5 & 23.8 & 4.7 & $6: 1$ \\
\hline 5 & 35.8 & 6.4 & \\
\hline 6 & & & $6: 1$ \\
\hline 7 & 41.1 & 6.9 & $5: 1$ \\
\hline 10 & 46.2 & 9.8 & \\
\hline 15 & & & $6: 1$ \\
\hline 20 & 60.1 & 9.7 & $7: 1$ \\
\hline 30 & 69.1 & 10.2 & $8: 1$ \\
\hline 60 & 79 & 10.5 & $8: 1$ \\
\hline 90 & 81.3 & 10.4 & $8: 1$ \\
\hline 120 & 81.9 & 9.7 & \\
\hline 150 & & & $10: 1$ \\
\hline 180 & 82 & 8.3 & \\
\hline & & & \\
\hline
\end{tabular}




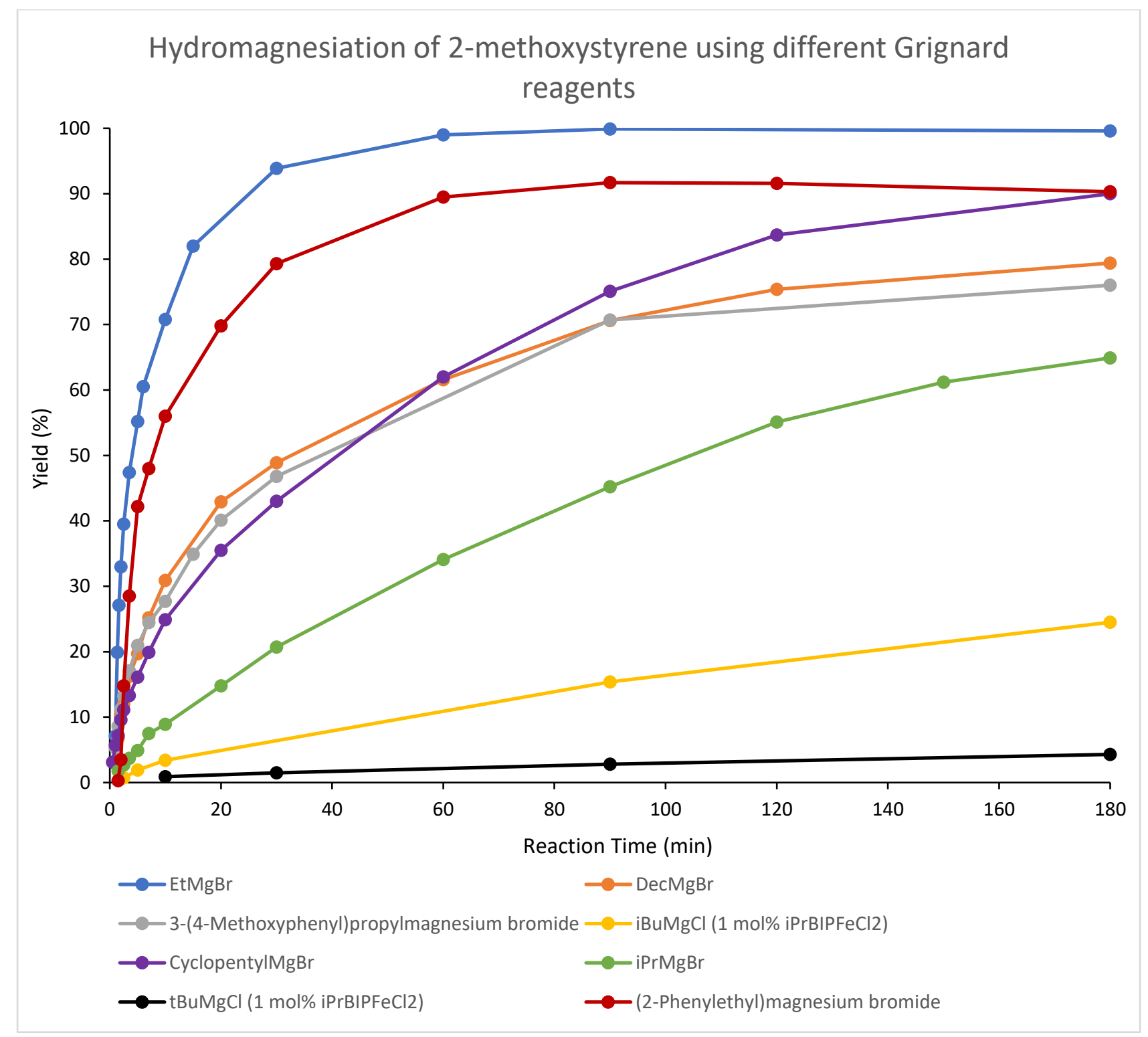

\section{Attempted hydromagnesiation using magnesium hydride}
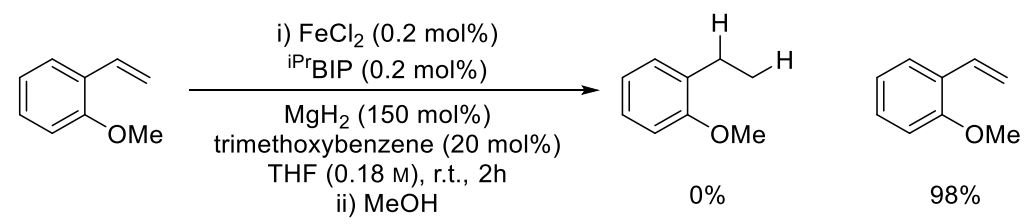

2-Methoxystyrene (47 $\mu \mathrm{L}, \quad 0.35 \mathrm{mmol})$ was added to a solution 2,6-bis-[1-(2,6diisopropylphenylimino)ethyl]pyridine iron(II) chloride $(0.5 \mathrm{~mL}, 0.0014 \mathrm{M}$ in THF, $0.0007 \mathrm{mmol}, 0.2$ $\mathrm{mol} \%$ ) and 1,3,5-trimethoxybenzene $(11.8 \mathrm{mg}, 0.07 \mathrm{mmol}, 20 \mathrm{~mol} \%$ ) in anhydrous tetrahydrofuran (total volume $2.0 \mathrm{~mL}$ ). Magnesium hydride (14 $\mathrm{mg}, 0.53 \mathrm{mmol}, 150 \mathrm{~mol} \%$ ) was added in one portion, and the reaction was stirred at room temperature $\left(20-22^{\circ} \mathrm{C}\right.$ ). After 2 hours aqueous sulfate buffer (approx. $5 \mathrm{~mL}$ ) was carefully added dropwise over 10 minutes, and the resulting aqueous phase was extracted with diethyl ether (approx. $15 \mathrm{~mL}$ ). The organic phase was washed with $\mathrm{H}_{2} \mathrm{O}$ and brine, dried $\left(\mathrm{MgSO}_{4}\right)$ and concentrated in vacuo to give the crude reaction products. The percentage yield of each product was determined by quantitative ${ }^{1} \mathrm{H}$ NMR spectroscopy, using 1,3,5-trimethoxybenzene $(20 \mathrm{~mol} \%)$ as an internal standard. 


\section{Hydride Transfer: ReVERSibility and Selectivity}

\section{Preparation of deuterium-labelled Grignard reagents}

$d_{5}-\mathrm{EtMgBr}:$

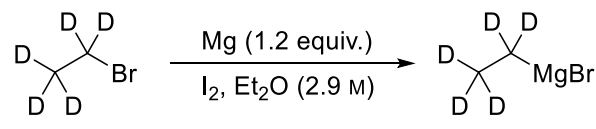

Magnesium turnings (1.3 g, $53 \mathrm{mmol})$ and anhydrous diethyl ether $(15 \mathrm{~mL})$ were added to an oven-dried multi-necked round-bottomed flask with a reflux condenser attached, under a nitrogen atmosphere. $d_{5}$ Bromoethane $(0.3 \mathrm{~mL}, 0.5 \mathrm{~g}, 4.4 \mathrm{mmol})$ was added, followed by a single crystal of iodine. The remaining $d_{5}$-bromoethane $(3.0 \mathrm{~mL}, 4.5 \mathrm{~g}, 39.6 \mathrm{mmol})$ was added over the course of an hour at a rate to maintain reflux. The reaction was stirred for a further 90 minutes, allowed settle, and the prepared Grignard reagent, $d_{5}$-ethylmagnesium bromide, was transferred by syringe to an oven-dried J Young sample flask. The concentration of the Grignard reagent was determined to be $3.0 \mathrm{M}$ by titration using 2hydroxybenzaldehyde phenylhydrazone.

$d_{7}$-iPrMgBr:

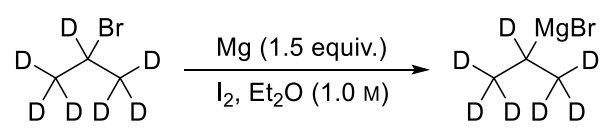

Magnesium turnings (280 mg, $11.5 \mathrm{mmol}$ ) and anhydrous diethyl ether $(8 \mathrm{~mL})$ were added to an oven-dried multi-necked round-bottomed flask with a reflux condenser attached, under a nitrogen atmosphere. $d_{7}-2-$ Bromopropane $(0.1 \mathrm{~mL}, 1.1 \mathrm{mmol})$ was added, followed by a single crystal of iodine. The remaining $d_{5}-$ bromoethane $(0.62 \mathrm{~mL}, 6.6 \mathrm{mmol})$ was added over the course of 30 minutes at a rate to maintain reflux. The reaction was heated at reflux for 1 hour and was then allowed to cool and settle. The prepared Grignard reagent, $d_{7}$-isopropylmagnesium bromide, was transferred by syringe to an oven-dried J Young sample flask. The concentration of the Grignard reagent was determined to be $1.5 \mathrm{M}$ by titration using 2hydroxybenzaldehyde phenylhydrazone. 


\section{General procedure and for the hydromagnesiation of 2-methoxystyrene using either $d_{5}$-EtMgBr or $d_{7}$-iPrMgBr}

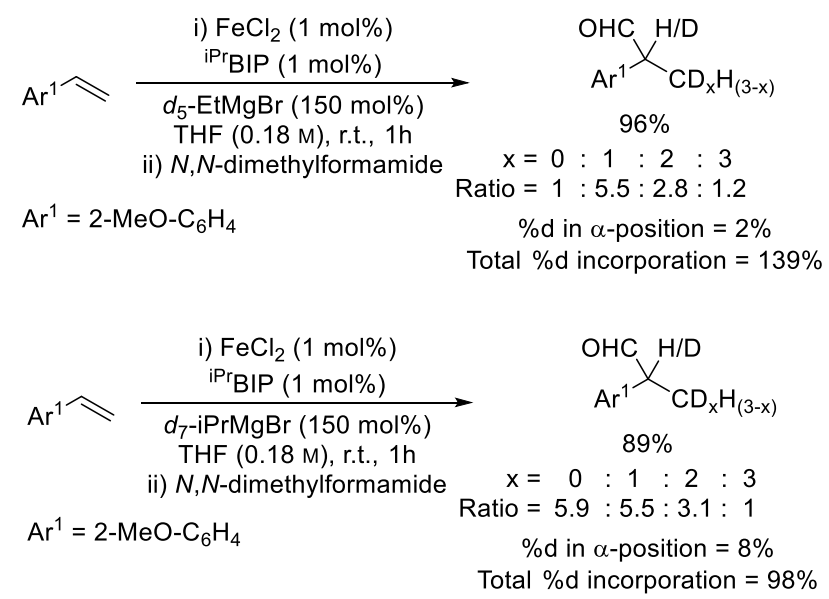

2-Methoxystyrene (94 $\mu \mathrm{L}, \quad 0.7 \mathrm{mmol})$ was added to a solution of 2,6-bis-[1-(2,6diisopropylphenylimino)ethyl]pyridine iron(II) chloride (4.3 $\mathrm{mg}, 0.007 \mathrm{mmol}, 1 \mathrm{~mol} \%$ ) and 1,3,5trimethoxybenzene $(23.5 \mathrm{mg}, 0.14 \mathrm{mmol}, 20 \mathrm{~mol} \%$ ) in anhydrous tetrahydrofuran (total volume $4 \mathrm{~mL}$ after addition of Grignard reagent). A deuterium-labelled Grignard reagent $(1.05 \mathrm{mmol}, 150 \mathrm{~mol} \%)$ was added in one portion, and the reaction was stirred at room temperature $\left(20-22^{\circ} \mathrm{C}\right)$. Aliquots $(2$ sets, $100 \mu \mathrm{L}$ each) were periodically removed and added to HPLC vials containing anhydrous $\mathrm{N}, \mathrm{N}$-dimethylformamide (approx. $10 \mu \mathrm{L}, 0.13 \mathrm{mmol}$ ), and the samples shaken for 30 minutes.

Aqueous sulfate buffer (approx. $0.3 \mathrm{~mL}$ per vial) was added to one set of vials followed by diethyl ether (approx. $0.7 \mathrm{~mL}$ ). The vial was shaken and the layers were allowed to settle. The diethyl ether layer was removed and added to a $7 \mathrm{~mL}$ glass vial, from which the diethyl ether was allowed to evaporate at room temperature (approx. 10-15 min) until the majority of the solvent had evaporated (but wasn't thoroughly dry). The residue was dissolved in $\mathrm{CDCl}_{3}$ and added to an NMR tube for analysis by ${ }^{1} \mathrm{H}$ and ${ }^{13} \mathrm{C}$ NMR spectroscopy.

The second (identical) set of sample vials were processed for analysis by ${ }^{2} \mathrm{H}$ NMR spectroscopy. Aqueous sulfate buffer (approx. $0.3 \mathrm{~mL}$ ) was added to each vial followed by $\mathrm{CH}_{2} \mathrm{Cl}_{2}$ (approx. $0.7 \mathrm{~mL}$ ). The vial was shaken and the layers were allowed to settle. The $\mathrm{CH}_{2} \mathrm{Cl}_{2}$ layer was removed and added to an NMR tube for analysis by ${ }^{2} \mathrm{H}$ NMR spectroscopy.

The percentage yield of each product was calculated using ${ }^{13} \mathrm{C},{ }^{2} \mathrm{H}$ and quantitative ${ }^{1} \mathrm{H}$ NMR spectroscopy, using 1,3,5-trimethoxybenzene $(20 \mathrm{~mol} \%)$ as an internal standard. All products were identified by comparison to their literature values: 2-(2-methoxyphenyl)-propanal, ${ }^{8} 3$-(2-Methoxyphenyl)-propanal. ${ }^{9}$ 


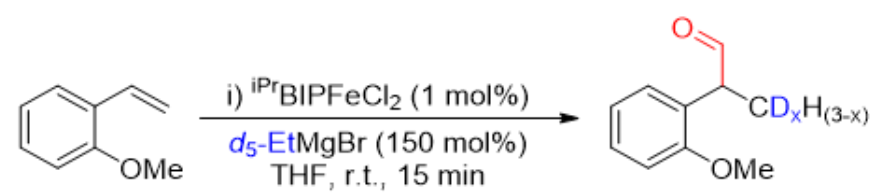

$0.18 \mathrm{M}$

ii) N,N-dimethylformamide

$x=0: 1: 2: 3$

Ratio $=1: 5.5: 2.8: 1.2$

$\% \mathrm{D}$ in $\alpha$-position $=2 \%$

Total $\% \mathrm{D}$ incorporation $=139 \%$

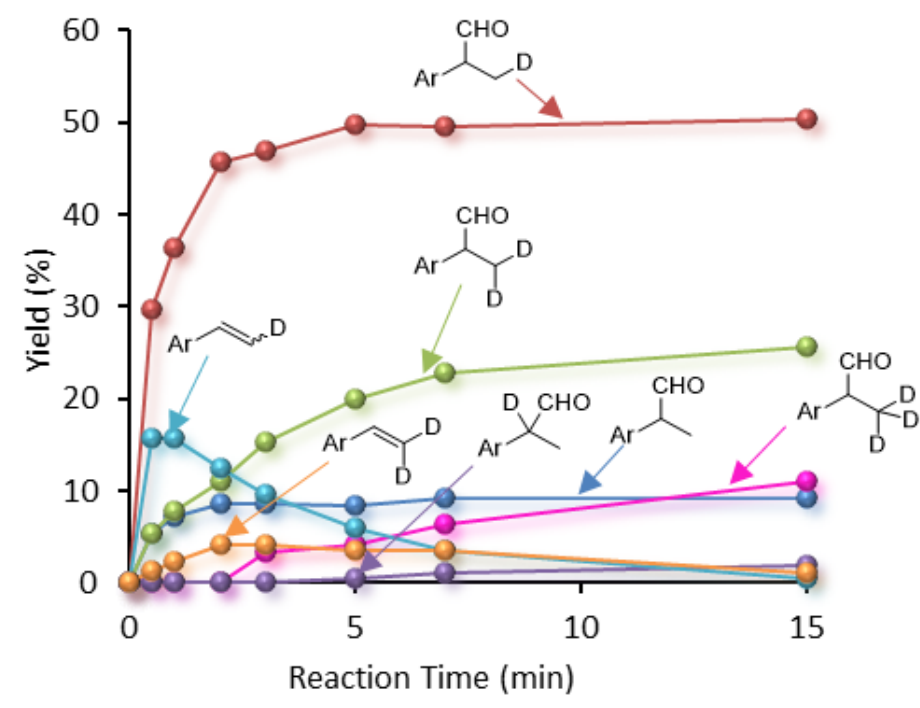

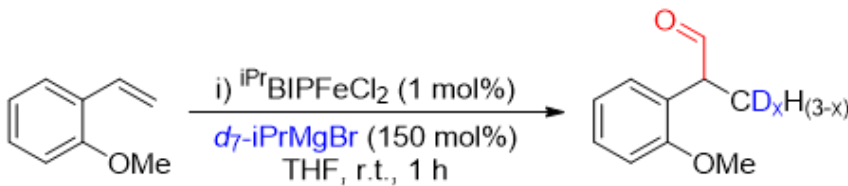

$0.18 \mathrm{M} \quad$ ii) N,N-dimethylformamide $\quad 89 \%$

$x=0: 1: 2: 3$

Ratio $=5.9: 5.5: 3.1: 1$

$\% \mathrm{D}$ in $\alpha$-position $=8 \%$

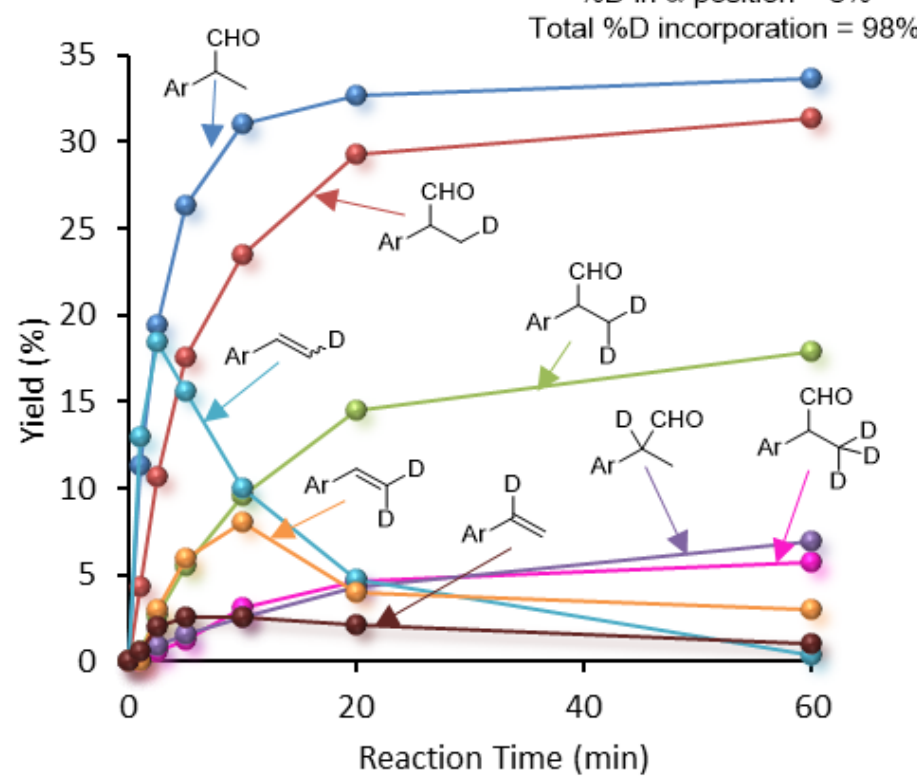




\section{KINETIC ISOTOPE EFFECT}

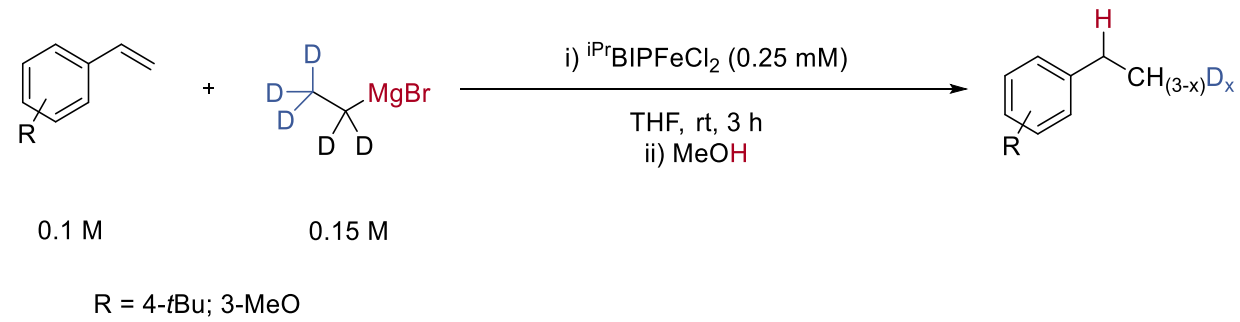

Styrene derivative $(0.5 \mathrm{~mL}, 0.8 \mathrm{~m}$ in THF, $0.1 \mathrm{mmol})$ was added to a solution of 2,6-bis-[1-(2,6diisopropylphenylimino)ethyl]pyridine iron(II) chloride $(1 \mathrm{~mL}, 0.001 \mathrm{M}$ in THF, $0.001 \mathrm{mmol})$ and 1,3,5trimethoxybenzene $(0.5 \mathrm{~mL}, 0.16 \mathrm{M}$ in THF, $0.08 \mathrm{mmol})$ in anhydrous tetrahydrofuran $(1.8 \mathrm{ml})$. Ethylmagnesium bromide or $d_{5}$-ethylmagnesium bromide $\left(0.2 \mathrm{~mL}, 3 \mathrm{M}\right.$ in $\left.\mathrm{Et}_{2} \mathrm{O}, 0.6 \mathrm{mmol}\right)$ was added in one portion, and the reaction was stirred at room temperature $\left(20-25{ }^{\circ} \mathrm{C}\right)$. Aliquots $(<100 \mu \mathrm{L})$ were periodically removed and added to HPLC vials containing anhydrous methanol (approx. 10-15 $\mu \mathrm{L}, 0.25$ $0.37 \mathrm{mmol}$ ). After all samples were taken, aqueous sulfate buffer (approx. $0.3 \mathrm{~mL}$ ) was added to each vial followed by diethyl ether (approx. $0.7 \mathrm{~mL}$ ). The vial was shaken and the layers were allowed to settle. The diethyl ether layer was removed and added to a $7 \mathrm{~mL}$ glass vial, from which the diethyl ether was allowed to evaporate at room temperature (approx. 10-15 min) until the majority of the solvent had evaporated (but was not thoroughly dry). The residue was dissolved in $\mathrm{CDCl}_{3}$ and added to an NMR tube for analysis by ${ }^{1} \mathrm{H}$ NMR spectroscopy.

The percentage yield of each product was determined by quantitative ${ }^{1} \mathrm{H}$ NMR spectroscopy, using 1,3,5trimethoxybenzene $(20 \mathrm{~mol} \%)$ as an internal standard.

For reactions with 4-tert-butylstyrene no side-products were observed and the mass balance could be accounted for by a combination of products (1-ethyl-4-tert-butylbenzene) ${ }^{25}$ and starting materials (4-tertbutylstyrene).

For reactions with 3-methoxystyrene, small quantities of unidentified side products were observed. The mass balance for the aromatic region was stable throughout, accounting for total mass balance. The majority of the mass balance could be accounted for by a combination of products (1-ethyl-3-methoxybenzene) ${ }^{26}$ and starting material (3-methoxystyrene). For clarity only yields of product (1-ethyl-3-methoxybenzene) are given.

Error bars on graphs are the standard deviation from the average of two runs. 


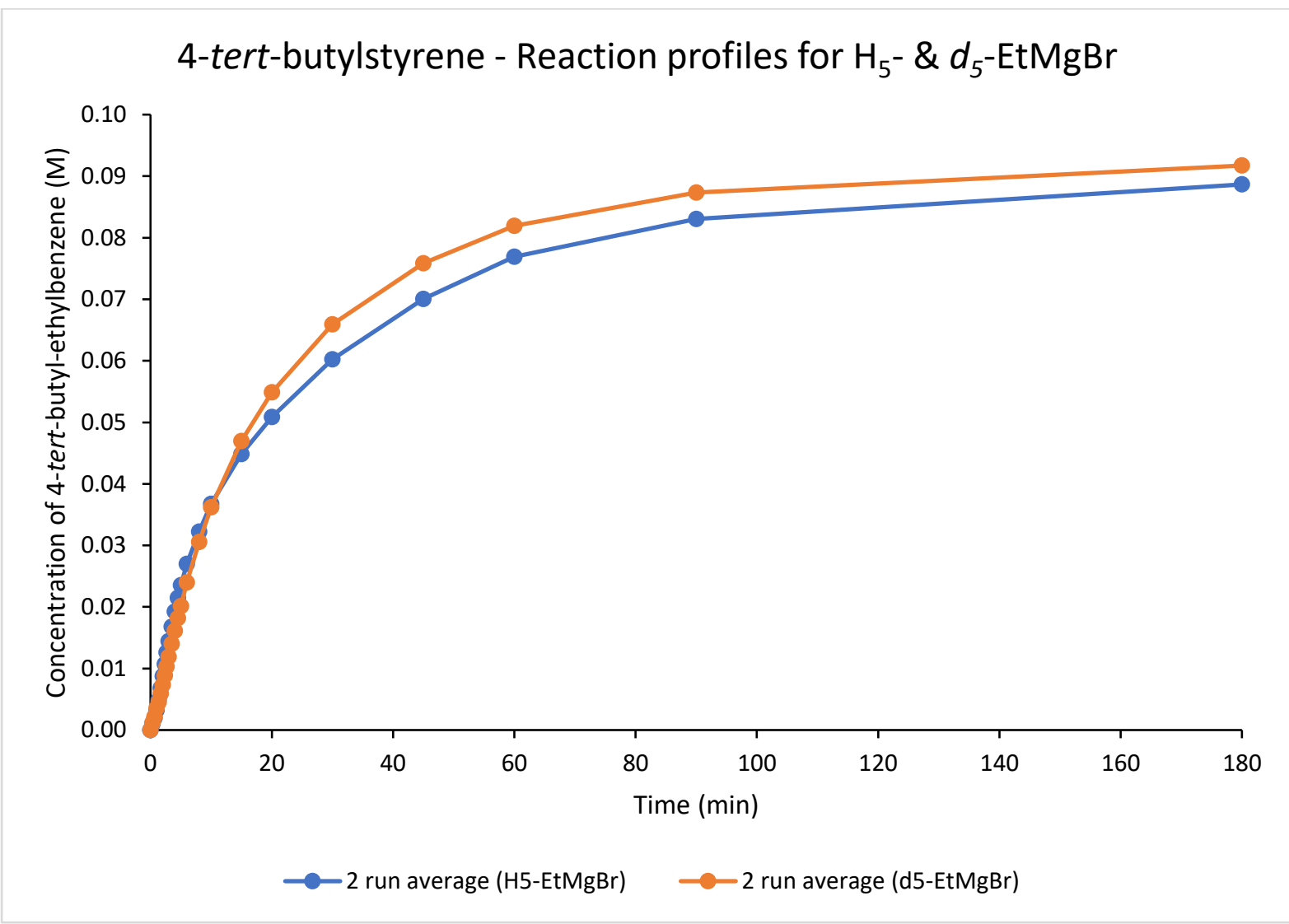


4-tert-butylstyrene - Reaction profiles for $\mathrm{H}_{5}-\& d_{5}$-EtMgBr expansion first 20 minutes

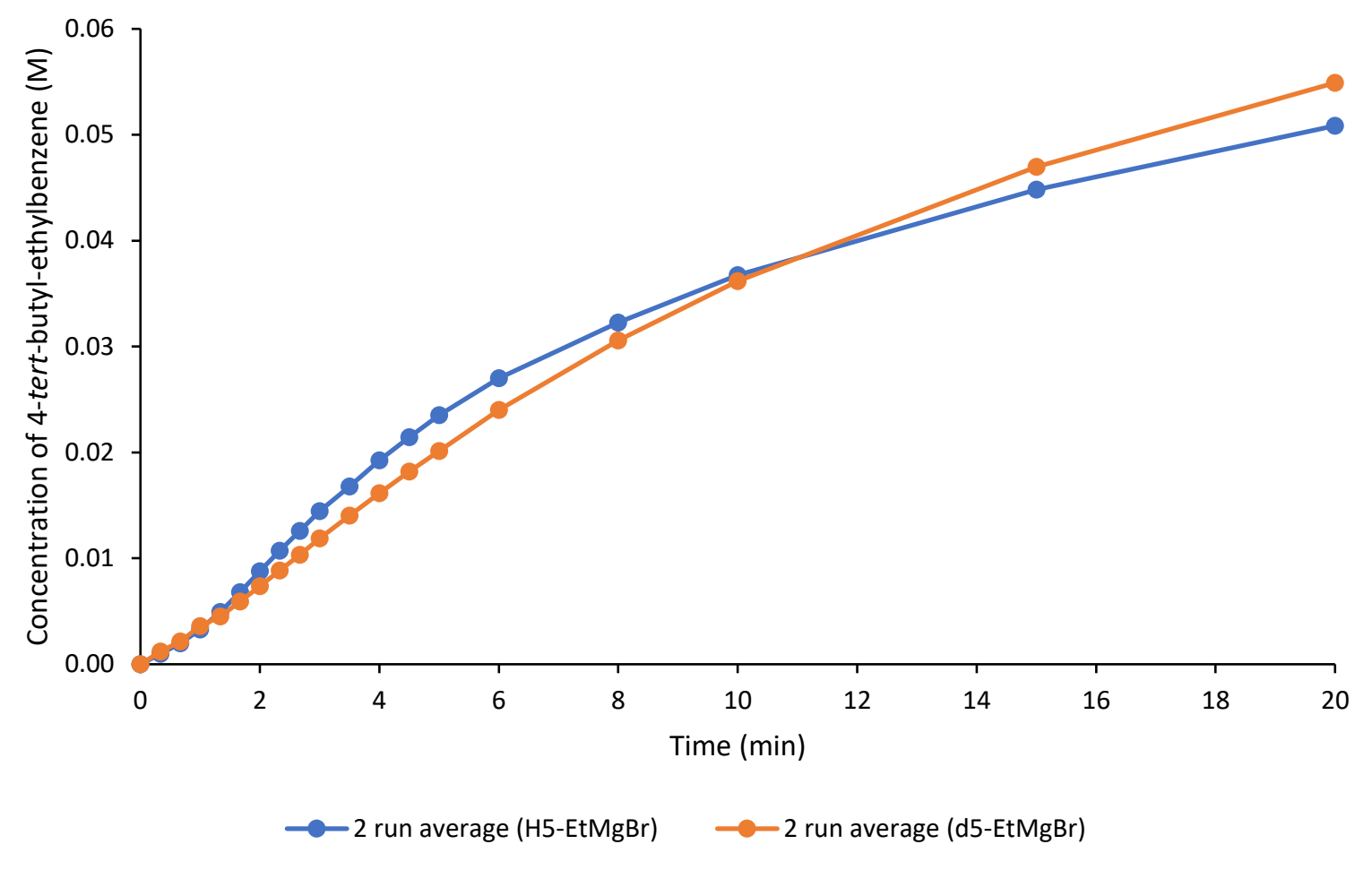

3-methoxystyrene

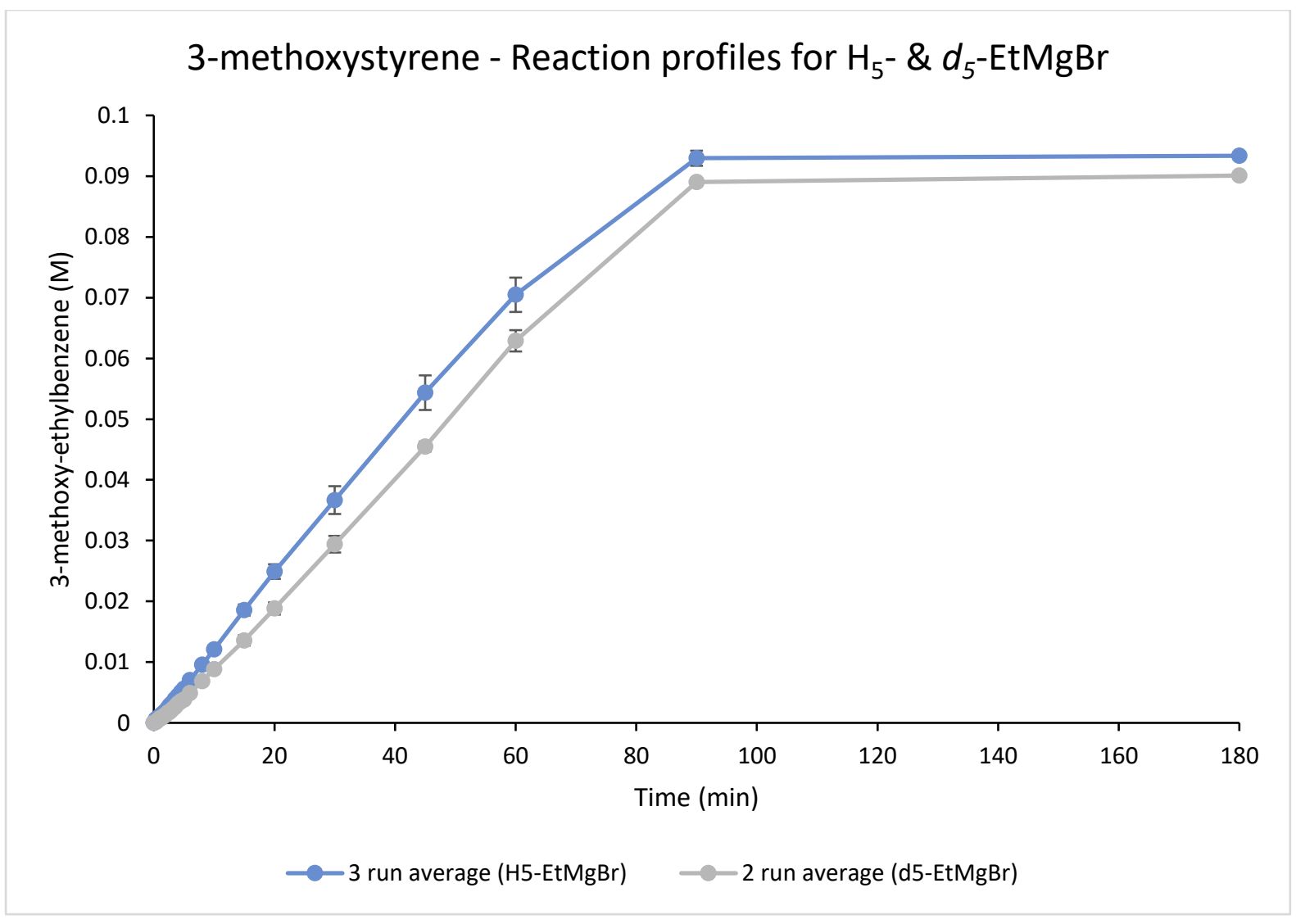




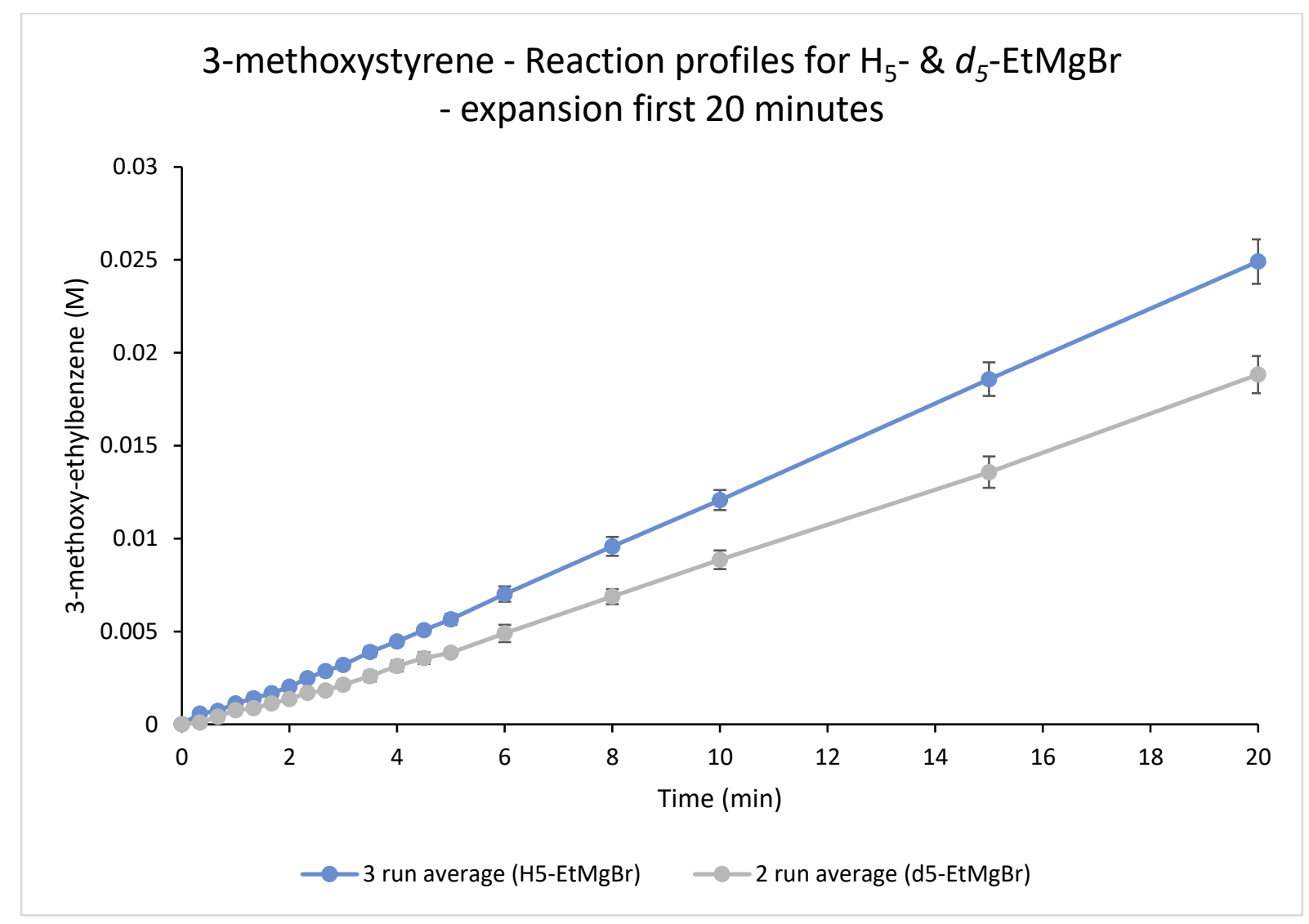

\section{Deuterium Incorporation for 3-methoxystyrene}

Using the same samples used for the kinetics above the percentage yield of each product was calculated using ${ }^{13} \mathrm{C},{ }^{2} \mathrm{H}$ and quantitative ${ }^{1} \mathrm{H}$ NMR spectroscopy, using $1,3,5$-trimethoxybenzene $(20 \mathrm{~mol} \%)$ as an internal standard. ${ }^{2} \mathrm{H}-\mathrm{NMR}$ was carried out on a sample taken at the end of the reaction (180 minutes), worked up as described for samples in the general procedure apart from the use of dichloromethane as the NMR solvent. This was carried out to check for deuterium incorporation in the $\alpha$-position, of which none was detected. 


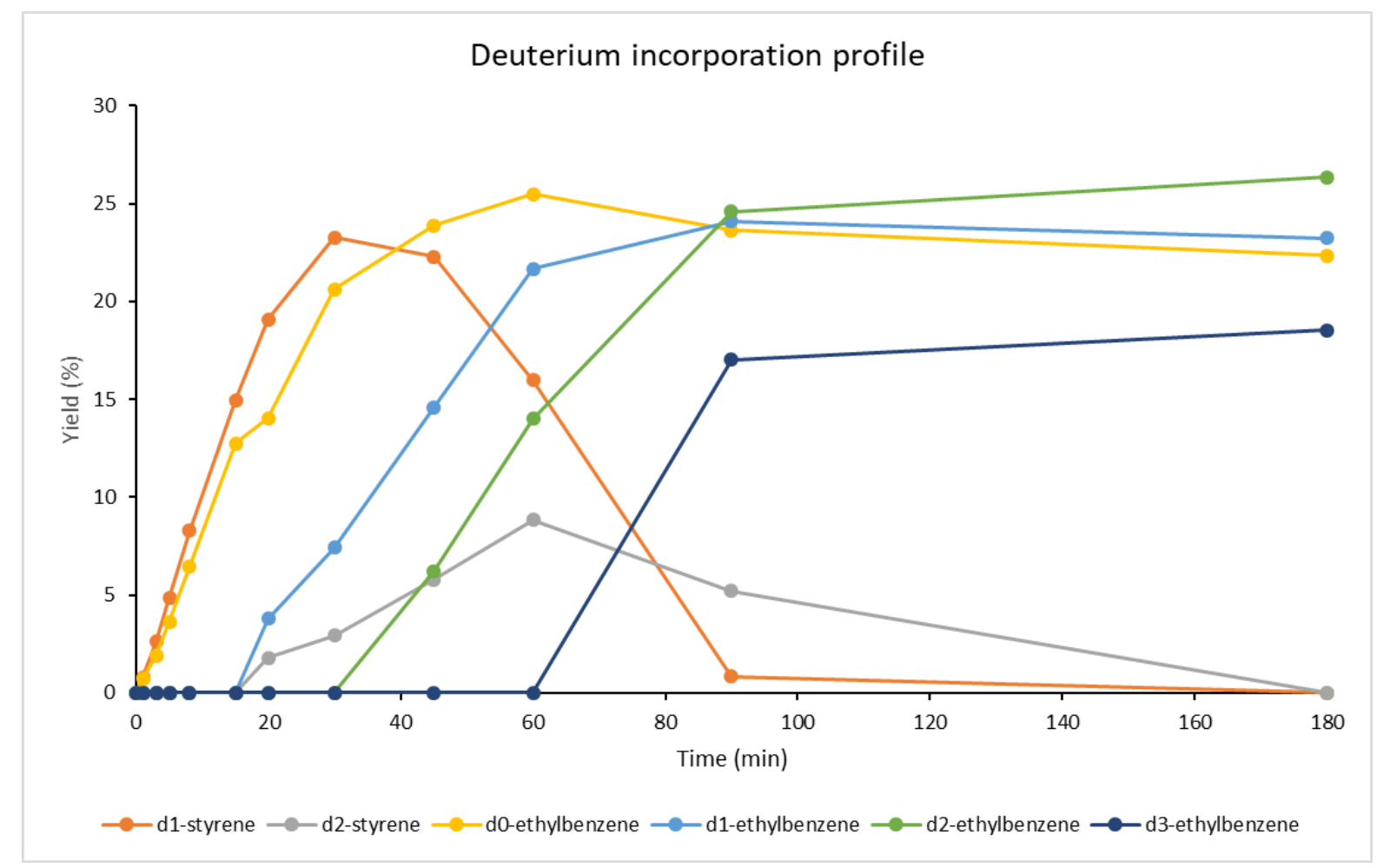

\section{Hydride Transfer Mechanism: IsOMERISATION PHENETHYLMAGNESIUM BROMIDE}

Preparation of phenethylmagnesium bromide

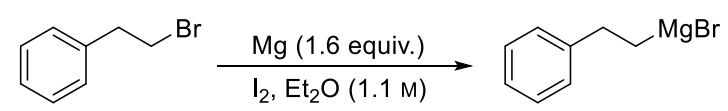

Magnesium turnings (970 mg, $40 \mathrm{mmol}$ ) were added to an oven-dried multi-necked round-bottomed flask with a reflux condenser attached, under a nitrogen atmosphere. Anhydrous diethyl ether $(22 \mathrm{~mL})$ was added, followed by approximately $10 \%$ of the (2-bromoethyl)benzene (approx. $0.46 \mathrm{~g}, 2.5 \mathrm{mmol}$ ). The reaction was stirred at room temperature, however no evolution of heat was noted so a small crystal of iodine was added. Within 1 minute, the brown colouration from iodine disappeared and the reaction began to evolve heat. The remaining (2-bromoethyl)benzene ( $4.14 \mathrm{~g} 22.5 \mathrm{mmol})$ was added over 30 minutes. The solution was stirred for a further 90 minutes, before being allowed to cool and settle. The prepared Grignard reagent, phenethylmagnesium bromide, was transferred by syringe to an oven-dried J Young sample flask. The concentration of the Grignard reagent was determined to be $1 \mathrm{M}$ by titration using 2-hydroxybenzaldehyde phenylhydrazone.

The prepared Grignard reagent contained approximately 1.5\% styrene [relative to phenethylmagnesium bromide]. In order to remove this, the solvent was removed from the Grignard reagent under high vacuum and the solid Grignard reagent was heated gently for 10 minutes. Anhydrous diethyl ether $(10 \mathrm{~mL})$ was added to dissolve the Grignard reagent, and was removed again under high vacuum. This procedure was repeated 3 times. Anhydrous diethyl ether $(15 \mathrm{~mL})$ was added and the concentration of phenethylmagnesium bromide was determined to be $1.15 \mathrm{M}$ by titration using 2-hydroxybenzaldehyde phenylhydrazone. Following this procedure the amount of styrene in the Grignard reagent was reduced to $0.4 \%$ [relative to phenethylmagnesium bromide]. 


\section{General procedure and data analysis for the isomerisation of phenethylmagnesium bromide}

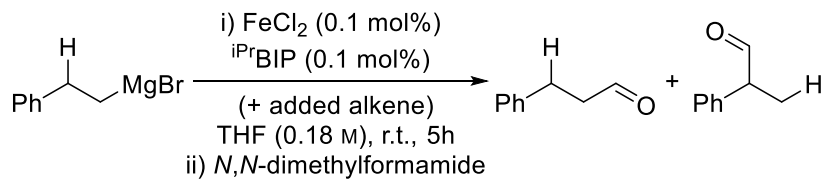

An alkene derivative (0-0.035 mmol, $0-10 \mathrm{~mol} \%)$ was added to a solution of 2,6-bis-[1-(2,6diisopropylphenylimino)ethyl]pyridine iron(II) chloride $(0.25 \mathrm{~mL}, 0.0014 \mathrm{M}$ in THF, $0.00035 \mathrm{mmol}, 0.1$ $\mathrm{mol} \%$ ) and 1,3,5-trimethoxybenzene $(11.8 \mathrm{mg}, 0.07 \mathrm{mmol}, 20 \mathrm{~mol} \%$ ) in anhydrous tetrahydrofuran (total volume $1.7 \mathrm{~mL})$. phenethylmagnesium bromide $\left(0.3 \mathrm{~mL}, 1.15 \mathrm{M}\right.$ in $\left.\mathrm{Et}_{2} \mathrm{O}, 0.35 \mathrm{mmol}, 100 \mathrm{~mol} \%\right)$ was added in one portion, and the reaction was stirred at room temperature $\left(20-22^{\circ} \mathrm{C}\right)$. Aliquots $(<100 \mu \mathrm{L})$ were periodically removed and added to HPLC vials containing anhydrous $N, N$-dimethylformamide $(10 \mu \mathrm{L}, 0.13$ $\mathrm{mmol}$ ). The samples were shaken for 30 minutes, after which aqueous sulfate buffer (approx. $0.3 \mathrm{~mL}$ ) was added to each vial followed by diethyl ether (approx. $0.7 \mathrm{~mL}$ ). The vial was shaken and the layers were allowed to settle. The diethyl ether layer was removed and added to a $7 \mathrm{~mL}$ glass vial, from which the diethyl ether was allowed to evaporate at room temperature (approx. 10-15 min) until the majority of the solvent had evaporated (but wasn't thoroughly dry). The residue was dissolved in $\mathrm{CDCl}_{3}$ and added to an NMR tube for analysis by ${ }^{1} \mathrm{H}$ NMR spectroscopy.

The percentage yield of each product was determined by quantitative ${ }^{1} \mathrm{H}$ NMR spectroscopy, using $1,3,5-$ trimethoxybenzene $(20 \mathrm{~mol} \%)$ as an internal standard. All products were identified by comparison to their literature values: 2-phenylpropanal, 3-phenylpropanal; ${ }^{21}$ nonanal. ${ }^{22}$

Empty cells indicate that data was not collected.

\begin{tabular}{|c|c|c|c|c|}
\cline { 2 - 5 } \multicolumn{1}{c|}{} & \multicolumn{2}{c|}{ No added Alkene } & \multicolumn{2}{c|}{ Styrene (10 mol\%) } \\
\hline Time & 2-Phenylpropanal & 3-Phenylpropanal & 2-Phenylpropanal & 3-Phenylpropanal \\
\hline 0 & 0 & 95 & 0 & 95 \\
\hline 1 & 0 & 93 & 0.4 & 95 \\
\hline 5 & 0.2 & 94 & 2.2 & 93 \\
\hline 10 & & & 3.6 & 91 \\
\hline 20 & & & 5.9 & 90 \\
\hline 45 & 0.4 & 95 & 9.5 & 86 \\
\hline 90 & 0.5 & 94 & 14 & 84 \\
\hline 120 & & & & 74 \\
\hline 180 & 0.7 & 94 & 18.6 & \\
\hline 210 & & & & 67 \\
\hline 300 & 1.1 & 92 & 23.3 & \\
\hline
\end{tabular}

\begin{tabular}{|c|c|c|c|}
\cline { 2 - 4 } \multicolumn{1}{c|}{} & \multicolumn{3}{c|}{ 1-Octene (100 mol\%) } \\
\hline Time & 2-Phenylpropanal & 3-Phenylpropanal & 1-Nonanal \\
\hline 0 & 0 & 91 & 0 \\
\hline 1 & 0.3 & 92 & 0.5 \\
\hline 5 & & & \\
\hline 10 & 1 & 87 & 3.8 \\
\cline { 2 - 4 }
\end{tabular}




\begin{tabular}{|c|c|c|c|}
20 & 1.7 & 82 & 5.3 \\
\hline 45 & 3.7 & 79 & 8.4 \\
\hline 90 & 6.6 & 75 & 11.1 \\
\hline 120 & & & \\
\hline 180 & 10.1 & 68 & 14.2 \\
\hline 210 & & & \\
\hline 300 & 13.2 & 61 & 15.1 \\
\hline
\end{tabular}

\begin{tabular}{|c|c|c|c|c|}
\hline & \multicolumn{2}{|c|}{$\alpha$-Methylstyrene (10 mol\%) } & \multicolumn{2}{|c|}{$\beta$-Methylstyrene (10 mol\%) } \\
\hline Time & 2-Phenylpropanal & 3-Phenylpropanal & 2-Phenylpropanal & 3-Phenylpropanal \\
\hline 0 & 0 & 87 & 0 & 94 \\
\hline 1 & & & & \\
\hline 5 & & & & \\
\hline 10 & & & & \\
\hline 20 & & & & \\
\hline 45 & 0.2 & 84 & 0.35 & 93 \\
\hline 90 & & & & \\
\hline 120 & 0.4 & 87 & 0.4 & 92 \\
\hline 180 & & & & \\
\hline 210 & & & & \\
\hline 300 & 0.5 & 88 & 0.5 & 93 \\
\hline
\end{tabular}

\begin{tabular}{|c|c|c|c|c|}
\hline & \multicolumn{2}{|c|}{ Indene (10 mol\%) } & \multicolumn{2}{|c|}{ Cyclopropene (10 mol\%) } \\
\hline Time & 2-Phenylpropanal & 3-Phenylpropanal & 2-Phenylpropanal & 3-Phenylpropanal \\
\hline 0 & 0 & 94 & 0 & 102 \\
\hline 1 & & & & \\
\hline 5 & & & & \\
\hline 10 & & & & \\
\hline 20 & & & & \\
\hline 45 & 0.2 & 94 & 0.3 & 103 \\
\hline 90 & & & & \\
\hline 120 & & & & \\
\hline 180 & & & & \\
\hline 210 & 0.3 & 93 & 0.4 & 100 \\
\hline 300 & 0.4 & 94 & 0.4 & 101 \\
\hline
\end{tabular}




\section{8. ${ }^{57} \mathrm{Fe}$ Mössbauer Spectroscopic Studies}

\section{General considerations}

All samples were prepared in a glovebox (MBraun), with a purified nitrogen atmosphere, equipped with a liquid nitrogen fill port to enable sample freezing to $77 \mathrm{~K}$ within the glovebox. All samples were loaded into a Delrin Mössbauer sample cup for measurement, stored and loaded under liquid nitrogen. Zero field ${ }^{57} \mathrm{Fe}$ Mössbauer measurements were carried out using SeeCo. MS4 Mössbauer spectrometer integrated with a Janis SVT-400T He/ $\mathrm{N}_{2}$ cryostat for measurements at $80 \mathrm{~K}$. Isomer shifts were determined relative to $\alpha-$ $\mathrm{Fe}$ at $298 \mathrm{~K}$. All Mössbauer spectra were fit using the program WMoss (SeeCo). ${ }^{57} \mathrm{Fe}$ metal was purchased from Isoflex (95.06\% isotope enriched; Certificate of analysis numbers 4609 and 5532).

\section{${ }^{57}$ Iron(II) chloride 28}

A suspension of ${ }^{57} \mathrm{Fe}$ metal $(206 \mathrm{mg} ; 3.62 \mathrm{mmol})$ in methanol $(15 \mathrm{ml})$ was sparged with nitrogen for 20 minutes. To this suspension was added aqueous hydrochloric acid $(37 \% \mathrm{w} / \mathrm{w} ; 12.1 \mathrm{M})$ rapidly dropwise. The suspension was heated at reflux for 21 hours, after which time the yellow solution was allowed to cool to room temperature and the solvent removed in vacuo. The pale yellow solids were heated at $120{ }^{\circ} \mathrm{C}$ under high vacuum for 5 hours to give ${ }^{57}$ iron(II) chloride ( $400 \mathrm{mg} ; 3.13 \mathrm{mmol} ; 86 \%$ ) as a sandy solid.

\section{$80 \mathrm{~K}{ }^{57} \mathrm{Fe}$ Mössbauer parameters:}

\section{Solid (BN)}

$$
\delta=1.23 \mathrm{~mm} / \mathrm{s}, \Delta \mathrm{E}_{\mathrm{Q}}=1.02 \mathrm{~mm} / \mathrm{s}
$$

Data in accordance with those previously reported. ${ }^{28}$

\section{2,6-Bis-[1-(2,6-diisopropylphenylimino)ethyl]pyridine ${ }^{57}$ iron(II) chloride $\left({ }^{\mathbb{P} r} \mathrm{BIP}^{57} \mathrm{FeCl}_{2}\right)$}

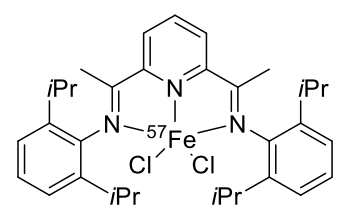

Prepared analogously to unlabelled complex using 2,6-bis-[1-(2,6-diisopropylphenylimino)ethyl]pyridine (483 mg; $1 \mathrm{mmol}$ ) and anhydrous ${ }^{57}$ iron(II) chloride (128 mg; $1 \mathrm{mmol}$ ) to give the ${ }^{57} \mathrm{Fe}$ labelled complex as a dark blue solid (551 mg; $0.9 \mathrm{mmol} ; 90 \%$ ).

1H NMR: spectrum identical to that of unlabelled complex and in accordance with that previously reported. ${ }^{6}$

\section{$80 \mathrm{~K}{ }^{57} \mathrm{Fe}$ Mössbauer spectra:}

Solid (BN)

$\delta=0.89 \mathrm{~mm} / \mathrm{s}, \Delta \mathrm{E}_{\mathrm{Q}}=2.41 \mathrm{~mm} / \mathrm{s}$ 


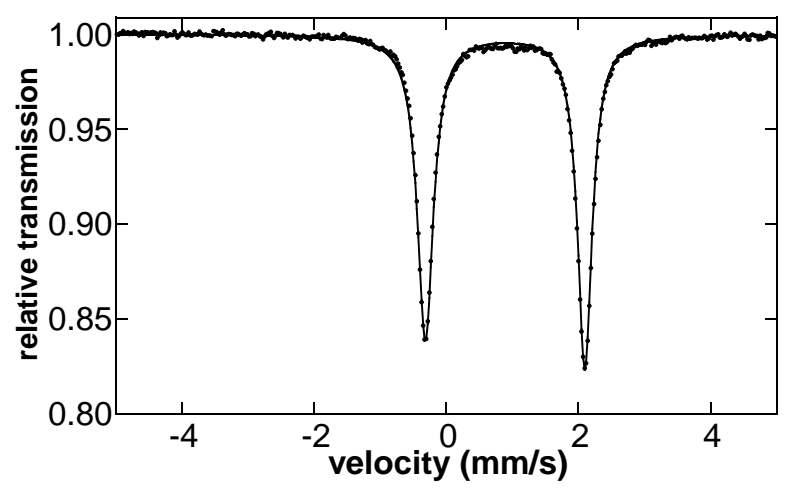

Solution (THF)

$\delta=0.96 \mathrm{~mm} / \mathrm{s}, \Delta \mathrm{E}_{\mathrm{Q}}=2.31 \mathrm{~mm} / \mathrm{s}$

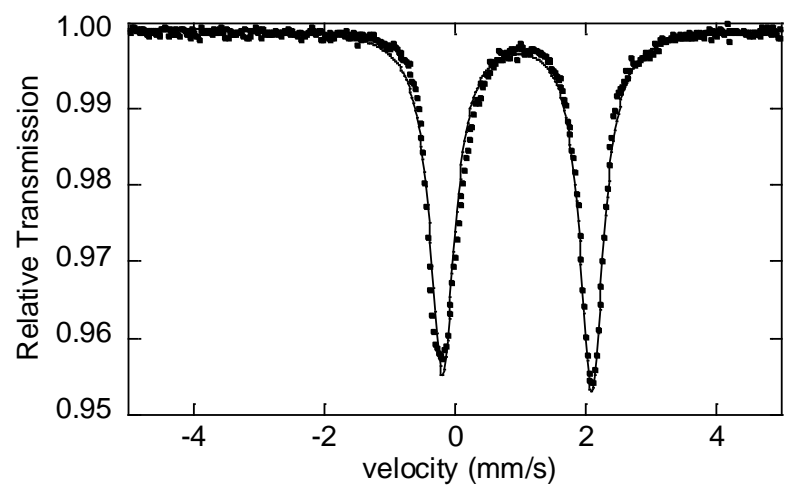

Data in accordance with those previously reported. ${ }^{29}$

\subsection{In Situ Iron Speciation on Reaction with $\mathrm{EtMgBr}$}

General Procedure for reactions at $-17^{\circ} \mathrm{C}$

A suspension of ${ }^{2 \mathrm{Pr} B I P}{ }^{57} \mathrm{FeCl}_{2}(1.8 \mathrm{mg} ; 0.003 \mathrm{mmol})$ in anhydrous tetrahydrofuran $(1 \mathrm{ml})$ was stirred at -17 $\mathrm{C}$ for 30 minutes. To the stirring suspension was added ethylmagnesium bromide (1 M in THF; 6-60 $\mu \mathrm{L}$; 0.006-0.06 mmol) and the resulting solution stirred for 2 minutes before being transferred to a Mössbauer sample cup and frozen in liquid nitrogen.

$80 \mathrm{~K}$ Mössbauer spectra for reactions at $-17^{\circ} \mathrm{C}$

\section{2 equivalents $\mathrm{EtMgBr}$}

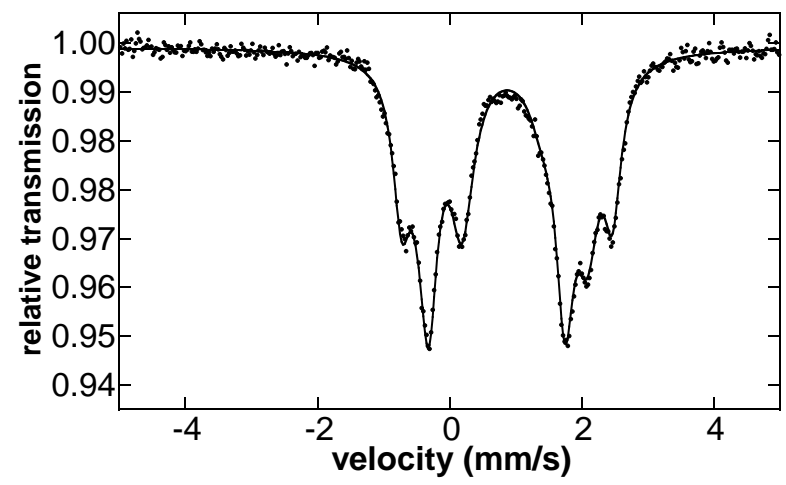


3 equivalents EtMgBr

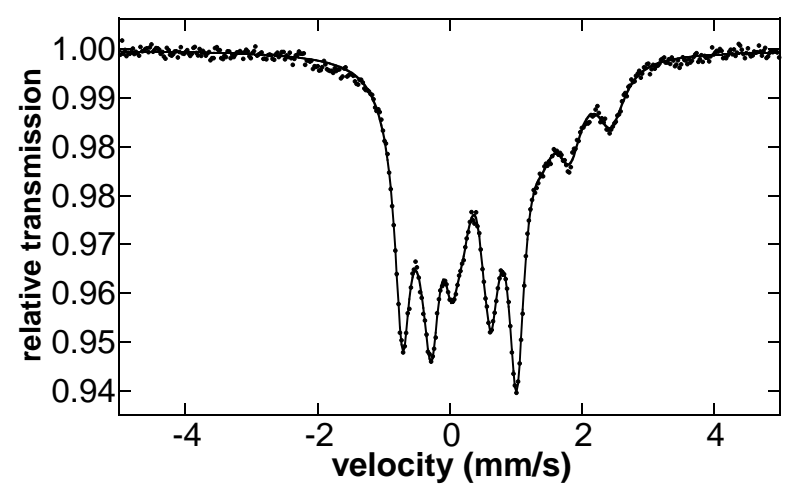

4 equivalents $\mathrm{EtMgBr}$

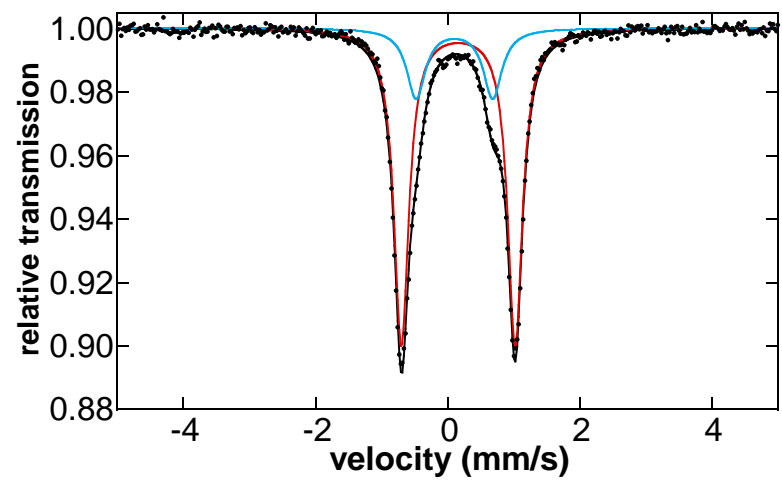

5 equivalents $\mathrm{EtMgBr}$

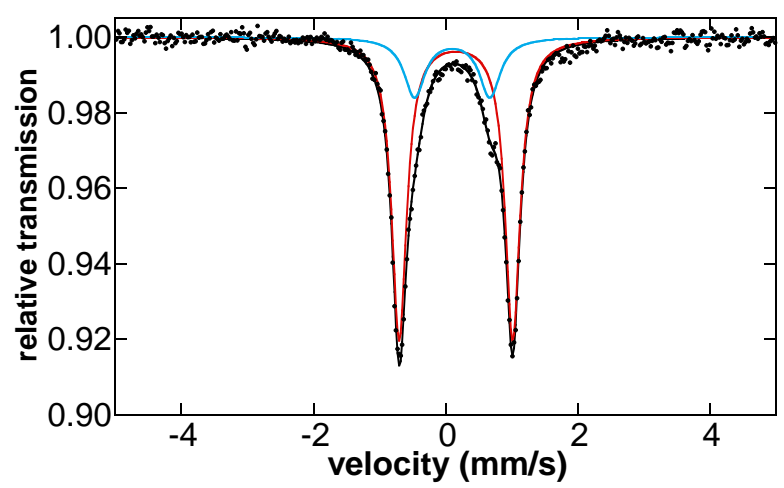




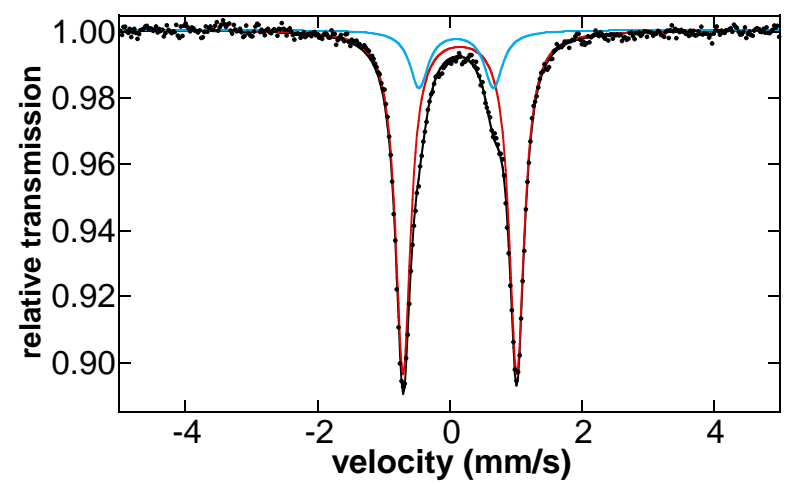

\begin{tabular}{|c|c|c|c|}
\cline { 2 - 4 } \multicolumn{1}{c|}{} & \multicolumn{2}{c|}{ Amount of Total Iron (\%) } \\
\hline Mössbauer Parameters & 4 equiv. EtMgBr & 5 equiv. EtMgBr & 20 equiv. EtMgBr \\
\hline$\delta=0.16 \mathrm{~mm} / \mathrm{s}$ and $\Delta \mathrm{E}_{\mathrm{Q}}=1.72 \mathrm{~mm} / \mathrm{s}$ & 78 & 78 & 83 \\
\hline$\delta=0.11 \mathrm{~mm} / \mathrm{s}$ and $\Delta \mathrm{E}_{\mathrm{Q}}=1.18 \mathrm{~mm} / \mathrm{s}$ & 22 & 22 & 17 \\
\hline
\end{tabular}

\section{In situ complexation of ${ }^{\mathrm{Pr}} \mathrm{BIP}$ and $\mathrm{FeCl}_{2}$}

A suspension of ${ }^{57} \mathrm{FeCl}_{2}(0.8 \mathrm{mg} ; 0.0063 \mathrm{mmol})$ and ${ }^{i \mathrm{PrBIP}}(3.0 \mathrm{mg} ; 0.0063 \mathrm{mmol})$ in anhydrous tetrahydrofuran $(2 \mathrm{ml})$ was stirred at $-17 \mathrm{C}$ for 15 minutes. To the stirring suspension was added ethylmagnesium bromide ( $1 \mathrm{M}$ in THF; $26 \mu \mathrm{L} ; 0.026 \mathrm{mmol}$ ) and the resulting solution stirred for 2 minutes before being transferred to a Mössbauer sample cup and frozen in liquid nitrogen.

\section{K Mössbauer spectrum}

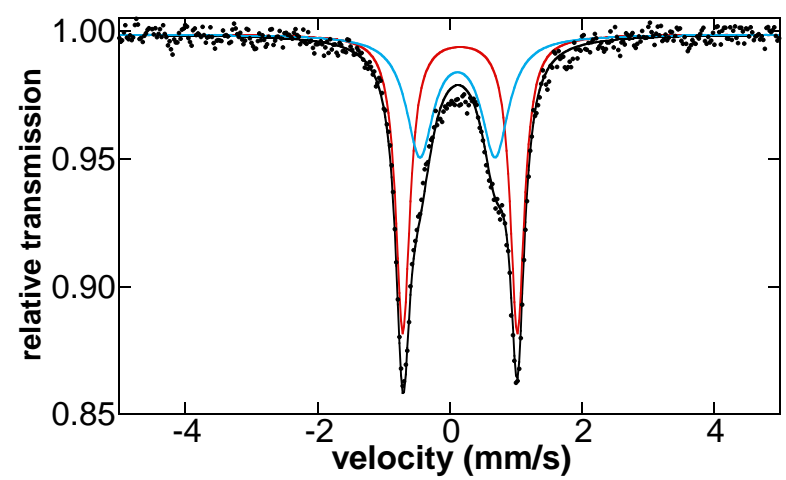

\begin{tabular}{|c|c|}
\hline Mössbauer Parameters & Amount of Total Iron (\%) \\
\hline$\delta=0.16 \mathrm{~mm} / \mathrm{s}$ and $\Delta \mathrm{E}_{\mathrm{Q}}=1.72 \mathrm{~mm} / \mathrm{s}$ & 57 \\
\hline$\delta=0.11 \mathrm{~mm} / \mathrm{s}$ and $\Delta \mathrm{E}_{\mathrm{Q}}=1.18 \mathrm{~mm} / \mathrm{s}$ & 43 \\
\hline
\end{tabular}


General Procedure for reactions at $10 \& 20^{\circ} \mathrm{C}$ using 20 equivalents EtMgBr

A suspension of ${ }^{2 \mathrm{Pr} B I P}{ }^{57} \mathrm{FeCl}_{2}(3.7 \mathrm{mg} ; 0.006 \mathrm{mmol})$ in anhydrous tetrahydrofuran $(2 \mathrm{ml})$ was stirred at the relevant temperature for 30 minutes. To the stirring suspension was added ethylmagnesium bromide $(0.86$ $\mathrm{M}$ in THF; $140 \mu \mathrm{L} ; 0.12 \mathrm{mmol})$ and portions $(\sim 1-1.5 \mathrm{ml})$ of the resulting solution transferred to a Mössbauer sample cup and frozen in liquid nitrogen.

$80 \mathrm{~K}$ Mössbauer spectra for reactions at $10 \& 20^{\circ} \mathrm{C}$

$10^{\circ} \mathrm{C} ; 30$ seconds

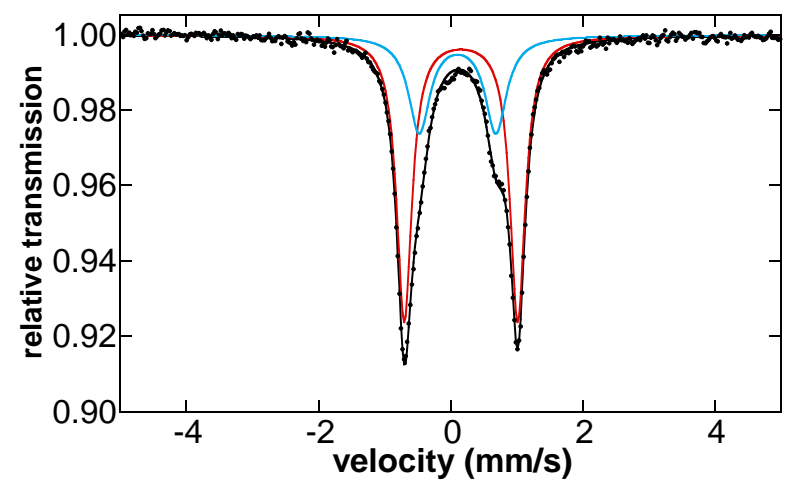

$20{ }^{\circ} \mathrm{C} ; 30$ seconds

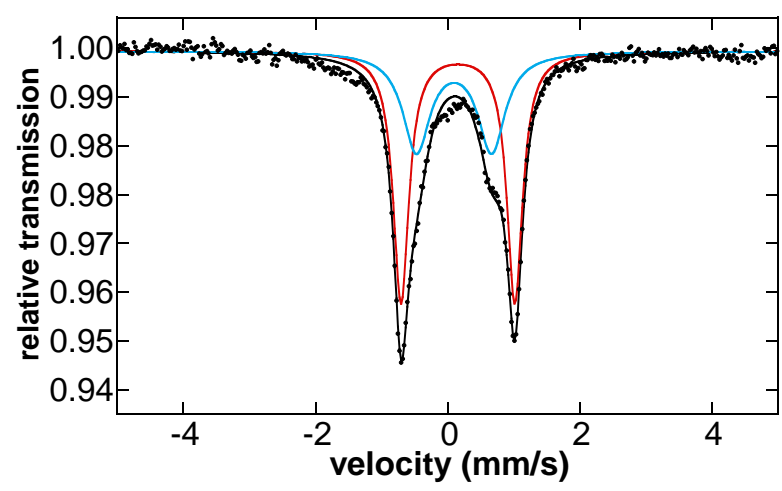

$20^{\circ} \mathrm{C} ; 70$ seconds

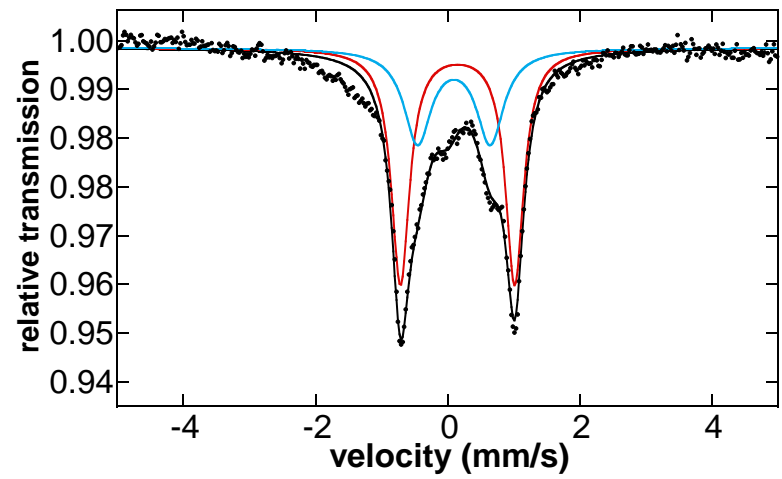




\begin{tabular}{|c|c|c|}
\cline { 2 - 3 } \multicolumn{1}{c|}{} & \multicolumn{2}{c|}{ Amount of Total Iron (\%) } \\
\hline Mössbauer Parameters & $10{ }^{\circ} \mathrm{C} ; 30$ seconds & $20{ }^{\circ} \mathrm{C} ; 30$ seconds \\
\hline$\delta=0.16 \mathrm{~mm} / \mathrm{s}$ and $\Delta \mathrm{EQ}_{\mathrm{Q}}=1.72 \mathrm{~mm} / \mathrm{s}$ & 68 & $\sim 60$ \\
\hline$\delta=0.11 \mathrm{~mm} / \mathrm{s}$ and $\Delta \mathrm{EQ}_{\mathrm{Q}}=1.18 \mathrm{~mm} / \mathrm{s}$ & 32 & $\sim 40$ \\
\hline
\end{tabular}

\subsection{In Situ Iron Speciation on Reaction with Phenethylmagnesium bromide/chloride}

General Procedure for reactions at $-17^{\circ} \mathrm{C}$

A suspension of ${ }^{2} \mathrm{PrBIP}^{57} \mathrm{FeCl}_{2}(9.2 \mathrm{mg} ; 0.015 \mathrm{mmol})$ in anhydrous tetrahydrofuran $(5 \mathrm{ml})$ was stirred at -17 ${ }^{\circ} \mathrm{C}$ for 30 minutes. To the stirring suspension was added phethylmagnesium halide (0.06-0.15 mmol) and the resulting solution stirred at $-17 \mathrm{C}$ for the specified time before being transferred to a Mössbauer sample cup and frozen in liquid nitrogen.

$80 \mathrm{~K}$ Mössbauer spectra for reactions at $-17^{\circ} \mathrm{C}$

10 equiv. phenethylmagnesium bromide; 5 minutes

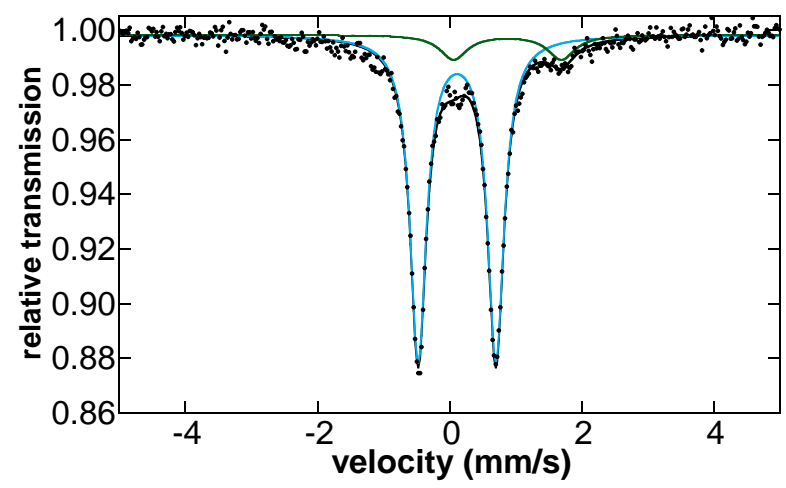

4 equiv. phenethylmagensium chloride; 5 minutes

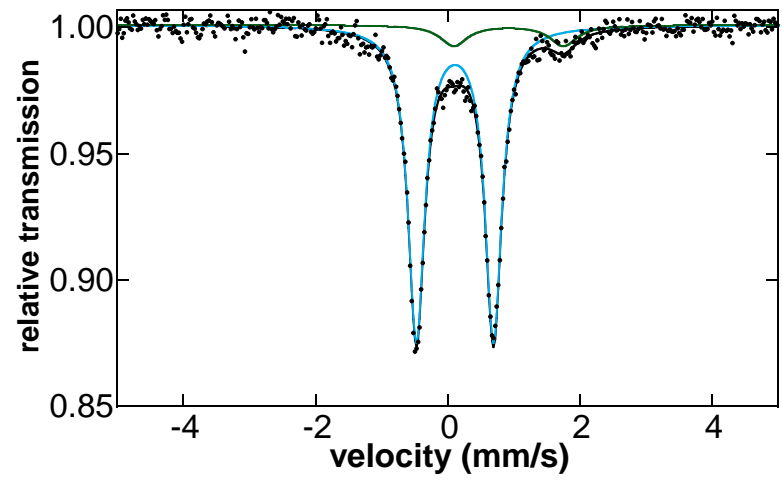




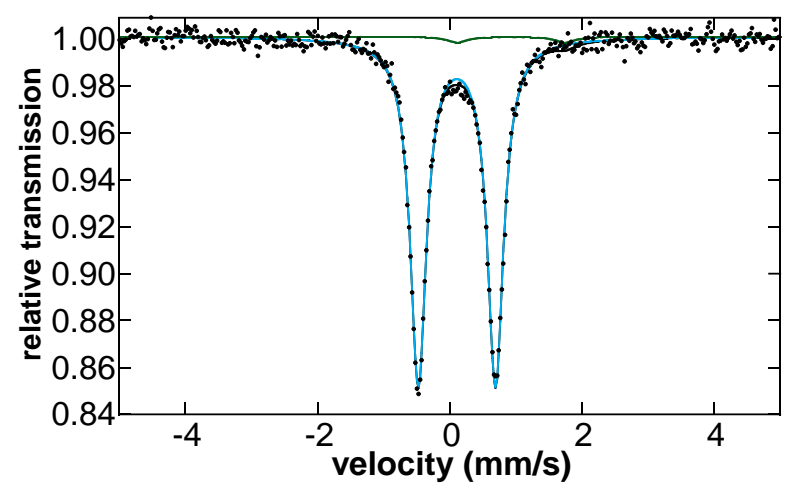

\begin{tabular}{|c|c|c|c|}
\cline { 2 - 4 } \multicolumn{1}{c|}{} & \multicolumn{3}{c|}{ Amount of Total Iron (\%) } \\
\hline Mössbauer Parameters & 10 equiv. 5 min. & 4 equiv. 5 min & 4 equiv. $10 \mathrm{~min}$ \\
\hline$\delta=0.11 \mathrm{~mm} / \mathrm{s}$ and $\Delta \mathrm{EQ}_{\mathrm{Q}}=1.18 \mathrm{~mm} / \mathrm{s}$ & 89 & 90 & 98 \\
\hline$\delta=0.88 \mathrm{~mm} / \mathrm{s}$ and $\Delta \mathrm{E}_{\mathrm{Q}}=1.63 \mathrm{~mm} / \mathrm{s}$ & 11 & 10 & 2 \\
\hline
\end{tabular}

\section{Reaction Profiles}

\subsection{Iron Speciation During Catalysis}

\section{General Procedure}

A suspension of ${ }^{\mathrm{Pr}} \mathrm{BIPFeCl}_{2}(7.3 \mathrm{mg} ; 0.012 \mathrm{mmol})$, styrene derivative $(0.4$ or $0.6 \mathrm{mmol})$ and dodecane (91 $\mu \mathrm{L} ; 0.1 \mathrm{mmol}$ ) in anhydrous tetrahydrofuran $(3.4$ or $3.6 \mathrm{ml}$; adjusted to have total volume $4 \mathrm{ml}$ after Grignard reagent addition) was stirred at $10{ }^{\circ} \mathrm{C}$ for 20 minutes. Pre-chilled ethylmagnesium bromide $(1 \mathrm{M}$ in THF; 0.4 or $0.6 \mathrm{ml} ; 0.4$ or $0.6 \mathrm{mmol}$ ) was added in one portion and the reaction stirred at $10^{\circ} \mathrm{C}$. Aliquots $(<100 \mu \mathrm{L})$ were periodically removed and added to HPLC vials containing anhydrous methanol (approx. 10-15 $\mu \mathrm{L}, 0.25-0.37 \mathrm{mmol}$ ). After all samples were taken, aqueous sulfate buffer (approx. $0.3 \mathrm{~mL}$ ) was added to each vial followed by diethyl ether (approx. $0.7 \mathrm{~mL}$ ). The vial was shaken and the layers were allowed to settle. Approximately $100 \mu \mathrm{L}$ of the organic phase was removed, diluted to between 1-1.5 $\mathrm{ml}$ in diethyl ether and filtered through a plug of silica $(30 \mathrm{~mm} \varnothing ; 0.5 \mathrm{~cm}$ diameter $\times 1.5 \mathrm{~cm}$ length). The filtrates were then analysed by GC.

Data points highlighted in red indicate the time-points freeze-quench Mössbauer samples were taken of an analogous reaction using ${ }^{2 \mathrm{Pr}} \mathrm{BIP}{ }^{57} \mathrm{FeCl}_{2}$ (vide infra). 
4-tert-Butylstyrene (0.1 M); Ethylmagnesium bromide (0.15 M)

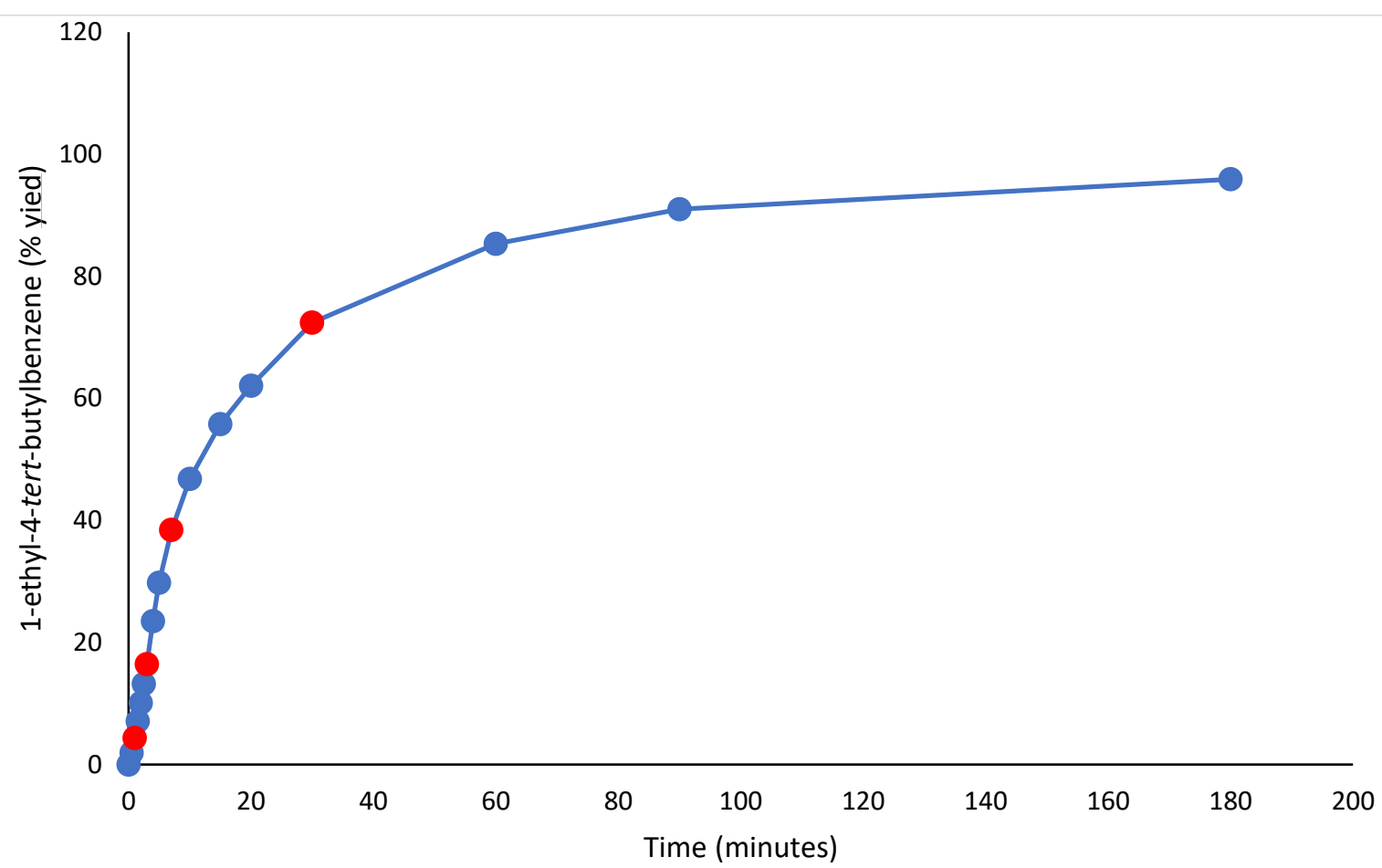

4-tert-Butylstyrene (0.15 M); Ethylmagnesium bromide (0.1 M)

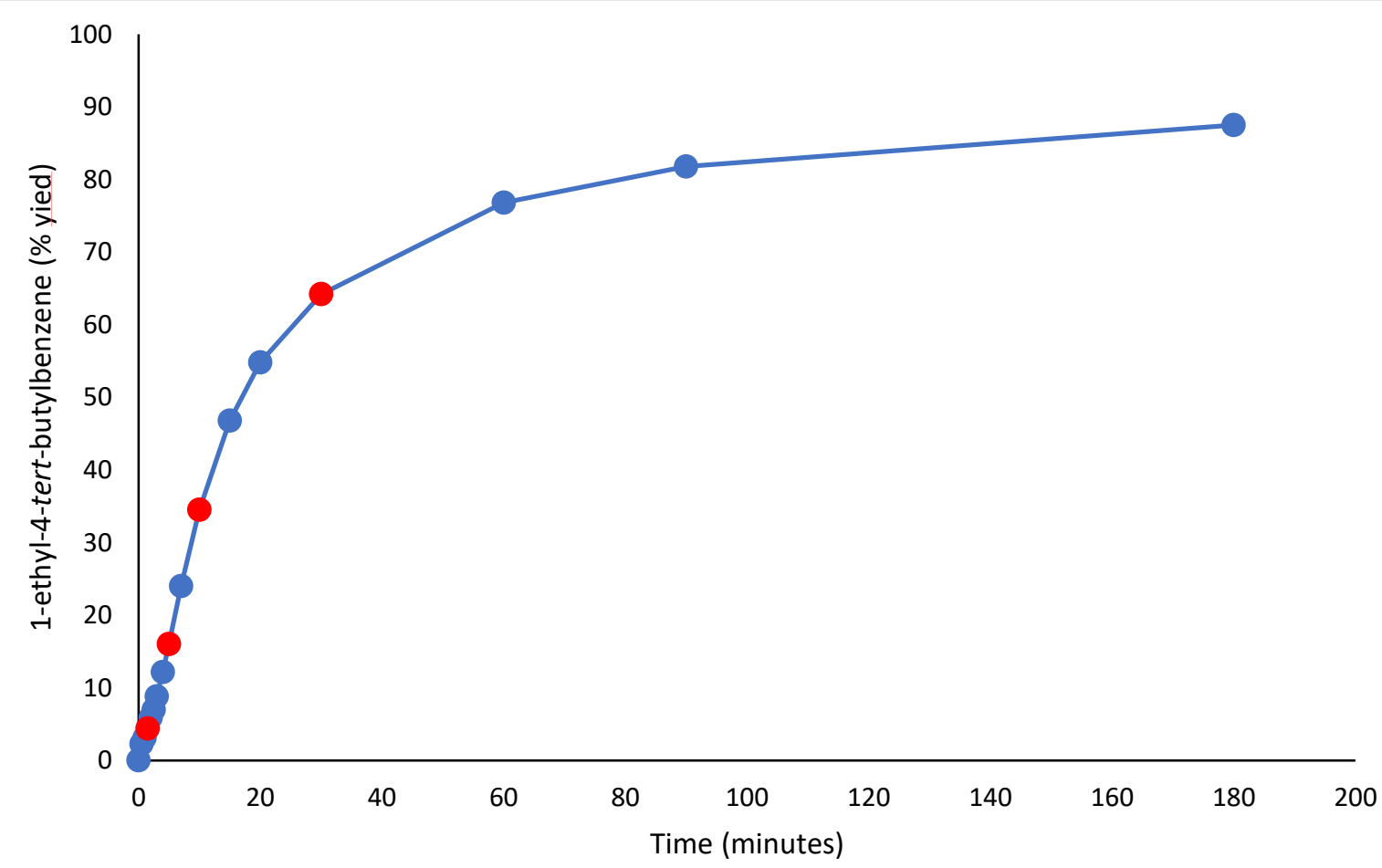




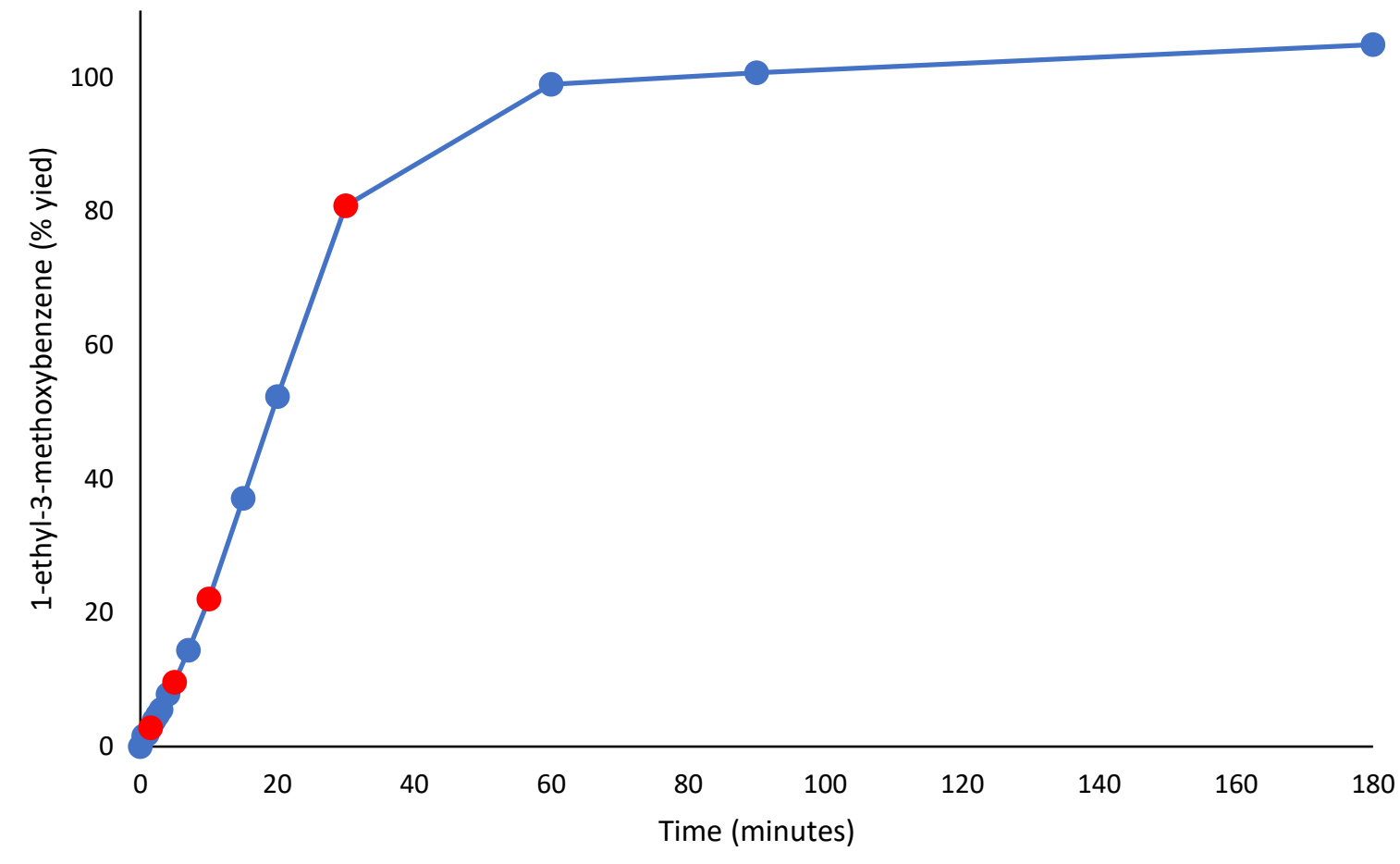

${ }^{57}$ Fe Mössbauer Sampling

\section{General Procedure}

A suspension of ${ }^{2 \mathrm{Pr} B I P} \mathrm{BI}^{57} \mathrm{FeCl}_{2}(7.3 \mathrm{mg} ; 0.012 \mathrm{mmol})$ and styrene derivative $(0.4$ or $0.6 \mathrm{mmol})$ in anhydrous tetrahydrofuran ( 3.3 or $3.5 \mathrm{ml}$; adjusted to have total volume $4 \mathrm{ml}$ after Grignard reagent addition) was stirred at $10^{\circ} \mathrm{C}$ for 20 minutes. Ethylmagnesium bromide ( $0.85 \mathrm{M}$ in THF; 0.47 or $0.71 \mathrm{ml} ; 0.4$ or $\left.0.6 \mathrm{mmol}\right)$ was added in one portion and the reaction stirred at $10{ }^{\circ} \mathrm{C}$. Aliquots (approx.. $1 \mathrm{~mL}$ ) transferred to a Mössbauer sample cup and frozen in liquid nitrogen. Time-points given are from addition of ethylmagnesium bromide to sample being frozen.

$80 \mathrm{~K}^{57} \mathrm{Fe}$ Mössbauer Spectra: 4-tert-Butylstyrene (0.1 M); Ethylmagnesium bromide (0.15 M)

\section{0 seconds}

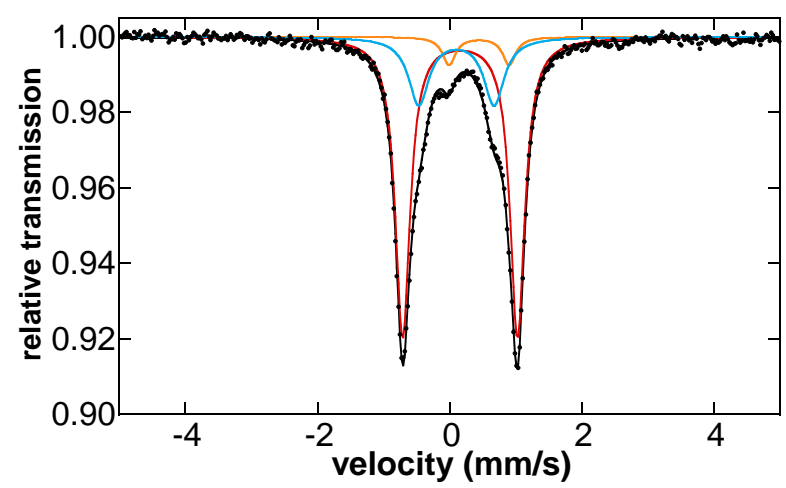


3.5 minutes

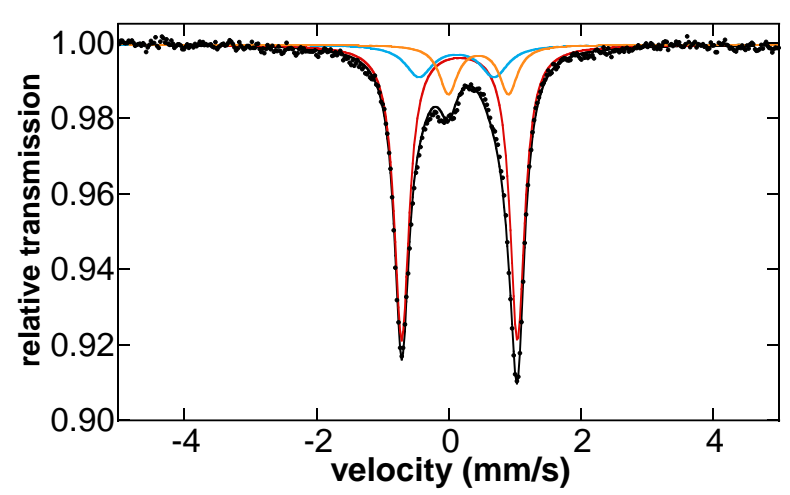

7.42 minutes

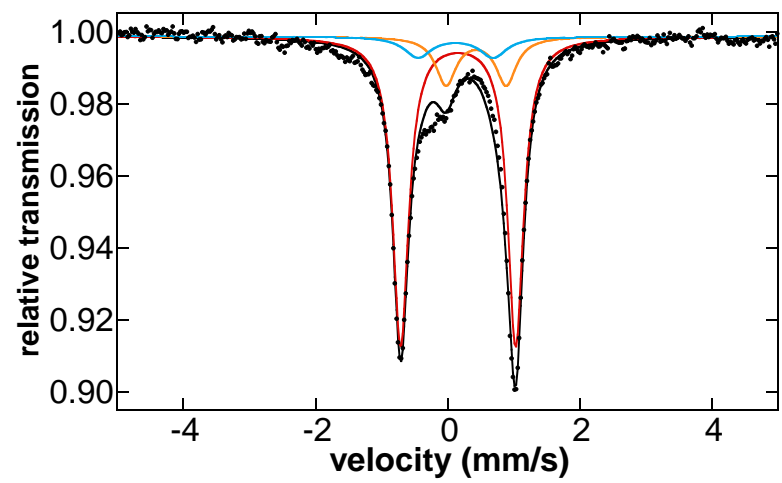

30.5 minutes

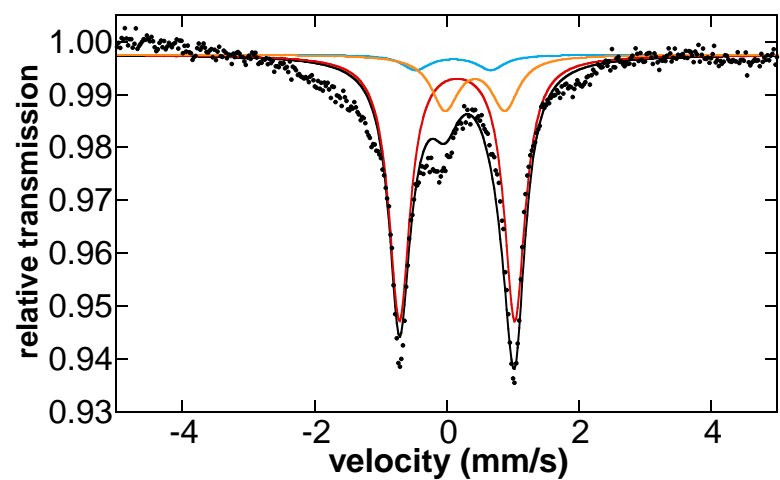

\begin{tabular}{|c|c|c|c|}
\cline { 2 - 4 } \multicolumn{1}{c|}{} & \multicolumn{3}{c|}{ Amount of Total Iron (\%) } \\
\hline Mössbauer Parameters & 70 seconds & $3.5 \mathrm{~min}$ & $7.42 \mathrm{~min}$ \\
\hline$\delta=0.16 \mathrm{~mm} / \mathrm{s}$ and $\Delta \mathrm{E}_{\mathrm{Q}}=1.72 \mathrm{~mm} / \mathrm{s}$ & 72 & 72 & 76 \\
\hline$\delta=0.11 \mathrm{~mm} / \mathrm{s}$ and $\Delta \mathrm{E}_{\mathrm{Q}}=1.18 \mathrm{~mm} / \mathrm{s}$ & 22 & 14 & 9 \\
\hline$\delta=0.44 \mathrm{~mm} / \mathrm{s}$ and $\Delta \mathrm{E}_{\mathrm{Q}}=0.88 \mathrm{~mm} / \mathrm{s}$ & 6 & 14 & 14 \\
\hline
\end{tabular}


80 K ${ }^{57} \mathrm{Fe}$ Mössbauer Spectra: 4-tert-Butylstyrene (0.15 M); Ethylmagnesium bromide (0.1 M) 1.5 minutes

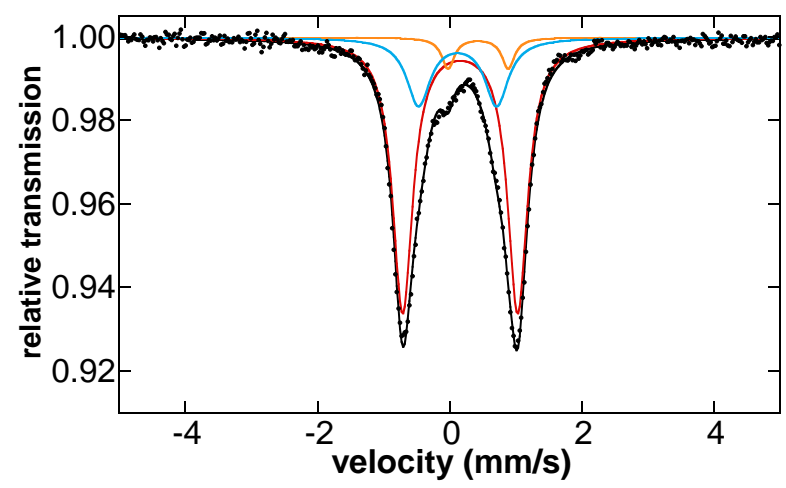

5 minutes

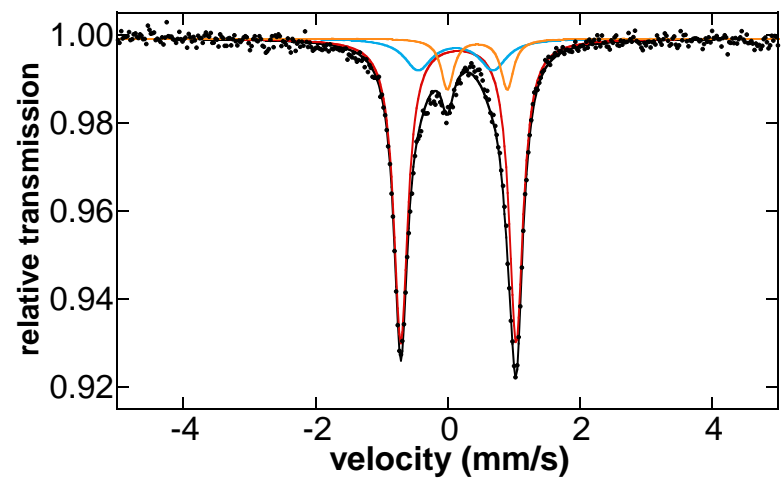

10 minutes

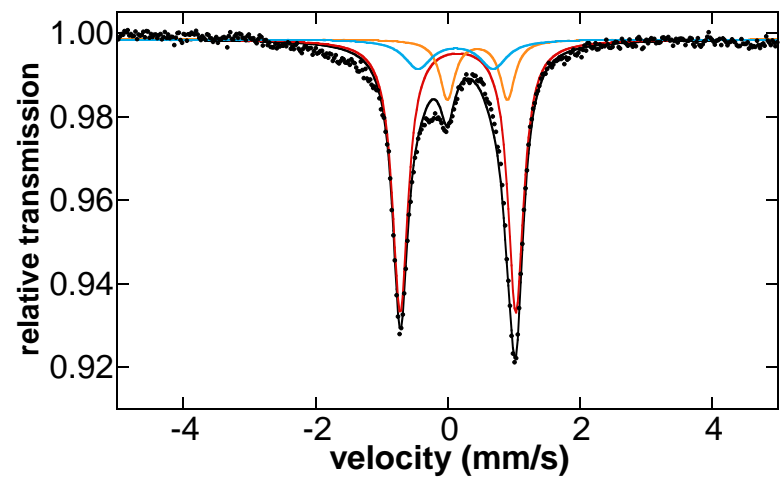


30 minutes

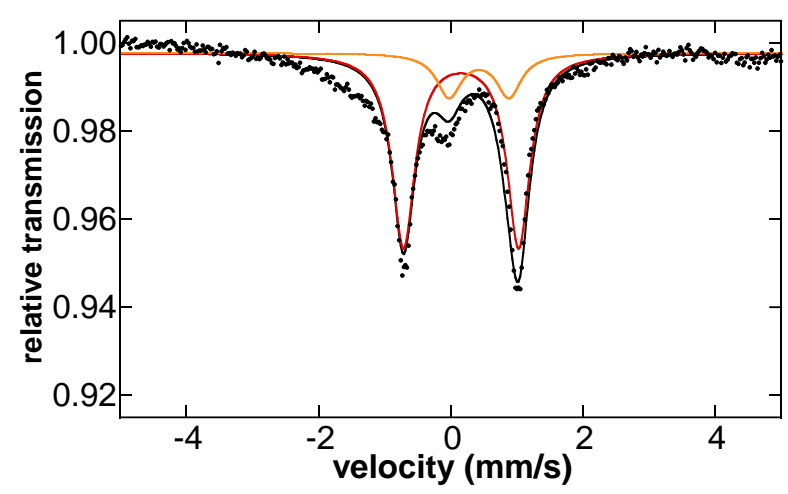

\begin{tabular}{|c|c|c|c|}
\cline { 2 - 4 } \multicolumn{1}{c|}{} & \multicolumn{3}{c|}{ Amount of Total Iron (\%) } \\
\hline Mössbauer Parameters & $1.5 \mathrm{~min}$ & $5 \mathrm{~min}$ & $10 \mathrm{~min}$ \\
\hline$\delta=0.16 \mathrm{~mm} / \mathrm{s}$ and $\Delta \mathrm{E}_{\mathrm{Q}}=1.72 \mathrm{~mm} / \mathrm{s}$ & 74 & 74 & 72 \\
\hline$\delta=0.11 \mathrm{~mm} / \mathrm{s}$ and $\Delta \mathrm{E}_{\mathrm{Q}}=1.18 \mathrm{~mm} / \mathrm{s}$ & 21 & 14 & 13 \\
\hline$\delta=0.44 \mathrm{~mm} / \mathrm{s}$ and $\Delta \mathrm{E}_{\mathrm{Q}}=0.88 \mathrm{~mm} / \mathrm{s}$ & 5 & 11 & 15 \\
\hline
\end{tabular}

80 K ${ }^{57} \mathrm{Fe}$ Mössbauer Spectra: 3-Methoxystyrene (0.1 M); Ethylmagnesium bromide (0.15 M)

1.5 minutes

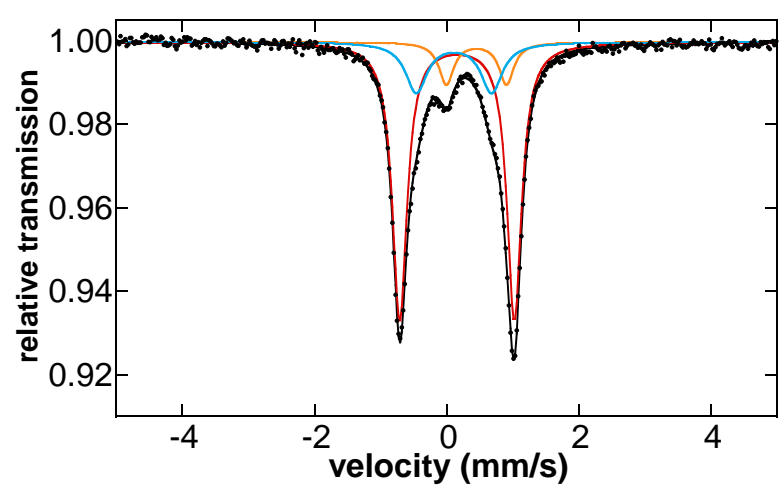


5 minutes

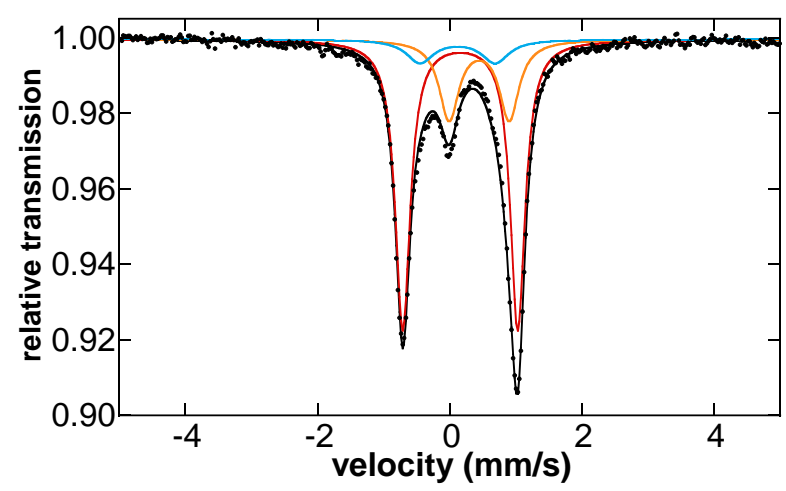

10 minutes

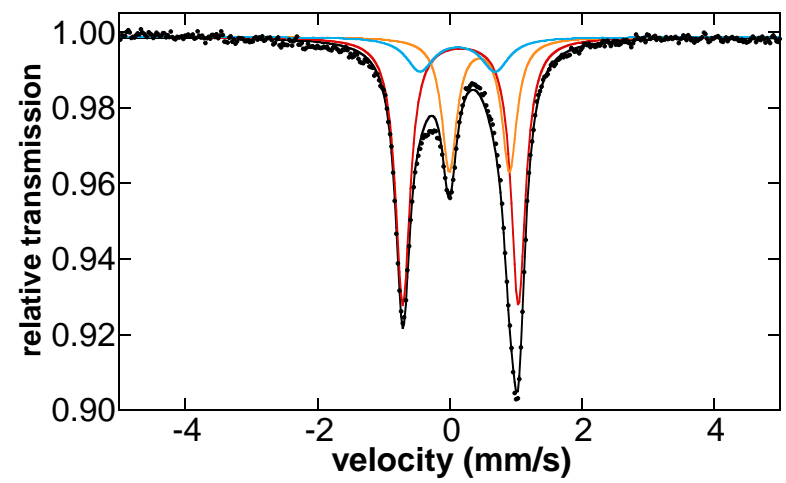

30 minutes

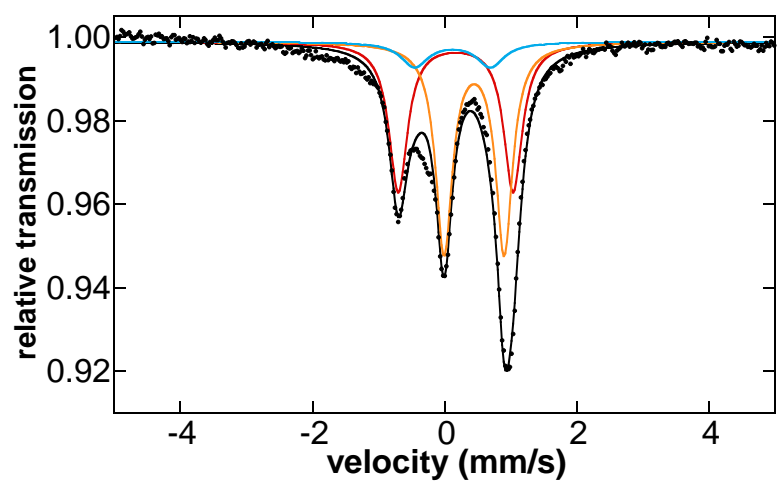

\begin{tabular}{|c|c|c|c|c|}
\cline { 2 - 4 } \multicolumn{2}{c|}{} & \multicolumn{3}{c|}{ Amount of Total Iron (\%) } \\
\hline Mössbauer Parameters & $1.5 \mathrm{~min}$ & $5 \mathrm{~min}$ & $10 \mathrm{~min}$ & $30 \mathrm{~min}$ \\
\hline$\delta=0.16 \mathrm{~mm} / \mathrm{s}$ and $\Delta \mathrm{EQ}_{\mathrm{Q}}=1.72 \mathrm{~mm} / \mathrm{s}$ & 71 & 66 & 57 & 40 \\
\hline$\delta=0.11 \mathrm{~mm} / \mathrm{s}$ and $\Delta \mathrm{EQ}_{\mathrm{Q}}=1.18 \mathrm{~mm} / \mathrm{s}$ & 19 & 10 & 14 & 10 \\
\hline$\delta=0.44 \mathrm{~mm} / \mathrm{s}$ and $\triangle \mathrm{EQ}_{\mathrm{Q}}=0.88 \mathrm{~mm} / \mathrm{s}$ & 11 & 24 & 29 & 51 \\
\hline
\end{tabular}




\section{Reaction with phenethylmagnesium bromide}

A suspension of ${ }^{\mathrm{P} r} \mathrm{BIPFeCl}_{2}(5.5 \mathrm{mg} ; 0.009 \mathrm{mmol})$, styrene $(55 \mu \mathrm{L} ; 0.3 \mathrm{mmol})$ and dodecane $(68 \mu \mathrm{L} ; 0.3$ $\mathrm{mmol})$ in anhydrous tetrahydrofuran $(2.5 \mathrm{ml})$ was stirred at $10{ }^{\circ} \mathrm{C}$ for 20 minutes. Phenethylmagnesium bromide $(0.8 \mathrm{M}$ in THF; $0.56 \mathrm{ml} ; 0.45 \mathrm{mmol})$ was added in one portion and the reaction stirred at $10^{\circ} \mathrm{C}$. Aliquots $(\sim 1 \mathrm{ml})$ were transferred to a Mössbauer sample cup and frozen in liquid nitrogen, immediately after which another aliquot $(<100 \mu \mathrm{L})$ was removed and added to an HPLC vial containing anhydrous isopropanol (approx. 10-15 $\mu \mathrm{L}$ ). After all samples were taken, aqueous sulfate buffer (approx. $0.3 \mathrm{~mL}$ ) was added to each vial followed by diethyl ether (approx. $0.7 \mathrm{~mL}$ ). The vial was shaken and the layers were allowed to settle. Approximately $100 \mu \mathrm{L}$ of the organic phase was removed, diluted to between 1-1.5 $\mathrm{ml}$ in diethyl ether and filtered through a plug of silica $(30 \mathrm{~mm} \varnothing ; 0.5 \mathrm{~cm}$ diameter $\times 1.5 \mathrm{~cm}$ length). The filtrates were then analysed by GC.

80 K ${ }^{57}$ Fe Mössbauer Spectra:

5 minutes; no product detected by GC

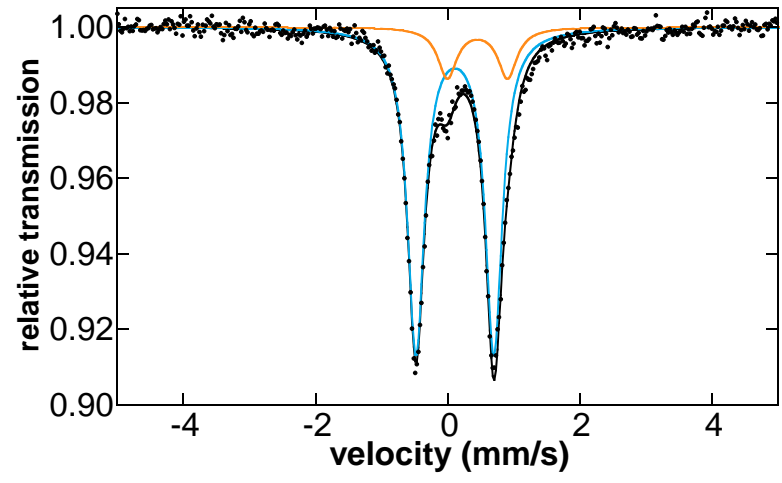

20 minutes; $46 \%$ yield

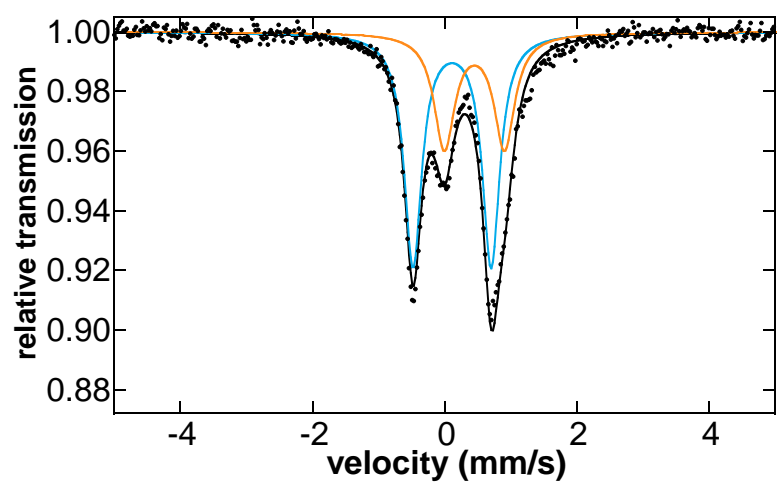

\begin{tabular}{|c|c|c|}
\cline { 2 - 3 } \multicolumn{1}{c|}{} & \multicolumn{2}{c|}{ Amount of Total Iron (\%) } \\
\hline Mössbauer Parameters & $5 \mathrm{~min}$ & $20 \mathrm{~min}$ \\
\hline$\delta=0.16 \mathrm{~mm} / \mathrm{s}$ and $\Delta \mathrm{E}_{\mathrm{Q}}=1.72 \mathrm{~mm} / \mathrm{s}$ & 85 & 63 \\
\hline$\delta=0.44 \mathrm{~mm} / \mathrm{s}$ and $\Delta \mathrm{E}_{\mathrm{Q}}=0.88 \mathrm{~mm} / \mathrm{s}$ & 15 & 37 \\
\hline
\end{tabular}




\section{Preparation of Complexes and Reactivity}

\section{1 \\ Preparation \\ of \\ Complex \\ [MgBr0.67 $\left.\mathrm{Cl}_{0.33}(\mathrm{THF}) 5\right]\left[\left({ }^{(\mathrm{Pr} B I P}\right) \mathrm{Fe}(\mathrm{Et})\left(\mathrm{H}_{2} \mathrm{C}=\mathrm{CH}_{2}\right)\right]$}

1 ,

A suspension of ${ }^{2} \mathrm{PBIPFeCl}_{2}(50 \mathrm{mg} ; 0.082 \mathrm{mmol})$ in anhydrous tetrahydrofuran $(5 \mathrm{ml})$ was stirred at -17 ${ }^{\circ} \mathrm{C}$ for 30 minutes. After this time, pre-chilled ethylmagnesium bromide $(0.85 \mathrm{M}$ in THF; $0.39 \mathrm{ml} ; 0.33$ $\mathrm{mmol}$ ) was added in one go and the resulting solution stirred at $-17^{\circ} \mathrm{C}$ for 3 minutes. Anhydrous dioxane $(0.2 \mathrm{ml})$ was added dropwise over 40 seconds and the solution left to stir at $-17{ }^{\circ} \mathrm{C}$ for an additional 5 minutes. The reaction mixture was filtered through a pre-chilled celite pad $(1 \mathrm{~cm}$ diameter $\times 3 \mathrm{~cm}$ length) and the filtrates layered with pre-chilled anhydrous hexane (approx. $1.5 \mathrm{ml}$ ). The reaction mixture was stored

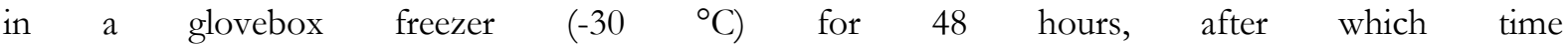
$\left[\mathrm{MgBr}_{0.67} \mathrm{Cl}_{0.33}(\mathrm{THF})_{5}\right]\left[\left({ }^{\mathrm{Pr} B} \mathrm{BIP}\right) \mathrm{Fe}(\mathrm{Et})\left(\mathrm{H}_{2} \mathrm{C}=\mathrm{CH}_{2}\right)\right] \cdot 2.5 \mathrm{THF}$ had formed as yellow/brown blocks. The mother-liquors were removed and the crystalline material washed with pre-chilled anhydrous pentane $(3 \times$ $\sim 1.5 \mathrm{ml}$ ). Residual pentane was removed under high vacuum.

Single crystal X-ray diffraction was carried out on crystals prior to washing with pentane (see Appendix for details).

\section{K ${ }^{57} \mathrm{Fe}$ Mössbauer spectrum:}

Solid crystalline material

$\delta=0.16 \mathrm{~mm} / \mathrm{s}, \Delta \mathrm{E}_{\mathrm{Q}}=1.67 \mathrm{~mm} / \mathrm{s}$

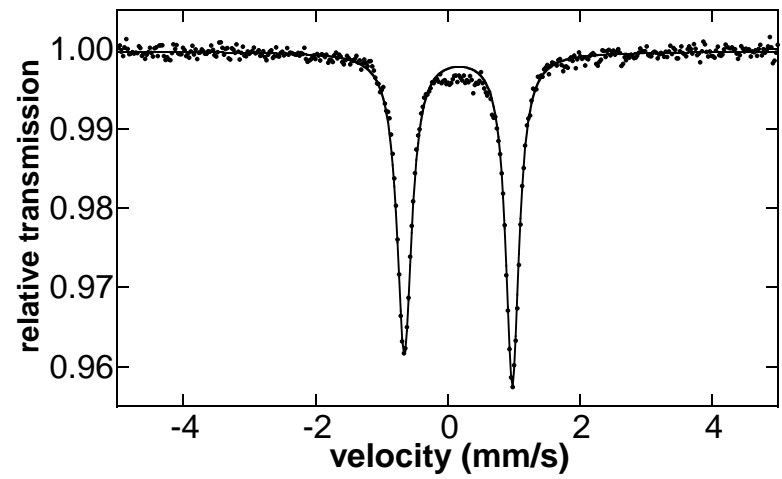


HMg complex 1

Avance $400-1$

Proton NMR

$\mathrm{CDC} 3$ solvent

${ }^{1} \mathrm{H}-\mathrm{NMR}$, d8-THF, $400 \mathrm{MHz},-30{ }^{\circ} \mathrm{C}$

Full Spectrum

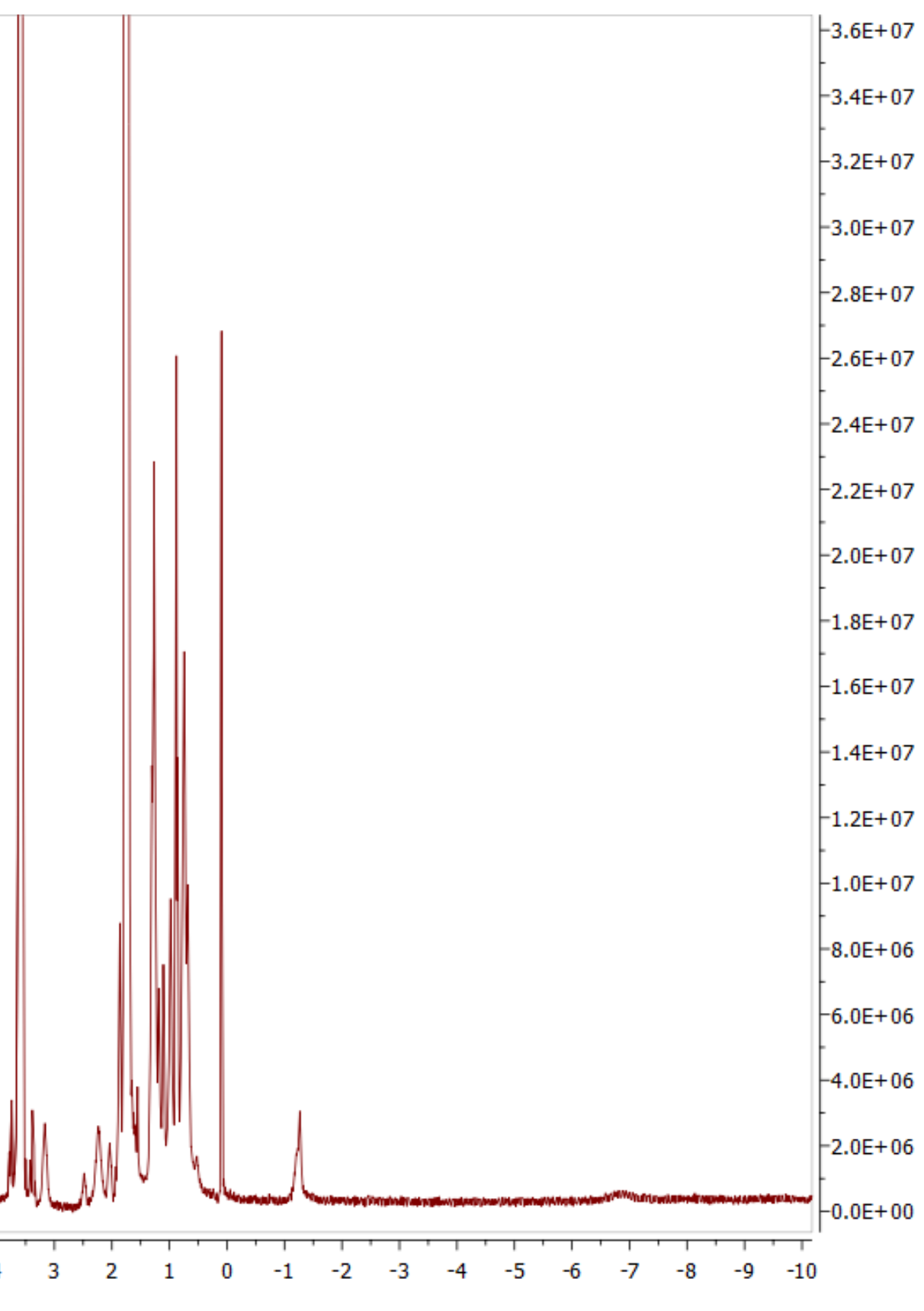


HMg complex 1

Avance 400-1

Proton NMR

$\mathrm{CDA} 3$ solvent

${ }^{1} \mathrm{H}-\mathrm{NMR}$, d8-THF, $400 \mathrm{MHz},-30{ }^{\circ} \mathrm{C}$

Zoom on selected region

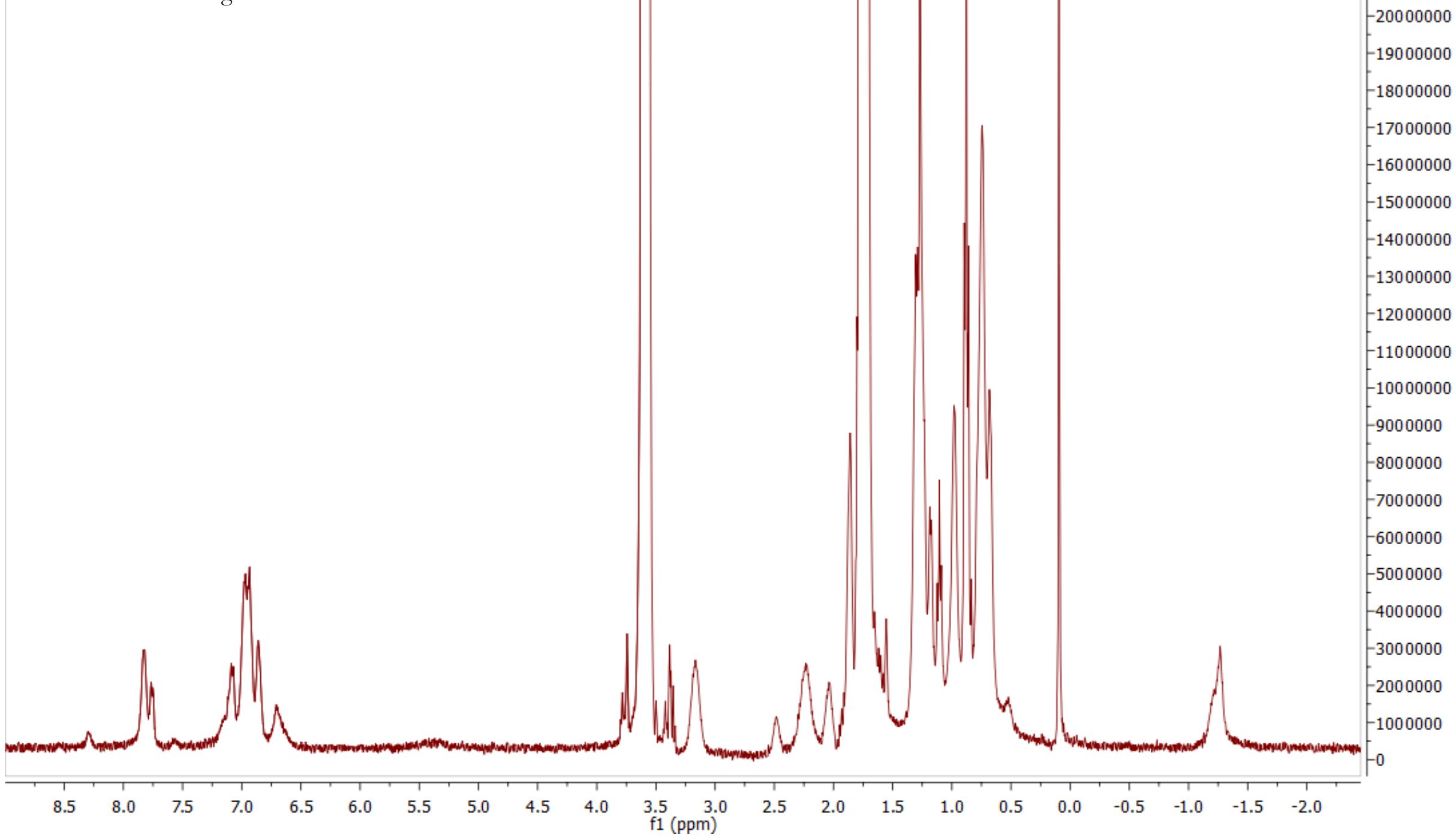


HMg complex 1_para

h1_para

Paramagnetic ${ }^{1} \mathrm{H}-\mathrm{NMR}$ experiment, $d 8$-THF, $400 \mathrm{MHz},-30{ }^{\circ} \mathrm{C}$

Full Spectrum

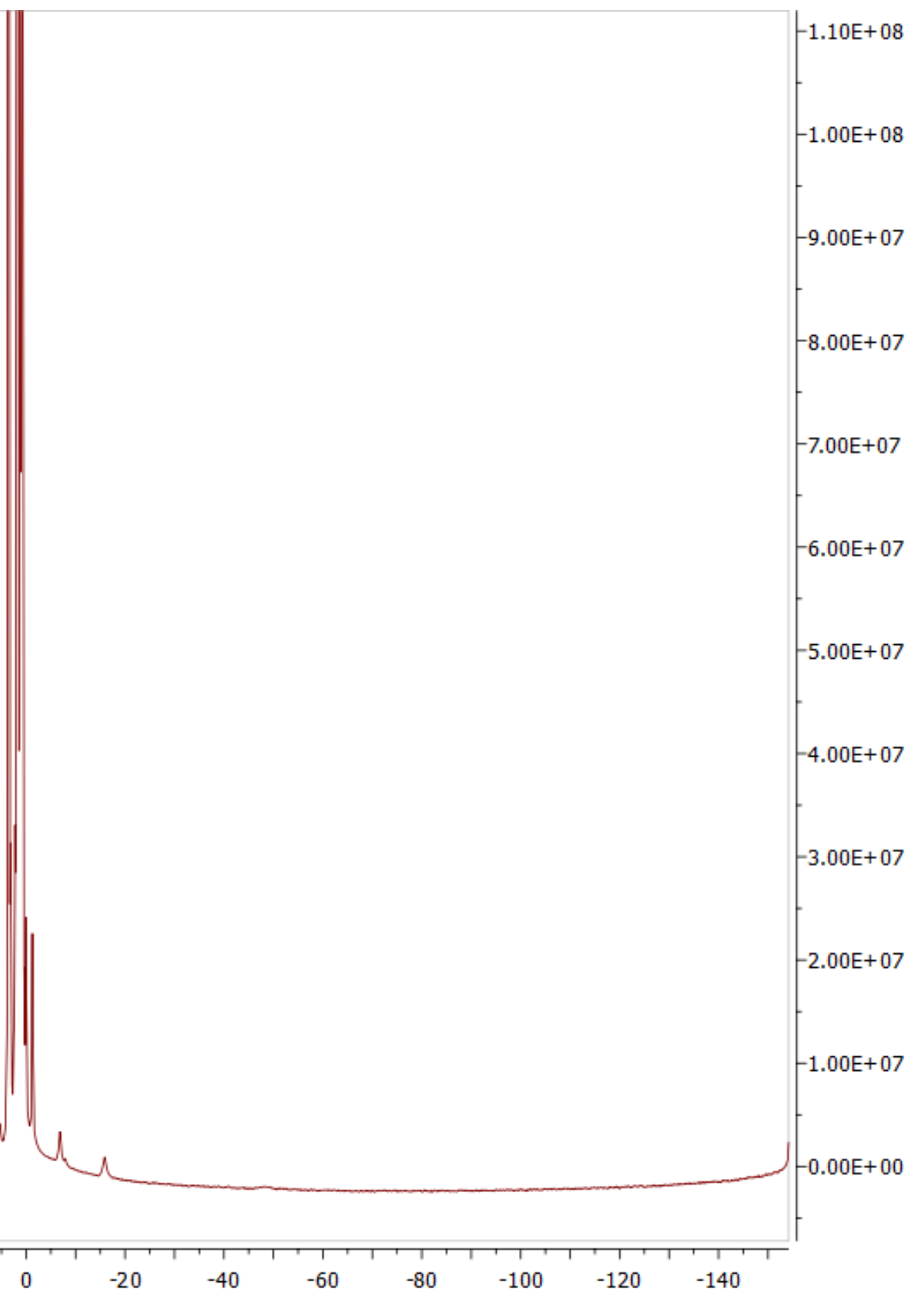

19

130

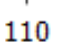

$\begin{array}{lllll}90 & 80 & 70 & 60\end{array}$

$\begin{array}{lll}40 & 30 & 20 \\ \mathrm{f} 1 & (\mathrm{ppm})\end{array}$ 


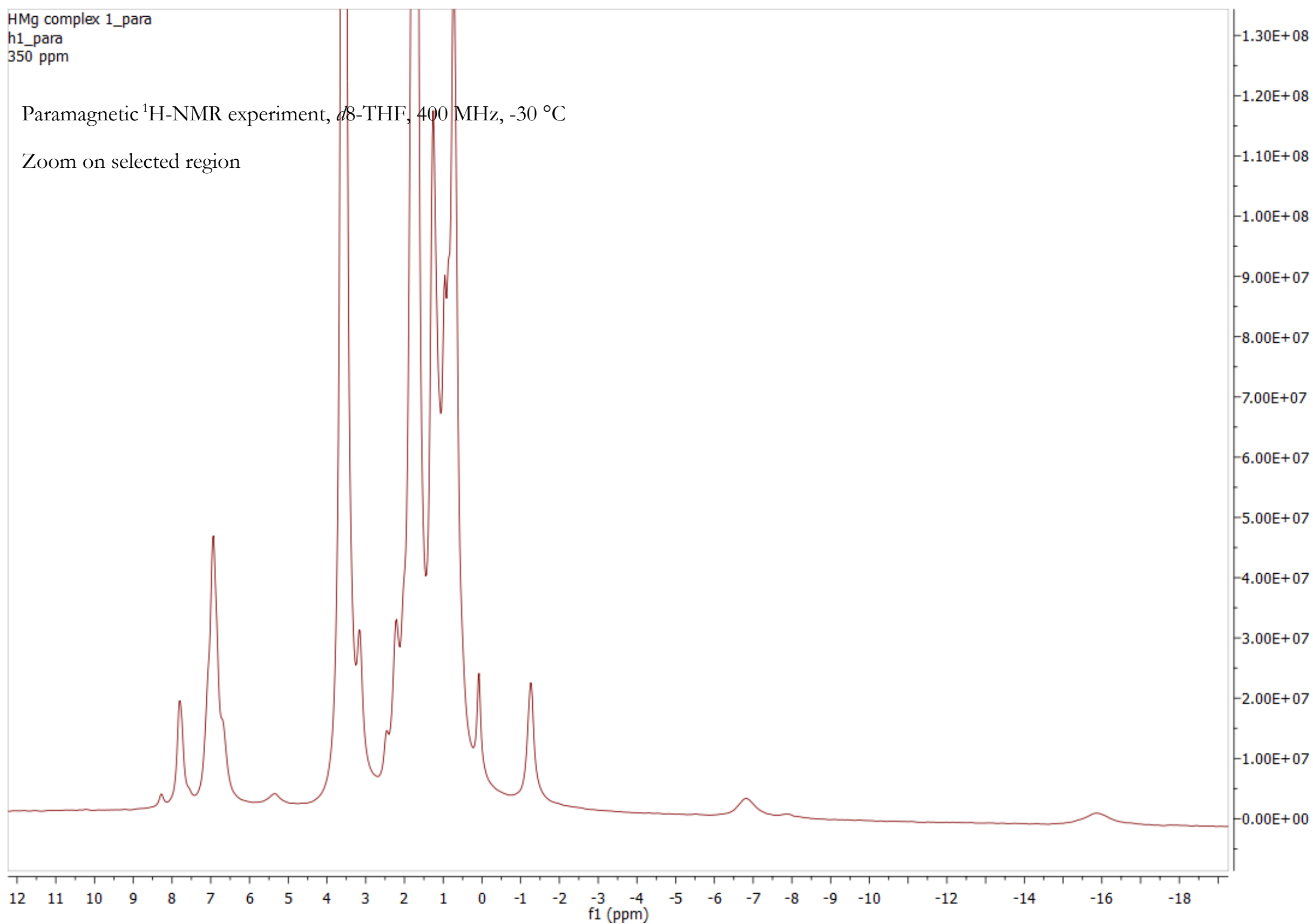




\subsection{Preparation of Complex \\ $\left[\mathrm{MgBr}_{0.6} \mathrm{Cl}_{0.4}(\mathrm{THF})_{5}\right]\left[\left({ }^{\mathrm{Pr}} \mathrm{BIP}\right) \mathrm{Fe}\left(\mathrm{N}_{2}\right)\left(\mathrm{CH}_{2} \mathrm{CH}_{2} \mathrm{Ph}\right)\right]$}

A suspension of ${ }^{\mathrm{Pr} B I P F e C l} 2(25 \mathrm{mg} ; 0.041 \mathrm{mmol})$ in anhydrous tetrahydrofuran $(2 \mathrm{ml})$ was stirred at -17 ${ }^{\circ} \mathrm{C}$ for 20 minutes. After this time, phenethylmagnesium bromide ( $0.8 \mathrm{M}$ in THF; $0.51 \mathrm{ml} ; 0.41 \mathrm{mmol}$ ) was added in one go and the resulting solution stirred at $-17^{\circ} \mathrm{C}$ for 5 minutes. The reaction mixture was moved to stir at $-68{ }^{\circ} \mathrm{C}$ in a cold well for 15 minutes. After this time anhydrous hexane $(2 \mathrm{ml}$; pre-cooled in cold well) was added and the reaction mixture allowed to stir for a further $\sim 2$ minutes. The reaction mixture was then filtered through a pre-chilled celite pad $(1 \mathrm{~cm}$ diameter $\times 3 \mathrm{~cm}$ length in a Pasteur pipette) and the filtrates stored in a $-80{ }^{\circ} \mathrm{C}$ freezer for 5 days, after which time $\left[\mathrm{MgBr}_{0.6} \mathrm{Cl}_{0.4}(\mathrm{THF})_{5}\right]\left[\left({ }^{\mathrm{Pr} B I P}\right) \mathrm{Fe}\left(\mathrm{N}_{2}\right)\left(\mathrm{CH}_{2} \mathrm{CH}_{2} \mathrm{Ph}\right)\right]$ had formed as dark red plates. The mother-liquors were removed and the crystalline material washed with pre-chilled anhydrous pentane $(3 \times \sim 1.5 \mathrm{ml})$. Residual pentane was removed under high vacuum.

Single crystal X-ray diffraction was carried out on crystals prior to washing with pentane (see Appendix for details).

\section{$80 \mathrm{~K}^{57} \mathrm{Fe}$ Mössbauer spectrum:}

Solid crystalline material

$\delta=0.11 \mathrm{~mm} / \mathrm{s}, \Delta \mathrm{E}_{\mathrm{Q}}=1.19 \mathrm{~mm} / \mathrm{s}$

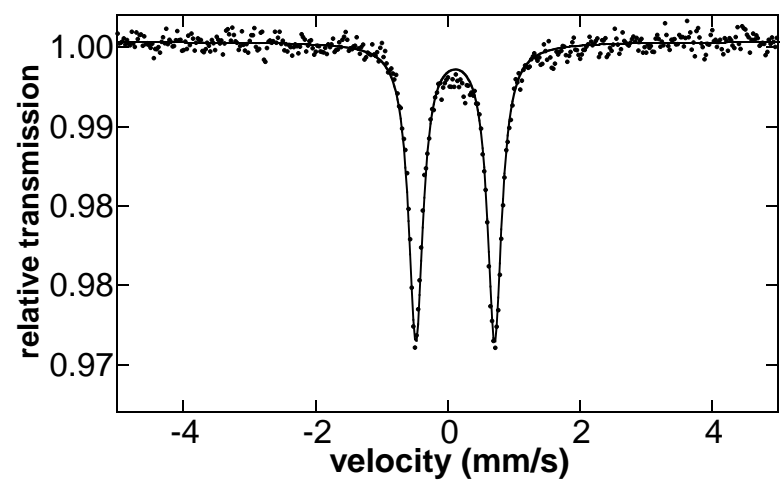


HMg complex 3

Avance $400-1$

Proton NMR

$\mathrm{CDC} 3$ solvent

${ }^{1} \mathrm{H}-\mathrm{NMR}, d 8-\mathrm{THF}, 400 \mathrm{MHz},-30{ }^{\circ} \mathrm{C}$

Full Spectrum

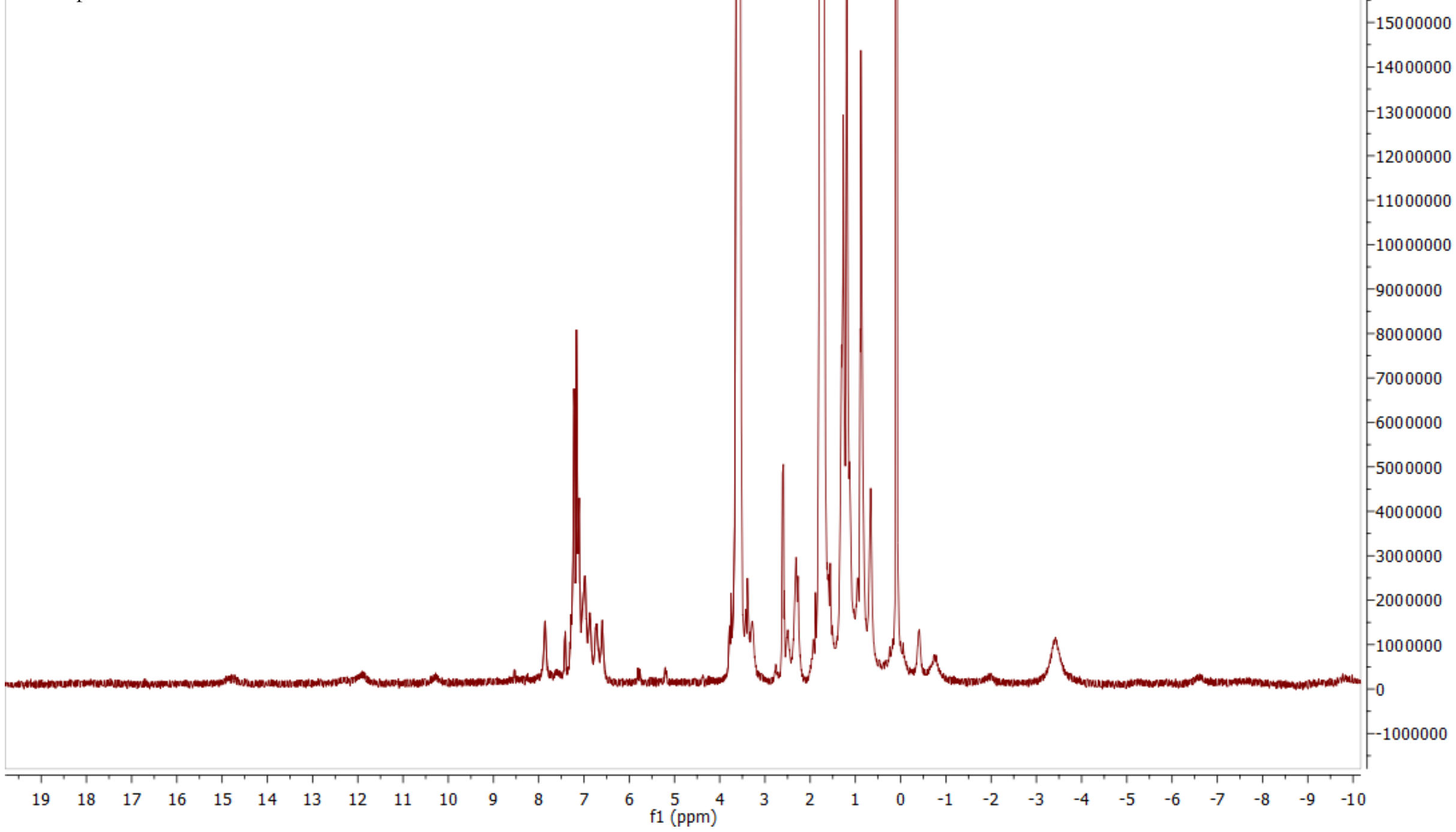


HMg complex 3

Avance $400-1$

Proton NMR

$\mathrm{CDC} 3$ solvent

${ }^{1} \mathrm{H}-\mathrm{NMR}$, d8-THF, $400 \mathrm{MHz},-30{ }^{\circ} \mathrm{C}$

Zoom on selected region
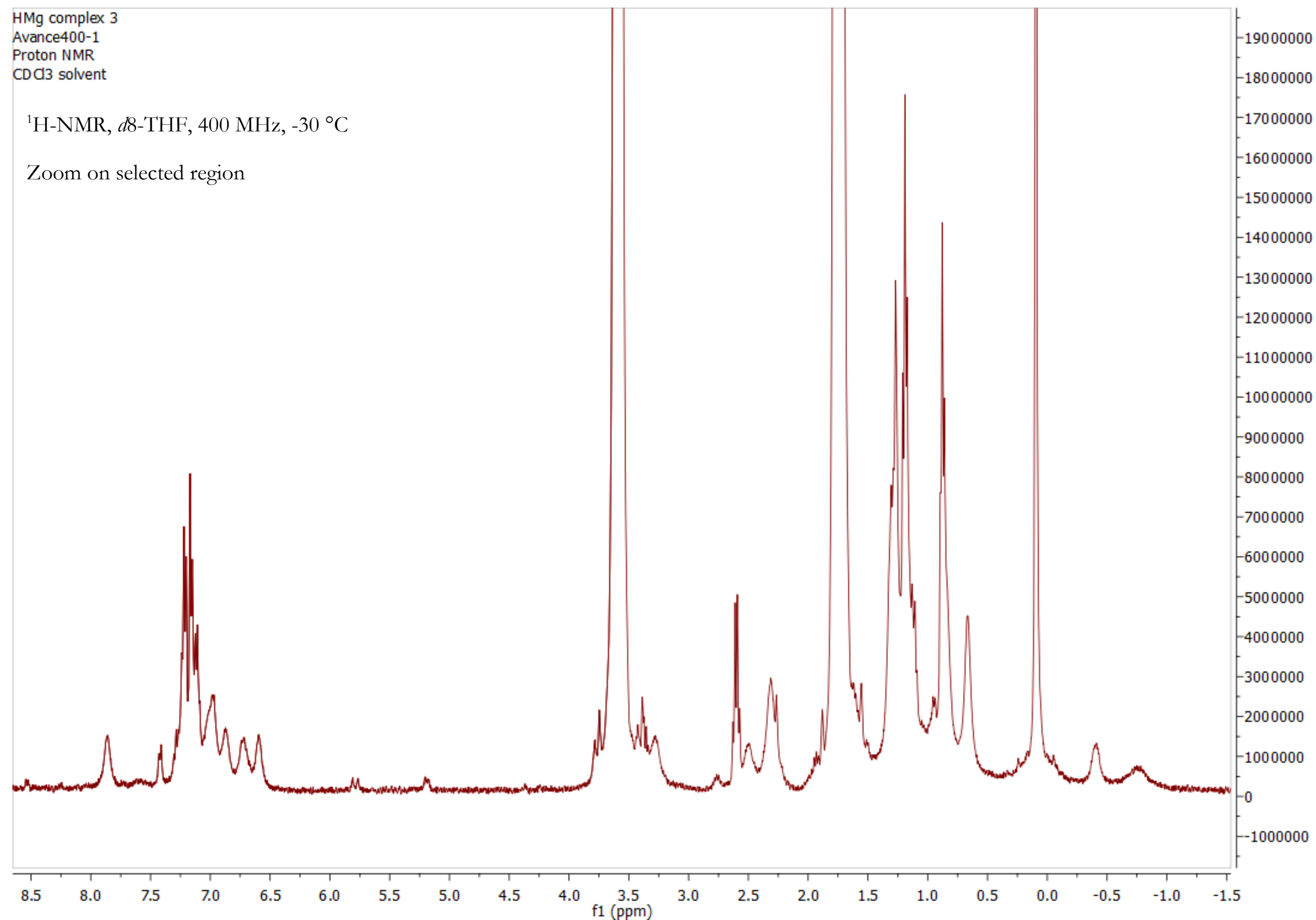

$\begin{array}{ll}7.0 & 6.5\end{array}$

6.0

5.5

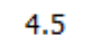

$4.0 \quad 3.5$

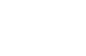


HMg complex 3_para

h1_para

Paramagnetic ${ }^{1} \mathrm{H}-\mathrm{NMR}$ experiment, d8-THF, $400 \mathrm{MHz},-30{ }^{\circ} \mathrm{C}$

Full Spectrum

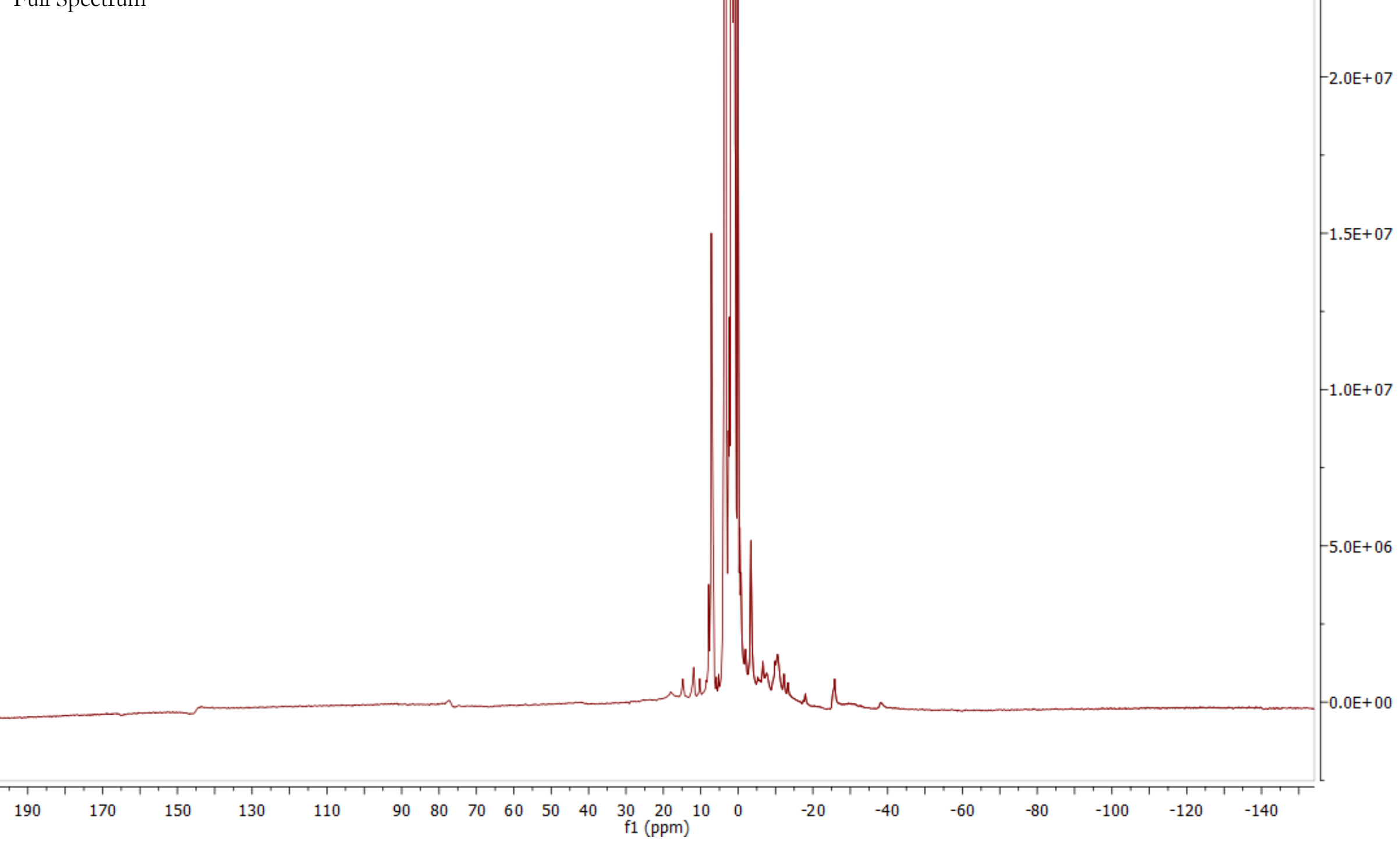




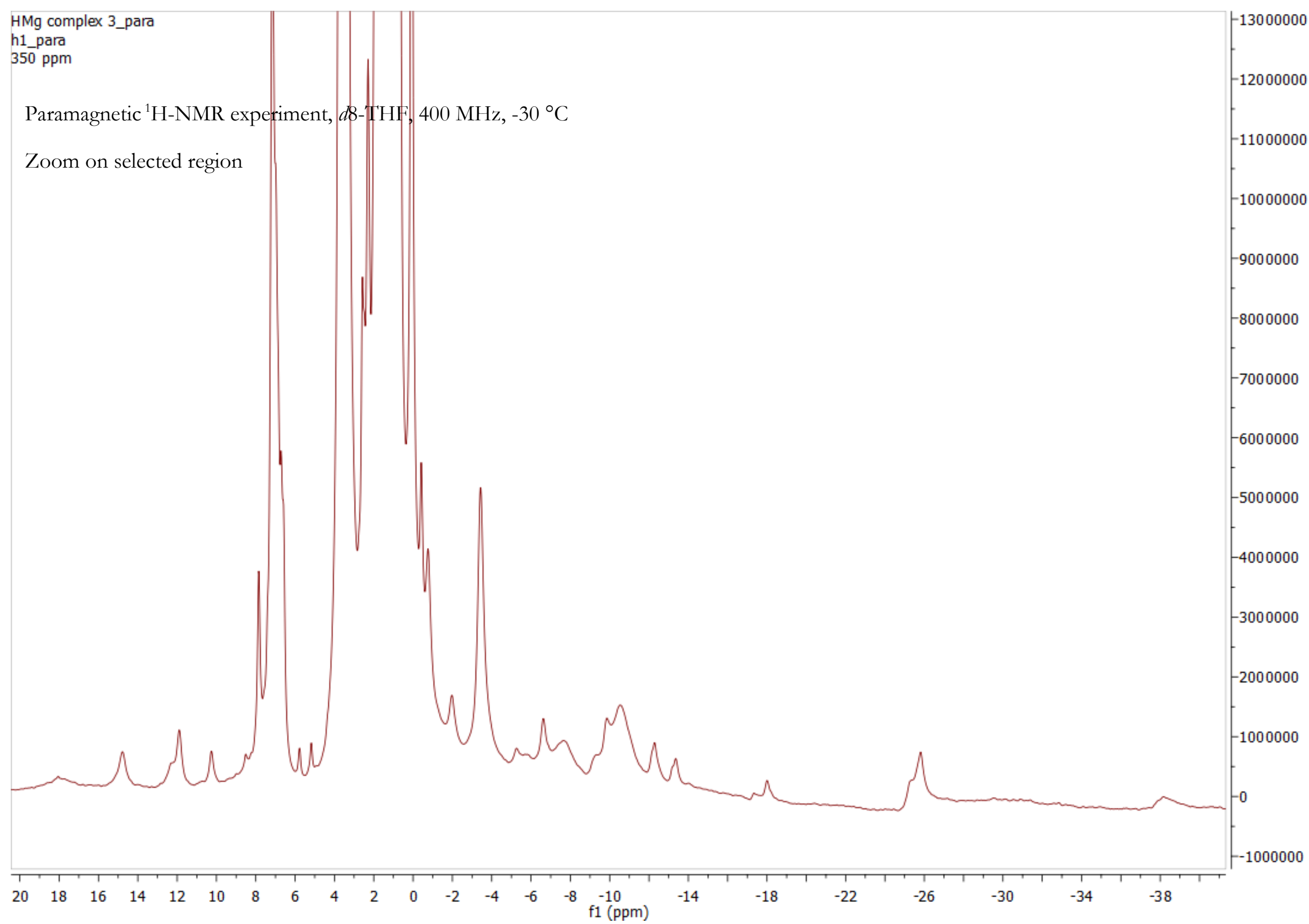




\subsection{Preparation of Complex 4, $\left[\mathrm{MgBr}_{0.69} \mathrm{Cl}_{0.31}(\mathrm{THF})_{5}\right]\left[\mathrm{Fe}\left(\eta^{2}-\right.\right.$ styrene $\left.)_{3}\left(\mathrm{~K}^{1}-\mathrm{CH}\left(\mathrm{CH}_{3}\right) \mathrm{Ph}\right)\right]$}

A suspension of ${ }^{\mathrm{Pr}} \mathrm{BIPFeCl} 2(12.5 \mathrm{mg} ; 0.021 \mathrm{mmol})$ in anhydrous tetrahydrofuran $(2.5 \mathrm{ml})$ was stirred at room temperature for 15 minutes. After this time, styrene $(47 \mu \mathrm{L} ; 0.41 \mathrm{mmol})$ was added followed immediately by phenethylmagnesium bromide ( $0.8 \mathrm{M}$ in THF; $0.26 \mathrm{ml} ; 0.21 \mathrm{mmol}$ ) in one go and the resulting solution stirred at room temperature for 2 minutes. The reaction mixture was moved to stir at -68 ${ }^{\circ} \mathrm{C}$ in a cold well for 30 minutes. After this time anhydrous hexane $(1.2 \mathrm{ml}$; pre-cooled in cold well) was added and the reaction mixture allowed to stir for a further $\sim 5$ minutes. The reaction mixture was then filtered through a pre-chilled celite pad $(1 \mathrm{~cm}$ diameter $\times 3 \mathrm{~cm}$ length in a Pasteur pipette $)$ and the filtrates stored in a $-80{ }^{\circ} \mathrm{C}$ freezer for 5 days, after which time $\left[\mathrm{MgBr}_{0.69} \mathrm{Cl}_{0.31}(\mathrm{THF})_{5}\right]\left[\mathrm{Fe}\left(\eta^{2}\right.\right.$-styrene $) 3\left(\varkappa^{1}-\right.$ $\left.\left.\mathrm{CH}\left(\mathrm{CH}_{3}\right) \mathrm{Ph}\right)\right]$ had formed as dark red plates. The mother-liquors were removed and the crystalline material washed with pre-chilled anhydrous pentane $(3 \times \sim 1.5 \mathrm{ml})$. Residual pentane was removed under high vacuum.

Single crystal X-ray diffraction was carried out on crystals prior to washing with pentane (see Appendix for details).

\section{K ${ }^{57} \mathrm{Fe}$ Mössbauer spectra:}

Solid crystalline material

$\delta=0.44 \mathrm{~mm} / \mathrm{s}, \Delta \mathrm{E}_{\mathrm{Q}}=0.89 \mathrm{~mm} / \mathrm{s}$

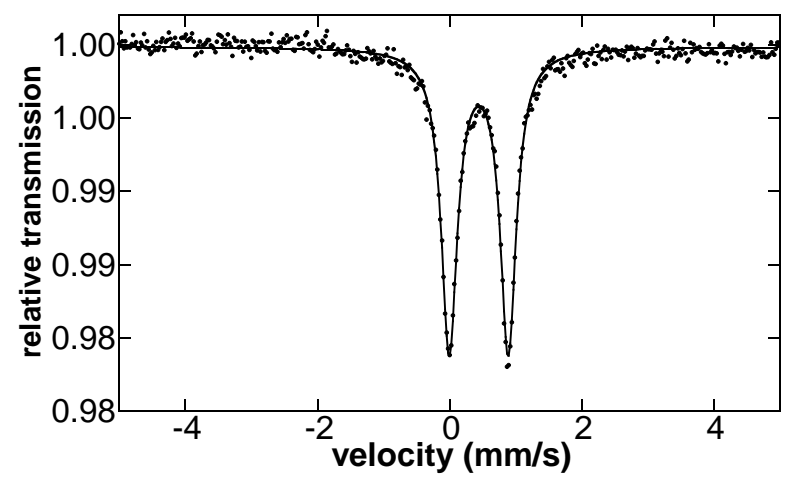

THF frozen solution of ${ }^{57} \mathrm{Fe}$-labelled crystalline material

$\delta=0.44 \mathrm{~mm} / \mathrm{s}, \Delta \mathrm{E}_{\mathrm{Q}}=0.88 \mathrm{~mm} / \mathrm{s}$

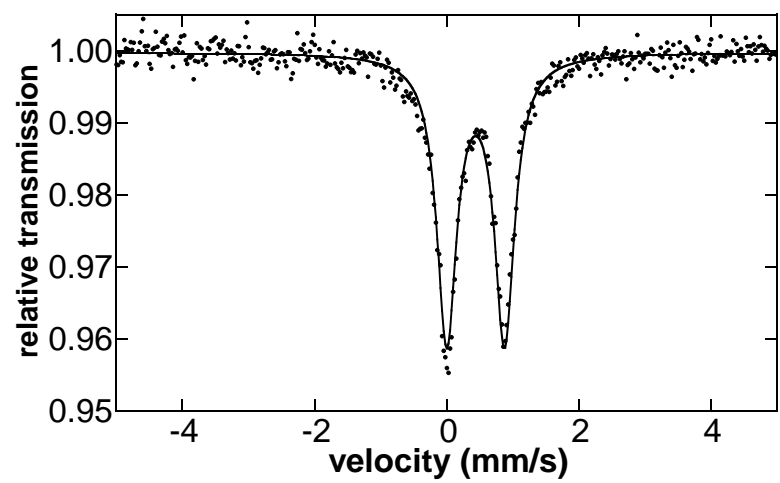


HMg complex 4

Avance $400-1$

Proton NMR

$\mathrm{CDC} 3$ solvent

${ }^{1} \mathrm{H}-\mathrm{NMR}$, d8-THF, $400 \mathrm{MHz},-30{ }^{\circ} \mathrm{C}$

Full Spectrum

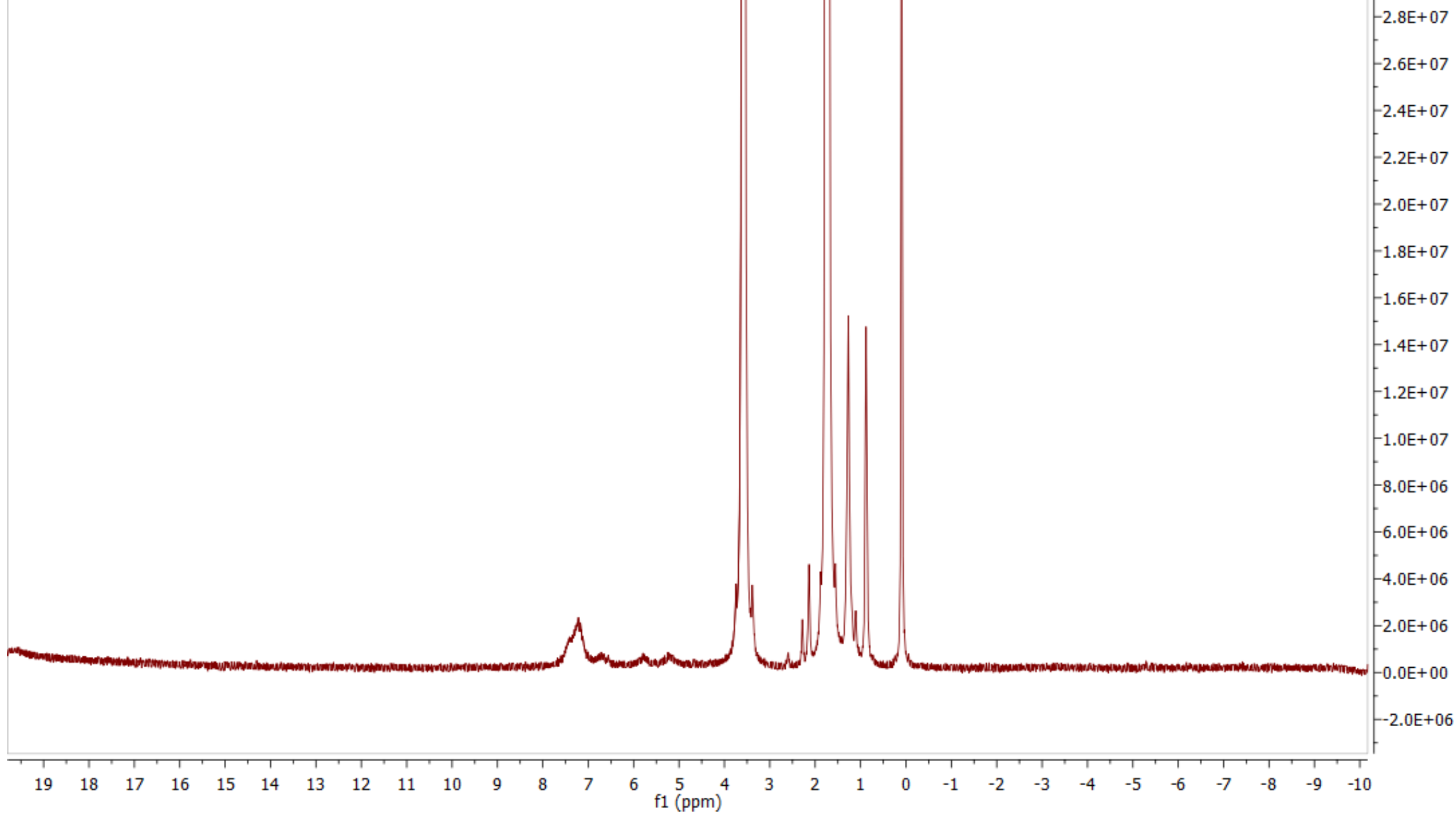


HMg complex 4

Avance 400-1

Proton NMR

$\mathrm{CDA} 3$ solvent

${ }^{1} \mathrm{H}-\mathrm{NMR}$, d8-THF, $400 \mathrm{MHz},-30{ }^{\circ} \mathrm{C}$

Zoom on selected region

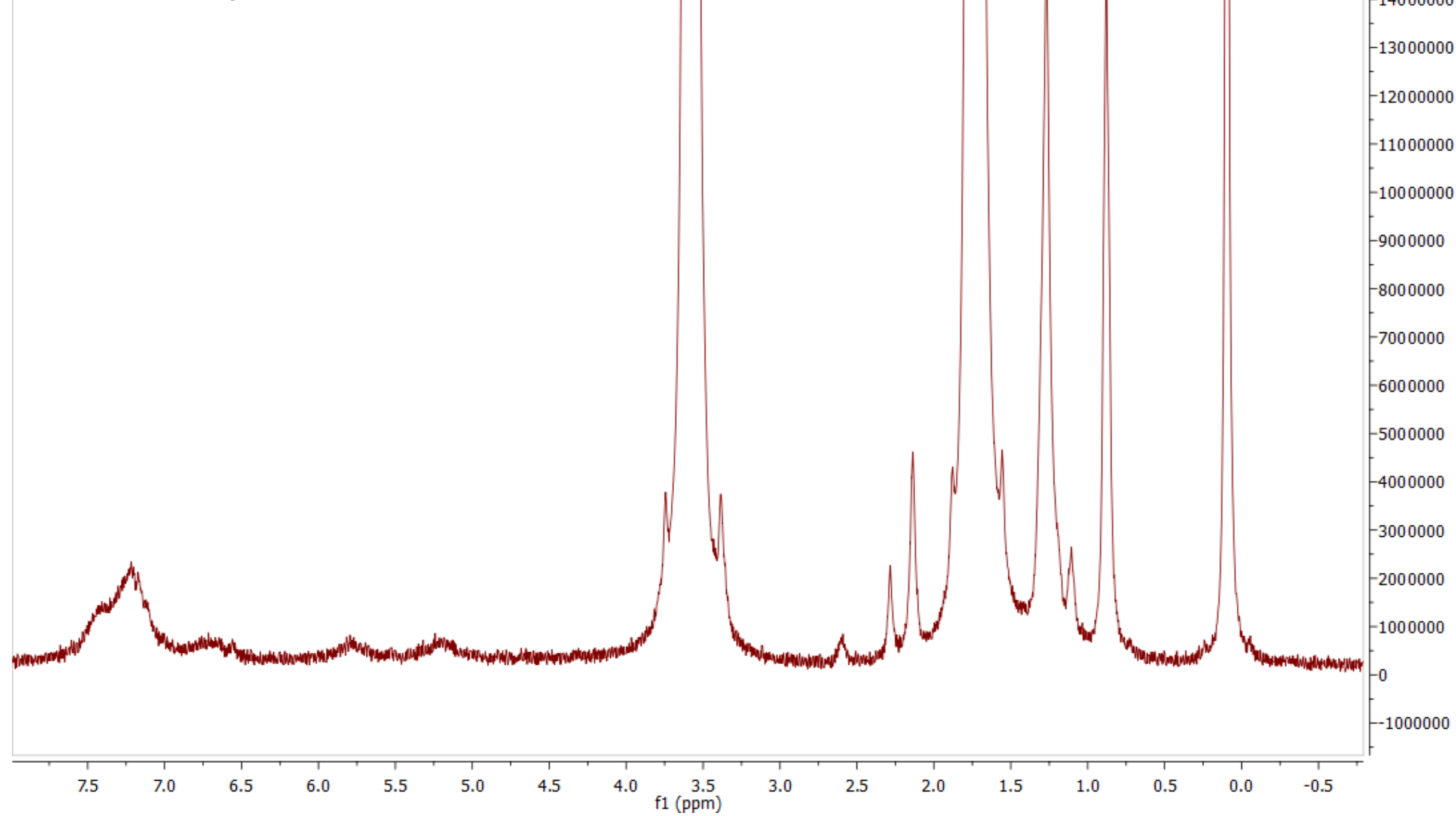


HMg complex 4_para

h1_para

$350 \mathrm{ppm}$

Paramagnetic ${ }^{1} \mathrm{H}$-NMR experiment, $d 8$-THF, $400 \mathrm{MHz},-30{ }^{\circ} \mathrm{C}$

Full Spectrum

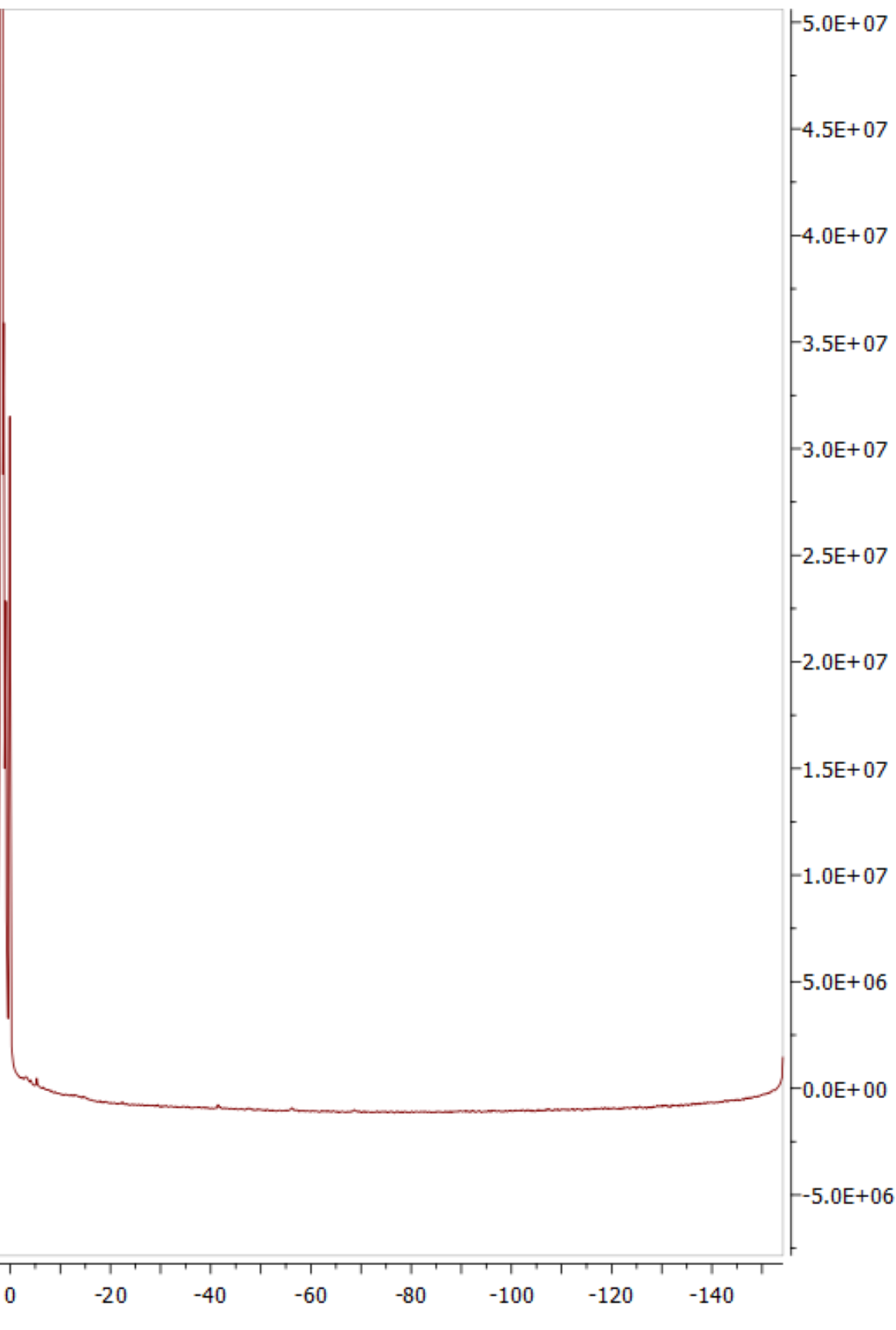


HMg complex 4_para

h1_para

$350 \mathrm{ppm}$

Paramagnetic ${ }^{1} \mathrm{H}$-NMR experiment, $d 8$-THF, $400 \mathrm{MHz},-30^{\circ} \mathrm{C}$

Zoom on selected region
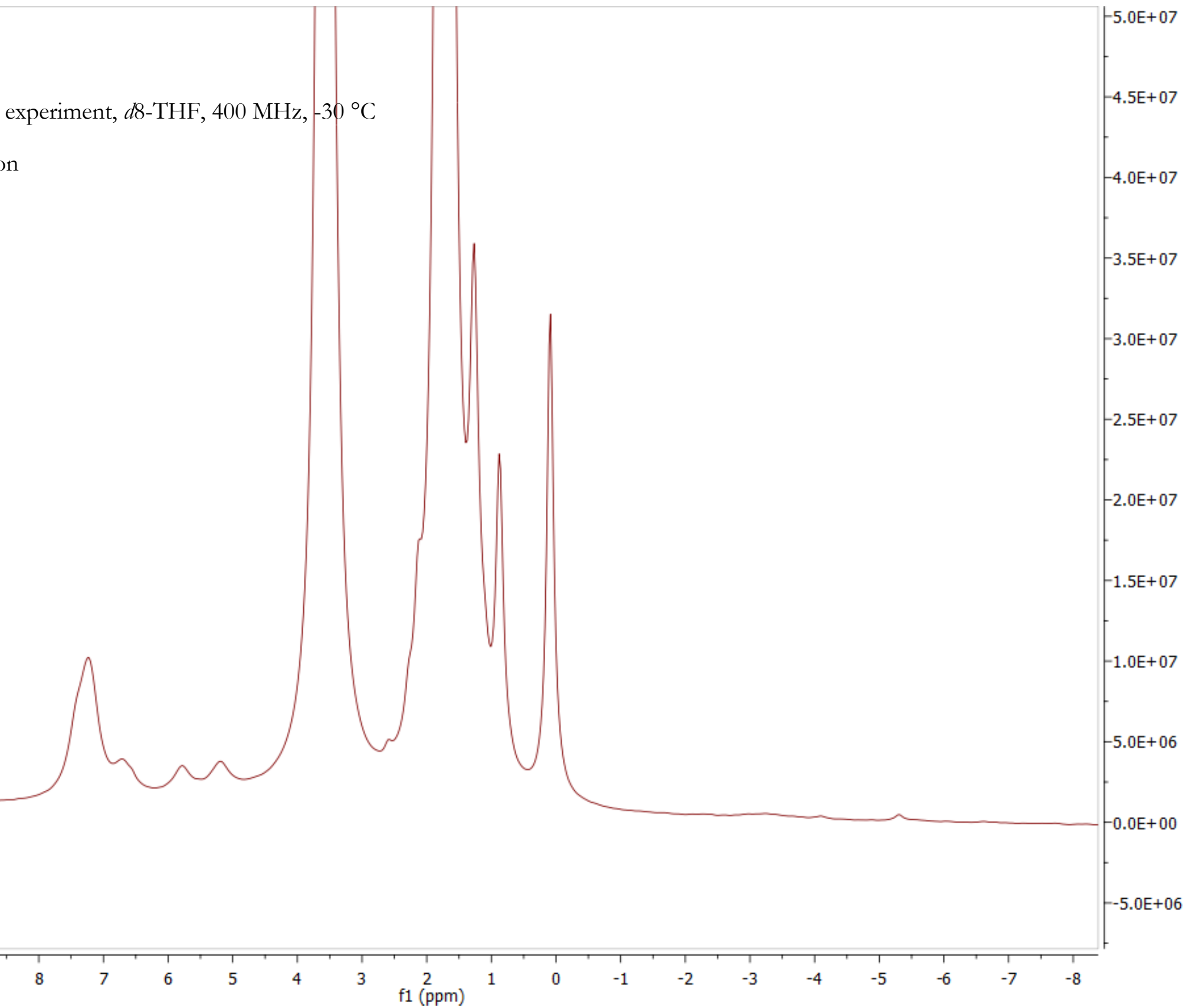

$1(\mathrm{ppm})$ 


\subsection{Reactivity Studies of Complexes 1 and 4 As a pre-catalyst under standard hydromagnesiation conditions}

The relevant iron complex $(0.0065 \mathrm{mmol})$ was charged to a stirring, room temperature solution of 4-tertbutylstyrene ( $36.5 \mu \mathrm{L} ; 0.2 \mathrm{mmol})$, ethylmagnesium bromide ( $1 \mathrm{M}$ in THF; $0.30 \mathrm{~mL} ; 0.3 \mathrm{mmol}$ ) and dodecane $(45.5 \mu \mathrm{L} ; 0.2 \mathrm{mmol})$ in anhydrous tetrahydrofuran $(1.65 \mathrm{~mL}$.$) . Aliquots (<100 \mu \mathrm{L})$ were periodically removed and added to HPLC vials containing anhydrous methanol (approx. 10-15 $\mu \mathrm{L}, 0.25-0.37 \mathrm{mmol}$ ). After all samples were taken, aqueous sulfate buffer (approx. $0.3 \mathrm{~mL}$ ) was added to each vial followed by diethyl ether (approx. $0.7 \mathrm{~mL}$ ). The vial was shaken and the layers were allowed to settle. Approximately $100 \mu \mathrm{L}$ of the organic phase was removed, diluted to between 1-1.5 $\mathrm{mL}$ in diethyl ether and filtered through a plug of silica $(30 \mathrm{~mm} \varnothing ; 0.5 \mathrm{~cm}$ diameter $\times 1.5 \mathrm{~cm}$ length). The filtrates were then analysed by GC.

Note: all traces are averages of two runs with error bars $( \pm 3 \%)$ representative of deviation between experiments.

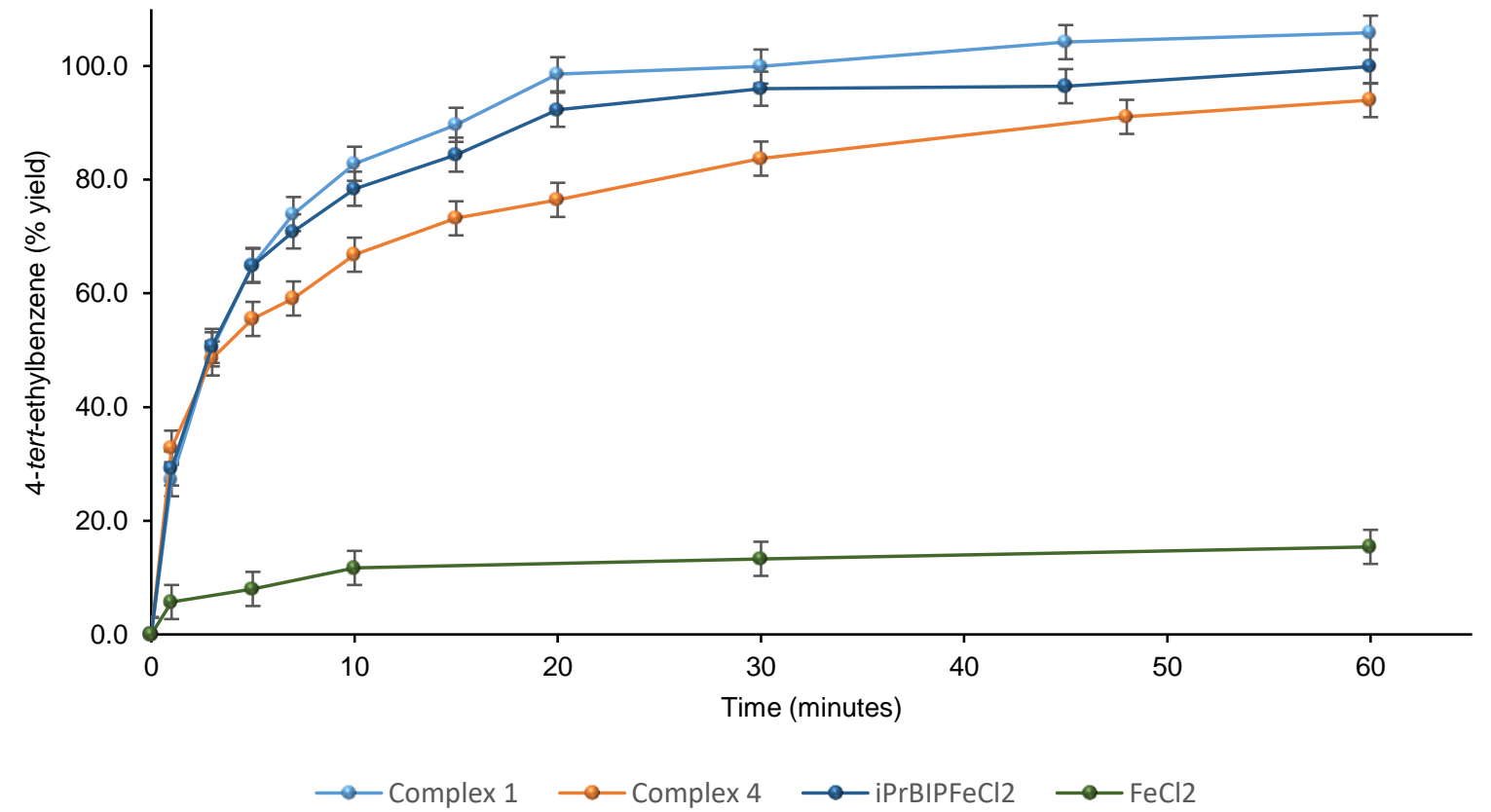

\section{Iron Speciation under pre-catalyst reactivity test conditions}

As per the general procedure above, the analogous reaction was carried out using ${ }^{2 \mathrm{P} B I P}{ }^{57} \mathrm{FeCl}_{2}$. Aliquots $(\sim 1 \mathrm{ml})$ were transferred to a Mössbauer sample cup and frozen in liquid nitrogen after 1 and 5 minutes. 
1 minute

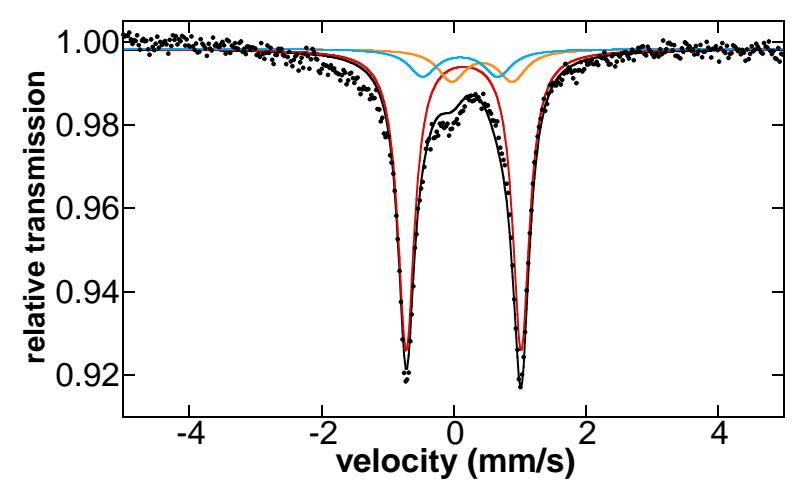

5 minutes

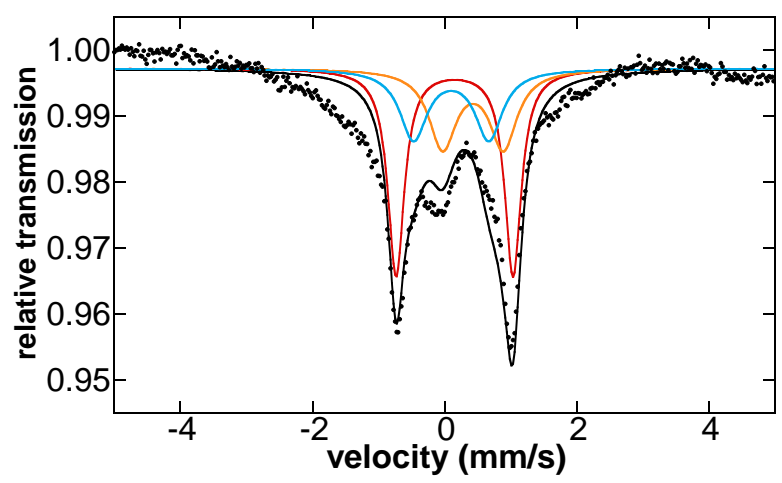

\begin{tabular}{|c|c|c|}
\cline { 2 - 3 } \multicolumn{1}{c|}{} & \multicolumn{2}{c|}{ Amount of Iron } \\
\hline Mössbauer Parameters & $1 \mathrm{~min}$ (\% total) & $\begin{array}{c}5 \mathrm{~min} \text { (rough relative } \\
\text { ratios) }\end{array}$ \\
\hline$\delta=0.16 \mathrm{~mm} / \mathrm{s}$ and $\Delta \mathrm{E}_{\mathrm{Q}}=1.72 \mathrm{~mm} / \mathrm{s}$ & 76 & 1.8 \\
\hline$\delta=0.11 \mathrm{~mm} / \mathrm{s}$ and $\Delta \mathrm{E}_{\mathrm{Q}}=1.18 \mathrm{~mm} / \mathrm{s}$ & 11 & 1 \\
\hline$\delta=0.44 \mathrm{~mm} / \mathrm{s}$ and $\Delta \mathrm{E}_{\mathrm{Q}}=0.88 \mathrm{~mm} / \mathrm{s}$ & 13 & 1.1 \\
\hline
\end{tabular}

Reaction of ${ }^{57} \mathrm{FeCl}_{2}$ with Phenethylmagnesium chloride in the presence of styrene

${ }^{57} \mathrm{FeCl}_{2}(0.8 \mathrm{mg} ; 0.0063 \mathrm{mmol})$ in anhydrous THF $(2 \mathrm{ml})$ was stirred at $-17{ }^{\circ} \mathrm{C}$ for 20 minutes. Styrene $(14.5 \mu \mathrm{L} ; 0.126 \mathrm{mmol} ; 20$ equiv.) was added and the reaction mixture left to stir for an additional 2 minutes after which phenethylmagnesium chloride (1 M in THF; $26 \mu \mathrm{L} ; 0.026 \mathrm{mmol} ; 4.13$ equiv.). After stirring for 2 minutes, an aliquot $(\sim 1 \mathrm{ml})$ was transferred to a Mössbauer sample cup and frozen in liquid nitrogen. 


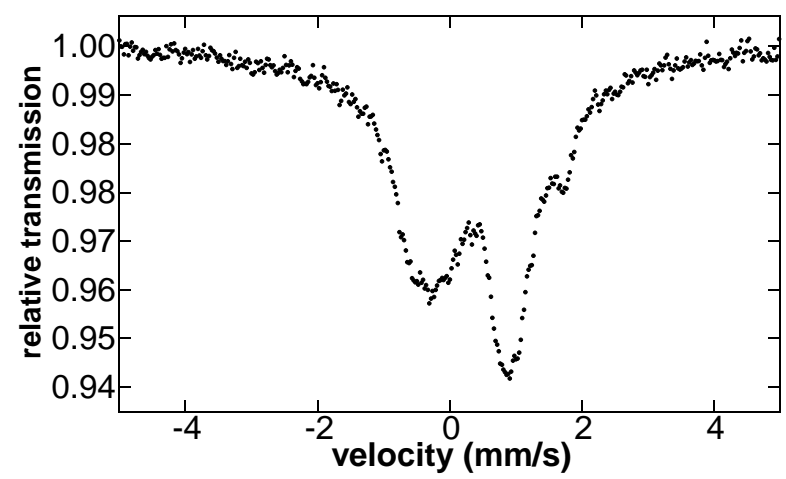

\section{Stoichiometric reactions of Complex 1 with styrene derivatives}

$\left.\left[\mathrm{MgBr}_{0.67} \mathrm{Cl}_{0.33}(\mathrm{THF})_{5}\right]\left[{ }^{\mathrm{P} r \mathrm{BIP}}\right) \mathrm{Fe}(\mathrm{Et})\left(\mathrm{H}_{2} \mathrm{C}=\mathrm{CH}_{2}\right)\right] \cdot 2.5 \mathrm{THF}(10 \mathrm{mg} ; 0.008 \mathrm{mmol})$ was charged to a stirring, room temperature solution of styrene derivative $(0.05 \mathrm{mmol})$ and dodecane $(11.5 \mu \mathrm{L} ; 0.05 \mathrm{mmol})$ in anhydrous tetrahydrofuran $(0.5 \mathrm{~mL}$.). Aliquots $(<100 \mu \mathrm{L})$ were removed after 1 minute and 5 minutes and added to HPLC vials containing anhydrous methanol (approx. 10-15 $\mu \mathrm{L}, 0.25-0.37 \mathrm{mmol}$ ). After all samples were taken, aqueous sulfate buffer (approx. $0.3 \mathrm{~mL}$ ) was added to each vial followed by diethyl ether (approx. $0.7 \mathrm{~mL}$ ). The vial was shaken and the layers were allowed to settle. Approximately $100 \mu \mathrm{L}$ of the organic phase was removed, diluted to between 1-1.5 mL in diethyl ether and filtered through a plug of silica $(30 \mathrm{~mm} \varnothing ; 0.5 \mathrm{~cm}$ diameter $\times 1.5 \mathrm{~cm}$ length). The filtrates were then analysed by GC.

For both styrene derivatives tested, 3-methoxystyrene and 4-tert-butylstyrene, no product formation was observed.

\section{Stoichiometric reaction with 4-tert-butylstyrene in the presence of ethylmagnesium bromide}

$\left[\mathrm{MgBr}_{0.67} \mathrm{Cl}_{0.33}(\mathrm{THF})_{5}\right]\left[\left({ }^{\mathrm{Pr} B I P}\right) \mathrm{Fe}(\mathrm{Et})\left(\mathrm{H}_{2} \mathrm{C}=\mathrm{CH}_{2}\right)\right] \cdot 2.5 \mathrm{THF}(12.7 \mathrm{mg} ; 0.01 \mathrm{mmol})$ was charged to a stirring, room temperature solution of 4-tert-butylstyrene $(9.2 \mu \mathrm{L} ; 0.05 \mathrm{mmol})$, ethylmagnesium bromide $(0.86 \mathrm{M}$ in THF; $11.5 \mu \mathrm{L} ; 0.01 \mathrm{mmol})$ and dodecane $(11.5 \mu \mathrm{L} ; 0.05 \mathrm{mmol})$ in anhydrous tetrahydrofuran $(0.5 \mathrm{~mL}$.$) .$ Aliquots $(<100 \mu \mathrm{L})$ were removed after 1 minute and 5 minutes and added to HPLC vials containing anhydrous methanol (approx. 10-15 $\mu \mathrm{L}, 0.25-0.37 \mathrm{mmol}$ ). After all samples were taken, aqueous sulfate buffer (approx. $0.3 \mathrm{~mL}$ ) was added to each vial followed by diethyl ether (approx. $0.7 \mathrm{~mL}$ ). The vial was shaken and the layers were allowed to settle. Approximately $100 \mu \mathrm{L}$ of the organic phase was removed, diluted to between 1-1.5 $\mathrm{mL}$ in diethyl ether and filtered through a plug of silica $(30 \mathrm{~mm} \varnothing ; 0.5 \mathrm{~cm}$ diameter $\times 1.5 \mathrm{~cm}$ length). The filtrates were then analysed by GC.

$23 \%$ yield of 1-ethyl-4-tert-butylbenzene with respect to 4-tert-butylstyrene; $114 \%$ yield with respect to $\left[\mathrm{MgBr}_{0.67} \mathrm{Cl}_{0.33}(\mathrm{THF})_{5}\right]\left[\left({ }^{\mathrm{Pr}} \mathrm{BIP}\right) \mathrm{Fe}(\mathrm{Et})\left(\mathrm{H}_{2} \mathrm{C}=\mathrm{CH}_{2}\right)\right] \cdot 2.5 \mathrm{THF}$ and ethylmagnesium bromide.

\section{In Situ generation of Complex 1 and gradual warming}

A suspension of ${ }^{2 \mathrm{r} B} \mathrm{BIP}{ }^{57} \mathrm{FeCl}_{2}(9.2 \mathrm{mg} ; 0.015 \mathrm{mmol})$ in anhydrous tetrahydrofuran $(5 \mathrm{ml})$ was stirred at -17 ${ }^{\circ} \mathrm{C}$ for 20 minutes. Styrene, if relevant, $(17.2 \mu \mathrm{L} ; 0.15 \mathrm{mmol})$ was added and the reaction mixture stirred for $\sim 2$ minutes, after which ethylmagnesium bromide ( $1 \mathrm{M}$ in THF; $60 \mu \mathrm{L} ; 0.06 \mathrm{mmol}$ ) was added in one portion and the reaction stirred at $-17^{\circ} \mathrm{C}$ for 2 minutes. An aliquot (approx.. $1 \mathrm{~mL}$ ) was transferred to a 
Mössbauer sample cup and frozen in liquid nitrogen after which the reaction mixture was moved to stir at room temperature. Aliquots were transferred to Mössbauer sample cups and frozen in liquid nitrogen at specified time-points.

80 K ${ }^{57} \mathrm{Fe}$ Mössbauer spectra:

With styrene: 2 minutes at $-17^{\circ} \mathrm{C}$

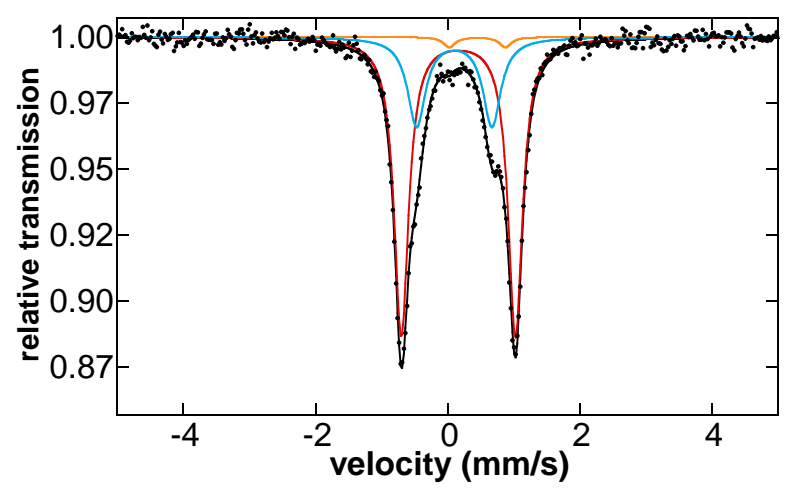

With styrene: 1 minute at room temperature

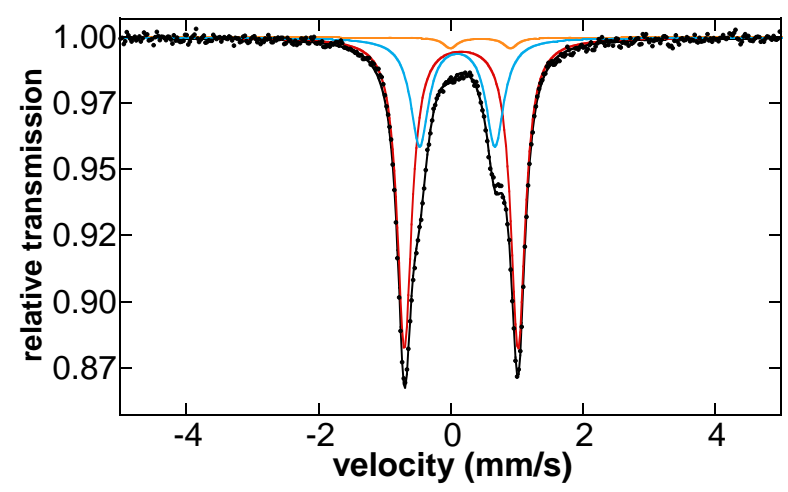

With styrene: 3 minutes at room temperature

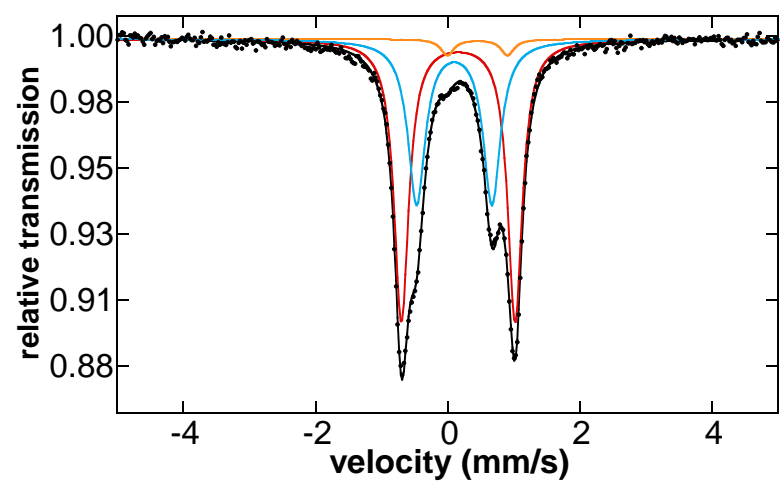


With styrene: 5 minutes at room temperature

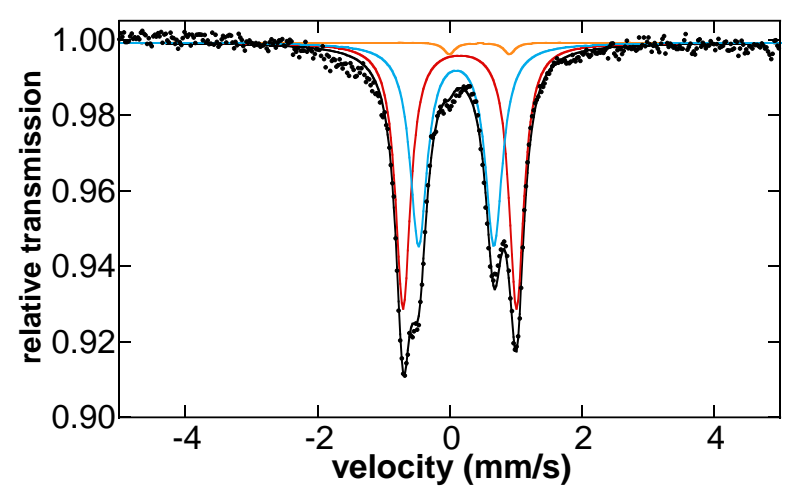

Without styrene: 5 minutes at room temperature

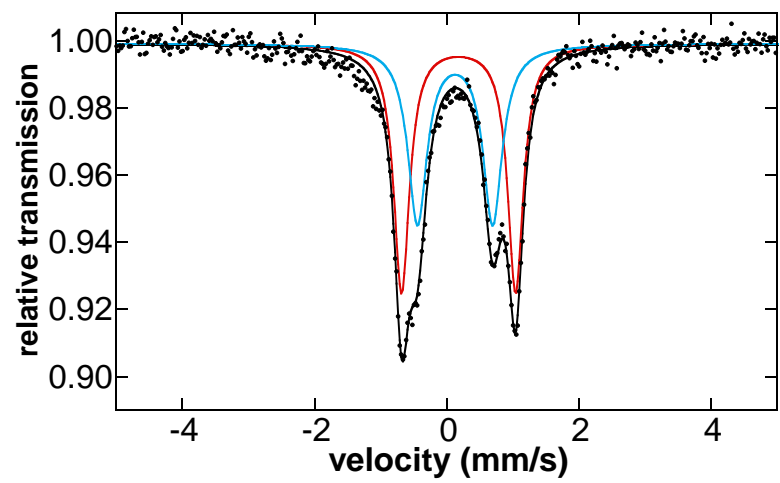

\begin{tabular}{|c|c|c|c|c|c|}
\hline & \multicolumn{5}{|c|}{ Amount of Total Iron (\%) } \\
\hline & \multicolumn{4}{|c|}{ With styrene } & \multirow{2}{*}{$\begin{array}{c}\begin{array}{c}\text { Without } \\
\text { styrene }\end{array} \\
5 \mathrm{~min} \\
\mathrm{rt}\end{array}$} \\
\hline Mössbauer Parameters & $\begin{array}{l}2 \mathrm{~min} \\
-17^{\circ} \mathrm{C}\end{array}$ & $\begin{array}{c}1 \mathrm{~min} \\
\mathrm{rt}\end{array}$ & $\begin{array}{c}3 \mathrm{~min} \\
\mathrm{rt}\end{array}$ & $\begin{array}{c}5 \mathrm{~min} \\
\mathrm{rt}\end{array}$ & \\
\hline $\begin{array}{c}\delta=0.16 \mathrm{~mm} / \mathrm{s} \text { and } \Delta \mathrm{E}_{\mathrm{Q}}=1.72 \\
\mathrm{~mm} / \mathrm{s}\end{array}$ & 72 & 68 & 58 & 53 & 53 \\
\hline $\begin{array}{c}\delta=0.11 \mathrm{~mm} / \mathrm{s} \text { and } \Delta \mathrm{E}_{\mathrm{Q}}=1.18 \\
\mathrm{~mm} / \mathrm{s}\end{array}$ & 26 & 29 & 39 & 45 & 47 \\
\hline $\begin{array}{c}\delta=0.44 \mathrm{~mm} / \mathrm{s} \text { and } \Delta \mathrm{E}_{\mathrm{Q}}=0.88 \\
\mathrm{~mm} / \mathrm{s}\end{array}$ & 2 & 2 & 3 & 2 & - \\
\hline
\end{tabular}

10. Kinetic AnALYSis

Initial Rates Kinetics

Reactions were performed in a glovebox $\left(20-25^{\circ} \mathrm{C}\right)$ to allow easy and accurate removal of aliquots. 
Standard solutions of 2,6-bis-[1-(2,6-diisopropylphenylimino)ethyl]pyridine iron(II) chloride (0.001 M in THF), styrene derivative ( $0.8 \mathrm{M}$ in THF) and trimethoxybenzene ( $0.16 \mathrm{M}$ in THF) were used for all reactions. The standard solutions were stored in a glovebox in the dark at $-35^{\circ} \mathrm{C}$ between reactions and were not stored for more than 3 weeks.

The concentration of 2,6-bis-[1-(2,6-diisopropylphenylimino)ethyl]pyridine iron(II) chloride, styrene derivative and ethylmagnesium bromide were varied, with the concentration of only one variable changed in each experiment.

\section{Summary figures}
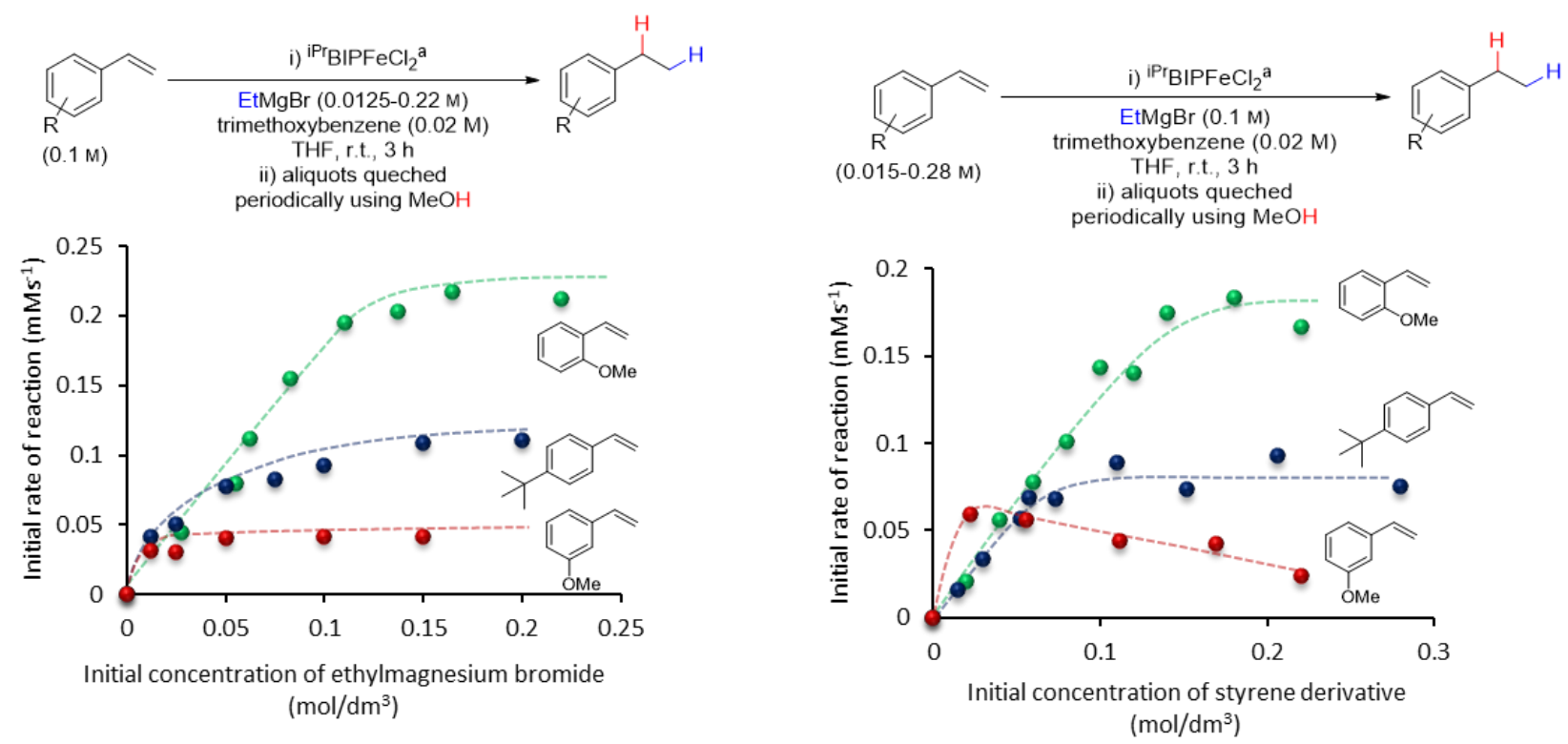

\section{Reactions using 2-methoxystyrene}

\section{General Procedure}<smiles>C=Cc1ccccc1OC</smiles>

$0.02-0.22 \mathrm{M}$

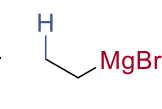

$0.025-0.2 \mathrm{M}$

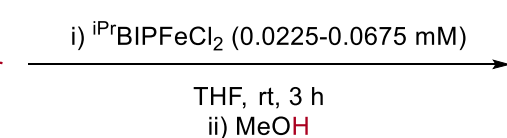

ii) $\mathrm{MeOH}$<smiles>C=Cc1ccccc1OC</smiles>

OMe

2-Methoxystyrene (0.1-1.1 mL, $0.8 \mathrm{~m}$ in THF, 0.08-0.88 mmol) was added to a solution 2,6-bis-[1-(2,6diisopropylphenylimino)ethyl]pyridine iron(II) chloride $(0.25-0.75 \mathrm{~mL}, 0.00036 \mathrm{M}$ in THF, $0.00009-0.00027$ $\mathrm{mmol}$ ) and 1,3,5-trimethoxybenzene $(0.5 \mathrm{~mL}, 0.16 \mathrm{M}$ in THF, $0.08 \mathrm{mmol})$ in anhydrous tetrahydrofuran (total volume after Grignard reagent $4 \mathrm{~mL}$ ). Ethylmagnesium bromide (0.1-0.8 mL, $1 \mathrm{M}$ in THF, 0.1-0.8 $\mathrm{mmol}$ ) was added in one portion, and the reaction was stirred at room temperature $\left(20-22^{\circ} \mathrm{C}\right)$. Aliquots $(<$ $100 \mu \mathrm{L}$ ) were periodically removed and added to HPLC vials containing anhydrous methanol (approx. 10$15 \mu \mathrm{L}, 0.25-0.37 \mathrm{mmol}$ ). After all samples were taken, aqueous sulfate buffer (approx. $0.3 \mathrm{~mL}$ ) was added to each vial followed by diethyl ether (approx. $0.7 \mathrm{~mL}$ ). The vial was shaken and the layers were allowed to settle. The diethyl ether layer was removed and added to a $7 \mathrm{~mL}$ glass vial, from which the diethyl ether was allowed to evaporate at room temperature (approx. 10-15 min) until the majority of the solvent had 
evaporated (but wasn't thoroughly dry). The residue was dissolved in $\mathrm{CDCl}_{3}$ and added to an NMR tube for analysis by ${ }^{1} \mathrm{H}$ NMR spectroscopy.

The percentage yield of each product was determined by quantitative ${ }^{1} \mathrm{H}$ NMR spectroscopy, using 1,3,5trimethoxybenzene $(20 \mathrm{~mol} \%)$ as an internal standard.

In these experiments, no side-products were observed and the mass balance could be accounted for by a combination of product (1-ethyl-2-methoxybenzene $)^{13}$ and starting material (2-methoxystyrene). For clarity only yields of product (1-ethyl-2-methoxybenzene) are given.

Reaction order with respect to 2,6-bis-[1-(2,6-diisopropylphenylimino)ethyl]pyridine iron(II) chloride concentration

2-Methoxystyrene $(0.4 \mathrm{mmol}, 0.1 \mathrm{M})$ and ethylmagnesium bromide $(0.4 \mathrm{mmol}, 0.1 \mathrm{M})$ kept constant in all reactions. The concentration of 2,6-bis-[1-(2,6-diisopropylphenylimino)ethyl]pyridine iron(II) chloride was varied in the range of $0.0000225-0.0000675 \mathrm{M}$. The data for product formation is the concentration of 1 ethyl-2-methoxybenzene (M) formed in the reaction $(0.1 \mathrm{M}=100 \%$ yield $)$

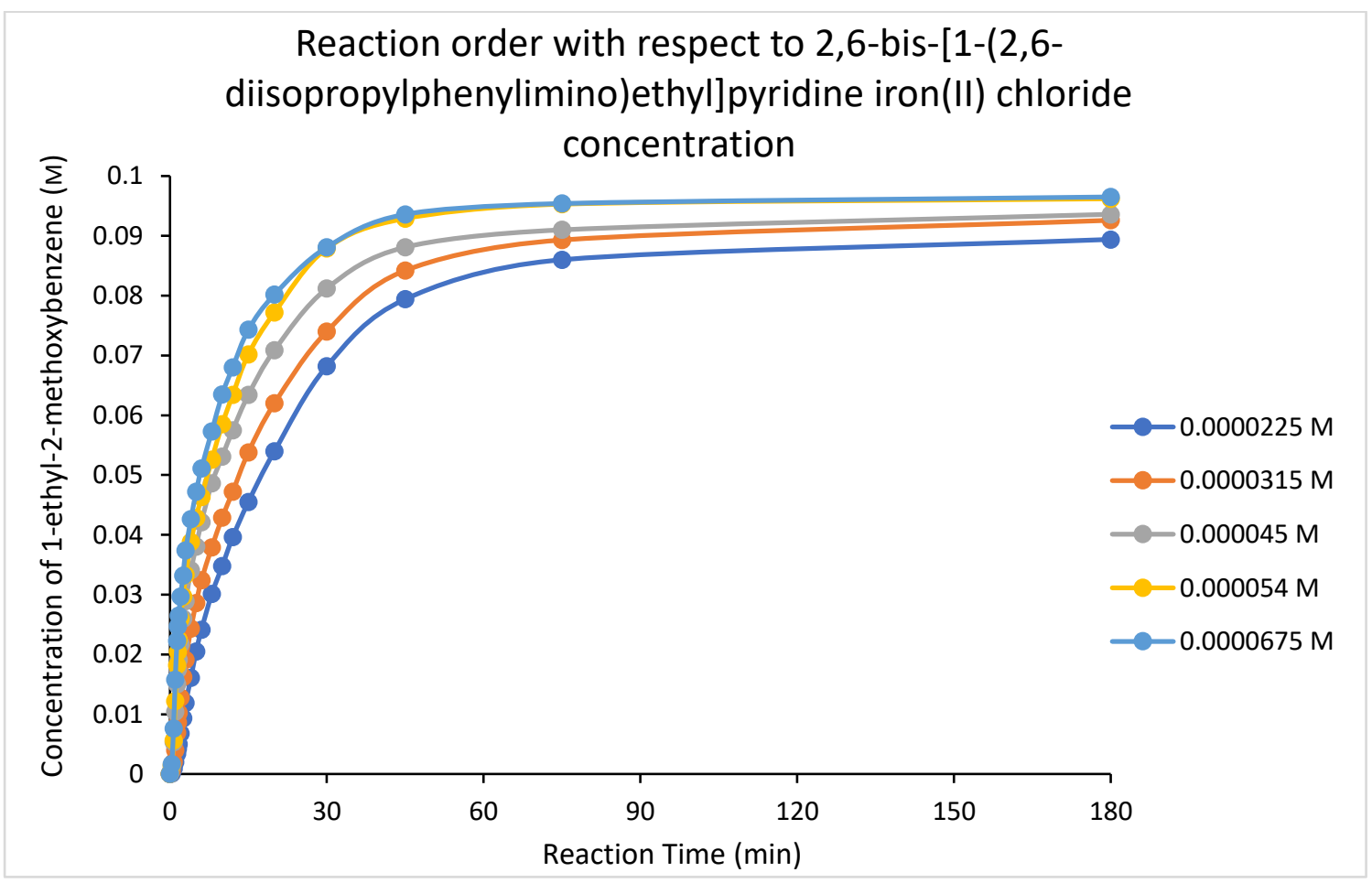



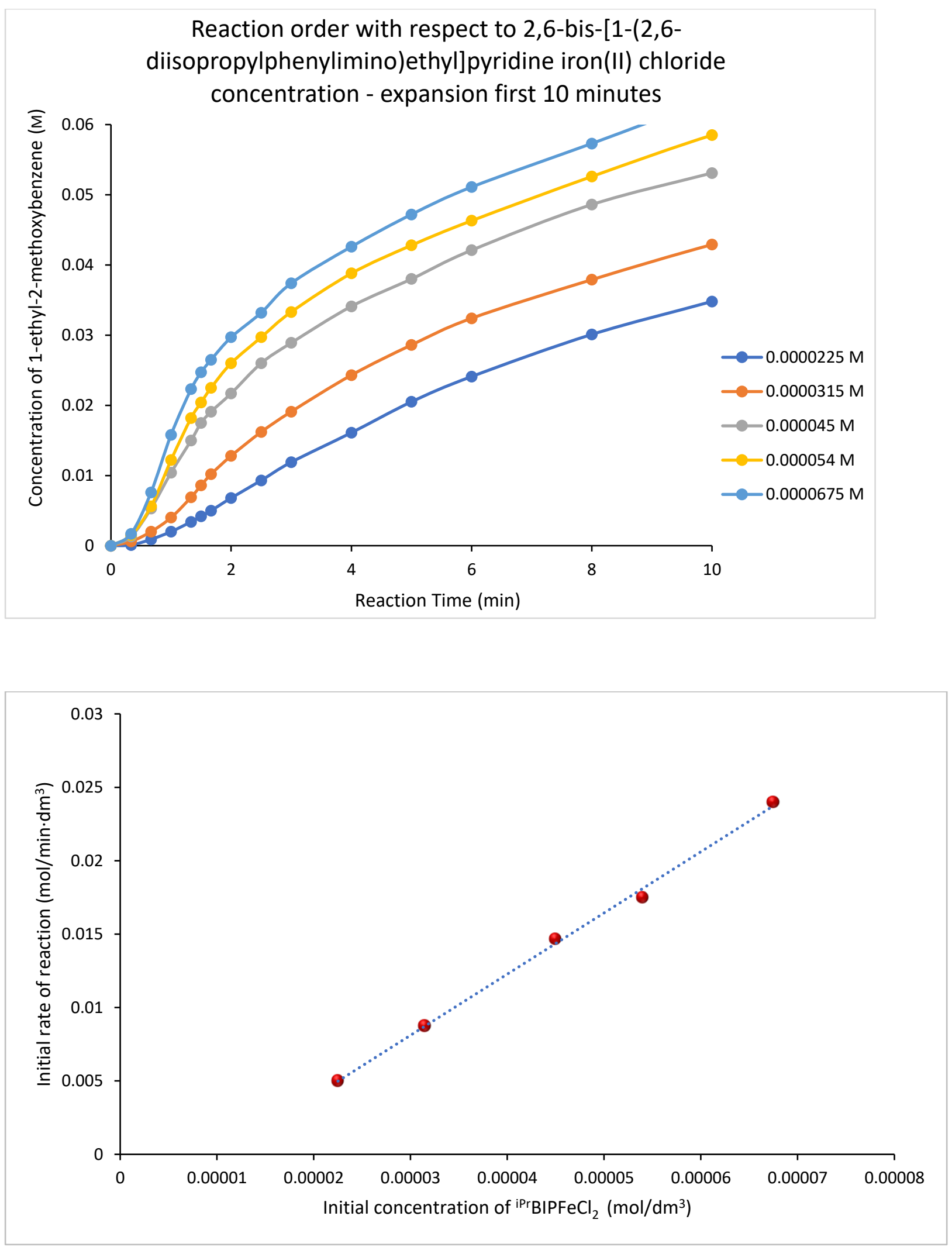


\section{Reaction order with respect to 2-methoxystyrene concentration}

2,6-Bis-[1-(2,6-diisopropylphenylimino)ethyl]pyridine iron(II) chloride $(0.000126 \mathrm{mmol}, 0.0000315 \mathrm{M})$ and ethylmagnesium bromide $(0.44 \mathrm{mmol}, 0.11 \mathrm{M})$ were kept constant in all reactions. The concentration of 2 methoxystyrene was varied in the range of $0.02-0.22 \mathrm{M}$. The data for product formation is the concentration of 1-ethyl-2-methoxybenzene (M) formed in the reaction.
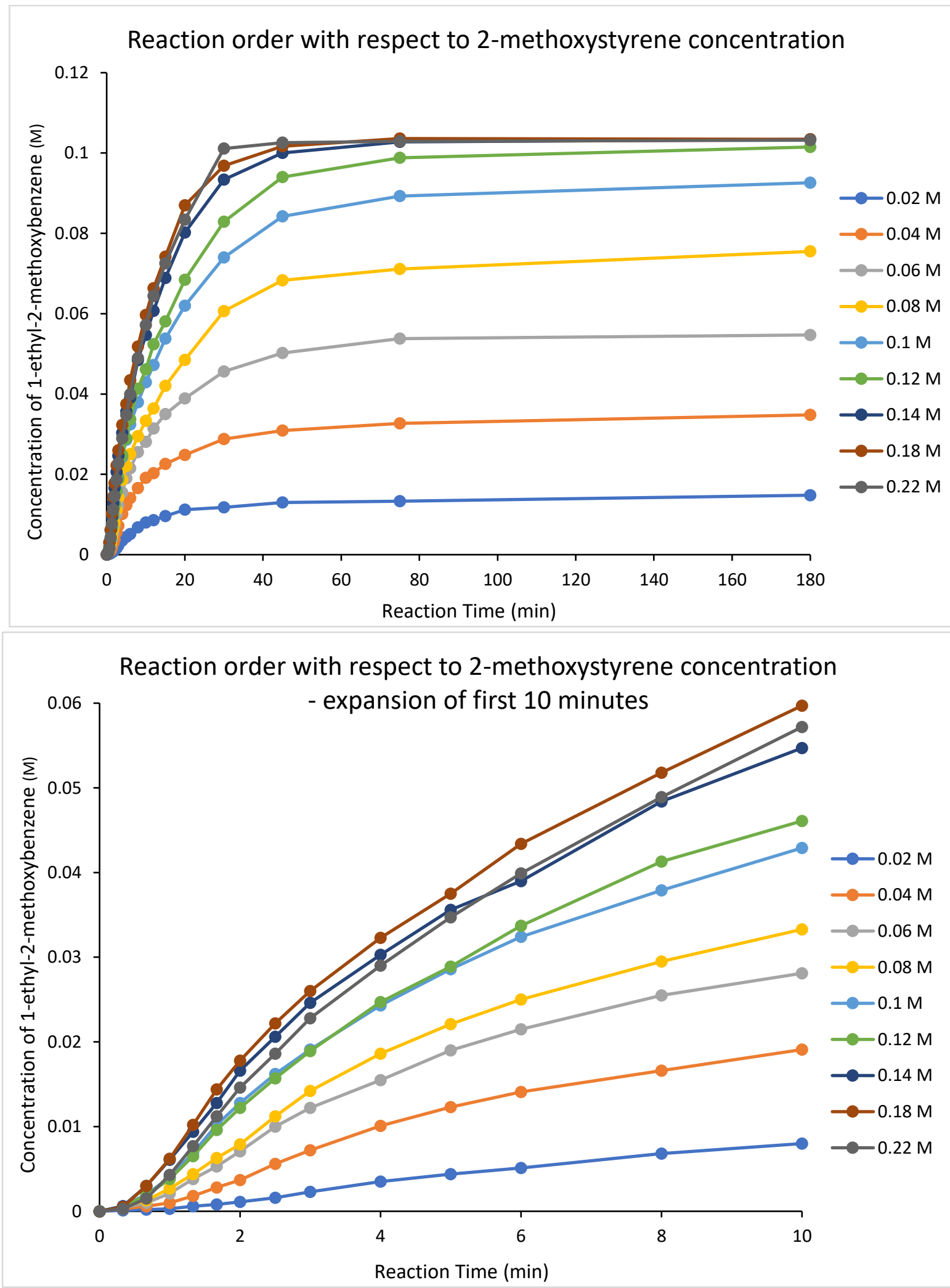


\section{Reaction order with respect to ethylmagnesium bromide concentration}

2,6-Bis-[1-(2,6-diisopropylphenylimino)ethyl]pyridine iron(II) chloride $(0.000126 \mathrm{mmol}, 0.0000315 \mathrm{M})$ and 2-methoxystyrene $(0.4 \mathrm{mmol}, 0.1 \mathrm{M})$ were kept constant in all reactions. The concentration of ethylmagnesium bromide was varied in the range of 0.0275-0.22 M. The data for product formation given is the concentration of 1-ethyl-2-methoxybenzene (M) formed in the reaction.

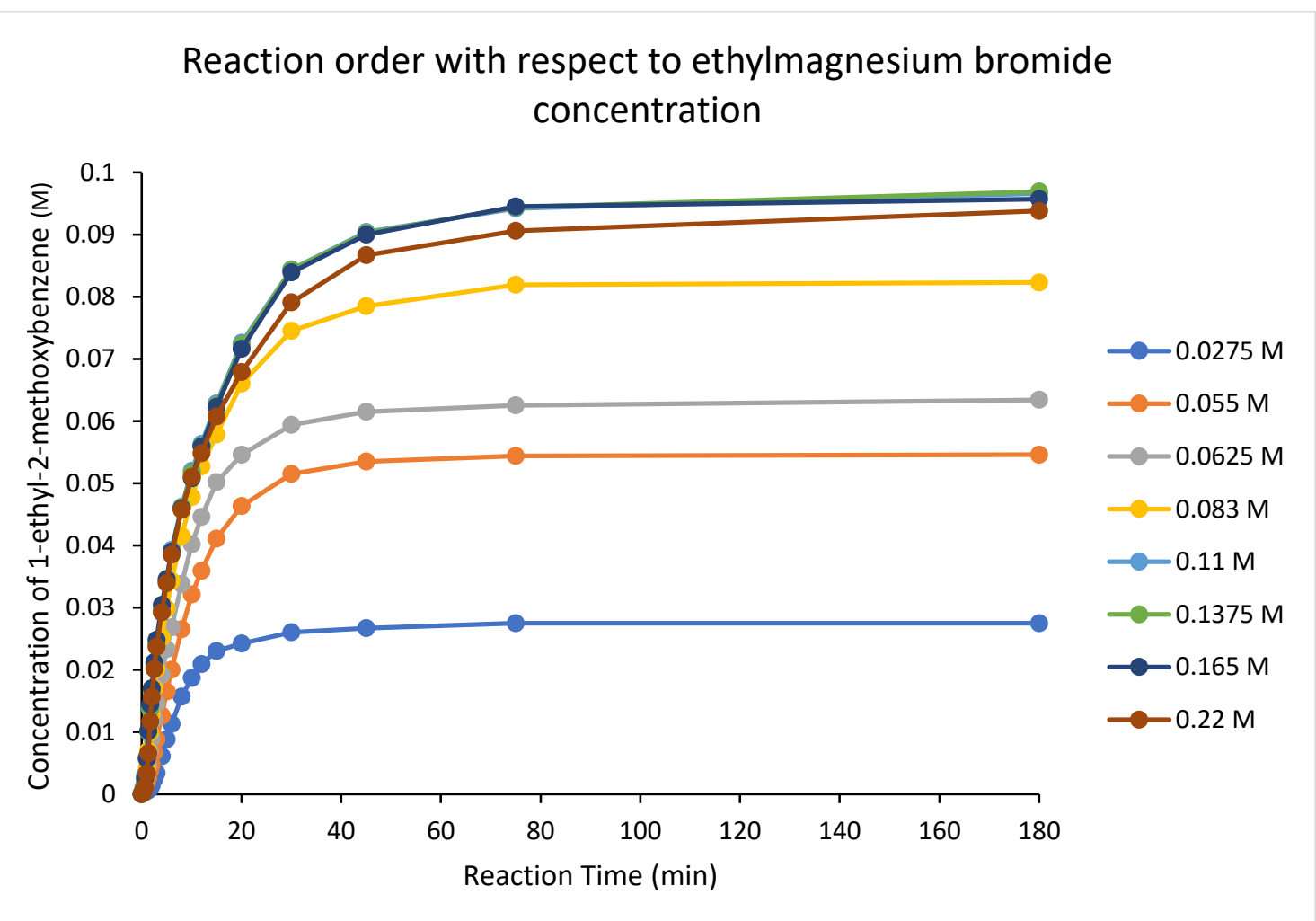




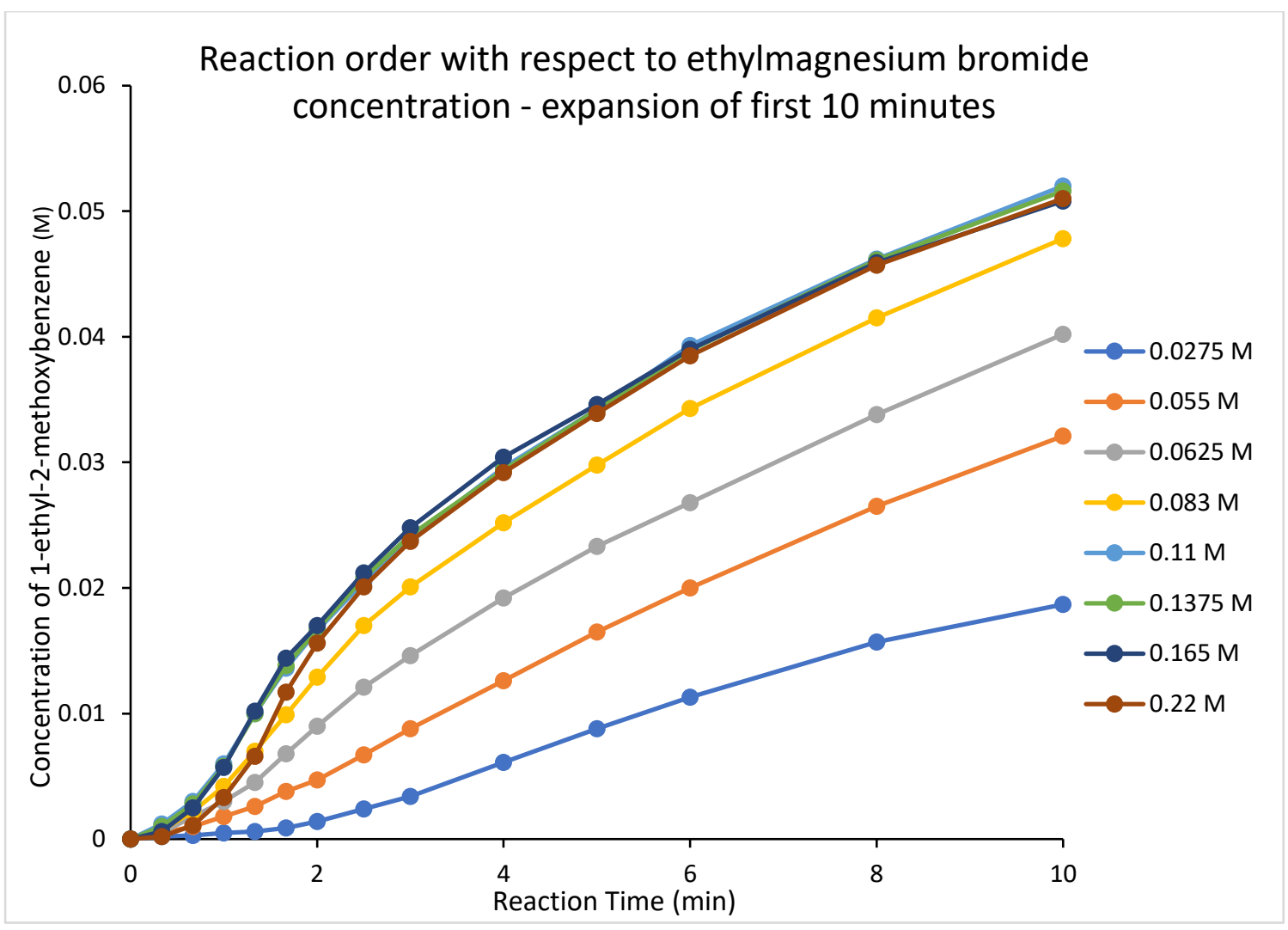

Reactions using 4-tert-butylstyrene:

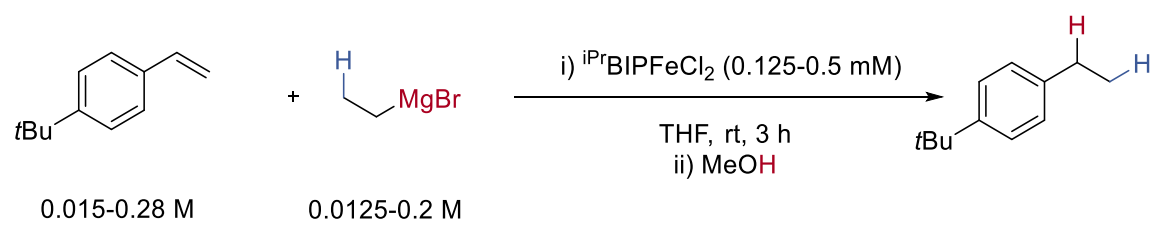

\section{General procedure}

4-tert-butylstyrene (0.1-1.25 mL, $0.8 \mathrm{M}$ in THF, 0.048-1.12 mmol) was added to a solution of 2,6-bis-[1-(2,6diisopropylphenylimino)ethyl]pyridine iron(II) chloride $(0.5-2.00 \mathrm{~mL}, 0.001 \mathrm{M}$ in THF, 0.0005-0.002 $\mathrm{mmol})$ and 1,3,5-trimethoxybenzene $(0.5 \mathrm{~mL}, 0.16 \mathrm{M}$ in THF, $0.08 \mathrm{mmol}$ ) in anhydrous tetrahydrofuran (total volume after Grignard reagent $4 \mathrm{~mL}$ ). Ethylmagnesium bromide (0.1-0.8 mL, $1 \mathrm{M}$ in THF, 0.1-0.8 mmol) was added in one portion, and the reaction was stirred at room temperature $\left(20-25{ }^{\circ} \mathrm{C}\right)$. Aliquots $(<100$ $\mu \mathrm{L}$ ) were periodically removed and added to HPLC vials containing anhydrous methanol (approx. 10-15 $\mu \mathrm{L}, 0.25-0.37 \mathrm{mmol}$ ). After all samples were taken, aqueous sulfate buffer (approx. $0.3 \mathrm{~mL}$ ) was added to each vial followed by diethyl ether (approx. $0.7 \mathrm{~mL}$ ). The vial was shaken and the layers were allowed to settle. The diethyl ether layer was removed and added to a $7 \mathrm{~mL}$ glass vial, from which the diethyl ether was allowed to evaporate at room temperature (approx. 10-15 min) until the majority of the solvent had evaporated (but was not thoroughly dry). The residue was dissolved in $\mathrm{CDCl}_{3}$ and added to an NMR tube for analysis by ${ }^{1} \mathrm{H}$ NMR spectroscopy. 
The percentage yield of each product was determined by quantitative ${ }^{1} \mathrm{H}$ NMR spectroscopy, using 1,3,5trimethoxybenzene $(20 \mathrm{~mol} \%)$ as an internal standard.

In these experiments, no side-products were observed and the mass balance could be accounted for by a combination of product (1-ethyl-4-tert-butylbenzene), ${ }^{25}$ and starting material (4-tert-butylstyrene). For clarity only yields of product (1-ethyl-4-tert-butylbenzene) are given.

Reaction order with respect to 2,6-bis-[1-(2,6-diisopropylphenylimino)ethyl]pyridine iron(II) chloride concentration

4-tert-butylstyrene $(0.4 \mathrm{mmol}, 0.1 \mathrm{M})$ and ethylmagnesium bromide $(0.4 \mathrm{mmol}, 0.1 \mathrm{M})$ kept constant in all reactions. The concentration of 2,6-bis-[1-(2,6-diisopropylphenylimino)ethyl]pyridine iron(II) chloride was varied in the range of $0.000125-0.0005 \mathrm{M}$. The data for product formation given is the concentration of 1 ethyl-4-tert-butylbenzene $(\mathrm{M})$ formed in the reaction $(0.1 \mathrm{M}=100 \%$ yield).

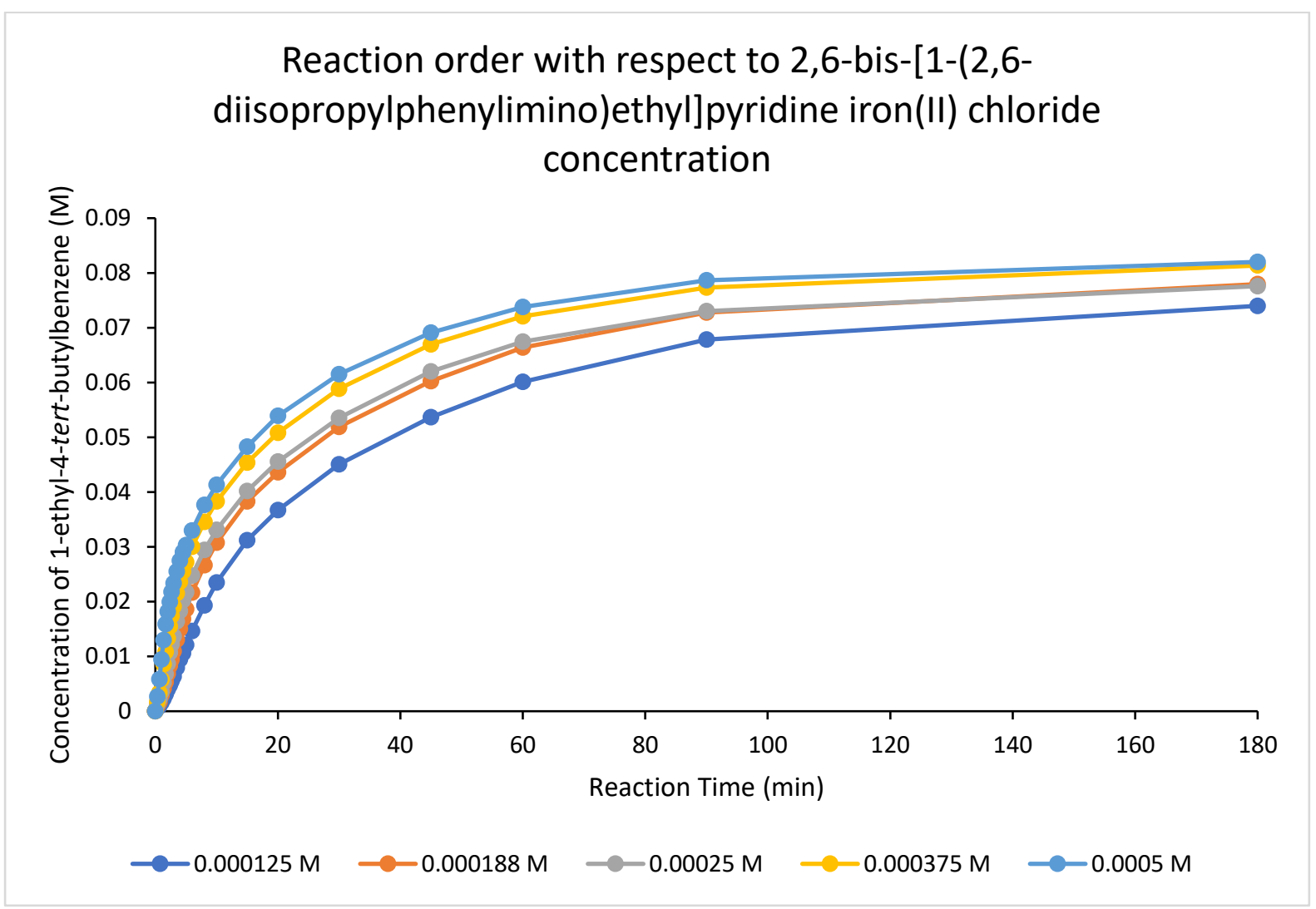



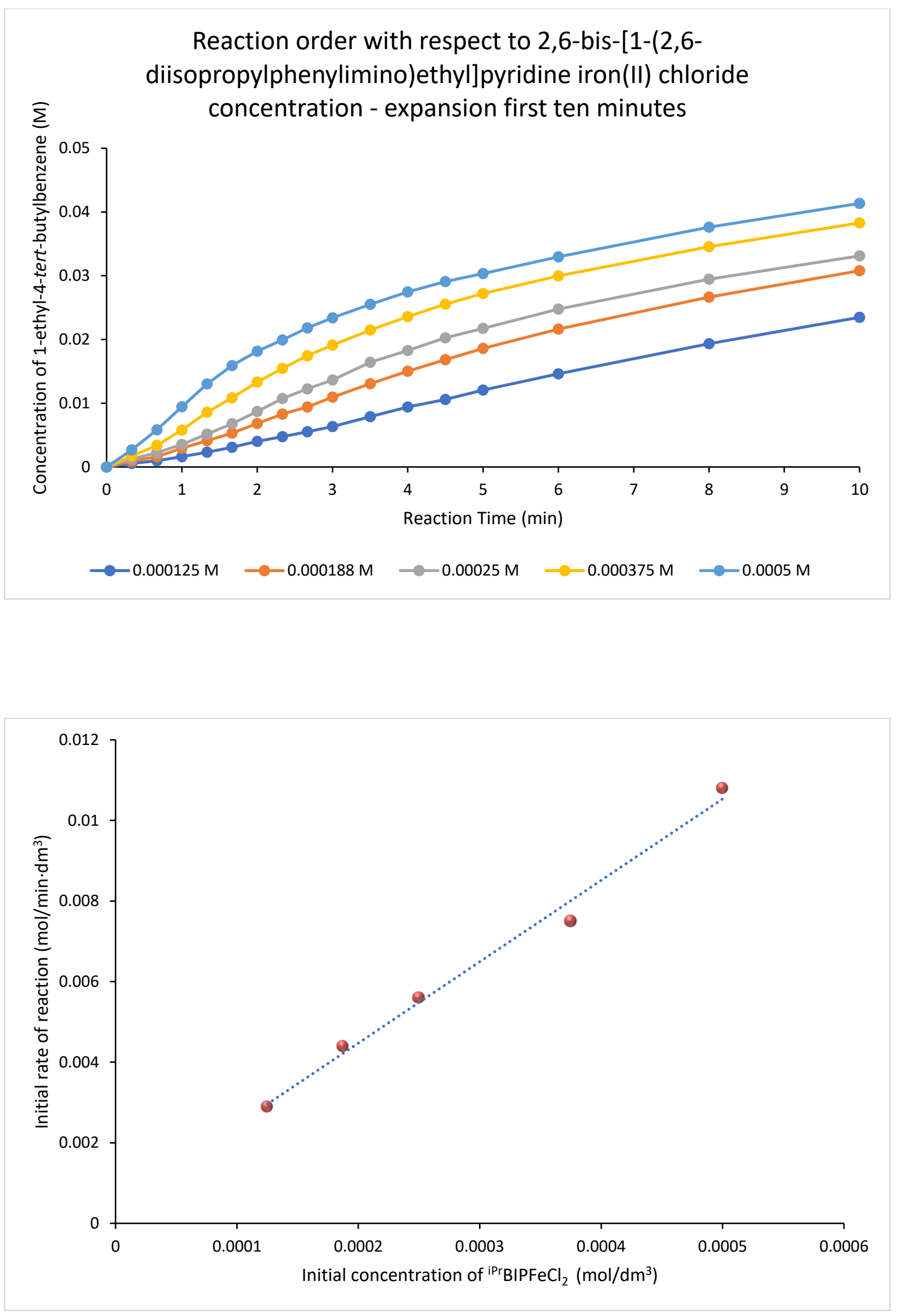


\section{Reaction order with respect to 4-tert-butylstyrene concentration}

2,6-Bis-[1-(2,6-diisopropylphenylimino)ethyl]pyridine iron(II) chloride (0.001 mmol, $0.00025 \mathrm{M})$ and ethylmagnesium bromide $(0.4 \mathrm{mmol}, 0.1 \mathrm{M})$ were kept constant in all reactions. The concentration of 4-tertbutylstyrene was varied in the range of 0.06-1.12 M. The data for product formation given is the concentration of 1-ethyl-4-tert-butylbenzene (M) formed in the reaction.

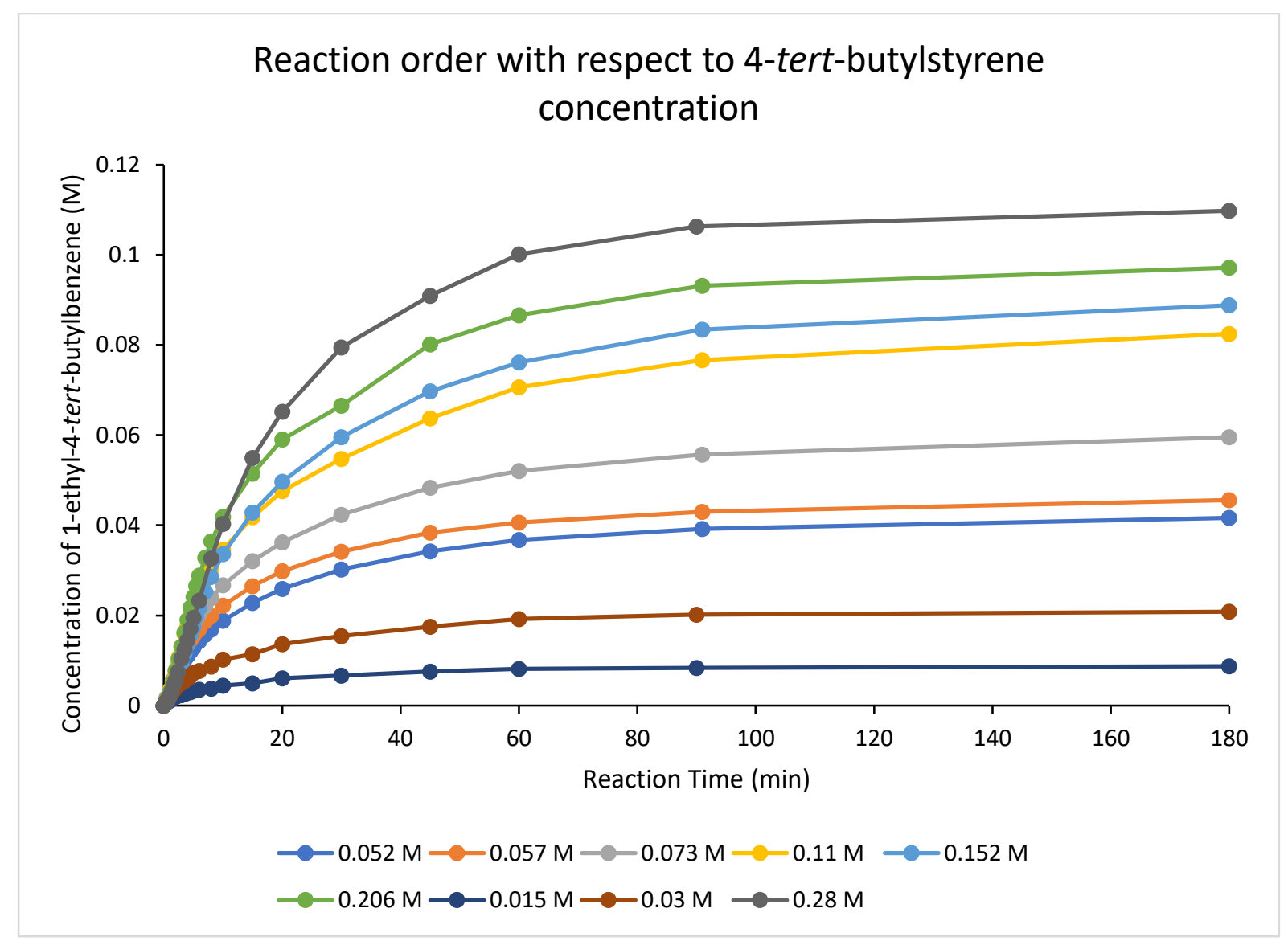




\section{Reaction order with respect to 4-tert-butylstyrene concentration - expansion first ten minutes}

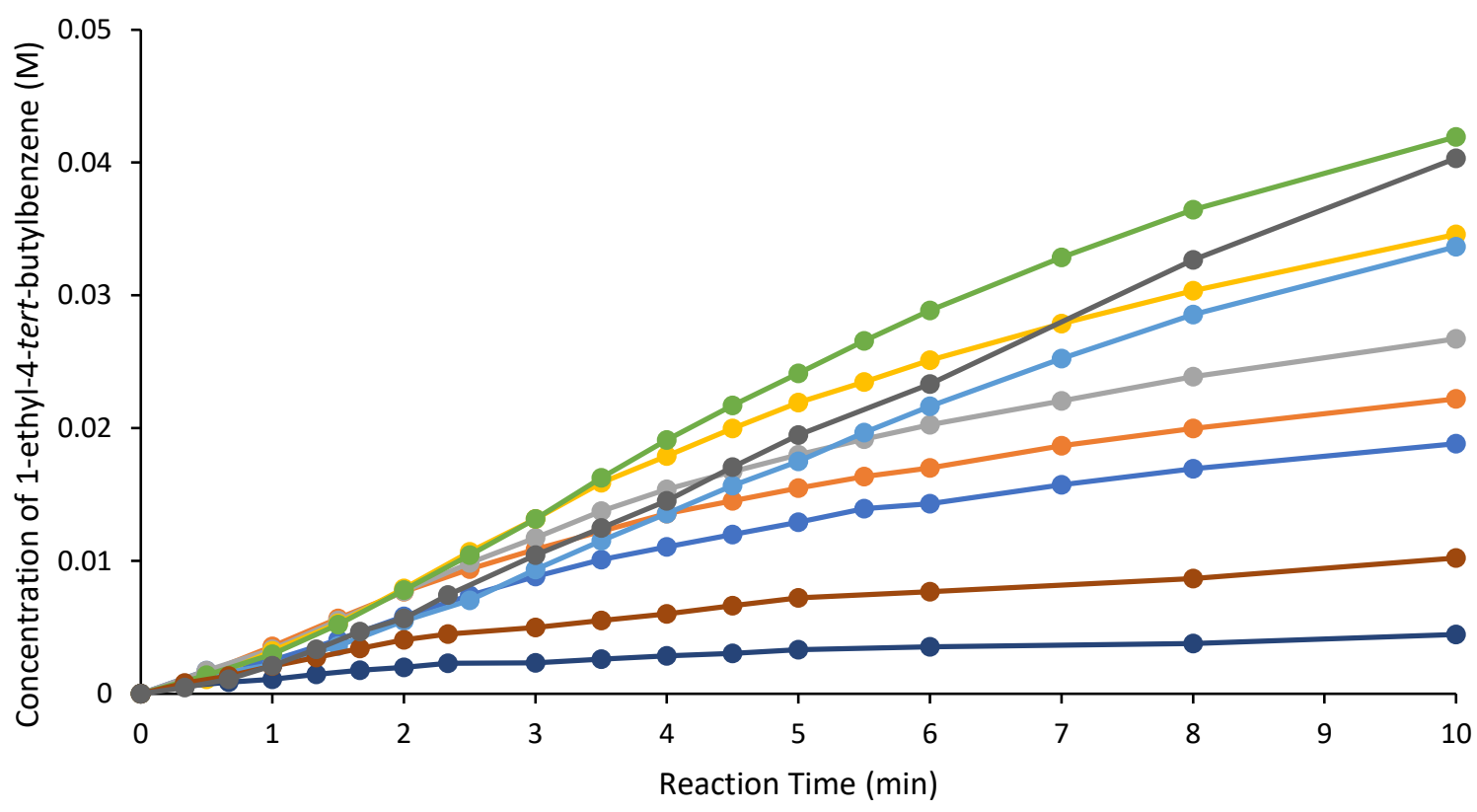

$\multimap 0.052 \mathrm{M}-0.057 \mathrm{M} \longrightarrow 0.073 \mathrm{M} \longrightarrow 0.11 \mathrm{M}-0.152 \mathrm{M}$

$-0.206 \mathrm{M} \longrightarrow 0.015 \mathrm{M} \longrightarrow 0.03 \mathrm{M} \longrightarrow 0.28 \mathrm{M}$

Reaction order with respect to ethylmagnesium bromide concentration

2,6-Bis-[1-(2,6-diisopropylphenylimino)ethyl]pyridine iron(II) chloride ( $0.001 \mathrm{mmol}, 0.00025 \mathrm{M})$ and 4-tertbutylstyrene $(0.44 \mathrm{mmol}, 0.11 \mathrm{M})$ were kept constant in all reactions. The concentration of ethylmagnesium bromide was varied in the range of $0.025-0.20 \mathrm{M}$. The data for product formation given is the concentration of 1-ethyl-4-tert-butylbenzene (M) formed in the reaction. 


\section{Reaction order with respect to EtMgBr concentration}

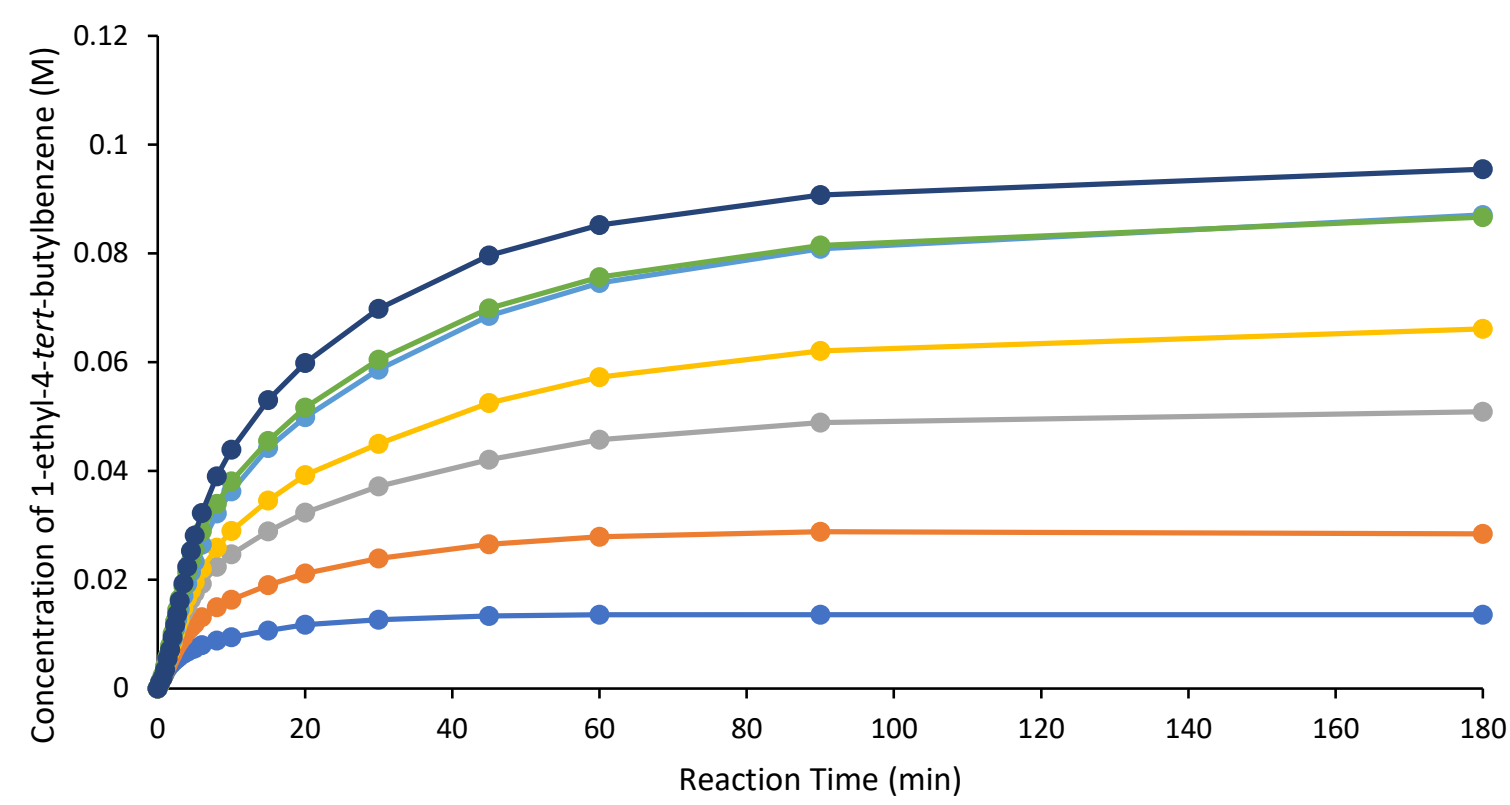

$\multimap 0.0125 \mathrm{M} \longrightarrow 0.025 \mathrm{M} \longrightarrow 0.05 \mathrm{M} \longrightarrow 0.075 \mathrm{M} \longrightarrow 0.1 \mathrm{M} \longrightarrow 0.15 \mathrm{M} \longrightarrow 0.2 \mathrm{M}$

Reaction order with respect to EtMgBr concentration expansion first ten minutes

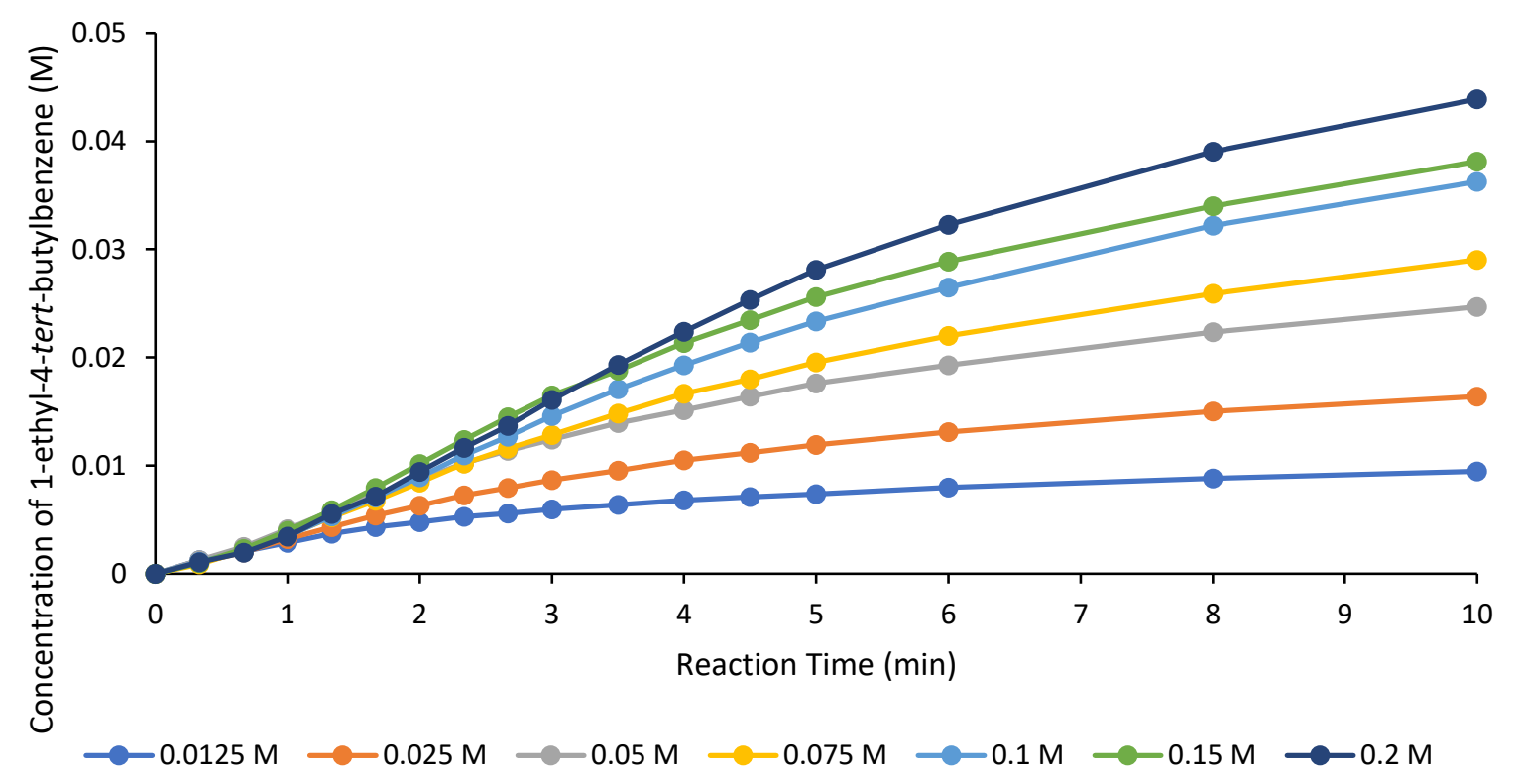




\section{Reactions using 3-methoxystyrene}

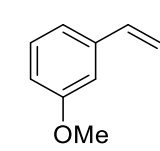

$0.02-0.22 \mathrm{M}$

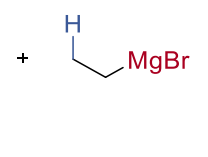

$0.0125-0.15 \mathrm{M}$

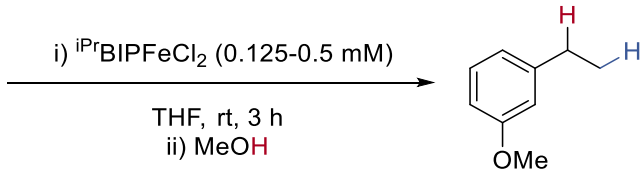

ii) $\mathrm{MeOH}$

\section{General procedure}

3-methoxystyrene $(0.1-1.1 \mathrm{~mL}, 0.8 \mathrm{~m}$ in THF, $0.08-0.88 \mathrm{mmol})$ was added to a solution 2,6-bis-[1-(2,6diisopropylphenylimino)ethyl]pyridine iron(II) chloride (0.5-2.00 mL, $0.001 \mathrm{M}$ in THF, $0.0005-0.002 \mathrm{mmol})$ and 1,3,5-trimethoxybenzene $(0.5 \mathrm{~mL}, 0.16 \mathrm{M}$ in THF, $0.08 \mathrm{mmol}$ ) in anhydrous tetrahydrofuran (total volume after Grignard reagent $4 \mathrm{~mL}$ ). Ethylmagnesium bromide (0.05-0.6 mL, $1 \mathrm{M}$ in THF, 0.05-0.6 mmol) was added in one portion, and the reaction was stirred at room temperature $\left(20-25^{\circ} \mathrm{C}\right)$. Aliquots $(<100$ $\mu \mathrm{L})$ were periodically removed and added to HPLC vials containing anhydrous methanol (approx. 10-15 $\mu \mathrm{L}, 0.25-0.37 \mathrm{mmol}$ ). After all samples were taken, aqueous sulfate buffer (approx. $0.3 \mathrm{~mL}$ ) was added to each vial followed by diethyl ether (approx. $0.7 \mathrm{~mL}$ ). The vial was shaken and the layers were allowed to settle. The diethyl ether layer was removed and added to a $7 \mathrm{~mL}$ glass vial, from which the diethyl ether was allowed to evaporate at room temperature (approx. 10-15 min) until the majority of the solvent had evaporated (but was not thoroughly dry). The residue was dissolved in $\mathrm{CDCl}_{3}$ and added to an NMR tube for analysis by ${ }^{1} \mathrm{H}$ NMR spectroscopy.

The percentage yield of each product was determined by quantitative ${ }^{1} \mathrm{H}$ NMR spectroscopy, using 1,3,5trimethoxybenzene $(20 \mathrm{~mol} \%)$ as an internal standard.

In these experiments, no side-products were generally observed and the mass balance could be accounted for by a combination of products (1-ethyl-3-methoxybenzene), ${ }^{26}$ and starting material (3-methoxystyrene). Under certain conditions, excess 3-methoxystyrene, unidentified side products were observed. The mass balance for the aromatic region was stable throughout, accounting for total mass balance. For clarity only yields of product (1-ethyl-3-methoxybenzene) are given below.

\section{Reaction order with respect to 2,6-bis-[1-(2,6-diisopropylphenylimino)ethyl]pyridine iron(II) chloride concentration}

3-methoxystyrene $(0.4 \mathrm{mmol}, 0.1 \mathrm{M})$ and ethylmagnesium bromide $(0.4 \mathrm{mmol}, 0.1 \mathrm{M})$ kept constant in all reactions. The concentration of 2,6-bis-[1-(2,6-diisopropylphenylimino)ethyl]pyridine iron(II) chloride was varied in the range of $0.000125-0.0005 \mathrm{M}$. The data for product formation given is the concentration of 3methoxy-ethylbenzene $(\mathrm{M})$ formed in the reaction $(0.1 \mathrm{M}=100 \%$ yield $)$. 
Reaction order with respect to 2,6-bis-[1-(2,6diisopropylphenylimino)ethyl]pyridine iron(II) chloride concentration

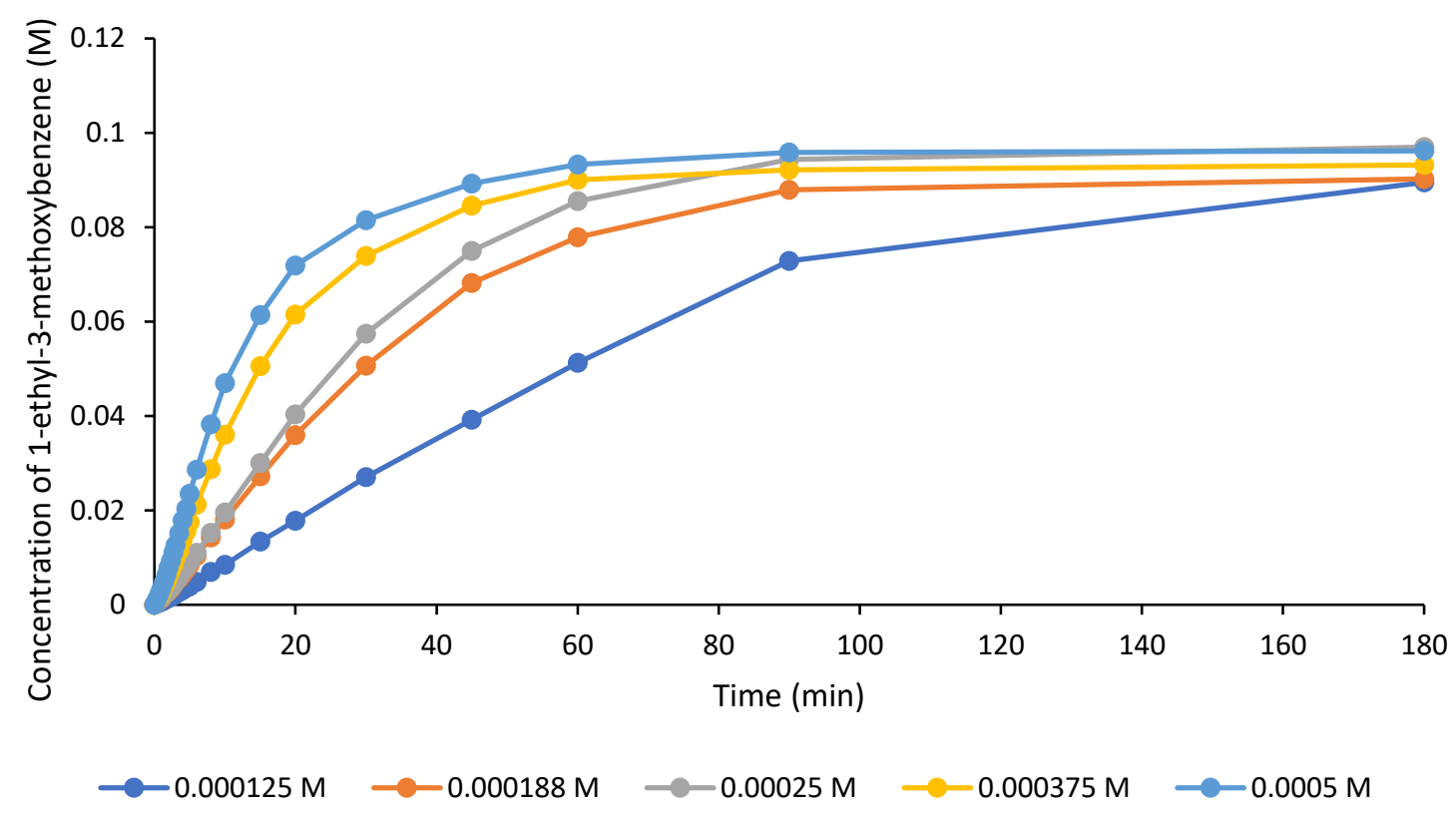

Reaction order with respect to 2,6-bis-[1-(2,6diisopropylphenylimino)ethyl]pyridine iron(II) chloride concentration - expansion first ten minutes

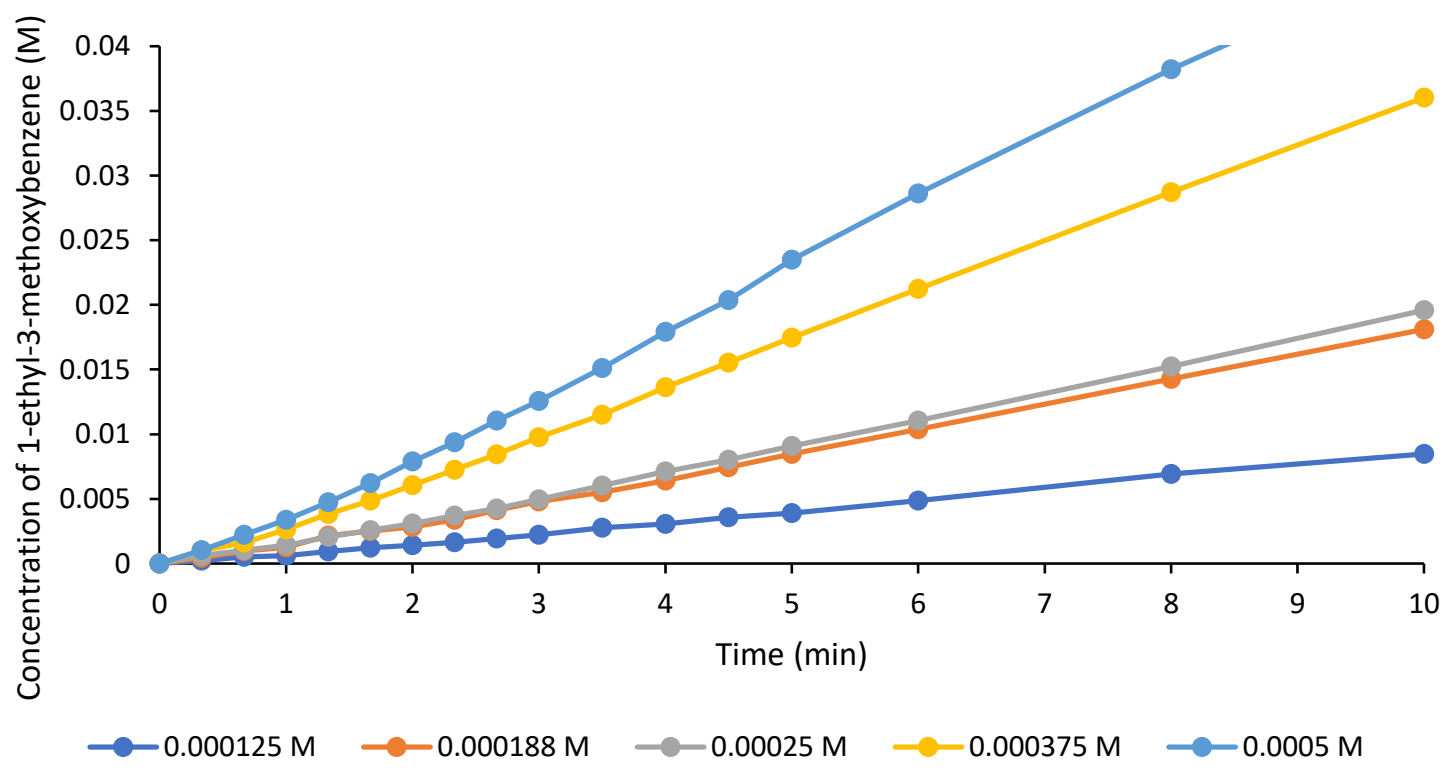




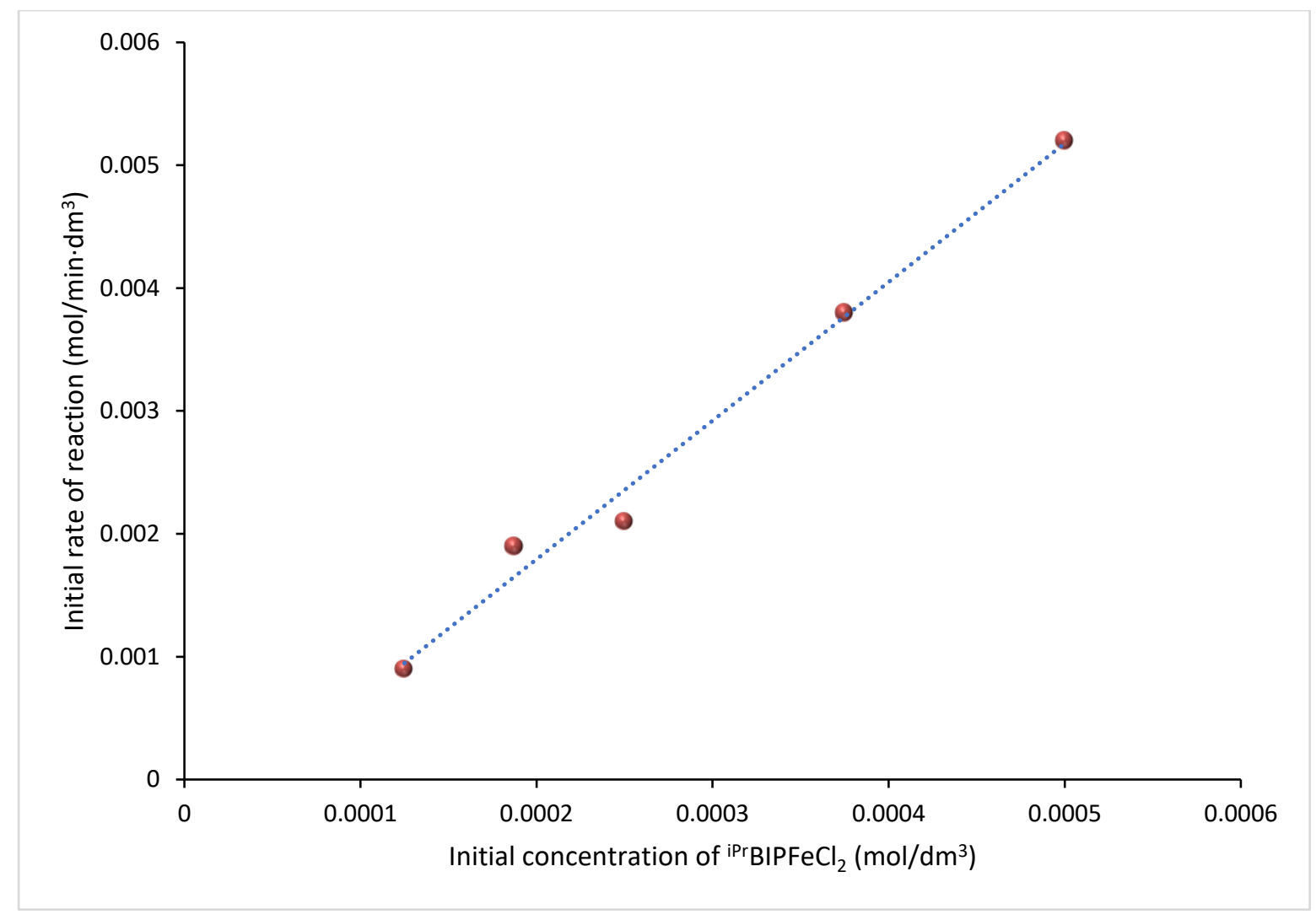

Reaction order with respect to 3-methoxystyrene concentration

2,6-Bis-[1-(2,6-diisopropylphenylimino)ethyl]pyridine iron(II) chloride $(0.001 \mathrm{mmol}, 0.00025 \mathrm{M})$ and ethylmagnesium bromide $(0.4 \mathrm{mmol}, 0.1 \mathrm{M})$ were kept constant in all reactions. The concentration of 3methoxystyrene was varied in the range of $0.02-0.22 \mathrm{M}$. The data for product formation given is the concentration of 1-ethyl-3-methoxybenzene (M) formed in the reaction. 

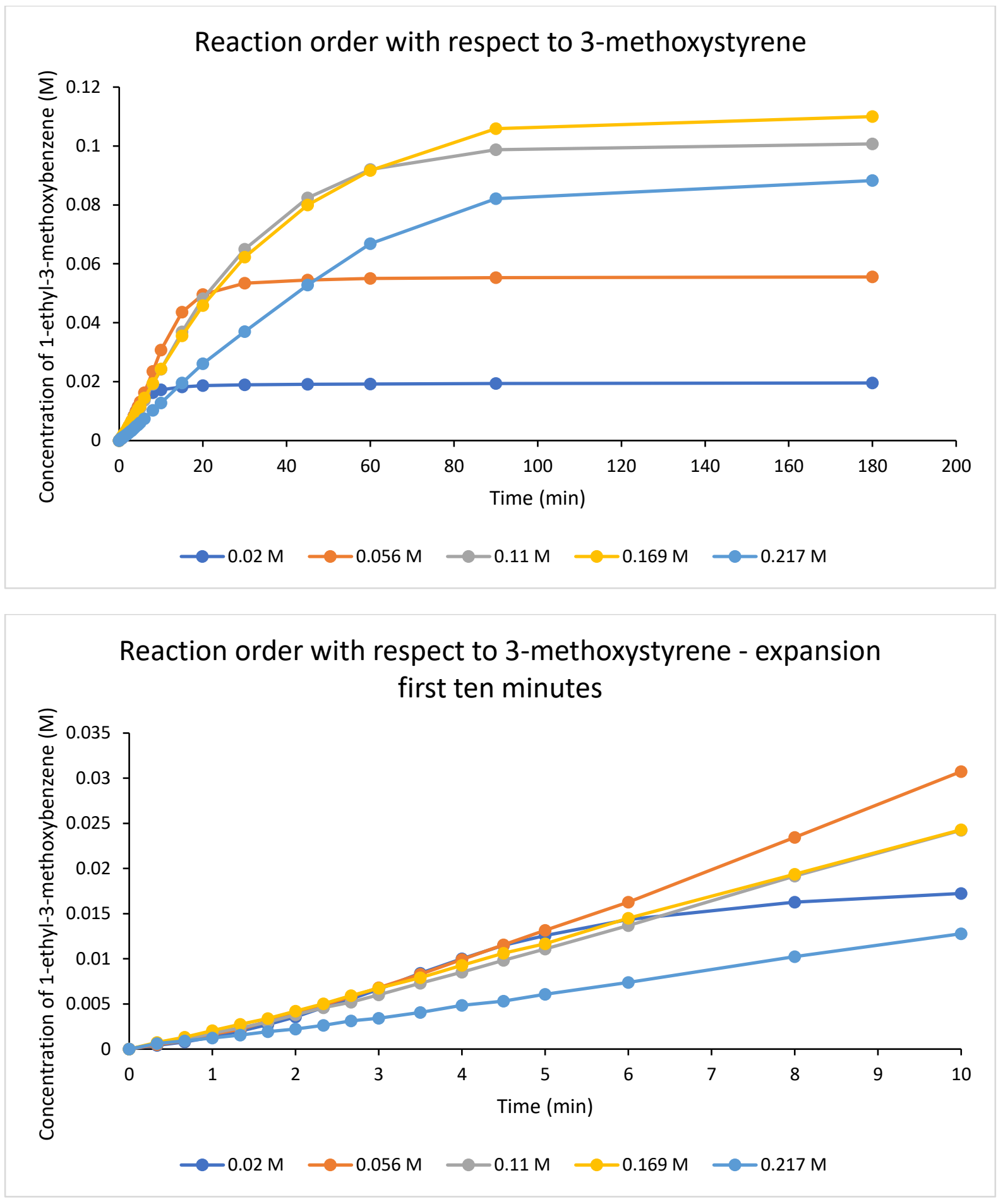

Reaction order with respect to ethylmagnesium bromide concentration

2,6-Bis-[1-(2,6-diisopropylphenylimino)ethyl]pyridine iron(II) chloride $(0.001 \mathrm{mmol}, 0.00025 \mathrm{M})$ and 3methoxystyrene $(0.44 \mathrm{mmol}, 0.11 \mathrm{M})$ were kept constant in all reactions. The concentration of ethylmagnesium bromide was varied in the range of 0.0125-0.15 $\mathrm{M}$. The data for product formation given is the concentration of 1-ethyl-3-methoxybenzene (M) formed in the reaction. 

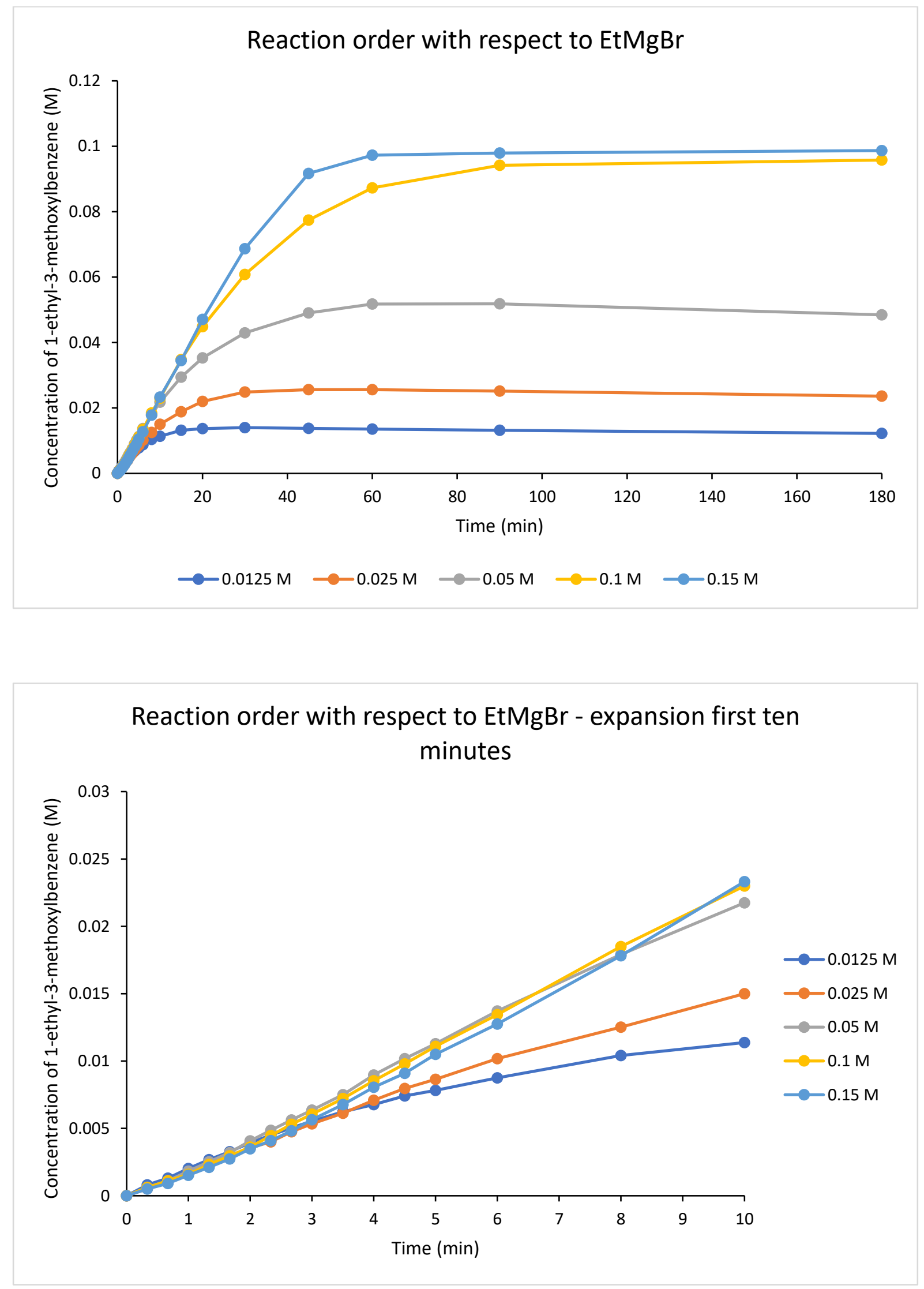


\section{General procedure}

Inhibition/Deactivation Studies: Same Excess Rate Profile Analysis

Experiments carried out as per general procedures described previously for 3-methoxy and 4-tertbutylstyrenes. The same procedure was used for 2-methoxystyrene. no side-products were observed and the mass balance could be accounted for by a combination of product (1-ethyl-2-methoxybenzene), ${ }^{13}$ and starting material (4-tert-butylstyrene). For clarity only yields of product (1-ethyl-4-tert-butylbenzene) are given in the tables below.

Starting concentrations of $0.075 ; 0.1$ and $0.125 \mathrm{M}$ were used for each styrene derivative. Ethyl magnesium bromide was used in $0.05 \mathrm{M}$ excess with respect to styrene derivative in all cases. 2,6-Bis-[1-(2,6diisopropylphenylimino)ethyl]pyridine iron(II) chloride was used at a concentration of $0.00025 \mathrm{M}$ for 4-tertbutylstyrene and 3-methoxystyrene and $0.000045 \mathrm{M}$ for 2-methoxystyrene. 1,3,5-Trimethoxybenzene $(0.02$ M) was kept constant across all reactions.

Fitting of functions to experimental data carried out in OriginLab ${ }^{\circledR}$ Origin 8.5.1. For 2-methoxy and 4-tertbutylstyrene the fitting was carried out on data obtained after the initial induction period ( $\geq 1$ minute). For 3-methoxystyrene the function was fitted to the entire data set.

Rate profiles were obtained by taking the first derivative of the function fitted to ethylbenzene formation over time. The rate was plotted against concentration of styrene, obtained by taking the concentration of ethylbenzene at each time point from the initial concentration of styrene. An accurate experimental value for the initial concentration of styrene was calculated from the total mass balance.

\section{2-Methoxystyrene:}

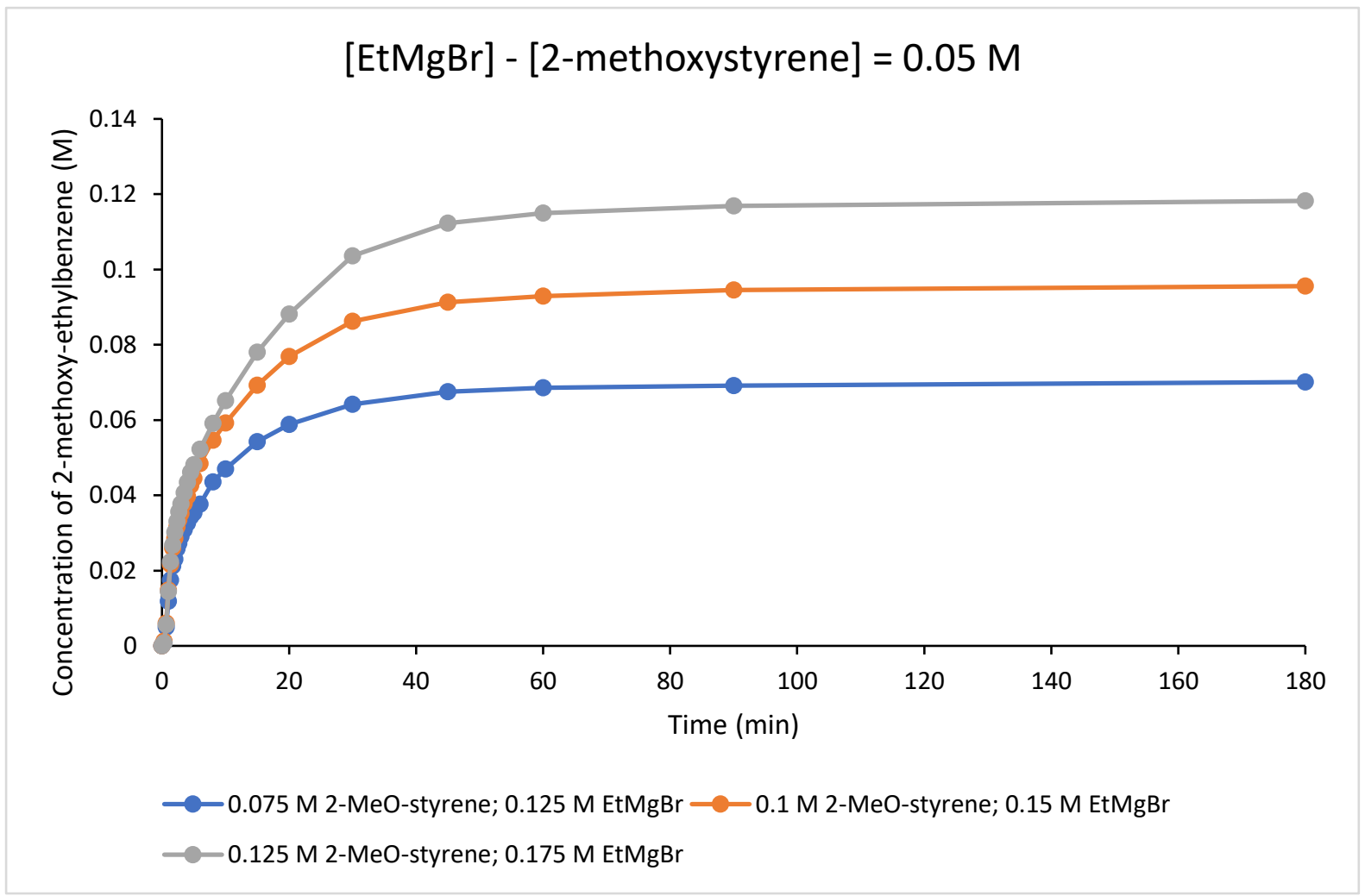


Example of fitting to data for 0.075 M 2-methoxystyrene; $0.125 \mathrm{M}$ EtMgBr:
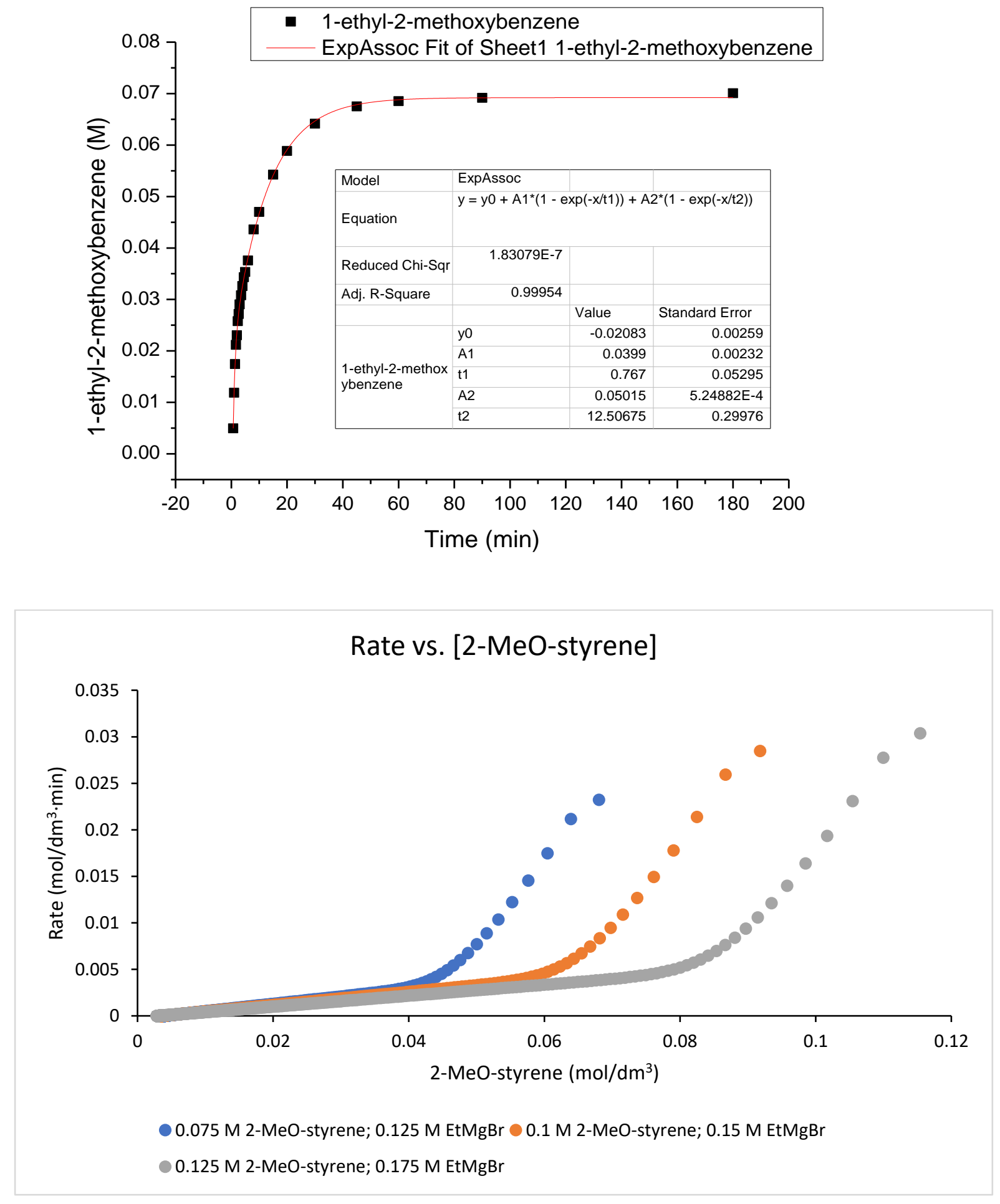

\section{4-tert-butylstyrene:}




\section{[EtMgBr] - [4-tert-butylstyrene] $=0.05 \mathrm{M}$}

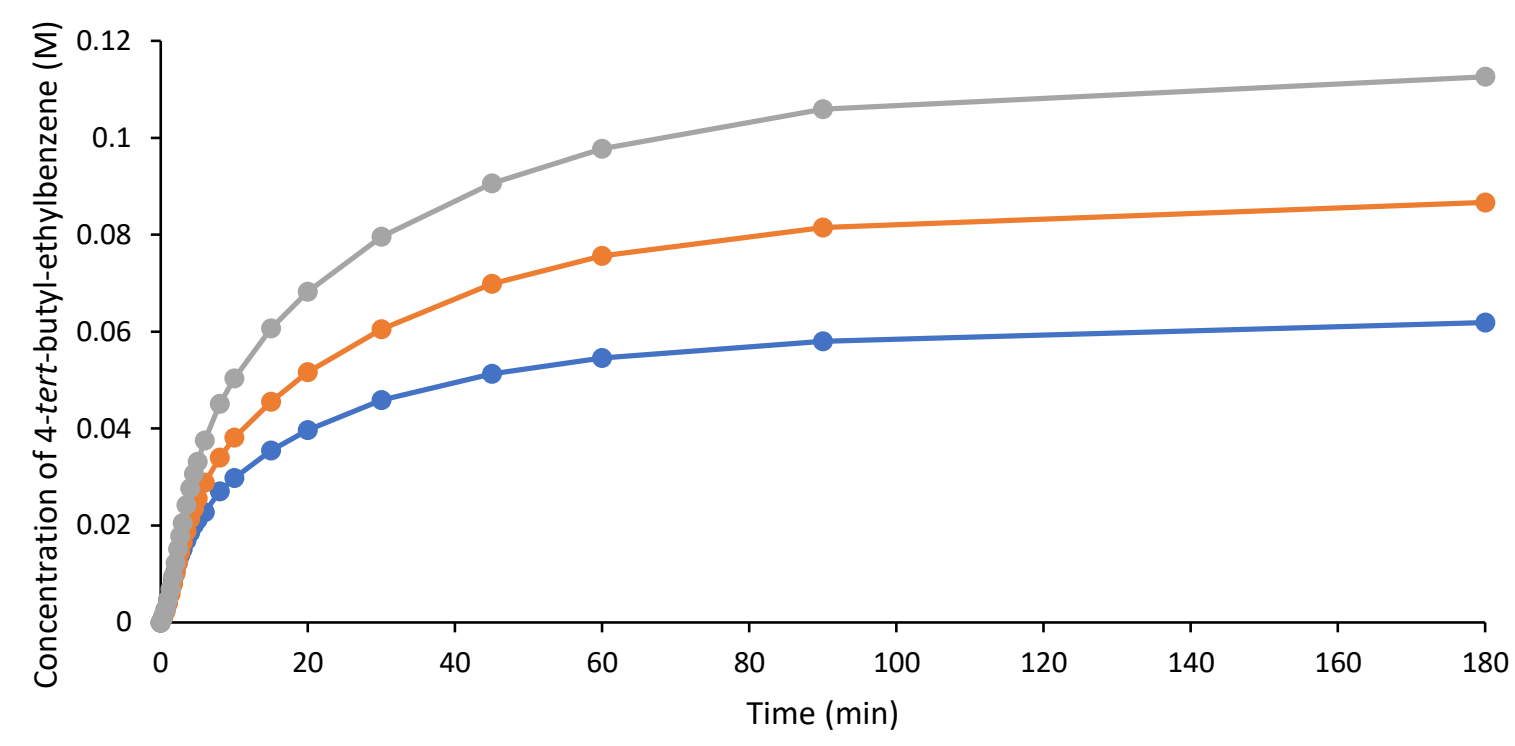

$\longrightarrow 0.075 \mathrm{M}$ 4-tBu-styrene; 0.125 M EtMgBr —0 0.1 M 4-tBu-styrene; 0.15 M EtMgBr

$\longrightarrow 0.125 \mathrm{M}$ 4-tBu-styrene; $0.175 \mathrm{M} \mathrm{EtMgBr}$

Example of fitting to data for 0.075 M 4-tert-butylstyrene; $0.125 \mathrm{M} \mathrm{EtMgBr:}$

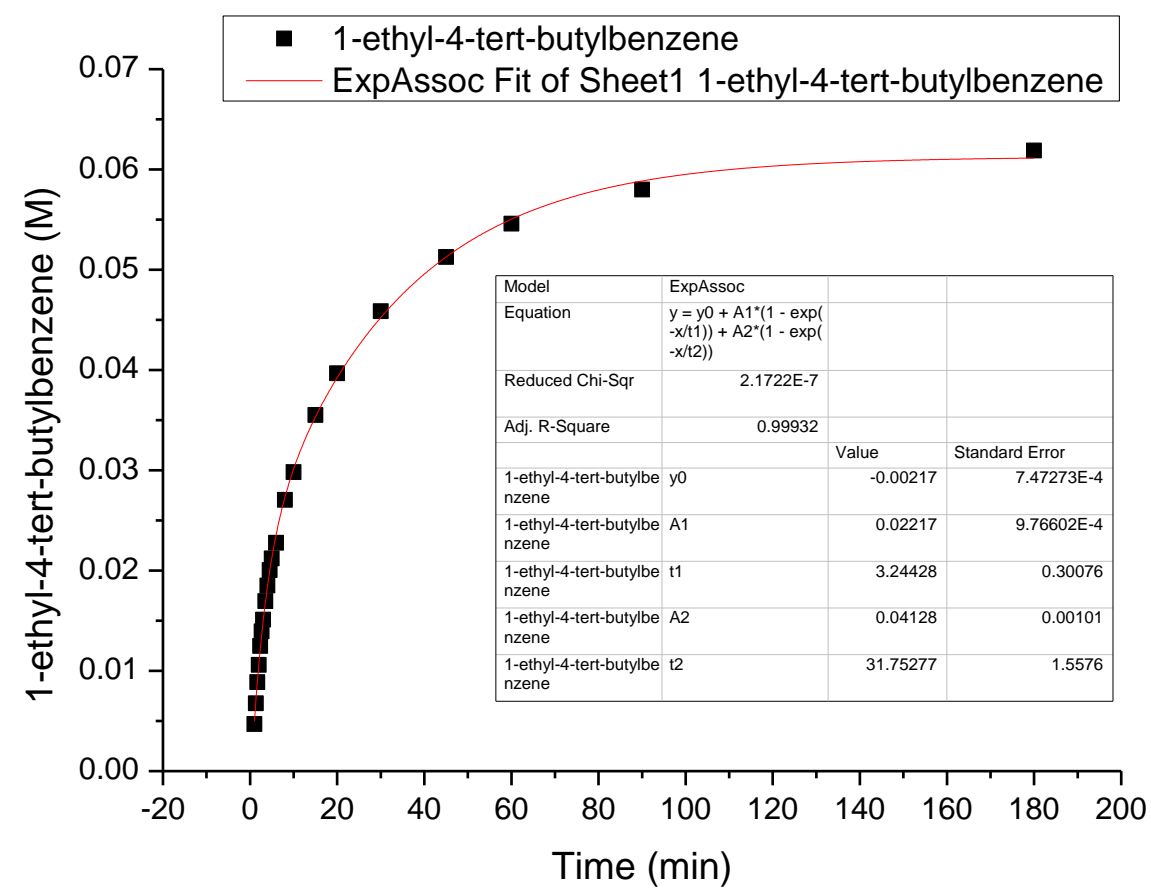




\section{Rate vs. [4-tBu-styrene]}

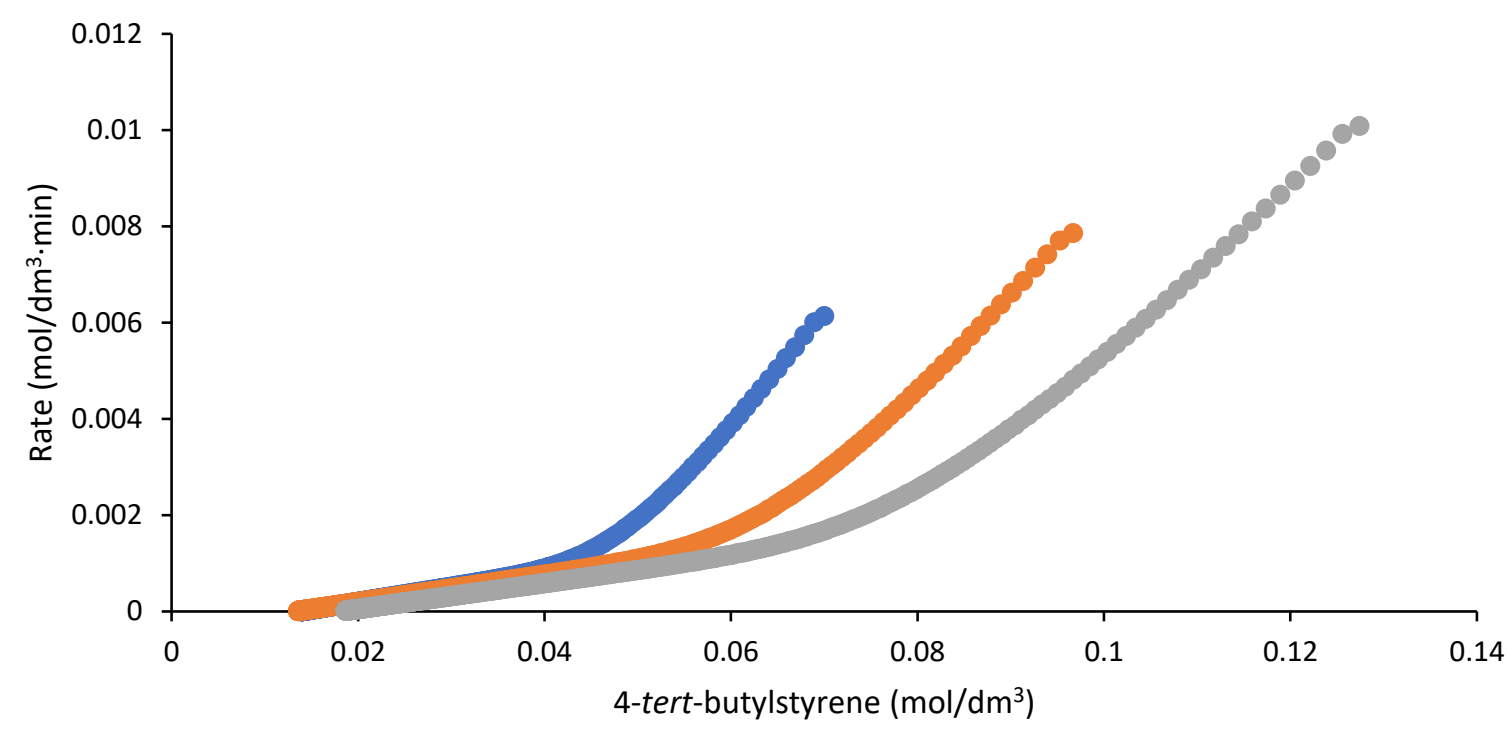

0.075 M 4-tBu-styrene; 0.125 M EtMgBr 0 0.1M 4-tBu-styrene; 0.15 M EtMgBr

0.125 M 4-tBu-styrene; 0.175 M EtMgBr

3-Methoxystyrene:

[EtMgBr] $-[3-$ methoxystyrene] $=0.05 \mathrm{M}$

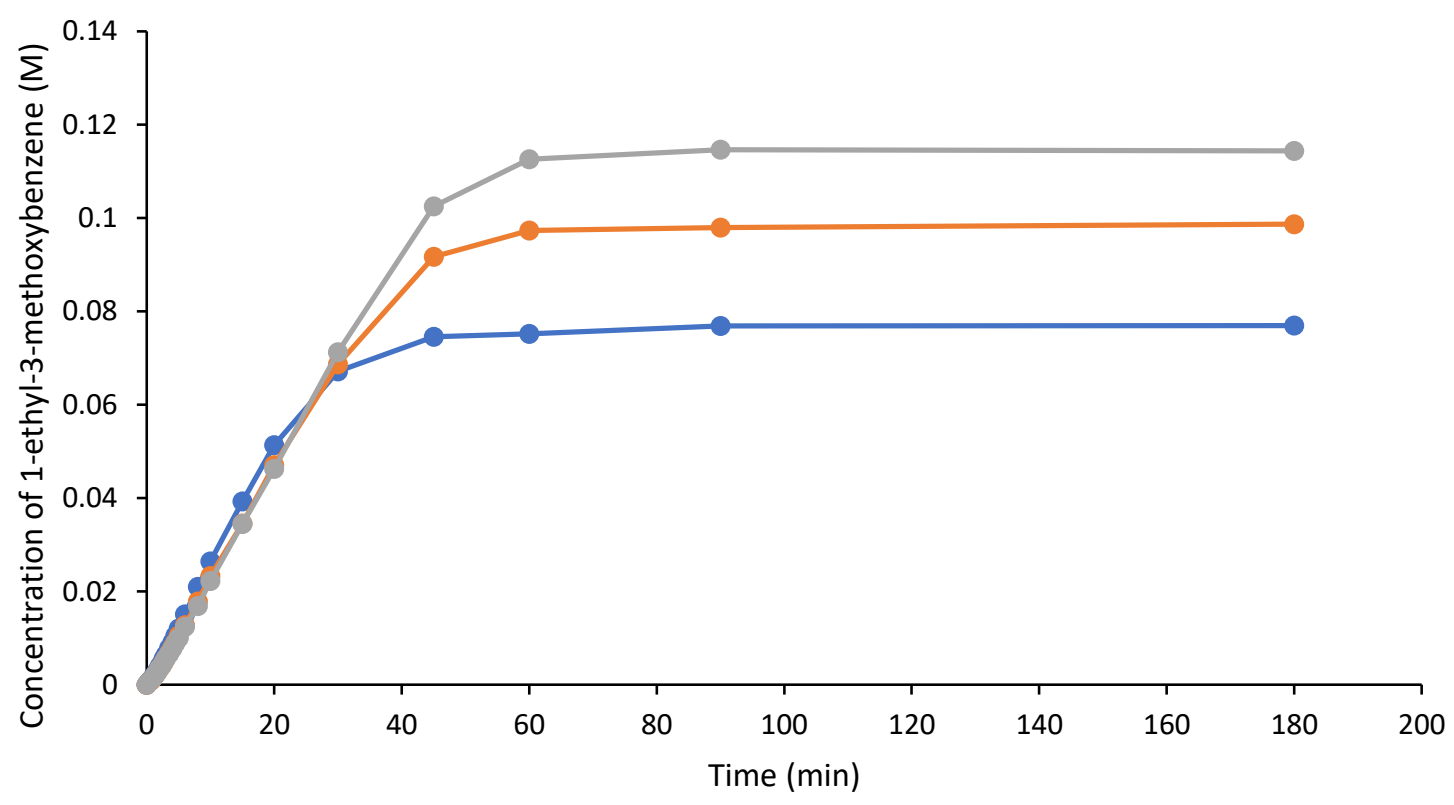

$\multimap 0.075 \mathrm{M}$ 3-MeO-styrene; 0.125 M EtMgBr —0 0.1 M 3-MeO-styrene; $0.15 \mathrm{M} \mathrm{EtMgBr}$

$-0.125 \mathrm{M}$ 3-MeO-styrene; $0.175 \mathrm{M} \mathrm{EtMgBr}$ 
Example of fitting to data for 0.075 M 3-methoxystyrene; $0.125 \mathrm{M} \mathrm{EtMgBr:}$
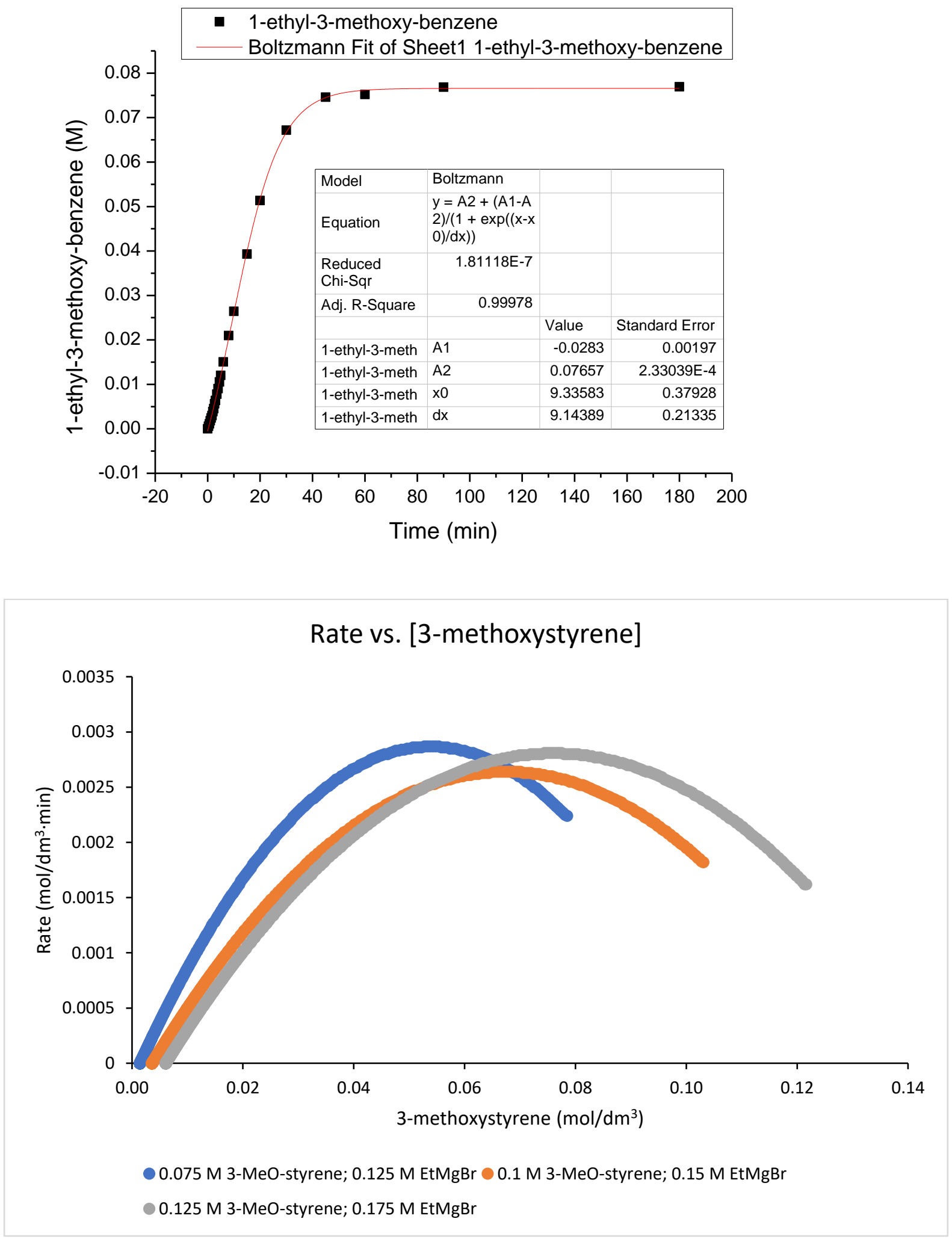


\section{4-TERT-BUTYLSTYRENE VS 3-METHOXYSTYRENE COMPETITION EXPERIMENT}

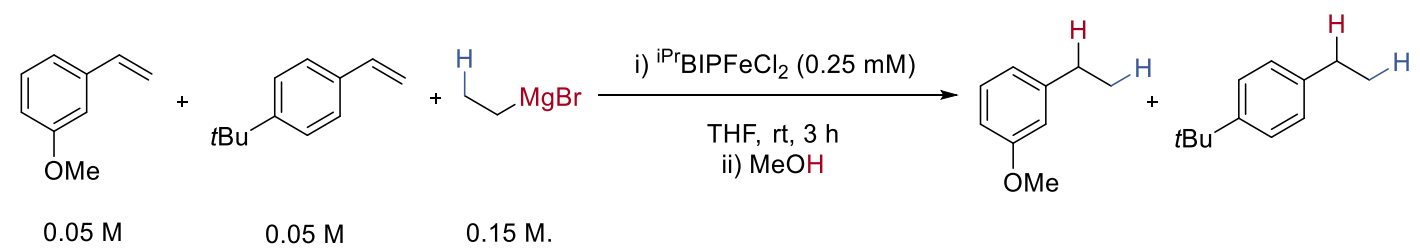

3-methoxystyrene $(0.4 \mathrm{~mL}, 0.5 \mathrm{M}$ in THF, $0.2 \mathrm{mmol})$ and 4-tert-butylstyrene $(0.25 \mathrm{~mL}, 0.8 \mathrm{M}$ in THF, 0.2 $\mathrm{mmol}$ ) were added to a solution 2,6-bis-[1-(2,6-diisopropylphenylimino)ethyl]pyridine iron(II) chloride (1 $\mathrm{mL}, 0.001 \mathrm{M}$ in THF, $0.001 \mathrm{mmol})$ and 1,3,5-trimethoxybenzene $(0.5 \mathrm{~mL}, 0.16 \mathrm{M}$ in THF, $0.08 \mathrm{mmol})$ in anhydrous tetrahydrofuran $(1.25 \mathrm{~mL})$. Ethylmagnesium bromide $(0.6 \mathrm{~mL}, 1 \mathrm{M}$ in THF, $0.6 \mathrm{mmol})$ was added in one portion, and the reaction was stirred at room temperature $\left(20-25^{\circ} \mathrm{C}\right)$. Aliquots $(<100 \mu \mathrm{L})$ were periodically removed and added to HPLC vials containing anhydrous methanol (approx. 10-15 $\mu \mathrm{L}$, 0.25-0.37 mmol). After all samples were taken, aqueous sulfate buffer (approx. $0.3 \mathrm{~mL}$ ) was added to each vial followed by diethyl ether (approx. $0.7 \mathrm{~mL}$ ). The vial was shaken and the layers were allowed to settle. The diethyl ether layer was removed and added to a $7 \mathrm{~mL}$ glass vial, from which the diethyl ether was allowed to evaporate at room temperature (approx. 10-15 min) until the majority of the solvent had evaporated (but was not thoroughly dry). The residue was dissolved in $\mathrm{CDCl}_{3}$ and added to an NMR tube for analysis by ${ }^{1} \mathrm{H}$ NMR spectroscopy.

The percentage yield of each product was determined by quantitative ${ }^{1} \mathrm{H}$ NMR spectroscopy, using $1,3,5-$ trimethoxybenzene $(20 \mathrm{~mol} \%)$ as an internal standard.

In these experiments, no side-products were observed and the mass balance could be accounted for by a combination of products (1-ethyl-3-methoxybenzene and 1-ethyl-4-tert-butylbenzene) $)^{25,26}$ and starting materials (3-methoxystyrene; 4-tert-butylstyrene). 


\section{3-MeO-Styrene vs. 4-tBu-Styrene Competition}

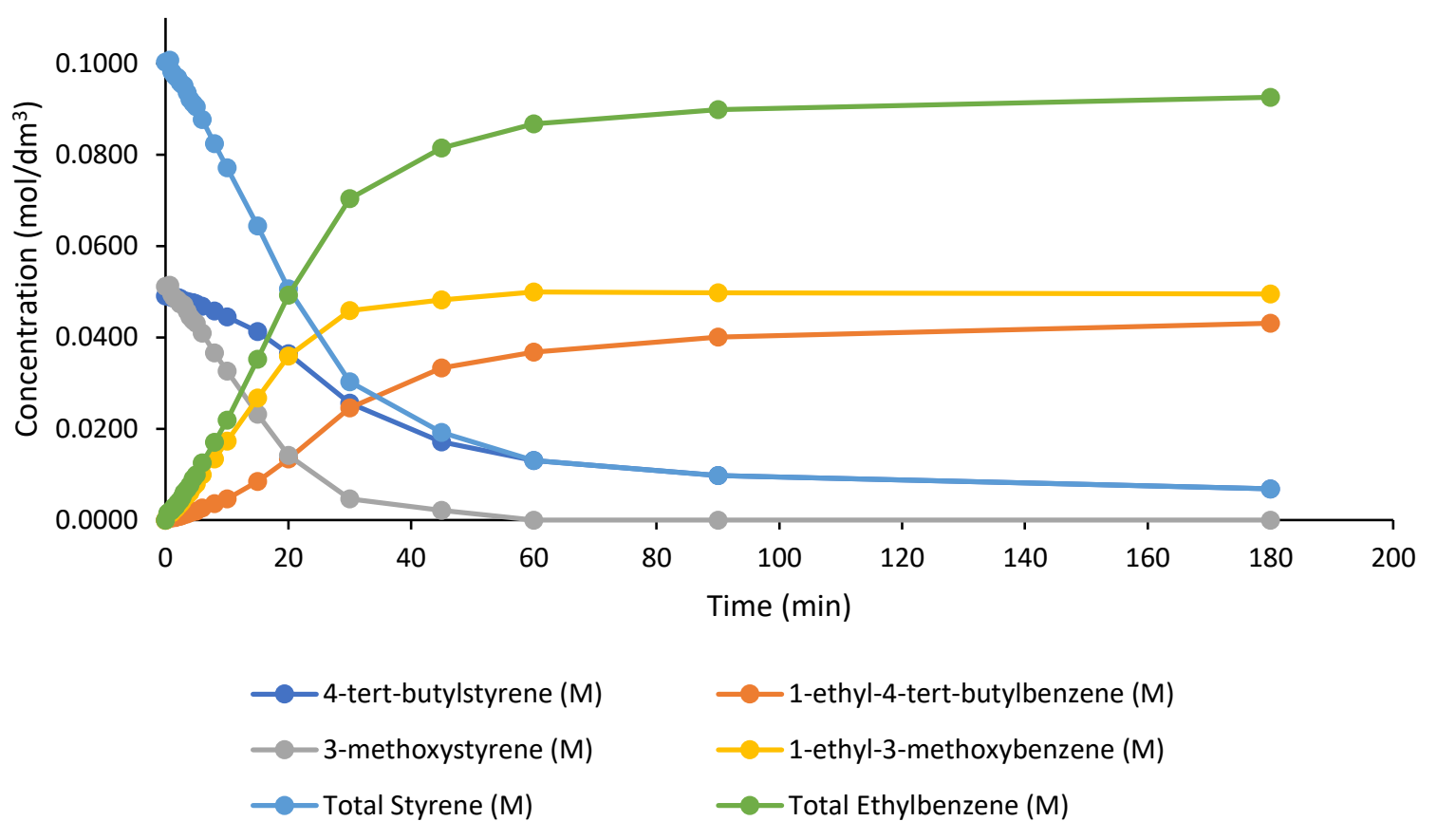

\section{RefERENCES}

(1) Greenhalgh, M. D.; Thomas, S. P. Iron-Catalyzed, Highly Regioselective Synthesis of $\alpha$-Aryl Carboxylic Acids from Styrene Derivatives and CO 2. J. Am. Chem. Soc. 2012, 134 (29), 11900-11903.

(2) Jones, A. S.; Paliga, J. F.; Greenhalgh, M. D.; Quibell, J. M.; Steven, A.; Thomas, S. P. Broad Scope Hydrofunctionalization of Styrene Derivatives Using Iron-Catalyzed Hydromagnesiation. Org. Lett. 2014, 16 (22), 5964-5967.

(3) Molander, G. A.; Brown, A. R. Suzuki-Miyaura Cross-Coupling Reactions of Potassium Vinyltrifluoroborate with Aryl and Heteroaryl Electrophiles. J. Org. Chem. 2006, 71 (26), 9681-9686.

(4) Sun, B.; Hoshino, J.; Jermihov, K.; Marler, L.; Pezzuto, J. M.; Mesecar, A. D.; Cushman, M. Design, Synthesis, and Biological Evaluation of Resveratrol Analogues as Aromatase and Quinone Reductase 2 Inhibitors for Chemoprevention of Cancer. Bioorg. Med. Chem. 2010, 18 (14), 53525366.

(5) Franck, G.; Brill, M.; Helmchem, G. Dibenzo[a,e]Cyclooctene: Multi-Gram Synthesis of a Bidentate Ligand. Org. Synth. 2012, 89, 55.

(6) Small, B. L.; Brookhart, M.; Bennett, A. M. A. Highly Active Iron and Cobalt Catalysts for the Polymerization of Ethylene. J. Am. Chem. Soc. 1998, 120 (16), 4049-4050.

(7) Esteruelas, M. A.; López, A. M.; Méndez, L.; Oliván, M.; Oñate, E. Preparation, Structure, and Ethylene Polymerization Behavior of Bis(Imino)Pyridyl Chromium(III) Complexes. Organometallics 2003, 22 (3), 395-406.

(8) Fuchs, C. S.; Hollauf, M.; Meissner, M.; Simon, R. C.; Besset, T.; Reek, J. N. H.; Riethorst, W.; Zepeck, F.; Kroutil, W. Dynamic Kinetic Resolution of 2-Phenylpropanal Derivatives to Yield $\beta$ Chiral Primary Amines via Bioamination. Adv. Synth. Catal. 356 (10), 2257-2265.

(9) Chen, M.; Wang, J.; Chai, Z.; You, C.; Lei, A. C $\square \mathrm{X}(\mathrm{X}=\mathrm{Br}, \mathrm{I})$ Bond-Tolerant Aerobic Oxidative 
Cross- Coupling: A Strategy to Selectively Construct $\beta$-Aryl Ketones and Aldehydes. Adv. Synth. Catal. 354 (2-3), 341-346.

(10) Carter, T. S.; Guiet, L.; Frank, D. J.; West, J.; Thomas, S. P. Iron-Catalysed Reduction of Olefins Using a Borohydride Reagent. Adv. Synth. Catal. 355 (5), 880-884.

(11) Tietze, L. F.; Vock, C. A.; Krimmelbein, I. K.; Nacke, L. Synthesis of Novel Structurally Simplified Estrogen Analogues with Electron-Donating Groups in Ring A. Synthesis (Stuttg). 2009, 2009 (12), 2040-2060.

(12) Sakai, N.; Nagasawa, K.; Ikeda, R.; Nakaike, Y.; Konakahara, T. InBr3-Catalyzed Reduction of Ketones with a Hydrosilane: Deoxygenation of Aromatic Ketones and Selective Synthesis of Secondary Alcohols and Symmetrical Ethers from Aliphatic Ketones. Tetrahedron Lett. 2011, 52 (24), 3133-3136.

(13) Wang, H.; Li, L.; Bai, X.-F.; Shang, J.-Y.; Yang, K.-F.; Xu, L.-W. Efficient Palladium-Catalyzed $\mathrm{C} \square \mathrm{O}$ Hydrogenolysis of Benzylic Alcohols and Aromatic Ketones with Polymethylhydrosiloxane. Adv. Synth. Catal. 2013, 355 (2-3), n/a-n/a.

(14) Brown, H. C.; Okamoto, Y. Electrophilic Substituent Constants. J. Am. Chem. Soc. 1958, 80 (18), 4979-4987.

(15) Dust, J. M.; Arnold, D. R. Substituent Effects on Benzyl Radical ESR Hyperfine Coupling Constants. The .Sigma..Alpha..Cntdot. Scale Based upon Spin Delocalization. J. Am. Chem. Soc. 1983, 105 (5), 1221-1227.

(16) Dust, J.; Arnold, D. Additions and Corrections - Substituent Effects on Benzyl Radical ESR Hyperfine Coupling Constants. The $\Sigma \alpha \cdot$ Scale Based upon Spin Delocalization. J. Am. Chem. Soc. 1983, 105 (21), 6531.

(17) Wayner, D. D. M.; Arnold, D. R. Substituent Effects on Benzyl Radical Hyperfine Coupling Constants. Part 2. The Effect of Sulphur Substituents. Can. J. Chem. 1984, 62 (6), 1164-1168.

(18) Jiang, X.-K. Establishment and Successful Application of the $\Sigma \mathrm{JJ} \bullet$ Scale of Spin-Delocalization Substituent Constants. Acc. Chem. Res. 1997, 30 (7), 283-289.

(19) Creary, X. Rearrangement of 2-Aryl-3,3-Dimethylmethylenecyclopropanes. Substituent Effects on a Nonpolar Radical-like Transition State. J. Org. Chem. 1980, 45 (2), 280-284.

(20) Creary, X.; Mehrsheikh-Mohammadi, M. E.; McDonald, S. Methylenecyclopropane Rearrangement as a Probe for Free Radical Substituent Effects. Sigma..Bul. Values for Commonly Encountered Conjugating and Organometallic Groups. J. Org. Chem. 1987, 52 (15), 3254-3263.

(21) Bézier, D.; Park, S.; Brookhart, M. Selective Reduction of Carboxylic Acids to Aldehydes Catalyzed by B(C6F5)3. Org. Lett. 2013, 15 (3), 496-499.

(22) Straub, A. T.; Otto, M.; Usui, I.; Breit, B. Room Temperature Ambient Pressure (RTAP)Hydroformylation in Water Using a Self-Assembling Ligand. Adv. Synth. Catal. 355 (10), 2071-2075.

(23) Schuerch, C.; Frechet, J. M. Solid-Phase Synthesis of Oligosaccharides. I. Preparation of the Solid Support. Poly[p-(1-Propen-3-Ol-1-Yl)Styrene]. J. Am. Chem. Soc. 1971, 93 (2), 492-496.

(24) Collman, J. P.; Kosydar, K. M.; Bressan, M.; Lamanna, W.; Garrett, T. Polymer-Bound Substrates: A Method to Distinguish between Homogeneous and Heterogeneous Catalysis. J. Am. Chem. Soc. 1984, 106 (9), 2569-2579.

(25) MacNair, A. J.; Tran, M.-M.; Nelson, J. E.; Sloan, G. U.; Ironmonger, A.; Thomas, S. P. IronCatalysed, General and Operationally Simple Formal Hydrogenation Using Fe(OTf)3 and NaBH4. Org. Biomol. Chem. 2014, 12 (28), 5082-5088. 
(26) Hilborn, J. W.; MacKnight, E.; Pincock, J. A.; Wedge, P. J. Photochemistry of Substituted Benzyl Acetates and Benzyl Pivalates: A Reinvestigation of Substituent Effects. J. Am. Chem. Soc. 1994, 116 (8), 3337-3346.

(27) Uccello-Barretta, G.; Lazzaroni, R.; Settambolo, R.; Salvadori, P. The Use of 2H NMR in the Elucidation of the Catalytic Pathway of the Hydroformylation Reaction. J. Organomet. Chem. 1991, $417(1), 111-119$.

(28) Winter, G.; Thompson, D. W.; Loehe, J. R. Iron(II) Halides. In Inorganic Syntheses; John Wiley \& Sons, Inc., 1973; pp 99-104.

(29) Bart, S. C.; Chłopek, K.; Bill, E.; Bouwkamp, M. W.; Lobkovsky, E.; Neese, F.; Wieghardt, K.; Chirik, P. J. Electronic Structure of Bis(Imino)Pyridine Iron Dichloride, Monochloride, and Neutral Ligand Complexes: A Combined Structural, Spectroscopic, and Computational Study. J. Am. Chem. Soc. 2006, 128 (42), 13901-13912. 
REFERENCE NUMBER: neipn01

CRYSTAL STRUCTURE REPORT

$\mathrm{C}_{67} \mathrm{H}_{112} \mathrm{Br}_{0.67} \mathrm{Cl}_{0.33} \mathrm{Fe} \mathrm{Mg} \mathrm{N} \mathrm{O}_{7.5}$

or

$\left[\mathrm{MgBr}_{0.67} \mathrm{Cl}_{0.33}(\mathrm{THF})_{5}\right]\left[(\mathrm{DIMPY}) \mathrm{Fe}(\mathrm{Et})\left(\mathrm{H}_{2} \mathrm{C}=\mathrm{CH}_{2}\right)\right] \cdot 2.5 \mathrm{THF}$

Report prepared for:

P. Neate, Prof. M. Neidig

June 13, 2016

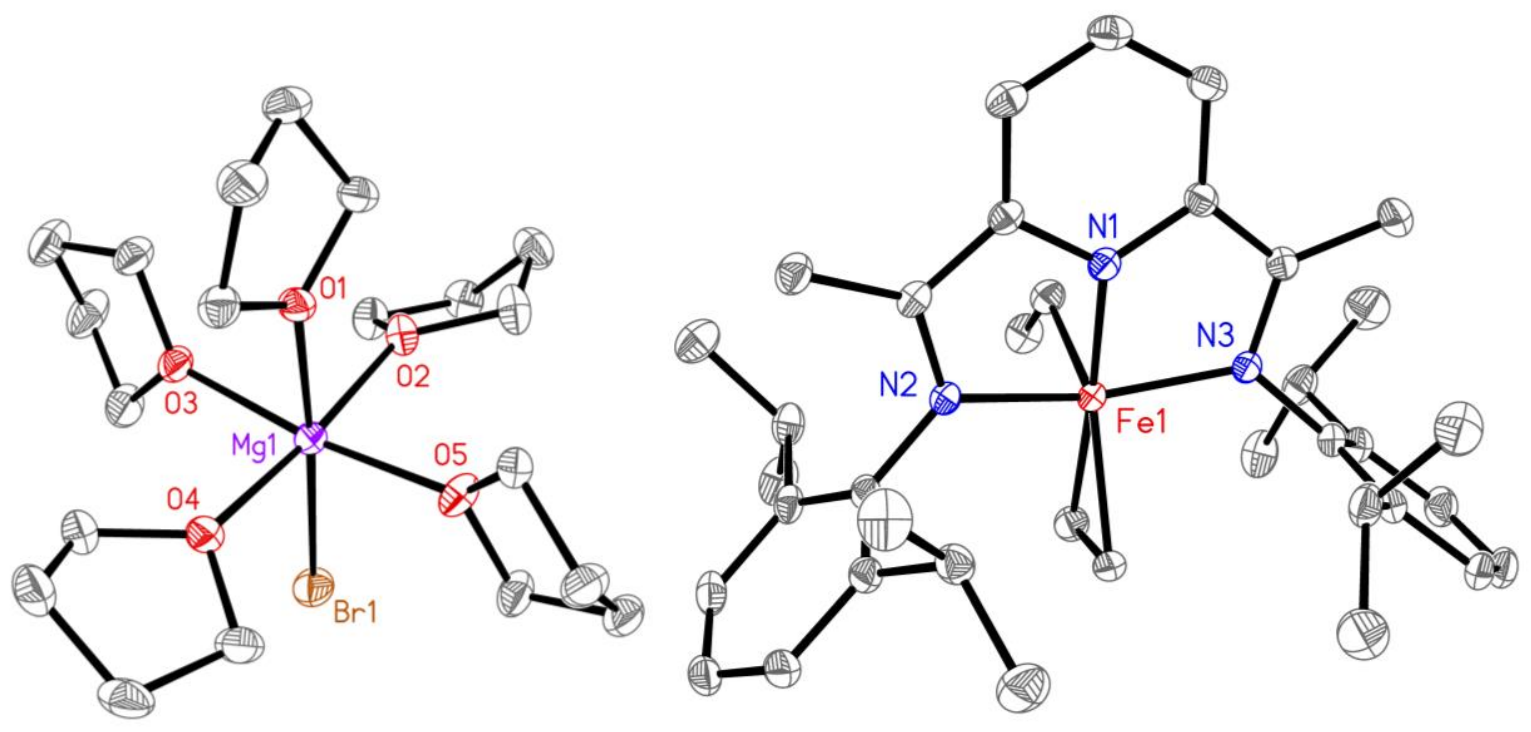

William W. Brennessel

X-ray Crystallographic Facility

Department of Chemistry, University of Rochester

120 Trustee Road

Rochester, NY 14627 


\section{Data collection}

A crystal $\left(0.48 \times 0.16 \times 0.16 \mathrm{~mm}^{3}\right)$ was placed onto the tip of a thin glass optical fiber and mounted on a Bruker SMART APEX II CCD platform diffractometer for a data collection at $100.0(5) \mathrm{K}^{1}{ }^{1}$ A preliminary set of cell constants and an orientation matrix were calculated from reflections harvested from three orthogonal wedges of reciprocal space. The full data collection was carried out using MoK $\alpha$ radiation (graphite monochromator) with a frame time of 45 seconds and a detector distance of $4.01 \mathrm{~cm}$. A randomly oriented region of reciprocal space was surveyed: five major sections of frames were collected with $0.50^{\circ}$ steps in $\omega$ at five different $\phi$ settings and a detector position of $-38^{\circ}$ in $2 \theta$. The intensity data were corrected for absorption. ${ }^{2}$ Final cell constants were calculated from the xyz centroids of 3719 strong reflections from the actual data collection after integration. ${ }^{3}$ See Table 1 for additional crystal and refinement information.

\section{Structure solution and refinement}

The structure was solved using SHELXT-2014/5 ${ }^{4}$ and refined using SHELXL-2014/7. ${ }^{5}$ The space group $P 2{ }_{1} / n$ was determined based on systematic absences. A direct-methods solution was calculated which provided most nonhydrogen atoms from the E-map. Full-matrix least squares / difference Fourier cycles were performed which located the remaining non-hydrogen atoms. All non-hydrogen atoms were refined with anisotropic displacement parameters. The hydrogen atoms on the coordinated ethylene ligand were found from the difference Fourier map and refined freely to confirm their existence and positions. All other hydrogen atoms were placed in ideal positions and refined as riding atoms with relative isotropic displacement parameters. The final full matrix least squares refinement converged to $R 1=0.0502\left(F^{2}, I>2 \sigma(I)\right)$ and $w R 2=0.1224\left(F^{2}\right.$, all data).

\section{Structure description}

The structure is the one suggested. The asymmetric unit contains one monoanionic iron complex, one monocationic magnesium complex, and two cocrystallized THF solvent molecules, all in general positions, and one half of an additional THF solvent molecule located at a crystallographic inversion center. The halido ligand on the cation is modeled as a site disorder of $\mathrm{Br}$ and $\mathrm{Cl}$ (0.67:0.33, respectively). Two THF molecules on the cation are modeled as disordered over two positions each (0.69:0.31 and 0.51:0.49). One uncoordinated THF solvent molecule is modeled as disordered over a crystallographic inversion center (0.50:0.50) and additionally over two general positions $(0.56: 0.44)$.

Unless noted otherwise all structural diagrams containing thermal displacement ellipsoids are drawn at the $50 \%$ probability level.

Data collection, structure solution, and structure refinement were conducted at the X-ray Crystallographic Facility, B51 Hutchison Hall, Department of Chemistry, University of Rochester. All publications arising from this report 
MUST either 1) include William W. Brennessel as a coauthor or 2) acknowledge William W. Brennessel and the Xray Crystallographic Facility of the Department of Chemistry at the University of Rochester.

1 APEX3, version 2015.9-0; Bruker AXS: Madison, WI, 2015.

2 Sheldrick, G. M. SADABS, version 2014/5; J. Appl. Cryst. 2015, 48, 3-10.

3 SAINT, version 8.34A; Bruker AXS: Madison, WI, 2013.

4 Sheldrick, G. M. SHELXT-2014/5; University of Göttingen: Göttingen, Germany, 2014.

5 Sheldrick, G. M. SHELXL-2014/7; Acta. Cryst. 2015, C71, 3-8.

Some equations of interest:

$$
\begin{gathered}
R_{\mathrm{int}}=\Sigma\left|F_{\mathrm{o}}{ }^{2}-\left\langle F_{\mathrm{o}}{ }^{2}\right\rangle\right| / \Sigma\left|F_{\mathrm{o}}{ }^{2}\right| \\
R 1=\Sigma\left\|F_{\mathrm{o}}|-| F_{\mathrm{c}}\right\| / \Sigma\left|F_{\mathrm{o}}\right| \\
w R 2=\left[\Sigma\left[w\left(F_{\mathrm{o}}{ }^{2}-F_{\mathrm{c}}{ }^{2}\right)^{2}\right] / \Sigma\left[w\left(F_{\mathrm{o}}{ }^{2}\right)^{2}\right]\right]^{1 / 2} \\
\text { where } w=1 /\left[\sigma^{2}\left(F_{\mathrm{o}}{ }^{2}\right)+(a P)^{2}+b P\right] \text { and } \\
P=1 / 3 \max \left(0, F_{\mathrm{o}}{ }^{2}\right)+2 / 3 F_{\mathrm{c}}{ }^{2} \\
\mathrm{GOF}=S=\left[\Sigma\left[w\left(F_{\mathrm{o}}{ }^{2} F_{\mathrm{c}}{ }^{2}\right)^{2}\right] /(m-n)\right]^{1 / 2}
\end{gathered}
$$

where $m=$ number of reflections and $n=$ number of parameters

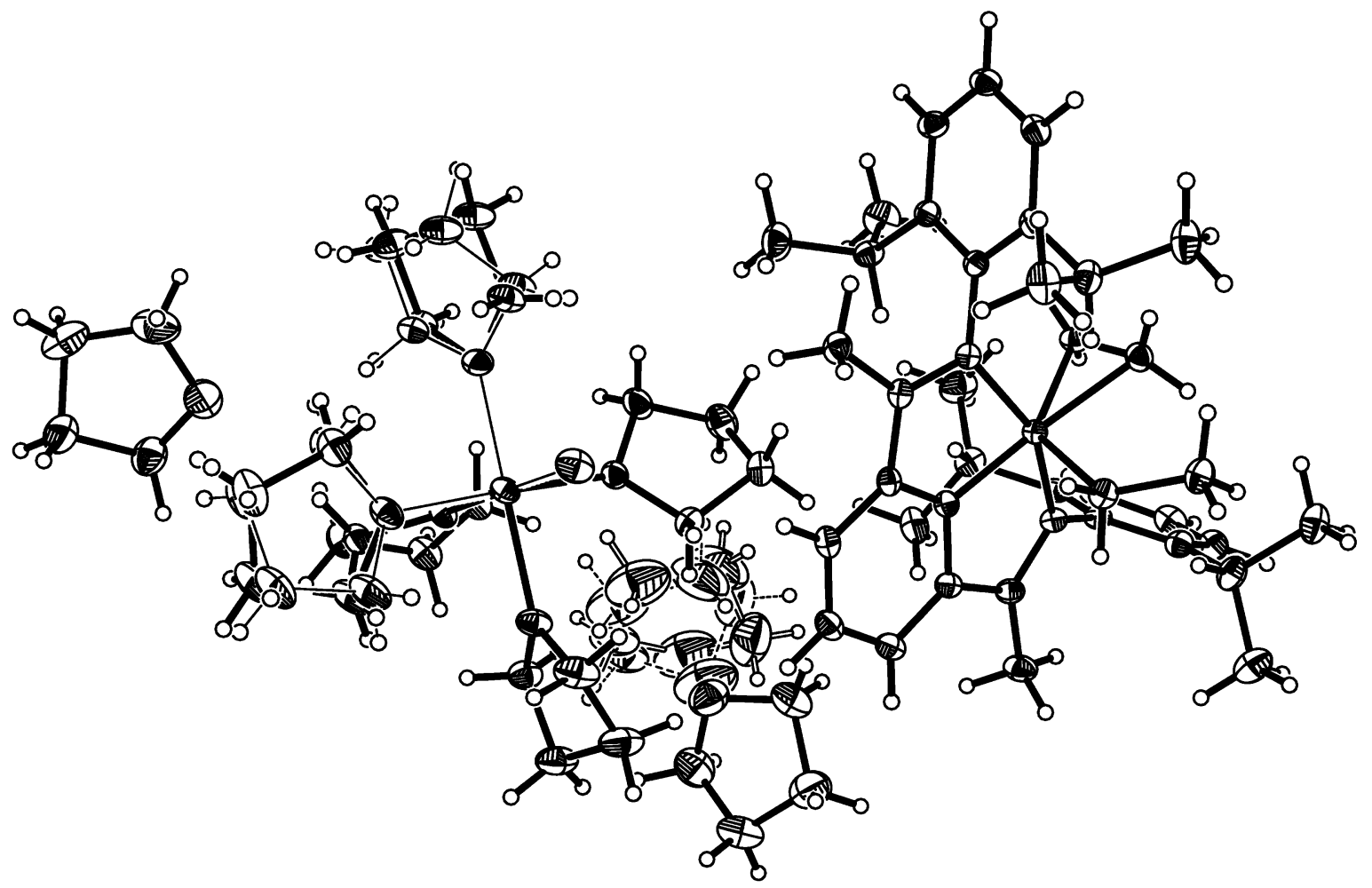



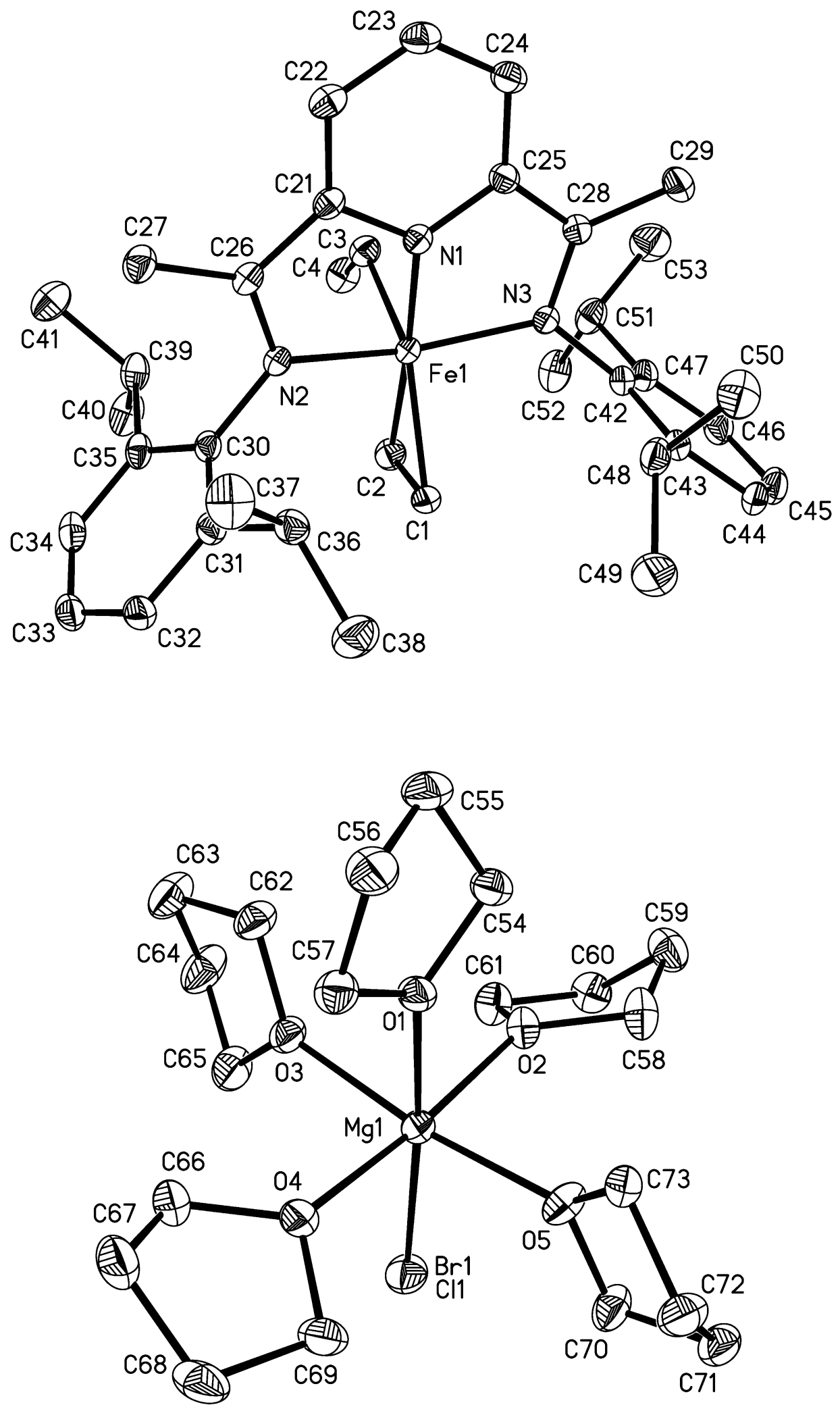
Table 1. Crystal data and structure refinement for neipn01.

\begin{tabular}{|c|c|c|}
\hline Identification code & \multicolumn{2}{|l|}{ neipn01 } \\
\hline Empirical formula & \multicolumn{2}{|c|}{ C67 H112 Br0.67 Cl0.33 Fe Mg N3 O7.50 } \\
\hline Formula weight & \multicolumn{2}{|l|}{1224.99} \\
\hline Temperature & \multicolumn{2}{|l|}{$100.0(5) \mathrm{K}$} \\
\hline Wavelength & \multicolumn{2}{|l|}{$0.71073 \AA$} \\
\hline Crystal system & \multicolumn{2}{|l|}{ monoclinic } \\
\hline Space group & \multicolumn{2}{|l|}{$P 2{ }_{1} / n$} \\
\hline \multirow[t]{3}{*}{ Unit cell dimensions } & $a=11.4045(18) \AA$ & $\alpha=90^{\circ}$ \\
\hline & $b=22.533(4) \AA$ & $\beta=99.122(3)^{\circ}$ \\
\hline & $c=26.176(4) \AA$ & $\gamma=90^{\circ}$ \\
\hline Volume & \multicolumn{2}{|l|}{$6641.8(18) \AA^{3}$} \\
\hline$Z$ & \multicolumn{2}{|l|}{4} \\
\hline Density (calculated) & \multicolumn{2}{|l|}{$1.225 \mathrm{Mg} / \mathrm{m}^{3}$} \\
\hline Absorption coefficient & \multicolumn{2}{|l|}{$0.706 \mathrm{~mm}^{-1}$} \\
\hline$F(000)$ & \multicolumn{2}{|l|}{2648} \\
\hline Crystal color, morphology & \multicolumn{2}{|l|}{ yellow-brown, block } \\
\hline Crystal size & \multicolumn{2}{|c|}{$0.48 \times 0.16 \times 0.16 \mathrm{~mm}^{3}$} \\
\hline Theta range for data collection & \multicolumn{2}{|l|}{1.807 to $33.762^{\circ}$} \\
\hline Index ranges & \multicolumn{2}{|c|}{$-17 \leq h \leq 17,-35 \leq k \leq 35,-40 \leq l \leq 40$} \\
\hline Reflections collected & \multicolumn{2}{|l|}{149257} \\
\hline Independent reflections & \multicolumn{2}{|c|}{$26483[R($ int $)=0.0801]$} \\
\hline Observed reflections & \multicolumn{2}{|l|}{17987} \\
\hline Completeness to theta $=33.729^{\circ}$ & \multicolumn{2}{|l|}{$99.8 \%$} \\
\hline Absorption correction & \multicolumn{2}{|l|}{ Multi-scan } \\
\hline Max. and min. transmission & \multicolumn{2}{|l|}{0.7467 and 0.5750} \\
\hline Refinement method & \multicolumn{2}{|c|}{ Full-matrix least-squares on $F^{2}$} \\
\hline Data / restraints / parameters & \multicolumn{2}{|l|}{$26483 / 82 / 812$} \\
\hline Goodness-of-fit on $F^{2}$ & \multicolumn{2}{|l|}{1.021} \\
\hline Final $R$ indices $[I>2 \operatorname{sigma}(I)]$ & \multicolumn{2}{|c|}{$R 1=0.0502, w R 2=0.1084$} \\
\hline$R$ indices (all data) & \multicolumn{2}{|c|}{$R 1=0.0884, w R 2=0.1224$} \\
\hline Largest diff. peak and hole & \multicolumn{2}{|c|}{0.978 and -0.604 e. $\AA^{-3}$} \\
\hline
\end{tabular}


Table 2. Atomic coordinates (x $\left.10^{4}\right)$ and equivalent isotropic displacement parameters $\left(\AA^{2} \times 10^{3}\right)$ for neipn01. $U_{e q}$ is defined as one third of the trace of the orthogonalized $U_{i j}$ tensor.

\begin{tabular}{|c|c|c|c|c|}
\hline & $\mathrm{x}$ & $\mathrm{y}$ & $\mathrm{z}$ & $\mathrm{U}_{\mathrm{eq}}$ \\
\hline $\mathrm{Fe} 1$ & 111(1) & $7382(1)$ & 6915(1) & $14(1)$ \\
\hline N1 & $236(1)$ & $7520(1)$ & 6231(1) & $16(1)$ \\
\hline $\mathrm{N} 2$ & $917(1)$ & $8142(1)$ & 6979(1) & $15(1)$ \\
\hline N3 & $-321(1)$ & $6608(1)$ & $6629(1)$ & $16(1)$ \\
\hline $\mathrm{C} 1$ & $932(1)$ & 7067(1) & 7616(1) & $18(1)$ \\
\hline $\mathrm{C} 2$ & $-204(2)$ & $7282(1)$ & 7661(1) & $20(1)$ \\
\hline C3 & $-1596(1)$ & $7722(1)$ & $6717(1)$ & $20(1)$ \\
\hline $\mathrm{C} 4$ & $-2514(1)$ & $7780(1)$ & 7079(1) & $25(1)$ \\
\hline $\mathrm{C} 21$ & $575(1)$ & $8077(1)$ & $6087(1)$ & $16(1)$ \\
\hline $\mathrm{C} 22$ & 494(1) & $8222(1)$ & $5562(1)$ & 19(1) \\
\hline $\mathrm{C} 23$ & $25(1)$ & 7808(1) & $5189(1)$ & $21(1)$ \\
\hline $\mathrm{C} 24$ & $-361(1)$ & $7252(1)$ & $5335(1)$ & $21(1)$ \\
\hline $\mathrm{C} 25$ & $-254(1)$ & 7113(1) & $5864(1)$ & $17(1)$ \\
\hline $\mathrm{C} 26$ & $1005(1)$ & $8422(1)$ & $6525(1)$ & $16(1)$ \\
\hline $\mathrm{C} 27$ & 1548(1) & $9023(1)$ & 6471(1) & $21(1)$ \\
\hline $\mathrm{C} 28$ & $-545(1)$ & $6584(1)$ & 6102(1) & $18(1)$ \\
\hline $\mathrm{C} 29$ & $-1014(2)$ & $6050(1)$ & $5788(1)$ & $25(1)$ \\
\hline $\mathrm{C} 30$ & $1506(1)$ & $8422(1)$ & 7443(1) & $16(1)$ \\
\hline C31 & $2726(1)$ & $8309(1)$ & $7608(1)$ & $17(1)$ \\
\hline C32 & $3303(2)$ & $8592(1)$ & $8051(1)$ & $21(1)$ \\
\hline C33 & $2705(2)$ & $8978(1)$ & $8330(1)$ & $23(1)$ \\
\hline C34 & $1510(2)$ & 9083(1) & $8170(1)$ & $22(1)$ \\
\hline $\mathrm{C} 35$ & $886(1)$ & $8808(1)$ & $7727(1)$ & $18(1)$ \\
\hline C36 & $3432(1)$ & $7905(1)$ & 7302(1) & $20(1)$ \\
\hline C37 & $4247(2)$ & $8278(1)$ & 7016(1) & $32(1)$ \\
\hline C38 & $4183(2)$ & $7450(1)$ & 7644(1) & $32(1)$ \\
\hline C39 & $-417(1)$ & $8945(1)$ & $7556(1)$ & $22(1)$ \\
\hline $\mathrm{C} 40$ & $-1116(2)$ & $8948(1)$ & $8010(1)$ & $30(1)$ \\
\hline $\mathrm{C} 41$ & $-592(2)$ & $9539(1)$ & $7268(1)$ & $29(1)$ \\
\hline C42 & $-303(1)$ & 6041(1) & 6885(1) & $17(1)$ \\
\hline
\end{tabular}




\begin{tabular}{|c|c|c|c|c|}
\hline $\mathrm{C} 43$ & $776(1)$ & $5718(1)$ & $6967(1)$ & $18(1)$ \\
\hline $\mathrm{C} 44$ & $783(2)$ & $5152(1)$ & 7183(1) & $22(1)$ \\
\hline $\mathrm{C} 45$ & $-242(2)$ & $4902(1)$ & $7313(1)$ & $26(1)$ \\
\hline $\mathrm{C} 46$ & $-1282(2)$ & $5226(1)$ & 7244(1) & $25(1)$ \\
\hline $\mathrm{C} 47$ & $-1335(1)$ & $5798(1)$ & $7035(1)$ & $20(1)$ \\
\hline C48 & 1906(1) & 5967(1) & 6810(1) & $22(1)$ \\
\hline C49 & 2992(2) & 5876(1) & $7230(1)$ & $35(1)$ \\
\hline C50 & $2140(2)$ & $5690(1)$ & 6303(1) & $31(1)$ \\
\hline C51 & $-2508(2)$ & $6130(1)$ & $6969(1)$ & $25(1)$ \\
\hline C52 & $-2976(2)$ & $6192(1)$ & $7486(1)$ & $31(1)$ \\
\hline $\mathrm{C} 53$ & $-3449(2)$ & $5820(1)$ & $6576(1)$ & $36(1)$ \\
\hline Mg1 & $4706(1)$ & $8308(1)$ & $4814(1)$ & 19(1) \\
\hline $\mathrm{Br} 1$ & $3237(1)$ & $9073(1)$ & $5074(1)$ & $29(1)$ \\
\hline $\mathrm{Cl} 1$ & $3237(1)$ & $9073(1)$ & $5074(1)$ & $29(1)$ \\
\hline $\mathrm{O} 1$ & $5938(1)$ & $7710(1)$ & $4545(1)$ & $20(1)$ \\
\hline C54 & 6313(2) & $7136(1)$ & 4761(1) & $23(1)$ \\
\hline C55 & $6798(2)$ & $6811(1)$ & $4334(1)$ & $29(1)$ \\
\hline C56 & 7401(2) & $7313(1)$ & 4080(1) & $29(1)$ \\
\hline C57 & $6565(2)$ & $7832(1)$ & $4106(1)$ & $23(1)$ \\
\hline $\mathrm{O} 2$ & $4330(1)$ & $7646(1)$ & $5327(1)$ & $21(1)$ \\
\hline C58 & $5050(2)$ & $7483(1)$ & $5819(1)$ & $28(1)$ \\
\hline C59 & $4313(2)$ & $7031(1)$ & 6054(1) & $31(1)$ \\
\hline C60 & $3057(2)$ & $7264(1)$ & $5883(1)$ & $27(1)$ \\
\hline C61 & $3102(1)$ & 7461(1) & $5334(1)$ & $26(1)$ \\
\hline $\mathrm{O} 3$ & $3373(1)$ & 7894(1) & $4251(1)$ & $24(1)$ \\
\hline C62 & $3524(2)$ & $7333(1)$ & $3985(1)$ & $26(1)$ \\
\hline C63 & $2337(2)$ & $7206(1)$ & $3648(1)$ & $35(1)$ \\
\hline C64 & $1466(2)$ & 7511(1) & $3944(1)$ & $38(1)$ \\
\hline C65 & $2133(2)$ & $8078(1)$ & 4119(1) & $34(1)$ \\
\hline $\mathrm{O} 4$ & $5159(1)$ & $8890(1)$ & $4260(1)$ & $25(1)$ \\
\hline C66 & 4599(4) & $8914(2)$ & $3723(1)$ & $34(1)$ \\
\hline C67 & 5512(3) & $9244(1)$ & $3462(1)$ & $38(1)$ \\
\hline C68 & $5905(5)$ & $9737(2)$ & $3867(2)$ & $34(1)$ \\
\hline C69 & 5794(8) & $9447(3)$ & $4383(3)$ & $29(1)$ \\
\hline $\mathrm{O} 5$ & $6121(1)$ & $8607(1)$ & $5375(1)$ & $25(1)$ \\
\hline
\end{tabular}




\begin{tabular}{|c|c|c|c|c|}
\hline $\mathrm{C} 70$ & $5872(4)$ & $9087(2)$ & $5739(2)$ & $28(1)$ \\
\hline C71 & 7080(3) & $9187(2)$ & $6067(2)$ & $29(1)$ \\
\hline $\mathrm{C} 72$ & $7942(12)$ & $9073(10)$ & $5680(10)$ & $28(1)$ \\
\hline $\mathrm{C} 73$ & 7393(9) & $8509(8)$ & $5420(7)$ & $22(2)$ \\
\hline O4' & $5159(1)$ & $8890(1)$ & $4260(1)$ & $25(1)$ \\
\hline C66' & 4311(9) & $9026(4)$ & $3798(3)$ & $34(1)$ \\
\hline C67' & 4907(7) & $9475(3)$ & $3494(2)$ & $38(1)$ \\
\hline C68' & $6071(12)$ & $9648(6)$ & $3837(6)$ & $34(1)$ \\
\hline C69' & $5960(20)$ & 9401(9) & $4372(7)$ & $29(1)$ \\
\hline O5' & $6121(1)$ & $8607(1)$ & $5375(1)$ & $25(1)$ \\
\hline C70' & $6108(5)$ & 8911(2) & $5865(2)$ & $28(1)$ \\
\hline C71' & $7026(4)$ & $9399(2)$ & $5855(2)$ & $29(1)$ \\
\hline C72' & $8017(13)$ & $9068(11)$ & $5637(10)$ & $28(1)$ \\
\hline C73' & 7398(9) & $8537(9)$ & $5353(8)$ & $22(2)$ \\
\hline O6 & $8658(2)$ & 8961(1) & $4250(1)$ & $49(1)$ \\
\hline C74 & $9415(2)$ & $9448(1)$ & $4436(1)$ & $50(1)$ \\
\hline C75 & $10301(2)$ & $9525(1)$ & $4059(1)$ & $45(1)$ \\
\hline C76 & $9651(2)$ & $9242(1)$ & $3570(1)$ & $41(1)$ \\
\hline C77 & $8961(2)$ & $8751(1)$ & $3780(1)$ & $36(1)$ \\
\hline $\mathrm{O} 7$ & $2370(1)$ & 6053(1) & $4582(1)$ & $44(1)$ \\
\hline $\mathrm{C} 78$ & $2175(2)$ & $5629(1)$ & $4177(1)$ & $43(1)$ \\
\hline C79 & $855(2)$ & $5669(1)$ & $3979(1)$ & $43(1)$ \\
\hline $\mathrm{C} 80$ & $322(2)$ & $5846(2)$ & $4443(1)$ & $64(1)$ \\
\hline $\mathrm{C} 81$ & $1416(2)$ & $5972(1)$ & $4860(1)$ & $48(1)$ \\
\hline $\mathrm{O} 8$ & $4822(15)$ & $4419(6)$ & $4893(7)$ & $96(2)$ \\
\hline $\mathrm{C} 82$ & $5410(20)$ & 4938(8) & $4673(8)$ & $59(5)$ \\
\hline $\mathrm{C} 83$ & $5240(30)$ & $5429(8)$ & $5039(10)$ & $96(2)$ \\
\hline $\mathrm{C} 84$ & $4670(30)$ & $5146(11)$ & $5457(9)$ & $97(6)$ \\
\hline $\mathrm{C} 85$ & $3900(13)$ & $4662(6)$ & $5196(6)$ & $81(3)$ \\
\hline O8' & $4175(13)$ & $4456(6)$ & $4798(5)$ & $96(2)$ \\
\hline C82' & $5330(20)$ & $4694(12)$ & $4626(11)$ & $59(5)$ \\
\hline C83' & $5380(30)$ & $5305(10)$ & $4862(12)$ & $96(2)$ \\
\hline C84' & $4710(40)$ & $5227(9)$ & $5310(12)$ & $97(6)$ \\
\hline C85' & $4695(17)$ & $4560(8)$ & $5388(6)$ & $81(3)$ \\
\hline
\end{tabular}


Table 3. Bond lengths $[\AA ̊]$ and angles $\left[{ }^{\circ}\right]$ for neipn01.

\begin{tabular}{|c|c|c|c|}
\hline $\mathrm{Fe}(1)-\mathrm{N}(1)$ & $1.8437(13)$ & $\mathrm{C}(27)-\mathrm{H}(27 \mathrm{~A})$ & 0.9800 \\
\hline $\mathrm{Fe}(1)-\mathrm{N}(3)$ & $1.9315(12)$ & $\mathrm{C}(27)-\mathrm{H}(27 \mathrm{~B})$ & 0.9800 \\
\hline $\mathrm{Fe}(1)-\mathrm{N}(2)$ & $1.9381(12)$ & $\mathrm{C}(27)-\mathrm{H}(27 \mathrm{C})$ & 0.9800 \\
\hline $\mathrm{Fe}(1)-\mathrm{C}(1)$ & $2.0503(15)$ & $\mathrm{C}(28)-\mathrm{C}(29)$ & $1.508(2)$ \\
\hline $\mathrm{Fe}(1)-\mathrm{C}(2)$ & $2.0527(16)$ & C(29)-H(29A) & 0.9800 \\
\hline $\mathrm{Fe}(1)-\mathrm{C}(3)$ & $2.0796(16)$ & $\mathrm{C}(29)-\mathrm{H}(29 \mathrm{~B})$ & 0.9800 \\
\hline $\mathrm{N}(1)-\mathrm{C}(25)$ & $1.3809(19)$ & C(29)-H(29C) & 0.9800 \\
\hline $\mathrm{N}(1)-\mathrm{C}(21)$ & $1.3841(18)$ & $\mathrm{C}(30)-\mathrm{C}(35)$ & $1.407(2)$ \\
\hline $\mathrm{N}(2)-\mathrm{C}(26)$ & $1.3647(18)$ & $\mathrm{C}(30)-\mathrm{C}(31)$ & $1.414(2)$ \\
\hline $\mathrm{N}(2)-\mathrm{C}(30)$ & $1.4356(19)$ & $\mathrm{C}(31)-\mathrm{C}(32)$ & $1.393(2)$ \\
\hline $\mathrm{N}(3)-\mathrm{C}(28)$ & $1.3624(19)$ & $C(31)-C(36)$ & $1.524(2)$ \\
\hline $\mathrm{N}(3)-\mathrm{C}(42)$ & $1.4415(18)$ & $\mathrm{C}(32)-\mathrm{C}(33)$ & $1.382(2)$ \\
\hline$C(1)-C(2)$ & $1.406(2)$ & $\mathrm{C}(32)-\mathrm{H}(32)$ & 0.9500 \\
\hline $\mathrm{C}(1)-\mathrm{H}(1 \mathrm{~A})$ & $0.937(19)$ & $\mathrm{C}(33)-\mathrm{C}(34)$ & $1.381(2)$ \\
\hline $\mathrm{C}(1)-\mathrm{H}(1 \mathrm{~B})$ & $0.958(18)$ & $\mathrm{C}(33)-\mathrm{H}(33)$ & 0.9500 \\
\hline $\mathrm{C}(2)-\mathrm{H}(2 \mathrm{~A})$ & $0.96(2)$ & $\mathrm{C}(34)-\mathrm{C}(35)$ & $1.404(2)$ \\
\hline $\mathrm{C}(2)-\mathrm{H}(2 \mathrm{~B})$ & $0.97(2)$ & $\mathrm{C}(34)-\mathrm{H}(34)$ & 0.9500 \\
\hline $\mathrm{C}(3)-\mathrm{C}(4)$ & $1.526(2)$ & $\mathrm{C}(35)-\mathrm{C}(39)$ & $1.514(2)$ \\
\hline $\mathrm{C}(3)-\mathrm{H}(3 \mathrm{~A})$ & 0.9900 & $\mathrm{C}(36)-\mathrm{C}(38)$ & $1.531(2)$ \\
\hline $\mathrm{C}(3)-\mathrm{H}(3 \mathrm{~B})$ & 0.9900 & $\mathrm{C}(36)-\mathrm{C}(37)$ & $1.534(2)$ \\
\hline $\mathrm{C}(4)-\mathrm{H}(4 \mathrm{~A})$ & 0.9800 & $\mathrm{C}(36)-\mathrm{H}(36)$ & 1.0000 \\
\hline $\mathrm{C}(4)-\mathrm{H}(4 \mathrm{~B})$ & 0.9800 & $\mathrm{C}(37)-\mathrm{H}(37 \mathrm{~A})$ & 0.9800 \\
\hline $\mathrm{C}(4)-\mathrm{H}(4 \mathrm{C})$ & 0.9800 & $\mathrm{C}(37)-\mathrm{H}(37 \mathrm{~B})$ & 0.9800 \\
\hline$C(21)-C(22)$ & $1.402(2)$ & $\mathrm{C}(37)-\mathrm{H}(37 \mathrm{C})$ & 0.9800 \\
\hline$C(21)-C(26)$ & $1.409(2)$ & $\mathrm{C}(38)-\mathrm{H}(38 \mathrm{~A})$ & 0.9800 \\
\hline$C(22)-C(23)$ & $1.394(2)$ & $\mathrm{C}(38)-\mathrm{H}(38 \mathrm{~B})$ & 0.9800 \\
\hline $\mathrm{C}(22)-\mathrm{H}(22)$ & 0.9500 & $\mathrm{C}(38)-\mathrm{H}(38 \mathrm{C})$ & 0.9800 \\
\hline$C(23)-C(24)$ & $1.400(2)$ & $\mathrm{C}(39)-\mathrm{C}(40)$ & $1.532(2)$ \\
\hline $\mathrm{C}(23)-\mathrm{H}(23)$ & 0.9500 & $\mathrm{C}(39)-\mathrm{C}(41)$ & $1.534(2)$ \\
\hline$C(24)-C(25)$ & $1.407(2)$ & $\mathrm{C}(39)-\mathrm{H}(39)$ & 1.0000 \\
\hline $\mathrm{C}(24)-\mathrm{H}(24)$ & 0.9500 & $\mathrm{C}(40)-\mathrm{H}(40 \mathrm{~A})$ & 0.9800 \\
\hline$C(25)-C(28)$ & $1.408(2)$ & $\mathrm{C}(40)-\mathrm{H}(40 \mathrm{~B})$ & 0.9800 \\
\hline$C(26)-C(27)$ & $1.505(2)$ & $\mathrm{C}(40)-\mathrm{H}(40 \mathrm{C})$ & 0.9800 \\
\hline
\end{tabular}




\begin{tabular}{|c|c|c|c|}
\hline $\mathrm{C}(41)-\mathrm{H}(41 \mathrm{~A})$ & 0.9800 & $\operatorname{Mg}(1)-\mathrm{O}\left(5^{\prime}\right)$ & $2.1116(13)$ \\
\hline $\mathrm{C}(41)-\mathrm{H}(41 \mathrm{~B})$ & 0.9800 & $\mathrm{Mg}(1)-\mathrm{O}(5)$ & $2.1116(13)$ \\
\hline $\mathrm{C}(41)-\mathrm{H}(41 \mathrm{C})$ & 0.9800 & $\mathrm{Mg}(1)-\mathrm{O}(1)$ & $2.1453(12)$ \\
\hline $\mathrm{C}(42)-\mathrm{C}(47)$ & $1.409(2)$ & $\mathrm{Mg}(1)-\mathrm{O}(3)$ & $2.1554(13)$ \\
\hline $\mathrm{C}(42)-\mathrm{C}(43)$ & $1.417(2)$ & $\operatorname{Mg}(1)-\mathrm{Cl}(1)$ & $2.5688(6)$ \\
\hline $\mathrm{C}(43)-\mathrm{C}(44)$ & $1.397(2)$ & $\operatorname{Mg}(1)-\operatorname{Br}(1)$ & $2.5688(6)$ \\
\hline $\mathrm{C}(43)-\mathrm{C}(48)$ & $1.521(2)$ & $\mathrm{O}(1)-\mathrm{C}(54)$ & $1.4508(19)$ \\
\hline$C(44)-C(45)$ & $1.387(2)$ & $\mathrm{O}(1)-\mathrm{C}(57)$ & $1.4702(19)$ \\
\hline $\mathrm{C}(44)-\mathrm{H}(44)$ & 0.9500 & $C(54)-C(55)$ & $1.513(2)$ \\
\hline C(45)-C(46) & $1.380(2)$ & $\mathrm{C}(54)-\mathrm{H}(54 \mathrm{~A})$ & 0.9900 \\
\hline $\mathrm{C}(45)-\mathrm{H}(45)$ & 0.9500 & $\mathrm{C}(54)-\mathrm{H}(54 \mathrm{~B})$ & 0.9900 \\
\hline$C(46)-C(47)$ & $1.398(2)$ & $\mathrm{C}(55)-\mathrm{C}(56)$ & $1.529(3)$ \\
\hline $\mathrm{C}(46)-\mathrm{H}(46)$ & 0.9500 & $\mathrm{C}(55)-\mathrm{H}(55 \mathrm{~A})$ & 0.9900 \\
\hline $\mathrm{C}(47)-\mathrm{C}(51)$ & $1.519(2)$ & $\mathrm{C}(55)-\mathrm{H}(55 \mathrm{~B})$ & 0.9900 \\
\hline $\mathrm{C}(48)-\mathrm{C}(50)$ & $1.528(2)$ & $C(56)-C(57)$ & $1.517(2)$ \\
\hline $\mathrm{C}(48)-\mathrm{C}(49)$ & $1.534(3)$ & $\mathrm{C}(56)-\mathrm{H}(56 \mathrm{~A})$ & 0.9900 \\
\hline $\mathrm{C}(48)-\mathrm{H}(48)$ & 1.0000 & $\mathrm{C}(56)-\mathrm{H}(56 \mathrm{~B})$ & 0.9900 \\
\hline $\mathrm{C}(49)-\mathrm{H}(49 \mathrm{~A})$ & 0.9800 & $\mathrm{C}(57)-\mathrm{H}(57 \mathrm{~A})$ & 0.9900 \\
\hline $\mathrm{C}(49)-\mathrm{H}(49 \mathrm{~B})$ & 0.9800 & $\mathrm{C}(57)-\mathrm{H}(57 \mathrm{~B})$ & 0.9900 \\
\hline $\mathrm{C}(49)-\mathrm{H}(49 \mathrm{C})$ & 0.9800 & $\mathrm{O}(2)-\mathrm{C}(58)$ & $1.459(2)$ \\
\hline $\mathrm{C}(50)-\mathrm{H}(50 \mathrm{~A})$ & 0.9800 & $\mathrm{O}(2)-\mathrm{C}(61)$ & $1.4644(19)$ \\
\hline $\mathrm{C}(50)-\mathrm{H}(50 \mathrm{~B})$ & 0.9800 & $\mathrm{C}(58)-\mathrm{C}(59)$ & $1.513(3)$ \\
\hline $\mathrm{C}(50)-\mathrm{H}(50 \mathrm{C})$ & 0.9800 & $\mathrm{C}(58)-\mathrm{H}(58 \mathrm{~A})$ & 0.9900 \\
\hline$C(51)-C(53)$ & $1.532(3)$ & $\mathrm{C}(58)-\mathrm{H}(58 \mathrm{~B})$ & 0.9900 \\
\hline$C(51)-C(52)$ & $1.539(3)$ & $C(59)-C(60)$ & $1.525(3)$ \\
\hline $\mathrm{C}(51)-\mathrm{H}(51)$ & 1.0000 & $\mathrm{C}(59)-\mathrm{H}(59 \mathrm{~A})$ & 0.9900 \\
\hline $\mathrm{C}(52)-\mathrm{H}(52 \mathrm{~A})$ & 0.9800 & $\mathrm{C}(59)-\mathrm{H}(59 \mathrm{~B})$ & 0.9900 \\
\hline $\mathrm{C}(52)-\mathrm{H}(52 \mathrm{~B})$ & 0.9800 & $C(60)-C(61)$ & $1.512(2)$ \\
\hline $\mathrm{C}(52)-\mathrm{H}(52 \mathrm{C})$ & 0.9800 & $\mathrm{C}(60)-\mathrm{H}(60 \mathrm{~A})$ & 0.9900 \\
\hline $\mathrm{C}(53)-\mathrm{H}(53 \mathrm{~A})$ & 0.9800 & $\mathrm{C}(60)-\mathrm{H}(60 \mathrm{~B})$ & 0.9900 \\
\hline $\mathrm{C}(53)-\mathrm{H}(53 \mathrm{~B})$ & 0.9800 & $\mathrm{C}(61)-\mathrm{H}(61 \mathrm{~A})$ & 0.9900 \\
\hline $\mathrm{C}(53)-\mathrm{H}(53 \mathrm{C})$ & 0.9800 & $\mathrm{C}(61)-\mathrm{H}(61 \mathrm{~B})$ & 0.9900 \\
\hline $\mathrm{Mg}(1)-\mathrm{O}\left(4^{\prime}\right)$ & $2.0808(13)$ & $\mathrm{O}(3)-\mathrm{C}(65)$ & $1.462(2)$ \\
\hline $\mathrm{Mg}(1)-\mathrm{O}(4)$ & $2.0808(13)$ & $\mathrm{O}(3)-\mathrm{C}(62)$ & $1.4665(19)$ \\
\hline $\mathrm{Mg}(1)-\mathrm{O}(2)$ & $2.0964(12)$ & $C(62)-C(63)$ & $1.521(3)$ \\
\hline
\end{tabular}




\begin{tabular}{|c|c|c|c|}
\hline $\mathrm{C}(62)-\mathrm{H}(62 \mathrm{~A})$ & 0.9900 & $\mathrm{C}(73)-\mathrm{H}(73 \mathrm{~B})$ & 0.9900 \\
\hline $\mathrm{C}(62)-\mathrm{H}(62 \mathrm{~B})$ & 0.9900 & $\mathrm{O}\left(4^{\prime}\right)-\mathrm{C}\left(66^{\prime}\right)$ & $1.457(9)$ \\
\hline $\mathrm{C}(63)-\mathrm{C}(64)$ & $1.517(3)$ & $\mathrm{O}\left(4^{\prime}\right)-\mathrm{C}\left(69^{\prime}\right)$ & $1.471(13)$ \\
\hline $\mathrm{C}(63)-\mathrm{H}(63 \mathrm{~A})$ & 0.9900 & $\mathrm{C}\left(66^{\prime}\right)-\mathrm{C}\left(67^{\prime}\right)$ & $1.513(11)$ \\
\hline $\mathrm{C}(63)-\mathrm{H}(63 \mathrm{~B})$ & 0.9900 & $\mathrm{C}\left(66^{\prime}\right)-\mathrm{H}(66 \mathrm{C})$ & 0.9900 \\
\hline$C(64)-C(65)$ & $1.521(3)$ & $\mathrm{C}\left(66^{\prime}\right)-\mathrm{H}(66 \mathrm{D})$ & 0.9900 \\
\hline $\mathrm{C}(64)-\mathrm{H}(64 \mathrm{~A})$ & 0.9900 & $\mathrm{C}\left(67^{\prime}\right)-\mathrm{C}\left(68^{\prime}\right)$ & $1.530(13)$ \\
\hline $\mathrm{C}(64)-\mathrm{H}(64 \mathrm{~B})$ & 0.9900 & $\mathrm{C}\left(67^{\prime}\right)-\mathrm{H}(67 \mathrm{C})$ & 0.9900 \\
\hline $\mathrm{C}(65)-\mathrm{H}(65 \mathrm{~A})$ & 0.9900 & $\mathrm{C}\left(67^{\prime}\right)-\mathrm{H}(67 \mathrm{D})$ & 0.9900 \\
\hline $\mathrm{C}(65)-\mathrm{H}(65 \mathrm{~B})$ & 0.9900 & $\mathrm{C}\left(68^{\prime}\right)-\mathrm{C}\left(69^{\prime}\right)$ & $1.530(13)$ \\
\hline $\mathrm{O}(4)-\mathrm{C}(66)$ & $1.449(4)$ & $\mathrm{C}\left(68^{\prime}\right)-\mathrm{H}(68 \mathrm{C})$ & 0.9900 \\
\hline $\mathrm{O}(4)-\mathrm{C}(69)$ & $1.459(6)$ & $\mathrm{C}\left(68^{\prime}\right)-\mathrm{H}(68 \mathrm{D})$ & 0.9900 \\
\hline$C(66)-C(67)$ & $1.526(5)$ & $\mathrm{C}\left(69^{\prime}\right)-\mathrm{H}(69 \mathrm{C})$ & 0.9900 \\
\hline $\mathrm{C}(66)-\mathrm{H}(66 \mathrm{~A})$ & 0.9900 & $\mathrm{C}\left(69^{\prime}\right)-\mathrm{H}(69 \mathrm{D})$ & 0.9900 \\
\hline $\mathrm{C}(66)-\mathrm{H}(66 \mathrm{~B})$ & 0.9900 & $\mathrm{O}\left(5^{\prime}\right)-\mathrm{C}\left(70^{\prime}\right)$ & $1.456(5)$ \\
\hline$C(67)-C(68)$ & $1.553(6)$ & $\mathrm{O}\left(5^{\prime}\right)-\mathrm{C}\left(73^{\prime}\right)$ & $1.475(10)$ \\
\hline $\mathrm{C}(67)-\mathrm{H}(67 \mathrm{~A})$ & 0.9900 & $\mathrm{C}\left(70^{\prime}\right)-\mathrm{C}\left(71^{\prime}\right)$ & $1.521(7)$ \\
\hline $\mathrm{C}(67)-\mathrm{H}(67 \mathrm{~B})$ & 0.9900 & $\mathrm{C}\left(70^{\prime}\right)-\mathrm{H}(70 \mathrm{C})$ & 0.9900 \\
\hline$C(68)-C(69)$ & $1.523(6)$ & $\mathrm{C}\left(70^{\prime}\right)-\mathrm{H}(70 \mathrm{D})$ & 0.9900 \\
\hline $\mathrm{C}(68)-\mathrm{H}(68 \mathrm{~A})$ & 0.9900 & $\mathrm{C}\left(71^{\prime}\right)-\mathrm{C}\left(72^{\prime}\right)$ & $1.538(12)$ \\
\hline $\mathrm{C}(68)-\mathrm{H}(68 \mathrm{~B})$ & 0.9900 & $\mathrm{C}\left(71^{\prime}\right)-\mathrm{H}(71 \mathrm{C})$ & 0.9900 \\
\hline $\mathrm{C}(69)-\mathrm{H}(69 \mathrm{~A})$ & 0.9900 & $\mathrm{C}\left(71^{\prime}\right)-\mathrm{H}(71 \mathrm{D})$ & 0.9900 \\
\hline $\mathrm{C}(69)-\mathrm{H}(69 \mathrm{~B})$ & 0.9900 & $\mathrm{C}\left(72^{\prime}\right)-\mathrm{C}\left(73^{\prime}\right)$ & $1.522(10)$ \\
\hline $\mathrm{O}(5)-\mathrm{C}(73)$ & $1.453(9)$ & $\mathrm{C}\left(72^{\prime}\right)-\mathrm{H}(72 \mathrm{C})$ & 0.9900 \\
\hline $\mathrm{O}(5)-\mathrm{C}(70)$ & $1.498(5)$ & $\mathrm{C}\left(72^{\prime}\right)-\mathrm{H}(72 \mathrm{D})$ & 0.9900 \\
\hline $\mathrm{C}(70)-\mathrm{C}(71)$ & $1.520(6)$ & $\mathrm{C}\left(73^{\prime}\right)-\mathrm{H}(73 \mathrm{C})$ & 0.9900 \\
\hline $\mathrm{C}(70)-\mathrm{H}(70 \mathrm{~A})$ & 0.9900 & $\mathrm{C}\left(73^{\prime}\right)-\mathrm{H}(73 \mathrm{D})$ & 0.9900 \\
\hline $\mathrm{C}(70)-\mathrm{H}(70 \mathrm{~B})$ & 0.9900 & $\mathrm{O}(6)-\mathrm{C}(77)$ & $1.412(3)$ \\
\hline$C(71)-C(72)$ & $1.541(12)$ & $\mathrm{O}(6)-\mathrm{C}(74)$ & $1.433(3)$ \\
\hline $\mathrm{C}(71)-\mathrm{H}(71 \mathrm{~A})$ & 0.9900 & $C(74)-C(75)$ & $1.529(4)$ \\
\hline $\mathrm{C}(71)-\mathrm{H}(71 \mathrm{~B})$ & 0.9900 & $\mathrm{C}(74)-\mathrm{H}(74 \mathrm{~A})$ & 0.9900 \\
\hline$C(72)-C(73)$ & $1.529(10)$ & $\mathrm{C}(74)-\mathrm{H}(74 \mathrm{~B})$ & 0.9900 \\
\hline $\mathrm{C}(72)-\mathrm{H}(72 \mathrm{~A})$ & 0.9900 & $C(75)-C(76)$ & $1.514(3)$ \\
\hline $\mathrm{C}(72)-\mathrm{H}(72 \mathrm{~B})$ & 0.9900 & $\mathrm{C}(75)-\mathrm{H}(75 \mathrm{~A})$ & 0.9900 \\
\hline $\mathrm{C}(73)-\mathrm{H}(73 \mathrm{~A})$ & 0.9900 & $\mathrm{C}(75)-\mathrm{H}(75 \mathrm{~B})$ & 0.9900 \\
\hline
\end{tabular}




\begin{tabular}{|c|c|c|c|}
\hline $\mathrm{C}(76)-\mathrm{C}(77)$ & $1.511(3)$ & $\mathrm{C}\left(82^{\prime}\right)-\mathrm{H}(82 \mathrm{D})$ & 0.9900 \\
\hline $\mathrm{C}(76)-\mathrm{H}(76 \mathrm{~A})$ & 0.9900 & $\mathrm{C}\left(83^{\prime}\right)-\mathrm{C}\left(84^{\prime}\right)$ & $1.513(15)$ \\
\hline $\mathrm{C}(76)-\mathrm{H}(76 \mathrm{~B})$ & 0.9900 & $\mathrm{C}\left(83^{\prime}\right)-\mathrm{H}(83 \mathrm{C})$ & 0.9900 \\
\hline $\mathrm{C}(77)-\mathrm{H}(77 \mathrm{~A})$ & 0.9900 & $\mathrm{C}\left(83^{\prime}\right)-\mathrm{H}(83 \mathrm{D})$ & 0.9900 \\
\hline $\mathrm{C}(77)-\mathrm{H}(77 \mathrm{~B})$ & 0.9900 & $\mathrm{C}\left(84^{\prime}\right)-\mathrm{C}\left(85^{\prime}\right)$ & $1.516(13)$ \\
\hline $\mathrm{O}(7)-\mathrm{C}(81)$ & $1.414(3)$ & $\mathrm{C}\left(84^{\prime}\right)-\mathrm{H}(84 \mathrm{C})$ & 0.9900 \\
\hline $\mathrm{O}(7)-\mathrm{C}(78)$ & $1.420(3)$ & $\mathrm{C}\left(84^{\prime}\right)-\mathrm{H}(84 \mathrm{D})$ & 0.9900 \\
\hline $\mathrm{C}(78)-\mathrm{C}(79)$ & $1.515(3)$ & $\mathrm{C}\left(85^{\prime}\right)-\mathrm{H}(85 \mathrm{C})$ & 0.9900 \\
\hline $\mathrm{C}(78)-\mathrm{H}(78 \mathrm{~A})$ & 0.9900 & $\mathrm{C}\left(85^{\prime}\right)-\mathrm{H}(85 \mathrm{D})$ & 0.9900 \\
\hline $\mathrm{C}(78)-\mathrm{H}(78 \mathrm{~B})$ & 0.9900 & $\mathrm{~N}(1)-\mathrm{Fe}(1)-\mathrm{N}(3)$ & $80.17(5)$ \\
\hline $\mathrm{C}(79)-\mathrm{C}(80)$ & $1.495(3)$ & $\mathrm{N}(1)-\mathrm{Fe}(1)-\mathrm{N}(2)$ & $80.07(5)$ \\
\hline $\mathrm{C}(79)-\mathrm{H}(79 \mathrm{~A})$ & 0.9900 & $\mathrm{~N}(3)-\mathrm{Fe}(1)-\mathrm{N}(2)$ & $156.91(5)$ \\
\hline C(79)-H(79B) & 0.9900 & $\mathrm{~N}(1)-\mathrm{Fe}(1)-\mathrm{C}(1)$ & $146.27(6)$ \\
\hline $\mathrm{C}(80)-\mathrm{C}(81)$ & $1.548(4)$ & $\mathrm{N}(3)-\mathrm{Fe}(1)-\mathrm{C}(1)$ & $94.92(6)$ \\
\hline $\mathrm{C}(80)-\mathrm{H}(80 \mathrm{~A})$ & 0.9900 & $\mathrm{~N}(2)-\mathrm{Fe}(1)-\mathrm{C}(1)$ & $94.89(6)$ \\
\hline $\mathrm{C}(80)-\mathrm{H}(80 \mathrm{~B})$ & 0.9900 & $\mathrm{~N}(1)-\mathrm{Fe}(1)-\mathrm{C}(2)$ & $173.59(6)$ \\
\hline $\mathrm{C}(81)-\mathrm{H}(81 \mathrm{~A})$ & 0.9900 & $\mathrm{~N}(3)-\mathrm{Fe}(1)-\mathrm{C}(2)$ & $101.37(6)$ \\
\hline $\mathrm{C}(81)-\mathrm{H}(81 \mathrm{~B})$ & 0.9900 & $\mathrm{~N}(2)-\mathrm{Fe}(1)-\mathrm{C}(2)$ & $99.59(6)$ \\
\hline $\mathrm{O}(8)-\mathrm{C}(82)$ & $1.507(15)$ & $\mathrm{C}(1)-\mathrm{Fe}(1)-\mathrm{C}(2)$ & $40.07(6)$ \\
\hline $\mathrm{O}(8)-\mathrm{C}(85)$ & $1.515(16)$ & $\mathrm{N}(1)-\mathrm{Fe}(1)-\mathrm{C}(3)$ & $84.82(6)$ \\
\hline $\mathrm{C}(82)-\mathrm{C}(83)$ & $1.496(12)$ & $\mathrm{N}(3)-\mathrm{Fe}(1)-\mathrm{C}(3)$ & $93.73(6)$ \\
\hline $\mathrm{C}(82)-\mathrm{H}(82 \mathrm{~A})$ & 0.9900 & $\mathrm{~N}(2)-\mathrm{Fe}(1)-\mathrm{C}(3)$ & $96.26(6)$ \\
\hline $\mathrm{C}(82)-\mathrm{H}(82 \mathrm{~B})$ & 0.9900 & $\mathrm{C}(1)-\mathrm{Fe}(1)-\mathrm{C}(3)$ & $128.90(6)$ \\
\hline $\mathrm{C}(83)-\mathrm{C}(84)$ & $1.502(14)$ & $\mathrm{C}(2)-\mathrm{Fe}(1)-\mathrm{C}(3)$ & $88.86(6)$ \\
\hline $\mathrm{C}(83)-\mathrm{H}(83 \mathrm{~A})$ & 0.9900 & $\mathrm{C}(25)-\mathrm{N}(1)-\mathrm{C}(21)$ & $120.74(12)$ \\
\hline $\mathrm{C}(83)-\mathrm{H}(83 \mathrm{~B})$ & 0.9900 & $\mathrm{C}(25)-\mathrm{N}(1)-\mathrm{Fe}(1)$ & $118.65(10)$ \\
\hline $\mathrm{C}(84)-\mathrm{C}(85)$ & $1.496(12)$ & $\mathrm{C}(21)-\mathrm{N}(1)-\mathrm{Fe}(1)$ & $119.07(10)$ \\
\hline $\mathrm{C}(84)-\mathrm{H}(84 \mathrm{~A})$ & 0.9900 & $\mathrm{C}(26)-\mathrm{N}(2)-\mathrm{C}(30)$ & $116.42(12)$ \\
\hline $\mathrm{C}(84)-\mathrm{H}(84 \mathrm{~B})$ & 0.9900 & $\mathrm{C}(26)-\mathrm{N}(2)-\mathrm{Fe}(1)$ & 115.60(10) \\
\hline $\mathrm{C}(85)-\mathrm{H}(85 \mathrm{~A})$ & 0.9900 & $\mathrm{C}(30)-\mathrm{N}(2)-\mathrm{Fe}(1)$ & $127.80(9)$ \\
\hline $\mathrm{C}(85)-\mathrm{H}(85 \mathrm{~B})$ & 0.9900 & $\mathrm{C}(28)-\mathrm{N}(3)-\mathrm{C}(42)$ & $115.01(12)$ \\
\hline $\mathrm{O}\left(8^{\prime}\right)-\mathrm{C}\left(82^{\prime}\right)$ & $1.555(16)$ & $\mathrm{C}(28)-\mathrm{N}(3)-\mathrm{Fe}(1)$ & $115.06(10)$ \\
\hline $\mathrm{O}\left(8^{\prime}\right)-\mathrm{C}\left(85^{\prime}\right)$ & $1.584(15)$ & $\mathrm{C}(42)-\mathrm{N}(3)-\mathrm{Fe}(1)$ & $129.47(10)$ \\
\hline $\mathrm{C}\left(82^{\prime}\right)-\mathrm{C}\left(83^{\prime}\right)$ & $1.506(12)$ & $\mathrm{C}(2)-\mathrm{C}(1)-\mathrm{Fe}(1)$ & $70.06(9)$ \\
\hline $\mathrm{C}\left(82^{\prime}\right)-\mathrm{H}(82 \mathrm{C})$ & 0.9900 & $\mathrm{C}(2)-\mathrm{C}(1)-\mathrm{H}(1 \mathrm{~A})$ & $119.8(11)$ \\
\hline
\end{tabular}




\begin{tabular}{|c|c|c|c|}
\hline $\mathrm{Fe}(1)-\mathrm{C}(1)-\mathrm{H}(1 \mathrm{~A})$ & $111.0(12)$ & $\mathrm{N}(1)-\mathrm{C}(25)-\mathrm{C}(28)$ & $110.53(13)$ \\
\hline $\mathrm{C}(2)-\mathrm{C}(1)-\mathrm{H}(1 \mathrm{~B})$ & $120.6(11)$ & $\mathrm{C}(24)-\mathrm{C}(25)-\mathrm{C}(28)$ & $129.42(14)$ \\
\hline $\mathrm{Fe}(1)-\mathrm{C}(1)-\mathrm{H}(1 \mathrm{~B})$ & $113.8(11)$ & $\mathrm{N}(2)-\mathrm{C}(26)-\mathrm{C}(21)$ & $112.97(12)$ \\
\hline $\mathrm{H}(1 \mathrm{~A})-\mathrm{C}(1)-\mathrm{H}(1 \mathrm{~B})$ & $113.2(16)$ & $\mathrm{N}(2)-\mathrm{C}(26)-\mathrm{C}(27)$ & $125.89(13)$ \\
\hline $\mathrm{C}(1)-\mathrm{C}(2)-\mathrm{Fe}(1)$ & $69.87(9)$ & $\mathrm{C}(21)-\mathrm{C}(26)-\mathrm{C}(27)$ & $121.08(13)$ \\
\hline $\mathrm{C}(1)-\mathrm{C}(2)-\mathrm{H}(2 \mathrm{~A})$ & $118.8(12)$ & $\mathrm{C}(26)-\mathrm{C}(27)-\mathrm{H}(27 \mathrm{~A})$ & 109.5 \\
\hline $\mathrm{Fe}(1)-\mathrm{C}(2)-\mathrm{H}(2 \mathrm{~A})$ & $110.4(12)$ & $\mathrm{C}(26)-\mathrm{C}(27)-\mathrm{H}(27 \mathrm{~B})$ & 109.5 \\
\hline $\mathrm{C}(1)-\mathrm{C}(2)-\mathrm{H}(2 \mathrm{~B})$ & $121.8(12)$ & $\mathrm{H}(27 \mathrm{~A})-\mathrm{C}(27)-\mathrm{H}(27 \mathrm{~B})$ & 109.5 \\
\hline $\mathrm{Fe}(1)-\mathrm{C}(2)-\mathrm{H}(2 \mathrm{~B})$ & $110.7(12)$ & $\mathrm{C}(26)-\mathrm{C}(27)-\mathrm{H}(27 \mathrm{C})$ & 109.5 \\
\hline $\mathrm{H}(2 \mathrm{~A})-\mathrm{C}(2)-\mathrm{H}(2 \mathrm{~B})$ & $114.9(17)$ & $\mathrm{H}(27 \mathrm{~A})-\mathrm{C}(27)-\mathrm{H}(27 \mathrm{C})$ & 109.5 \\
\hline $\mathrm{C}(4)-\mathrm{C}(3)-\mathrm{Fe}(1)$ & $125.73(11)$ & $\mathrm{H}(27 \mathrm{~B})-\mathrm{C}(27)-\mathrm{H}(27 \mathrm{C})$ & 109.5 \\
\hline $\mathrm{C}(4)-\mathrm{C}(3)-\mathrm{H}(3 \mathrm{~A})$ & 105.9 & $\mathrm{~N}(3)-\mathrm{C}(28)-\mathrm{C}(25)$ & $113.26(13)$ \\
\hline $\mathrm{Fe}(1)-\mathrm{C}(3)-\mathrm{H}(3 \mathrm{~A})$ & 105.9 & $\mathrm{~N}(3)-\mathrm{C}(28)-\mathrm{C}(29)$ & $125.22(13)$ \\
\hline $\mathrm{C}(4)-\mathrm{C}(3)-\mathrm{H}(3 \mathrm{~B})$ & 105.9 & $\mathrm{C}(25)-\mathrm{C}(28)-\mathrm{C}(29)$ & $121.49(14)$ \\
\hline $\mathrm{Fe}(1)-\mathrm{C}(3)-\mathrm{H}(3 \mathrm{~B})$ & 105.9 & $\mathrm{C}(28)-\mathrm{C}(29)-\mathrm{H}(29 \mathrm{~A})$ & 109.5 \\
\hline $\mathrm{H}(3 \mathrm{~A})-\mathrm{C}(3)-\mathrm{H}(3 \mathrm{~B})$ & 106.2 & $\mathrm{C}(28)-\mathrm{C}(29)-\mathrm{H}(29 B)$ & 109.5 \\
\hline $\mathrm{C}(3)-\mathrm{C}(4)-\mathrm{H}(4 \mathrm{~A})$ & 109.5 & $H(29 A)-C(29)-H(29 B)$ & 109.5 \\
\hline $\mathrm{C}(3)-\mathrm{C}(4)-\mathrm{H}(4 \mathrm{~B})$ & 109.5 & $\mathrm{C}(28)-\mathrm{C}(29)-\mathrm{H}(29 \mathrm{C})$ & 109.5 \\
\hline $\mathrm{H}(4 \mathrm{~A})-\mathrm{C}(4)-\mathrm{H}(4 \mathrm{~B})$ & 109.5 & $\mathrm{H}(29 \mathrm{~A})-\mathrm{C}(29)-\mathrm{H}(29 \mathrm{C})$ & 109.5 \\
\hline $\mathrm{C}(3)-\mathrm{C}(4)-\mathrm{H}(4 \mathrm{C})$ & 109.5 & $\mathrm{H}(29 \mathrm{~B})-\mathrm{C}(29)-\mathrm{H}(29 \mathrm{C})$ & 109.5 \\
\hline $\mathrm{H}(4 \mathrm{~A})-\mathrm{C}(4)-\mathrm{H}(4 \mathrm{C})$ & 109.5 & $\mathrm{C}(35)-\mathrm{C}(30)-\mathrm{C}(31)$ & $120.15(14)$ \\
\hline $\mathrm{H}(4 \mathrm{~B})-\mathrm{C}(4)-\mathrm{H}(4 \mathrm{C})$ & 109.5 & $\mathrm{C}(35)-\mathrm{C}(30)-\mathrm{N}(2)$ & $120.79(13)$ \\
\hline $\mathrm{N}(1)-\mathrm{C}(21)-\mathrm{C}(22)$ & $120.21(13)$ & $\mathrm{C}(31)-\mathrm{C}(30)-\mathrm{N}(2)$ & $119.06(12)$ \\
\hline $\mathrm{N}(1)-\mathrm{C}(21)-\mathrm{C}(26)$ & $110.77(12)$ & $\mathrm{C}(32)-\mathrm{C}(31)-\mathrm{C}(30)$ & $118.99(14)$ \\
\hline $\mathrm{C}(22)-\mathrm{C}(21)-\mathrm{C}(26)$ & $128.99(14)$ & $C(32)-C(31)-C(36)$ & $119.43(14)$ \\
\hline $\mathrm{C}(23)-\mathrm{C}(22)-\mathrm{C}(21)$ & $119.11(14)$ & $\mathrm{C}(30)-\mathrm{C}(31)-\mathrm{C}(36)$ & $121.54(13)$ \\
\hline $\mathrm{C}(23)-\mathrm{C}(22)-\mathrm{H}(22)$ & 120.4 & $\mathrm{C}(33)-\mathrm{C}(32)-\mathrm{C}(31)$ & $121.30(15)$ \\
\hline $\mathrm{C}(21)-\mathrm{C}(22)-\mathrm{H}(22)$ & 120.4 & $\mathrm{C}(33)-\mathrm{C}(32)-\mathrm{H}(32)$ & 119.3 \\
\hline $\mathrm{C}(22)-\mathrm{C}(23)-\mathrm{C}(24)$ & $120.77(14)$ & $\mathrm{C}(31)-\mathrm{C}(32)-\mathrm{H}(32)$ & 119.3 \\
\hline $\mathrm{C}(22)-\mathrm{C}(23)-\mathrm{H}(23)$ & 119.6 & $\mathrm{C}(34)-\mathrm{C}(33)-\mathrm{C}(32)$ & $119.57(15)$ \\
\hline $\mathrm{C}(24)-\mathrm{C}(23)-\mathrm{H}(23)$ & 119.6 & $\mathrm{C}(34)-\mathrm{C}(33)-\mathrm{H}(33)$ & 120.2 \\
\hline $\mathrm{C}(23)-\mathrm{C}(24)-\mathrm{C}(25)$ & $119.06(14)$ & $\mathrm{C}(32)-\mathrm{C}(33)-\mathrm{H}(33)$ & 120.2 \\
\hline $\mathrm{C}(23)-\mathrm{C}(24)-\mathrm{H}(24)$ & 120.5 & $\mathrm{C}(33)-\mathrm{C}(34)-\mathrm{C}(35)$ & $121.47(14)$ \\
\hline $\mathrm{C}(25)-\mathrm{C}(24)-\mathrm{H}(24)$ & 120.5 & $\mathrm{C}(33)-\mathrm{C}(34)-\mathrm{H}(34)$ & 119.3 \\
\hline $\mathrm{N}(1)-\mathrm{C}(25)-\mathrm{C}(24)$ & $120.00(13)$ & $\mathrm{C}(35)-\mathrm{C}(34)-\mathrm{H}(34)$ & 119.3 \\
\hline
\end{tabular}




\begin{tabular}{|c|c|c|c|}
\hline $\mathrm{C}(34)-\mathrm{C}(35)-\mathrm{C}(30)$ & $118.51(15)$ & $\mathrm{H}(41 \mathrm{~A})-\mathrm{C}(41)-\mathrm{H}(41 \mathrm{~B})$ & 109.5 \\
\hline $\mathrm{C}(34)-\mathrm{C}(35)-\mathrm{C}(39)$ & $120.07(14)$ & $\mathrm{C}(39)-\mathrm{C}(41)-\mathrm{H}(41 \mathrm{C})$ & 109.5 \\
\hline $\mathrm{C}(30)-\mathrm{C}(35)-\mathrm{C}(39)$ & $121.40(14)$ & $\mathrm{H}(41 \mathrm{~A})-\mathrm{C}(41)-\mathrm{H}(41 \mathrm{C})$ & 109.5 \\
\hline $\mathrm{C}(31)-\mathrm{C}(36)-\mathrm{C}(38)$ & $112.71(14)$ & $\mathrm{H}(41 \mathrm{~B})-\mathrm{C}(41)-\mathrm{H}(41 \mathrm{C})$ & 109.5 \\
\hline $\mathrm{C}(31)-\mathrm{C}(36)-\mathrm{C}(37)$ & $110.02(13)$ & $\mathrm{C}(47)-\mathrm{C}(42)-\mathrm{C}(43)$ & $120.16(13)$ \\
\hline $\mathrm{C}(38)-\mathrm{C}(36)-\mathrm{C}(37)$ & $109.10(14)$ & $\mathrm{C}(47)-\mathrm{C}(42)-\mathrm{N}(3)$ & $121.59(13)$ \\
\hline $\mathrm{C}(31)-\mathrm{C}(36)-\mathrm{H}(36)$ & 108.3 & $\mathrm{C}(43)-\mathrm{C}(42)-\mathrm{N}(3)$ & $118.20(13)$ \\
\hline $\mathrm{C}(38)-\mathrm{C}(36)-\mathrm{H}(36)$ & 108.3 & $C(44)-C(43)-C(42)$ & $118.68(14)$ \\
\hline $\mathrm{C}(37)-\mathrm{C}(36)-\mathrm{H}(36)$ & 108.3 & $C(44)-C(43)-C(48)$ & $119.71(14)$ \\
\hline $\mathrm{C}(36)-\mathrm{C}(37)-\mathrm{H}(37 \mathrm{~A})$ & 109.5 & $\mathrm{C}(42)-\mathrm{C}(43)-\mathrm{C}(48)$ & $121.59(13)$ \\
\hline $\mathrm{C}(36)-\mathrm{C}(37)-\mathrm{H}(37 \mathrm{~B})$ & 109.5 & $C(45)-C(44)-C(43)$ & $121.26(15)$ \\
\hline $\mathrm{H}(37 \mathrm{~A})-\mathrm{C}(37)-\mathrm{H}(37 \mathrm{~B})$ & 109.5 & $\mathrm{C}(45)-\mathrm{C}(44)-\mathrm{H}(44)$ & 119.4 \\
\hline $\mathrm{C}(36)-\mathrm{C}(37)-\mathrm{H}(37 \mathrm{C})$ & 109.5 & $\mathrm{C}(43)-\mathrm{C}(44)-\mathrm{H}(44)$ & 119.4 \\
\hline $\mathrm{H}(37 \mathrm{~A})-\mathrm{C}(37)-\mathrm{H}(37 \mathrm{C})$ & 109.5 & $C(46)-C(45)-C(44)$ & $119.62(15)$ \\
\hline $\mathrm{H}(37 \mathrm{~B})-\mathrm{C}(37)-\mathrm{H}(37 \mathrm{C})$ & 109.5 & $\mathrm{C}(46)-\mathrm{C}(45)-\mathrm{H}(45)$ & 120.2 \\
\hline $\mathrm{C}(36)-\mathrm{C}(38)-\mathrm{H}(38 \mathrm{~A})$ & 109.5 & $\mathrm{C}(44)-\mathrm{C}(45)-\mathrm{H}(45)$ & 120.2 \\
\hline $\mathrm{C}(36)-\mathrm{C}(38)-\mathrm{H}(38 \mathrm{~B})$ & 109.5 & $C(45)-C(46)-C(47)$ & $121.47(16)$ \\
\hline $\mathrm{H}(38 \mathrm{~A})-\mathrm{C}(38)-\mathrm{H}(38 \mathrm{~B})$ & 109.5 & $\mathrm{C}(45)-\mathrm{C}(46)-\mathrm{H}(46)$ & 119.3 \\
\hline $\mathrm{C}(36)-\mathrm{C}(38)-\mathrm{H}(38 \mathrm{C})$ & 109.5 & $\mathrm{C}(47)-\mathrm{C}(46)-\mathrm{H}(46)$ & 119.3 \\
\hline $\mathrm{H}(38 \mathrm{~A})-\mathrm{C}(38)-\mathrm{H}(38 \mathrm{C})$ & 109.5 & $C(46)-C(47)-C(42)$ & $118.74(15)$ \\
\hline $\mathrm{H}(38 \mathrm{~B})-\mathrm{C}(38)-\mathrm{H}(38 \mathrm{C})$ & 109.5 & $\mathrm{C}(46)-\mathrm{C}(47)-\mathrm{C}(51)$ & $118.87(14)$ \\
\hline $\mathrm{C}(35)-\mathrm{C}(39)-\mathrm{C}(40)$ & $112.22(15)$ & $\mathrm{C}(42)-\mathrm{C}(47)-\mathrm{C}(51)$ & $122.37(13)$ \\
\hline $\mathrm{C}(35)-\mathrm{C}(39)-\mathrm{C}(41)$ & $111.58(13)$ & $C(43)-C(48)-C(50)$ & $110.86(14)$ \\
\hline $\mathrm{C}(40)-\mathrm{C}(39)-\mathrm{C}(41)$ & $109.49(13)$ & $\mathrm{C}(43)-\mathrm{C}(48)-\mathrm{C}(49)$ & $112.31(15)$ \\
\hline C(35)-C(39)-H(39) & 107.8 & $\mathrm{C}(50)-\mathrm{C}(48)-\mathrm{C}(49)$ & $109.63(14)$ \\
\hline $\mathrm{C}(40)-\mathrm{C}(39)-\mathrm{H}(39)$ & 107.8 & $\mathrm{C}(43)-\mathrm{C}(48)-\mathrm{H}(48)$ & 108.0 \\
\hline $\mathrm{C}(41)-\mathrm{C}(39)-\mathrm{H}(39)$ & 107.8 & $\mathrm{C}(50)-\mathrm{C}(48)-\mathrm{H}(48)$ & 108.0 \\
\hline $\mathrm{C}(39)-\mathrm{C}(40)-\mathrm{H}(40 \mathrm{~A})$ & 109.5 & $\mathrm{C}(49)-\mathrm{C}(48)-\mathrm{H}(48)$ & 108.0 \\
\hline $\mathrm{C}(39)-\mathrm{C}(40)-\mathrm{H}(40 \mathrm{~B})$ & 109.5 & $\mathrm{C}(48)-\mathrm{C}(49)-\mathrm{H}(49 \mathrm{~A})$ & 109.5 \\
\hline $\mathrm{H}(40 \mathrm{~A})-\mathrm{C}(40)-\mathrm{H}(40 \mathrm{~B})$ & 109.5 & $\mathrm{C}(48)-\mathrm{C}(49)-\mathrm{H}(49 \mathrm{~B})$ & 109.5 \\
\hline $\mathrm{C}(39)-\mathrm{C}(40)-\mathrm{H}(40 \mathrm{C})$ & 109.5 & $\mathrm{H}(49 \mathrm{~A})-\mathrm{C}(49)-\mathrm{H}(49 \mathrm{~B})$ & 109.5 \\
\hline $\mathrm{H}(40 \mathrm{~A})-\mathrm{C}(40)-\mathrm{H}(40 \mathrm{C})$ & 109.5 & $\mathrm{C}(48)-\mathrm{C}(49)-\mathrm{H}(49 \mathrm{C})$ & 109.5 \\
\hline $\mathrm{H}(40 \mathrm{~B})-\mathrm{C}(40)-\mathrm{H}(40 \mathrm{C})$ & 109.5 & $\mathrm{H}(49 \mathrm{~A})-\mathrm{C}(49)-\mathrm{H}(49 \mathrm{C})$ & 109.5 \\
\hline $\mathrm{C}(39)-\mathrm{C}(41)-\mathrm{H}(41 \mathrm{~A})$ & 109.5 & $\mathrm{H}(49 \mathrm{~B})-\mathrm{C}(49)-\mathrm{H}(49 \mathrm{C})$ & 109.5 \\
\hline $\mathrm{C}(39)-\mathrm{C}(41)-\mathrm{H}(41 \mathrm{~B})$ & 109.5 & $\mathrm{C}(48)-\mathrm{C}(50)-\mathrm{H}(50 \mathrm{~A})$ & 109.5 \\
\hline
\end{tabular}




\begin{tabular}{|c|c|c|c|}
\hline $\mathrm{C}(48)-\mathrm{C}(50)-\mathrm{H}(50 \mathrm{~B})$ & 109.5 & $\mathrm{O}(4)-\mathrm{Mg}(1)-\mathrm{O}(3)$ & $91.26(5)$ \\
\hline $\mathrm{H}(50 \mathrm{~A})-\mathrm{C}(50)-\mathrm{H}(50 \mathrm{~B})$ & 109.5 & $\mathrm{O}(2)-\mathrm{Mg}(1)-\mathrm{O}(3)$ & $86.35(5)$ \\
\hline $\mathrm{C}(48)-\mathrm{C}(50)-\mathrm{H}(50 \mathrm{C})$ & 109.5 & $\mathrm{O}\left(5^{\prime}\right)-\mathrm{Mg}(1)-\mathrm{O}(3)$ & $172.62(5)$ \\
\hline $\mathrm{H}(50 \mathrm{~A})-\mathrm{C}(50)-\mathrm{H}(50 \mathrm{C})$ & 109.5 & $\mathrm{O}(5)-\mathrm{Mg}(1)-\mathrm{O}(3)$ & $172.62(5)$ \\
\hline $\mathrm{H}(50 \mathrm{~B})-\mathrm{C}(50)-\mathrm{H}(50 \mathrm{C})$ & 109.5 & $\mathrm{O}(1)-\mathrm{Mg}(1)-\mathrm{O}(3)$ & $86.01(5)$ \\
\hline $\mathrm{C}(47)-\mathrm{C}(51)-\mathrm{C}(53)$ & 111.24(14) & $\mathrm{O}\left(4^{\prime}\right)-\mathrm{Mg}(1)-\mathrm{Cl}(1)$ & $90.37(4)$ \\
\hline $\mathrm{C}(47)-\mathrm{C}(51)-\mathrm{C}(52)$ & $111.45(15)$ & $\mathrm{O}(2)-\mathrm{Mg}(1)-\mathrm{Cl}(1)$ & $95.70(4)$ \\
\hline $\mathrm{C}(53)-\mathrm{C}(51)-\mathrm{C}(52)$ & $109.17(15)$ & $\mathrm{O}\left(5^{\prime}\right)-\mathrm{Mg}(1)-\mathrm{Cl}(1)$ & $93.50(4)$ \\
\hline $\mathrm{C}(47)-\mathrm{C}(51)-\mathrm{H}(51)$ & 108.3 & $\mathrm{O}(1)-\mathrm{Mg}(1)-\mathrm{Cl}(1)$ & $175.57(4)$ \\
\hline $\mathrm{C}(53)-\mathrm{C}(51)-\mathrm{H}(51)$ & 108.3 & $\mathrm{O}(3)-\mathrm{Mg}(1)-\mathrm{Cl}(1)$ & $93.02(4)$ \\
\hline $\mathrm{C}(52)-\mathrm{C}(51)-\mathrm{H}(51)$ & 108.3 & $\mathrm{O}(4)-\mathrm{Mg}(1)-\mathrm{Br}(1)$ & $90.37(4)$ \\
\hline $\mathrm{C}(51)-\mathrm{C}(52)-\mathrm{H}(52 \mathrm{~A})$ & 109.5 & $\mathrm{O}(2)-\mathrm{Mg}(1)-\mathrm{Br}(1)$ & $95.70(4)$ \\
\hline $\mathrm{C}(51)-\mathrm{C}(52)-\mathrm{H}(52 \mathrm{~B})$ & 109.5 & $\mathrm{O}(5)-\mathrm{Mg}(1)-\mathrm{Br}(1)$ & $93.50(4)$ \\
\hline $\mathrm{H}(52 \mathrm{~A})-\mathrm{C}(52)-\mathrm{H}(52 \mathrm{~B})$ & 109.5 & $\mathrm{O}(1)-\mathrm{Mg}(1)-\mathrm{Br}(1)$ & $175.57(4)$ \\
\hline $\mathrm{C}(51)-\mathrm{C}(52)-\mathrm{H}(52 \mathrm{C})$ & 109.5 & $\mathrm{O}(3)-\mathrm{Mg}(1)-\mathrm{Br}(1)$ & $93.02(4)$ \\
\hline $\mathrm{H}(52 \mathrm{~A})-\mathrm{C}(52)-\mathrm{H}(52 \mathrm{C})$ & 109.5 & $\mathrm{C}(54)-\mathrm{O}(1)-\mathrm{C}(57)$ & $108.73(11)$ \\
\hline $\mathrm{H}(52 \mathrm{~B})-\mathrm{C}(52)-\mathrm{H}(52 \mathrm{C})$ & 109.5 & $\mathrm{C}(54)-\mathrm{O}(1)-\mathrm{Mg}(1)$ & $126.85(9)$ \\
\hline $\mathrm{C}(51)-\mathrm{C}(53)-\mathrm{H}(53 \mathrm{~A})$ & 109.5 & $\mathrm{C}(57)-\mathrm{O}(1)-\mathrm{Mg}(1)$ & $124.40(9)$ \\
\hline $\mathrm{C}(51)-\mathrm{C}(53)-\mathrm{H}(53 \mathrm{~B})$ & 109.5 & $\mathrm{O}(1)-\mathrm{C}(54)-\mathrm{C}(55)$ & $105.20(13)$ \\
\hline $\mathrm{H}(53 \mathrm{~A})-\mathrm{C}(53)-\mathrm{H}(53 \mathrm{~B})$ & 109.5 & $\mathrm{O}(1)-\mathrm{C}(54)-\mathrm{H}(54 \mathrm{~A})$ & 110.7 \\
\hline $\mathrm{C}(51)-\mathrm{C}(53)-\mathrm{H}(53 \mathrm{C})$ & 109.5 & $\mathrm{C}(55)-\mathrm{C}(54)-\mathrm{H}(54 \mathrm{~A})$ & 110.7 \\
\hline $\mathrm{H}(53 \mathrm{~A})-\mathrm{C}(53)-\mathrm{H}(53 \mathrm{C})$ & 109.5 & $\mathrm{O}(1)-\mathrm{C}(54)-\mathrm{H}(54 \mathrm{~B})$ & 110.7 \\
\hline $\mathrm{H}(53 \mathrm{~B})-\mathrm{C}(53)-\mathrm{H}(53 \mathrm{C})$ & 109.5 & $\mathrm{C}(55)-\mathrm{C}(54)-\mathrm{H}(54 \mathrm{~B})$ & 110.7 \\
\hline $\mathrm{O}\left(4^{\prime}\right)-\mathrm{Mg}(1)-\mathrm{O}(2)$ & $173.58(5)$ & $\mathrm{H}(54 \mathrm{~A})-\mathrm{C}(54)-\mathrm{H}(54 \mathrm{~B})$ & 108.8 \\
\hline $\mathrm{O}(4)-\mathrm{Mg}(1)-\mathrm{O}(2)$ & $173.58(5)$ & $C(54)-C(55)-C(56)$ & $101.87(13)$ \\
\hline $\mathrm{O}\left(4^{\prime}\right)-\mathrm{Mg}(1)-\mathrm{O}\left(5^{\prime}\right)$ & $92.15(5)$ & $\mathrm{C}(54)-\mathrm{C}(55)-\mathrm{H}(55 \mathrm{~A})$ & 111.4 \\
\hline $\mathrm{O}(2)-\mathrm{Mg}(1)-\mathrm{O}\left(5^{\prime}\right)$ & $89.57(5)$ & $\mathrm{C}(56)-\mathrm{C}(55)-\mathrm{H}(55 \mathrm{~A})$ & 111.4 \\
\hline $\mathrm{O}(4)-\mathrm{Mg}(1)-\mathrm{O}(5)$ & $92.15(5)$ & $\mathrm{C}(54)-\mathrm{C}(55)-\mathrm{H}(55 \mathrm{~B})$ & 111.4 \\
\hline $\mathrm{O}(2)-\mathrm{Mg}(1)-\mathrm{O}(5)$ & $89.57(5)$ & $\mathrm{C}(56)-\mathrm{C}(55)-\mathrm{H}(55 \mathrm{~B})$ & 111.4 \\
\hline $\mathrm{O}\left(4^{\prime}\right)-\mathrm{Mg}(1)-\mathrm{O}(1)$ & $85.32(5)$ & $\mathrm{H}(55 \mathrm{~A})-\mathrm{C}(55)-\mathrm{H}(55 \mathrm{~B})$ & 109.3 \\
\hline $\mathrm{O}(4)-\mathrm{Mg}(1)-\mathrm{O}(1)$ & $85.32(5)$ & $\mathrm{C}(57)-\mathrm{C}(56)-\mathrm{C}(55)$ & $102.75(13)$ \\
\hline $\mathrm{O}(2)-\mathrm{Mg}(1)-\mathrm{O}(1)$ & $88.56(5)$ & $\mathrm{C}(57)-\mathrm{C}(56)-\mathrm{H}(56 \mathrm{~A})$ & 111.2 \\
\hline $\mathrm{O}\left(5^{\prime}\right)-\mathrm{Mg}(1)-\mathrm{O}(1)$ & $87.74(5)$ & $\mathrm{C}(55)-\mathrm{C}(56)-\mathrm{H}(56 \mathrm{~A})$ & 111.2 \\
\hline $\mathrm{O}(5)-\mathrm{Mg}(1)-\mathrm{O}(1)$ & $87.74(5)$ & $\mathrm{C}(57)-\mathrm{C}(56)-\mathrm{H}(56 \mathrm{~B})$ & 111.2 \\
\hline $\mathrm{O}\left(4^{\prime}\right)-\mathrm{Mg}(1)-\mathrm{O}(3)$ & $91.26(5)$ & $\mathrm{C}(55)-\mathrm{C}(56)-\mathrm{H}(56 \mathrm{~B})$ & 111.2 \\
\hline
\end{tabular}




\begin{tabular}{|c|c|c|c|}
\hline $\mathrm{H}(56 \mathrm{~A})-\mathrm{C}(56)-\mathrm{H}(56 \mathrm{~B})$ & 109.1 & $\mathrm{C}(65)-\mathrm{O}(3)-\mathrm{Mg}(1)$ & $126.16(10)$ \\
\hline $\mathrm{O}(1)-\mathrm{C}(57)-\mathrm{C}(56)$ & $106.20(13)$ & $\mathrm{C}(62)-\mathrm{O}(3)-\mathrm{Mg}(1)$ & $125.10(10)$ \\
\hline $\mathrm{O}(1)-\mathrm{C}(57)-\mathrm{H}(57 \mathrm{~A})$ & 110.5 & $\mathrm{O}(3)-\mathrm{C}(62)-\mathrm{C}(63)$ & $106.07(13)$ \\
\hline $\mathrm{C}(56)-\mathrm{C}(57)-\mathrm{H}(57 \mathrm{~A})$ & 110.5 & $\mathrm{O}(3)-\mathrm{C}(62)-\mathrm{H}(62 \mathrm{~A})$ & 110.5 \\
\hline $\mathrm{O}(1)-\mathrm{C}(57)-\mathrm{H}(57 \mathrm{~B})$ & 110.5 & $\mathrm{C}(63)-\mathrm{C}(62)-\mathrm{H}(62 \mathrm{~A})$ & 110.5 \\
\hline $\mathrm{C}(56)-\mathrm{C}(57)-\mathrm{H}(57 \mathrm{~B})$ & 110.5 & $\mathrm{O}(3)-\mathrm{C}(62)-\mathrm{H}(62 \mathrm{~B})$ & 110.5 \\
\hline $\mathrm{H}(57 \mathrm{~A})-\mathrm{C}(57)-\mathrm{H}(57 \mathrm{~B})$ & 108.7 & $\mathrm{C}(63)-\mathrm{C}(62)-\mathrm{H}(62 \mathrm{~B})$ & 110.5 \\
\hline $\mathrm{C}(58)-\mathrm{O}(2)-\mathrm{C}(61)$ & $108.85(12)$ & $\mathrm{H}(62 \mathrm{~A})-\mathrm{C}(62)-\mathrm{H}(62 \mathrm{~B})$ & 108.7 \\
\hline $\mathrm{C}(58)-\mathrm{O}(2)-\mathrm{Mg}(1)$ & $126.90(10)$ & $\mathrm{C}(64)-\mathrm{C}(63)-\mathrm{C}(62)$ & $102.33(14)$ \\
\hline $\mathrm{C}(61)-\mathrm{O}(2)-\mathrm{Mg}(1)$ & $120.24(10)$ & $\mathrm{C}(64)-\mathrm{C}(63)-\mathrm{H}(63 \mathrm{~A})$ & 111.3 \\
\hline $\mathrm{O}(2)-\mathrm{C}(58)-\mathrm{C}(59)$ & 104.93(14) & $\mathrm{C}(62)-\mathrm{C}(63)-\mathrm{H}(63 \mathrm{~A})$ & 111.3 \\
\hline $\mathrm{O}(2)-\mathrm{C}(58)-\mathrm{H}(58 \mathrm{~A})$ & 110.8 & $\mathrm{C}(64)-\mathrm{C}(63)-\mathrm{H}(63 \mathrm{~B})$ & 111.3 \\
\hline $\mathrm{C}(59)-\mathrm{C}(58)-\mathrm{H}(58 \mathrm{~A})$ & 110.8 & $\mathrm{C}(62)-\mathrm{C}(63)-\mathrm{H}(63 \mathrm{~B})$ & 111.3 \\
\hline $\mathrm{O}(2)-\mathrm{C}(58)-\mathrm{H}(58 \mathrm{~B})$ & 110.8 & $\mathrm{H}(63 \mathrm{~A})-\mathrm{C}(63)-\mathrm{H}(63 \mathrm{~B})$ & 109.2 \\
\hline $\mathrm{C}(59)-\mathrm{C}(58)-\mathrm{H}(58 \mathrm{~B})$ & 110.8 & $\mathrm{C}(63)-\mathrm{C}(64)-\mathrm{C}(65)$ & $101.40(16)$ \\
\hline $\mathrm{H}(58 \mathrm{~A})-\mathrm{C}(58)-\mathrm{H}(58 \mathrm{~B})$ & 108.8 & $\mathrm{C}(63)-\mathrm{C}(64)-\mathrm{H}(64 \mathrm{~A})$ & 111.5 \\
\hline $\mathrm{C}(58)-\mathrm{C}(59)-\mathrm{C}(60)$ & $101.83(14)$ & $\mathrm{C}(65)-\mathrm{C}(64)-\mathrm{H}(64 \mathrm{~A})$ & 111.5 \\
\hline $\mathrm{C}(58)-\mathrm{C}(59)-\mathrm{H}(59 \mathrm{~A})$ & 111.4 & $\mathrm{C}(63)-\mathrm{C}(64)-\mathrm{H}(64 \mathrm{~B})$ & 111.5 \\
\hline $\mathrm{C}(60)-\mathrm{C}(59)-\mathrm{H}(59 \mathrm{~A})$ & 111.4 & $\mathrm{C}(65)-\mathrm{C}(64)-\mathrm{H}(64 \mathrm{~B})$ & 111.5 \\
\hline C(58)-C(59)-H(59B) & 111.4 & $\mathrm{H}(64 \mathrm{~A})-\mathrm{C}(64)-\mathrm{H}(64 \mathrm{~B})$ & 109.3 \\
\hline $\mathrm{C}(60)-\mathrm{C}(59)-\mathrm{H}(59 \mathrm{~B})$ & 111.4 & $\mathrm{O}(3)-\mathrm{C}(65)-\mathrm{C}(64)$ & $104.55(14)$ \\
\hline $\mathrm{H}(59 \mathrm{~A})-\mathrm{C}(59)-\mathrm{H}(59 \mathrm{~B})$ & 109.3 & $\mathrm{O}(3)-\mathrm{C}(65)-\mathrm{H}(65 \mathrm{~A})$ & 110.8 \\
\hline $\mathrm{C}(61)-\mathrm{C}(60)-\mathrm{C}(59)$ & $102.09(13)$ & $\mathrm{C}(64)-\mathrm{C}(65)-\mathrm{H}(65 \mathrm{~A})$ & 110.8 \\
\hline $\mathrm{C}(61)-\mathrm{C}(60)-\mathrm{H}(60 \mathrm{~A})$ & 111.4 & $\mathrm{O}(3)-\mathrm{C}(65)-\mathrm{H}(65 \mathrm{~B})$ & 110.8 \\
\hline $\mathrm{C}(59)-\mathrm{C}(60)-\mathrm{H}(60 \mathrm{~A})$ & 111.4 & $\mathrm{C}(64)-\mathrm{C}(65)-\mathrm{H}(65 \mathrm{~B})$ & 110.8 \\
\hline $\mathrm{C}(61)-\mathrm{C}(60)-\mathrm{H}(60 \mathrm{~B})$ & 111.4 & $\mathrm{H}(65 \mathrm{~A})-\mathrm{C}(65)-\mathrm{H}(65 \mathrm{~B})$ & 108.9 \\
\hline $\mathrm{C}(59)-\mathrm{C}(60)-\mathrm{H}(60 \mathrm{~B})$ & 111.4 & $\mathrm{C}(66)-\mathrm{O}(4)-\mathrm{C}(69)$ & $108.0(3)$ \\
\hline $\mathrm{H}(60 \mathrm{~A})-\mathrm{C}(60)-\mathrm{H}(60 \mathrm{~B})$ & 109.2 & $\mathrm{C}(66)-\mathrm{O}(4)-\mathrm{Mg}(1)$ & $125.43(18)$ \\
\hline $\mathrm{O}(2)-\mathrm{C}(61)-\mathrm{C}(60)$ & $105.77(13)$ & $\mathrm{C}(69)-\mathrm{O}(4)-\mathrm{Mg}(1)$ & $123.9(3)$ \\
\hline $\mathrm{O}(2)-\mathrm{C}(61)-\mathrm{H}(61 \mathrm{~A})$ & 110.6 & $\mathrm{O}(4)-\mathrm{C}(66)-\mathrm{C}(67)$ & $103.1(3)$ \\
\hline $\mathrm{C}(60)-\mathrm{C}(61)-\mathrm{H}(61 \mathrm{~A})$ & 110.6 & $\mathrm{O}(4)-\mathrm{C}(66)-\mathrm{H}(66 \mathrm{~A})$ & 111.2 \\
\hline $\mathrm{O}(2)-\mathrm{C}(61)-\mathrm{H}(61 \mathrm{~B})$ & 110.6 & $\mathrm{C}(67)-\mathrm{C}(66)-\mathrm{H}(66 \mathrm{~A})$ & 111.2 \\
\hline $\mathrm{C}(60)-\mathrm{C}(61)-\mathrm{H}(61 \mathrm{~B})$ & 110.6 & $\mathrm{O}(4)-\mathrm{C}(66)-\mathrm{H}(66 \mathrm{~B})$ & 111.2 \\
\hline $\mathrm{H}(61 \mathrm{~A})-\mathrm{C}(61)-\mathrm{H}(61 \mathrm{~B})$ & 108.7 & $\mathrm{C}(67)-\mathrm{C}(66)-\mathrm{H}(66 \mathrm{~B})$ & 111.2 \\
\hline $\mathrm{C}(65)-\mathrm{O}(3)-\mathrm{C}(62)$ & 108.31(12) & $H(66 A)-C(66)-H(66 B)$ & 109.1 \\
\hline
\end{tabular}




\begin{tabular}{|c|c|c|c|}
\hline $\mathrm{C}(66)-\mathrm{C}(67)-\mathrm{C}(68)$ & $100.7(3)$ & $\mathrm{C}(71)-\mathrm{C}(72)-\mathrm{H}(72 \mathrm{~A})$ & 111.8 \\
\hline $\mathrm{C}(66)-\mathrm{C}(67)-\mathrm{H}(67 \mathrm{~A})$ & 111.6 & $\mathrm{C}(73)-\mathrm{C}(72)-\mathrm{H}(72 \mathrm{~B})$ & 111.8 \\
\hline $\mathrm{C}(68)-\mathrm{C}(67)-\mathrm{H}(67 \mathrm{~A})$ & 111.6 & $\mathrm{C}(71)-\mathrm{C}(72)-\mathrm{H}(72 \mathrm{~B})$ & 111.8 \\
\hline $\mathrm{C}(66)-\mathrm{C}(67)-\mathrm{H}(67 \mathrm{~B})$ & 111.6 & $\mathrm{H}(72 \mathrm{~A})-\mathrm{C}(72)-\mathrm{H}(72 \mathrm{~B})$ & 109.5 \\
\hline $\mathrm{C}(68)-\mathrm{C}(67)-\mathrm{H}(67 \mathrm{~B})$ & 111.6 & $\mathrm{O}(5)-\mathrm{C}(73)-\mathrm{C}(72)$ & 104.1(9) \\
\hline $\mathrm{H}(67 \mathrm{~A})-\mathrm{C}(67)-\mathrm{H}(67 \mathrm{~B})$ & 109.4 & $\mathrm{O}(5)-\mathrm{C}(73)-\mathrm{H}(73 \mathrm{~A})$ & 110.9 \\
\hline $\mathrm{C}(69)-\mathrm{C}(68)-\mathrm{C}(67)$ & $104.1(4)$ & $\mathrm{C}(72)-\mathrm{C}(73)-\mathrm{H}(73 \mathrm{~A})$ & 110.9 \\
\hline $\mathrm{C}(69)-\mathrm{C}(68)-\mathrm{H}(68 \mathrm{~A})$ & 110.9 & $\mathrm{O}(5)-\mathrm{C}(73)-\mathrm{H}(73 \mathrm{~B})$ & 110.9 \\
\hline $\mathrm{C}(67)-\mathrm{C}(68)-\mathrm{H}(68 \mathrm{~A})$ & 110.9 & $\mathrm{C}(72)-\mathrm{C}(73)-\mathrm{H}(73 \mathrm{~B})$ & 110.9 \\
\hline $\mathrm{C}(69)-\mathrm{C}(68)-\mathrm{H}(68 \mathrm{~B})$ & 110.9 & $\mathrm{H}(73 \mathrm{~A})-\mathrm{C}(73)-\mathrm{H}(73 \mathrm{~B})$ & 109.0 \\
\hline $\mathrm{C}(67)-\mathrm{C}(68)-\mathrm{H}(68 \mathrm{~B})$ & 110.9 & $\mathrm{C}\left(66^{\prime}\right)-\mathrm{O}\left(4^{\prime}\right)-\mathrm{C}\left(69^{\prime}\right)$ & $108.1(9)$ \\
\hline$H(68 A)-C(68)-H(68 B)$ & 109.0 & $\mathrm{C}\left(66^{\prime}\right)-\mathrm{O}\left(4^{\prime}\right)-\mathrm{Mg}(1)$ & $120.4(4)$ \\
\hline $\mathrm{O}(4)-\mathrm{C}(69)-\mathrm{C}(68)$ & $106.4(5)$ & $\mathrm{C}\left(69^{\prime}\right)-\mathrm{O}\left(4^{\prime}\right)-\mathrm{Mg}(1)$ & $124.8(7)$ \\
\hline $\mathrm{O}(4)-\mathrm{C}(69)-\mathrm{H}(69 \mathrm{~A})$ & 110.5 & $\mathrm{O}\left(4^{\prime}\right)-\mathrm{C}\left(66^{\prime}\right)-\mathrm{C}\left(67^{\prime}\right)$ & $106.4(7)$ \\
\hline $\mathrm{C}(68)-\mathrm{C}(69)-\mathrm{H}(69 \mathrm{~A})$ & 110.5 & $\mathrm{O}\left(4^{\prime}\right)-\mathrm{C}\left(66^{\prime}\right)-\mathrm{H}(66 \mathrm{C})$ & 110.5 \\
\hline $\mathrm{O}(4)-\mathrm{C}(69)-\mathrm{H}(69 \mathrm{~B})$ & 110.5 & $\mathrm{C}\left(67^{\prime}\right)-\mathrm{C}\left(66^{\prime}\right)-\mathrm{H}(66 \mathrm{C})$ & 110.5 \\
\hline $\mathrm{C}(68)-\mathrm{C}(69)-\mathrm{H}(69 \mathrm{~B})$ & 110.5 & $\mathrm{O}\left(4^{\prime}\right)-\mathrm{C}\left(66^{\prime}\right)-\mathrm{H}(66 \mathrm{D})$ & 110.5 \\
\hline$H(69 A)-C(69)-H(69 B)$ & 108.6 & $\mathrm{C}\left(67^{\prime}\right)-\mathrm{C}\left(66^{\prime}\right)-\mathrm{H}(66 \mathrm{D})$ & 110.5 \\
\hline $\mathrm{C}(73)-\mathrm{O}(5)-\mathrm{C}(70)$ & $110.2(6)$ & $H(66 C)-C\left(66^{\prime}\right)-H(66 D)$ & 108.6 \\
\hline $\mathrm{C}(73)-\mathrm{O}(5)-\mathrm{Mg}(1)$ & $130.6(6)$ & $\mathrm{C}\left(66^{\prime}\right)-\mathrm{C}\left(67^{\prime}\right)-\mathrm{C}\left(68^{\prime}\right)$ & $106.4(8)$ \\
\hline $\mathrm{C}(70)-\mathrm{O}(5)-\mathrm{Mg}(1)$ & $118.10(19)$ & $\mathrm{C}\left(66^{\prime}\right)-\mathrm{C}\left(67^{\prime}\right)-\mathrm{H}(67 \mathrm{C})$ & 110.4 \\
\hline $\mathrm{O}(5)-\mathrm{C}(70)-\mathrm{C}(71)$ & $102.7(3)$ & $\mathrm{C}\left(68^{\prime}\right)-\mathrm{C}\left(67^{\prime}\right)-\mathrm{H}(67 \mathrm{C})$ & 110.4 \\
\hline $\mathrm{O}(5)-\mathrm{C}(70)-\mathrm{H}(70 \mathrm{~A})$ & 111.2 & $\mathrm{C}\left(66^{\prime}\right)-\mathrm{C}\left(67^{\prime}\right)-\mathrm{H}(67 \mathrm{D})$ & 110.4 \\
\hline $\mathrm{C}(71)-\mathrm{C}(70)-\mathrm{H}(70 \mathrm{~A})$ & 111.2 & $\mathrm{C}\left(68^{\prime}\right)-\mathrm{C}\left(67^{\prime}\right)-\mathrm{H}(67 \mathrm{D})$ & 110.4 \\
\hline $\mathrm{O}(5)-\mathrm{C}(70)-\mathrm{H}(70 \mathrm{~B})$ & 111.2 & $\mathrm{H}(67 \mathrm{C})-\mathrm{C}\left(67^{\prime}\right)-\mathrm{H}(67 \mathrm{D})$ & 108.6 \\
\hline $\mathrm{C}(71)-\mathrm{C}(70)-\mathrm{H}(70 \mathrm{~B})$ & 111.2 & $\mathrm{C}\left(67^{\prime}\right)-\mathrm{C}\left(68^{\prime}\right)-\mathrm{C}\left(69^{\prime}\right)$ & $104.8(11)$ \\
\hline $\mathrm{H}(70 \mathrm{~A})-\mathrm{C}(70)-\mathrm{H}(70 \mathrm{~B})$ & 109.1 & $\mathrm{C}\left(67^{\prime}\right)-\mathrm{C}\left(68^{\prime}\right)-\mathrm{H}(68 \mathrm{C})$ & 110.8 \\
\hline $\mathrm{C}(70)-\mathrm{C}(71)-\mathrm{C}(72)$ & $102.6(8)$ & $\mathrm{C}\left(69^{\prime}\right)-\mathrm{C}\left(68^{\prime}\right)-\mathrm{H}(68 \mathrm{C})$ & 110.8 \\
\hline $\mathrm{C}(70)-\mathrm{C}(71)-\mathrm{H}(71 \mathrm{~A})$ & 111.2 & $\mathrm{C}\left(67^{\prime}\right)-\mathrm{C}\left(68^{\prime}\right)-\mathrm{H}(68 \mathrm{D})$ & 110.8 \\
\hline $\mathrm{C}(72)-\mathrm{C}(71)-\mathrm{H}(71 \mathrm{~A})$ & 111.2 & $\mathrm{C}\left(69^{\prime}\right)-\mathrm{C}\left(68^{\prime}\right)-\mathrm{H}(68 \mathrm{D})$ & 110.8 \\
\hline $\mathrm{C}(70)-\mathrm{C}(71)-\mathrm{H}(71 \mathrm{~B})$ & 111.2 & $H(68 C)-C\left(68^{\prime}\right)-H(68 D)$ & 108.9 \\
\hline $\mathrm{C}(72)-\mathrm{C}(71)-\mathrm{H}(71 \mathrm{~B})$ & 111.2 & $\mathrm{O}\left(4^{\prime}\right)-\mathrm{C}\left(69^{\prime}\right)-\mathrm{C}\left(68^{\prime}\right)$ & $103.9(10)$ \\
\hline $\mathrm{H}(71 \mathrm{~A})-\mathrm{C}(71)-\mathrm{H}(71 \mathrm{~B})$ & 109.2 & $\mathrm{O}\left(4^{\prime}\right)-\mathrm{C}\left(69^{\prime}\right)-\mathrm{H}(69 \mathrm{C})$ & 111.0 \\
\hline $\mathrm{C}(73)-\mathrm{C}(72)-\mathrm{C}(71)$ & $100.0(9)$ & $\mathrm{C}\left(68^{\prime}\right)-\mathrm{C}\left(69^{\prime}\right)-\mathrm{H}(69 \mathrm{C})$ & 111.0 \\
\hline $\mathrm{C}(73)-\mathrm{C}(72)-\mathrm{H}(72 \mathrm{~A})$ & 111.8 & $\mathrm{O}\left(4^{\prime}\right)-\mathrm{C}\left(69^{\prime}\right)-\mathrm{H}(69 \mathrm{D})$ & 111.0 \\
\hline
\end{tabular}




\begin{tabular}{|c|c|c|c|}
\hline $\mathrm{C}\left(68^{\prime}\right)-\mathrm{C}\left(69^{\prime}\right)-\mathrm{H}(69 \mathrm{D})$ & 111.0 & $\mathrm{H}(74 \mathrm{~A})-\mathrm{C}(74)-\mathrm{H}(74 \mathrm{~B})$ & 108.6 \\
\hline $\mathrm{H}(69 \mathrm{C})-\mathrm{C}\left(69^{\prime}\right)-\mathrm{H}(69 \mathrm{D})$ & 109.0 & $\mathrm{C}(76)-\mathrm{C}(75)-\mathrm{C}(74)$ & $102.32(17)$ \\
\hline $\mathrm{C}\left(70^{\prime}\right)-\mathrm{O}\left(5^{\prime}\right)-\mathrm{C}\left(73^{\prime}\right)$ & $103.5(6)$ & $\mathrm{C}(76)-\mathrm{C}(75)-\mathrm{H}(75 \mathrm{~A})$ & 111.3 \\
\hline $\mathrm{C}\left(70^{\prime}\right)-\mathrm{O}\left(5^{\prime}\right)-\mathrm{Mg}(1)$ & $130.5(2)$ & $\mathrm{C}(74)-\mathrm{C}(75)-\mathrm{H}(75 \mathrm{~A})$ & 111.3 \\
\hline $\mathrm{C}\left(73^{\prime}\right)-\mathrm{O}\left(5^{\prime}\right)-\mathrm{Mg}(1)$ & $126.1(6)$ & $\mathrm{C}(76)-\mathrm{C}(75)-\mathrm{H}(75 \mathrm{~B})$ & 111.3 \\
\hline $\mathrm{O}\left(5^{\prime}\right)-\mathrm{C}\left(70^{\prime}\right)-\mathrm{C}\left(71^{\prime}\right)$ & $102.9(4)$ & $\mathrm{C}(74)-\mathrm{C}(75)-\mathrm{H}(75 \mathrm{~B})$ & 111.3 \\
\hline $\mathrm{O}\left(5^{\prime}\right)-\mathrm{C}\left(70^{\prime}\right)-\mathrm{H}(70 \mathrm{C})$ & 111.2 & $\mathrm{H}(75 \mathrm{~A})-\mathrm{C}(75)-\mathrm{H}(75 \mathrm{~B})$ & 109.2 \\
\hline $\mathrm{C}\left(71^{\prime}\right)-\mathrm{C}\left(70^{\prime}\right)-\mathrm{H}(70 \mathrm{C})$ & 111.2 & $C(77)-C(76)-C(75)$ & $102.31(18)$ \\
\hline $\mathrm{O}\left(5^{\prime}\right)-\mathrm{C}\left(70^{\prime}\right)-\mathrm{H}(70 \mathrm{D})$ & 111.2 & $\mathrm{C}(77)-\mathrm{C}(76)-\mathrm{H}(76 \mathrm{~A})$ & 111.3 \\
\hline $\mathrm{C}\left(71^{\prime}\right)-\mathrm{C}\left(70^{\prime}\right)-\mathrm{H}(70 \mathrm{D})$ & 111.2 & $\mathrm{C}(75)-\mathrm{C}(76)-\mathrm{H}(76 \mathrm{~A})$ & 111.3 \\
\hline $\mathrm{H}(70 \mathrm{C})-\mathrm{C}\left(70^{\prime}\right)-\mathrm{H}(70 \mathrm{D})$ & 109.1 & $\mathrm{C}(77)-\mathrm{C}(76)-\mathrm{H}(76 \mathrm{~B})$ & 111.3 \\
\hline $\mathrm{C}\left(70^{\prime}\right)-\mathrm{C}\left(71^{\prime}\right)-\mathrm{C}\left(72^{\prime}\right)$ & $101.7(7)$ & $\mathrm{C}(75)-\mathrm{C}(76)-\mathrm{H}(76 \mathrm{~B})$ & 111.3 \\
\hline $\mathrm{C}\left(70^{\prime}\right)-\mathrm{C}\left(71^{\prime}\right)-\mathrm{H}(71 \mathrm{C})$ & 111.4 & $\mathrm{H}(76 \mathrm{~A})-\mathrm{C}(76)-\mathrm{H}(76 \mathrm{~B})$ & 109.2 \\
\hline $\mathrm{C}\left(72^{\prime}\right)-\mathrm{C}\left(71^{\prime}\right)-\mathrm{H}(71 \mathrm{C})$ & 111.4 & $\mathrm{O}(6)-\mathrm{C}(77)-\mathrm{C}(76)$ & 106.61(17) \\
\hline $\mathrm{C}\left(70^{\prime}\right)-\mathrm{C}\left(71^{\prime}\right)-\mathrm{H}(71 \mathrm{D})$ & 111.4 & $\mathrm{O}(6)-\mathrm{C}(77)-\mathrm{H}(77 \mathrm{~A})$ & 110.4 \\
\hline $\mathrm{C}\left(72^{\prime}\right)-\mathrm{C}\left(71^{\prime}\right)-\mathrm{H}(71 \mathrm{D})$ & 111.4 & $\mathrm{C}(76)-\mathrm{C}(77)-\mathrm{H}(77 \mathrm{~A})$ & 110.4 \\
\hline $\mathrm{H}(71 \mathrm{C})-\mathrm{C}\left(71^{\prime}\right)-\mathrm{H}(71 \mathrm{D})$ & 109.3 & $\mathrm{O}(6)-\mathrm{C}(77)-\mathrm{H}(77 \mathrm{~B})$ & 110.4 \\
\hline $\mathrm{C}\left(73^{\prime}\right)-\mathrm{C}\left(72^{\prime}\right)-\mathrm{C}\left(71^{\prime}\right)$ & $104.6(8)$ & $\mathrm{C}(76)-\mathrm{C}(77)-\mathrm{H}(77 \mathrm{~B})$ & 110.4 \\
\hline $\mathrm{C}\left(73^{\prime}\right)-\mathrm{C}\left(72^{\prime}\right)-\mathrm{H}(72 \mathrm{C})$ & 110.8 & $\mathrm{H}(77 \mathrm{~A})-\mathrm{C}(77)-\mathrm{H}(77 \mathrm{~B})$ & 108.6 \\
\hline $\mathrm{C}\left(71^{\prime}\right)-\mathrm{C}\left(72^{\prime}\right)-\mathrm{H}(72 \mathrm{C})$ & 110.8 & $\mathrm{C}(81)-\mathrm{O}(7)-\mathrm{C}(78)$ & $104.77(17)$ \\
\hline $\mathrm{C}\left(73^{\prime}\right)-\mathrm{C}\left(72^{\prime}\right)-\mathrm{H}(72 \mathrm{D})$ & 110.8 & $\mathrm{O}(7)-\mathrm{C}(78)-\mathrm{C}(79)$ & $104.17(17)$ \\
\hline $\mathrm{C}\left(71^{\prime}\right)-\mathrm{C}\left(72^{\prime}\right)-\mathrm{H}(72 \mathrm{D})$ & 110.8 & $\mathrm{O}(7)-\mathrm{C}(78)-\mathrm{H}(78 \mathrm{~A})$ & 110.9 \\
\hline $\mathrm{H}(72 \mathrm{C})-\mathrm{C}\left(72^{\prime}\right)-\mathrm{H}(72 \mathrm{D})$ & 108.9 & $\mathrm{C}(79)-\mathrm{C}(78)-\mathrm{H}(78 \mathrm{~A})$ & 110.9 \\
\hline $\mathrm{O}\left(5^{\prime}\right)-\mathrm{C}\left(73^{\prime}\right)-\mathrm{C}\left(72^{\prime}\right)$ & $106.3(8)$ & $\mathrm{O}(7)-\mathrm{C}(78)-\mathrm{H}(78 \mathrm{~B})$ & 110.9 \\
\hline $\mathrm{O}\left(5^{\prime}\right)-\mathrm{C}\left(73^{\prime}\right)-\mathrm{H}(73 \mathrm{C})$ & 110.5 & $\mathrm{C}(79)-\mathrm{C}(78)-\mathrm{H}(78 \mathrm{~B})$ & 110.9 \\
\hline $\mathrm{C}\left(72^{\prime}\right)-\mathrm{C}\left(73^{\prime}\right)-\mathrm{H}(73 \mathrm{C})$ & 110.5 & $\mathrm{H}(78 \mathrm{~A})-\mathrm{C}(78)-\mathrm{H}(78 \mathrm{~B})$ & 108.9 \\
\hline $\mathrm{O}\left(5^{\prime}\right)-\mathrm{C}\left(73^{\prime}\right)-\mathrm{H}(73 \mathrm{D})$ & 110.5 & $\mathrm{C}(80)-\mathrm{C}(79)-\mathrm{C}(78)$ & 104.36(19) \\
\hline $\mathrm{C}\left(72^{\prime}\right)-\mathrm{C}\left(73^{\prime}\right)-\mathrm{H}(73 \mathrm{D})$ & 110.5 & $\mathrm{C}(80)-\mathrm{C}(79)-\mathrm{H}(79 \mathrm{~A})$ & 110.9 \\
\hline $\mathrm{H}(73 \mathrm{C})-\mathrm{C}\left(73^{\prime}\right)-\mathrm{H}(73 \mathrm{D})$ & 108.7 & $\mathrm{C}(78)-\mathrm{C}(79)-\mathrm{H}(79 \mathrm{~A})$ & 110.9 \\
\hline $\mathrm{C}(77)-\mathrm{O}(6)-\mathrm{C}(74)$ & $109.52(17)$ & $\mathrm{C}(80)-\mathrm{C}(79)-\mathrm{H}(79 \mathrm{~B})$ & 110.9 \\
\hline $\mathrm{O}(6)-\mathrm{C}(74)-\mathrm{C}(75)$ & $106.97(18)$ & $\mathrm{C}(78)-\mathrm{C}(79)-\mathrm{H}(79 \mathrm{~B})$ & 110.9 \\
\hline $\mathrm{O}(6)-\mathrm{C}(74)-\mathrm{H}(74 \mathrm{~A})$ & 110.3 & H(79A)-C(79)-H(79B) & 108.9 \\
\hline $\mathrm{C}(75)-\mathrm{C}(74)-\mathrm{H}(74 \mathrm{~A})$ & 110.3 & $\mathrm{C}(79)-\mathrm{C}(80)-\mathrm{C}(81)$ & $103.7(2)$ \\
\hline $\mathrm{O}(6)-\mathrm{C}(74)-\mathrm{H}(74 \mathrm{~B})$ & 110.3 & $\mathrm{C}(79)-\mathrm{C}(80)-\mathrm{H}(80 \mathrm{~A})$ & 111.0 \\
\hline $\mathrm{C}(75)-\mathrm{C}(74)-\mathrm{H}(74 \mathrm{~B})$ & 110.3 & $\mathrm{C}(81)-\mathrm{C}(80)-\mathrm{H}(80 \mathrm{~A})$ & 111.0 \\
\hline
\end{tabular}




\begin{tabular}{|c|c|c|c|}
\hline $\mathrm{C}(79)-\mathrm{C}(80)-\mathrm{H}(80 \mathrm{~B})$ & 111.0 & $\mathrm{O}(8)-\mathrm{C}(85)-\mathrm{H}(85 \mathrm{~A})$ & 112.6 \\
\hline $\mathrm{C}(81)-\mathrm{C}(80)-\mathrm{H}(80 \mathrm{~B})$ & 111.0 & $\mathrm{C}(84)-\mathrm{C}(85)-\mathrm{H}(85 \mathrm{~B})$ & 112.6 \\
\hline $\mathrm{H}(80 \mathrm{~A})-\mathrm{C}(80)-\mathrm{H}(80 \mathrm{~B})$ & 109.0 & $\mathrm{O}(8)-\mathrm{C}(85)-\mathrm{H}(85 \mathrm{~B})$ & 112.6 \\
\hline $\mathrm{O}(7)-\mathrm{C}(81)-\mathrm{C}(80)$ & $105.10(18)$ & $\mathrm{H}(85 \mathrm{~A})-\mathrm{C}(85)-\mathrm{H}(85 \mathrm{~B})$ & 110.1 \\
\hline $\mathrm{O}(7)-\mathrm{C}(81)-\mathrm{H}(81 \mathrm{~A})$ & 110.7 & $\mathrm{C}\left(82^{\prime}\right)-\mathrm{O}\left(8^{\prime}\right)-\mathrm{C}\left(85^{\prime}\right)$ & $91.6(13)$ \\
\hline $\mathrm{C}(80)-\mathrm{C}(81)-\mathrm{H}(81 \mathrm{~A})$ & 110.7 & $\mathrm{C}\left(83^{\prime}\right)-\mathrm{C}\left(82^{\prime}\right)-\mathrm{O}\left(8^{\prime}\right)$ & $100.3(13)$ \\
\hline $\mathrm{O}(7)-\mathrm{C}(81)-\mathrm{H}(81 \mathrm{~B})$ & 110.7 & $\mathrm{C}\left(83^{\prime}\right)-\mathrm{C}\left(82^{\prime}\right)-\mathrm{H}(82 \mathrm{C})$ & 111.7 \\
\hline $\mathrm{C}(80)-\mathrm{C}(81)-\mathrm{H}(81 \mathrm{~B})$ & 110.7 & $\mathrm{O}\left(8^{\prime}\right)-\mathrm{C}\left(82^{\prime}\right)-\mathrm{H}(82 \mathrm{C})$ & 111.7 \\
\hline $\mathrm{H}(81 \mathrm{~A})-\mathrm{C}(81)-\mathrm{H}(81 \mathrm{~B})$ & 108.8 & $\mathrm{C}\left(83^{\prime}\right)-\mathrm{C}\left(82^{\prime}\right)-\mathrm{H}(82 \mathrm{D})$ & 111.7 \\
\hline $\mathrm{C}(82)-\mathrm{O}(8)-\mathrm{C}(85)$ & $107.8(12)$ & $\mathrm{O}\left(8^{\prime}\right)-\mathrm{C}\left(82^{\prime}\right)-\mathrm{H}(82 \mathrm{D})$ & 111.7 \\
\hline $\mathrm{C}(83)-\mathrm{C}(82)-\mathrm{O}(8)$ & $102.7(10)$ & $\mathrm{H}(82 \mathrm{C})-\mathrm{C}\left(82^{\prime}\right)-\mathrm{H}(82 \mathrm{D})$ & 109.5 \\
\hline $\mathrm{C}(83)-\mathrm{C}(82)-\mathrm{H}(82 \mathrm{~A})$ & 111.2 & $\mathrm{C}\left(82^{\prime}\right)-\mathrm{C}\left(83^{\prime}\right)-\mathrm{C}\left(84^{\prime}\right)$ & $102.7(11)$ \\
\hline $\mathrm{O}(8)-\mathrm{C}(82)-\mathrm{H}(82 \mathrm{~A})$ & 111.2 & $\mathrm{C}\left(82^{\prime}\right)-\mathrm{C}\left(83^{\prime}\right)-\mathrm{H}(83 \mathrm{C})$ & 111.2 \\
\hline $\mathrm{C}(83)-\mathrm{C}(82)-\mathrm{H}(82 \mathrm{~B})$ & 111.2 & $\mathrm{C}\left(84^{\prime}\right)-\mathrm{C}\left(83^{\prime}\right)-\mathrm{H}(83 \mathrm{C})$ & 111.2 \\
\hline $\mathrm{O}(8)-\mathrm{C}(82)-\mathrm{H}(82 \mathrm{~B})$ & 111.2 & $\mathrm{C}\left(82^{\prime}\right)-\mathrm{C}\left(83^{\prime}\right)-\mathrm{H}(83 \mathrm{D})$ & 111.2 \\
\hline $\mathrm{H}(82 \mathrm{~A})-\mathrm{C}(82)-\mathrm{H}(82 \mathrm{~B})$ & 109.1 & $\mathrm{C}\left(84^{\prime}\right)-\mathrm{C}\left(83^{\prime}\right)-\mathrm{H}(83 \mathrm{D})$ & 111.2 \\
\hline $\mathrm{C}(82)-\mathrm{C}(83)-\mathrm{C}(84)$ & $105.4(11)$ & $\mathrm{H}(83 \mathrm{C})-\mathrm{C}\left(83^{\prime}\right)-\mathrm{H}(83 \mathrm{D})$ & 109.1 \\
\hline $\mathrm{C}(82)-\mathrm{C}(83)-\mathrm{H}(83 \mathrm{~A})$ & 110.7 & $\mathrm{C}\left(83^{\prime}\right)-\mathrm{C}\left(84^{\prime}\right)-\mathrm{C}\left(85^{\prime}\right)$ & $103.8(13)$ \\
\hline $\mathrm{C}(84)-\mathrm{C}(83)-\mathrm{H}(83 \mathrm{~A})$ & 110.7 & $\mathrm{C}\left(83^{\prime}\right)-\mathrm{C}\left(84^{\prime}\right)-\mathrm{H}(84 \mathrm{C})$ & 111.0 \\
\hline $\mathrm{C}(82)-\mathrm{C}(83)-\mathrm{H}(83 \mathrm{~B})$ & 110.7 & $\mathrm{C}\left(85^{\prime}\right)-\mathrm{C}\left(84^{\prime}\right)-\mathrm{H}(84 \mathrm{C})$ & 111.0 \\
\hline $\mathrm{C}(84)-\mathrm{C}(83)-\mathrm{H}(83 \mathrm{~B})$ & 110.7 & $\mathrm{C}\left(83^{\prime}\right)-\mathrm{C}\left(84^{\prime}\right)-\mathrm{H}(84 \mathrm{D})$ & 111.0 \\
\hline $\mathrm{H}(83 \mathrm{~A})-\mathrm{C}(83)-\mathrm{H}(83 \mathrm{~B})$ & 108.8 & $\mathrm{C}\left(85^{\prime}\right)-\mathrm{C}\left(84^{\prime}\right)-\mathrm{H}(84 \mathrm{D})$ & 111.0 \\
\hline $\mathrm{C}(85)-\mathrm{C}(84)-\mathrm{C}(83)$ & $105.5(13)$ & $\mathrm{H}(84 \mathrm{C})-\mathrm{C}\left(84^{\prime}\right)-\mathrm{H}(84 \mathrm{D})$ & 109.0 \\
\hline $\mathrm{C}(85)-\mathrm{C}(84)-\mathrm{H}(84 \mathrm{~A})$ & 110.6 & $\mathrm{C}\left(84^{\prime}\right)-\mathrm{C}\left(85^{\prime}\right)-\mathrm{O}\left(8^{\prime}\right)$ & $91.5(14)$ \\
\hline $\mathrm{C}(83)-\mathrm{C}(84)-\mathrm{H}(84 \mathrm{~A})$ & 110.6 & $\mathrm{C}\left(84^{\prime}\right)-\mathrm{C}\left(85^{\prime}\right)-\mathrm{H}(85 \mathrm{C})$ & 113.4 \\
\hline $\mathrm{C}(85)-\mathrm{C}(84)-\mathrm{H}(84 \mathrm{~B})$ & 110.6 & $\mathrm{O}\left(8^{\prime}\right)-\mathrm{C}\left(85^{\prime}\right)-\mathrm{H}(85 \mathrm{C})$ & 113.4 \\
\hline $\mathrm{C}(83)-\mathrm{C}(84)-\mathrm{H}(84 \mathrm{~B})$ & 110.6 & $\mathrm{C}\left(84^{\prime}\right)-\mathrm{C}\left(85^{\prime}\right)-\mathrm{H}(85 \mathrm{D})$ & 113.4 \\
\hline $\mathrm{H}(84 \mathrm{~A})-\mathrm{C}(84)-\mathrm{H}(84 \mathrm{~B})$ & 108.8 & $\mathrm{O}\left(8^{\prime}\right)-\mathrm{C}\left(85^{\prime}\right)-\mathrm{H}(85 \mathrm{D})$ & 113.4 \\
\hline $\mathrm{C}(84)-\mathrm{C}(85)-\mathrm{O}(8)$ & $95.5(12)$ & $\mathrm{H}(85 \mathrm{C})-\mathrm{C}\left(85^{\prime}\right)-\mathrm{H}(85 \mathrm{D})$ & 110.7 \\
\hline $\mathrm{C}(84)-\mathrm{C}(85)-\mathrm{H}(85 \mathrm{~A})$ & 112.6 & & \\
\hline
\end{tabular}


Table 4. Anisotropic displacement parameters $\left(\AA^{2} \times 10^{3}\right)$ for neipn01. The anisotropic displacement factor exponent takes the form: $-2 \pi^{2}\left[h^{2} a^{* 2} U_{11}+\ldots+2 h \mathrm{k} \mathrm{a}^{*} \mathrm{~b}^{*} \mathrm{U}_{12}\right]$

\begin{tabular}{|c|c|c|c|c|c|c|}
\hline & $\mathrm{U}_{11}$ & $\mathrm{U}_{22}$ & $\mathrm{U}_{33}$ & $\mathrm{U}_{23}$ & $\mathrm{U}_{13}$ & $\mathrm{U}_{12}$ \\
\hline $\mathrm{Fe} 1$ & $15(1)$ & $12(1)$ & $14(1)$ & $1(1)$ & $2(1)$ & $1(1)$ \\
\hline N1 & $16(1)$ & $14(1)$ & $16(1)$ & $1(1)$ & $3(1)$ & $1(1)$ \\
\hline $\mathrm{N} 2$ & $15(1)$ & $13(1)$ & $16(1)$ & $1(1)$ & $3(1)$ & $2(1)$ \\
\hline N3 & $17(1)$ & $13(1)$ & $17(1)$ & $1(1)$ & $0(1)$ & $1(1)$ \\
\hline $\mathrm{C} 1$ & $23(1)$ & $16(1)$ & $16(1)$ & $2(1)$ & $-1(1)$ & $-1(1)$ \\
\hline $\mathrm{C} 2$ & $24(1)$ & $19(1)$ & $19(1)$ & $1(1)$ & $5(1)$ & $-1(1)$ \\
\hline $\mathrm{C} 3$ & $19(1)$ & $19(1)$ & $22(1)$ & $2(1)$ & $3(1)$ & $2(1)$ \\
\hline $\mathrm{C} 4$ & 19(1) & $25(1)$ & $31(1)$ & $1(1)$ & $6(1)$ & $2(1)$ \\
\hline $\mathrm{C} 21$ & $15(1)$ & $16(1)$ & $18(1)$ & $2(1)$ & $5(1)$ & $2(1)$ \\
\hline $\mathrm{C} 22$ & $18(1)$ & $21(1)$ & $19(1)$ & $4(1)$ & $6(1)$ & $3(1)$ \\
\hline $\mathrm{C} 23$ & 21(1) & $27(1)$ & $16(1)$ & $2(1)$ & $4(1)$ & $4(1)$ \\
\hline $\mathrm{C} 24$ & $21(1)$ & $23(1)$ & $17(1)$ & $-1(1)$ & $1(1)$ & $3(1)$ \\
\hline $\mathrm{C} 25$ & $16(1)$ & $17(1)$ & $17(1)$ & $-2(1)$ & $2(1)$ & $2(1)$ \\
\hline $\mathrm{C} 26$ & $16(1)$ & $14(1)$ & $19(1)$ & $2(1)$ & $4(1)$ & $2(1)$ \\
\hline $\mathrm{C} 27$ & $24(1)$ & $17(1)$ & $23(1)$ & $3(1)$ & $6(1)$ & $-2(1)$ \\
\hline $\mathrm{C} 28$ & $19(1)$ & $16(1)$ & $18(1)$ & $-1(1)$ & $0(1)$ & $1(1)$ \\
\hline $\mathrm{C} 29$ & $33(1)$ & $20(1)$ & $21(1)$ & $-4(1)$ & $1(1)$ & $-4(1)$ \\
\hline $\mathrm{C} 30$ & 19(1) & $12(1)$ & $16(1)$ & $1(1)$ & $4(1)$ & $-2(1)$ \\
\hline C31 & $20(1)$ & $15(1)$ & $17(1)$ & $1(1)$ & $3(1)$ & $-2(1)$ \\
\hline C32 & $24(1)$ & $19(1)$ & $20(1)$ & $1(1)$ & $0(1)$ & $-4(1)$ \\
\hline C33 & $33(1)$ & $18(1)$ & $18(1)$ & $-1(1)$ & $3(1)$ & $-8(1)$ \\
\hline C34 & $32(1)$ & $15(1)$ & $22(1)$ & $-3(1)$ & $10(1)$ & $-4(1)$ \\
\hline C35 & $23(1)$ & $13(1)$ & $20(1)$ & $0(1)$ & $8(1)$ & $-3(1)$ \\
\hline C36 & $18(1)$ & $20(1)$ & $22(1)$ & $-3(1)$ & $0(1)$ & $1(1)$ \\
\hline C37 & $27(1)$ & $34(1)$ & $38(1)$ & $-3(1)$ & $15(1)$ & $0(1)$ \\
\hline C38 & $29(1)$ & $32(1)$ & $35(1)$ & $2(1)$ & $2(1)$ & $9(1)$ \\
\hline C39 & $22(1)$ & $17(1)$ & $28(1)$ & $-2(1)$ & $10(1)$ & $1(1)$ \\
\hline $\mathrm{C} 40$ & $31(1)$ & $24(1)$ & $40(1)$ & $2(1)$ & $18(1)$ & $3(1)$ \\
\hline $\mathrm{C} 41$ & $28(1)$ & $27(1)$ & $33(1)$ & $7(1)$ & $10(1)$ & $6(1)$ \\
\hline $\mathrm{C} 42$ & $21(1)$ & $13(1)$ & $18(1)$ & $-1(1)$ & $1(1)$ & $0(1)$ \\
\hline
\end{tabular}




\begin{tabular}{|c|c|c|c|c|c|c|}
\hline $\mathrm{C} 43$ & $24(1)$ & $14(1)$ & $17(1)$ & $-3(1)$ & $1(1)$ & 2(1) \\
\hline $\mathrm{C} 44$ & $31(1)$ & $15(1)$ & 21(1) & $-1(1)$ & $2(1)$ & $6(1)$ \\
\hline $\mathrm{C} 45$ & $40(1)$ & $14(1)$ & $24(1)$ & $1(1)$ & $6(1)$ & $1(1)$ \\
\hline $\mathrm{C} 46$ & $32(1)$ & $18(1)$ & $25(1)$ & $0(1)$ & $7(1)$ & $-4(1)$ \\
\hline C47 & $23(1)$ & $16(1)$ & $22(1)$ & $0(1)$ & $3(1)$ & $-2(1)$ \\
\hline $\mathrm{C} 48$ & $22(1)$ & $16(1)$ & $28(1)$ & $-2(1)$ & $3(1)$ & $4(1)$ \\
\hline C49 & $23(1)$ & $39(1)$ & $41(1)$ & $-7(1)$ & $-1(1)$ & $7(1)$ \\
\hline C50 & $37(1)$ & $30(1)$ & $31(1)$ & 1(1) & $15(1)$ & $1(1)$ \\
\hline C51 & $22(1)$ & $20(1)$ & $34(1)$ & $4(1)$ & $6(1)$ & $-2(1)$ \\
\hline C52 & $28(1)$ & $24(1)$ & $43(1)$ & 1(1) & $14(1)$ & $-2(1)$ \\
\hline C53 & $26(1)$ & $38(1)$ & $43(1)$ & $2(1)$ & $-2(1)$ & $-2(1)$ \\
\hline Mg1 & $23(1)$ & $18(1)$ & $16(1)$ & $-2(1)$ & $3(1)$ & $2(1)$ \\
\hline $\mathrm{Br} 1$ & $31(1)$ & $27(1)$ & $28(1)$ & $-5(1)$ & $5(1)$ & $7(1)$ \\
\hline $\mathrm{Cl} 1$ & $31(1)$ & $27(1)$ & $28(1)$ & $-5(1)$ & $5(1)$ & $7(1)$ \\
\hline $\mathrm{O} 1$ & $25(1)$ & $17(1)$ & $18(1)$ & $0(1)$ & $6(1)$ & $3(1)$ \\
\hline C54 & $28(1)$ & $18(1)$ & $22(1)$ & 1(1) & $5(1)$ & $4(1)$ \\
\hline C55 & $38(1)$ & 21(1) & $28(1)$ & $-4(1)$ & $9(1)$ & $6(1)$ \\
\hline C56 & $33(1)$ & $29(1)$ & $26(1)$ & $-2(1)$ & $12(1)$ & $8(1)$ \\
\hline C57 & $28(1)$ & $23(1)$ & $20(1)$ & $-1(1)$ & $8(1)$ & $-1(1)$ \\
\hline $\mathrm{O} 2$ & $18(1)$ & $28(1)$ & $18(1)$ & $2(1)$ & $2(1)$ & 1(1) \\
\hline C58 & $23(1)$ & $43(1)$ & 19(1) & $4(1)$ & $2(1)$ & $4(1)$ \\
\hline C59 & $34(1)$ & $32(1)$ & $26(1)$ & $7(1)$ & $7(1)$ & $6(1)$ \\
\hline C60 & $27(1)$ & $30(1)$ & $27(1)$ & $2(1)$ & $10(1)$ & $-2(1)$ \\
\hline C61 & $19(1)$ & $32(1)$ & $25(1)$ & $0(1)$ & $4(1)$ & $-3(1)$ \\
\hline $\mathrm{O} 3$ & $24(1)$ & $24(1)$ & 21(1) & $-6(1)$ & $-1(1)$ & $6(1)$ \\
\hline C62 & $24(1)$ & $27(1)$ & $26(1)$ & $-8(1)$ & $3(1)$ & $3(1)$ \\
\hline C63 & $30(1)$ & $43(1)$ & $31(1)$ & $-15(1)$ & $-2(1)$ & $4(1)$ \\
\hline C64 & $25(1)$ & $52(1)$ & $35(1)$ & $-18(1)$ & $-4(1)$ & $8(1)$ \\
\hline C65 & $30(1)$ & $39(1)$ & $30(1)$ & $-8(1)$ & $-5(1)$ & $16(1)$ \\
\hline $\mathrm{O} 4$ & $38(1)$ & $19(1)$ & 19(1) & 1(1) & $5(1)$ & $2(1)$ \\
\hline C66 & $53(2)$ & $28(2)$ & $20(1)$ & $3(1)$ & $1(1)$ & $6(1)$ \\
\hline C67 & $60(2)$ & $33(1)$ & $22(1)$ & $7(1)$ & $9(1)$ & $8(1)$ \\
\hline C68 & $54(2)$ & $19(2)$ & $34(1)$ & $3(1)$ & $21(1)$ & $10(1)$ \\
\hline C69 & $42(3)$ & $17(2)$ & $29(1)$ & $1(1)$ & 11(1) & $1(2)$ \\
\hline O5 & $25(1)$ & $28(1)$ & $22(1)$ & $-9(1)$ & $5(1)$ & $-3(1)$ \\
\hline
\end{tabular}




\begin{tabular}{|c|c|c|c|c|c|c|}
\hline C70 & $28(2)$ & $33(2)$ & $21(2)$ & $-9(1)$ & $0(1)$ & $4(1)$ \\
\hline C71 & $31(1)$ & $25(2)$ & $29(2)$ & $-9(1)$ & $-4(1)$ & $7(1)$ \\
\hline C72 & $25(2)$ & $24(1)$ & $35(3)$ & $-8(2)$ & $-1(1)$ & $1(1)$ \\
\hline C73 & $24(1)$ & $22(1)$ & $17(4)$ & $-1(2)$ & $0(1)$ & 1(1) \\
\hline O4' & $38(1)$ & $19(1)$ & $19(1)$ & $1(1)$ & $5(1)$ & $2(1)$ \\
\hline C66' & $53(2)$ & $28(2)$ & $20(1)$ & $3(1)$ & 1(1) & $6(1)$ \\
\hline C67' & $60(2)$ & $33(1)$ & $22(1)$ & $7(1)$ & $9(1)$ & $8(1)$ \\
\hline C68' & $54(2)$ & $19(2)$ & $34(1)$ & $3(1)$ & $21(1)$ & $10(1)$ \\
\hline C69' & $42(3)$ & $17(2)$ & $29(1)$ & $1(1)$ & $11(1)$ & $1(2)$ \\
\hline O5' & $25(1)$ & $28(1)$ & $22(1)$ & $-9(1)$ & $5(1)$ & $-3(1)$ \\
\hline C70' & $28(2)$ & $33(2)$ & $21(2)$ & $-9(1)$ & $0(1)$ & $4(1)$ \\
\hline C71' & $31(1)$ & $25(2)$ & $29(2)$ & $-9(1)$ & $-4(1)$ & $7(1)$ \\
\hline C72' & $25(2)$ & $24(1)$ & $35(3)$ & $-8(2)$ & $-1(1)$ & $1(1)$ \\
\hline C73' & $24(1)$ & $22(1)$ & $17(4)$ & $-1(2)$ & $0(1)$ & $1(1)$ \\
\hline O6 & $65(1)$ & $45(1)$ & $39(1)$ & $-5(1)$ & $13(1)$ & $-18(1)$ \\
\hline C74 & $72(2)$ & $35(1)$ & $36(1)$ & $3(1)$ & $-11(1)$ & $-6(1)$ \\
\hline C75 & $37(1)$ & $28(1)$ & $62(2)$ & $7(1)$ & $-16(1)$ & $-4(1)$ \\
\hline C76 & $41(1)$ & $38(1)$ & $44(1)$ & $4(1)$ & $6(1)$ & $-11(1)$ \\
\hline C77 & $38(1)$ & $27(1)$ & $44(1)$ & $-1(1)$ & $10(1)$ & $-3(1)$ \\
\hline O7 & $39(1)$ & $43(1)$ & $49(1)$ & $-10(1)$ & $6(1)$ & $-5(1)$ \\
\hline C78 & $49(1)$ & $43(1)$ & $39(1)$ & $-2(1)$ & $10(1)$ & $9(1)$ \\
\hline C79 & $52(1)$ & $41(1)$ & $32(1)$ & $-6(1)$ & $-5(1)$ & $9(1)$ \\
\hline $\mathrm{C} 80$ & $41(1)$ & $100(2)$ & $52(2)$ & $-24(2)$ & $10(1)$ & $-14(1)$ \\
\hline C81 & $57(1)$ & $57(2)$ & $31(1)$ & $-11(1)$ & $9(1)$ & $-4(1)$ \\
\hline O8 & $89(5)$ & $72(5)$ & $113(6)$ & $11(4)$ & $-29(5)$ & $-4(5)$ \\
\hline C82 & $49(6)$ & $82(13)$ & $41(6)$ & $-3(8)$ & $-15(5)$ & $14(8)$ \\
\hline C83 & $89(5)$ & $72(5)$ & $113(6)$ & $11(4)$ & $-29(5)$ & $-4(5)$ \\
\hline C84 & $118(12)$ & $119(12)$ & $54(12)$ & $-33(9)$ & $13(10)$ & $0(10)$ \\
\hline $\mathrm{C} 85$ & $74(7)$ & $78(7)$ & $93(8)$ & $13(6)$ & $25(7)$ & $-18(6)$ \\
\hline O8' & $89(5)$ & $72(5)$ & $113(6)$ & $11(4)$ & $-29(5)$ & $-4(5)$ \\
\hline C82' & $49(6)$ & $82(13)$ & $41(6)$ & $-3(8)$ & $-15(5)$ & $14(8)$ \\
\hline C83' & $89(5)$ & $72(5)$ & $113(6)$ & $11(4)$ & $-29(5)$ & $-4(5)$ \\
\hline C84' & $118(12)$ & $119(12)$ & $54(12)$ & $-33(9)$ & $13(10)$ & $0(10)$ \\
\hline C85' & $74(7)$ & $78(7)$ & $93(8)$ & $13(6)$ & $25(7)$ & $-18(6)$ \\
\hline
\end{tabular}


Table 5. Hydrogen coordinates $\left(\mathrm{x} 10^{4}\right)$ and isotropic displacement parameters $\left(\AA^{2} \times 10^{3}\right)$ for neipn01.

\begin{tabular}{|c|c|c|c|c|}
\hline & $\mathrm{x}$ & $\mathrm{y}$ & $\mathrm{z}$ & $\mathrm{U}(\mathrm{eq})$ \\
\hline $\mathrm{H} 1 \mathrm{~A}$ & $1606(17)$ & 7293(8) & 7741(7) & $19(5)$ \\
\hline H1B & $1086(16)$ & 6649(8) & $7618(7)$ & $18(4)$ \\
\hline $\mathrm{H} 2 \mathrm{~A}$ & $-271(18)$ & 7662(9) & 7818(8) & $28(5)$ \\
\hline $\mathrm{H} 2 \mathrm{~B}$ & $-868(19)$ & 7018(9) & $7672(8)$ & $30(5)$ \\
\hline $\mathrm{H} 3 \mathrm{~A}$ & -1498 & 8126 & 6580 & 24 \\
\hline H3B & -1979 & 7482 & 6420 & 24 \\
\hline $\mathrm{H} 4 \mathrm{~A}$ & -3216 & 7988 & 6901 & 37 \\
\hline $\mathrm{H} 4 \mathrm{~B}$ & -2173 & 8006 & 7387 & 37 \\
\hline $\mathrm{H} 4 \mathrm{C}$ & -2744 & 7385 & 7183 & 37 \\
\hline $\mathrm{H} 22$ & 756 & 8599 & 5461 & 23 \\
\hline $\mathrm{H} 23$ & -33 & 7903 & 4833 & 25 \\
\hline $\mathrm{H} 24$ & -690 & 6973 & 5080 & 25 \\
\hline $\mathrm{H} 27 \mathrm{~A}$ & 1907 & 9169 & 6813 & 32 \\
\hline H27B & 931 & 9301 & 6316 & 32 \\
\hline $\mathrm{H} 27 \mathrm{C}$ & 2160 & 8992 & 6248 & 32 \\
\hline H29A & -1011 & 5705 & 6017 & 38 \\
\hline $\mathrm{H} 29 \mathrm{~B}$ & -508 & 5968 & 5527 & 38 \\
\hline $\mathrm{H} 29 \mathrm{C}$ & -1827 & 6128 & 5617 & 38 \\
\hline H32 & 4123 & 8518 & 8164 & 26 \\
\hline H33 & 3114 & 9169 & 8629 & 27 \\
\hline H34 & 1102 & 9346 & 8364 & 27 \\
\hline H36 & 2860 & 7686 & 7040 & 24 \\
\hline H37A & 3769 & 8565 & 6791 & 48 \\
\hline H37B & 4665 & 8017 & 6805 & 48 \\
\hline $\mathrm{H} 37 \mathrm{C}$ & 4826 & 8490 & 7267 & 48 \\
\hline $\mathrm{H} 38 \mathrm{~A}$ & 3670 & 7218 & 7836 & 49 \\
\hline H38B & 4787 & 7656 & 7889 & 49 \\
\hline $\mathrm{H} 38 \mathrm{C}$ & 4572 & 7184 & 7427 & 49 \\
\hline H39 & -756 & 8626 & 7311 & 26 \\
\hline
\end{tabular}




\begin{tabular}{|c|c|c|c|c|}
\hline $\mathrm{H} 40 \mathrm{~A}$ & -974 & 8576 & 8204 & 45 \\
\hline H40B & -1966 & 8987 & 7878 & 45 \\
\hline $\mathrm{H} 40 \mathrm{C}$ & -856 & 9283 & 8239 & 45 \\
\hline $\mathrm{H} 41 \mathrm{~A}$ & -188 & 9527 & 6965 & 43 \\
\hline H41B & -257 & 9860 & 7499 & 43 \\
\hline $\mathrm{H} 41 \mathrm{C}$ & -1442 & 9610 & 7157 & 43 \\
\hline $\mathrm{H} 44$ & 1504 & 4933 & 7243 & 27 \\
\hline $\mathrm{H} 45$ & -228 & 4511 & 7448 & 31 \\
\hline $\mathrm{H} 46$ & -1978 & 5055 & 7340 & 30 \\
\hline $\mathrm{H} 48$ & 1794 & 6404 & 6753 & 27 \\
\hline $\mathrm{H} 49 \mathrm{~A}$ & 2829 & 6042 & 7558 & 52 \\
\hline H49B & 3681 & 6078 & 7128 & 52 \\
\hline $\mathrm{H} 49 \mathrm{C}$ & 3160 & 5451 & 7273 & 52 \\
\hline H50A & 1479 & 5782 & 6027 & 47 \\
\hline H50B & 2214 & 5258 & 6344 & 47 \\
\hline H50C & 2878 & 5851 & 6212 & 47 \\
\hline H51 & -2377 & 6537 & 6836 & 30 \\
\hline H52A & -2378 & 6391 & 7738 & 46 \\
\hline H52B & -3141 & 5798 & 7615 & 46 \\
\hline H52C & -3708 & 6428 & 7434 & 46 \\
\hline H53A & -3184 & 5809 & 6238 & 55 \\
\hline H53B & -4200 & 6038 & 6547 & 55 \\
\hline H53C & -3565 & 5414 & 6692 & 55 \\
\hline H54A & 5633 & 6918 & 4864 & 27 \\
\hline H54B & 6935 & 7182 & 5069 & 27 \\
\hline H55A & 6153 & 6627 & 4087 & 35 \\
\hline H55B & 7375 & 6501 & 4475 & 35 \\
\hline H56A & 8201 & 7398 & 4275 & 35 \\
\hline H56B & 7472 & 7215 & 3718 & 35 \\
\hline H57A & 7016 & 8208 & 4162 & 28 \\
\hline H57B & 5993 & 7863 & 3781 & 28 \\
\hline H58A & 5212 & 7834 & 6047 & 34 \\
\hline H58B & 5816 & 7308 & 5762 & 34 \\
\hline H59A & 4519 & 7023 & 6436 & 37 \\
\hline H59B & 4412 & 6628 & 5916 & 37 \\
\hline
\end{tabular}




\begin{tabular}{|c|c|c|c|c|}
\hline H60A & 2458 & 6948 & 5893 & 33 \\
\hline H60B & 2878 & 7600 & 6101 & 33 \\
\hline H61A & 2881 & 7131 & 5089 & 31 \\
\hline H61B & 2549 & 7796 & 5237 & 31 \\
\hline H62A & 3737 & 7010 & 4239 & 31 \\
\hline H62B & 4160 & 7370 & 3769 & 31 \\
\hline H63A & 2303 & 7377 & 3298 & 42 \\
\hline H63B & 2182 & 6774 & 3618 & 42 \\
\hline H64A & 1314 & 7270 & 4243 & 46 \\
\hline H64B & 704 & 7596 & 3718 & 46 \\
\hline H65A & 2038 & 8376 & 3837 & 41 \\
\hline H65B & 1842 & 8250 & 4423 & 41 \\
\hline H66A & 3838 & 9134 & 3685 & 41 \\
\hline H66B & 4451 & 8511 & 3578 & 41 \\
\hline H67A & 5149 & 9413 & 3125 & 46 \\
\hline H67B & 6184 & 8983 & 3412 & 46 \\
\hline H68A & 6735 & 9861 & 3857 & 41 \\
\hline H68B & 5381 & 10088 & 3804 & 41 \\
\hline H69A & 6590 & 9371 & 4585 & 35 \\
\hline H69B & 5348 & 9708 & 4588 & 35 \\
\hline $\mathrm{H} 70 \mathrm{~A}$ & 5280 & 8957 & 5954 & 33 \\
\hline H70B & 5582 & 9452 & 5549 & 33 \\
\hline $\mathrm{H} 71 \mathrm{~A}$ & 7219 & 8905 & 6360 & 35 \\
\hline H71B & 7157 & 9598 & 6203 & 35 \\
\hline $\mathrm{H} 72 \mathrm{~A}$ & 7936 & 9404 & 5431 & 34 \\
\hline H72B & 8763 & 9005 & 5858 & 34 \\
\hline H73A & 7628 & 8456 & 5075 & 26 \\
\hline H73B & 7639 & 8155 & 5634 & 26 \\
\hline H66C & 3573 & 9194 & 3894 & 41 \\
\hline H66D & 4107 & 8663 & 3590 & 41 \\
\hline H67C & 4394 & 9827 & 3412 & 46 \\
\hline H67D & 5068 & 9298 & 3165 & 46 \\
\hline H68C & 6167 & 10085 & 3849 & 41 \\
\hline H68D & 6759 & 9470 & 3705 & 41 \\
\hline H69C & 6745 & 9275 & 4558 & 35 \\
\hline
\end{tabular}




\begin{tabular}{|c|c|c|c|c|}
\hline H69D & 5620 & 9701 & 4582 & 35 \\
\hline $\mathrm{H} 70 \mathrm{C}$ & 6338 & 8640 & 6162 & 33 \\
\hline H70D & 5314 & 9080 & 5884 & 33 \\
\hline $\mathrm{H} 71 \mathrm{C}$ & 7311 & 9554 & 6207 & 35 \\
\hline H71D & 6705 & 9731 & 5627 & 35 \\
\hline $\mathrm{H} 72 \mathrm{C}$ & 8376 & 9324 & 5396 & 34 \\
\hline H72D & 8646 & 8937 & 5919 & 34 \\
\hline $\mathrm{H} 73 \mathrm{C}$ & 7537 & 8529 & 4989 & 26 \\
\hline H73D & 7700 & 8162 & 5523 & 26 \\
\hline $\mathrm{H} 74 \mathrm{~A}$ & 9839 & 9363 & 4788 & 60 \\
\hline H74B & 8941 & 9814 & 4449 & 60 \\
\hline H75A & 10467 & 9949 & 4005 & 54 \\
\hline H75B & 11056 & 9316 & 4184 & 54 \\
\hline H76A & 9113 & 9530 & 3364 & 49 \\
\hline H76B & 10214 & 9082 & 3353 & 49 \\
\hline H77A & 8236 & 8657 & 3532 & 43 \\
\hline H77B & 9453 & 8388 & 3840 & 43 \\
\hline H78A & 2394 & 5225 & 4308 & 52 \\
\hline H78B & 2641 & 5727 & 3900 & 52 \\
\hline H79A & 688 & 5971 & 3702 & 51 \\
\hline H79B & 538 & 5282 & 3842 & 51 \\
\hline H80A & -167 & 5521 & 4553 & 77 \\
\hline H80B & -177 & 6205 & 4371 & 77 \\
\hline H81A & 1288 & 6333 & 5060 & 57 \\
\hline H81B & 1572 & 5633 & 5102 & 57 \\
\hline $\mathrm{H} 82 \mathrm{~A}$ & 6261 & 4860 & 4670 & 71 \\
\hline H82B & 5015 & 5031 & 4317 & 71 \\
\hline $\mathrm{H} 83 \mathrm{~A}$ & 4723 & 5743 & 4860 & 115 \\
\hline H83B & 6016 & 5608 & 5185 & 115 \\
\hline H84A & 5282 & 4981 & 5732 & 116 \\
\hline H84B & 4191 & 5440 & 5615 & 116 \\
\hline H85A & 3188 & 4817 & 4969 & 97 \\
\hline H85B & 3665 & 4371 & 5444 & 97 \\
\hline $\mathrm{H} 82 \mathrm{C}$ & 6031 & 4452 & 4770 & 71 \\
\hline H82D & 5263 & 4711 & 4245 & 71 \\
\hline
\end{tabular}




\begin{tabular}{lllll} 
H83C & 4994 & 5602 & 4612 & 115 \\
H83D & 6214 & 5428 & 4983 & 115 \\
H84C & 3892 & 5385 & 5225 & 116 \\
H84D & 5120 & 5429 & 5624 & 116 \\
H85C & 4151 & 4431 & 5627 & 97 \\
H85D & 5495 & 4388 & 5493 & 97 \\
\hline
\end{tabular}


Table 6. Torsion angles $\left[{ }^{\circ}\right]$ for neipn01.

\begin{tabular}{|c|c|c|c|}
\hline N3-Fe1-N1-C25 & $14.29(10)$ & Fe1-N3-C28-C29 & $-173.56(12)$ \\
\hline N2-Fe1-N1-C25 & $-177.71(11)$ & $\mathrm{N} 1-\mathrm{C} 25-\mathrm{C} 28-\mathrm{N} 3$ & $2.39(18)$ \\
\hline C1-Fe1-N1-C25 & $98.39(14)$ & $\mathrm{C} 24-\mathrm{C} 25-\mathrm{C} 28-\mathrm{N} 3$ & $-179.98(14)$ \\
\hline C3-Fe1-N1-C25 & $-80.41(11)$ & $\mathrm{N} 1-\mathrm{C} 25-\mathrm{C} 28-\mathrm{C} 29$ & $-175.57(14)$ \\
\hline N3-Fe1-N1-C21 & $-179.76(11)$ & $\mathrm{C} 24-\mathrm{C} 25-\mathrm{C} 28-\mathrm{C} 29$ & $2.1(2)$ \\
\hline N2-Fe1-N1-C21 & $-11.75(11)$ & C26-N2-C30-C35 & $94.44(16)$ \\
\hline C1-Fe1-N1-C21 & $-95.66(14)$ & Fe1-N2-C30-C35 & $-90.66(15)$ \\
\hline C3-Fe1-N1-C21 & $85.54(11)$ & C26-N2-C30-C31 & $-84.82(16)$ \\
\hline C25-N1-C21-C22 & $-4.1(2)$ & Fe1-N2-C30-C31 & $90.08(15)$ \\
\hline Fe1-N1-C21-C22 & $-169.73(11)$ & C35-C30-C31-C32 & $-0.8(2)$ \\
\hline C25-N1-C21-C26 & $177.64(12)$ & N2-C30-C31-C32 & $178.43(13)$ \\
\hline Fe1-N1-C21-C26 & $11.98(16)$ & C35-C30-C31-C36 & $-178.40(13)$ \\
\hline $\mathrm{N} 1-\mathrm{C} 21-\mathrm{C} 22-\mathrm{C} 23$ & $2.5(2)$ & N2-C30-C31-C36 & $0.9(2)$ \\
\hline C26-C21-C22-C23 & $-179.54(15)$ & C30-C31-C32-C33 & $0.1(2)$ \\
\hline C21-C22-C23-C24 & $-0.1(2)$ & C36-C31-C32-C33 & $177.69(14)$ \\
\hline $\mathrm{C} 22-\mathrm{C} 23-\mathrm{C} 24-\mathrm{C} 25$ & $-0.9(2)$ & $\mathrm{C} 31-\mathrm{C} 32-\mathrm{C} 33-\mathrm{C} 34$ & $0.5(2)$ \\
\hline C21-N1-C25-C24 & $3.1(2)$ & C32-C33-C34-C35 & $-0.4(2)$ \\
\hline Fe1-N1-C25-C24 & $168.81(11)$ & $\mathrm{C} 33-\mathrm{C} 34-\mathrm{C} 35-\mathrm{C} 30$ & $-0.4(2)$ \\
\hline C21-N1-C25-C28 & $-179.02(13)$ & C33-C34-C35-C39 & $-178.55(14)$ \\
\hline Fe1-N1-C25-C28 & $-13.31(16)$ & C31-C30-C35-C34 & $1.0(2)$ \\
\hline $\mathrm{C} 23-\mathrm{C} 24-\mathrm{C} 25-\mathrm{N} 1$ & $-0.6(2)$ & N2-C30-C35-C34 & $-178.27(13)$ \\
\hline $\mathrm{C} 23-\mathrm{C} 24-\mathrm{C} 25-\mathrm{C} 28$ & $-178.04(15)$ & C31-C30-C35-C39 & $179.12(13)$ \\
\hline C30-N2-C26-C21 & $170.34(12)$ & N2-C30-C35-C39 & $-0.1(2)$ \\
\hline Fe1-N2-C26-C21 & $-5.19(15)$ & C32-C31-C36-C38 & $50.08(19)$ \\
\hline C30-N2-C26-C27 & $-6.8(2)$ & C30-C31-C36-C38 & $-132.37(15)$ \\
\hline Fe1-N2-C26-C27 & $177.66(11)$ & C32-C31-C36-C37 & $-71.93(18)$ \\
\hline $\mathrm{N} 1-\mathrm{C} 21-\mathrm{C} 26-\mathrm{N} 2$ & $-3.75(17)$ & C30-C31-C36-C37 & $105.62(16)$ \\
\hline $\mathrm{C} 22-\mathrm{C} 21-\mathrm{C} 26-\mathrm{N} 2$ & $178.16(14)$ & C34-C35-C39-C40 & $-44.34(19)$ \\
\hline N1-C21-C26-C27 & $173.56(13)$ & C30-C35-C39-C40 & $137.55(15)$ \\
\hline C22-C21-C26-C27 & $-4.5(2)$ & C34-C35-C39-C41 & $78.97(18)$ \\
\hline C42-N3-C28-C25 & $-164.37(13)$ & C30-C35-C39-C41 & $-99.15(17)$ \\
\hline Fe1-N3-C28-C25 & $8.57(16)$ & C28-N3-C42-C47 & $-91.04(17)$ \\
\hline C42-N3-C28-C29 & $13.5(2)$ & Fe1-N3-C42-C47 & $97.26(16)$ \\
\hline
\end{tabular}




\begin{tabular}{|c|c|c|c|}
\hline C28-N3-C42-C43 & $86.47(17)$ & C58-O2-C61-C60 & $8.71(18)$ \\
\hline Fe1-N3-C42-C43 & $-85.24(16)$ & Mg1-O2-C61-C60 & $-150.27(11)$ \\
\hline C47-C42-C43-C44 & $1.8(2)$ & C59-C60-C61-O2 & $-30.47(17)$ \\
\hline N3-C42-C43-C44 & $-175.73(13)$ & $\mathrm{C} 65-\mathrm{O} 3-\mathrm{C} 62-\mathrm{C} 63$ & $4.34(19)$ \\
\hline C47-C42-C43-C48 & $180.00(14)$ & Mg1-O3-C62-C63 & $177.23(12)$ \\
\hline N3-C42-C43-C48 & $2.5(2)$ & O3-C62-C63-C64 & $-28.2(2)$ \\
\hline C42-C43-C44-C45 & $0.7(2)$ & C62-C63-C64-C65 & $40.2(2)$ \\
\hline C48-C43-C44-C45 & $-177.55(15)$ & C62-O3-C65-C64 & 21.36(19) \\
\hline C43-C44-C45-C46 & $-2.2(3)$ & Mg1-O3-C65-C64 & $-151.43(12)$ \\
\hline C44-C45-C46-C47 & $1.3(3)$ & C63-C64-C65-O3 & $-38.3(2)$ \\
\hline C45-C46-C47-C42 & $1.2(2)$ & C69-O4-C66-C67 & $37.1(5)$ \\
\hline C45-C46-C47-C51 & 179.92(16) & Mg1-O4-C66-C67 & $-161.02(16)$ \\
\hline C43-C42-C47-C46 & $-2.7(2)$ & O4-C66-C67-C68 & $-41.9(3)$ \\
\hline N3-C42-C47-C46 & $174.75(14)$ & C66-C67-C68-C69 & $31.8(5)$ \\
\hline C43-C42-C47-C51 & $178.58(15)$ & C66-O4-C69-C68 & $-16.2(7)$ \\
\hline N3-C42-C47-C51 & $-4.0(2)$ & Mg1-O4-C69-C68 & $-178.4(3)$ \\
\hline C44-C43-C48-C50 & $76.55(19)$ & C67-C68-C69-O4 & $-10.8(7)$ \\
\hline C42-C43-C48-C50 & $-101.63(17)$ & C73-O5-C70-C71 & $-9.7(10)$ \\
\hline C44-C43-C48-C49 & $-46.5(2)$ & $\mathrm{Mg} 1-\mathrm{O} 5-\mathrm{C} 70-\mathrm{C} 71$ & $-178.9(2)$ \\
\hline C42-C43-C48-C49 & $135.36(15)$ & $\mathrm{O} 5-\mathrm{C} 70-\mathrm{C} 71-\mathrm{C} 72$ & $33.8(11)$ \\
\hline C46-C47-C51-C53 & $-64.4(2)$ & C70-C71-C72-C73 & $-44.7(17)$ \\
\hline C42-C47-C51-C53 & $114.27(17)$ & $\mathrm{C} 70-\mathrm{O} 5-\mathrm{C} 73-\mathrm{C} 72$ & $-18.6(18)$ \\
\hline C46-C47-C51-C52 & $57.7(2)$ & Mg1-O5-C73-C72 & $148.8(12)$ \\
\hline C42-C47-C51-C52 & $-123.64(16)$ & C71-C72-C73-O5 & $39(2)$ \\
\hline C57-O1-C54-C55 & $-21.34(17)$ & C69'-O4'-C66'-C67' & $25.4(12)$ \\
\hline Mg1-O1-C54-C55 & $159.87(11)$ & Mg1-O4'-C66'-C67' & $178.0(4)$ \\
\hline O1-C54-C55-C56 & $36.55(18)$ & O4'-C66'-C67'-C68' & $-7.1(9)$ \\
\hline C54-C55-C56-C57 & $-37.49(18)$ & C66'-C67'-C68'-C69' & $-12.7(14)$ \\
\hline C54-O1-C57-C56 & $-2.90(17)$ & C66'-O4'-C69'-C68' & $-33.2(17)$ \\
\hline Mg1-O1-C57-C56 & $175.93(11)$ & Mg1-O4'-C69'-C68' & $175.7(8)$ \\
\hline C55-C56-C57-O1 & $25.46(18)$ & C67'-C68'-C69'-O4' & $27.5(18)$ \\
\hline C61-O2-C58-C59 & $17.00(18)$ & C73'-O5'-C70'-C71' & $45.7(10)$ \\
\hline Mg1-O2-C58-C59 & $174.21(10)$ & Mg1-O5'-C70'-C71' & $-135.1(3)$ \\
\hline O2-C58-C59-C60 & $-35.46(18)$ & O5'-C70'-C71'-C72' & $-41.7(12)$ \\
\hline C58-C59-C60-C61 & $40.04(18)$ & C70'-C71'-C72'-C73' & $22(2)$ \\
\hline
\end{tabular}




$\begin{array}{lclc}\text { C70'-O5'-C73'-C72' } & -31.3(19) & \text { C79-C80-C81-O7 } & 18.5(3) \\ \text { Mg1-O5'-C73'-C72' } & 149.5(14) & \text { C85-O8-C82-C83 } & 25(3) \\ \text { C71'-C72'-C73'-O5' } & 5(2) & \text { O8-C82-C83-C84 } & 4(3) \\ \text { C77-O6-C74-C75 } & -2.9(2) & \mathrm{C} 82-\mathrm{C} 83-\mathrm{C} 84-\mathrm{C} 85 & -33(3) \\ \text { O6-C74-C75-C76 } & 23.3(2) & \mathrm{C} 83-\mathrm{C} 84-\mathrm{C} 85-\mathrm{O} 8 & 46(2) \\ \mathrm{C} 74-\mathrm{C} 75-\mathrm{C} 76-\mathrm{C} 77 & -33.3(2) & \mathrm{C} 82-\mathrm{O} 8-\mathrm{C} 85-\mathrm{C} 84 & -44(2) \\ \text { C74-O6-C77-C76 } & -19.0(2) & \mathrm{C} 85^{\prime}-\mathrm{O} 8^{\prime}-\mathrm{C} 82^{\prime}-\mathrm{C} 83^{\prime} & -58(2) \\ \text { C75-C76-C77-O6 } & 33.1(2) & \text { O8'-C82'-C83'-C84' } & 26(3) \\ \text { C81-O7-C78-C79 } & 43.2(2) & \mathrm{C} 82^{\prime}-\mathrm{C} 83^{\prime}-\mathrm{C} 84^{\prime}-\mathrm{C} 85^{\prime} & 18(3) \\ \text { O7-C78-C79-C80 } & -30.2(3) & \mathrm{C} 83^{\prime}-\mathrm{C} 84^{\prime}-\mathrm{C} 85^{\prime}-\mathrm{O} 8^{\prime} & -53(3) \\ \text { C78-C79-C80-C81 } & 7.0(3) & \mathrm{C} 82^{\prime}-\mathrm{O} 8^{\prime}-\mathrm{C} 85^{\prime}-\mathrm{C} 84^{\prime} & 65.8(17) \\ \text { C78-O7-C81-C80 } & -38.5(3) & & \\ \end{array}$


REFERENCE NUMBER: neipn21

CRYSTAL STRUCTURE REPORT

$\mathrm{C}_{61} \mathrm{H}_{92} \mathrm{Br}_{0.6} \mathrm{Cl}_{0.4} \mathrm{Fe} \mathrm{Mg} \mathrm{N} \mathrm{O}_{5}$

or

$\left[\mathrm{MgBr}_{0.6} \mathrm{Cl}_{0.4}(\mathrm{THF})_{5}\right]\left[(\mathrm{Dipp}-\mathrm{DIMPY}) \mathrm{Fe}\left(\mathrm{N}_{2}\right)\left(\mathrm{CH}_{2} \mathrm{CH}_{2} \mathrm{Ph}\right)\right] \cdot \mathrm{xSolvent}$

Report prepared for:

Dr. P. Neate, Prof. M. Neidig

May 26, 2018
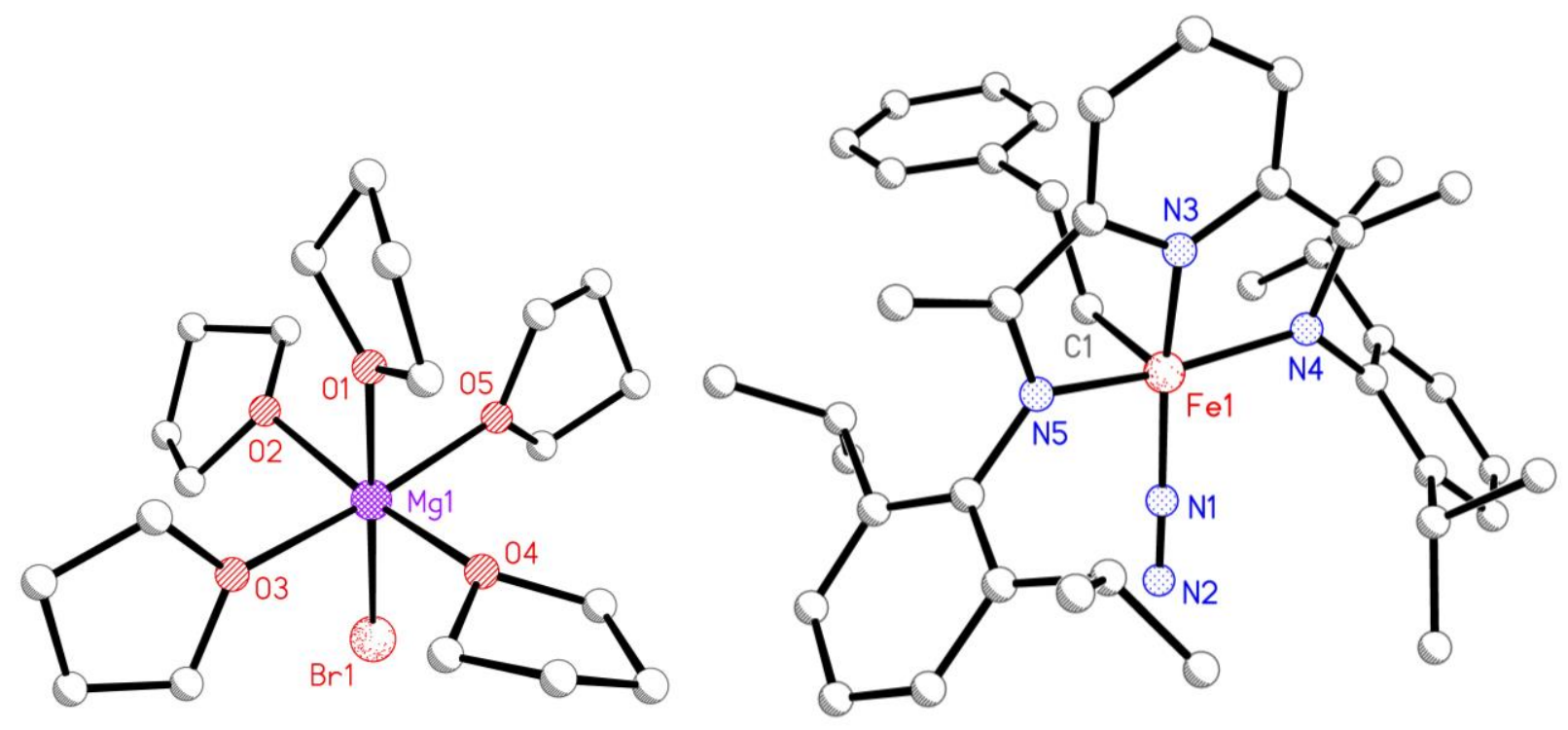

William W. Brennessel

X-ray Crystallographic Facility

Department of Chemistry, University of Rochester

120 Trustee Road

Rochester, NY 14627 


\section{Data collection}

A crystal $\left(0.354 \times 0.163 \times 0.077 \mathrm{~mm}^{3}\right)$ was placed onto a thin glass optical fiber or a nylon loop and mounted on a XtaLab Synergy-S Dualflex diffractometer equipped with a HyPix-6000HE HPC area detector for data collection at 99.99(10) K. A preliminary set of cell constants and an orientation matrix were calculated from a small sampling of reflections. ${ }^{1}$ A short pre-experiment was run, from which an optimal data collection strategy was determined. The full data collection was carried out using a PhotonJet $(\mathrm{Cu})$ X-ray Source with frame times of 17.89 and 71.56 seconds and a detector distance of $31.2 \mathrm{~mm}$. Series of frames were collected in $0.50^{\circ}$ steps in $\omega$ at different $2 \theta, \kappa$, and $\phi$ settings. After the intensity data were corrected for absorption, the final cell constants were calculated from the xyz centroids of 7618 strong reflections from the actual data collection after integration. ${ }^{1}$ See Table 1 for additional crystal and refinement information.

\section{Structure solution and refinement}

The structure was solved using SHELXT-2018/2 ${ }^{2}$ and refined using SHELXL-2018/3. ${ }^{3}$ The space group Pca2 $2_{1}$ was determined based on systematic absences and intensity statistics. Most or all non-hydrogen atoms were assigned from the solution. Full-matrix least squares / difference Fourier cycles were performed which located any remaining non-hydrogen atoms. All non-hydrogen atoms were refined with anisotropic displacement parameters. All hydrogen atoms were placed in ideal positions and refined as riding atoms with relative isotropic displacement parameters.

Reflection contributions from highly disordered solvent were fixed and added to the calculated structure factors using the SQUEEZE routine of program Platon, ${ }^{4}$ which determined there to be four pockets per unit cell of 79 electrons (possibly two THF molecules) in $237 \AA^{3}$ each that were handled this way. Because the exact identity and amount of solvent were not known, no solvent was included in the atom list or molecular formula. Thus all calculated quantities that derive from the molecular formula (e.g., $\mathrm{F}(000)$, density, molecular weight, etc.) are known to be incorrect.

The crystal was an inversion twin whose component mass ratio refined to 0.888(9):112(9).

The final full matrix least squares refinement converged to $R 1=0.0753\left(F^{2}, I>2 \sigma(I)\right)$ and $w R 2=0.2282\left(F^{2}\right.$, all data).

\section{Structure description}

The structure is the one suggested. The asymmetric unit contains one cationic Mg complex and one anionic Fe complex in general positions, and cocrystallized solvent that was not modeled (see above). The $-\mathrm{CH}_{2} \mathrm{CH}_{2} \mathrm{Ph}$ ligand is modeled as disordered over two positions (0.80:0.20). The halido site is modeled as a disorder of $\mathrm{Br}$ and $\mathrm{Cl}$ 
(0.60:0.40). Four THF ligands were modeled as disordered over two positions each: O1/C54-C57, 0.59:0.41, O2/C58-C61, 0.80:0.20, O4/C66-C69, 0.58:0.42, O5/C70-C73, 0.50:0.50.

Unless noted otherwise all structural diagrams containing thermal displacement ellipsoids are drawn at the $50 \%$ probability level.

Data collection, structure solution, and structure refinement were conducted at the X-ray Crystallographic Facility, B04 Hutchison Hall, Department of Chemistry, University of Rochester. All publications arising from this report MUST either 1) include William W. Brennessel as a coauthor or 2) acknowledge William W. Brennessel and the Xray Crystallographic Facility of the Department of Chemistry at the University of Rochester.

1 CrysAlisPro, version 171.39.46; Rigaku Corporation: Oxford, UK, 2018.

2 Sheldrick, G. M. SHELXT, version 2018/2; Acta. Crystallogr. 2015, A71, 3-8.

3 Sheldrick, G. M. SHELXL, version 2018/3; Acta. Crystallogr. 2015, C71, 3-8.

4 Spek, A. L. PLATON, version 150216; Acta. Crystallogr. 2015, C71, 9-18.

Some equations of interest:

$$
\begin{gathered}
R_{\text {int }}=\Sigma\left|F_{\mathrm{o}}^{2}-<F_{\mathrm{o}}^{2}>\right| / \Sigma\left|F_{\mathrm{o}}{ }^{2}\right| \\
R 1=\Sigma|| F_{\mathrm{o}}|-| F_{\mathrm{c}} \| / \Sigma\left|F_{\mathrm{o}}\right| \\
w R 2=\left[\Sigma\left[w\left(F_{\mathrm{o}}{ }^{2}-F_{\mathrm{c}}{ }^{2}\right)^{2}\right] / \Sigma\left[w\left(F_{\mathrm{o}}{ }^{2}\right)^{2}\right]\right]^{1 / 2} \\
\text { where } w=1 /\left[\sigma^{2}\left(F_{\mathrm{o}}^{2}\right)+(a P)^{2}+b P\right] \text { and } \\
P=1 / 3 \max \left(0, F_{\mathrm{o}}{ }^{2}\right)+2 / 3 F_{\mathrm{c}}^{2} \\
\mathrm{GOF}=S=\left[\Sigma\left[w\left(F_{\mathrm{o}}^{2}-F_{\mathrm{c}}{ }^{2}\right)^{2}\right] /(m-n)\right]^{1 / 2}
\end{gathered}
$$

where $m=$ number of reflections and $n=$ number of parameters 

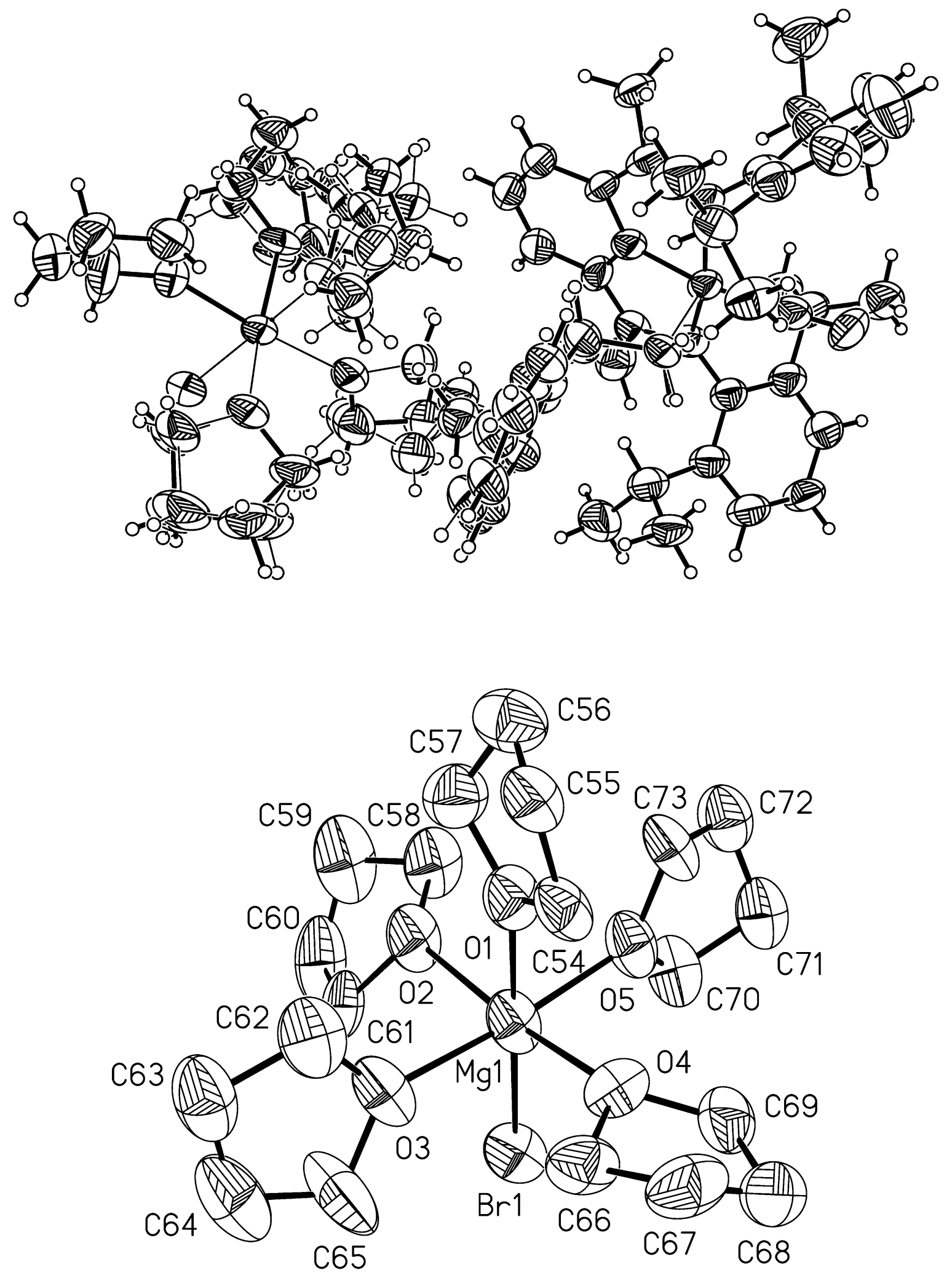

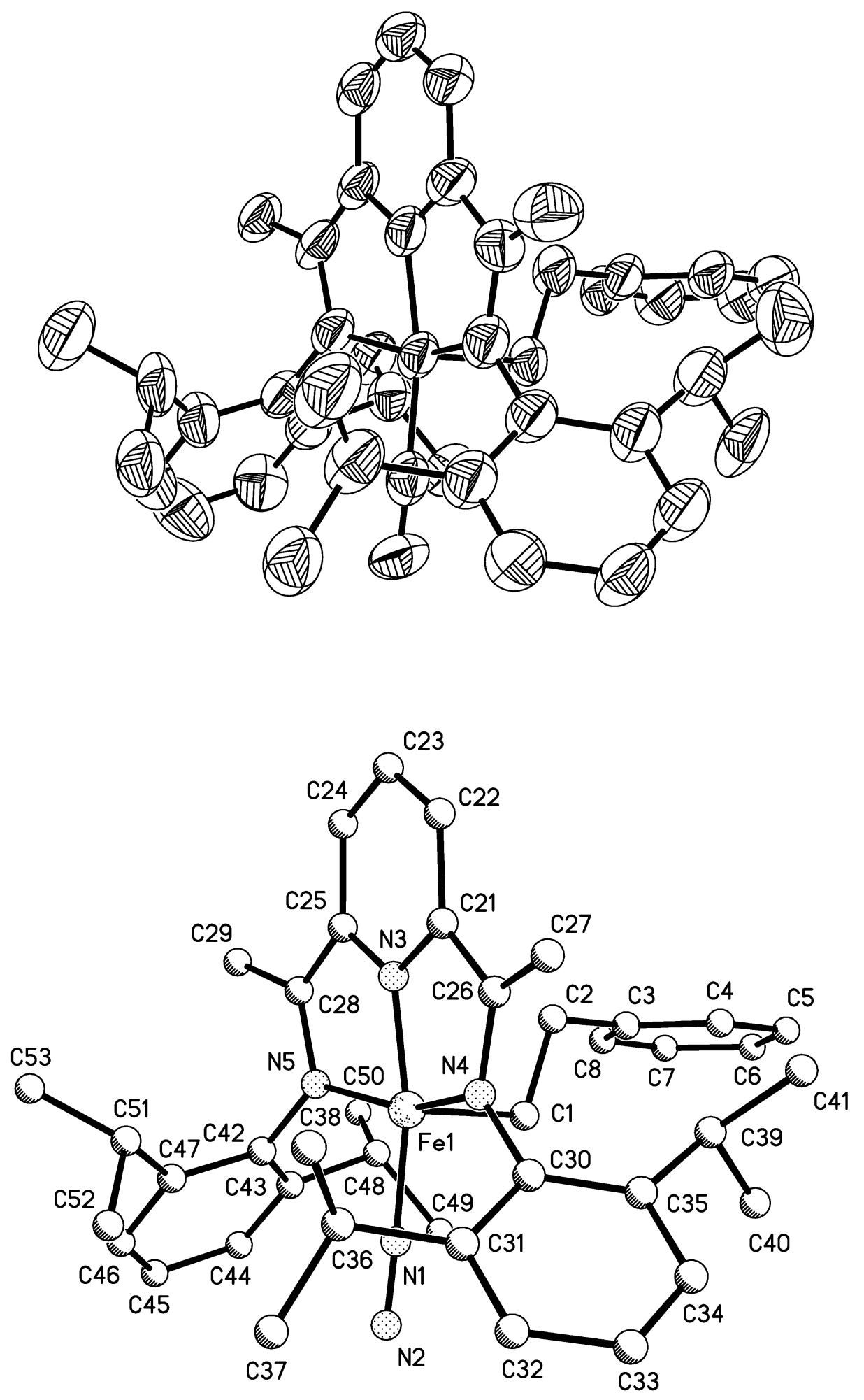
Table 1. Crystal data and structure refinement for neipn21.

\begin{tabular}{|c|c|c|}
\hline Identification code & \multicolumn{2}{|l|}{ neipn21 } \\
\hline Empirical formula & \multicolumn{2}{|c|}{ C61 H92 Br0.60 Cl0.40 Fe Mg N5 O5 } \\
\hline Formula weight & \multicolumn{2}{|l|}{1117.79} \\
\hline Temperature & \multicolumn{2}{|l|}{$99.99(10) \mathrm{K}$} \\
\hline Wavelength & \multicolumn{2}{|l|}{$1.54184 \AA$} \\
\hline Crystal system & \multicolumn{2}{|l|}{ orthorhombic } \\
\hline Space group & \multicolumn{2}{|l|}{$\operatorname{Pca}_{1}$} \\
\hline \multirow[t]{3}{*}{ Unit cell dimensions } & $a=22.6754(5) \AA$ & $\alpha=90^{\circ}$ \\
\hline & $b=12.3150(7) \AA$ & $\beta=90^{\circ}$ \\
\hline & $c=24.0776(7) \AA$ & $\gamma=90^{\circ}$ \\
\hline Volume & \multicolumn{2}{|l|}{$6723.6(5) \AA^{3}$} \\
\hline$Z$ & \multicolumn{2}{|l|}{4} \\
\hline Density (calculated) & \multicolumn{2}{|l|}{$1.104 \mathrm{Mg} / \mathrm{m}^{3}$} \\
\hline Absorption coefficient & \multicolumn{2}{|l|}{$2.804 \mathrm{~mm}^{-1}$} \\
\hline$F(000)$ & \multicolumn{2}{|l|}{2395} \\
\hline Crystal color, morphology & \multicolumn{2}{|l|}{ dark red, plate } \\
\hline Crystal size & \multicolumn{2}{|c|}{$0.354 \times 0.163 \times 0.077 \mathrm{~mm}^{3}$} \\
\hline Theta range for data collection & \multicolumn{2}{|l|}{3.589 to $78.434^{\circ}$} \\
\hline Index ranges & \multicolumn{2}{|c|}{$-28 \leq h \leq 21,-15 \leq k \leq 15,-29 \leq l \leq 28$} \\
\hline Reflections collected & \multicolumn{2}{|l|}{33365} \\
\hline Independent reflections & \multicolumn{2}{|c|}{$12301[R($ int $)=0.0533]$} \\
\hline Observed reflections & \multicolumn{2}{|l|}{8676} \\
\hline Completeness to theta $=67.684^{\circ}$ & \multicolumn{2}{|l|}{$99.9 \%$} \\
\hline Absorption correction & \multicolumn{2}{|l|}{ Multi-scan } \\
\hline Max. and min. transmission & \multicolumn{2}{|l|}{1.0000 and 0.5791} \\
\hline Refinement method & \multicolumn{2}{|c|}{ Full-matrix least-squares on $F^{2}$} \\
\hline Data / restraints / parameters & \multicolumn{2}{|l|}{$12301 / 131 / 757$} \\
\hline Goodness-of-fit on $F^{2}$ & \multicolumn{2}{|l|}{1.052} \\
\hline Final $R$ indices $[I>2 \operatorname{sigma}(I)]$ & \multicolumn{2}{|c|}{$R 1=0.0753, w R 2=0.2054$} \\
\hline$R$ indices (all data) & \multicolumn{2}{|c|}{$R 1=0.1008, w R 2=0.2282$} \\
\hline Absolute structure parameter & \multicolumn{2}{|l|}{$0.112(9)$} \\
\hline Largest diff. peak and hole & \multicolumn{2}{|c|}{1.239 and -0.928 e. $\AA^{-3}$} \\
\hline
\end{tabular}


Table 2. Atomic coordinates $\left(\mathrm{x} 10^{4}\right)$ and equivalent isotropic displacement parameters $\left(\AA^{2} \times 10^{3}\right)$ for neipn21. $U_{e q}$ is defined as one third of the trace of the orthogonalized $U_{i j}$ tensor.

\begin{tabular}{|c|c|c|c|c|}
\hline & $\mathrm{x}$ & $\mathrm{y}$ & $\mathrm{z}$ & $\mathrm{U}_{\mathrm{eq}}$ \\
\hline $\mathrm{Fe} 1$ & 9096(1) & $4721(1)$ & $4214(1)$ & $51(1)$ \\
\hline N1 & $9748(3)$ & $5532(6)$ & $4188(3)$ & $58(2)$ \\
\hline $\mathrm{N} 2$ & $10156(3)$ & $6066(8)$ & 4161(4) & $78(2)$ \\
\hline N3 & $8468(3)$ & $3849(6)$ & $4084(2)$ & $53(2)$ \\
\hline N4 & $9453(3)$ & $3346(6)$ & $4383(3)$ & $53(2)$ \\
\hline N5 & $8587(3)$ & $5728(7)$ & $3857(3)$ & $56(2)$ \\
\hline $\mathrm{C} 1$ & $8937(3)$ & $5196(8)$ & 5014(3) & $53(2)$ \\
\hline $\mathrm{C} 2$ & $8333(7)$ & 4832(19) & $5217(6)$ & $69(4)$ \\
\hline $\mathrm{C} 3$ & $8187(7)$ & $5261(17)$ & $5789(5)$ & $68(4)$ \\
\hline $\mathrm{C} 4$ & $8349(7)$ & $4680(20)$ & $6261(5)$ & $75(5)$ \\
\hline $\mathrm{C} 5$ & $8239(7)$ & $5040(20)$ & $6800(6)$ & $90(6)$ \\
\hline C6 & $7984(6)$ & $6100(20)$ & 6849(6) & $89(6)$ \\
\hline $\mathrm{C} 7$ & $7825(7)$ & $6650(20)$ & 6379(6) & $81(5)$ \\
\hline $\mathrm{C} 8$ & $7935(7)$ & $6261(17)$ & $5858(5)$ & $69(4)$ \\
\hline $\mathrm{C} 1^{\prime}$ & $8937(3)$ & $5196(8)$ & 5014(3) & $53(2)$ \\
\hline $\mathrm{C} 2^{\prime}$ & $8380(20)$ & $4680(70)$ & $5230(20)$ & $69(4)$ \\
\hline C3' & $8240(30)$ & $4930(60)$ & $5835(18)$ & $68(4)$ \\
\hline $\mathrm{C}^{\prime}$ & $8340(30)$ & $4150(60)$ & $6248(19)$ & $75(5)$ \\
\hline $\mathrm{C}^{\prime}$ & $8280(30)$ & $4380(70)$ & $6815(19)$ & $90(6)$ \\
\hline C6' & $8010(30)$ & $5410(70)$ & 6930(20) & $89(6)$ \\
\hline $\mathrm{C} 7^{\prime}$ & $7860(30)$ & $6110(60)$ & $6520(20)$ & $81(5)$ \\
\hline C $8^{\prime}$ & $7950(30)$ & $5870(60)$ & $5970(20)$ & $69(4)$ \\
\hline $\mathrm{C} 21$ & $8504(3)$ & 2753(8) & 4203(3) & $59(2)$ \\
\hline $\mathrm{C} 22$ & $8000(4)$ & 2079(9) & 4149(4) & $64(2)$ \\
\hline $\mathrm{C} 23$ & $7467(4)$ & $2544(9)$ & 3984(3) & $64(2)$ \\
\hline $\mathrm{C} 24$ & 7434(3) & $3630(10)$ & $3866(3)$ & $63(3)$ \\
\hline $\mathrm{C} 25$ & 7942(3) & $4309(9)$ & $3902(3)$ & $54(2)$ \\
\hline $\mathrm{C} 26$ & $9085(4)$ & $2449(7)$ & 4372(3) & $53(2)$ \\
\hline $\mathrm{C} 27$ & $9263(5)$ & 1333(9) & $4452(5)$ & $79(3)$ \\
\hline $\mathrm{C} 28$ & 8012(3) & 5395(9) & 3768(3) & $57(2)$ \\
\hline
\end{tabular}




\begin{tabular}{|c|c|c|c|c|}
\hline $\mathrm{C} 29$ & $7550(3)$ & 6078(9) & $3507(4)$ & $65(2)$ \\
\hline $\mathrm{C} 30$ & $10045(3)$ & $3123(7)$ & $4538(3)$ & $54(2)$ \\
\hline C31 & $10489(4)$ & $3117(9)$ & $4118(4)$ & $64(2)$ \\
\hline C32 & 11071(4) & $2877(8)$ & $4262(4)$ & $64(2)$ \\
\hline C33 & $11213(4)$ & $2649(10)$ & $4816(4)$ & $71(3)$ \\
\hline C34 & 10791(4) & $2655(9)$ & $5216(4)$ & $69(3)$ \\
\hline C35 & $10202(4)$ & 2901(9) & $5094(3)$ & $62(2)$ \\
\hline C36 & $10340(4)$ & $3287(10)$ & $3508(4)$ & $74(3)$ \\
\hline C37 & $10802(4)$ & $3941(12)$ & $3203(4)$ & $86(3)$ \\
\hline C38 & 10244(5) & $2166(13)$ & $3230(5)$ & $98(4)$ \\
\hline C39 & $9774(4)$ & 2952(9) & $5574(4)$ & $69(2)$ \\
\hline $\mathrm{C} 40$ & $9942(4)$ & $3838(13)$ & $5990(4)$ & $95(4)$ \\
\hline $\mathrm{C} 41$ & $9729(5)$ & $1843(12)$ & $5870(5)$ & $96(4)$ \\
\hline $\mathrm{C} 42$ & $8737(4)$ & $6788(8)$ & $3643(4)$ & $59(2)$ \\
\hline $\mathrm{C} 43$ & $8669(4)$ & $7745(9)$ & $3936(4)$ & $62(2)$ \\
\hline $\mathrm{C} 44$ & $8828(5)$ & 8742(9) & $3710(5)$ & $78(3)$ \\
\hline $\mathrm{C} 45$ & $9040(6)$ & $8796(11)$ & $3166(7)$ & 101(4) \\
\hline C46 & $9099(5)$ & $7862(12)$ & $2872(5)$ & $90(4)$ \\
\hline $\mathrm{C} 47$ & $8950(4)$ & $6819(10)$ & $3088(4)$ & $73(3)$ \\
\hline $\mathrm{C} 48$ & $8405(4)$ & $7730(8)$ & $4519(4)$ & $58(2)$ \\
\hline C49 & $8854(5)$ & $8178(9)$ & $4949(5)$ & $73(3)$ \\
\hline C50 & $7841(4)$ & $8437(10)$ & $4550(4)$ & $75(3)$ \\
\hline C51 & $9026(5)$ & $5817(11)$ & $2726(4)$ & $76(3)$ \\
\hline C52 & $9668(5)$ & $5622(12)$ & $2580(4)$ & $87(3)$ \\
\hline C53 & $8661(5)$ & $5886(16)$ & $2202(5)$ & $114(5)$ \\
\hline Mg1 & $6240(1)$ & 1586(3) & $6039(1)$ & $59(1)$ \\
\hline $\mathrm{Br} 1$ & $6096(1)$ & $-232(1)$ & $6510(1)$ & $72(1)$ \\
\hline $\mathrm{Cl1}$ & $6096(1)$ & $-232(1)$ & $6510(1)$ & $72(1)$ \\
\hline $\mathrm{O} 3$ & $5328(2)$ & $2027(7)$ & $6142(3)$ & $73(2)$ \\
\hline C62 & $5096(5)$ & $3117(10)$ & $6085(5)$ & $81(3)$ \\
\hline C63 & $4532(5)$ & $3143(12)$ & $6403(5)$ & $90(4)$ \\
\hline C64 & $4398(5)$ & $1976(14)$ & $6528(5)$ & $103(4)$ \\
\hline C65 & $4846(5)$ & 1351(14) & $6303(7)$ & $119(5)$ \\
\hline $\mathrm{O} 1$ & $6355(3)$ & $3121(5)$ & $5638(2)$ & $60(2)$ \\
\hline C54 & $6171(10)$ & $3278(16)$ & $5051(6)$ & $56(5)$ \\
\hline
\end{tabular}




\begin{tabular}{|c|c|c|c|c|}
\hline C55 & $6241(7)$ & $4470(13)$ & $4945(6)$ & $57(3)$ \\
\hline C56 & $6700(8)$ & $4816(15)$ & $5374(9)$ & $71(4)$ \\
\hline C57 & $6520(40)$ & $4180(20)$ & $5861(11)$ & $71(6)$ \\
\hline $\mathrm{O} 2$ & 6434(3) & $2374(6)$ & $6797(2)$ & $69(2)$ \\
\hline C58 & $7000(20)$ & $2640(150)$ & $7050(30)$ & $79(7)$ \\
\hline C59 & $6830(60)$ & 2920(130) & $7630(30)$ & $112(7)$ \\
\hline C60 & $6360(40)$ & $2040(100)$ & $7758(15)$ & $103(9)$ \\
\hline C61 & $6020(20)$ & $1960(80)$ & $7223(19)$ & $67(5)$ \\
\hline $\mathrm{O} 4$ & $6037(13)$ & $1160(20)$ & $5211(8)$ & $52(4)$ \\
\hline C66 & $5447(11)$ & $1170(20)$ & 4995(9) & $66(5)$ \\
\hline C67 & $5522(11)$ & $970(20)$ & $4400(9)$ & $76(4)$ \\
\hline C68 & $5989(14)$ & $70(20)$ & $4398(10)$ & $74(5)$ \\
\hline C69 & $6359(17)$ & $290(50)$ & 4904(17) & $71(6)$ \\
\hline O5 & $7156(3)$ & $1332(6)$ & $5898(2)$ & $66(2)$ \\
\hline C70 & $7510(14)$ & $410(40)$ & $6080(40)$ & $81(5)$ \\
\hline C71 & $8052(9)$ & $515(19)$ & $5730(11)$ & $80(4)$ \\
\hline C72 & $8154(8)$ & 1732(19) & $5767(11)$ & $75(4)$ \\
\hline C73 & $7546(11)$ & $2140(30)$ & $5640(30)$ & $70(6)$ \\
\hline O1' & 6355(3) & $3121(5)$ & $5638(2)$ & $60(2)$ \\
\hline C54' & $6342(18)$ & $3390(20)$ & $5038(8)$ & $56(5)$ \\
\hline C55' & $6543(11)$ & $4543(18)$ & 4998(8) & $57(3)$ \\
\hline C56' & $6426(12)$ & $5008(18)$ & $5582(11)$ & $71(4)$ \\
\hline C57' & $6590(50)$ & $4070(30)$ & $5928(15)$ & $71(6)$ \\
\hline $\mathrm{O} 2^{\prime}$ & 6434(3) & $2374(6)$ & $6797(2)$ & $69(2)$ \\
\hline C58' & $7029(7)$ & $2440(30)$ & $7023(7)$ & $79(7)$ \\
\hline C59' & 6952(12) & $2980(40)$ & $7568(8)$ & $112(7)$ \\
\hline C60' & 6354(9) & $2530(30)$ & $7772(5)$ & $103(9)$ \\
\hline C61' & $6000(6)$ & $2470(30)$ & $7247(4)$ & $67(5)$ \\
\hline O4' & 6072(9) & $862(14)$ & $5272(6)$ & $52(4)$ \\
\hline C66' & $5517(8)$ & $544(18)$ & $5036(6)$ & $66(5)$ \\
\hline C67' & $5617(10)$ & $92(18)$ & $4485(7)$ & $76(4)$ \\
\hline C68' & $6268(10)$ & $250(20)$ & $4350(7)$ & $74(5)$ \\
\hline C69' & $6541(10)$ & $340(40)$ & $4922(12)$ & $71(6)$ \\
\hline O5' & $7156(3)$ & $1332(6)$ & $5898(2)$ & $66(2)$ \\
\hline C70' & $7450(13)$ & $320(40)$ & $6060(40)$ & $81(5)$ \\
\hline
\end{tabular}




$\begin{array}{llrll}\text { C71' } & 8095(9) & 580(20) & 6045(10) & 80(4) \\ \mathrm{C}^{\prime} 2^{\prime} & 8125(9) & 1280(20) & 5528(9) & 75(4) \\ \mathrm{C}^{\prime} 3^{\prime} & 7585(11) & 1970(30) & 5580(30) & 70(6)\end{array}$

Table 3. Bond lengths $[\AA]$ and angles $\left[{ }^{\circ}\right]$ for neipn 21 .

\begin{tabular}{|c|c|c|c|}
\hline $\mathrm{Fe}(1)-\mathrm{N}(1)$ & $1.784(7)$ & $\mathrm{C}\left(1^{\prime}\right)-\mathrm{C}\left(2^{\prime}\right)$ & $1.52(3)$ \\
\hline $\mathrm{Fe}(1)-\mathrm{N}(3)$ & $1.813(7)$ & $\mathrm{C}\left(1^{\prime}\right)-\mathrm{H}(1 \mathrm{C})$ & 0.9900 \\
\hline $\mathrm{Fe}(1)-\mathrm{N}(5)$ & $1.901(8)$ & $\mathrm{C}\left(1^{\prime}\right)-\mathrm{H}(1 \mathrm{D})$ & 0.9900 \\
\hline $\mathrm{Fe}(1)-\mathrm{N}(4)$ & $1.920(7)$ & $\mathrm{C}\left(2^{\prime}\right)-\mathrm{C}\left(3^{\prime}\right)$ & $1.51(2)$ \\
\hline $\mathrm{Fe}(1)-\mathrm{C}\left(1^{\prime}\right)$ & $2.045(8)$ & $\mathrm{C}\left(2^{\prime}\right)-\mathrm{H}(2 \mathrm{C})$ & 0.9900 \\
\hline $\mathrm{Fe}(1)-\mathrm{C}(1)$ & $2.045(8)$ & $\mathrm{C}\left(2^{\prime}\right)-\mathrm{H}(2 \mathrm{D})$ & 0.9900 \\
\hline $\mathrm{N}(1)-\mathrm{N}(2)$ & $1.137(10)$ & $\mathrm{C}\left(3^{\prime}\right)-\mathrm{C}\left(8^{\prime}\right)$ & $1.37(3)$ \\
\hline $\mathrm{N}(3)-\mathrm{C}(21)$ & $1.382(12)$ & $C\left(3^{\prime}\right)-C\left(4^{\prime}\right)$ & $1.40(3)$ \\
\hline $\mathrm{N}(3)-\mathrm{C}(25)$ & $1.391(10)$ & $C\left(4^{\prime}\right)-C\left(5^{\prime}\right)$ & $1.40(3)$ \\
\hline$N(4)-C(26)$ & $1.384(10)$ & $\mathrm{C}\left(4^{\prime}\right)-\mathrm{H}\left(4^{\prime}\right)$ & 0.9500 \\
\hline $\mathrm{N}(4)-\mathrm{C}(30)$ & $1.421(10)$ & $C\left(5^{\prime}\right)-C\left(6^{\prime}\right)$ & $1.44(4)$ \\
\hline $\mathrm{N}(5)-\mathrm{C}(28)$ & $1.381(9)$ & $\mathrm{C}\left(5^{\prime}\right)-\mathrm{H}\left(5^{\prime}\right)$ & 0.9500 \\
\hline$N(5)-C(42)$ & $1.444(13)$ & $\mathrm{C}\left(6^{\prime}\right)-\mathrm{C}\left(7^{\prime}\right)$ & $1.37(3)$ \\
\hline$C(1)-C(2)$ & $1.522(13)$ & $\mathrm{C}\left(6^{\prime}\right)-\mathrm{H}\left(6^{\prime}\right)$ & 0.9500 \\
\hline $\mathrm{C}(1)-\mathrm{H}(1 \mathrm{~A})$ & 0.9900 & $\mathrm{C}\left(7^{\prime}\right)-\mathrm{C}\left(8^{\prime}\right)$ & $1.36(3)$ \\
\hline $\mathrm{C}(1)-\mathrm{H}(1 \mathrm{~B})$ & 0.9900 & $\mathrm{C}\left(7^{\prime}\right)-\mathrm{H}\left(7^{\prime}\right)$ & 0.9500 \\
\hline $\mathrm{C}(2)-\mathrm{C}(3)$ & $1.510(14)$ & $\mathrm{C}\left(8^{\prime}\right)-\mathrm{H}\left(8^{\prime}\right)$ & 0.9500 \\
\hline $\mathrm{C}(2)-\mathrm{H}(2 \mathrm{~A})$ & 0.9900 & $C(21)-C(22)$ & $1.419(11)$ \\
\hline $\mathrm{C}(2)-\mathrm{H}(2 \mathrm{~B})$ & 0.9900 & $C(21)-C(26)$ & $1.428(12)$ \\
\hline$C(3)-C(8)$ & $1.368(19)$ & $C(22)-C(23)$ & $1.393(14)$ \\
\hline $\mathrm{C}(3)-\mathrm{C}(4)$ & $1.396(18)$ & $\mathrm{C}(22)-\mathrm{H}(22)$ & 0.9500 \\
\hline$C(4)-C(5)$ & $1.392(18)$ & $C(23)-C(24)$ & $1.368(14)$ \\
\hline $\mathrm{C}(4)-\mathrm{H}(4)$ & 0.9500 & $\mathrm{C}(23)-\mathrm{H}(23)$ & 0.9500 \\
\hline$C(5)-C(6)$ & $1.44(3)$ & $C(24)-C(25)$ & $1.426(12)$ \\
\hline $\mathrm{C}(5)-\mathrm{H}(5)$ & 0.9500 & $\mathrm{C}(24)-\mathrm{H}(24)$ & 0.9500 \\
\hline$C(6)-C(7)$ & $1.37(2)$ & $C(25)-C(28)$ & $1.385(14)$ \\
\hline $\mathrm{C}(6)-\mathrm{H}(6)$ & 0.9500 & $C(26)-C(27)$ & $1.446(14)$ \\
\hline $\mathrm{C}(7)-\mathrm{C}(8)$ & $1.368(15)$ & $\mathrm{C}(27)-\mathrm{H}(27 \mathrm{~A})$ & 0.9800 \\
\hline $\mathrm{C}(7)-\mathrm{H}(7)$ & 0.9500 & $\mathrm{C}(27)-\mathrm{H}(27 \mathrm{~B})$ & 0.9800 \\
\hline $\mathrm{C}(8)-\mathrm{H}(8)$ & 0.9500 & $\mathrm{C}(27)-\mathrm{H}(27 \mathrm{C})$ & 0.9800 \\
\hline
\end{tabular}




\begin{tabular}{|c|c|c|c|}
\hline $\mathrm{C}(28)-\mathrm{C}(29)$ & $1.484(12)$ & $\mathrm{C}(43)-\mathrm{C}(44)$ & $1.391(15)$ \\
\hline $\mathrm{C}(29)-\mathrm{H}(29 \mathrm{~A})$ & 0.9800 & $\mathrm{C}(43)-\mathrm{C}(48)$ & $1.525(12)$ \\
\hline $\mathrm{C}(29)-\mathrm{H}(29 B)$ & 0.9800 & $\mathrm{C}(44)-\mathrm{C}(45)$ & $1.396(18)$ \\
\hline $\mathrm{C}(29)-\mathrm{H}(29 \mathrm{C})$ & 0.9800 & $\mathrm{C}(44)-\mathrm{H}(44)$ & 0.9500 \\
\hline $\mathrm{C}(30)-\mathrm{C}(35)$ & $1.411(12)$ & $\mathrm{C}(45)-\mathrm{C}(46)$ & $1.36(2)$ \\
\hline$C(30)-C(31)$ & $1.427(12)$ & $\mathrm{C}(45)-\mathrm{H}(45)$ & 0.9500 \\
\hline$C(31)-C(32)$ & $1.396(12)$ & $\mathrm{C}(46)-\mathrm{C}(47)$ & $1.425(17)$ \\
\hline$C(31)-C(36)$ & $1.520(12)$ & $\mathrm{C}(46)-\mathrm{H}(46)$ & 0.9500 \\
\hline$C(32)-C(33)$ & $1.401(13)$ & $\mathrm{C}(47)-\mathrm{C}(51)$ & $1.521(16)$ \\
\hline $\mathrm{C}(32)-\mathrm{H}(32)$ & 0.9500 & $\mathrm{C}(48)-\mathrm{C}(50)$ & $1.550(13)$ \\
\hline$C(33)-C(34)$ & $1.359(13)$ & $\mathrm{C}(48)-\mathrm{C}(49)$ & $1.552(13)$ \\
\hline $\mathrm{C}(33)-\mathrm{H}(33)$ & 0.9500 & $\mathrm{C}(48)-\mathrm{H}(48)$ & 1.0000 \\
\hline $\mathrm{C}(34)-\mathrm{C}(35)$ & $1.399(12)$ & $\mathrm{C}(49)-\mathrm{H}(49 \mathrm{~A})$ & 0.9800 \\
\hline $\mathrm{C}(34)-\mathrm{H}(34)$ & 0.9500 & $\mathrm{C}(49)-\mathrm{H}(49 \mathrm{~B})$ & 0.9800 \\
\hline $\mathrm{C}(35)-\mathrm{C}(39)$ & $1.512(13)$ & $\mathrm{C}(49)-\mathrm{H}(49 \mathrm{C})$ & 0.9800 \\
\hline$C(36)-C(37)$ & $1.512(15)$ & $\mathrm{C}(50)-\mathrm{H}(50 \mathrm{~A})$ & 0.9800 \\
\hline$C(36)-C(38)$ & $1.550(18)$ & $\mathrm{C}(50)-\mathrm{H}(50 \mathrm{~B})$ & 0.9800 \\
\hline $\mathrm{C}(36)-\mathrm{H}(36)$ & 1.0000 & $\mathrm{C}(50)-\mathrm{H}(50 \mathrm{C})$ & 0.9800 \\
\hline $\mathrm{C}(37)-\mathrm{H}(37 \mathrm{~A})$ & 0.9800 & $\mathrm{C}(51)-\mathrm{C}(53)$ & $1.510(15)$ \\
\hline $\mathrm{C}(37)-\mathrm{H}(37 \mathrm{~B})$ & 0.9800 & $\mathrm{C}(51)-\mathrm{C}(52)$ & $1.516(15)$ \\
\hline $\mathrm{C}(37)-\mathrm{H}(37 \mathrm{C})$ & 0.9800 & $\mathrm{C}(51)-\mathrm{H}(51)$ & 1.0000 \\
\hline $\mathrm{C}(38)-\mathrm{H}(38 \mathrm{~A})$ & 0.9800 & $\mathrm{C}(52)-\mathrm{H}(52 \mathrm{~A})$ & 0.9800 \\
\hline $\mathrm{C}(38)-\mathrm{H}(38 \mathrm{~B})$ & 0.9800 & $\mathrm{C}(52)-\mathrm{H}(52 \mathrm{~B})$ & 0.9800 \\
\hline $\mathrm{C}(38)-\mathrm{H}(38 \mathrm{C})$ & 0.9800 & $\mathrm{C}(52)-\mathrm{H}(52 \mathrm{C})$ & 0.9800 \\
\hline $\mathrm{C}(39)-\mathrm{C}(40)$ & $1.530(16)$ & $\mathrm{C}(53)-\mathrm{H}(53 \mathrm{~A})$ & 0.9800 \\
\hline $\mathrm{C}(39)-\mathrm{C}(41)$ & $1.544(16)$ & $\mathrm{C}(53)-\mathrm{H}(53 \mathrm{~B})$ & 0.9800 \\
\hline $\mathrm{C}(39)-\mathrm{H}(39)$ & 1.0000 & $\mathrm{C}(53)-\mathrm{H}(53 \mathrm{C})$ & 0.9800 \\
\hline $\mathrm{C}(40)-\mathrm{H}(40 \mathrm{~A})$ & 0.9800 & $\operatorname{Mg}(1)-\mathrm{O}\left(4^{\prime}\right)$ & $2.085(11)$ \\
\hline $\mathrm{C}(40)-\mathrm{H}(40 \mathrm{~B})$ & 0.9800 & $\operatorname{Mg}(1)-\mathrm{O}(4)$ & $2.110(15)$ \\
\hline $\mathrm{C}(40)-\mathrm{H}(40 \mathrm{C})$ & 0.9800 & $\operatorname{Mg}(1)-\mathrm{O}\left(2^{\prime}\right)$ & $2.115(6)$ \\
\hline $\mathrm{C}(41)-\mathrm{H}(41 \mathrm{~A})$ & 0.9800 & $\operatorname{Mg}(1)-\mathrm{O}(2)$ & $2.115(6)$ \\
\hline $\mathrm{C}(41)-\mathrm{H}(41 \mathrm{~B})$ & 0.9800 & $\operatorname{Mg}(1)-\mathrm{O}\left(5^{\prime}\right)$ & $2.128(6)$ \\
\hline $\mathrm{C}(41)-\mathrm{H}(41 \mathrm{C})$ & 0.9800 & $\operatorname{Mg}(1)-\mathrm{O}(5)$ & $2.128(6)$ \\
\hline$C(42)-C(43)$ & $1.384(14)$ & $\operatorname{Mg}(1)-\mathrm{O}(1)$ & $2.138(7)$ \\
\hline$C(42)-C(47)$ & $1.422(12)$ & $\operatorname{Mg}(1)-\mathrm{O}\left(1^{\prime}\right)$ & $2.138(7)$ \\
\hline
\end{tabular}




\begin{tabular}{|c|c|c|c|}
\hline $\mathrm{Mg}(1)-\mathrm{O}(3)$ & $2.153(6)$ & $\mathrm{C}(59)-\mathrm{H}(59 \mathrm{~A})$ & 0.9900 \\
\hline $\operatorname{Mg}(1)-\mathrm{Cl}(1)$ & $2.532(4)$ & $\mathrm{C}(59)-\mathrm{H}(59 \mathrm{~B})$ & 0.9900 \\
\hline $\operatorname{Mg}(1)-\operatorname{Br}(1)$ & $2.532(4)$ & $C(60)-C(61)$ & $1.50(3)$ \\
\hline $\mathrm{O}(3)-\mathrm{C}(65)$ & $1.426(14)$ & $\mathrm{C}(60)-\mathrm{H}(60 \mathrm{~A})$ & 0.9900 \\
\hline $\mathrm{O}(3)-\mathrm{C}(62)$ & $1.448(13)$ & $\mathrm{C}(60)-\mathrm{H}(60 \mathrm{~B})$ & 0.9900 \\
\hline$C(62)-C(63)$ & $1.491(15)$ & $\mathrm{C}(61)-\mathrm{H}(61 \mathrm{~A})$ & 0.9900 \\
\hline $\mathrm{C}(62)-\mathrm{H}(62 \mathrm{~A})$ & 0.9900 & $\mathrm{C}(61)-\mathrm{H}(61 \mathrm{~B})$ & 0.9900 \\
\hline $\mathrm{C}(62)-\mathrm{H}(62 \mathrm{~B})$ & 0.9900 & $\mathrm{O}(4)-\mathrm{C}(66)$ & $1.44(2)$ \\
\hline $\mathrm{C}(63)-\mathrm{C}(64)$ & $1.50(2)$ & $\mathrm{O}(4)-\mathrm{C}(69)$ & $1.49(2)$ \\
\hline $\mathrm{C}(63)-\mathrm{H}(63 \mathrm{~A})$ & 0.9900 & $\mathrm{C}(66)-\mathrm{C}(67)$ & $1.47(2)$ \\
\hline $\mathrm{C}(63)-\mathrm{H}(63 \mathrm{~B})$ & 0.9900 & $\mathrm{C}(66)-\mathrm{H}(66 \mathrm{~A})$ & 0.9900 \\
\hline$C(64)-C(65)$ & $1.385(19)$ & $\mathrm{C}(66)-\mathrm{H}(66 \mathrm{~B})$ & 0.9900 \\
\hline $\mathrm{C}(64)-\mathrm{H}(64 \mathrm{~A})$ & 0.9900 & $\mathrm{C}(67)-\mathrm{C}(68)$ & $1.53(3)$ \\
\hline $\mathrm{C}(64)-\mathrm{H}(64 \mathrm{~B})$ & 0.9900 & $\mathrm{C}(67)-\mathrm{H}(67 \mathrm{~A})$ & 0.9900 \\
\hline $\mathrm{C}(65)-\mathrm{H}(65 \mathrm{~A})$ & 0.9900 & $\mathrm{C}(67)-\mathrm{H}(67 \mathrm{~B})$ & 0.9900 \\
\hline $\mathrm{C}(65)-\mathrm{H}(65 \mathrm{~B})$ & 0.9900 & $\mathrm{C}(68)-\mathrm{C}(69)$ & $1.50(3)$ \\
\hline $\mathrm{O}(1)-\mathrm{C}(57)$ & $1.455(17)$ & $\mathrm{C}(68)-\mathrm{H}(68 \mathrm{~A})$ & 0.9900 \\
\hline $\mathrm{O}(1)-\mathrm{C}(54)$ & $1.486(14)$ & $\mathrm{C}(68)-\mathrm{H}(68 \mathrm{~B})$ & 0.9900 \\
\hline$C(54)-C(55)$ & $1.50(2)$ & $\mathrm{C}(69)-\mathrm{H}(69 \mathrm{~A})$ & 0.9900 \\
\hline $\mathrm{C}(54)-\mathrm{H}(54 \mathrm{~A})$ & 0.9900 & $\mathrm{C}(69)-\mathrm{H}(69 \mathrm{~B})$ & 0.9900 \\
\hline $\mathrm{C}(54)-\mathrm{H}(54 \mathrm{~B})$ & 0.9900 & $\mathrm{O}(5)-\mathrm{C}(70)$ & $1.462(19)$ \\
\hline$C(55)-C(56)$ & $1.53(2)$ & $\mathrm{O}(5)-\mathrm{C}(73)$ & $1.465(18)$ \\
\hline $\mathrm{C}(55)-\mathrm{H}(55 \mathrm{~A})$ & 0.9900 & $\mathrm{C}(70)-\mathrm{C}(71)$ & $1.49(4)$ \\
\hline $\mathrm{C}(55)-\mathrm{H}(55 \mathrm{~B})$ & 0.9900 & $\mathrm{C}(70)-\mathrm{H}(70 \mathrm{~A})$ & 0.9900 \\
\hline$C(56)-C(57)$ & $1.47(4)$ & $\mathrm{C}(70)-\mathrm{H}(70 \mathrm{~B})$ & 0.9900 \\
\hline $\mathrm{C}(56)-\mathrm{H}(56 \mathrm{~A})$ & 0.9900 & $\mathrm{C}(71)-\mathrm{C}(72)$ & $1.52(2)$ \\
\hline $\mathrm{C}(56)-\mathrm{H}(56 \mathrm{~B})$ & 0.9900 & $\mathrm{C}(71)-\mathrm{H}(71 \mathrm{~A})$ & 0.9900 \\
\hline $\mathrm{C}(57)-\mathrm{H}(57 \mathrm{~A})$ & 0.9900 & $\mathrm{C}(71)-\mathrm{H}(71 \mathrm{~B})$ & 0.9900 \\
\hline $\mathrm{C}(57)-\mathrm{H}(57 \mathrm{~B})$ & 0.9900 & $C(72)-C(73)$ & $1.50(3)$ \\
\hline $\mathrm{O}(2)-\mathrm{C}(58)$ & $1.46(3)$ & $\mathrm{C}(72)-\mathrm{H}(72 \mathrm{~A})$ & 0.9900 \\
\hline $\mathrm{O}(2)-\mathrm{C}(61)$ & $1.48(3)$ & $\mathrm{C}(72)-\mathrm{H}(72 \mathrm{~B})$ & 0.9900 \\
\hline C(58)-C(59) & $1.49(3)$ & $\mathrm{C}(73)-\mathrm{H}(73 \mathrm{~A})$ & 0.9900 \\
\hline $\mathrm{C}(58)-\mathrm{H}(58 \mathrm{~A})$ & 0.9900 & $\mathrm{C}(73)-\mathrm{H}(73 \mathrm{~B})$ & 0.9900 \\
\hline $\mathrm{C}(58)-\mathrm{H}(58 \mathrm{~B})$ & 0.9900 & $\mathrm{O}\left(1^{\prime}\right)-\mathrm{C}\left(57^{\prime}\right)$ & $1.46(2)$ \\
\hline C(59)-C(60) & $1.54(4)$ & $\mathrm{O}\left(1^{\prime}\right)-\mathrm{C}\left(54^{\prime}\right)$ & $1.484(18)$ \\
\hline
\end{tabular}




\begin{tabular}{|c|c|c|c|}
\hline$C\left(54^{\prime}\right)-C\left(55^{\prime}\right)$ & $1.49(2)$ & $\mathrm{C}\left(69^{\prime}\right)-\mathrm{H}(69 \mathrm{C})$ & 0.9900 \\
\hline $\mathrm{C}\left(54^{\prime}\right)-\mathrm{H}(54 \mathrm{C})$ & 0.9900 & $\mathrm{C}\left(69^{\prime}\right)-\mathrm{H}(69 \mathrm{D})$ & 0.9900 \\
\hline $\mathrm{C}\left(54^{\prime}\right)-\mathrm{H}(54 \mathrm{D})$ & 0.9900 & $\mathrm{O}\left(5^{\prime}\right)-\mathrm{C}\left(73^{\prime}\right)$ & $1.463(18)$ \\
\hline $\mathrm{C}\left(55^{\prime}\right)-\mathrm{C}\left(56^{\prime}\right)$ & $1.54(3)$ & $\mathrm{O}\left(5^{\prime}\right)-\mathrm{C}\left(70^{\prime}\right)$ & $1.467(19)$ \\
\hline $\mathrm{C}\left(55^{\prime}\right)-\mathrm{H}(55 \mathrm{C})$ & 0.9900 & $\mathrm{C}\left(70^{\prime}\right)-\mathrm{C}\left(71^{\prime}\right)$ & $1.50(4)$ \\
\hline $\mathrm{C}\left(55^{\prime}\right)-\mathrm{H}(55 \mathrm{D})$ & 0.9900 & $\mathrm{C}\left(70^{\prime}\right)-\mathrm{H}(70 \mathrm{C})$ & 0.9900 \\
\hline$C\left(56^{\prime}\right)-C\left(57^{\prime}\right)$ & $1.47(4)$ & $\mathrm{C}\left(70^{\prime}\right)-\mathrm{H}(70 \mathrm{D})$ & 0.9900 \\
\hline $\mathrm{C}\left(56^{\prime}\right)-\mathrm{H}(56 \mathrm{C})$ & 0.9900 & $\mathrm{C}\left(71^{\prime}\right)-\mathrm{C}\left(72^{\prime}\right)$ & $1.51(2)$ \\
\hline $\mathrm{C}\left(56^{\prime}\right)-\mathrm{H}(56 \mathrm{D})$ & 0.9900 & $\mathrm{C}\left(71^{\prime}\right)-\mathrm{H}(71 \mathrm{C})$ & 0.9900 \\
\hline $\mathrm{C}\left(57^{\prime}\right)-\mathrm{H}(57 \mathrm{C})$ & 0.9900 & $\mathrm{C}\left(71^{\prime}\right)-\mathrm{H}(71 \mathrm{D})$ & 0.9900 \\
\hline $\mathrm{C}\left(57^{\prime}\right)-\mathrm{H}(57 \mathrm{D})$ & 0.9900 & $\mathrm{C}\left(72^{\prime}\right)-\mathrm{C}\left(73^{\prime}\right)$ & $1.50(3)$ \\
\hline $\mathrm{O}\left(2^{\prime}\right)-\mathrm{C}\left(58^{\prime}\right)$ & $1.457(14)$ & $\mathrm{C}\left(72^{\prime}\right)-\mathrm{H}(72 \mathrm{C})$ & 0.9900 \\
\hline $\mathrm{O}\left(2^{\prime}\right)-\mathrm{C}\left(61^{\prime}\right)$ & $1.469(12)$ & $\mathrm{C}\left(72^{\prime}\right)-\mathrm{H}(72 \mathrm{D})$ & 0.9900 \\
\hline $\mathrm{C}\left(58^{\prime}\right)-\mathrm{C}\left(59^{\prime}\right)$ & $1.483(17)$ & $\mathrm{C}\left(73^{\prime}\right)-\mathrm{H}(73 \mathrm{C})$ & 0.9900 \\
\hline $\mathrm{C}\left(58^{\prime}\right)-\mathrm{H}(58 \mathrm{C})$ & 0.9900 & $\mathrm{C}\left(73^{\prime}\right)-\mathrm{H}(73 \mathrm{D})$ & 0.9900 \\
\hline $\mathrm{C}\left(58^{\prime}\right)-\mathrm{H}(58 \mathrm{D})$ & 0.9900 & $\mathrm{~N}(1)-\mathrm{Fe}(1)-\mathrm{N}(3)$ & $167.7(3)$ \\
\hline $\mathrm{C}\left(59^{\prime}\right)-\mathrm{C}\left(60^{\prime}\right)$ & $1.54(3)$ & $\mathrm{N}(1)-\mathrm{Fe}(1)-\mathrm{N}(5)$ & $97.1(3)$ \\
\hline $\mathrm{C}\left(59^{\prime}\right)-\mathrm{H}(59 \mathrm{C})$ & 0.9900 & $\mathrm{~N}(3)-\mathrm{Fe}(1)-\mathrm{N}(5)$ & $80.2(3)$ \\
\hline $\mathrm{C}\left(5^{\prime}\right)-\mathrm{H}(59 \mathrm{D})$ & 0.9900 & $\mathrm{~N}(1)-\mathrm{Fe}(1)-\mathrm{N}(4)$ & $98.8(3)$ \\
\hline $\mathrm{C}\left(60^{\prime}\right)-\mathrm{C}\left(61^{\prime}\right)$ & $1.500(16)$ & $\mathrm{N}(3)-\mathrm{Fe}(1)-\mathrm{N}(4)$ & $81.0(3)$ \\
\hline $\mathrm{C}\left(60^{\prime}\right)-\mathrm{H}(60 \mathrm{C})$ & 0.9900 & $\mathrm{~N}(5)-\mathrm{Fe}(1)-\mathrm{N}(4)$ & $158.0(3)$ \\
\hline $\mathrm{C}\left(60^{\prime}\right)-\mathrm{H}(60 \mathrm{D})$ & 0.9900 & $\mathrm{~N}(1)-\mathrm{Fe}(1)-\mathrm{C}\left(1^{\prime}\right)$ & 91.1(3) \\
\hline $\mathrm{C}\left(61^{\prime}\right)-\mathrm{H}(61 \mathrm{C})$ & 0.9900 & $\mathrm{~N}(3)-\mathrm{Fe}(1)-\mathrm{C}\left(1^{\prime}\right)$ & $101.1(3)$ \\
\hline $\mathrm{C}\left(61^{\prime}\right)-\mathrm{H}(61 \mathrm{D})$ & 0.9900 & $\mathrm{~N}(5)-\mathrm{Fe}(1)-\mathrm{C}\left(1^{\prime}\right)$ & $97.6(3)$ \\
\hline $\mathrm{O}\left(4^{\prime}\right)-\mathrm{C}\left(66^{\prime}\right)$ & $1.436(16)$ & $\mathrm{N}(4)-\mathrm{Fe}(1)-\mathrm{C}\left(1^{\prime}\right)$ & $97.3(3)$ \\
\hline $\mathrm{O}\left(4^{\prime}\right)-\mathrm{C}\left(69^{\prime}\right)$ & $1.501(19)$ & $\mathrm{N}(1)-\mathrm{Fe}(1)-\mathrm{C}(1)$ & $91.1(3)$ \\
\hline$C\left(66^{\prime}\right)-C\left(67^{\prime}\right)$ & $1.46(2)$ & $\mathrm{N}(3)-\mathrm{Fe}(1)-\mathrm{C}(1)$ & $101.1(3)$ \\
\hline $\mathrm{C}\left(66^{\prime}\right)-\mathrm{H}(66 \mathrm{C})$ & 0.9900 & $\mathrm{~N}(5)-\mathrm{Fe}(1)-\mathrm{C}(1)$ & $97.6(3)$ \\
\hline $\mathrm{C}\left(66^{\prime}\right)-\mathrm{H}(66 \mathrm{D})$ & 0.9900 & $\mathrm{~N}(4)-\mathrm{Fe}(1)-\mathrm{C}(1)$ & $97.3(3)$ \\
\hline$C\left(67^{\prime}\right)-C\left(68^{\prime}\right)$ & $1.52(2)$ & $\mathrm{N}(2)-\mathrm{N}(1)-\mathrm{Fe}(1)$ & $178.2(8)$ \\
\hline $\mathrm{C}\left(67^{\prime}\right)-\mathrm{H}(67 \mathrm{C})$ & 0.9900 & $\mathrm{C}(21)-\mathrm{N}(3)-\mathrm{C}(25)$ & $121.0(7)$ \\
\hline $\mathrm{C}\left(67^{\prime}\right)-\mathrm{H}(67 \mathrm{D})$ & 0.9900 & $\mathrm{C}(21)-\mathrm{N}(3)-\mathrm{Fe}(1)$ & $119.7(5)$ \\
\hline $\mathrm{C}\left(68^{\prime}\right)-\mathrm{C}\left(69^{\prime}\right)$ & $1.51(2)$ & $\mathrm{C}(25)-\mathrm{N}(3)-\mathrm{Fe}(1)$ & $119.1(7)$ \\
\hline $\mathrm{C}\left(68^{\prime}\right)-\mathrm{H}(68 \mathrm{C})$ & 0.9900 & $\mathrm{C}(26)-\mathrm{N}(4)-\mathrm{C}(30)$ & $114.8(7)$ \\
\hline $\mathrm{C}\left(68^{\prime}\right)-\mathrm{H}(68 \mathrm{D})$ & 0.9900 & $\mathrm{C}(26)-\mathrm{N}(4)-\mathrm{Fe}(1)$ & $116.5(6)$ \\
\hline
\end{tabular}




\begin{tabular}{|c|c|c|c|}
\hline $\mathrm{C}(30)-\mathrm{N}(4)-\mathrm{Fe}(1)$ & $128.6(6)$ & $\mathrm{C}\left(2^{\prime}\right)-\mathrm{C}\left(1^{\prime}\right)-\mathrm{H}(1 \mathrm{C})$ & 109.5 \\
\hline $\mathrm{C}(28)-\mathrm{N}(5)-\mathrm{C}(42)$ & $115.8(7)$ & $\mathrm{Fe}(1)-\mathrm{C}\left(1^{\prime}\right)-\mathrm{H}(1 \mathrm{C})$ & 109.5 \\
\hline $\mathrm{C}(28)-\mathrm{N}(5)-\mathrm{Fe}(1)$ & $116.7(7)$ & $\mathrm{C}\left(2^{\prime}\right)-\mathrm{C}\left(1^{\prime}\right)-\mathrm{H}(1 \mathrm{D})$ & 109.5 \\
\hline $\mathrm{C}(42)-\mathrm{N}(5)-\mathrm{Fe}(1)$ & $127.4(5)$ & $\mathrm{Fe}(1)-\mathrm{C}\left(1^{\prime}\right)-\mathrm{H}(1 \mathrm{D})$ & 109.5 \\
\hline $\mathrm{C}(2)-\mathrm{C}(1)-\mathrm{Fe}(1)$ & $112.2(7)$ & $\mathrm{H}(1 \mathrm{C})-\mathrm{C}\left(1^{\prime}\right)-\mathrm{H}(1 \mathrm{D})$ & 108.0 \\
\hline $\mathrm{C}(2)-\mathrm{C}(1)-\mathrm{H}(1 \mathrm{~A})$ & 109.2 & $\mathrm{C}\left(3^{\prime}\right)-\mathrm{C}\left(2^{\prime}\right)-\mathrm{C}\left(1^{\prime}\right)$ & $115(3)$ \\
\hline $\mathrm{Fe}(1)-\mathrm{C}(1)-\mathrm{H}(1 \mathrm{~A})$ & 109.2 & $\mathrm{C}\left(3^{\prime}\right)-\mathrm{C}\left(2^{\prime}\right)-\mathrm{H}(2 \mathrm{C})$ & 108.6 \\
\hline $\mathrm{C}(2)-\mathrm{C}(1)-\mathrm{H}(1 \mathrm{~B})$ & 109.2 & $\mathrm{C}\left(1^{\prime}\right)-\mathrm{C}\left(2^{\prime}\right)-\mathrm{H}(2 \mathrm{C})$ & 108.6 \\
\hline $\mathrm{Fe}(1)-\mathrm{C}(1)-\mathrm{H}(1 \mathrm{~B})$ & 109.2 & $\mathrm{C}\left(3^{\prime}\right)-\mathrm{C}\left(2^{\prime}\right)-\mathrm{H}(2 \mathrm{D})$ & 108.6 \\
\hline $\mathrm{H}(1 \mathrm{~A})-\mathrm{C}(1)-\mathrm{H}(1 \mathrm{~B})$ & 107.9 & $\mathrm{C}\left(1^{\prime}\right)-\mathrm{C}\left(2^{\prime}\right)-\mathrm{H}(2 \mathrm{D})$ & 108.6 \\
\hline $\mathrm{C}(3)-\mathrm{C}(2)-\mathrm{C}(1)$ & $112.8(10)$ & $\mathrm{H}(2 \mathrm{C})-\mathrm{C}\left(2^{\prime}\right)-\mathrm{H}(2 \mathrm{D})$ & 107.6 \\
\hline $\mathrm{C}(3)-\mathrm{C}(2)-\mathrm{H}(2 \mathrm{~A})$ & 109.0 & $\mathrm{C}\left(8^{\prime}\right)-\mathrm{C}\left(3^{\prime}\right)-\mathrm{C}\left(4^{\prime}\right)$ & $119(3)$ \\
\hline $\mathrm{C}(1)-\mathrm{C}(2)-\mathrm{H}(2 \mathrm{~A})$ & 109.0 & $\mathrm{C}\left(8^{\prime}\right)-\mathrm{C}\left(3^{\prime}\right)-\mathrm{C}\left(2^{\prime}\right)$ & $120(3)$ \\
\hline $\mathrm{C}(3)-\mathrm{C}(2)-\mathrm{H}(2 \mathrm{~B})$ & 109.0 & $\mathrm{C}\left(4^{\prime}\right)-\mathrm{C}\left(3^{\prime}\right)-\mathrm{C}\left(2^{\prime}\right)$ & $121(3)$ \\
\hline $\mathrm{C}(1)-\mathrm{C}(2)-\mathrm{H}(2 \mathrm{~B})$ & 109.0 & $\mathrm{C}\left(5^{\prime}\right)-\mathrm{C}\left(4^{\prime}\right)-\mathrm{C}\left(3^{\prime}\right)$ & $123(4)$ \\
\hline $\mathrm{H}(2 \mathrm{~A})-\mathrm{C}(2)-\mathrm{H}(2 \mathrm{~B})$ & 107.8 & $\mathrm{C}\left(5^{\prime}\right)-\mathrm{C}\left(4^{\prime}\right)-\mathrm{H}\left(4^{\prime}\right)$ & 118.5 \\
\hline $\mathrm{C}(8)-\mathrm{C}(3)-\mathrm{C}(4)$ & $118.3(12)$ & $\mathrm{C}\left(3^{\prime}\right)-\mathrm{C}\left(4^{\prime}\right)-\mathrm{H}\left(4^{\prime}\right)$ & 118.5 \\
\hline $\mathrm{C}(8)-\mathrm{C}(3)-\mathrm{C}(2)$ & $121.2(12)$ & $\mathrm{C}\left(4^{\prime}\right)-\mathrm{C}\left(5^{\prime}\right)-\mathrm{C}\left(6^{\prime}\right)$ & $114(3)$ \\
\hline $\mathrm{C}(4)-\mathrm{C}(3)-\mathrm{C}(2)$ & $120.3(15)$ & $\mathrm{C}\left(4^{\prime}\right)-\mathrm{C}\left(5^{\prime}\right)-\mathrm{H}\left(5^{\prime}\right)$ & 123.0 \\
\hline $\mathrm{C}(5)-\mathrm{C}(4)-\mathrm{C}(3)$ & $123.2(18)$ & $\mathrm{C}\left(6^{\prime}\right)-\mathrm{C}\left(5^{\prime}\right)-\mathrm{H}\left(5^{\prime}\right)$ & 123.0 \\
\hline $\mathrm{C}(5)-\mathrm{C}(4)-\mathrm{H}(4)$ & 118.4 & $C\left(7^{\prime}\right)-C\left(6^{\prime}\right)-C\left(5^{\prime}\right)$ & $121(3)$ \\
\hline $\mathrm{C}(3)-\mathrm{C}(4)-\mathrm{H}(4)$ & 118.4 & $\mathrm{C}\left(7^{\prime}\right)-\mathrm{C}\left(6^{\prime}\right)-\mathrm{H}\left(6^{\prime}\right)$ & 119.5 \\
\hline$C(4)-C(5)-C(6)$ & $116.1(15)$ & $\mathrm{C}\left(5^{\prime}\right)-\mathrm{C}\left(6^{\prime}\right)-\mathrm{H}\left(6^{\prime}\right)$ & 119.5 \\
\hline $\mathrm{C}(4)-\mathrm{C}(5)-\mathrm{H}(5)$ & 122.0 & $\mathrm{C}\left(8^{\prime}\right)-\mathrm{C}\left(7^{\prime}\right)-\mathrm{C}\left(6^{\prime}\right)$ & $122(3)$ \\
\hline $\mathrm{C}(6)-\mathrm{C}(5)-\mathrm{H}(5)$ & 122.0 & $\mathrm{C}\left(8^{\prime}\right)-\mathrm{C}\left(7^{\prime}\right)-\mathrm{H}\left(7^{\prime}\right)$ & 118.9 \\
\hline$C(7)-C(6)-C(5)$ & $119.5(12)$ & $\mathrm{C}\left(6^{\prime}\right)-\mathrm{C}\left(7^{\prime}\right)-\mathrm{H}\left(7^{\prime}\right)$ & 118.9 \\
\hline$C(7)-C(6)-H(6)$ & 120.3 & $\mathrm{C}\left(7^{\prime}\right)-\mathrm{C}\left(8^{\prime}\right)-\mathrm{C}\left(3^{\prime}\right)$ & $119(3)$ \\
\hline $\mathrm{C}(5)-\mathrm{C}(6)-\mathrm{H}(6)$ & 120.3 & $\mathrm{C}\left(7^{\prime}\right)-\mathrm{C}\left(8^{\prime}\right)-\mathrm{H}\left(8^{\prime}\right)$ & 120.5 \\
\hline$C(8)-C(7)-C(6)$ & $122.2(16)$ & $\mathrm{C}\left(3^{\prime}\right)-\mathrm{C}\left(8^{\prime}\right)-\mathrm{H}\left(8^{\prime}\right)$ & 120.5 \\
\hline $\mathrm{C}(8)-\mathrm{C}(7)-\mathrm{H}(7)$ & 118.9 & $\mathrm{~N}(3)-\mathrm{C}(21)-\mathrm{C}(22)$ & $120.2(8)$ \\
\hline $\mathrm{C}(6)-\mathrm{C}(7)-\mathrm{H}(7)$ & 118.9 & $\mathrm{~N}(3)-\mathrm{C}(21)-\mathrm{C}(26)$ & $111.7(7)$ \\
\hline$C(7)-C(8)-C(3)$ & $120.5(13)$ & $C(22)-C(21)-C(26)$ & 128.1(9) \\
\hline $\mathrm{C}(7)-\mathrm{C}(8)-\mathrm{H}(8)$ & 119.8 & $\mathrm{C}(23)-\mathrm{C}(22)-\mathrm{C}(21)$ & $119.0(10)$ \\
\hline $\mathrm{C}(3)-\mathrm{C}(8)-\mathrm{H}(8)$ & 119.8 & $\mathrm{C}(23)-\mathrm{C}(22)-\mathrm{H}(22)$ & 120.5 \\
\hline $\mathrm{C}\left(2^{\prime}\right)-\mathrm{C}\left(1^{\prime}\right)-\mathrm{Fe}(1)$ & $110.9(18)$ & $\mathrm{C}(21)-\mathrm{C}(22)-\mathrm{H}(22)$ & 120.5 \\
\hline
\end{tabular}




\begin{tabular}{|c|c|}
\hline $\mathrm{C}(24)-\mathrm{C}(23)-\mathrm{C}(22)$ & $120.5(8)$ \\
\hline $\mathrm{C}(24)-\mathrm{C}(23)-\mathrm{H}(23)$ & 119.7 \\
\hline $\mathrm{C}(22)-\mathrm{C}(23)-\mathrm{H}(23)$ & 119.7 \\
\hline$C(23)-C(24)-C(25)$ & $121.1(8)$ \\
\hline $\mathrm{C}(23)-\mathrm{C}(24)-\mathrm{H}(24)$ & 119.5 \\
\hline $\mathrm{C}(25)-\mathrm{C}(24)-\mathrm{H}(24)$ & 119.5 \\
\hline $\mathrm{C}(28)-\mathrm{C}(25)-\mathrm{N}(3)$ & $111.6(7)$ \\
\hline $\mathrm{C}(28)-\mathrm{C}(25)-\mathrm{C}(24)$ & $130.2(8)$ \\
\hline $\mathrm{N}(3)-\mathrm{C}(25)-\mathrm{C}(24)$ & $118.2(9)$ \\
\hline $\mathrm{N}(4)-\mathrm{C}(26)-\mathrm{C}(21)$ & $110.6(7)$ \\
\hline $\mathrm{N}(4)-\mathrm{C}(26)-\mathrm{C}(27)$ & $126.0(8)$ \\
\hline $\mathrm{C}(21)-\mathrm{C}(26)-\mathrm{C}(27)$ & $123.0(8)$ \\
\hline $\mathrm{C}(26)-\mathrm{C}(27)-\mathrm{H}(27 \mathrm{~A})$ & 109.5 \\
\hline $\mathrm{C}(26)-\mathrm{C}(27)-\mathrm{H}(27 \mathrm{~B})$ & 109.5 \\
\hline $\mathrm{H}(27 \mathrm{~A})-\mathrm{C}(27)-\mathrm{H}(27 \mathrm{~B})$ & 109.5 \\
\hline $\mathrm{C}(26)-\mathrm{C}(27)-\mathrm{H}(27 \mathrm{C})$ & 109.5 \\
\hline $\mathrm{H}(27 \mathrm{~A})-\mathrm{C}(27)-\mathrm{H}(27 \mathrm{C})$ & 109.5 \\
\hline $\mathrm{H}(27 \mathrm{~B})-\mathrm{C}(27)-\mathrm{H}(27 \mathrm{C})$ & 109.5 \\
\hline $\mathrm{N}(5)-\mathrm{C}(28)-\mathrm{C}(25)$ & $111.0(7)$ \\
\hline $\mathrm{N}(5)-\mathrm{C}(28)-\mathrm{C}(29)$ & $124.3(9)$ \\
\hline$C(25)-C(28)-C(29)$ & $124.4(7)$ \\
\hline $\mathrm{C}(28)-\mathrm{C}(29)-\mathrm{H}(29 \mathrm{~A})$ & 109.5 \\
\hline $\mathrm{C}(28)-\mathrm{C}(29)-\mathrm{H}(29 \mathrm{~B})$ & 109.5 \\
\hline $\mathrm{H}(29 \mathrm{~A})-\mathrm{C}(29)-\mathrm{H}(29 \mathrm{~B})$ & 109.5 \\
\hline $\mathrm{C}(28)-\mathrm{C}(29)-\mathrm{H}(29 \mathrm{C})$ & 109.5 \\
\hline $\mathrm{H}(29 \mathrm{~A})-\mathrm{C}(29)-\mathrm{H}(29 \mathrm{C})$ & 109.5 \\
\hline H(29B)-C(29)-H(29C) & 109.5 \\
\hline $\mathrm{C}(35)-\mathrm{C}(30)-\mathrm{N}(4)$ & $121.7(7)$ \\
\hline $\mathrm{C}(35)-\mathrm{C}(30)-\mathrm{C}(31)$ & $119.5(7)$ \\
\hline $\mathrm{N}(4)-\mathrm{C}(30)-\mathrm{C}(31)$ & $118.7(7)$ \\
\hline$C(32)-C(31)-C(30)$ & $119.4(8)$ \\
\hline $\mathrm{C}(32)-\mathrm{C}(31)-\mathrm{C}(36)$ & $118.6(8)$ \\
\hline $\mathrm{C}(30)-\mathrm{C}(31)-\mathrm{C}(36)$ & $121.8(7)$ \\
\hline $\mathrm{C}(31)-\mathrm{C}(32)-\mathrm{C}(33)$ & $119.8(8)$ \\
\hline $\mathrm{C}(31)-\mathrm{C}(32)-\mathrm{H}(32)$ & 120.1 \\
\hline
\end{tabular}

\begin{tabular}{|c|c|}
\hline $\mathrm{C}(33)-\mathrm{C}(32)-\mathrm{H}(32)$ & 120.1 \\
\hline$C(34)-C(33)-C(32)$ & $120.7(8)$ \\
\hline $\mathrm{C}(34)-\mathrm{C}(33)-\mathrm{H}(33)$ & 119.7 \\
\hline $\mathrm{C}(32)-\mathrm{C}(33)-\mathrm{H}(33)$ & 119.7 \\
\hline $\mathrm{C}(33)-\mathrm{C}(34)-\mathrm{C}(35)$ & $121.7(9)$ \\
\hline $\mathrm{C}(33)-\mathrm{C}(34)-\mathrm{H}(34)$ & 119.2 \\
\hline $\mathrm{C}(35)-\mathrm{C}(34)-\mathrm{H}(34)$ & 119.2 \\
\hline$C(34)-C(35)-C(30)$ & $118.8(8)$ \\
\hline$C(34)-C(35)-C(39)$ & $117.4(8)$ \\
\hline $\mathrm{C}(30)-\mathrm{C}(35)-\mathrm{C}(39)$ & $123.7(7)$ \\
\hline$C(37)-C(36)-C(31)$ & $112.8(8)$ \\
\hline $\mathrm{C}(37)-\mathrm{C}(36)-\mathrm{C}(38)$ & 111.2(9) \\
\hline $\mathrm{C}(31)-\mathrm{C}(36)-\mathrm{C}(38)$ & $109.1(10$ \\
\hline $\mathrm{C}(37)-\mathrm{C}(36)-\mathrm{H}(36)$ & 107.9 \\
\hline $\mathrm{C}(31)-\mathrm{C}(36)-\mathrm{H}(36)$ & 107.9 \\
\hline $\mathrm{C}(38)-\mathrm{C}(36)-\mathrm{H}(36)$ & 107.9 \\
\hline $\mathrm{C}(36)-\mathrm{C}(37)-\mathrm{H}(37 \mathrm{~A})$ & 109.5 \\
\hline $\mathrm{C}(36)-\mathrm{C}(37)-\mathrm{H}(37 \mathrm{~B})$ & 109.5 \\
\hline $\mathrm{H}(37 \mathrm{~A})-\mathrm{C}(37)-\mathrm{H}(37 \mathrm{~B})$ & 109.5 \\
\hline $\mathrm{C}(36)-\mathrm{C}(37)-\mathrm{H}(37 \mathrm{C})$ & 109.5 \\
\hline $\mathrm{H}(37 \mathrm{~A})-\mathrm{C}(37)-\mathrm{H}(37 \mathrm{C})$ & 109.5 \\
\hline $\mathrm{H}(37 \mathrm{~B})-\mathrm{C}(37)-\mathrm{H}(37 \mathrm{C})$ & 109.5 \\
\hline $\mathrm{C}(36)-\mathrm{C}(38)-\mathrm{H}(38 \mathrm{~A})$ & 109.5 \\
\hline $\mathrm{C}(36)-\mathrm{C}(38)-\mathrm{H}(38 \mathrm{~B})$ & 109.5 \\
\hline $\mathrm{H}(38 \mathrm{~A})-\mathrm{C}(38)-\mathrm{H}(38 \mathrm{~B})$ & 109.5 \\
\hline $\mathrm{C}(36)-\mathrm{C}(38)-\mathrm{H}(38 \mathrm{C})$ & 109.5 \\
\hline $\mathrm{H}(38 \mathrm{~A})-\mathrm{C}(38)-\mathrm{H}(38 \mathrm{C})$ & 109.5 \\
\hline $\mathrm{H}(38 \mathrm{~B})-\mathrm{C}(38)-\mathrm{H}(38 \mathrm{C})$ & 109.5 \\
\hline$C(35)-C(39)-C(40)$ & 111.7(9) \\
\hline $\mathrm{C}(35)-\mathrm{C}(39)-\mathrm{C}(41)$ & 111.1(9) \\
\hline$C(40)-C(39)-C(41)$ & 110.2(9) \\
\hline $\mathrm{C}(35)-\mathrm{C}(39)-\mathrm{H}(39)$ & 107.9 \\
\hline $\mathrm{C}(40)-\mathrm{C}(39)-\mathrm{H}(39)$ & 107.9 \\
\hline $\mathrm{C}(41)-\mathrm{C}(39)-\mathrm{H}(39)$ & 107.9 \\
\hline $\mathrm{C}(39)-\mathrm{C}(40)-\mathrm{H}(40 \mathrm{~A})$ & 109.5 \\
\hline
\end{tabular}




\begin{tabular}{|c|c|c|c|}
\hline $\mathrm{C}(39)-\mathrm{C}(40)-\mathrm{H}(40 \mathrm{~B})$ & 109.5 & $\mathrm{C}(48)-\mathrm{C}(49)-\mathrm{H}(49 \mathrm{~A})$ & 109.5 \\
\hline $\mathrm{H}(40 \mathrm{~A})-\mathrm{C}(40)-\mathrm{H}(40 \mathrm{~B})$ & 109.5 & $\mathrm{C}(48)-\mathrm{C}(49)-\mathrm{H}(49 \mathrm{~B})$ & 109.5 \\
\hline $\mathrm{C}(39)-\mathrm{C}(40)-\mathrm{H}(40 \mathrm{C})$ & 109.5 & $\mathrm{H}(49 \mathrm{~A})-\mathrm{C}(49)-\mathrm{H}(49 \mathrm{~B})$ & 109.5 \\
\hline $\mathrm{H}(40 \mathrm{~A})-\mathrm{C}(40)-\mathrm{H}(40 \mathrm{C})$ & 109.5 & $\mathrm{C}(48)-\mathrm{C}(49)-\mathrm{H}(49 \mathrm{C})$ & 109.5 \\
\hline $\mathrm{H}(40 \mathrm{~B})-\mathrm{C}(40)-\mathrm{H}(40 \mathrm{C})$ & 109.5 & $\mathrm{H}(49 \mathrm{~A})-\mathrm{C}(49)-\mathrm{H}(49 \mathrm{C})$ & 109.5 \\
\hline $\mathrm{C}(39)-\mathrm{C}(41)-\mathrm{H}(41 \mathrm{~A})$ & 109.5 & H(49B)-C(49)-H(49C) & 109.5 \\
\hline $\mathrm{C}(39)-\mathrm{C}(41)-\mathrm{H}(41 \mathrm{~B})$ & 109.5 & $\mathrm{C}(48)-\mathrm{C}(50)-\mathrm{H}(50 \mathrm{~A})$ & 109.5 \\
\hline $\mathrm{H}(41 \mathrm{~A})-\mathrm{C}(41)-\mathrm{H}(41 \mathrm{~B})$ & 109.5 & $\mathrm{C}(48)-\mathrm{C}(50)-\mathrm{H}(50 \mathrm{~B})$ & 109.5 \\
\hline $\mathrm{C}(39)-\mathrm{C}(41)-\mathrm{H}(41 \mathrm{C})$ & 109.5 & $\mathrm{H}(50 \mathrm{~A})-\mathrm{C}(50)-\mathrm{H}(50 \mathrm{~B})$ & 109.5 \\
\hline $\mathrm{H}(41 \mathrm{~A})-\mathrm{C}(41)-\mathrm{H}(41 \mathrm{C})$ & 109.5 & $\mathrm{C}(48)-\mathrm{C}(50)-\mathrm{H}(50 \mathrm{C})$ & 109.5 \\
\hline $\mathrm{H}(41 \mathrm{~B})-\mathrm{C}(41)-\mathrm{H}(41 \mathrm{C})$ & 109.5 & $\mathrm{H}(50 \mathrm{~A})-\mathrm{C}(50)-\mathrm{H}(50 \mathrm{C})$ & 109.5 \\
\hline $\mathrm{C}(43)-\mathrm{C}(42)-\mathrm{C}(47)$ & $119.7(9)$ & $\mathrm{H}(50 \mathrm{~B})-\mathrm{C}(50)-\mathrm{H}(50 \mathrm{C})$ & 109.5 \\
\hline $\mathrm{C}(43)-\mathrm{C}(42)-\mathrm{N}(5)$ & $124.2(8)$ & $C(53)-C(51)-C(52)$ & $110.0(8)$ \\
\hline $\mathrm{C}(47)-\mathrm{C}(42)-\mathrm{N}(5)$ & $116.1(9)$ & $C(53)-C(51)-C(47)$ & $111.7(11)$ \\
\hline$C(42)-C(43)-C(44)$ & $121.5(9)$ & $\mathrm{C}(52)-\mathrm{C}(51)-\mathrm{C}(47)$ & $111.7(9)$ \\
\hline$C(42)-C(43)-C(48)$ & $120.2(9)$ & $\mathrm{C}(53)-\mathrm{C}(51)-\mathrm{H}(51)$ & 107.8 \\
\hline $\mathrm{C}(44)-\mathrm{C}(43)-\mathrm{C}(48)$ & 118.3(9) & $\mathrm{C}(52)-\mathrm{C}(51)-\mathrm{H}(51)$ & 107.8 \\
\hline $\mathrm{C}(43)-\mathrm{C}(44)-\mathrm{C}(45)$ & $120.0(10)$ & $\mathrm{C}(47)-\mathrm{C}(51)-\mathrm{H}(51)$ & 107.8 \\
\hline $\mathrm{C}(43)-\mathrm{C}(44)-\mathrm{H}(44)$ & 120.0 & $\mathrm{C}(51)-\mathrm{C}(52)-\mathrm{H}(52 \mathrm{~A})$ & 109.5 \\
\hline $\mathrm{C}(45)-\mathrm{C}(44)-\mathrm{H}(44)$ & 120.0 & $\mathrm{C}(51)-\mathrm{C}(52)-\mathrm{H}(52 \mathrm{~B})$ & 109.5 \\
\hline$C(46)-C(45)-C(44)$ & $118.9(11)$ & $\mathrm{H}(52 \mathrm{~A})-\mathrm{C}(52)-\mathrm{H}(52 \mathrm{~B})$ & 109.5 \\
\hline $\mathrm{C}(46)-\mathrm{C}(45)-\mathrm{H}(45)$ & 120.6 & $\mathrm{C}(51)-\mathrm{C}(52)-\mathrm{H}(52 \mathrm{C})$ & 109.5 \\
\hline $\mathrm{C}(44)-\mathrm{C}(45)-\mathrm{H}(45)$ & 120.6 & $\mathrm{H}(52 \mathrm{~A})-\mathrm{C}(52)-\mathrm{H}(52 \mathrm{C})$ & 109.5 \\
\hline$C(45)-C(46)-C(47)$ & $123.3(11)$ & $\mathrm{H}(52 \mathrm{~B})-\mathrm{C}(52)-\mathrm{H}(52 \mathrm{C})$ & 109.5 \\
\hline $\mathrm{C}(45)-\mathrm{C}(46)-\mathrm{H}(46)$ & 118.3 & $\mathrm{C}(51)-\mathrm{C}(53)-\mathrm{H}(53 \mathrm{~A})$ & 109.5 \\
\hline $\mathrm{C}(47)-\mathrm{C}(46)-\mathrm{H}(46)$ & 118.3 & $\mathrm{C}(51)-\mathrm{C}(53)-\mathrm{H}(53 \mathrm{~B})$ & 109.5 \\
\hline$C(42)-C(47)-C(46)$ & $116.6(10)$ & $\mathrm{H}(53 \mathrm{~A})-\mathrm{C}(53)-\mathrm{H}(53 \mathrm{~B})$ & 109.5 \\
\hline $\mathrm{C}(42)-\mathrm{C}(47)-\mathrm{C}(51)$ & $123.7(10)$ & $\mathrm{C}(51)-\mathrm{C}(53)-\mathrm{H}(53 \mathrm{C})$ & 109.5 \\
\hline $\mathrm{C}(46)-\mathrm{C}(47)-\mathrm{C}(51)$ & $119.7(9)$ & $\mathrm{H}(53 \mathrm{~A})-\mathrm{C}(53)-\mathrm{H}(53 \mathrm{C})$ & 109.5 \\
\hline$C(43)-C(48)-C(50)$ & $111.2(8)$ & $\mathrm{H}(53 \mathrm{~B})-\mathrm{C}(53)-\mathrm{H}(53 \mathrm{C})$ & 109.5 \\
\hline $\mathrm{C}(43)-\mathrm{C}(48)-\mathrm{C}(49)$ & $110.5(8)$ & $\mathrm{O}\left(4^{\prime}\right)-\mathrm{Mg}(1)-\mathrm{O}\left(2^{\prime}\right)$ & $177.4(6)$ \\
\hline$C(50)-C(48)-C(49)$ & $108.1(8)$ & $\mathrm{O}(4)-\mathrm{Mg}(1)-\mathrm{O}(2)$ & $166.9(9)$ \\
\hline $\mathrm{C}(43)-\mathrm{C}(48)-\mathrm{H}(48)$ & 109.0 & $\mathrm{O}\left(4^{\prime}\right)-\mathrm{Mg}(1)-\mathrm{O}\left(5^{\prime}\right)$ & $88.5(6)$ \\
\hline $\mathrm{C}(50)-\mathrm{C}(48)-\mathrm{H}(48)$ & 109.0 & $\mathrm{O}\left(2^{\prime}\right)-\mathrm{Mg}(1)-\mathrm{O}\left(5^{\prime}\right)$ & $90.1(3)$ \\
\hline $\mathrm{C}(49)-\mathrm{C}(48)-\mathrm{H}(48)$ & 109.0 & $\mathrm{O}(4)-\mathrm{Mg}(1)-\mathrm{O}(5)$ & $91.5(8)$ \\
\hline
\end{tabular}




\begin{tabular}{|c|c|c|c|}
\hline $\mathrm{O}(2)-\mathrm{Mg}(1)-\mathrm{O}(5)$ & $90.1(3)$ & $\mathrm{C}(62)-\mathrm{C}(63)-\mathrm{H}(63 \mathrm{~A})$ & 110.8 \\
\hline $\mathrm{O}(4)-\mathrm{Mg}(1)-\mathrm{O}(1)$ & $79.5(9)$ & $\mathrm{C}(64)-\mathrm{C}(63)-\mathrm{H}(63 \mathrm{~A})$ & 110.8 \\
\hline $\mathrm{O}(2)-\mathrm{Mg}(1)-\mathrm{O}(1)$ & $87.6(3)$ & $\mathrm{C}(62)-\mathrm{C}(63)-\mathrm{H}(63 \mathrm{~B})$ & 110.8 \\
\hline $\mathrm{O}(5)-\mathrm{Mg}(1)-\mathrm{O}(1)$ & $86.5(3)$ & $\mathrm{C}(64)-\mathrm{C}(63)-\mathrm{H}(63 \mathrm{~B})$ & 110.8 \\
\hline $\mathrm{O}\left(4^{\prime}\right)-\mathrm{Mg}(1)-\mathrm{O}\left(1^{\prime}\right)$ & $90.1(6)$ & $\mathrm{H}(63 \mathrm{~A})-\mathrm{C}(63)-\mathrm{H}(63 \mathrm{~B})$ & 108.9 \\
\hline $\mathrm{O}\left(2^{\prime}\right)-\mathrm{Mg}(1)-\mathrm{O}\left(1^{\prime}\right)$ & $87.6(3)$ & $C(65)-C(64)-C(63)$ & $107.8(10)$ \\
\hline $\mathrm{O}\left(5^{\prime}\right)-\mathrm{Mg}(1)-\mathrm{O}\left(1^{\prime}\right)$ & $86.5(3)$ & $\mathrm{C}(65)-\mathrm{C}(64)-\mathrm{H}(64 \mathrm{~A})$ & 110.2 \\
\hline $\mathrm{O}\left(4^{\prime}\right)-\mathrm{Mg}(1)-\mathrm{O}(3)$ & $91.9(6)$ & $\mathrm{C}(63)-\mathrm{C}(64)-\mathrm{H}(64 \mathrm{~A})$ & 110.2 \\
\hline $\mathrm{O}(4)-\mathrm{Mg}(1)-\mathrm{O}(3)$ & $87.8(8)$ & $\mathrm{C}(65)-\mathrm{C}(64)-\mathrm{H}(64 \mathrm{~B})$ & 110.2 \\
\hline $\mathrm{O}\left(2^{\prime}\right)-\mathrm{Mg}(1)-\mathrm{O}(3)$ & $89.1(3)$ & $\mathrm{C}(63)-\mathrm{C}(64)-\mathrm{H}(64 \mathrm{~B})$ & 110.2 \\
\hline $\mathrm{O}(2)-\mathrm{Mg}(1)-\mathrm{O}(3)$ & $89.1(3)$ & $H(64 A)-C(64)-H(64 B)$ & 108.5 \\
\hline $\mathrm{O}\left(5^{\prime}\right)-\mathrm{Mg}(1)-\mathrm{O}(3)$ & $173.4(3)$ & $\mathrm{C}(64)-\mathrm{C}(65)-\mathrm{O}(3)$ & $110.2(13)$ \\
\hline $\mathrm{O}(5)-\mathrm{Mg}(1)-\mathrm{O}(3)$ & $173.4(3)$ & $C(64)-C(65)-H(65 A)$ & 109.6 \\
\hline $\mathrm{O}(1)-\mathrm{Mg}(1)-\mathrm{O}(3)$ & $86.9(3)$ & $\mathrm{O}(3)-\mathrm{C}(65)-\mathrm{H}(65 \mathrm{~A})$ & 109.6 \\
\hline $\mathrm{O}\left(1^{\prime}\right)-\mathrm{Mg}(1)-\mathrm{O}(3)$ & $86.9(3)$ & $\mathrm{C}(64)-\mathrm{C}(65)-\mathrm{H}(65 \mathrm{~B})$ & 109.6 \\
\hline $\mathrm{O}\left(4^{\prime}\right)-\mathrm{Mg}(1)-\mathrm{Cl}(1)$ & $89.7(5)$ & $\mathrm{O}(3)-\mathrm{C}(65)-\mathrm{H}(65 \mathrm{~B})$ & 109.6 \\
\hline $\mathrm{O}\left(2^{\prime}\right)-\mathrm{Mg}(1)-\mathrm{Cl}(1)$ & $92.6(2)$ & $H(65 A)-C(65)-H(65 B)$ & 108.1 \\
\hline $\mathrm{O}\left(5^{\prime}\right)-\mathrm{Mg}(1)-\mathrm{Cl}(1)$ & $93.9(2)$ & $\mathrm{C}(57)-\mathrm{O}(1)-\mathrm{C}(54)$ & $107.7(11)$ \\
\hline $\mathrm{O}\left(1^{\prime}\right)-\mathrm{Mg}(1)-\mathrm{Cl}(1)$ & $179.6(2)$ & $\mathrm{C}(57)-\mathrm{O}(1)-\mathrm{Mg}(1)$ & $131.0(8)$ \\
\hline $\mathrm{O}(3)-\mathrm{Mg}(1)-\mathrm{Cl}(1)$ & $92.7(2)$ & $\mathrm{C}(54)-\mathrm{O}(1)-\mathrm{Mg}(1)$ & $120.7(8)$ \\
\hline $\mathrm{O}(4)-\mathrm{Mg}(1)-\mathrm{Br}(1)$ & $100.3(9)$ & $\mathrm{O}(1)-\mathrm{C}(54)-\mathrm{C}(55)$ & $105.1(12)$ \\
\hline $\mathrm{O}(2)-\mathrm{Mg}(1)-\mathrm{Br}(1)$ & $92.6(2)$ & $\mathrm{O}(1)-\mathrm{C}(54)-\mathrm{H}(54 \mathrm{~A})$ & 110.7 \\
\hline $\mathrm{O}(5)-\mathrm{Mg}(1)-\mathrm{Br}(1)$ & $93.9(2)$ & $\mathrm{C}(55)-\mathrm{C}(54)-\mathrm{H}(54 \mathrm{~A})$ & 110.7 \\
\hline $\mathrm{O}(1)-\mathrm{Mg}(1)-\mathrm{Br}(1)$ & $179.6(2)$ & $\mathrm{O}(1)-\mathrm{C}(54)-\mathrm{H}(54 \mathrm{~B})$ & 110.7 \\
\hline $\mathrm{O}(3)-\mathrm{Mg}(1)-\mathrm{Br}(1)$ & $92.7(2)$ & $\mathrm{C}(55)-\mathrm{C}(54)-\mathrm{H}(54 \mathrm{~B})$ & 110.7 \\
\hline $\mathrm{C}(65)-\mathrm{O}(3)-\mathrm{C}(62)$ & $106.7(8)$ & $\mathrm{H}(54 \mathrm{~A})-\mathrm{C}(54)-\mathrm{H}(54 \mathrm{~B})$ & 108.8 \\
\hline $\mathrm{C}(65)-\mathrm{O}(3)-\mathrm{Mg}(1)$ & $128.3(8)$ & $C(54)-C(55)-C(56)$ & $103.3(12)$ \\
\hline $\mathrm{C}(62)-\mathrm{O}(3)-\mathrm{Mg}(1)$ & $124.9(6)$ & $\mathrm{C}(54)-\mathrm{C}(55)-\mathrm{H}(55 \mathrm{~A})$ & 111.1 \\
\hline $\mathrm{O}(3)-\mathrm{C}(62)-\mathrm{C}(63)$ & $106.5(10)$ & $\mathrm{C}(56)-\mathrm{C}(55)-\mathrm{H}(55 \mathrm{~A})$ & 111.1 \\
\hline $\mathrm{O}(3)-\mathrm{C}(62)-\mathrm{H}(62 \mathrm{~A})$ & 110.4 & $\mathrm{C}(54)-\mathrm{C}(55)-\mathrm{H}(55 \mathrm{~B})$ & 111.1 \\
\hline $\mathrm{C}(63)-\mathrm{C}(62)-\mathrm{H}(62 \mathrm{~A})$ & 110.4 & $\mathrm{C}(56)-\mathrm{C}(55)-\mathrm{H}(55 \mathrm{~B})$ & 111.1 \\
\hline $\mathrm{O}(3)-\mathrm{C}(62)-\mathrm{H}(62 \mathrm{~B})$ & 110.4 & $\mathrm{H}(55 \mathrm{~A})-\mathrm{C}(55)-\mathrm{H}(55 \mathrm{~B})$ & 109.1 \\
\hline $\mathrm{C}(63)-\mathrm{C}(62)-\mathrm{H}(62 \mathrm{~B})$ & 110.4 & $C(57)-C(56)-C(55)$ & $101(2)$ \\
\hline $\mathrm{H}(62 \mathrm{~A})-\mathrm{C}(62)-\mathrm{H}(62 \mathrm{~B})$ & 108.6 & $\mathrm{C}(57)-\mathrm{C}(56)-\mathrm{H}(56 \mathrm{~A})$ & 111.5 \\
\hline $\mathrm{C}(62)-\mathrm{C}(63)-\mathrm{C}(64)$ & $104.8(10)$ & $\mathrm{C}(55)-\mathrm{C}(56)-\mathrm{H}(56 \mathrm{~A})$ & 111.5 \\
\hline
\end{tabular}




\begin{tabular}{|c|c|c|c|}
\hline $\mathrm{C}(57)-\mathrm{C}(56)-\mathrm{H}(56 \mathrm{~B})$ & 111.5 & $\mathrm{H}(61 \mathrm{~A})-\mathrm{C}(61)-\mathrm{H}(61 \mathrm{~B})$ & 108.9 \\
\hline $\mathrm{C}(55)-\mathrm{C}(56)-\mathrm{H}(56 \mathrm{~B})$ & 111.5 & $\mathrm{C}(66)-\mathrm{O}(4)-\mathrm{C}(69)$ & $106.2(17)$ \\
\hline $\mathrm{H}(56 \mathrm{~A})-\mathrm{C}(56)-\mathrm{H}(56 \mathrm{~B})$ & 109.3 & $\mathrm{C}(66)-\mathrm{O}(4)-\mathrm{Mg}(1)$ & $122.9(18)$ \\
\hline $\mathrm{O}(1)-\mathrm{C}(57)-\mathrm{C}(56)$ & $105(2)$ & $\mathrm{C}(69)-\mathrm{O}(4)-\mathrm{Mg}(1)$ & $122.6(17)$ \\
\hline $\mathrm{O}(1)-\mathrm{C}(57)-\mathrm{H}(57 \mathrm{~A})$ & 110.8 & $\mathrm{O}(4)-\mathrm{C}(66)-\mathrm{C}(67)$ & $104.2(16)$ \\
\hline $\mathrm{C}(56)-\mathrm{C}(57)-\mathrm{H}(57 \mathrm{~A})$ & 110.8 & $\mathrm{O}(4)-\mathrm{C}(66)-\mathrm{H}(66 \mathrm{~A})$ & 110.9 \\
\hline $\mathrm{O}(1)-\mathrm{C}(57)-\mathrm{H}(57 \mathrm{~B})$ & 110.8 & $\mathrm{C}(67)-\mathrm{C}(66)-\mathrm{H}(66 \mathrm{~A})$ & 110.9 \\
\hline $\mathrm{C}(56)-\mathrm{C}(57)-\mathrm{H}(57 \mathrm{~B})$ & 110.8 & $\mathrm{O}(4)-\mathrm{C}(66)-\mathrm{H}(66 \mathrm{~B})$ & 110.9 \\
\hline $\mathrm{H}(57 \mathrm{~A})-\mathrm{C}(57)-\mathrm{H}(57 \mathrm{~B})$ & 108.9 & $\mathrm{C}(67)-\mathrm{C}(66)-\mathrm{H}(66 \mathrm{~B})$ & 110.9 \\
\hline $\mathrm{C}(58)-\mathrm{O}(2)-\mathrm{C}(61)$ & $111(3)$ & $\mathrm{H}(66 \mathrm{~A})-\mathrm{C}(66)-\mathrm{H}(66 \mathrm{~B})$ & 108.9 \\
\hline $\mathrm{C}(58)-\mathrm{O}(2)-\mathrm{Mg}(1)$ & $130(5)$ & $C(66)-C(67)-C(68)$ & $101.8(18)$ \\
\hline $\mathrm{C}(61)-\mathrm{O}(2)-\mathrm{Mg}(1)$ & $108(3)$ & $\mathrm{C}(66)-\mathrm{C}(67)-\mathrm{H}(67 \mathrm{~A})$ & 111.4 \\
\hline $\mathrm{O}(2)-\mathrm{C}(58)-\mathrm{C}(59)$ & $102(3)$ & $\mathrm{C}(68)-\mathrm{C}(67)-\mathrm{H}(67 \mathrm{~A})$ & 111.4 \\
\hline $\mathrm{O}(2)-\mathrm{C}(58)-\mathrm{H}(58 \mathrm{~A})$ & 111.4 & $\mathrm{C}(66)-\mathrm{C}(67)-\mathrm{H}(67 \mathrm{~B})$ & 111.4 \\
\hline $\mathrm{C}(59)-\mathrm{C}(58)-\mathrm{H}(58 \mathrm{~A})$ & 111.4 & $\mathrm{C}(68)-\mathrm{C}(67)-\mathrm{H}(67 \mathrm{~B})$ & 111.4 \\
\hline $\mathrm{O}(2)-\mathrm{C}(58)-\mathrm{H}(58 \mathrm{~B})$ & 111.4 & $\mathrm{H}(67 \mathrm{~A})-\mathrm{C}(67)-\mathrm{H}(67 \mathrm{~B})$ & 109.3 \\
\hline $\mathrm{C}(59)-\mathrm{C}(58)-\mathrm{H}(58 \mathrm{~B})$ & 111.4 & $\mathrm{C}(69)-\mathrm{C}(68)-\mathrm{C}(67)$ & $104.6(19)$ \\
\hline $\mathrm{H}(58 \mathrm{~A})-\mathrm{C}(58)-\mathrm{H}(58 \mathrm{~B})$ & 109.3 & $\mathrm{C}(69)-\mathrm{C}(68)-\mathrm{H}(68 \mathrm{~A})$ & 110.8 \\
\hline$C(58)-C(59)-C(60)$ & $103(3)$ & $\mathrm{C}(67)-\mathrm{C}(68)-\mathrm{H}(68 \mathrm{~A})$ & 110.8 \\
\hline $\mathrm{C}(58)-\mathrm{C}(59)-\mathrm{H}(59 \mathrm{~A})$ & 111.3 & $\mathrm{C}(69)-\mathrm{C}(68)-\mathrm{H}(68 \mathrm{~B})$ & 110.8 \\
\hline $\mathrm{C}(60)-\mathrm{C}(59)-\mathrm{H}(59 \mathrm{~A})$ & 111.3 & $\mathrm{C}(67)-\mathrm{C}(68)-\mathrm{H}(68 \mathrm{~B})$ & 110.8 \\
\hline $\mathrm{C}(58)-\mathrm{C}(59)-\mathrm{H}(59 \mathrm{~B})$ & 111.3 & $H(68 A)-C(68)-H(68 B)$ & 108.9 \\
\hline $\mathrm{C}(60)-\mathrm{C}(59)-\mathrm{H}(59 \mathrm{~B})$ & 111.3 & $\mathrm{O}(4)-\mathrm{C}(69)-\mathrm{C}(68)$ & $105.1(18)$ \\
\hline H(59A)-C(59)-H(59B) & 109.2 & $\mathrm{O}(4)-\mathrm{C}(69)-\mathrm{H}(69 \mathrm{~A})$ & 110.7 \\
\hline $\mathrm{C}(61)-\mathrm{C}(60)-\mathrm{C}(59)$ & $103(3)$ & $\mathrm{C}(68)-\mathrm{C}(69)-\mathrm{H}(69 \mathrm{~A})$ & 110.7 \\
\hline$C(61)-C(60)-H(60 A)$ & 111.2 & $\mathrm{O}(4)-\mathrm{C}(69)-\mathrm{H}(69 \mathrm{~B})$ & 110.7 \\
\hline$C(59)-C(60)-H(60 A)$ & 111.2 & $\mathrm{C}(68)-\mathrm{C}(69)-\mathrm{H}(69 \mathrm{~B})$ & 110.7 \\
\hline $\mathrm{C}(61)-\mathrm{C}(60)-\mathrm{H}(60 \mathrm{~B})$ & 111.2 & H(69A)-C(69)-H(69B) & 108.8 \\
\hline $\mathrm{C}(59)-\mathrm{C}(60)-\mathrm{H}(60 \mathrm{~B})$ & 111.2 & $\mathrm{C}(70)-\mathrm{O}(5)-\mathrm{C}(73)$ & $108.9(13)$ \\
\hline $\mathrm{H}(60 \mathrm{~A})-\mathrm{C}(60)-\mathrm{H}(60 \mathrm{~B})$ & 109.1 & $\mathrm{C}(70)-\mathrm{O}(5)-\mathrm{Mg}(1)$ & $127.1(10)$ \\
\hline $\mathrm{O}(2)-\mathrm{C}(61)-\mathrm{C}(60)$ & $104(2)$ & $\mathrm{C}(73)-\mathrm{O}(5)-\mathrm{Mg}(1)$ & $123.8(10)$ \\
\hline $\mathrm{O}(2)-\mathrm{C}(61)-\mathrm{H}(61 \mathrm{~A})$ & 110.9 & $\mathrm{O}(5)-\mathrm{C}(70)-\mathrm{C}(71)$ & $102(2)$ \\
\hline$C(60)-C(61)-H(61 A)$ & 110.9 & $\mathrm{O}(5)-\mathrm{C}(70)-\mathrm{H}(70 \mathrm{~A})$ & 111.3 \\
\hline $\mathrm{O}(2)-\mathrm{C}(61)-\mathrm{H}(61 \mathrm{~B})$ & 110.9 & $\mathrm{C}(71)-\mathrm{C}(70)-\mathrm{H}(70 \mathrm{~A})$ & 111.3 \\
\hline $\mathrm{C}(60)-\mathrm{C}(61)-\mathrm{H}(61 \mathrm{~B})$ & 110.9 & $\mathrm{O}(5)-\mathrm{C}(70)-\mathrm{H}(70 \mathrm{~B})$ & 111.3 \\
\hline
\end{tabular}




\begin{tabular}{|c|c|c|c|}
\hline $\mathrm{C}(71)-\mathrm{C}(70)-\mathrm{H}(70 \mathrm{~B})$ & 111.3 & $\mathrm{C}\left(57^{\prime}\right)-\mathrm{C}\left(56^{\prime}\right)-\mathrm{C}\left(55^{\prime}\right)$ & $100(3)$ \\
\hline $\mathrm{H}(70 \mathrm{~A})-\mathrm{C}(70)-\mathrm{H}(70 \mathrm{~B})$ & 109.2 & $\mathrm{C}\left(57^{\prime}\right)-\mathrm{C}\left(56^{\prime}\right)-\mathrm{H}(56 \mathrm{C})$ & 111.7 \\
\hline $\mathrm{C}(70)-\mathrm{C}(71)-\mathrm{C}(72)$ & $100(3)$ & $\mathrm{C}\left(55^{\prime}\right)-\mathrm{C}\left(56^{\prime}\right)-\mathrm{H}(56 \mathrm{C})$ & 111.7 \\
\hline $\mathrm{C}(70)-\mathrm{C}(71)-\mathrm{H}(71 \mathrm{~A})$ & 111.7 & $\mathrm{C}\left(57^{\prime}\right)-\mathrm{C}\left(56^{\prime}\right)-\mathrm{H}(56 \mathrm{D})$ & 111.7 \\
\hline $\mathrm{C}(72)-\mathrm{C}(71)-\mathrm{H}(71 \mathrm{~A})$ & 111.7 & $\mathrm{C}\left(55^{\prime}\right)-\mathrm{C}\left(56^{\prime}\right)-\mathrm{H}(56 \mathrm{D})$ & 111.7 \\
\hline $\mathrm{C}(70)-\mathrm{C}(71)-\mathrm{H}(71 \mathrm{~B})$ & 111.7 & $\mathrm{H}(56 \mathrm{C})-\mathrm{C}\left(56^{\prime}\right)-\mathrm{H}(56 \mathrm{D})$ & 109.5 \\
\hline $\mathrm{C}(72)-\mathrm{C}(71)-\mathrm{H}(71 \mathrm{~B})$ & 111.7 & $\mathrm{O}\left(1^{\prime}\right)-\mathrm{C}\left(57^{\prime}\right)-\mathrm{C}\left(56^{\prime}\right)$ & $105(3)$ \\
\hline $\mathrm{H}(71 \mathrm{~A})-\mathrm{C}(71)-\mathrm{H}(71 \mathrm{~B})$ & 109.5 & $\mathrm{O}\left(1^{\prime}\right)-\mathrm{C}\left(57^{\prime}\right)-\mathrm{H}(57 \mathrm{C})$ & 110.7 \\
\hline $\mathrm{C}(73)-\mathrm{C}(72)-\mathrm{C}(71)$ & $100(2)$ & $\mathrm{C}\left(56^{\prime}\right)-\mathrm{C}\left(57^{\prime}\right)-\mathrm{H}(57 \mathrm{C})$ & 110.7 \\
\hline $\mathrm{C}(73)-\mathrm{C}(72)-\mathrm{H}(72 \mathrm{~A})$ & 111.7 & $\mathrm{O}\left(1^{\prime}\right)-\mathrm{C}\left(57^{\prime}\right)-\mathrm{H}(57 \mathrm{D})$ & 110.7 \\
\hline $\mathrm{C}(71)-\mathrm{C}(72)-\mathrm{H}(72 \mathrm{~A})$ & 111.7 & $\mathrm{C}\left(56^{\prime}\right)-\mathrm{C}\left(57^{\prime}\right)-\mathrm{H}(57 \mathrm{D})$ & 110.7 \\
\hline $\mathrm{C}(73)-\mathrm{C}(72)-\mathrm{H}(72 \mathrm{~B})$ & 111.7 & $\mathrm{H}(57 \mathrm{C})-\mathrm{C}\left(57^{\prime}\right)-\mathrm{H}(57 \mathrm{D})$ & 108.8 \\
\hline $\mathrm{C}(71)-\mathrm{C}(72)-\mathrm{H}(72 \mathrm{~B})$ & 111.7 & $\mathrm{C}\left(58^{\prime}\right)-\mathrm{O}\left(2^{\prime}\right)-\mathrm{C}\left(61^{\prime}\right)$ & $110.0(9)$ \\
\hline $\mathrm{H}(72 \mathrm{~A})-\mathrm{C}(72)-\mathrm{H}(72 \mathrm{~B})$ & 109.5 & $\mathrm{C}\left(58^{\prime}\right)-\mathrm{O}\left(2^{\prime}\right)-\mathrm{Mg}(1)$ & $122.6(11)$ \\
\hline $\mathrm{O}(5)-\mathrm{C}(73)-\mathrm{C}(72)$ & $104.1(15)$ & $\mathrm{C}\left(61^{\prime}\right)-\mathrm{O}\left(2^{\prime}\right)-\mathrm{Mg}(1)$ & $122.3(9)$ \\
\hline $\mathrm{O}(5)-\mathrm{C}(73)-\mathrm{H}(73 \mathrm{~A})$ & 110.9 & $\mathrm{O}\left(2^{\prime}\right)-\mathrm{C}\left(58^{\prime}\right)-\mathrm{C}\left(59^{\prime}\right)$ & $104.1(13)$ \\
\hline $\mathrm{C}(72)-\mathrm{C}(73)-\mathrm{H}(73 \mathrm{~A})$ & 110.9 & $\mathrm{O}\left(2^{\prime}\right)-\mathrm{C}\left(58^{\prime}\right)-\mathrm{H}(58 \mathrm{C})$ & 110.9 \\
\hline $\mathrm{O}(5)-\mathrm{C}(73)-\mathrm{H}(73 \mathrm{~B})$ & 110.9 & $\mathrm{C}\left(59^{\prime}\right)-\mathrm{C}\left(58^{\prime}\right)-\mathrm{H}(58 \mathrm{C})$ & 110.9 \\
\hline $\mathrm{C}(72)-\mathrm{C}(73)-\mathrm{H}(73 \mathrm{~B})$ & 110.9 & $\mathrm{O}\left(2^{\prime}\right)-\mathrm{C}\left(58^{\prime}\right)-\mathrm{H}(58 \mathrm{D})$ & 110.9 \\
\hline $\mathrm{H}(73 \mathrm{~A})-\mathrm{C}(73)-\mathrm{H}(73 \mathrm{~B})$ & 108.9 & $\mathrm{C}\left(59^{\prime}\right)-\mathrm{C}\left(58^{\prime}\right)-\mathrm{H}(58 \mathrm{D})$ & 110.9 \\
\hline $\mathrm{C}\left(57^{\prime}\right)-\mathrm{O}\left(1^{\prime}\right)-\mathrm{C}\left(54^{\prime}\right)$ & $106.9(16)$ & $\mathrm{H}(58 \mathrm{C})-\mathrm{C}\left(58^{\prime}\right)-\mathrm{H}(58 \mathrm{D})$ & 109.0 \\
\hline $\mathrm{C}\left(57^{\prime}\right)-\mathrm{O}\left(1^{\prime}\right)-\mathrm{Mg}(1)$ & $122.4(10)$ & $\mathrm{C}\left(58^{\prime}\right)-\mathrm{C}\left(59^{\prime}\right)-\mathrm{C}\left(60^{\prime}\right)$ & $103.2(13)$ \\
\hline $\mathrm{C}\left(54^{\prime}\right)-\mathrm{O}\left(1^{\prime}\right)-\mathrm{Mg}(1)$ & $129.6(10)$ & $\mathrm{C}\left(58^{\prime}\right)-\mathrm{C}\left(59^{\prime}\right)-\mathrm{H}(59 \mathrm{C})$ & 111.1 \\
\hline $\mathrm{O}\left(1^{\prime}\right)-\mathrm{C}\left(54^{\prime}\right)-\mathrm{C}\left(55^{\prime}\right)$ & $105.8(15)$ & $\mathrm{C}\left(60^{\prime}\right)-\mathrm{C}\left(59^{\prime}\right)-\mathrm{H}(59 \mathrm{C})$ & 111.1 \\
\hline $\mathrm{O}\left(1^{\prime}\right)-\mathrm{C}\left(54^{\prime}\right)-\mathrm{H}(54 \mathrm{C})$ & 110.6 & $\mathrm{C}\left(58^{\prime}\right)-\mathrm{C}\left(59^{\prime}\right)-\mathrm{H}(59 \mathrm{D})$ & 111.1 \\
\hline $\mathrm{C}\left(55^{\prime}\right)-\mathrm{C}\left(54^{\prime}\right)-\mathrm{H}(54 \mathrm{C})$ & 110.6 & $\mathrm{C}\left(60^{\prime}\right)-\mathrm{C}\left(59^{\prime}\right)-\mathrm{H}(59 \mathrm{D})$ & 111.1 \\
\hline $\mathrm{O}\left(1^{\prime}\right)-\mathrm{C}\left(54^{\prime}\right)-\mathrm{H}(54 \mathrm{D})$ & 110.6 & $\mathrm{H}(59 \mathrm{C})-\mathrm{C}\left(59^{\prime}\right)-\mathrm{H}(59 \mathrm{D})$ & 109.1 \\
\hline $\mathrm{C}\left(55^{\prime}\right)-\mathrm{C}\left(54^{\prime}\right)-\mathrm{H}(54 \mathrm{D})$ & 110.6 & $\mathrm{C}\left(61^{\prime}\right)-\mathrm{C}\left(60^{\prime}\right)-\mathrm{C}\left(59^{\prime}\right)$ & $102.7(11)$ \\
\hline $\mathrm{H}(54 \mathrm{C})-\mathrm{C}\left(54^{\prime}\right)-\mathrm{H}(54 \mathrm{D})$ & 108.7 & $\mathrm{C}\left(61^{\prime}\right)-\mathrm{C}\left(60^{\prime}\right)-\mathrm{H}(60 \mathrm{C})$ & 111.2 \\
\hline $\mathrm{C}\left(54^{\prime}\right)-\mathrm{C}\left(55^{\prime}\right)-\mathrm{C}\left(56^{\prime}\right)$ & $103.9(17)$ & $\mathrm{C}\left(59^{\prime}\right)-\mathrm{C}\left(60^{\prime}\right)-\mathrm{H}(60 \mathrm{C})$ & 111.2 \\
\hline $\mathrm{C}\left(54^{\prime}\right)-\mathrm{C}\left(55^{\prime}\right)-\mathrm{H}(55 \mathrm{C})$ & 111.0 & $\mathrm{C}\left(61^{\prime}\right)-\mathrm{C}\left(60^{\prime}\right)-\mathrm{H}(60 \mathrm{D})$ & 111.2 \\
\hline $\mathrm{C}\left(56^{\prime}\right)-\mathrm{C}\left(55^{\prime}\right)-\mathrm{H}(55 \mathrm{C})$ & 111.0 & $\mathrm{C}\left(59^{\prime}\right)-\mathrm{C}\left(60^{\prime}\right)-\mathrm{H}(60 \mathrm{D})$ & 111.2 \\
\hline $\mathrm{C}\left(54^{\prime}\right)-\mathrm{C}\left(55^{\prime}\right)-\mathrm{H}(55 \mathrm{D})$ & 111.0 & $\mathrm{H}(60 \mathrm{C})-\mathrm{C}\left(60^{\prime}\right)-\mathrm{H}(60 \mathrm{D})$ & 109.1 \\
\hline $\mathrm{C}\left(56^{\prime}\right)-\mathrm{C}\left(55^{\prime}\right)-\mathrm{H}(55 \mathrm{D})$ & 111.0 & $\mathrm{O}\left(2^{\prime}\right)-\mathrm{C}\left(61^{\prime}\right)-\mathrm{C}\left(60^{\prime}\right)$ & $105.5(10)$ \\
\hline $\mathrm{H}(55 \mathrm{C})-\mathrm{C}\left(55^{\prime}\right)-\mathrm{H}(55 \mathrm{D})$ & 109.0 & $\mathrm{O}\left(2^{\prime}\right)-\mathrm{C}\left(61^{\prime}\right)-\mathrm{H}(61 \mathrm{C})$ & 110.6 \\
\hline
\end{tabular}




\begin{tabular}{|c|c|c|c|}
\hline $\mathrm{C}\left(60^{\prime}\right)-\mathrm{C}\left(61^{\prime}\right)-\mathrm{H}(61 \mathrm{C})$ & 110.6 & $\mathrm{C}\left(68^{\prime}\right)-\mathrm{C}\left(69^{\prime}\right)-\mathrm{H}(69 \mathrm{D})$ & 110.8 \\
\hline $\mathrm{O}\left(2^{\prime}\right)-\mathrm{C}\left(61^{\prime}\right)-\mathrm{H}(61 \mathrm{D})$ & 110.6 & $\mathrm{H}(69 \mathrm{C})-\mathrm{C}\left(6^{\prime}\right)-\mathrm{H}(69 \mathrm{D})$ & 108.9 \\
\hline $\mathrm{C}\left(60^{\prime}\right)-\mathrm{C}\left(61^{\prime}\right)-\mathrm{H}(61 \mathrm{D})$ & 110.6 & $\mathrm{C}\left(73^{\prime}\right)-\mathrm{O}\left(5^{\prime}\right)-\mathrm{C}\left(70^{\prime}\right)$ & $107.0(14)$ \\
\hline $\mathrm{H}(61 \mathrm{C})-\mathrm{C}\left(61^{\prime}\right)-\mathrm{H}(61 \mathrm{D})$ & 108.8 & $\mathrm{C}\left(73^{\prime}\right)-\mathrm{O}\left(5^{\prime}\right)-\mathrm{Mg}(1)$ & $130.8(9)$ \\
\hline $\mathrm{C}\left(66^{\prime}\right)-\mathrm{O}\left(4^{\prime}\right)-\mathrm{C}\left(6^{\prime}\right)$ & $106.4(12)$ & $\mathrm{C}\left(70^{\prime}\right)-\mathrm{O}\left(5^{\prime}\right)-\mathrm{Mg}(1)$ & $121.7(10)$ \\
\hline $\mathrm{C}\left(66^{\prime}\right)-\mathrm{O}\left(4^{\prime}\right)-\mathrm{Mg}(1)$ & $128.9(14)$ & $\mathrm{O}\left(5^{\prime}\right)-\mathrm{C}\left(70^{\prime}\right)-\mathrm{C}\left(71^{\prime}\right)$ & $105(2)$ \\
\hline $\mathrm{C}\left(69^{\prime}\right)-\mathrm{O}\left(4^{\prime}\right)-\mathrm{Mg}(1)$ & $123.4(13)$ & $\mathrm{O}\left(5^{\prime}\right)-\mathrm{C}\left(70^{\prime}\right)-\mathrm{H}(70 \mathrm{C})$ & 110.8 \\
\hline $\mathrm{O}\left(4^{\prime}\right)-\mathrm{C}\left(66^{\prime}\right)-\mathrm{C}\left(67^{\prime}\right)$ & 109.1(14) & $\mathrm{C}\left(71^{\prime}\right)-\mathrm{C}\left(70^{\prime}\right)-\mathrm{H}(70 \mathrm{C})$ & 110.8 \\
\hline $\mathrm{O}\left(4^{\prime}\right)-\mathrm{C}\left(66^{\prime}\right)-\mathrm{H}(66 \mathrm{C})$ & 109.9 & $\mathrm{O}\left(5^{\prime}\right)-\mathrm{C}\left(70^{\prime}\right)-\mathrm{H}(70 \mathrm{D})$ & 110.8 \\
\hline $\mathrm{C}\left(67^{\prime}\right)-\mathrm{C}\left(66^{\prime}\right)-\mathrm{H}(66 \mathrm{C})$ & 109.9 & $\mathrm{C}\left(71^{\prime}\right)-\mathrm{C}\left(70^{\prime}\right)-\mathrm{H}(70 \mathrm{D})$ & 110.8 \\
\hline $\mathrm{O}\left(4^{\prime}\right)-\mathrm{C}\left(66^{\prime}\right)-\mathrm{H}(66 \mathrm{D})$ & 109.9 & $\mathrm{H}(70 \mathrm{C})-\mathrm{C}\left(70^{\prime}\right)-\mathrm{H}(70 \mathrm{D})$ & 108.9 \\
\hline $\mathrm{C}\left(67^{\prime}\right)-\mathrm{C}\left(66^{\prime}\right)-\mathrm{H}(66 \mathrm{D})$ & 109.9 & $\mathrm{C}\left(70^{\prime}\right)-\mathrm{C}\left(71^{\prime}\right)-\mathrm{C}\left(72^{\prime}\right)$ & 101(3) \\
\hline $\mathrm{H}(66 \mathrm{C})-\mathrm{C}\left(66^{\prime}\right)-\mathrm{H}(66 \mathrm{D})$ & 108.3 & $\mathrm{C}\left(70^{\prime}\right)-\mathrm{C}\left(71^{\prime}\right)-\mathrm{H}(71 \mathrm{C})$ & 111.6 \\
\hline $\mathrm{C}\left(66^{\prime}\right)-\mathrm{C}\left(67^{\prime}\right)-\mathrm{C}\left(68^{\prime}\right)$ & $107.3(13)$ & $\mathrm{C}\left(72^{\prime}\right)-\mathrm{C}\left(71^{\prime}\right)-\mathrm{H}(71 \mathrm{C})$ & 111.6 \\
\hline $\mathrm{C}\left(66^{\prime}\right)-\mathrm{C}\left(67^{\prime}\right)-\mathrm{H}(67 \mathrm{C})$ & 110.2 & $\mathrm{C}\left(70^{\prime}\right)-\mathrm{C}\left(71^{\prime}\right)-\mathrm{H}(71 \mathrm{D})$ & 111.6 \\
\hline $\mathrm{C}\left(68^{\prime}\right)-\mathrm{C}\left(67^{\prime}\right)-\mathrm{H}(67 \mathrm{C})$ & 110.2 & $\mathrm{C}\left(72^{\prime}\right)-\mathrm{C}\left(71^{\prime}\right)-\mathrm{H}(71 \mathrm{D})$ & 111.6 \\
\hline $\mathrm{C}\left(66^{\prime}\right)-\mathrm{C}\left(67^{\prime}\right)-\mathrm{H}(67 \mathrm{D})$ & 110.2 & $\mathrm{H}(71 \mathrm{C})-\mathrm{C}\left(71^{\prime}\right)-\mathrm{H}(71 \mathrm{D})$ & 109.4 \\
\hline $\mathrm{C}\left(68^{\prime}\right)-\mathrm{C}\left(67^{\prime}\right)-\mathrm{H}(67 \mathrm{D})$ & 110.2 & $\mathrm{C}\left(73^{\prime}\right)-\mathrm{C}\left(72^{\prime}\right)-\mathrm{C}\left(71^{\prime}\right)$ & $102(2)$ \\
\hline $\mathrm{H}(67 \mathrm{C})-\mathrm{C}\left(67^{\prime}\right)-\mathrm{H}(67 \mathrm{D})$ & 108.5 & $\mathrm{C}\left(73^{\prime}\right)-\mathrm{C}\left(72^{\prime}\right)-\mathrm{H}(72 \mathrm{C})$ & 111.3 \\
\hline $\mathrm{C}\left(69^{\prime}\right)-\mathrm{C}\left(68^{\prime}\right)-\mathrm{C}\left(67^{\prime}\right)$ & $102.2(15)$ & $\mathrm{C}\left(71^{\prime}\right)-\mathrm{C}\left(72^{\prime}\right)-\mathrm{H}(72 \mathrm{C})$ & 111.3 \\
\hline $\mathrm{C}\left(69^{\prime}\right)-\mathrm{C}\left(68^{\prime}\right)-\mathrm{H}(68 \mathrm{C})$ & 111.3 & $\mathrm{C}\left(73^{\prime}\right)-\mathrm{C}\left(72^{\prime}\right)-\mathrm{H}(72 \mathrm{D})$ & 111.3 \\
\hline $\mathrm{C}\left(67^{\prime}\right)-\mathrm{C}\left(68^{\prime}\right)-\mathrm{H}(68 \mathrm{C})$ & 111.3 & $\mathrm{C}\left(71^{\prime}\right)-\mathrm{C}\left(72^{\prime}\right)-\mathrm{H}(72 \mathrm{D})$ & 111.3 \\
\hline $\mathrm{C}\left(69^{\prime}\right)-\mathrm{C}\left(68^{\prime}\right)-\mathrm{H}(68 \mathrm{D})$ & 111.3 & $\mathrm{H}(72 \mathrm{C})-\mathrm{C}\left(72^{\prime}\right)-\mathrm{H}(72 \mathrm{D})$ & 109.2 \\
\hline $\mathrm{C}\left(67^{\prime}\right)-\mathrm{C}\left(68^{\prime}\right)-\mathrm{H}(68 \mathrm{D})$ & 111.3 & $\mathrm{O}\left(5^{\prime}\right)-\mathrm{C}\left(73^{\prime}\right)-\mathrm{C}\left(72^{\prime}\right)$ & $106.5(15)$ \\
\hline $\mathrm{H}(68 \mathrm{C})-\mathrm{C}\left(68^{\prime}\right)-\mathrm{H}(68 \mathrm{D})$ & 109.2 & $\mathrm{O}\left(5^{\prime}\right)-\mathrm{C}\left(73^{\prime}\right)-\mathrm{H}(73 \mathrm{C})$ & 110.4 \\
\hline $\mathrm{O}\left(4^{\prime}\right)-\mathrm{C}\left(69^{\prime}\right)-\mathrm{C}\left(68^{\prime}\right)$ & $104.7(15)$ & $\mathrm{C}\left(72^{\prime}\right)-\mathrm{C}\left(73^{\prime}\right)-\mathrm{H}(73 \mathrm{C})$ & 110.4 \\
\hline $\mathrm{O}\left(4^{\prime}\right)-\mathrm{C}\left(69^{\prime}\right)-\mathrm{H}(69 \mathrm{C})$ & 110.8 & $\mathrm{O}\left(5^{\prime}\right)-\mathrm{C}\left(73^{\prime}\right)-\mathrm{H}(73 \mathrm{D})$ & 110.4 \\
\hline $\mathrm{C}\left(68^{\prime}\right)-\mathrm{C}\left(69^{\prime}\right)-\mathrm{H}(69 \mathrm{C})$ & 110.8 & $\mathrm{C}\left(72^{\prime}\right)-\mathrm{C}\left(73^{\prime}\right)-\mathrm{H}(73 \mathrm{D})$ & 110.4 \\
\hline $\mathrm{O}\left(4^{\prime}\right)-\mathrm{C}\left(69^{\prime}\right)-\mathrm{H}(69 \mathrm{D})$ & 110.8 & $\mathrm{H}(73 \mathrm{C})-\mathrm{C}\left(73^{\prime}\right)-\mathrm{H}(73 \mathrm{D})$ & 108.6 \\
\hline
\end{tabular}


Table 4. Anisotropic displacement parameters $\left(\AA^{2} \times 10^{3}\right)$ for neipn21. The anisotropic displacement factor exponent takes the form: $-2 \pi^{2}\left[\mathrm{~h}^{2} \mathrm{a}^{* 2} \mathrm{U}_{11}+\ldots+2 \mathrm{hk} \mathrm{a}^{*} \mathrm{~b}^{*} \mathrm{U}_{12}\right]$

\begin{tabular}{|c|c|c|c|c|c|c|}
\hline & $\mathrm{U}_{11}$ & $\mathrm{U}_{22}$ & $\mathrm{U}_{33}$ & $\mathrm{U}_{23}$ & $\mathrm{U}_{13}$ & $\mathrm{U}_{12}$ \\
\hline $\mathrm{Fe} 1$ & $38(1)$ & $85(1)$ & $32(1)$ & $-3(1)$ & $-1(1)$ & $-1(1)$ \\
\hline N1 & $54(3)$ & $84(5)$ & $37(3)$ & $-1(3)$ & $1(3)$ & $6(3)$ \\
\hline $\mathrm{N} 2$ & $45(3)$ & 111(7) & $77(5)$ & $-4(5)$ & $-10(4)$ & $-15(4)$ \\
\hline N3 & $44(3)$ & $82(5)$ & $32(3)$ & $-2(3)$ & $-2(2)$ & $0(3)$ \\
\hline N4 & $63(4)$ & $55(4)$ & $42(3)$ & $-2(3)$ & $-7(3)$ & $-2(3)$ \\
\hline N5 & $45(3)$ & $88(5)$ & $35(3)$ & $-11(3)$ & $-3(2)$ & $-6(3)$ \\
\hline $\mathrm{C} 1$ & $52(4)$ & $77(6)$ & $30(3)$ & $1(3)$ & $3(3)$ & $-2(4)$ \\
\hline $\mathrm{C} 2$ & $59(5)$ & 119(10) & $30(4)$ & $-5(5)$ & $8(3)$ & $-14(6)$ \\
\hline $\mathrm{C} 3$ & $47(5)$ & $120(12)$ & $39(4)$ & $7(6)$ & $-5(4)$ & $-15(7)$ \\
\hline $\mathrm{C} 4$ & $55(5)$ & $133(14)$ & $37(4)$ & $2(7)$ & $0(4)$ & $-27(9)$ \\
\hline $\mathrm{C} 5$ & $73(7)$ & $150(17)$ & $46(6)$ & $-1(9)$ & $9(5)$ & $-29(11)$ \\
\hline C6 & $72(7)$ & $153(17)$ & $42(6)$ & $-6(9)$ & $19(5)$ & $-22(9)$ \\
\hline $\mathrm{C} 7$ & $66(6)$ & $127(14)$ & $50(7)$ & $-11(7)$ & $17(5)$ & $-2(8)$ \\
\hline $\mathrm{C} 8$ & $61(5)$ & $108(13)$ & $39(6)$ & $1(6)$ & $3(5)$ & $-8(8)$ \\
\hline $\mathrm{C} 1^{\prime}$ & $52(4)$ & $77(6)$ & $30(3)$ & $1(3)$ & $3(3)$ & $-2(4)$ \\
\hline $\mathrm{C} 2^{\prime}$ & $59(5)$ & 119(10) & $30(4)$ & $-5(5)$ & $8(3)$ & $-14(6)$ \\
\hline C3' & $47(5)$ & $120(12)$ & $39(4)$ & $7(6)$ & $-5(4)$ & $-15(7)$ \\
\hline C4' & $55(5)$ & 133(14) & $37(4)$ & $2(7)$ & $0(4)$ & $-27(9)$ \\
\hline $\mathrm{C} 5^{\prime}$ & $73(7)$ & 150(17) & $46(6)$ & $-1(9)$ & $9(5)$ & $-29(11)$ \\
\hline C6' & $72(7)$ & 153(17) & $42(6)$ & $-6(9)$ & $19(5)$ & $-22(9)$ \\
\hline $\mathrm{C}^{\prime}$ & $66(6)$ & 127(14) & $50(7)$ & $-11(7)$ & $17(5)$ & $-2(8)$ \\
\hline C $8 '$ & $61(5)$ & 108(13) & $39(6)$ & $1(6)$ & $3(5)$ & $-8(8)$ \\
\hline $\mathrm{C} 21$ & $38(3)$ & $98(7)$ & $40(4)$ & $-9(4)$ & $4(3)$ & $-11(3)$ \\
\hline $\mathrm{C} 22$ & $61(4)$ & $87(7)$ & $46(4)$ & $-3(4)$ & $-1(4)$ & $-17(4)$ \\
\hline $\mathrm{C} 23$ & $48(4)$ & $101(8)$ & $41(4)$ & $-11(5)$ & $3(3)$ & $-17(5)$ \\
\hline $\mathrm{C} 24$ & $41(4)$ & $117(9)$ & $32(4)$ & $-10(4)$ & $4(3)$ & $-4(4)$ \\
\hline $\mathrm{C} 25$ & $29(3)$ & $101(7)$ & $33(3)$ & $-7(4)$ & $-2(3)$ & $-1(3)$ \\
\hline $\mathrm{C} 26$ & $72(5)$ & $38(4)$ & $49(4)$ & $-1(3)$ & $-2(3)$ & $-7(3)$ \\
\hline $\mathrm{C} 27$ & $77(6)$ & $74(7)$ & $88(7)$ & $-4(5)$ & $-6(5)$ & $-14(5)$ \\
\hline $\mathrm{C} 28$ & $33(3)$ & $102(8)$ & $36(4)$ & $-15(4)$ & $-5(3)$ & $6(4)$ \\
\hline
\end{tabular}




\begin{tabular}{|c|c|c|c|c|c|c|}
\hline $\mathrm{C} 29$ & $41(4)$ & $108(8)$ & $46(4)$ & $-2(4)$ & $-10(3)$ & $0(4)$ \\
\hline $\mathrm{C} 30$ & $49(4)$ & $66(6)$ & $47(4)$ & $-6(4)$ & $-4(3)$ & $0(3)$ \\
\hline C31 & $51(4)$ & $92(7)$ & $48(5)$ & $-4(4)$ & $-1(3)$ & $0(4)$ \\
\hline C32 & $57(4)$ & $75(6)$ & $58(5)$ & $-7(5)$ & $4(4)$ & $4(4)$ \\
\hline C33 & $45(4)$ & $115(9)$ & $54(5)$ & $-8(5)$ & $-8(4)$ & $10(4)$ \\
\hline C34 & $58(5)$ & $96(8)$ & $53(5)$ & $-6(5)$ & $-14(4)$ & $5(4)$ \\
\hline C35 & $55(4)$ & $84(7)$ & $46(4)$ & $-2(4)$ & $-5(3)$ & $6(4)$ \\
\hline C36 & $48(4)$ & $125(9)$ & $49(5)$ & $-22(5)$ & $2(3)$ & $10(5)$ \\
\hline C37 & $66(6)$ & $139(11)$ & $55(5)$ & $-6(6)$ & $2(4)$ & $6(6)$ \\
\hline C38 & $73(6)$ & 164(13) & $58(6)$ & $-24(7)$ & $-3(5)$ & $-3(7)$ \\
\hline C39 & $54(4)$ & $100(8)$ & $52(5)$ & $-1(5)$ & $-7(4)$ & $4(5)$ \\
\hline $\mathrm{C} 40$ & $55(5)$ & 192(14) & $37(4)$ & $-11(6)$ & $-5(4)$ & $16(6)$ \\
\hline $\mathrm{C} 41$ & $70(6)$ & 134(11) & $85(8)$ & $41(8)$ & $3(5)$ & $15(6)$ \\
\hline $\mathrm{C} 42$ & $51(4)$ & $79(7)$ & $48(4)$ & $1(4)$ & $-11(3)$ & $-2(4)$ \\
\hline $\mathrm{C} 43$ & $57(4)$ & $71(6)$ & $56(5)$ & $-4(4)$ & $-6(4)$ & $-2(4)$ \\
\hline $\mathrm{C} 44$ & $95(7)$ & $57(6)$ & $81(7)$ & $0(5)$ & $-2(6)$ & $5(5)$ \\
\hline $\mathrm{C} 45$ & $129(10)$ & $62(8)$ & $112(10)$ & $17(7)$ & $28(8)$ & $-8(7)$ \\
\hline $\mathrm{C} 46$ & $97(8)$ & $103(10)$ & $69(7)$ & $19(6)$ & $13(6)$ & $-11(7)$ \\
\hline $\mathrm{C} 47$ & $66(5)$ & $111(9)$ & $43(4)$ & $9(5)$ & $5(4)$ & $-5(5)$ \\
\hline $\mathrm{C} 48$ & $66(5)$ & $61(6)$ & $47(4)$ & $-9(4)$ & $2(4)$ & 1(4) \\
\hline C49 & $75(6)$ & $67(7)$ & $75(6)$ & $-8(5)$ & $-20(5)$ & $5(5)$ \\
\hline C50 & $65(5)$ & $99(8)$ & $61(5)$ & $-15(5)$ & $-8(4)$ & $10(5)$ \\
\hline C51 & $87(6)$ & $108(9)$ & $32(4)$ & $0(5)$ & $8(4)$ & $-1(6)$ \\
\hline C52 & $77(6)$ & $138(11)$ & $44(5)$ & $-1(6)$ & $9(4)$ & $2(6)$ \\
\hline C53 & $74(7)$ & $207(17)$ & $61(7)$ & $-28(9)$ & $-9(5)$ & $-3(8)$ \\
\hline $\operatorname{Mg} 1$ & $51(1)$ & $96(2)$ & $31(1)$ & $1(1)$ & $-4(1)$ & $-1(1)$ \\
\hline $\mathrm{Br} 1$ & $71(1)$ & $90(1)$ & $54(1)$ & $14(1)$ & $-6(1)$ & $-7(1)$ \\
\hline $\mathrm{Cl1}$ & $71(1)$ & $90(1)$ & $54(1)$ & $14(1)$ & $-6(1)$ & $-7(1)$ \\
\hline $\mathrm{O} 3$ & $47(3)$ & $110(6)$ & $62(4)$ & $10(3)$ & $6(3)$ & $-2(3)$ \\
\hline C62 & $79(6)$ & $98(9)$ & $65(6)$ & $9(6)$ & $3(5)$ & $12(6)$ \\
\hline C63 & $58(5)$ & $137(12)$ & $74(7)$ & $-13(7)$ & $-3(5)$ & $17(6)$ \\
\hline C64 & $65(6)$ & $172(15)$ & $71(7)$ & $17(8)$ & $13(5)$ & $-3(7)$ \\
\hline C65 & $53(5)$ & $148(13)$ & $154(14)$ & $27(10)$ & $40(7)$ & $1(6)$ \\
\hline $\mathrm{O} 1$ & $66(3)$ & $77(4)$ & $37(3)$ & $-1(3)$ & $2(2)$ & $-2(3)$ \\
\hline C54 & $54(16)$ & $79(8)$ & $34(4)$ & $8(4)$ & $9(5)$ & $-9(7)$ \\
\hline
\end{tabular}




\begin{tabular}{|c|c|c|c|c|c|c|}
\hline C55 & $44(8)$ & $76(8)$ & $50(6)$ & $3(5)$ & 2(7) & $-3(8)$ \\
\hline C56 & $55(10)$ & $70(10)$ & $88(13)$ & 11(9) & $-6(8)$ & $-4(8)$ \\
\hline C57 & $81(17)$ & $70(9)$ & $62(7)$ & $-3(6)$ & $3(9)$ & $-6(10)$ \\
\hline $\mathrm{O} 2$ & $71(4)$ & $109(6)$ & $28(2)$ & $-5(3)$ & $-1(2)$ & $0(3)$ \\
\hline C58 & $82(7)$ & 117(19) & $38(4)$ & $-12(6)$ & $-15(4)$ & $6(8)$ \\
\hline C59 & $84(15)$ & 201(17) & $50(7)$ & $-27(9)$ & $-21(8)$ & $19(12)$ \\
\hline C60 & $112(10)$ & $160(30)$ & $36(5)$ & $-12(8)$ & $1(6)$ & $47(14)$ \\
\hline C61 & $83(7)$ & $86(16)$ & $32(4)$ & $-16(6)$ & $14(4)$ & $14(7)$ \\
\hline $\mathrm{O} 4$ & $77(5)$ & $42(12)$ & $37(4)$ & $11(6)$ & $-16(3)$ & $2(6)$ \\
\hline C66 & $66(7)$ & $78(14)$ & $52(6)$ & $0(10)$ & $-15(5)$ & $-17(10)$ \\
\hline C67 & $93(10)$ & $75(10)$ & $59(8)$ & $-4(8)$ & $-23(7)$ & $-20(9)$ \\
\hline C68 & $92(16)$ & $93(12)$ & $38(6)$ & $-1(6)$ & $4(9)$ & $-28(11)$ \\
\hline C69 & $74(17)$ & $88(9)$ & $50(6)$ & $-2(5)$ & 13(9) & $-7(14)$ \\
\hline $\mathrm{O} 5$ & $58(3)$ & $98(5)$ & $43(3)$ & $5(3)$ & $5(2)$ & $6(3)$ \\
\hline $\mathrm{C} 70$ & $77(7)$ & $98(10)$ & $69(7)$ & $10(7)$ & $10(8)$ & 20(7) \\
\hline C71 & $69(7)$ & 104(11) & $68(10)$ & $0(11)$ & $7(9)$ & 20(7) \\
\hline C72 & $56(6)$ & $99(13)$ & $68(10)$ & $-2(8)$ & $1(8)$ & $9(8)$ \\
\hline C73 & $43(4)$ & $110(11)$ & $58(12)$ & $11(12)$ & $11(5)$ & $-3(5)$ \\
\hline $\mathrm{O} 1^{\prime}$ & $66(3)$ & $77(4)$ & $37(3)$ & $-1(3)$ & $2(2)$ & $-2(3)$ \\
\hline C54' & $54(16)$ & $79(8)$ & $34(4)$ & $8(4)$ & $9(5)$ & $-9(7)$ \\
\hline C55' & $44(8)$ & $76(8)$ & $50(6)$ & $3(5)$ & $2(7)$ & $-3(8)$ \\
\hline C56' & $55(10)$ & $70(10)$ & $88(13)$ & $11(9)$ & $-6(8)$ & $-4(8)$ \\
\hline C57' & $81(17)$ & $70(9)$ & $62(7)$ & $-3(6)$ & $3(9)$ & $-6(10)$ \\
\hline $\mathrm{O} 2^{\prime}$ & $71(4)$ & $109(6)$ & $28(2)$ & $-5(3)$ & $-1(2)$ & $0(3)$ \\
\hline C58' & $82(7)$ & 117(19) & $38(4)$ & $-12(6)$ & $-15(4)$ & $6(8)$ \\
\hline C59' & $84(15)$ & 201(17) & $50(7)$ & $-27(9)$ & $-21(8)$ & $19(12)$ \\
\hline C60' & $112(10)$ & $160(30)$ & $36(5)$ & $-12(8)$ & $1(6)$ & $47(14)$ \\
\hline C61' & $83(7)$ & $86(16)$ & $32(4)$ & $-16(6)$ & $14(4)$ & $14(7)$ \\
\hline O4' & $77(5)$ & $42(12)$ & $37(4)$ & $11(6)$ & $-16(3)$ & $2(6)$ \\
\hline C66' & $66(7)$ & $78(14)$ & $52(6)$ & $0(10)$ & $-15(5)$ & $-17(10)$ \\
\hline C67' & $93(10)$ & $75(10)$ & $59(8)$ & $-4(8)$ & $-23(7)$ & $-20(9)$ \\
\hline C68' & $92(16)$ & $93(12)$ & $38(6)$ & $-1(6)$ & $4(9)$ & $-28(11)$ \\
\hline C69' & $74(17)$ & $88(9)$ & $50(6)$ & $-2(5)$ & $13(9)$ & $-7(14)$ \\
\hline O5' & $58(3)$ & $98(5)$ & $43(3)$ & $5(3)$ & $5(2)$ & $6(3)$ \\
\hline $\mathrm{C} 70^{\prime}$ & $77(7)$ & $98(10)$ & $69(7)$ & $10(7)$ & $10(8)$ & $20(7)$ \\
\hline
\end{tabular}




$\begin{array}{lllllll}\text { C71' } & 69(7) & 104(11) & 68(10) & 0(11) & 7(9) & 20(7) \\ \text { C72' }^{\prime} & 56(6) & 99(13) & 68(10) & -2(8) & 1(8) & 9(8) \\ \text { C73' } & 43(4) & 110(11) & 58(12) & 11(12) & 11(5) & -3(5)\end{array}$

Table 5. Hydrogen coordinates $\left(\mathrm{x} 10^{4}\right)$ and isotropic displacement parameters $\left(\AA^{2} \times 10^{3}\right)$ for neipn21.

\begin{tabular}{|c|c|c|c|c|}
\hline & $\mathrm{x}$ & $\mathrm{y}$ & $\mathrm{z}$ & $\mathrm{U}(\mathrm{eq})$ \\
\hline $\mathrm{H} 1 \mathrm{~A}$ & 9244 & 4888 & 5259 & 64 \\
\hline H1B & 8962 & 5998 & 5037 & 64 \\
\hline $\mathrm{H} 2 \mathrm{~A}$ & 8029 & 5083 & 4952 & 83 \\
\hline $\mathrm{H} 2 \mathrm{~B}$ & 8321 & 4028 & 5225 & 83 \\
\hline $\mathrm{H} 4$ & 8543 & 3998 & 6213 & 90 \\
\hline H5 & 8328 & 4604 & 7116 & 108 \\
\hline H6 & 7926 & 6415 & 7205 & 107 \\
\hline H7 & 7631 & 7334 & 6417 & 97 \\
\hline H8 & 7837 & 6686 & 5542 & 83 \\
\hline $\mathrm{H} 1 \mathrm{C}$ & 9274 & 4985 & 5252 & 64 \\
\hline H1D & 8898 & 5997 & 5028 & 64 \\
\hline $\mathrm{H} 2 \mathrm{C}$ & 8040 & 4922 & 5004 & 83 \\
\hline $\mathrm{H} 2 \mathrm{D}$ & 8409 & 3879 & 5192 & 83 \\
\hline H4' & 8439 & 3436 & 6139 & 90 \\
\hline H5' & 8415 & 3895 & 7096 & 108 \\
\hline H6' & 7931 & 5602 & 7309 & 107 \\
\hline $\mathrm{H} 7^{\prime}$ & 7688 & 6792 & 6609 & 97 \\
\hline H8' & 7813 & 6348 & 5687 & 83 \\
\hline H22 & 8024 & 1323 & 4223 & 77 \\
\hline H23 & 7125 & 2104 & 3953 & 76 \\
\hline $\mathrm{H} 24$ & 7067 & 3935 & 3759 & 76 \\
\hline $\mathrm{H} 27 \mathrm{~A}$ & 9590 & 1303 & 4718 & 119 \\
\hline $\mathrm{H} 27 \mathrm{~B}$ & 9390 & 1025 & 4096 & 119 \\
\hline $\mathrm{H} 27 \mathrm{C}$ & 8929 & 913 & 4596 & 119 \\
\hline $\mathrm{H} 29 \mathrm{~A}$ & 7632 & 6151 & 3109 & 98 \\
\hline H29B & 7549 & 6798 & 3680 & 98 \\
\hline
\end{tabular}




\begin{tabular}{|c|c|c|c|c|}
\hline $\mathrm{H} 29 \mathrm{C}$ & 7164 & 5736 & 3559 & 98 \\
\hline H32 & 11369 & 2869 & 3985 & 76 \\
\hline H33 & 11610 & 2487 & 4913 & 85 \\
\hline H34 & 10897 & 2489 & 5588 & 83 \\
\hline H36 & 9959 & 3695 & 3489 & 89 \\
\hline H37A & 10842 & 4655 & 3379 & 130 \\
\hline H37B & 10681 & 4034 & 2815 & 130 \\
\hline $\mathrm{H} 37 \mathrm{C}$ & 11180 & 3558 & 3218 & 130 \\
\hline H38A & 9933 & 1770 & 3427 & 148 \\
\hline H38B & 10612 & 1748 & 3245 & 148 \\
\hline $\mathrm{H} 38 \mathrm{C}$ & 10128 & 2270 & 2841 & 148 \\
\hline H39 & 9376 & 3132 & 5421 & 82 \\
\hline $\mathrm{H} 40 \mathrm{~A}$ & 9956 & 4542 & 5800 & 142 \\
\hline $\mathrm{H} 40 \mathrm{~B}$ & 10329 & 3675 & 6150 & 142 \\
\hline $\mathrm{H} 40 \mathrm{C}$ & 9647 & 3866 & 6287 & 142 \\
\hline $\mathrm{H} 41 \mathrm{~A}$ & 9571 & 1301 & 5612 & 144 \\
\hline H41B & 9465 & 1907 & 6191 & 144 \\
\hline $\mathrm{H} 41 \mathrm{C}$ & 10121 & 1617 & 5996 & 144 \\
\hline H44 & 8792 & 9385 & 3925 & 93 \\
\hline H45 & 9142 & 9475 & 3005 & 121 \\
\hline H46 & 9246 & 7905 & 2503 & 108 \\
\hline H48 & 8303 & 6965 & 4620 & 70 \\
\hline $\mathrm{H} 49 \mathrm{~A}$ & 8907 & 8960 & 4890 & 109 \\
\hline H49B & 9233 & 7808 & 4902 & 109 \\
\hline $\mathrm{H} 49 \mathrm{C}$ & 8706 & 8050 & 5325 & 109 \\
\hline H50A & 7934 & 9182 & 4436 & 113 \\
\hline H50B & 7691 & 8441 & 4932 & 113 \\
\hline $\mathrm{H} 50 \mathrm{C}$ & 7540 & 8137 & 4302 & 113 \\
\hline H51 & 8884 & 5176 & 2943 & 91 \\
\hline $\mathrm{H} 52 \mathrm{~A}$ & 9801 & 6179 & 2318 & 130 \\
\hline H52B & 9710 & 4903 & 2410 & 130 \\
\hline $\mathrm{H} 52 \mathrm{C}$ & 9908 & 5658 & 2919 & 130 \\
\hline H53A & 8799 & 6495 & 1975 & 172 \\
\hline H53B & 8246 & 5999 & 2300 & 172 \\
\hline $\mathrm{H} 53 \mathrm{C}$ & 8700 & 5209 & 1992 & 172 \\
\hline
\end{tabular}




\begin{tabular}{|c|c|c|c|c|}
\hline H62A & 5024 & 3289 & 5689 & 97 \\
\hline H62B & 5378 & 3653 & 6237 & 97 \\
\hline H63A & 4213 & 3472 & 6178 & 108 \\
\hline H63B & 4578 & 3566 & 6750 & 108 \\
\hline H64A & 4377 & 1863 & 6935 & 123 \\
\hline H64B & 4014 & 1768 & 6364 & 123 \\
\hline H65A & 4696 & 952 & 5975 & 142 \\
\hline H65B & 4982 & 813 & 6580 & 142 \\
\hline H54A & 5756 & 3052 & 4998 & 67 \\
\hline H54B & 6425 & 2851 & 4798 & 67 \\
\hline H55A & 5864 & 4860 & 5002 & 68 \\
\hline H55B & 6383 & 4607 & 4563 & 68 \\
\hline H56A & 7104 & 4625 & 5254 & 85 \\
\hline H56B & 6679 & 5606 & 5449 & 85 \\
\hline H57A & 6845 & 4109 & 6130 & 85 \\
\hline H57B & 6177 & 4522 & 6049 & 85 \\
\hline H58A & 7187 & 3273 & 6859 & 94 \\
\hline H58B & 7275 & 2019 & 7036 & 94 \\
\hline H59A & 6658 & 3654 & 7649 & 134 \\
\hline H59B & 7170 & 2865 & 7881 & 134 \\
\hline H60A & 6550 & 1339 & 7854 & 123 \\
\hline H60B & 6104 & 2269 & 8068 & 123 \\
\hline H61A & 5913 & 1192 & 7145 & 81 \\
\hline H61B & 5659 & 2401 & 7238 & 81 \\
\hline H66A & 5255 & 1882 & 5061 & 79 \\
\hline H66B & 5206 & 594 & 5169 & 79 \\
\hline H67A & 5664 & 1629 & 4204 & 91 \\
\hline H67B & 5150 & 723 & 4227 & 91 \\
\hline H68A & 5802 & -654 & 4421 & 89 \\
\hline H68B & 6232 & 105 & 4056 & 89 \\
\hline H69A & 6396 & -369 & 5135 & 85 \\
\hline H69B & 6758 & 540 & 4796 & 85 \\
\hline $\mathrm{H} 70 \mathrm{~A}$ & 7305 & -289 & 6007 & 97 \\
\hline H70B & 7606 & 457 & 6480 & 97 \\
\hline H71A & 7980 & 279 & 5343 & 96 \\
\hline
\end{tabular}




\begin{tabular}{|c|c|c|c|c|}
\hline H71B & 8387 & 100 & 5887 & 96 \\
\hline $\mathrm{H} 72 \mathrm{~A}$ & 8287 & 1952 & 6142 & 89 \\
\hline H72B & 8443 & 1983 & 5487 & 89 \\
\hline $\mathrm{H} 73 \mathrm{~A}$ & 7483 & 2867 & 5811 & 84 \\
\hline H73B & 7478 & 2188 & 5238 & 84 \\
\hline H54C & 5937 & 3317 & 4889 & 67 \\
\hline H54D & 6608 & 2910 & 4827 & 67 \\
\hline H55C & 6316 & 4944 & 4713 & 68 \\
\hline H55D & 6968 & 4582 & 4905 & 68 \\
\hline H56C & 6678 & 5646 & 5661 & 85 \\
\hline H56D & 6007 & 5208 & 5633 & 85 \\
\hline $\mathrm{H} 57 \mathrm{C}$ & 7024 & 4015 & 5965 & 85 \\
\hline H57D & 6415 & 4131 & 6304 & 85 \\
\hline H58C & 7289 & 2869 & 6777 & 94 \\
\hline H58D & 7201 & 1702 & 7068 & 94 \\
\hline H59C & 6940 & 3775 & 7527 & 134 \\
\hline H59D & 7273 & 2778 & 7827 & 134 \\
\hline H60C & 6399 & 1808 & 7945 & 123 \\
\hline H60D & 6170 & 3032 & 8044 & 123 \\
\hline H61C & 5736 & 1831 & 7253 & 81 \\
\hline H61D & 5758 & 3133 & 7200 & 81 \\
\hline H66C & 5252 & 1182 & 5010 & 79 \\
\hline H66D & 5325 & -5 & 5276 & 79 \\
\hline H67C & 5370 & 471 & 4208 & 91 \\
\hline H67D & 5515 & -690 & 4480 & 91 \\
\hline H68C & 6429 & -386 & 4146 & 89 \\
\hline H68D & 6334 & 913 & 4129 & 89 \\
\hline H69C & 6647 & -384 & 5070 & 85 \\
\hline H69D & 6900 & 798 & 4911 & 85 \\
\hline H70C & 7355 & -272 & 5797 & 97 \\
\hline H70D & 7328 & 96 & 6439 & 97 \\
\hline $\mathrm{H} 71 \mathrm{C}$ & 8338 & -82 & 6007 & 96 \\
\hline H71D & 8220 & 988 & 6380 & 96 \\
\hline $\mathrm{H} 72 \mathrm{C}$ & 8487 & 1729 & 5524 & 89 \\
\hline H72D & 8111 & 832 & 5187 & 89 \\
\hline
\end{tabular}


H73C

H73D
7678

7426
2654

2151
5778

5210

84 
Table 6. Torsion angles $\left[{ }^{\circ}\right]$ for neipn 21.

\begin{tabular}{|c|c|c|c|}
\hline N1-Fe1-N3-C21 & $96.1(16)$ & Fe1-N3-C21-C22 & $174.5(6)$ \\
\hline N5-Fe1-N3-C21 & $174.2(6)$ & C25-N3-C21-C26 & $178.9(7)$ \\
\hline N4-Fe1-N3-C21 & $5.9(5)$ & Fe1-N3-C21-C26 & $-5.7(8)$ \\
\hline C1'-Fe1-N3-C21 & $-89.9(6)$ & N3-C21-C22-C23 & $-1.2(12)$ \\
\hline C1-Fe1-N3-C21 & $-89.9(6)$ & C26-C21-C22-C23 & 179.1(8) \\
\hline N1-Fe1-N3-C25 & $-88.5(17)$ & C21-C22-C23-C24 & $1.3(12)$ \\
\hline N5-Fe1-N3-C25 & $-10.3(5)$ & $\mathrm{C} 22-\mathrm{C} 23-\mathrm{C} 24-\mathrm{C} 25$ & $0.8(12)$ \\
\hline N4-Fe1-N3-C25 & $-178.6(6)$ & C21-N3-C25-C28 & $-175.7(7)$ \\
\hline C1'-Fe1-N3-C25 & $85.6(6)$ & Fe1-N3-C25-C28 & $8.9(8)$ \\
\hline C1-Fe1-N3-C25 & $85.6(6)$ & $\mathrm{C} 21-\mathrm{N} 3-\mathrm{C} 25-\mathrm{C} 24$ & $2.8(10)$ \\
\hline $\mathrm{Fe} 1-\mathrm{C} 1-\mathrm{C} 2-\mathrm{C} 3$ & $-174.9(11)$ & Fe1-N3-C25-C24 & $-172.6(5)$ \\
\hline $\mathrm{C} 1-\mathrm{C} 2-\mathrm{C} 3-\mathrm{C} 8$ & $86(2)$ & $\mathrm{C} 23-\mathrm{C} 24-\mathrm{C} 25-\mathrm{C} 28$ & $175.4(8)$ \\
\hline C1-C2-C3-C4 & $-89(2)$ & $\mathrm{C} 23-\mathrm{C} 24-\mathrm{C} 25-\mathrm{N} 3$ & $-2.8(10)$ \\
\hline C8-C3-C4-C5 & $3(2)$ & C30-N4-C26-C21 & $-179.0(7)$ \\
\hline $\mathrm{C} 2-\mathrm{C} 3-\mathrm{C} 4-\mathrm{C} 5$ & $178.6(13)$ & Fe1-N4-C26-C21 & $3.1(8)$ \\
\hline C3-C4-C5-C6 & $-4(2)$ & C30-N4-C26-C27 & $-6.1(12)$ \\
\hline C4-C5-C6-C7 & $5(2)$ & Fe1-N4-C26-C27 & $176.0(8)$ \\
\hline C5-C6-C7-C8 & $-4(2)$ & N3-C21-C26-N4 & $1.4(9)$ \\
\hline C6-C7-C8-C3 & $3(2)$ & $\mathrm{C} 22-\mathrm{C} 21-\mathrm{C} 26-\mathrm{N} 4$ & $-178.9(8)$ \\
\hline C4-C3-C8-C7 & $-3(2)$ & N3-C21-C26-C27 & $-171.8(8)$ \\
\hline C2-C3-C8-C7 & $-177.7(15)$ & $\mathrm{C} 22-\mathrm{C} 21-\mathrm{C} 26-\mathrm{C} 27$ & $7.9(14)$ \\
\hline $\mathrm{Fe} 1-\mathrm{C} 1{ }^{\prime}-\mathrm{C} 2 '-\mathrm{C} 3{ }^{\prime}$ & $177(4)$ & C42-N5-C28-C25 & $169.7(7)$ \\
\hline C1'-C2'-C3'-C8' & $85(9)$ & Fe1-N5-C28-C25 & $-7.6(8)$ \\
\hline C1'-C2'-C3'-C4' & $-105(8)$ & C42-N5-C28-C29 & $-4.1(11)$ \\
\hline C8'-C3'-C4'-C5' & $-17(12)$ & Fe1-N5-C28-C29 & $178.7(6)$ \\
\hline C2'-C3'-C4'-C5' & $173(6)$ & N3-C25-C28-N5 & $-0.5(9)$ \\
\hline C3'-C4'-C5'-C6' & $12(11)$ & $\mathrm{C} 24-\mathrm{C} 25-\mathrm{C} 28-\mathrm{N} 5$ & $-178.7(7)$ \\
\hline C4'-C5'-C6'-C7' & $-4(10)$ & N3-C25-C28-C29 & $173.3(7)$ \\
\hline C5'-C6'-C7'-C8' & $1(11)$ & $\mathrm{C} 24-\mathrm{C} 25-\mathrm{C} 28-\mathrm{C} 29$ & $-4.9(13)$ \\
\hline C6'-C7'-C8'-C3' & $-5(12)$ & C26-N4-C30-C35 & $-74.5(11)$ \\
\hline C4'-C3'-C8'-C7' & $12(12)$ & Fe1-N4-C30-C35 & $103.0(9)$ \\
\hline C2'-C3'-C8'-C7' & $-177(6)$ & C26-N4-C30-C31 & $105.0(9)$ \\
\hline $\mathrm{C} 25-\mathrm{N} 3-\mathrm{C} 21-\mathrm{C} 22$ & $-0.9(11)$ & Fe1-N4-C30-C31 & $-77.5(10)$ \\
\hline
\end{tabular}




\begin{tabular}{|c|c|c|c|}
\hline C35-C30-C31-C32 & $0.9(14)$ & N5-C42-C47-C46 & $179.8(8)$ \\
\hline N4-C30-C31-C32 & $-178.7(9)$ & C43-C42-C47-C51 & $-178.5(9)$ \\
\hline C35-C30-C31-C36 & $176.5(10)$ & N5-C42-C47-C51 & $-0.4(12)$ \\
\hline N4-C30-C31-C36 & $-3.1(14)$ & $\mathrm{C} 45-\mathrm{C} 46-\mathrm{C} 47-\mathrm{C} 42$ & $-0.7(17)$ \\
\hline C30-C31-C32-C33 & $-0.2(15)$ & C45-C46-C47-C51 & $179.6(12)$ \\
\hline C36-C31-C32-C33 & $-175.9(10)$ & $\mathrm{C} 42-\mathrm{C} 43-\mathrm{C} 48-\mathrm{C} 50$ & $-120.9(9)$ \\
\hline C31-C32-C33-C34 & $0.1(17)$ & C44-C43-C48-C50 & $58.1(11)$ \\
\hline C32-C33-C34-C35 & $-0.8(18)$ & C42-C43-C48-C49 & 119.1(9) \\
\hline C33-C34-C35-C30 & $1.4(16)$ & C44-C43-C48-C49 & $-61.9(11)$ \\
\hline C33-C34-C35-C39 & $-176.5(11)$ & C42-C47-C51-C53 & $120.7(11)$ \\
\hline N4-C30-C35-C34 & 178.1(9) & C46-C47-C51-C53 & $-59.5(13)$ \\
\hline C31-C30-C35-C34 & $-1.5(15)$ & C42-C47-C51-C52 & $-115.6(10)$ \\
\hline N4-C30-C35-C39 & $-4.2(15)$ & C46-C47-C51-C52 & $64.2(13)$ \\
\hline C31-C30-C35-C39 & $176.3(10)$ & C65-O3-C62-C63 & $19.6(13)$ \\
\hline C32-C31-C36-C37 & $-41.3(14)$ & Mg1-O3-C62-C63 & $-157.5(7)$ \\
\hline C30-C31-C36-C37 & $143.0(10)$ & O3-C62-C63-C64 & $-12.1(12)$ \\
\hline C32-C31-C36-C38 & $82.7(11)$ & C62-C63-C64-C65 & $0.1(15)$ \\
\hline C30-C31-C36-C38 & $-92.9(11)$ & C63-C64-C65-O3 & $12.4(17)$ \\
\hline C34-C35-C39-C40 & $61.7(13)$ & C62-O3-C65-C64 & $-20.3(16)$ \\
\hline C30-C35-C39-C40 & $-116.1(11)$ & Mg1-O3-C65-C64 & $156.6(9)$ \\
\hline C34-C35-C39-C41 & $-61.8(13)$ & C57-O1-C54-C55 & $1(4)$ \\
\hline C30-C35-C39-C41 & $120.4(11)$ & Mg1-O1-C54-C55 & $172.4(9)$ \\
\hline C28-N5-C42-C43 & $88.6(9)$ & O1-C54-C55-C56 & $24.0(18)$ \\
\hline Fe1-N5-C42-C43 & $-94.5(9)$ & C54-C55-C56-C57 & $-40(3)$ \\
\hline C28-N5-C42-C47 & $-89.4(9)$ & C54-O1-C57-C56 & $-26(5)$ \\
\hline Fe1-N5-C42-C47 & $87.6(8)$ & Mg1-O1-C57-C56 & $163.2(15)$ \\
\hline C47-C42-C43-C44 & $-2.8(13)$ & C55-C56-C57-O1 & $40(5)$ \\
\hline N5-C42-C43-C44 & $179.4(8)$ & C61-O2-C58-C59 & $-28(9)$ \\
\hline C47-C42-C43-C48 & $176.1(8)$ & Mg1-O2-C58-C59 & $-166(6)$ \\
\hline N5-C42-C43-C48 & $-1.7(12)$ & O2-C58-C59-C60 & $41(8)$ \\
\hline C42-C43-C44-C45 & $2.5(16)$ & C58-C59-C60-C61 & $-40(8)$ \\
\hline C48-C43-C44-C45 & $-176.4(11)$ & C58-O2-C61-C60 & $3(10)$ \\
\hline C43-C44-C45-C46 & $-1(2)$ & Mg1-O2-C61-C60 & $150(5)$ \\
\hline C44-C45-C46-C47 & $0(2)$ & C59-C60-C61-O2 & $22(8)$ \\
\hline C43-C42-C47-C46 & $1.8(13)$ & C69-O4-C66-C67 & $-38(4)$ \\
\hline
\end{tabular}




\begin{tabular}{|c|c|c|c|}
\hline Mg1-O4-C66-C67 & $173(2)$ & Mg1-O2'-C58'-C59' & $-175.9(16)$ \\
\hline O4-C66-C67-C68 & $43(3)$ & O2'-C58'-C59'-C60' & $35(2)$ \\
\hline C66-C67-C68-C69 & $-31(4)$ & C58'-C59'-C60'-C61' & $-37(2)$ \\
\hline C66-O4-C69-C68 & $17(5)$ & C58'-O2'-C61'-C60' & $-3(2)$ \\
\hline Mg1-O4-C69-C68 & $167(3)$ & Mg1-O2'-C61'-C60' & $152.2(11)$ \\
\hline C67-C68-C69-O4 & $9(5)$ & C59'-C60'-C61'-O2' & $25(2)$ \\
\hline C73-O5-C70-C71 & $-22(8)$ & C69'-O4'-C66'-C67' & $-14(3)$ \\
\hline Mg1-O5-C70-C71 & $164(2)$ & Mg1-O4'-C66'-C67' & $178.8(14)$ \\
\hline O5-C70-C71-C72 & $43(6)$ & O4'-C66'-C67'-C68' & $-6(2)$ \\
\hline C70-C71-C72-C73 & $-48(5)$ & C66'-C67'-C68'-C69' & $23(3)$ \\
\hline C70-O5-C73-C72 & $-9(7)$ & C66'-O4'-C69'-C68' & $29(3)$ \\
\hline Mg1-O5-C73-C72 & $166(2)$ & Mg1-O4'-C69'-C68' & $-163.2(17)$ \\
\hline C71-C72-C73-O5 & $35(5)$ & C67'-C68'-C69'-O4' & $-31(3)$ \\
\hline C57'-O1'-C54'-C55' & $-3(6)$ & C73'-O5'-C70'-C71' & $23(8)$ \\
\hline Mg1-O1'-C54'-C55' & $-171.2(13)$ & Mg1-O5'-C70'-C71' & $-164(3)$ \\
\hline O1'-C54'-C55'-C56' & $-22(3)$ & O5'-C70'-C71'-C72' & $-40(7)$ \\
\hline C54'-C55'-C56'-C57' & $38(5)$ & C70'-C71'-C72'-C73' & $41(5)$ \\
\hline C54'-O1'-C57'-C56' & $28(8)$ & C70'-O5'-C73'-C72' & $4(7)$ \\
\hline Mg1-O1'-C57'-C56' & $-162(3)$ & Mg1-O5'-C73'-C72' & $-168.2(19)$ \\
\hline C55'-C56'-C57'-O1' & $-41(7)$ & C71'-C72'-C73'-O5' & $-28(5)$ \\
\hline C61'-O2'-C58'-C59' & $-21(2)$ & & \\
\hline
\end{tabular}


REFERENCE NUMBER: neipn25

CRYSTAL STRUCTURE REPORT

$\mathrm{C}_{64} \mathrm{H}_{96} \mathrm{Br}_{0.69} \mathrm{Cl}_{0.31} \mathrm{Fe} \mathrm{Mg} \mathrm{O} 8$

or

$\left[\mathrm{MgBr}_{0.69} \mathrm{Cl}_{0.31}(\mathrm{THF})_{5}\right]\left[\mathrm{Fe}\left(\eta^{2} \text {-styrene }\right)_{3}\left(\kappa^{1}-\mathrm{CH}\left(\mathrm{CH}_{3}\right) \mathrm{Ph}\right)\right] \cdot 3 \mathrm{THF}$

Report prepared for:

Dr. P. Neate, Prof. M. Neidig

July 30, 2018
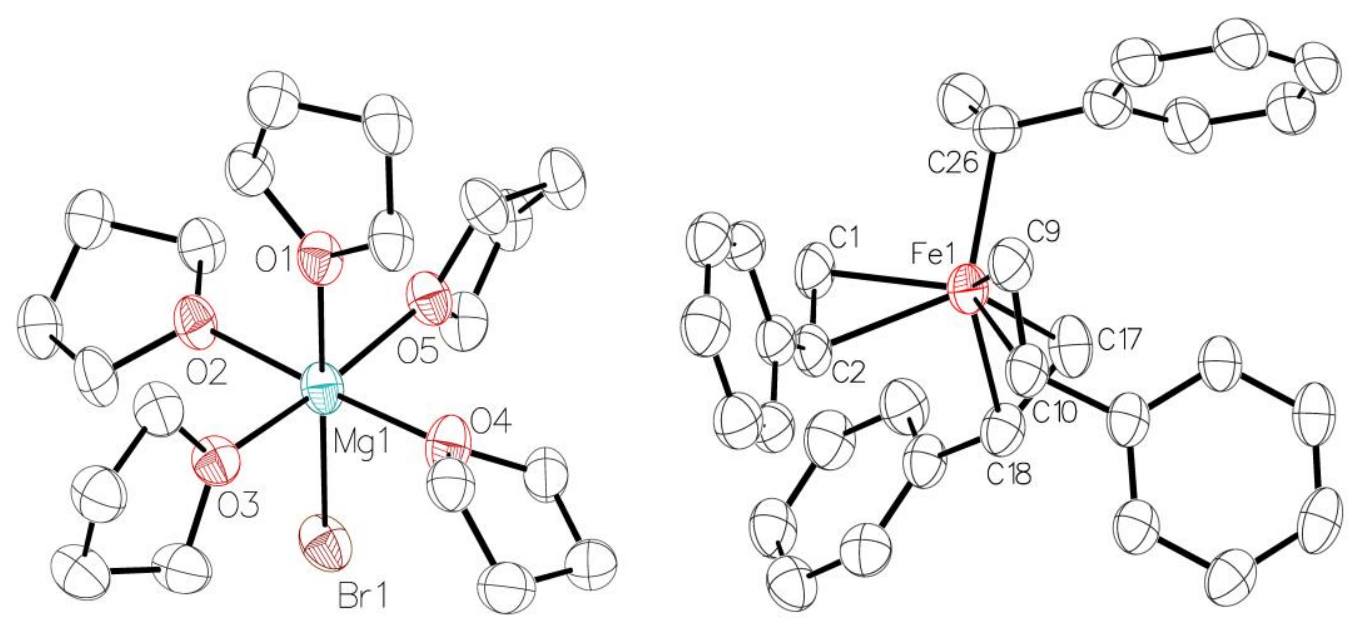

William W. Brennessel

X-ray Crystallographic Facility

Department of Chemistry, University of Rochester

120 Trustee Road

Rochester, NY 14627 


\section{Data collection}

A crystal $\left(0.215 \times 0.108 \times 0.048 \mathrm{~mm}^{3}\right)$ was placed onto a thin glass optical fiber or a nylon loop and mounted on a XtaLab Synergy-S Dualflex diffractometer equipped with a HyPix-6000HE HPC area detector for data collection at 100.00(10) K. A preliminary set of cell constants and an orientation matrix were calculated from a small sampling of reflections. ${ }^{1}$ A short pre-experiment was run, from which an optimal data collection strategy was determined. The full data collection was carried out using a PhotonJet $(\mathrm{Cu}) \mathrm{X}$-ray Source with frame times of 0.58 and 2.33 seconds and a detector distance of $31.2 \mathrm{~mm}$. Series of frames were collected in $0.50^{\circ}$ steps in $\omega$ at different $2 \theta, \kappa$, and $\phi$ settings. After the intensity data were corrected for absorption, the final cell constants were calculated from the xyz centroids of 23238 strong reflections from the actual data collection after integration. ${ }^{1}$ See Table 1 for additional crystal and refinement information.

\section{Structure solution and refinement}

The structure was solved using ShelXT ${ }^{2}$ and refined using ShelXL. ${ }^{3}$ The space group $P-1$ was determined based on intensity statistics. Most or all non-hydrogen atoms were assigned from the solution. Full-matrix least squares / difference Fourier cycles were performed which located any remaining non-hydrogen atoms. All non-hydrogen atoms were refined with anisotropic displacement parameters. All hydrogen atoms were placed in ideal positions and refined as riding atoms with relative isotropic displacement parameters. The final full matrix least squares refinement converged to $R 1=0.0564\left(F^{2}, I>2 \sigma(I)\right)$ and $w R 2=0.1662\left(F^{2}\right.$, all data).

\section{Structure description}

The structure is the one suggested. The asymmetric unit contains one cationic $\mathrm{Mg}$ complex, one anionic $\mathrm{Fe}$ complex, and three cocrystallized THF solvent molecules, all in general positions. The $\mathrm{CH}(\mathrm{Me}) \mathrm{Ph}$ ligand is modeled as disordered over two positions (0.69:0.31). Several THF ligand and cocrystallized solvent molecules are modeled as disordered over two positions: O3/C41-C44, 0.87:0.13, O4/C45-C48, 0.82:0.18, O7/C57-C60, 0.60:0.40, O8/C61-C64, 0.53:0.47. The halido ligand is modeled as a site disorder of $\mathrm{Br}: \mathrm{Cl}, 0.69: 0.31$; positional and anisotropic displacement parameters were respectively constrained to be equivalent between the two atom types.

Structure manipulation and figure generation were performed using Olex $2 .{ }^{4}$ Unless noted otherwise all structural diagrams containing thermal displacement ellipsoids are drawn at the $50 \%$ probability level.

Data collection, structure solution, and structure refinement were conducted at the X-ray Crystallographic Facility, B04 Hutchison Hall, Department of Chemistry, University of Rochester. The instrument was purchased with funding from NSF MRI program grant CHE-1725028. All publications arising from this report MUST either 1) include William W. Brennessel as a coauthor or 2) acknowledge William W. Brennessel and the X-ray Crystallographic Facility of the Department of Chemistry at the University of Rochester. 
1 CrysAlisPro, version 171.39.46; Rigaku Corporation: Oxford, UK, 2018.

2 Sheldrick, G. M. SHELXT, version 2018/2; Acta. Crystallogr. 2015, A71, 3-8.

3 Sheldrick, G. M. SHELXL, version 2018/3; Acta. Crystallogr. 2015, C71, 3-8.

4 Dolomanov, O. V.; Bourhis, L. J.; Gildea, R. J.; Howard, J. A. K.; Puschmann, H. Olex2, version 1.2-ac3; J. Appl. Cryst. 2009, 42, 339-341.

Some equations of interest:

$$
\begin{gathered}
R_{\mathrm{int}}=\Sigma\left|F_{\mathrm{o}}^{2}-\left\langle F_{\mathrm{o}}^{2}\right\rangle\right| / \Sigma\left|F_{\mathrm{o}}{ }^{2}\right| \\
R 1=\Sigma\left\|F_{\mathrm{o}}|-| F_{\mathrm{c}}\right\| / \Sigma\left|F_{\mathrm{o}}\right| \\
w R 2=\left[\Sigma\left[w\left(F_{\mathrm{o}}{ }^{2} F_{\mathrm{c}}{ }^{2}\right)^{2}\right] / \Sigma\left[w\left(F_{\mathrm{o}}{ }^{2}\right)^{2}\right]\right]^{1 / 2} \\
\text { where } w=1 /\left[\sigma^{2}\left(F_{\mathrm{o}}{ }^{2}\right)+(a P)^{2}+b P\right] \text { and } \\
P=1 / 3 \max \left(0, F_{\mathrm{o}}{ }^{2}\right)+2 / 3 F_{\mathrm{c}}{ }^{2} \\
\mathrm{GOF}=S=\left[\Sigma\left[w\left(F_{\mathrm{o}}{ }^{2}-F_{\mathrm{c}}{ }^{2}\right)^{2}\right] /(m-n)\right]^{1 / 2}
\end{gathered}
$$

where $m=$ number of reflections and $n=$ number of parameters
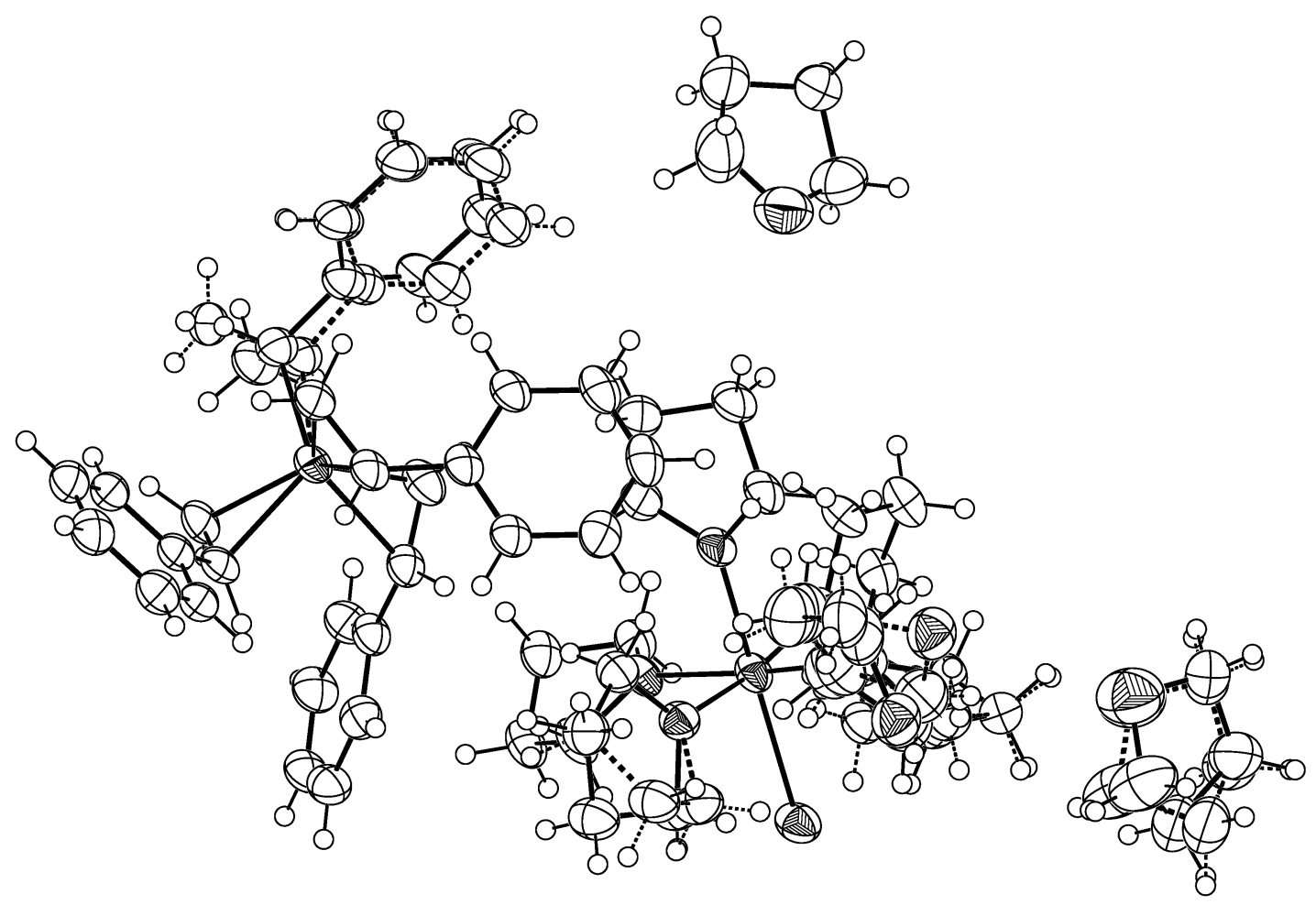


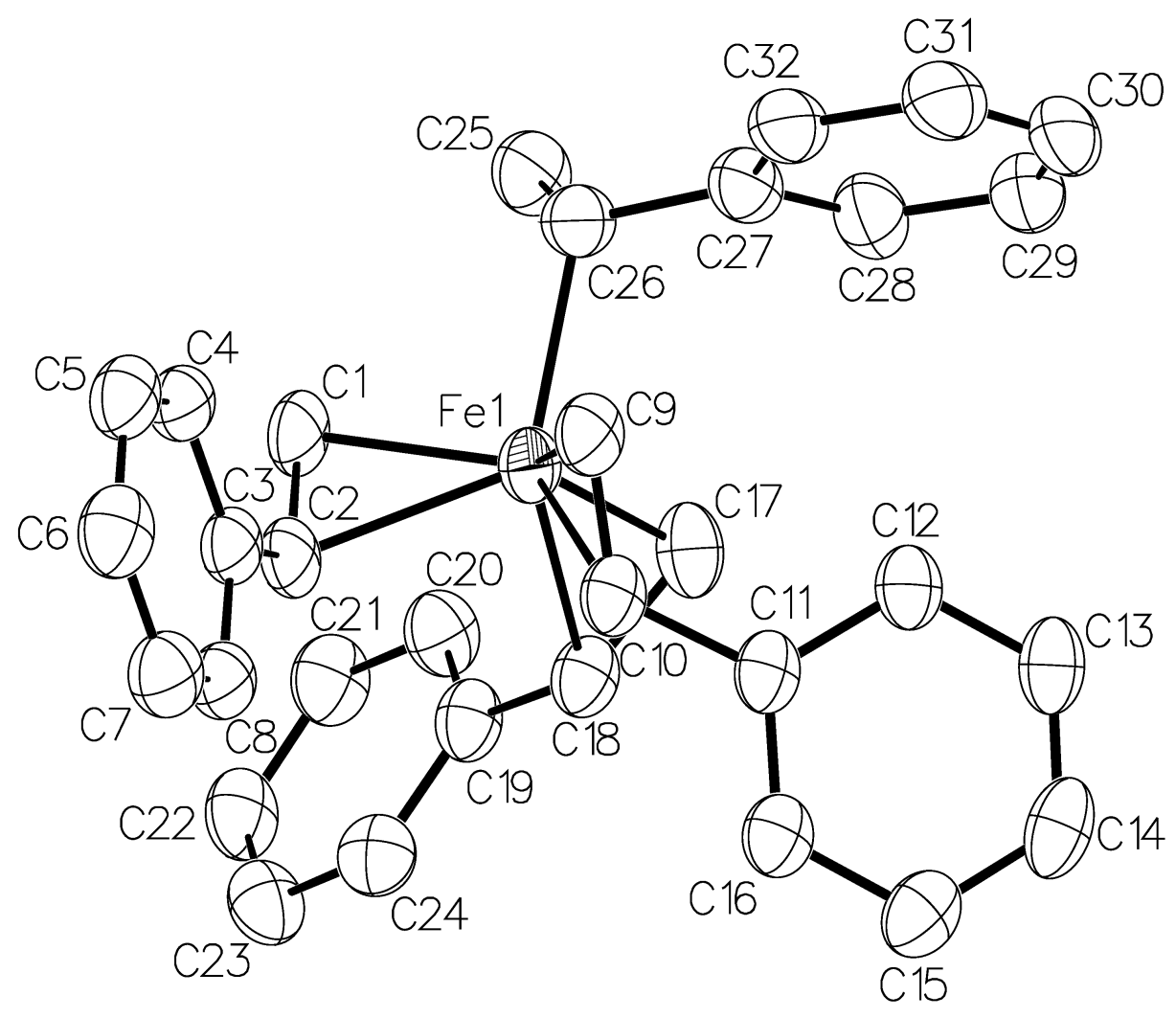




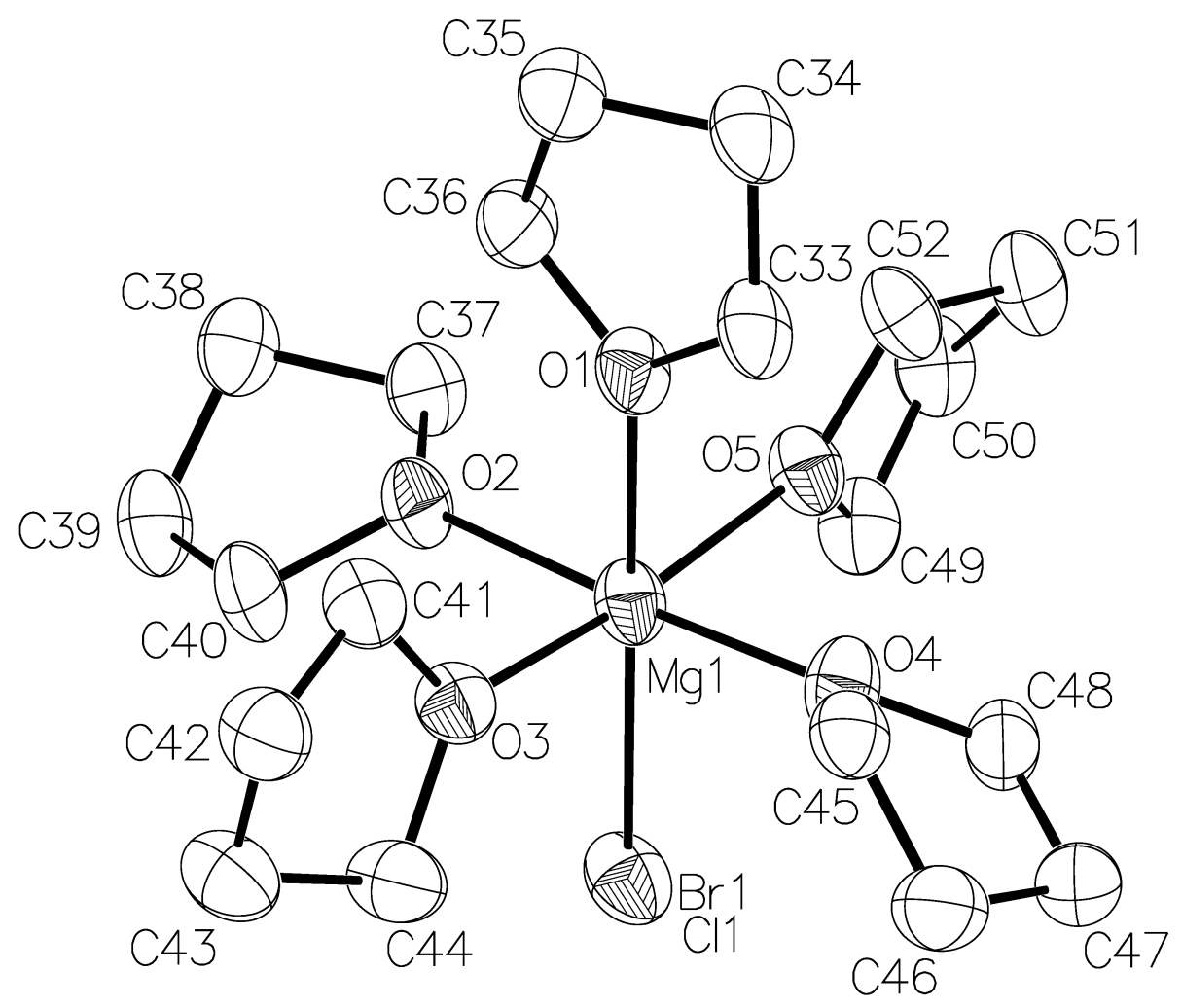




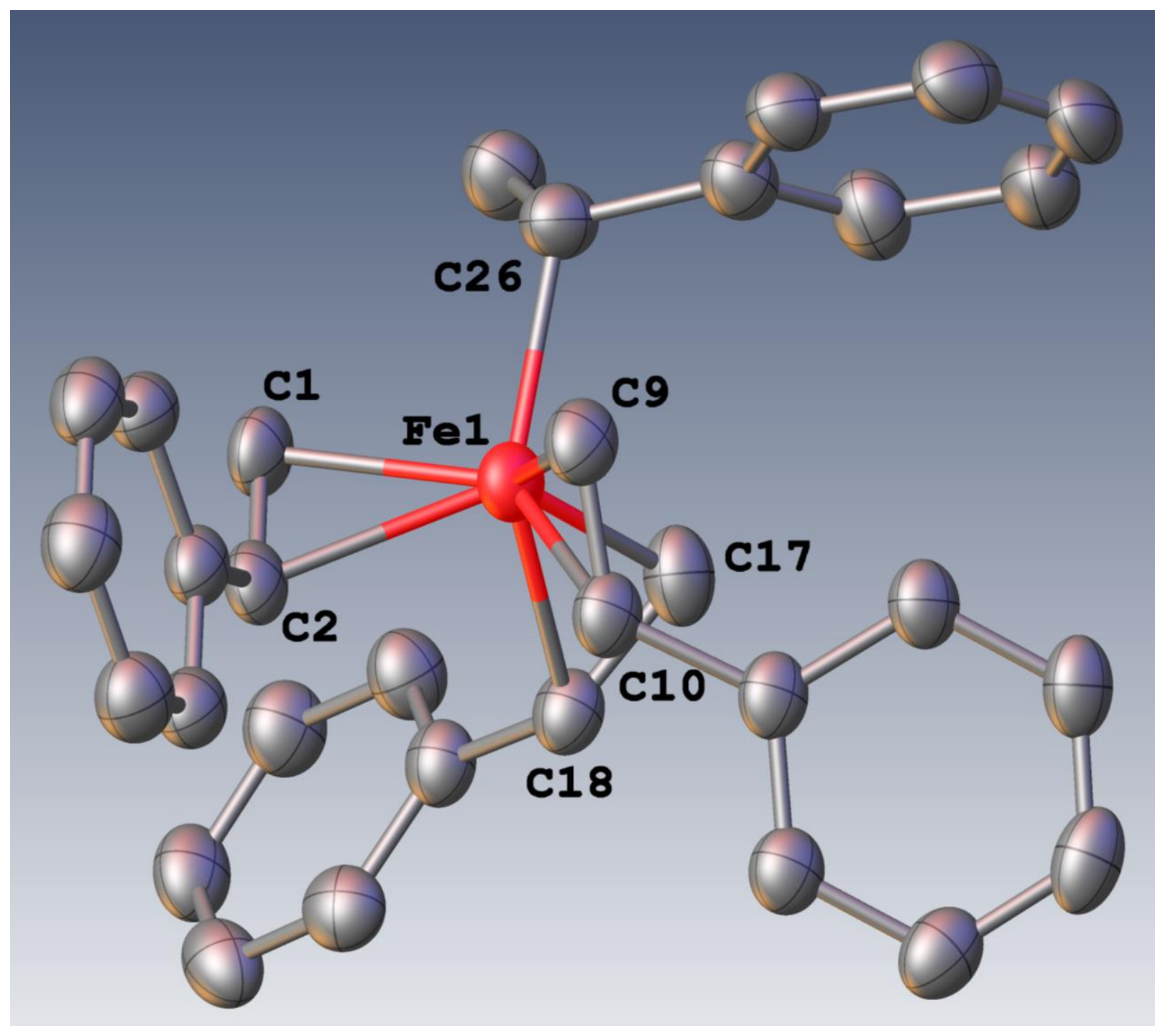


Table 1. Crystal data and structure refinement for neipn25.

\begin{tabular}{|c|c|c|}
\hline Identification code & \multicolumn{2}{|l|}{ neipn25 } \\
\hline Empirical formula & \multicolumn{2}{|c|}{ C64 H96 Br0.69 Cl0.31 Fe Mg O8 } \\
\hline Formula weight & \multicolumn{2}{|l|}{1139.69} \\
\hline Temperature & \multicolumn{2}{|l|}{$100.00(10) \mathrm{K}$} \\
\hline Wavelength & \multicolumn{2}{|l|}{$1.54184 \AA$} \\
\hline Crystal system & \multicolumn{2}{|l|}{ triclinic } \\
\hline Space group & \multicolumn{2}{|l|}{$P-1$} \\
\hline \multirow[t]{3}{*}{ Unit cell dimensions } & $a=11.94400(10) \AA$ & $\alpha=72.3390(10)^{\circ}$ \\
\hline & $b=13.0469(2) \AA$ & $\beta=80.7430(10)^{\circ}$ \\
\hline & $c=21.0494(2) \AA$ & $\gamma=74.6990(10)^{\circ}$ \\
\hline Volume & \multicolumn{2}{|l|}{$3003.11(6) \AA^{3}$} \\
\hline$Z$ & \multicolumn{2}{|l|}{2} \\
\hline Density (calculated) & \multicolumn{2}{|l|}{$1.260 \mathrm{Mg} / \mathrm{m}^{3}$} \\
\hline Absorption coefficient & \multicolumn{2}{|l|}{$3.192 \mathrm{~mm}^{-1}$} \\
\hline$F(000)$ & \multicolumn{2}{|l|}{1223} \\
\hline Crystal color, morphology & \multicolumn{2}{|l|}{ red-black, plate } \\
\hline Crystal size & \multicolumn{2}{|c|}{$0.215 \times 0.108 \times 0.048 \mathrm{~mm}^{3}$} \\
\hline Theta range for data collection & \multicolumn{2}{|l|}{3.652 to $77.714^{\circ}$} \\
\hline Index ranges & \multicolumn{2}{|c|}{$-15 \leq h \leq 14,-14 \leq k \leq 16,-26 \leq l \leq 26$} \\
\hline Reflections collected & \multicolumn{2}{|l|}{52439} \\
\hline Independent reflections & \multicolumn{2}{|c|}{$12578[R($ int $)=0.0425]$} \\
\hline Observed reflections & \multicolumn{2}{|l|}{10793} \\
\hline Completeness to theta $=74.504^{\circ}$ & \multicolumn{2}{|l|}{$99.8 \%$} \\
\hline Absorption correction & \multicolumn{2}{|l|}{ Multi-scan } \\
\hline Max. and min. transmission & \multicolumn{2}{|l|}{1.00000 and 0.77574} \\
\hline Refinement method & \multicolumn{2}{|c|}{ Full-matrix least-squares on $F^{2}$} \\
\hline Data / restraints / parameters & \multicolumn{2}{|l|}{$12578 / 160 / 757$} \\
\hline Goodness-of-fit on $F^{2}$ & \multicolumn{2}{|l|}{1.079} \\
\hline Final $R$ indices $[I>2 \operatorname{sigma}(I)]$ & \multicolumn{2}{|c|}{$R 1=0.0564, w R 2=0.1597$} \\
\hline$R$ indices (all data) & \multicolumn{2}{|c|}{$R 1=0.0635, w R 2=0.1662$} \\
\hline Extinction coefficient & \multicolumn{2}{|l|}{$0.00113(19)$} \\
\hline Largest diff. peak and hole & \multicolumn{2}{|c|}{0.846 and -0.699 e. $\AA^{-3}$} \\
\hline
\end{tabular}


Table 2. Atomic coordinates (x $\left.10^{4}\right)$ and equivalent isotropic displacement parameters $\left(\AA^{2} \times 10^{3}\right)$ for neipn25. $U_{e q}$ is defined as one third of the trace of the orthogonalized $U_{i j}$ tensor.

\begin{tabular}{|c|c|c|c|c|}
\hline & $\mathrm{x}$ & $\mathrm{y}$ & $\mathrm{z}$ & $\mathrm{U}_{\mathrm{eq}}$ \\
\hline $\mathrm{Fe} 1$ & 3172(1) & $1545(1)$ & $1547(1)$ & $39(1)$ \\
\hline $\mathrm{C} 1$ & 4070(2) & $-85(2)$ & 1702(2) & $45(1)$ \\
\hline $\mathrm{C} 2$ & $3238(2)$ & $-108(2)$ & $2256(1)$ & $42(1)$ \\
\hline $\mathrm{C} 3$ & $2189(2)$ & $-527(2)$ & $2350(1)$ & $40(1)$ \\
\hline $\mathrm{C} 4$ & $1859(2)$ & $-926(2)$ & 1871(1) & $43(1)$ \\
\hline C5 & $861(3)$ & $-1323(2)$ & 1983(2) & $49(1)$ \\
\hline C6 & $154(3)$ & $-1349(2)$ & $2569(2)$ & $52(1)$ \\
\hline $\mathrm{C} 7$ & $448(3)$ & $-955(2)$ & 3051(2) & $50(1)$ \\
\hline $\mathrm{C} 8$ & $1445(2)$ & $-554(2)$ & 2941(1) & $44(1)$ \\
\hline C9 & $1405(2)$ & $1949(2)$ & 1436(1) & $44(1)$ \\
\hline $\mathrm{C} 10$ & $1450(2)$ & $2164(2)$ & 2040(1) & $40(1)$ \\
\hline $\mathrm{C} 11$ & $1259(2)$ & $3267(2)$ & $2135(1)$ & $39(1)$ \\
\hline $\mathrm{C} 12$ & $1189(2)$ & $4234(2)$ & $1600(1)$ & $42(1)$ \\
\hline $\mathrm{C} 13$ & 1001(2) & $5261(2)$ & $1717(2)$ & $48(1)$ \\
\hline C14 & $870(2)$ & $5361(2)$ & $2360(2)$ & $50(1)$ \\
\hline $\mathrm{C} 15$ & $929(2)$ & $4420(2)$ & 2896(2) & 49(1) \\
\hline C16 & $1125(2)$ & $3391(2)$ & $2780(1)$ & $43(1)$ \\
\hline $\mathrm{C} 17$ & 4009(2) & $2696(2)$ & 1610(2) & $49(1)$ \\
\hline $\mathrm{C} 18$ & $4015(2)$ & $2000(2)$ & $2263(1)$ & $41(1)$ \\
\hline C19 & $5041(2)$ & $1200(2)$ & $2548(1)$ & $41(1)$ \\
\hline $\mathrm{C} 20$ & $6128(2)$ & $989(2)$ & $2180(2)$ & $48(1)$ \\
\hline $\mathrm{C} 21$ & 7083(2) & $225(2)$ & $2475(2)$ & $51(1)$ \\
\hline $\mathrm{C} 22$ & 6993(3) & $-356(2)$ & $3142(2)$ & $51(1)$ \\
\hline $\mathrm{C} 23$ & 5925(3) & $-163(2)$ & $3517(2)$ & $49(1)$ \\
\hline $\mathrm{C} 24$ & 4974(2) & $596(2)$ & $3222(2)$ & $46(1)$ \\
\hline $\mathrm{C} 25$ & $4855(4)$ & $1473(4)$ & 290(2) & $52(1)$ \\
\hline $\mathrm{C} 26$ & $3556(4)$ & 1811(4) & $484(2)$ & $43(1)$ \\
\hline $\mathrm{C} 27$ & 3011(5) & 2973(4) & 131(4) & $44(1)$ \\
\hline $\mathrm{C} 28$ & $3535(7)$ & $3862(5)$ & $46(4)$ & $51(1)$ \\
\hline $\mathrm{C} 29$ & 2964(8) & 4954(5) & $-240(4)$ & $54(1)$ \\
\hline
\end{tabular}




\begin{tabular}{|c|c|c|c|c|}
\hline $\mathrm{C} 30$ & $1867(10)$ & 5193(9) & $-458(6)$ & $58(1)$ \\
\hline $\mathrm{C} 31$ & $1344(9)$ & $4335(10)$ & $-399(7)$ & $58(2)$ \\
\hline $\mathrm{C} 32$ & 1903(6) & $3248(8)$ & $-105(5)$ & $50(2)$ \\
\hline $\mathrm{C} 25^{\prime}$ & $3887(11)$ & $1168(8)$ & $158(5)$ & $61(3)$ \\
\hline C26' & $3867(11)$ & 2027(9) & $513(4)$ & $43(1)$ \\
\hline $\mathrm{C} 27^{\prime}$ & $3235(15)$ & $3163(11)$ & 135(9) & $44(1)$ \\
\hline C28' & $3521(17)$ & 4121(13) & 144(9) & $51(1)$ \\
\hline C29' & $2850(20)$ & $5168(13)$ & $-116(9)$ & $54(1)$ \\
\hline C30' & $1840(20)$ & $5290(20)$ & $-403(14)$ & $58(1)$ \\
\hline C31' & $1540(20)$ & $4340(20)$ & $-426(16)$ & $58(2)$ \\
\hline C $32^{\prime}$ & $2205(15)$ & $3280(20)$ & $-163(13)$ & $50(2)$ \\
\hline $\mathrm{Br} 1$ & $7029(1)$ & 4951(1) & $4018(1)$ & $49(1)$ \\
\hline $\mathrm{Cl} 1$ & $7029(1)$ & 4951(1) & $4018(1)$ & $49(1)$ \\
\hline Mg1 & 5794(1) & $5330(1)$ & $3050(1)$ & $38(1)$ \\
\hline $\mathrm{O} 1$ & $4761(2)$ & $5650(1)$ & $2239(1)$ & $40(1)$ \\
\hline C33 & $3700(2)$ & $6516(2)$ & 2086(2) & $47(1)$ \\
\hline C34 & $3598(3)$ & $6704(2)$ & $1353(2)$ & $52(1)$ \\
\hline C35 & 4041(3) & $5539(2)$ & $1277(2)$ & $52(1)$ \\
\hline C36 & $5038(2)$ & $5064(2)$ & $1724(1)$ & $46(1)$ \\
\hline $\mathrm{O} 2$ & $6918(2)$ & $4040(1)$ & 2714(1) & $41(1)$ \\
\hline C37 & 7897(2) & $4149(2)$ & $2208(1)$ & $43(1)$ \\
\hline C38 & $8345(2)$ & $3003(2)$ & $2119(2)$ & $47(1)$ \\
\hline C39 & $8275(2)$ & $2306(2)$ & $2842(2)$ & $51(1)$ \\
\hline $\mathrm{C} 40$ & $7124(3)$ & 2904(2) & $3130(2)$ & $50(1)$ \\
\hline $\mathrm{O} 3$ & $4733(2)$ & $4211(1)$ & $3606(1)$ & $41(1)$ \\
\hline $\mathrm{C} 41$ & $3957(2)$ & $3796(2)$ & $3332(2)$ & $46(1)$ \\
\hline $\mathrm{C} 42$ & $3357(3)$ & $3088(3)$ & $3924(2)$ & $55(1)$ \\
\hline $\mathrm{C} 43$ & $4246(3)$ & 2667(3) & $4424(2)$ & $55(1)$ \\
\hline $\mathrm{C} 44$ & $4744(4)$ & $3660(4)$ & $4318(2)$ & $54(1)$ \\
\hline C43' & $3490(20)$ & $3460(20)$ & $4518(8)$ & $55(1)$ \\
\hline C44' & $4550(30)$ & $3940(40)$ & $4338(5)$ & $54(1)$ \\
\hline $\mathrm{O} 4$ & $4594(2)$ & $6632(2)$ & $3339(1)$ & $46(1)$ \\
\hline $\mathrm{C} 45$ & $3394(3)$ & $6706(3)$ & $3600(2)$ & $44(1)$ \\
\hline $\mathrm{C} 46$ & $3344(5)$ & $7090(5)$ & 4213(4) & $55(1)$ \\
\hline $\mathrm{C} 45^{\prime}$ & $3895(11)$ & $6285(11)$ & 3992(5) & $44(1)$ \\
\hline
\end{tabular}




\begin{tabular}{|c|c|c|c|c|}
\hline C46' & $3168(19)$ & $7280(20)$ & $4200(20)$ & $55(1)$ \\
\hline $\mathrm{C} 47$ & $4115(3)$ & $7922(2)$ & $3992(1)$ & $50(1)$ \\
\hline $\mathrm{C} 48$ & 4963(3) & $7542(2)$ & $3444(2)$ & $46(1)$ \\
\hline $\mathrm{O} 5$ & $6696(2)$ & $6500(1)$ & $2388(1)$ & $40(1)$ \\
\hline C49 & $7788(2)$ & $6700(2)$ & $2495(2)$ & $47(1)$ \\
\hline C50 & $8237(2)$ & $7306(2)$ & $1810(2)$ & $49(1)$ \\
\hline C51 & $7110(3)$ & $8043(2)$ & $1521(2)$ & $52(1)$ \\
\hline C52 & $6287(2)$ & $7275(2)$ & $1766(2)$ & $46(1)$ \\
\hline O6 & 1114(3) & $8404(2)$ & $424(1)$ & $78(1)$ \\
\hline C53 & 1774(4) & 9199(4) & $91(2)$ & $75(1)$ \\
\hline C54 & $1603(3)$ & $9509(3)$ & $-640(2)$ & $60(1)$ \\
\hline C55 & $1350(5)$ & $8477(3)$ & $-714(2)$ & $80(1)$ \\
\hline C56 & $778(7)$ & $8024(4)$ & $-39(2)$ & $109(2)$ \\
\hline $\mathrm{O} 7$ & $1440(40)$ & $9510(30)$ & $4588(12)$ & $100(1)$ \\
\hline C57 & $1850(40)$ & $10520(30)$ & $4393(14)$ & $102(3)$ \\
\hline C58 & $2730(30)$ & $10350(20)$ & $4877(11)$ & $88(2)$ \\
\hline C59 & $2628(7)$ & $9275(6)$ & $5386(4)$ & $72(2)$ \\
\hline C60 & 1451(9) & $9150(13)$ & $5303(7)$ & $96(3)$ \\
\hline O8 & $-886(4)$ & $6724(4)$ & $5081(2)$ & $64(1)$ \\
\hline C61 & $-1417(17)$ & $6820(20)$ & $4499(11)$ & $72(2)$ \\
\hline C62 & $-510(20)$ & $6270(40)$ & $4050(20)$ & $74(3)$ \\
\hline C63 & $630(18)$ & $6240(40)$ & $4290(20)$ & $69(2)$ \\
\hline C64 & $297(8)$ & $6789(10)$ & $4862(6)$ & $74(2)$ \\
\hline O7' & $1460(60)$ & $9510(50)$ & $4614(18)$ & $100(1)$ \\
\hline C57' & $1960(60)$ & $10470(50)$ & $4420(20)$ & $102(3)$ \\
\hline C58' & $2820(40)$ & $10220(40)$ & $4933(16)$ & $88(2)$ \\
\hline C59' & $2129(12)$ & $9619(10)$ & $5543(6)$ & $72(2)$ \\
\hline C60' & $1878(18)$ & $8806(17)$ & $5241(12)$ & $96(3)$ \\
\hline O8' & $-1257(4)$ & $7632(4)$ & $4509(3)$ & $64(1)$ \\
\hline C61' & $-1561(19)$ & $6730(20)$ & $4376(14)$ & $72(2)$ \\
\hline C62' & $-490(30)$ & $6110(40)$ & $4060(20)$ & $74(3)$ \\
\hline C63' & $490(20)$ & $6380(50)$ & $4300(30)$ & $69(2)$ \\
\hline C64' & $-106(9)$ & $7138(11)$ & $4742(8)$ & $74(2)$ \\
\hline
\end{tabular}


Table 3. Bond lengths $[\AA ̊]$ and angles $\left[{ }^{\circ}\right]$ for neipn 25 .

\begin{tabular}{|c|c|c|c|}
\hline $\mathrm{Fe}(1)-\mathrm{C}(1)$ & $2.065(2)$ & $\mathrm{C}(13)-\mathrm{H}(13)$ & 0.9300 \\
\hline $\mathrm{Fe}(1)-\mathrm{C}(2)$ & $2.209(2)$ & $C(13)-C(14)$ & $1.380(4)$ \\
\hline $\mathrm{Fe}(1)-\mathrm{C}(9)$ & $2.070(3)$ & $\mathrm{C}(14)-\mathrm{H}(14)$ & 0.9300 \\
\hline $\mathrm{Fe}(1)-\mathrm{C}(10)$ & $2.215(2)$ & $C(14)-C(15)$ & $1.387(4)$ \\
\hline $\mathrm{Fe}(1)-\mathrm{C}(17)$ & $2.056(3)$ & $\mathrm{C}(15)-\mathrm{H}(15)$ & 0.9300 \\
\hline $\mathrm{Fe}(1)-\mathrm{C}(18)$ & $2.233(3)$ & $C(15)-C(16)$ & $1.389(4)$ \\
\hline $\mathrm{Fe}(1)-\mathrm{C}(26)$ & $2.150(4)$ & $\mathrm{C}(16)-\mathrm{H}(16)$ & 0.9300 \\
\hline $\mathrm{Fe}(1)-\mathrm{C}\left(26^{\prime}\right)$ & $2.164(8)$ & $\mathrm{C}(17)-\mathrm{H}(17)$ & 0.9300 \\
\hline $\mathrm{C}(1)-\mathrm{H}(1 \mathrm{~A})$ & 0.9700 & $\mathrm{C}(17)-\mathrm{C}(18)$ & $1.398(4)$ \\
\hline C(1)-H(1B) & 0.9700 & $\mathrm{C}(18)-\mathrm{H}(18)$ & 0.9800 \\
\hline$C(1)-C(2)$ & $1.403(4)$ & $\mathrm{C}(18)-\mathrm{C}(19)$ & $1.461(3)$ \\
\hline $\mathrm{C}(2)-\mathrm{H}(2)$ & 0.9800 & $C(19)-C(20)$ & $1.407(4)$ \\
\hline$C(2)-C(3)$ & $1.457(4)$ & $C(19)-C(24)$ & $1.398(4)$ \\
\hline$C(3)-C(4)$ & $1.412(4)$ & $\mathrm{C}(20)-\mathrm{H}(20)$ & 0.9300 \\
\hline $\mathrm{C}(3)-\mathrm{C}(8)$ & $1.405(4)$ & $C(20)-C(21)$ & $1.389(4)$ \\
\hline $\mathrm{C}(4)-\mathrm{H}(4)$ & 0.9300 & $\mathrm{C}(21)-\mathrm{H}(21)$ & 0.9300 \\
\hline$C(4)-C(5)$ & $1.380(4)$ & $C(21)-C(22)$ & $1.381(5)$ \\
\hline $\mathrm{C}(5)-\mathrm{H}(5)$ & 0.9300 & $\mathrm{C}(22)-\mathrm{H}(22)$ & 0.9300 \\
\hline$C(5)-C(6)$ & $1.375(5)$ & $\mathrm{C}(22)-\mathrm{C}(23)$ & $1.394(4)$ \\
\hline $\mathrm{C}(6)-\mathrm{H}(6)$ & 0.9300 & $\mathrm{C}(23)-\mathrm{H}(23)$ & 0.9300 \\
\hline$C(6)-C(7)$ & $1.393(4)$ & $C(23)-C(24)$ & $1.384(4)$ \\
\hline $\mathrm{C}(7)-\mathrm{H}(7)$ & 0.9300 & $\mathrm{C}(24)-\mathrm{H}(24)$ & 0.9300 \\
\hline$C(7)-C(8)$ & $1.383(4)$ & $\mathrm{C}(25)-\mathrm{H}(25 \mathrm{~A})$ & 0.9600 \\
\hline $\mathrm{C}(8)-\mathrm{H}(8)$ & 0.9300 & $\mathrm{C}(25)-\mathrm{H}(25 \mathrm{~B})$ & 0.9600 \\
\hline $\mathrm{C}(9)-\mathrm{H}(9 \mathrm{~A})$ & 0.9700 & $\mathrm{C}(25)-\mathrm{H}(25 \mathrm{C})$ & 0.9600 \\
\hline C(9)-H(9B) & 0.9700 & $C(25)-C(26)$ & $1.521(6)$ \\
\hline C(9)-C(10) & $1.395(4)$ & $\mathrm{C}(26)-\mathrm{H}(26)$ & 0.9800 \\
\hline $\mathrm{C}(10)-\mathrm{H}(10)$ & 0.9800 & $C(26)-C(27)$ & $1.491(6)$ \\
\hline$C(10)-C(11)$ & $1.467(3)$ & $C(27)-C(28)$ & $1.410(7)$ \\
\hline$C(11)-C(12)$ & $1.407(4)$ & $\mathrm{C}(27)-\mathrm{C}(32)$ & $1.407(6)$ \\
\hline$C(11)-C(16)$ & $1.394(4)$ & $\mathrm{C}(28)-\mathrm{H}(28)$ & 0.9300 \\
\hline $\mathrm{C}(12)-\mathrm{H}(12)$ & 0.9300 & $\mathrm{C}(28)-\mathrm{C}(29)$ & $1.398(6)$ \\
\hline $\mathrm{C}(12)-\mathrm{C}(13)$ & $1.389(4)$ & $\mathrm{C}(29)-\mathrm{H}(29)$ & 0.9300 \\
\hline
\end{tabular}




\begin{tabular}{|c|c|c|c|}
\hline C(29)-C(30) & $1.385(8)$ & $\mathrm{C}(34)-\mathrm{H}(34 \mathrm{~A})$ & 0.9700 \\
\hline $\mathrm{C}(30)-\mathrm{H}(30)$ & 0.9300 & $\mathrm{C}(34)-\mathrm{H}(34 \mathrm{~B})$ & 0.9700 \\
\hline$C(30)-C(31)$ & $1.384(8)$ & $\mathrm{C}(34)-\mathrm{C}(35)$ & $1.520(4)$ \\
\hline $\mathrm{C}(31)-\mathrm{H}(31)$ & 0.9300 & $\mathrm{C}(35)-\mathrm{H}(35 \mathrm{~A})$ & 0.9700 \\
\hline$C(31)-C(32)$ & $1.392(7)$ & $\mathrm{C}(35)-\mathrm{H}(35 \mathrm{~B})$ & 0.9700 \\
\hline $\mathrm{C}(32)-\mathrm{H}(32)$ & 0.9300 & $\mathrm{C}(35)-\mathrm{C}(36)$ & $1.519(4)$ \\
\hline $\mathrm{C}\left(25^{\prime}\right)-\mathrm{H}(25 \mathrm{D})$ & 0.9600 & $\mathrm{C}(36)-\mathrm{H}(36 \mathrm{~A})$ & 0.9700 \\
\hline $\mathrm{C}\left(25^{\prime}\right)-\mathrm{H}(25 \mathrm{E})$ & 0.9600 & $\mathrm{C}(36)-\mathrm{H}(36 \mathrm{~B})$ & 0.9700 \\
\hline $\mathrm{C}\left(25^{\prime}\right)-\mathrm{H}(25 \mathrm{~F})$ & 0.9600 & $\mathrm{O}(2)-\mathrm{C}(37)$ & $1.455(3)$ \\
\hline$C\left(25^{\prime}\right)-C\left(26^{\prime}\right)$ & $1.519(12)$ & $\mathrm{O}(2)-\mathrm{C}(40)$ & $1.454(3)$ \\
\hline $\mathrm{C}\left(26^{\prime}\right)-\mathrm{H}\left(26^{\prime}\right)$ & 0.9800 & $\mathrm{C}(37)-\mathrm{H}(37 \mathrm{~A})$ & 0.9700 \\
\hline$C\left(26^{\prime}\right)-C\left(27^{\prime}\right)$ & $1.512(13)$ & $\mathrm{C}(37)-\mathrm{H}(37 \mathrm{~B})$ & 0.9700 \\
\hline $\mathrm{C}\left(27^{\prime}\right)-\mathrm{C}\left(28^{\prime}\right)$ & $1.385(13)$ & $\mathrm{C}(37)-\mathrm{C}(38)$ & $1.508(4)$ \\
\hline $\mathrm{C}\left(27^{\prime}\right)-\mathrm{C}\left(32^{\prime}\right)$ & $1.421(14)$ & $\mathrm{C}(38)-\mathrm{H}(38 \mathrm{~A})$ & 0.9700 \\
\hline $\mathrm{C}\left(28^{\prime}\right)-\mathrm{H}\left(28^{\prime}\right)$ & 0.9300 & $\mathrm{C}(38)-\mathrm{H}(38 \mathrm{~B})$ & 0.9700 \\
\hline $\mathrm{C}\left(28^{\prime}\right)-\mathrm{C}\left(29^{\prime}\right)$ & $1.387(13)$ & $\mathrm{C}(38)-\mathrm{C}(39)$ & $1.519(4)$ \\
\hline $\mathrm{C}\left(29^{\prime}\right)-\mathrm{H}\left(29^{\prime}\right)$ & 0.9300 & $\mathrm{C}(39)-\mathrm{H}(39 \mathrm{~A})$ & 0.9700 \\
\hline $\mathrm{C}\left(29^{\prime}\right)-\mathrm{C}\left(30^{\prime}\right)$ & $1.384(15)$ & $\mathrm{C}(39)-\mathrm{H}(39 \mathrm{~B})$ & 0.9700 \\
\hline $\mathrm{C}\left(30^{\prime}\right)-\mathrm{H}\left(30^{\prime}\right)$ & 0.9300 & $\mathrm{C}(39)-\mathrm{C}(40)$ & $1.523(4)$ \\
\hline $\mathrm{C}\left(30^{\prime}\right)-\mathrm{C}\left(31^{\prime}\right)$ & $1.390(14)$ & $\mathrm{C}(40)-\mathrm{H}(40 \mathrm{~A})$ & 0.9700 \\
\hline $\mathrm{C}\left(31^{\prime}\right)-\mathrm{H}\left(31^{\prime}\right)$ & 0.9300 & $\mathrm{C}(40)-\mathrm{H}(40 \mathrm{~B})$ & 0.9700 \\
\hline $\mathrm{C}\left(31^{\prime}\right)-\mathrm{C}\left(32^{\prime}\right)$ & $1.394(13)$ & $\mathrm{O}(3)-\mathrm{C}(41)$ & $1.453(3)$ \\
\hline $\mathrm{C}\left(32^{\prime}\right)-\mathrm{H}\left(32^{\prime}\right)$ & 0.9300 & $\mathrm{O}(3)-\mathrm{C}(44)$ & $1.452(4)$ \\
\hline $\operatorname{Br}(1)-\operatorname{Mg}(1)$ & $2.5579(9)$ & $\mathrm{O}(3)-\mathrm{C}\left(44^{\prime}\right)$ & $1.465(9)$ \\
\hline $\mathrm{Cl}(1)-\mathrm{Mg}(1)$ & $2.5579(9)$ & $\mathrm{C}(41)-\mathrm{H}(41 \mathrm{~A})$ & 0.9700 \\
\hline $\operatorname{Mg}(1)-\mathrm{O}(1)$ & $2.1414(19)$ & $\mathrm{C}(41)-\mathrm{H}(41 \mathrm{~B})$ & 0.9700 \\
\hline $\mathrm{Mg}(1)-\mathrm{O}(2)$ & $2.0887(18)$ & $\mathrm{C}(41)-\mathrm{C}(42)$ & $1.511(4)$ \\
\hline $\operatorname{Mg}(1)-\mathrm{O}(3)$ & $2.1380(19)$ & $\mathrm{C}(42)-\mathrm{H}(42 \mathrm{~A})$ & 0.9700 \\
\hline $\mathrm{Mg}(1)-\mathrm{O}(4)$ & $2.0896(19)$ & $\mathrm{C}(42)-\mathrm{H}(42 \mathrm{~B})$ & 0.9700 \\
\hline $\operatorname{Mg}(1)-\mathrm{O}(5)$ & $2.1273(19)$ & $\mathrm{C}(42)-\mathrm{H}(42 \mathrm{C})$ & 0.9700 \\
\hline $\mathrm{O}(1)-\mathrm{C}(33)$ & $1.464(3)$ & $\mathrm{C}(42)-\mathrm{H}(42 \mathrm{D})$ & 0.9700 \\
\hline $\mathrm{O}(1)-\mathrm{C}(36)$ & $1.457(3)$ & $\mathrm{C}(42)-\mathrm{C}(43)$ & $1.495(4)$ \\
\hline $\mathrm{C}(33)-\mathrm{H}(33 \mathrm{~A})$ & 0.9700 & $\mathrm{C}(42)-\mathrm{C}\left(43^{\prime}\right)$ & $1.510(8)$ \\
\hline $\mathrm{C}(33)-\mathrm{H}(33 \mathrm{~B})$ & 0.9700 & $\mathrm{C}(43)-\mathrm{H}(43 \mathrm{~A})$ & 0.9700 \\
\hline$C(33)-C(34)$ & $1.506(4)$ & $\mathrm{C}(43)-\mathrm{H}(43 \mathrm{~B})$ & 0.9700 \\
\hline
\end{tabular}




\begin{tabular}{|c|c|c|c|}
\hline $\mathrm{C}(43)-\mathrm{C}(44)$ & $1.508(4)$ & $\mathrm{C}(50)-\mathrm{H}(50 \mathrm{~A})$ & 0.9700 \\
\hline $\mathrm{C}(44)-\mathrm{H}(44 \mathrm{~A})$ & 0.9700 & $\mathrm{C}(50)-\mathrm{H}(50 \mathrm{~B})$ & 0.9700 \\
\hline $\mathrm{C}(44)-\mathrm{H}(44 \mathrm{~B})$ & 0.9700 & $C(50)-C(51)$ & $1.527(4)$ \\
\hline $\mathrm{C}\left(43^{\prime}\right)-\mathrm{H}(43 \mathrm{C})$ & 0.9700 & $\mathrm{C}(51)-\mathrm{H}(51 \mathrm{~A})$ & 0.9700 \\
\hline $\mathrm{C}\left(43^{\prime}\right)-\mathrm{H}(43 \mathrm{D})$ & 0.9700 & $\mathrm{C}(51)-\mathrm{H}(51 \mathrm{~B})$ & 0.9700 \\
\hline $\mathrm{C}\left(43^{\prime}\right)-\mathrm{C}\left(44^{\prime}\right)$ & $1.508(8)$ & $\mathrm{C}(51)-\mathrm{C}(52)$ & $1.510(4)$ \\
\hline $\mathrm{C}\left(44^{\prime}\right)-\mathrm{H}(44 \mathrm{C})$ & 0.9700 & $\mathrm{C}(52)-\mathrm{H}(52 \mathrm{~A})$ & 0.9700 \\
\hline $\mathrm{C}\left(44^{\prime}\right)-\mathrm{H}(44 \mathrm{D})$ & 0.9700 & $\mathrm{C}(52)-\mathrm{H}(52 \mathrm{~B})$ & 0.9700 \\
\hline $\mathrm{O}(4)-\mathrm{C}(45)$ & $1.440(4)$ & $\mathrm{O}(6)-\mathrm{C}(53)$ & $1.414(5)$ \\
\hline $\mathrm{O}(4)-\mathrm{C}\left(45^{\prime}\right)$ & $1.499(8)$ & $\mathrm{O}(6)-\mathrm{C}(56)$ & $1.372(6)$ \\
\hline $\mathrm{O}(4)-\mathrm{C}(48)$ & $1.457(3)$ & $\mathrm{C}(53)-\mathrm{H}(53 \mathrm{~A})$ & 0.9700 \\
\hline $\mathrm{C}(45)-\mathrm{H}(45 \mathrm{~A})$ & 0.9700 & $\mathrm{C}(53)-\mathrm{H}(53 \mathrm{~B})$ & 0.9700 \\
\hline $\mathrm{C}(45)-\mathrm{H}(45 \mathrm{~B})$ & 0.9700 & $\mathrm{C}(53)-\mathrm{C}(54)$ & $1.500(5)$ \\
\hline $\mathrm{C}(45)-\mathrm{C}(46)$ & $1.508(7)$ & $\mathrm{C}(54)-\mathrm{H}(54 \mathrm{~A})$ & 0.9700 \\
\hline $\mathrm{C}(46)-\mathrm{H}(46 \mathrm{~A})$ & 0.9700 & $\mathrm{C}(54)-\mathrm{H}(54 \mathrm{~B})$ & 0.9700 \\
\hline $\mathrm{C}(46)-\mathrm{H}(46 \mathrm{~B})$ & 0.9700 & $\mathrm{C}(54)-\mathrm{C}(55)$ & $1.512(5)$ \\
\hline $\mathrm{C}(46)-\mathrm{C}(47)$ & $1.525(5)$ & $\mathrm{C}(55)-\mathrm{H}(55 \mathrm{~A})$ & 0.9700 \\
\hline $\mathrm{C}\left(45^{\prime}\right)-\mathrm{H}(45 \mathrm{C})$ & 0.9700 & $\mathrm{C}(55)-\mathrm{H}(55 \mathrm{~B})$ & 0.9700 \\
\hline $\mathrm{C}\left(45^{\prime}\right)-\mathrm{H}(45 \mathrm{D})$ & 0.9700 & $C(55)-C(56)$ & $1.492(6)$ \\
\hline$C\left(45^{\prime}\right)-C\left(46^{\prime}\right)$ & $1.508(8)$ & $\mathrm{C}(56)-\mathrm{H}(56 \mathrm{~A})$ & 0.9700 \\
\hline $\mathrm{C}\left(46^{\prime}\right)-\mathrm{H}(46 \mathrm{C})$ & 0.9700 & $\mathrm{C}(56)-\mathrm{H}(56 \mathrm{~B})$ & 0.9700 \\
\hline $\mathrm{C}\left(46^{\prime}\right)-\mathrm{H}(46 \mathrm{D})$ & 0.9700 & $\mathrm{O}(7)-\mathrm{C}(57)$ & $1.449(11)$ \\
\hline $\mathrm{C}\left(46^{\prime}\right)-\mathrm{C}(47)$ & $1.511(8)$ & $\mathrm{O}(7)-\mathrm{C}(60)$ & $1.435(16)$ \\
\hline $\mathrm{C}(47)-\mathrm{H}(47 \mathrm{~A})$ & 0.9700 & $\mathrm{C}(57)-\mathrm{H}(57 \mathrm{~A})$ & 0.9700 \\
\hline C(47)-H(47B) & 0.9700 & $\mathrm{C}(57)-\mathrm{H}(57 \mathrm{~B})$ & 0.9700 \\
\hline $\mathrm{C}(47)-\mathrm{H}(47 \mathrm{C})$ & 0.9700 & $\mathrm{C}(57)-\mathrm{C}(58)$ & $1.513(10)$ \\
\hline C(47)-H(47D) & 0.9700 & $\mathrm{C}(58)-\mathrm{H}(58 \mathrm{~A})$ & 0.9700 \\
\hline C(47)-C(48) & $1.519(4)$ & $\mathrm{C}(58)-\mathrm{H}(58 \mathrm{~B})$ & 0.9700 \\
\hline $\mathrm{C}(48)-\mathrm{H}(48 \mathrm{~A})$ & 0.9700 & $\mathrm{C}(58)-\mathrm{C}(59)$ & $1.509(15)$ \\
\hline C(48)-H(48B) & 0.9700 & $\mathrm{C}(59)-\mathrm{H}(59 \mathrm{~A})$ & 0.9700 \\
\hline $\mathrm{O}(5)-\mathrm{C}(49)$ & $1.459(3)$ & $\mathrm{C}(59)-\mathrm{H}(59 \mathrm{~B})$ & 0.9700 \\
\hline $\mathrm{O}(5)-\mathrm{C}(52)$ & $1.457(3)$ & $\mathrm{C}(59)-\mathrm{C}(60)$ & $1.501(10)$ \\
\hline C(49)-H(49A) & 0.9700 & $\mathrm{C}(60)-\mathrm{H}(60 \mathrm{~A})$ & 0.9700 \\
\hline C(49)-H(49B) & 0.9700 & $\mathrm{C}(60)-\mathrm{H}(60 \mathrm{~B})$ & 0.9700 \\
\hline $\mathrm{C}(49)-\mathrm{C}(50)$ & $1.508(4)$ & $\mathrm{O}(8)-\mathrm{C}(61)$ & $1.428(14)$ \\
\hline
\end{tabular}




\begin{tabular}{|c|c|c|c|}
\hline $\mathrm{O}(8)-\mathrm{C}(64)$ & $1.431(11)$ & $C\left(63^{\prime}\right)-C\left(64^{\prime}\right)$ & $1.519(12)$ \\
\hline $\mathrm{C}(61)-\mathrm{H}(61 \mathrm{~A})$ & 0.9700 & $\mathrm{C}\left(64^{\prime}\right)-\mathrm{H}(64 \mathrm{C})$ & 0.9700 \\
\hline $\mathrm{C}(61)-\mathrm{H}(61 \mathrm{~B})$ & 0.9700 & $\mathrm{C}\left(64^{\prime}\right)-\mathrm{H}(64 \mathrm{D})$ & 0.9700 \\
\hline$C(61)-C(62)$ & $1.495(11)$ & $\mathrm{C}(1)-\mathrm{Fe}(1)-\mathrm{C}(2)$ & $38.13(11)$ \\
\hline $\mathrm{C}(62)-\mathrm{H}(62 \mathrm{~A})$ & 0.9700 & $\mathrm{C}(1)-\mathrm{Fe}(1)-\mathrm{C}(9)$ & $119.06(11)$ \\
\hline $\mathrm{C}(62)-\mathrm{H}(62 \mathrm{~B})$ & 0.9700 & $\mathrm{C}(1)-\mathrm{Fe}(1)-\mathrm{C}(10)$ & $126.48(11)$ \\
\hline $\mathrm{C}(62)-\mathrm{C}(63)$ & $1.512(12)$ & $\mathrm{C}(1)-\mathrm{Fe}(1)-\mathrm{C}(18)$ & $98.58(10)$ \\
\hline $\mathrm{C}(63)-\mathrm{H}(63 \mathrm{~A})$ & 0.9700 & $\mathrm{C}(1)-\mathrm{Fe}(1)-\mathrm{C}(26)$ & $90.29(16)$ \\
\hline $\mathrm{C}(63)-\mathrm{H}(63 \mathrm{~B})$ & 0.9700 & $\mathrm{C}(1)-\mathrm{Fe}(1)-\mathrm{C}\left(26^{\prime}\right)$ & $94.0(3)$ \\
\hline$C(63)-C(64)$ & $1.532(13)$ & $\mathrm{C}(2)-\mathrm{Fe}(1)-\mathrm{C}(10)$ & $89.54(10)$ \\
\hline $\mathrm{C}(64)-\mathrm{H}(64 \mathrm{~A})$ & 0.9700 & $\mathrm{C}(2)-\mathrm{Fe}(1)-\mathrm{C}(18)$ & $89.67(10)$ \\
\hline $\mathrm{C}(64)-\mathrm{H}(64 \mathrm{~B})$ & 0.9700 & $\mathrm{C}(9)-\mathrm{Fe}(1)-\mathrm{C}(2)$ & $96.99(10)$ \\
\hline $\mathrm{O}\left(7^{\prime}\right)-\mathrm{C}\left(57^{\prime}\right)$ & $1.448(13)$ & $\mathrm{C}(9)-\mathrm{Fe}(1)-\mathrm{C}(10)$ & $37.82(10)$ \\
\hline $\mathrm{O}\left(7^{\prime}\right)-\mathrm{C}\left(60^{\prime}\right)$ & $1.438(17)$ & $\mathrm{C}(9)-\mathrm{Fe}(1)-\mathrm{C}(18)$ & $125.81(10)$ \\
\hline $\mathrm{C}\left(57^{\prime}\right)-\mathrm{H}(57 \mathrm{C})$ & 0.9700 & $\mathrm{C}(9)-\mathrm{Fe}(1)-\mathrm{C}(26)$ & $90.39(16)$ \\
\hline $\mathrm{C}\left(57^{\prime}\right)-\mathrm{H}(57 \mathrm{D})$ & 0.9700 & $\mathrm{C}(9)-\mathrm{Fe}(1)-\mathrm{C}\left(26^{\prime}\right)$ & $100.7(4)$ \\
\hline $\mathrm{C}\left(57^{\prime}\right)-\mathrm{C}\left(58^{\prime}\right)$ & $1.517(13)$ & $\mathrm{C}(10)-\mathrm{Fe}(1)-\mathrm{C}(18)$ & $88.91(9)$ \\
\hline $\mathrm{C}\left(58^{\prime}\right)-\mathrm{H}(58 \mathrm{C})$ & 0.9700 & $\mathrm{C}(17)-\mathrm{Fe}(1)-\mathrm{C}(1)$ & $119.23(11)$ \\
\hline $\mathrm{C}\left(58^{\prime}\right)-\mathrm{H}(58 \mathrm{D})$ & 0.9700 & $\mathrm{C}(17)-\mathrm{Fe}(1)-\mathrm{C}(2)$ & $125.92(11)$ \\
\hline $\mathrm{C}\left(58^{\prime}\right)-\mathrm{C}\left(59^{\prime}\right)$ & $1.531(19)$ & $\mathrm{C}(17)-\mathrm{Fe}(1)-\mathrm{C}(9)$ & $121.36(11)$ \\
\hline $\mathrm{C}\left(59^{\prime}\right)-\mathrm{H}(59 \mathrm{C})$ & 0.9700 & $\mathrm{C}(17)-\mathrm{Fe}(1)-\mathrm{C}(10)$ & $98.56(10)$ \\
\hline C(59')-H(59D) & 0.9700 & $\mathrm{C}(17)-\mathrm{Fe}(1)-\mathrm{C}(18)$ & $37.76(11)$ \\
\hline $\mathrm{C}\left(59^{\prime}\right)-\mathrm{C}\left(60^{\prime}\right)$ & $1.502(13)$ & $\mathrm{C}(17)-\mathrm{Fe}(1)-\mathrm{C}(26)$ & $95.22(18)$ \\
\hline $\mathrm{C}\left(60^{\prime}\right)-\mathrm{H}(60 \mathrm{C})$ & 0.9700 & $\mathrm{C}(17)-\mathrm{Fe}(1)-\mathrm{C}\left(26^{\prime}\right)$ & $81.2(3)$ \\
\hline $\mathrm{C}\left(60^{\prime}\right)-\mathrm{H}(60 \mathrm{D})$ & 0.9700 & $\mathrm{C}(26)-\mathrm{Fe}(1)-\mathrm{C}(2)$ & $123.23(16)$ \\
\hline $\mathrm{O}\left(8^{\prime}\right)-\mathrm{C}\left(61^{\prime}\right)$ & $1.435(15)$ & $\mathrm{C}(26)-\mathrm{Fe}(1)-\mathrm{C}(10)$ & $124.52(14)$ \\
\hline $\mathrm{O}\left(8^{\prime}\right)-\mathrm{C}\left(64^{\prime}\right)$ & $1.450(10)$ & $\mathrm{C}(26)-\mathrm{Fe}(1)-\mathrm{C}(18)$ & $129.27(17)$ \\
\hline $\mathrm{C}\left(61^{\prime}\right)-\mathrm{H}(61 \mathrm{C})$ & 0.9700 & $\mathrm{C}\left(26^{\prime}\right)-\mathrm{Fe}(1)-\mathrm{C}(2)$ & $130.7(3)$ \\
\hline $\mathrm{C}\left(61^{\prime}\right)-\mathrm{H}(61 \mathrm{D})$ & 0.9700 & $\mathrm{C}\left(26^{\prime}\right)-\mathrm{Fe}(1)-\mathrm{C}(10)$ & $130.3(3)$ \\
\hline$C\left(61^{\prime}\right)-C\left(62^{\prime}\right)$ & $1.498(12)$ & $\mathrm{C}\left(26^{\prime}\right)-\mathrm{Fe}(1)-\mathrm{C}(18)$ & $114.8(3)$ \\
\hline $\mathrm{C}\left(62^{\prime}\right)-\mathrm{H}(62 \mathrm{C})$ & 0.9700 & $\mathrm{Fe}(1)-\mathrm{C}(1)-\mathrm{H}(1 \mathrm{~A})$ & 115.8 \\
\hline $\mathrm{C}\left(62^{\prime}\right)-\mathrm{H}(62 \mathrm{D})$ & 0.9700 & $\mathrm{Fe}(1)-\mathrm{C}(1)-\mathrm{H}(1 \mathrm{~B})$ & 115.8 \\
\hline$C\left(62^{\prime}\right)-C\left(63^{\prime}\right)$ & $1.510(13)$ & $\mathrm{H}(1 \mathrm{~A})-\mathrm{C}(1)-\mathrm{H}(1 \mathrm{~B})$ & 112.8 \\
\hline $\mathrm{C}\left(63^{\prime}\right)-\mathrm{H}(63 \mathrm{C})$ & 0.9700 & $\mathrm{C}(2)-\mathrm{C}(1)-\mathrm{Fe}(1)$ & $76.50(14)$ \\
\hline $\mathrm{C}\left(63^{\prime}\right)-\mathrm{H}(63 \mathrm{D})$ & 0.9700 & $\mathrm{C}(2)-\mathrm{C}(1)-\mathrm{H}(1 \mathrm{~A})$ & 115.8 \\
\hline
\end{tabular}




\begin{tabular}{|c|c|c|c|}
\hline $\mathrm{C}(2)-\mathrm{C}(1)-\mathrm{H}(1 \mathrm{~B})$ & 115.8 & $\mathrm{C}(11)-\mathrm{C}(10)-\mathrm{Fe}(1)$ & $115.68(17)$ \\
\hline $\mathrm{Fe}(1)-\mathrm{C}(2)-\mathrm{H}(2)$ & 113.7 & $\mathrm{C}(11)-\mathrm{C}(10)-\mathrm{H}(10)$ & 113.9 \\
\hline $\mathrm{C}(1)-\mathrm{C}(2)-\mathrm{Fe}(1)$ & $65.37(14)$ & $\mathrm{C}(12)-\mathrm{C}(11)-\mathrm{C}(10)$ & $123.0(2)$ \\
\hline $\mathrm{C}(1)-\mathrm{C}(2)-\mathrm{H}(2)$ & 113.7 & $C(16)-C(11)-C(10)$ & $119.8(2)$ \\
\hline $\mathrm{C}(1)-\mathrm{C}(2)-\mathrm{C}(3)$ & $125.4(2)$ & $\mathrm{C}(16)-\mathrm{C}(11)-\mathrm{C}(12)$ & $117.2(2)$ \\
\hline $\mathrm{C}(3)-\mathrm{C}(2)-\mathrm{Fe}(1)$ & $115.81(16)$ & $\mathrm{C}(11)-\mathrm{C}(12)-\mathrm{H}(12)$ & 119.6 \\
\hline $\mathrm{C}(3)-\mathrm{C}(2)-\mathrm{H}(2)$ & 113.7 & $\mathrm{C}(13)-\mathrm{C}(12)-\mathrm{C}(11)$ & $120.8(3)$ \\
\hline $\mathrm{C}(4)-\mathrm{C}(3)-\mathrm{C}(2)$ & $123.4(3)$ & $\mathrm{C}(13)-\mathrm{C}(12)-\mathrm{H}(12)$ & 119.6 \\
\hline $\mathrm{C}(8)-\mathrm{C}(3)-\mathrm{C}(2)$ & $120.2(2)$ & $\mathrm{C}(12)-\mathrm{C}(13)-\mathrm{H}(13)$ & 119.5 \\
\hline $\mathrm{C}(8)-\mathrm{C}(3)-\mathrm{C}(4)$ & $116.3(2)$ & $\mathrm{C}(14)-\mathrm{C}(13)-\mathrm{C}(12)$ & $121.0(3)$ \\
\hline $\mathrm{C}(3)-\mathrm{C}(4)-\mathrm{H}(4)$ & 119.2 & $\mathrm{C}(14)-\mathrm{C}(13)-\mathrm{H}(13)$ & 119.5 \\
\hline $\mathrm{C}(5)-\mathrm{C}(4)-\mathrm{C}(3)$ & $121.5(3)$ & $\mathrm{C}(13)-\mathrm{C}(14)-\mathrm{H}(14)$ & 120.4 \\
\hline $\mathrm{C}(5)-\mathrm{C}(4)-\mathrm{H}(4)$ & 119.2 & $\mathrm{C}(13)-\mathrm{C}(14)-\mathrm{C}(15)$ & $119.3(2)$ \\
\hline $\mathrm{C}(4)-\mathrm{C}(5)-\mathrm{H}(5)$ & 119.5 & $\mathrm{C}(15)-\mathrm{C}(14)-\mathrm{H}(14)$ & 120.4 \\
\hline$C(6)-C(5)-C(4)$ & $120.9(3)$ & $\mathrm{C}(14)-\mathrm{C}(15)-\mathrm{H}(15)$ & 120.0 \\
\hline $\mathrm{C}(6)-\mathrm{C}(5)-\mathrm{H}(5)$ & 119.5 & $\mathrm{C}(14)-\mathrm{C}(15)-\mathrm{C}(16)$ & $119.9(3)$ \\
\hline $\mathrm{C}(5)-\mathrm{C}(6)-\mathrm{H}(6)$ & 120.4 & $\mathrm{C}(16)-\mathrm{C}(15)-\mathrm{H}(15)$ & 120.0 \\
\hline$C(5)-C(6)-C(7)$ & 119.1(3) & $\mathrm{C}(11)-\mathrm{C}(16)-\mathrm{H}(16)$ & 119.0 \\
\hline $\mathrm{C}(7)-\mathrm{C}(6)-\mathrm{H}(6)$ & 120.4 & $C(15)-C(16)-C(11)$ & $121.9(3)$ \\
\hline $\mathrm{C}(6)-\mathrm{C}(7)-\mathrm{H}(7)$ & 119.9 & $\mathrm{C}(15)-\mathrm{C}(16)-\mathrm{H}(16)$ & 119.0 \\
\hline$C(8)-C(7)-C(6)$ & $120.2(3)$ & $\mathrm{Fe}(1)-\mathrm{C}(17)-\mathrm{H}(17)$ & 141.0 \\
\hline $\mathrm{C}(8)-\mathrm{C}(7)-\mathrm{H}(7)$ & 119.9 & $\mathrm{C}(18)-\mathrm{C}(17)-\mathrm{Fe}(1)$ & $78.00(16)$ \\
\hline C(3)-C(8)-H(8) & 119.1 & $\mathrm{C}(18)-\mathrm{C}(17)-\mathrm{H}(17)$ & 141.0 \\
\hline $\mathrm{C}(7)-\mathrm{C}(8)-\mathrm{C}(3)$ & $121.9(3)$ & $\mathrm{Fe}(1)-\mathrm{C}(18)-\mathrm{H}(18)$ & 114.1 \\
\hline $\mathrm{C}(7)-\mathrm{C}(8)-\mathrm{H}(8)$ & 119.1 & $\mathrm{C}(17)-\mathrm{C}(18)-\mathrm{Fe}(1)$ & $64.24(16)$ \\
\hline $\mathrm{Fe}(1)-\mathrm{C}(9)-\mathrm{H}(9 \mathrm{~A})$ & 115.7 & $\mathrm{C}(17)-\mathrm{C}(18)-\mathrm{H}(18)$ & 114.1 \\
\hline $\mathrm{Fe}(1)-\mathrm{C}(9)-\mathrm{H}(9 \mathrm{~B})$ & 115.7 & $\mathrm{C}(17)-\mathrm{C}(18)-\mathrm{C}(19)$ & $124.5(2)$ \\
\hline $\mathrm{H}(9 \mathrm{~A})-\mathrm{C}(9)-\mathrm{H}(9 \mathrm{~B})$ & 112.7 & $\mathrm{C}(19)-\mathrm{C}(18)-\mathrm{Fe}(1)$ & $116.54(17)$ \\
\hline $\mathrm{C}(10)-\mathrm{C}(9)-\mathrm{Fe}(1)$ & $76.73(15)$ & $\mathrm{C}(19)-\mathrm{C}(18)-\mathrm{H}(18)$ & 114.1 \\
\hline $\mathrm{C}(10)-\mathrm{C}(9)-\mathrm{H}(9 \mathrm{~A})$ & 115.7 & $\mathrm{C}(20)-\mathrm{C}(19)-\mathrm{C}(18)$ & $123.5(3)$ \\
\hline $\mathrm{C}(10)-\mathrm{C}(9)-\mathrm{H}(9 \mathrm{~B})$ & 115.7 & $\mathrm{C}(24)-\mathrm{C}(19)-\mathrm{C}(18)$ & $120.0(2)$ \\
\hline $\mathrm{Fe}(1)-\mathrm{C}(10)-\mathrm{H}(10)$ & 113.9 & $C(24)-C(19)-C(20)$ & $116.4(2)$ \\
\hline $\mathrm{C}(9)-\mathrm{C}(10)-\mathrm{Fe}(1)$ & $65.46(14)$ & $\mathrm{C}(19)-\mathrm{C}(20)-\mathrm{H}(20)$ & 119.3 \\
\hline C(9)-C(10)-H(10) & 113.9 & $\mathrm{C}(21)-\mathrm{C}(20)-\mathrm{C}(19)$ & $121.5(3)$ \\
\hline $\mathrm{C}(9)-\mathrm{C}(10)-\mathrm{C}(11)$ & $125.1(2)$ & $\mathrm{C}(21)-\mathrm{C}(20)-\mathrm{H}(20)$ & 119.3 \\
\hline
\end{tabular}




\begin{tabular}{|c|c|c|c|}
\hline $\mathrm{C}(20)-\mathrm{C}(21)-\mathrm{H}(21)$ & 119.6 & $\mathrm{C}(31)-\mathrm{C}(30)-\mathrm{H}(30)$ & 120.4 \\
\hline $\mathrm{C}(22)-\mathrm{C}(21)-\mathrm{C}(20)$ & $120.8(3)$ & $\mathrm{C}(30)-\mathrm{C}(31)-\mathrm{H}(31)$ & 119.9 \\
\hline $\mathrm{C}(22)-\mathrm{C}(21)-\mathrm{H}(21)$ & 119.6 & $\mathrm{C}(30)-\mathrm{C}(31)-\mathrm{C}(32)$ & $120.3(7)$ \\
\hline $\mathrm{C}(21)-\mathrm{C}(22)-\mathrm{H}(22)$ & 120.6 & $\mathrm{C}(32)-\mathrm{C}(31)-\mathrm{H}(31)$ & 119.9 \\
\hline $\mathrm{C}(21)-\mathrm{C}(22)-\mathrm{C}(23)$ & $118.8(2)$ & $\mathrm{C}(27)-\mathrm{C}(32)-\mathrm{H}(32)$ & 118.9 \\
\hline $\mathrm{C}(23)-\mathrm{C}(22)-\mathrm{H}(22)$ & 120.6 & $\mathrm{C}(31)-\mathrm{C}(32)-\mathrm{C}(27)$ & $122.3(7)$ \\
\hline $\mathrm{C}(22)-\mathrm{C}(23)-\mathrm{H}(23)$ & 119.9 & $\mathrm{C}(31)-\mathrm{C}(32)-\mathrm{H}(32)$ & 118.9 \\
\hline$C(24)-C(23)-C(22)$ & $120.3(3)$ & $\mathrm{H}(25 \mathrm{D})-\mathrm{C}\left(25^{\prime}\right)-\mathrm{H}(25 \mathrm{E})$ & 109.5 \\
\hline $\mathrm{C}(24)-\mathrm{C}(23)-\mathrm{H}(23)$ & 119.9 & $\mathrm{H}(25 \mathrm{D})-\mathrm{C}\left(25^{\prime}\right)-\mathrm{H}(25 \mathrm{~F})$ & 109.5 \\
\hline $\mathrm{C}(19)-\mathrm{C}(24)-\mathrm{H}(24)$ & 118.9 & $\mathrm{H}(25 \mathrm{E})-\mathrm{C}\left(25^{\prime}\right)-\mathrm{H}(25 \mathrm{~F})$ & 109.5 \\
\hline $\mathrm{C}(23)-\mathrm{C}(24)-\mathrm{C}(19)$ & $122.2(3)$ & $\mathrm{C}\left(26^{\prime}\right)-\mathrm{C}\left(25^{\prime}\right)-\mathrm{H}(25 \mathrm{D})$ & 109.5 \\
\hline $\mathrm{C}(23)-\mathrm{C}(24)-\mathrm{H}(24)$ & 118.9 & $\mathrm{C}\left(26^{\prime}\right)-\mathrm{C}\left(25^{\prime}\right)-\mathrm{H}(25 \mathrm{E})$ & 109.5 \\
\hline $\mathrm{H}(25 \mathrm{~A})-\mathrm{C}(25)-\mathrm{H}(25 \mathrm{~B})$ & 109.5 & $\mathrm{C}\left(26^{\prime}\right)-\mathrm{C}\left(25^{\prime}\right)-\mathrm{H}(25 \mathrm{~F})$ & 109.5 \\
\hline $\mathrm{H}(25 \mathrm{~A})-\mathrm{C}(25)-\mathrm{H}(25 \mathrm{C})$ & 109.5 & $\mathrm{Fe}(1)-\mathrm{C}\left(26^{\prime}\right)-\mathrm{H}\left(26^{\prime}\right)$ & 107.1 \\
\hline $\mathrm{H}(25 \mathrm{~B})-\mathrm{C}(25)-\mathrm{H}(25 \mathrm{C})$ & 109.5 & $\mathrm{C}\left(25^{\prime}\right)-\mathrm{C}\left(26^{\prime}\right)-\mathrm{Fe}(1)$ & $111.2(7)$ \\
\hline $\mathrm{C}(26)-\mathrm{C}(25)-\mathrm{H}(25 \mathrm{~A})$ & 109.5 & $\mathrm{C}\left(25^{\prime}\right)-\mathrm{C}\left(26^{\prime}\right)-\mathrm{H}\left(26^{\prime}\right)$ & 107.1 \\
\hline $\mathrm{C}(26)-\mathrm{C}(25)-\mathrm{H}(25 \mathrm{~B})$ & 109.5 & $\mathrm{C}\left(27^{\prime}\right)-\mathrm{C}\left(26^{\prime}\right)-\mathrm{Fe}(1)$ & $112.8(9)$ \\
\hline $\mathrm{C}(26)-\mathrm{C}(25)-\mathrm{H}(25 \mathrm{C})$ & 109.5 & $\mathrm{C}\left(27^{\prime}\right)-\mathrm{C}\left(26^{\prime}\right)-\mathrm{C}\left(25^{\prime}\right)$ & $111.2(9)$ \\
\hline $\mathrm{Fe}(1)-\mathrm{C}(26)-\mathrm{H}(26)$ & 107.0 & $\mathrm{C}\left(27^{\prime}\right)-\mathrm{C}\left(26^{\prime}\right)-\mathrm{H}\left(26^{\prime}\right)$ & 107.1 \\
\hline$C(25)-C(26)-F e(1)$ & $112.0(3)$ & $\mathrm{C}\left(28^{\prime}\right)-\mathrm{C}\left(27^{\prime}\right)-\mathrm{C}\left(26^{\prime}\right)$ & $122.5(13)$ \\
\hline $\mathrm{C}(25)-\mathrm{C}(26)-\mathrm{H}(26)$ & 107.0 & $\mathrm{C}\left(28^{\prime}\right)-\mathrm{C}\left(27^{\prime}\right)-\mathrm{C}\left(32^{\prime}\right)$ & $117.3(13)$ \\
\hline $\mathrm{C}(27)-\mathrm{C}(26)-\mathrm{Fe}(1)$ & $109.8(4)$ & $\mathrm{C}\left(32^{\prime}\right)-\mathrm{C}\left(27^{\prime}\right)-\mathrm{C}\left(26^{\prime}\right)$ & $119.6(13)$ \\
\hline $\mathrm{C}(27)-\mathrm{C}(26)-\mathrm{C}(25)$ & $113.7(4)$ & $\mathrm{C}\left(27^{\prime}\right)-\mathrm{C}\left(28^{\prime}\right)-\mathrm{H}\left(28^{\prime}\right)$ & 118.5 \\
\hline $\mathrm{C}(27)-\mathrm{C}(26)-\mathrm{H}(26)$ & 107.0 & $\mathrm{C}\left(27^{\prime}\right)-\mathrm{C}\left(28^{\prime}\right)-\mathrm{C}\left(29^{\prime}\right)$ & $123.1(15)$ \\
\hline$C(28)-C(27)-C(26)$ & $122.7(5)$ & $\mathrm{C}\left(29^{\prime}\right)-\mathrm{C}\left(28^{\prime}\right)-\mathrm{H}\left(28^{\prime}\right)$ & 118.5 \\
\hline$C(32)-C(27)-C(26)$ & $121.1(5)$ & $\mathrm{C}\left(28^{\prime}\right)-\mathrm{C}\left(29^{\prime}\right)-\mathrm{H}\left(29^{\prime}\right)$ & 120.1 \\
\hline $\mathrm{C}(32)-\mathrm{C}(27)-\mathrm{C}(28)$ & $116.1(5)$ & $\mathrm{C}\left(30^{\prime}\right)-\mathrm{C}\left(29^{\prime}\right)-\mathrm{C}\left(28^{\prime}\right)$ & $119.8(15)$ \\
\hline $\mathrm{C}(27)-\mathrm{C}(28)-\mathrm{H}(28)$ & 119.3 & $\mathrm{C}\left(30^{\prime}\right)-\mathrm{C}\left(29^{\prime}\right)-\mathrm{H}\left(29^{\prime}\right)$ & 120.1 \\
\hline $\mathrm{C}(29)-\mathrm{C}(28)-\mathrm{C}(27)$ & $121.5(6)$ & $\mathrm{C}\left(29^{\prime}\right)-\mathrm{C}\left(30^{\prime}\right)-\mathrm{H}\left(30^{\prime}\right)$ & 120.8 \\
\hline $\mathrm{C}(29)-\mathrm{C}(28)-\mathrm{H}(28)$ & 119.3 & $\mathrm{C}\left(29^{\prime}\right)-\mathrm{C}\left(30^{\prime}\right)-\mathrm{C}\left(31^{\prime}\right)$ & $118.4(16)$ \\
\hline $\mathrm{C}(28)-\mathrm{C}(29)-\mathrm{H}(29)$ & 119.7 & $\mathrm{C}\left(31^{\prime}\right)-\mathrm{C}\left(30^{\prime}\right)-\mathrm{H}\left(30^{\prime}\right)$ & 120.8 \\
\hline$C(30)-C(29)-C(28)$ & $120.7(6)$ & $\mathrm{C}\left(30^{\prime}\right)-\mathrm{C}\left(31^{\prime}\right)-\mathrm{H}\left(31^{\prime}\right)$ & 118.8 \\
\hline $\mathrm{C}(30)-\mathrm{C}(29)-\mathrm{H}(29)$ & 119.7 & $\mathrm{C}\left(30^{\prime}\right)-\mathrm{C}\left(31^{\prime}\right)-\mathrm{C}\left(32^{\prime}\right)$ & $122.4(17)$ \\
\hline $\mathrm{C}(29)-\mathrm{C}(30)-\mathrm{H}(30)$ & 120.4 & $\mathrm{C}\left(32^{\prime}\right)-\mathrm{C}\left(31^{\prime}\right)-\mathrm{H}\left(31^{\prime}\right)$ & 118.8 \\
\hline $\mathrm{C}(31)-\mathrm{C}(30)-\mathrm{C}(29)$ & 119.2(7) & $\mathrm{C}\left(27^{\prime}\right)-\mathrm{C}\left(32^{\prime}\right)-\mathrm{H}\left(32^{\prime}\right)$ & 120.4 \\
\hline
\end{tabular}




\begin{tabular}{|c|c|}
\hline $\mathrm{C}\left(31^{\prime}\right)-\mathrm{C}\left(32^{\prime}\right)-\mathrm{C}\left(27^{\prime}\right)$ & $119.1(15)$ \\
\hline $\mathrm{C}\left(31^{\prime}\right)-\mathrm{C}\left(32^{\prime}\right)-\mathrm{H}\left(32^{\prime}\right)$ & 120.4 \\
\hline $\mathrm{O}(1)-\mathrm{Mg}(1)-\mathrm{Br}(1)$ & $179.92(8)$ \\
\hline $\mathrm{O}(1)-\mathrm{Mg}(1)-\mathrm{Cl}(1)$ & $179.92(8)$ \\
\hline $\mathrm{O}(2)-\mathrm{Mg}(1)-\mathrm{Br}(1)$ & $91.33(6)$ \\
\hline $\mathrm{O}(2)-\mathrm{Mg}(1)-\mathrm{Cl}(1)$ & $91.33(6)$ \\
\hline $\mathrm{O}(2)-\mathrm{Mg}(1)-\mathrm{O}(1)$ & $88.69(7)$ \\
\hline $\mathrm{O}(2)-\mathrm{Mg}(1)-\mathrm{O}(3)$ & $88.86(7)$ \\
\hline $\mathrm{O}(2)-\mathrm{Mg}(1)-\mathrm{O}(4)$ & $176.10(9)$ \\
\hline $\mathrm{O}(2)-\mathrm{Mg}(1)-\mathrm{O}(5)$ & $91.46(8)$ \\
\hline $\mathrm{O}(3)-\mathrm{Mg}(1)-\mathrm{Br}(1)$ & $94.02(6)$ \\
\hline $\mathrm{O}(3)-\mathrm{Mg}(1)-\mathrm{Cl}(1)$ & $94.02(6)$ \\
\hline $\mathrm{O}(3)-\mathrm{Mg}(1)-\mathrm{O}(1)$ & $86.07(7)$ \\
\hline $\mathrm{O}(4)-\mathrm{Mg}(1)-\mathrm{Br}(1)$ & $92.54(6)$ \\
\hline $\mathrm{O}(4)-\mathrm{Mg}(1)-\mathrm{Cl}(1)$ & $92.54(6)$ \\
\hline $\mathrm{O}(4)-\mathrm{Mg}(1)-\mathrm{O}(1)$ & $87.44(8)$ \\
\hline $\mathrm{O}(4)-\mathrm{Mg}(1)-\mathrm{O}(3)$ & $90.41(8)$ \\
\hline $\mathrm{O}(4)-\mathrm{Mg}(1)-\mathrm{O}(5)$ & $88.74(8)$ \\
\hline $\mathrm{O}(5)-\mathrm{Mg}(1)-\mathrm{Br}(1)$ & $93.96(6)$ \\
\hline $\mathrm{O}(5)-\mathrm{Mg}(1)-\mathrm{Cl}(1)$ & $93.96(6)$ \\
\hline $\mathrm{O}(5)-\mathrm{Mg}(1)-\mathrm{O}(1)$ & $85.95(7)$ \\
\hline $\mathrm{O}(5)-\mathrm{Mg}(1)-\mathrm{O}(3)$ & $172.01(8)$ \\
\hline $\mathrm{C}(33)-\mathrm{O}(1)-\mathrm{Mg}(1)$ & $126.53(16)$ \\
\hline $\mathrm{C}(36)-\mathrm{O}(1)-\mathrm{Mg}(1)$ & $125.06(14)$ \\
\hline $\mathrm{C}(36)-\mathrm{O}(1)-\mathrm{C}(33)$ & $108.35(19)$ \\
\hline $\mathrm{O}(1)-\mathrm{C}(33)-\mathrm{H}(33 \mathrm{~A})$ & 110.7 \\
\hline $\mathrm{O}(1)-\mathrm{C}(33)-\mathrm{H}(33 \mathrm{~B})$ & 110.7 \\
\hline $\mathrm{O}(1)-\mathrm{C}(33)-\mathrm{C}(34)$ & $105.2(2)$ \\
\hline $\mathrm{H}(33 \mathrm{~A})-\mathrm{C}(33)-\mathrm{H}(33 \mathrm{~B})$ & 108.8 \\
\hline $\mathrm{C}(34)-\mathrm{C}(33)-\mathrm{H}(33 \mathrm{~A})$ & 110.7 \\
\hline $\mathrm{C}(34)-\mathrm{C}(33)-\mathrm{H}(33 \mathrm{~B})$ & 110.7 \\
\hline $\mathrm{C}(33)-\mathrm{C}(34)-\mathrm{H}(34 \mathrm{~A})$ & 111.4 \\
\hline $\mathrm{C}(33)-\mathrm{C}(34)-\mathrm{H}(34 \mathrm{~B})$ & 111.4 \\
\hline $\mathrm{C}(33)-\mathrm{C}(34)-\mathrm{C}(35)$ & $101.7(2)$ \\
\hline $\mathrm{H}(34 \mathrm{~A})-\mathrm{C}(34)-\mathrm{H}(34 \mathrm{~B})$ & 109.3 \\
\hline
\end{tabular}

\begin{tabular}{|c|c|}
\hline $\mathrm{C}(35)-\mathrm{C}(34)-\mathrm{H}(34 \mathrm{~A})$ & 111.4 \\
\hline $\mathrm{C}(35)-\mathrm{C}(34)-\mathrm{H}(34 \mathrm{~B})$ & 111.4 \\
\hline $\mathrm{C}(34)-\mathrm{C}(35)-\mathrm{H}(35 \mathrm{~A})$ & 111.3 \\
\hline $\mathrm{C}(34)-\mathrm{C}(35)-\mathrm{H}(35 \mathrm{~B})$ & 111.3 \\
\hline $\mathrm{H}(35 \mathrm{~A})-\mathrm{C}(35)-\mathrm{H}(35 \mathrm{~B})$ & 109.2 \\
\hline $\mathrm{C}(36)-\mathrm{C}(35)-\mathrm{C}(34)$ & $102.6(2)$ \\
\hline $\mathrm{C}(36)-\mathrm{C}(35)-\mathrm{H}(35 \mathrm{~A})$ & 111.3 \\
\hline $\mathrm{C}(36)-\mathrm{C}(35)-\mathrm{H}(35 \mathrm{~B})$ & 111.3 \\
\hline $\mathrm{O}(1)-\mathrm{C}(36)-\mathrm{C}(35)$ & $106.3(2)$ \\
\hline $\mathrm{O}(1)-\mathrm{C}(36)-\mathrm{H}(36 \mathrm{~A})$ & 110.5 \\
\hline $\mathrm{O}(1)-\mathrm{C}(36)-\mathrm{H}(36 \mathrm{~B})$ & 110.5 \\
\hline $\mathrm{C}(35)-\mathrm{C}(36)-\mathrm{H}(36 \mathrm{~A})$ & 110.5 \\
\hline $\mathrm{C}(35)-\mathrm{C}(36)-\mathrm{H}(36 \mathrm{~B})$ & 110.5 \\
\hline $\mathrm{H}(36 \mathrm{~A})-\mathrm{C}(36)-\mathrm{H}(36 \mathrm{~B})$ & 108.7 \\
\hline $\mathrm{C}(37)-\mathrm{O}(2)-\mathrm{Mg}(1)$ & $125.52(14)$ \\
\hline $\mathrm{C}(40)-\mathrm{O}(2)-\mathrm{Mg}(1)$ & $121.85(16)$ \\
\hline $\mathrm{C}(40)-\mathrm{O}(2)-\mathrm{C}(37)$ & $108.30(18)$ \\
\hline $\mathrm{O}(2)-\mathrm{C}(37)-\mathrm{H}(37 \mathrm{~A})$ & 111.0 \\
\hline $\mathrm{O}(2)-\mathrm{C}(37)-\mathrm{H}(37 \mathrm{~B})$ & 111.0 \\
\hline $\mathrm{O}(2)-\mathrm{C}(37)-\mathrm{C}(38)$ & $103.7(2)$ \\
\hline $\mathrm{H}(37 \mathrm{~A})-\mathrm{C}(37)-\mathrm{H}(37 \mathrm{~B})$ & 109.0 \\
\hline $\mathrm{C}(38)-\mathrm{C}(37)-\mathrm{H}(37 \mathrm{~A})$ & 111.0 \\
\hline $\mathrm{C}(38)-\mathrm{C}(37)-\mathrm{H}(37 \mathrm{~B})$ & 111.0 \\
\hline $\mathrm{C}(37)-\mathrm{C}(38)-\mathrm{H}(38 \mathrm{~A})$ & 111.6 \\
\hline C(37)-C(38)-H(38B) & 111.6 \\
\hline C(37)-C(38)-C(39) & $100.9(2)$ \\
\hline H(38A)-C(38)-H(38B) & 109.4 \\
\hline C(39)-C(38)-H(38A) & 111.6 \\
\hline C(39)-C(38)-H(38B) & 111.6 \\
\hline C(38)-C(39)-H(39A) & 111.3 \\
\hline C(38)-C(39)-H(39B) & 111.3 \\
\hline C(38)-C(39)-C(40) & $102.2(2)$ \\
\hline H(39A)-C(39)-H(39B) & 109.2 \\
\hline C(40)-C(39)-H(39A) & 111.3 \\
\hline C(40)-C(39)-H(39B) & 111.3 \\
\hline
\end{tabular}




\begin{tabular}{|c|c|c|c|}
\hline $\mathrm{O}(2)-\mathrm{C}(40)-\mathrm{C}(39)$ & $106.0(2)$ & $\mathrm{O}(3)-\mathrm{C}(44)-\mathrm{C}(43)$ & $105.5(3)$ \\
\hline $\mathrm{O}(2)-\mathrm{C}(40)-\mathrm{H}(40 \mathrm{~A})$ & 110.5 & $\mathrm{O}(3)-\mathrm{C}(44)-\mathrm{H}(44 \mathrm{~A})$ & 110.6 \\
\hline $\mathrm{O}(2)-\mathrm{C}(40)-\mathrm{H}(40 \mathrm{~B})$ & 110.5 & $\mathrm{O}(3)-\mathrm{C}(44)-\mathrm{H}(44 \mathrm{~B})$ & 110.6 \\
\hline $\mathrm{C}(39)-\mathrm{C}(40)-\mathrm{H}(40 \mathrm{~A})$ & 110.5 & $\mathrm{C}(43)-\mathrm{C}(44)-\mathrm{H}(44 \mathrm{~A})$ & 110.6 \\
\hline C(39)-C(40)-H(40B) & 110.5 & $\mathrm{C}(43)-\mathrm{C}(44)-\mathrm{H}(44 \mathrm{~B})$ & 110.6 \\
\hline $\mathrm{H}(40 \mathrm{~A})-\mathrm{C}(40)-\mathrm{H}(40 \mathrm{~B})$ & 108.7 & $\mathrm{H}(44 \mathrm{~A})-\mathrm{C}(44)-\mathrm{H}(44 \mathrm{~B})$ & 108.8 \\
\hline $\mathrm{C}(41)-\mathrm{O}(3)-\mathrm{Mg}(1)$ & $126.20(16)$ & $\mathrm{C}(42)-\mathrm{C}\left(43^{\prime}\right)-\mathrm{H}(43 \mathrm{C})$ & 110.5 \\
\hline $\mathrm{C}(41)-\mathrm{O}(3)-\mathrm{C}\left(44^{\prime}\right)$ & $111.3(10)$ & $\mathrm{C}(42)-\mathrm{C}\left(43^{\prime}\right)-\mathrm{H}(43 \mathrm{D})$ & 110.5 \\
\hline $\mathrm{C}(44)-\mathrm{O}(3)-\mathrm{Mg}(1)$ & $125.38(18)$ & $\mathrm{H}(43 \mathrm{C})-\mathrm{C}\left(43^{\prime}\right)-\mathrm{H}(43 \mathrm{D})$ & 108.6 \\
\hline $\mathrm{C}(44)-\mathrm{O}(3)-\mathrm{C}(41)$ & $108.2(2)$ & $\mathrm{C}\left(44^{\prime}\right)-\mathrm{C}\left(43^{\prime}\right)-\mathrm{C}(42)$ & $106.4(16)$ \\
\hline $\mathrm{C}\left(44^{\prime}\right)-\mathrm{O}(3)-\mathrm{Mg}(1)$ & $121.5(11)$ & $\mathrm{C}\left(44^{\prime}\right)-\mathrm{C}\left(43^{\prime}\right)-\mathrm{H}(43 \mathrm{C})$ & 110.5 \\
\hline $\mathrm{O}(3)-\mathrm{C}(41)-\mathrm{H}(41 \mathrm{~A})$ & 110.5 & $\mathrm{C}\left(44^{\prime}\right)-\mathrm{C}\left(43^{\prime}\right)-\mathrm{H}(43 \mathrm{D})$ & 110.5 \\
\hline $\mathrm{O}(3)-\mathrm{C}(41)-\mathrm{H}(41 \mathrm{~B})$ & 110.5 & $\mathrm{O}(3)-\mathrm{C}\left(44^{\prime}\right)-\mathrm{C}\left(43^{\prime}\right)$ & $105.2(14)$ \\
\hline $\mathrm{O}(3)-\mathrm{C}(41)-\mathrm{C}(42)$ & $106.2(2)$ & $\mathrm{O}(3)-\mathrm{C}\left(44^{\prime}\right)-\mathrm{H}(44 \mathrm{C})$ & 110.7 \\
\hline $\mathrm{H}(41 \mathrm{~A})-\mathrm{C}(41)-\mathrm{H}(41 \mathrm{~B})$ & 108.7 & $\mathrm{O}(3)-\mathrm{C}\left(44^{\prime}\right)-\mathrm{H}(44 \mathrm{D})$ & 110.7 \\
\hline $\mathrm{C}(42)-\mathrm{C}(41)-\mathrm{H}(41 \mathrm{~A})$ & 110.5 & $\mathrm{C}\left(43^{\prime}\right)-\mathrm{C}\left(44^{\prime}\right)-\mathrm{H}(44 \mathrm{C})$ & 110.7 \\
\hline $\mathrm{C}(42)-\mathrm{C}(41)-\mathrm{H}(41 \mathrm{~B})$ & 110.5 & $\mathrm{C}\left(43^{\prime}\right)-\mathrm{C}\left(44^{\prime}\right)-\mathrm{H}(44 \mathrm{D})$ & 110.7 \\
\hline $\mathrm{C}(41)-\mathrm{C}(42)-\mathrm{H}(42 \mathrm{~A})$ & 111.3 & $\mathrm{H}(44 \mathrm{C})-\mathrm{C}\left(44^{\prime}\right)-\mathrm{H}(44 \mathrm{D})$ & 108.8 \\
\hline $\mathrm{C}(41)-\mathrm{C}(42)-\mathrm{H}(42 \mathrm{~B})$ & 111.3 & $\mathrm{C}(45)-\mathrm{O}(4)-\mathrm{Mg}(1)$ & $129.32(17)$ \\
\hline $\mathrm{C}(41)-\mathrm{C}(42)-\mathrm{H}(42 \mathrm{C})$ & 110.7 & $\mathrm{C}(45)-\mathrm{O}(4)-\mathrm{C}(48)$ & $107.8(2)$ \\
\hline $\mathrm{C}(41)-\mathrm{C}(42)-\mathrm{H}(42 \mathrm{D})$ & 110.7 & $\mathrm{C}\left(45^{\prime}\right)-\mathrm{O}(4)-\mathrm{Mg}(1)$ & $114.2(5)$ \\
\hline $\mathrm{H}(42 \mathrm{~A})-\mathrm{C}(42)-\mathrm{H}(42 \mathrm{~B})$ & 109.2 & $\mathrm{C}(48)-\mathrm{O}(4)-\mathrm{Mg}(1)$ & $121.58(16)$ \\
\hline $\mathrm{H}(42 \mathrm{C})-\mathrm{C}(42)-\mathrm{H}(42 \mathrm{D})$ & 108.8 & $\mathrm{C}(48)-\mathrm{O}(4)-\mathrm{C}\left(45^{\prime}\right)$ & $100.1(6)$ \\
\hline$C(43)-C(42)-C(41)$ & $102.6(2)$ & $\mathrm{O}(4)-\mathrm{C}(45)-\mathrm{H}(45 \mathrm{~A})$ & 111.3 \\
\hline $\mathrm{C}(43)-\mathrm{C}(42)-\mathrm{H}(42 \mathrm{~A})$ & 111.3 & $\mathrm{O}(4)-\mathrm{C}(45)-\mathrm{H}(45 \mathrm{~B})$ & 111.3 \\
\hline $\mathrm{C}(43)-\mathrm{C}(42)-\mathrm{H}(42 \mathrm{~B})$ & 111.3 & $\mathrm{O}(4)-\mathrm{C}(45)-\mathrm{C}(46)$ & $102.5(3)$ \\
\hline$C\left(43^{\prime}\right)-C(42)-C(41)$ & $105.1(9)$ & $\mathrm{H}(45 \mathrm{~A})-\mathrm{C}(45)-\mathrm{H}(45 \mathrm{~B})$ & 109.2 \\
\hline $\mathrm{C}\left(43^{\prime}\right)-\mathrm{C}(42)-\mathrm{H}(42 \mathrm{C})$ & 110.7 & $\mathrm{C}(46)-\mathrm{C}(45)-\mathrm{H}(45 \mathrm{~A})$ & 111.3 \\
\hline $\mathrm{C}\left(43^{\prime}\right)-\mathrm{C}(42)-\mathrm{H}(42 \mathrm{D})$ & 110.7 & $\mathrm{C}(46)-\mathrm{C}(45)-\mathrm{H}(45 \mathrm{~B})$ & 111.3 \\
\hline $\mathrm{C}(42)-\mathrm{C}(43)-\mathrm{H}(43 \mathrm{~A})$ & 111.3 & $\mathrm{C}(45)-\mathrm{C}(46)-\mathrm{H}(46 \mathrm{~A})$ & 111.0 \\
\hline $\mathrm{C}(42)-\mathrm{C}(43)-\mathrm{H}(43 \mathrm{~B})$ & 111.3 & $\mathrm{C}(45)-\mathrm{C}(46)-\mathrm{H}(46 \mathrm{~B})$ & 111.0 \\
\hline$C(42)-C(43)-C(44)$ & $102.2(3)$ & $C(45)-C(46)-C(47)$ & $103.7(4)$ \\
\hline H(43A)-C(43)-H(43B) & 109.2 & $\mathrm{H}(46 \mathrm{~A})-\mathrm{C}(46)-\mathrm{H}(46 \mathrm{~B})$ & 109.0 \\
\hline $\mathrm{C}(44)-\mathrm{C}(43)-\mathrm{H}(43 \mathrm{~A})$ & 111.3 & $\mathrm{C}(47)-\mathrm{C}(46)-\mathrm{H}(46 \mathrm{~A})$ & 111.0 \\
\hline C(44)-C(43)-H(43B) & 111.3 & $\mathrm{C}(47)-\mathrm{C}(46)-\mathrm{H}(46 \mathrm{~B})$ & 111.0 \\
\hline
\end{tabular}




\begin{tabular}{|c|c|c|c|}
\hline $\mathrm{O}(4)-\mathrm{C}\left(45^{\prime}\right)-\mathrm{H}(45 \mathrm{C})$ & 109.6 & $\mathrm{O}(5)-\mathrm{C}(49)-\mathrm{C}(50)$ & $104.4(2)$ \\
\hline $\mathrm{O}(4)-\mathrm{C}\left(45^{\prime}\right)-\mathrm{H}(45 \mathrm{D})$ & 109.6 & $\mathrm{H}(49 \mathrm{~A})-\mathrm{C}(49)-\mathrm{H}(49 \mathrm{~B})$ & 108.9 \\
\hline $\mathrm{O}(4)-\mathrm{C}\left(45^{\prime}\right)-\mathrm{C}\left(46^{\prime}\right)$ & $110.5(14)$ & $\mathrm{C}(50)-\mathrm{C}(49)-\mathrm{H}(49 \mathrm{~A})$ & 110.9 \\
\hline $\mathrm{H}(45 \mathrm{C})-\mathrm{C}\left(45^{\prime}\right)-\mathrm{H}(45 \mathrm{D})$ & 108.1 & $\mathrm{C}(50)-\mathrm{C}(49)-\mathrm{H}(49 \mathrm{~B})$ & 110.9 \\
\hline $\mathrm{C}\left(46^{\prime}\right)-\mathrm{C}\left(45^{\prime}\right)-\mathrm{H}(45 \mathrm{C})$ & 109.6 & $\mathrm{C}(49)-\mathrm{C}(50)-\mathrm{H}(50 \mathrm{~A})$ & 111.4 \\
\hline $\mathrm{C}\left(46^{\prime}\right)-\mathrm{C}\left(45^{\prime}\right)-\mathrm{H}(45 \mathrm{D})$ & 109.6 & $\mathrm{C}(49)-\mathrm{C}(50)-\mathrm{H}(50 \mathrm{~B})$ & 111.4 \\
\hline $\mathrm{C}\left(45^{\prime}\right)-\mathrm{C}\left(46^{\prime}\right)-\mathrm{H}(46 \mathrm{C})$ & 112.8 & $\mathrm{C}(49)-\mathrm{C}(50)-\mathrm{C}(51)$ & $101.6(2)$ \\
\hline $\mathrm{C}\left(45^{\prime}\right)-\mathrm{C}\left(46^{\prime}\right)-\mathrm{H}(46 \mathrm{D})$ & 112.8 & $\mathrm{H}(50 \mathrm{~A})-\mathrm{C}(50)-\mathrm{H}(50 \mathrm{~B})$ & 109.3 \\
\hline$C\left(45^{\prime}\right)-C\left(46^{\prime}\right)-C(47)$ & $94.7(9)$ & $\mathrm{C}(51)-\mathrm{C}(50)-\mathrm{H}(50 \mathrm{~A})$ & 111.4 \\
\hline $\mathrm{H}(46 \mathrm{C})-\mathrm{C}\left(46^{\prime}\right)-\mathrm{H}(46 \mathrm{D})$ & 110.2 & $\mathrm{C}(51)-\mathrm{C}(50)-\mathrm{H}(50 \mathrm{~B})$ & 111.4 \\
\hline $\mathrm{C}(47)-\mathrm{C}\left(46^{\prime}\right)-\mathrm{H}(46 \mathrm{C})$ & 112.8 & $\mathrm{C}(50)-\mathrm{C}(51)-\mathrm{H}(51 \mathrm{~A})$ & 111.4 \\
\hline $\mathrm{C}(47)-\mathrm{C}\left(46^{\prime}\right)-\mathrm{H}(46 \mathrm{D})$ & 112.8 & $\mathrm{C}(50)-\mathrm{C}(51)-\mathrm{H}(51 \mathrm{~B})$ & 111.4 \\
\hline $\mathrm{C}(46)-\mathrm{C}(47)-\mathrm{H}(47 \mathrm{~A})$ & 111.0 & $\mathrm{H}(51 \mathrm{~A})-\mathrm{C}(51)-\mathrm{H}(51 \mathrm{~B})$ & 109.3 \\
\hline $\mathrm{C}(46)-\mathrm{C}(47)-\mathrm{H}(47 \mathrm{~B})$ & 111.0 & $\mathrm{C}(52)-\mathrm{C}(51)-\mathrm{C}(50)$ & $101.8(2)$ \\
\hline $\mathrm{C}\left(46^{\prime}\right)-\mathrm{C}(47)-\mathrm{H}(47 \mathrm{C})$ & 109.5 & $\mathrm{C}(52)-\mathrm{C}(51)-\mathrm{H}(51 \mathrm{~A})$ & 111.4 \\
\hline $\mathrm{C}\left(46^{\prime}\right)-\mathrm{C}(47)-\mathrm{H}(47 \mathrm{D})$ & 109.5 & $\mathrm{C}(52)-\mathrm{C}(51)-\mathrm{H}(51 \mathrm{~B})$ & 111.4 \\
\hline $\mathrm{C}\left(46^{\prime}\right)-\mathrm{C}(47)-\mathrm{C}(48)$ & $110.6(9)$ & $\mathrm{O}(5)-\mathrm{C}(52)-\mathrm{C}(51)$ & $106.3(2)$ \\
\hline $\mathrm{H}(47 \mathrm{~A})-\mathrm{C}(47)-\mathrm{H}(47 \mathrm{~B})$ & 109.0 & $\mathrm{O}(5)-\mathrm{C}(52)-\mathrm{H}(52 \mathrm{~A})$ & 110.5 \\
\hline $\mathrm{H}(47 \mathrm{C})-\mathrm{C}(47)-\mathrm{H}(47 \mathrm{D})$ & 108.1 & $\mathrm{O}(5)-\mathrm{C}(52)-\mathrm{H}(52 \mathrm{~B})$ & 110.5 \\
\hline$C(48)-C(47)-C(46)$ & $103.6(3)$ & $\mathrm{C}(51)-\mathrm{C}(52)-\mathrm{H}(52 \mathrm{~A})$ & 110.5 \\
\hline $\mathrm{C}(48)-\mathrm{C}(47)-\mathrm{H}(47 \mathrm{~A})$ & 111.0 & $\mathrm{C}(51)-\mathrm{C}(52)-\mathrm{H}(52 \mathrm{~B})$ & 110.5 \\
\hline $\mathrm{C}(48)-\mathrm{C}(47)-\mathrm{H}(47 \mathrm{~B})$ & 111.0 & $\mathrm{H}(52 \mathrm{~A})-\mathrm{C}(52)-\mathrm{H}(52 \mathrm{~B})$ & 108.7 \\
\hline $\mathrm{C}(48)-\mathrm{C}(47)-\mathrm{H}(47 \mathrm{C})$ & 109.5 & $\mathrm{C}(56)-\mathrm{O}(6)-\mathrm{C}(53)$ & $109.2(3)$ \\
\hline $\mathrm{C}(48)-\mathrm{C}(47)-\mathrm{H}(47 \mathrm{D})$ & 109.5 & $\mathrm{O}(6)-\mathrm{C}(53)-\mathrm{H}(53 \mathrm{~A})$ & 110.3 \\
\hline $\mathrm{O}(4)-\mathrm{C}(48)-\mathrm{C}(47)$ & $106.6(2)$ & $\mathrm{O}(6)-\mathrm{C}(53)-\mathrm{H}(53 \mathrm{~B})$ & 110.3 \\
\hline $\mathrm{O}(4)-\mathrm{C}(48)-\mathrm{H}(48 \mathrm{~A})$ & 110.4 & $\mathrm{O}(6)-\mathrm{C}(53)-\mathrm{C}(54)$ & $107.1(3)$ \\
\hline $\mathrm{O}(4)-\mathrm{C}(48)-\mathrm{H}(48 \mathrm{~B})$ & 110.4 & $\mathrm{H}(53 \mathrm{~A})-\mathrm{C}(53)-\mathrm{H}(53 \mathrm{~B})$ & 108.5 \\
\hline $\mathrm{C}(47)-\mathrm{C}(48)-\mathrm{H}(48 \mathrm{~A})$ & 110.4 & $\mathrm{C}(54)-\mathrm{C}(53)-\mathrm{H}(53 \mathrm{~A})$ & 110.3 \\
\hline $\mathrm{C}(47)-\mathrm{C}(48)-\mathrm{H}(48 \mathrm{~B})$ & 110.4 & $\mathrm{C}(54)-\mathrm{C}(53)-\mathrm{H}(53 \mathrm{~B})$ & 110.3 \\
\hline $\mathrm{H}(48 \mathrm{~A})-\mathrm{C}(48)-\mathrm{H}(48 \mathrm{~B})$ & 108.6 & $\mathrm{C}(53)-\mathrm{C}(54)-\mathrm{H}(54 \mathrm{~A})$ & 111.3 \\
\hline $\mathrm{C}(49)-\mathrm{O}(5)-\mathrm{Mg}(1)$ & $126.12(16)$ & $\mathrm{C}(53)-\mathrm{C}(54)-\mathrm{H}(54 \mathrm{~B})$ & 111.3 \\
\hline $\mathrm{C}(52)-\mathrm{O}(5)-\mathrm{Mg}(1)$ & $125.12(15)$ & $\mathrm{C}(53)-\mathrm{C}(54)-\mathrm{C}(55)$ & $102.4(3)$ \\
\hline $\mathrm{C}(52)-\mathrm{O}(5)-\mathrm{C}(49)$ & 108.70(19) & $\mathrm{H}(54 \mathrm{~A})-\mathrm{C}(54)-\mathrm{H}(54 \mathrm{~B})$ & 109.2 \\
\hline $\mathrm{O}(5)-\mathrm{C}(49)-\mathrm{H}(49 \mathrm{~A})$ & 110.9 & $\mathrm{C}(55)-\mathrm{C}(54)-\mathrm{H}(54 \mathrm{~A})$ & 111.3 \\
\hline $\mathrm{O}(5)-\mathrm{C}(49)-\mathrm{H}(49 \mathrm{~B})$ & 110.9 & $\mathrm{C}(55)-\mathrm{C}(54)-\mathrm{H}(54 \mathrm{~B})$ & 111.3 \\
\hline
\end{tabular}




\begin{tabular}{|c|c|c|c|}
\hline $\mathrm{C}(54)-\mathrm{C}(55)-\mathrm{H}(55 \mathrm{~A})$ & 111.4 & $\mathrm{C}(59)-\mathrm{C}(60)-\mathrm{H}(60 \mathrm{~B})$ & 111.5 \\
\hline $\mathrm{C}(54)-\mathrm{C}(55)-\mathrm{H}(55 \mathrm{~B})$ & 111.4 & $\mathrm{H}(60 \mathrm{~A})-\mathrm{C}(60)-\mathrm{H}(60 \mathrm{~B})$ & 109.3 \\
\hline $\mathrm{H}(55 \mathrm{~A})-\mathrm{C}(55)-\mathrm{H}(55 \mathrm{~B})$ & 109.3 & $\mathrm{C}(61)-\mathrm{O}(8)-\mathrm{C}(64)$ & $106.2(10)$ \\
\hline$C(56)-C(55)-C(54)$ & $101.9(3)$ & $\mathrm{O}(8)-\mathrm{C}(61)-\mathrm{H}(61 \mathrm{~A})$ & 110.2 \\
\hline $\mathrm{C}(56)-\mathrm{C}(55)-\mathrm{H}(55 \mathrm{~A})$ & 111.4 & $\mathrm{O}(8)-\mathrm{C}(61)-\mathrm{H}(61 \mathrm{~B})$ & 110.2 \\
\hline $\mathrm{C}(56)-\mathrm{C}(55)-\mathrm{H}(55 \mathrm{~B})$ & 111.4 & $\mathrm{O}(8)-\mathrm{C}(61)-\mathrm{C}(62)$ & $107.7(13)$ \\
\hline $\mathrm{O}(6)-\mathrm{C}(56)-\mathrm{C}(55)$ & $109.7(4)$ & $\mathrm{H}(61 \mathrm{~A})-\mathrm{C}(61)-\mathrm{H}(61 \mathrm{~B})$ & 108.5 \\
\hline $\mathrm{O}(6)-\mathrm{C}(56)-\mathrm{H}(56 \mathrm{~A})$ & 109.7 & $\mathrm{C}(62)-\mathrm{C}(61)-\mathrm{H}(61 \mathrm{~A})$ & 110.2 \\
\hline $\mathrm{O}(6)-\mathrm{C}(56)-\mathrm{H}(56 \mathrm{~B})$ & 109.7 & $\mathrm{C}(62)-\mathrm{C}(61)-\mathrm{H}(61 \mathrm{~B})$ & 110.2 \\
\hline $\mathrm{C}(55)-\mathrm{C}(56)-\mathrm{H}(56 \mathrm{~A})$ & 109.7 & $\mathrm{C}(61)-\mathrm{C}(62)-\mathrm{H}(62 \mathrm{~A})$ & 110.9 \\
\hline $\mathrm{C}(55)-\mathrm{C}(56)-\mathrm{H}(56 \mathrm{~B})$ & 109.7 & $\mathrm{C}(61)-\mathrm{C}(62)-\mathrm{H}(62 \mathrm{~B})$ & 110.9 \\
\hline $\mathrm{H}(56 \mathrm{~A})-\mathrm{C}(56)-\mathrm{H}(56 \mathrm{~B})$ & 108.2 & $\mathrm{C}(61)-\mathrm{C}(62)-\mathrm{C}(63)$ & $104.1(10)$ \\
\hline $\mathrm{C}(60)-\mathrm{O}(7)-\mathrm{C}(57)$ & $104.2(14)$ & $\mathrm{H}(62 \mathrm{~A})-\mathrm{C}(62)-\mathrm{H}(62 \mathrm{~B})$ & 109.0 \\
\hline $\mathrm{O}(7)-\mathrm{C}(57)-\mathrm{H}(57 \mathrm{~A})$ & 110.6 & $\mathrm{C}(63)-\mathrm{C}(62)-\mathrm{H}(62 \mathrm{~A})$ & 110.9 \\
\hline $\mathrm{O}(7)-\mathrm{C}(57)-\mathrm{H}(57 \mathrm{~B})$ & 110.6 & $\mathrm{C}(63)-\mathrm{C}(62)-\mathrm{H}(62 \mathrm{~B})$ & 110.9 \\
\hline $\mathrm{O}(7)-\mathrm{C}(57)-\mathrm{C}(58)$ & $105.7(11)$ & $\mathrm{C}(62)-\mathrm{C}(63)-\mathrm{H}(63 \mathrm{~A})$ & 110.6 \\
\hline $\mathrm{H}(57 \mathrm{~A})-\mathrm{C}(57)-\mathrm{H}(57 \mathrm{~B})$ & 108.7 & $\mathrm{C}(62)-\mathrm{C}(63)-\mathrm{H}(63 \mathrm{~B})$ & 110.6 \\
\hline $\mathrm{C}(58)-\mathrm{C}(57)-\mathrm{H}(57 \mathrm{~A})$ & 110.6 & $\mathrm{C}(62)-\mathrm{C}(63)-\mathrm{C}(64)$ & $105.5(9)$ \\
\hline $\mathrm{C}(58)-\mathrm{C}(57)-\mathrm{H}(57 \mathrm{~B})$ & 110.6 & $H(63 A)-C(63)-H(63 B)$ & 108.8 \\
\hline $\mathrm{C}(57)-\mathrm{C}(58)-\mathrm{H}(58 \mathrm{~A})$ & 111.0 & $\mathrm{C}(64)-\mathrm{C}(63)-\mathrm{H}(63 \mathrm{~A})$ & 110.6 \\
\hline $\mathrm{C}(57)-\mathrm{C}(58)-\mathrm{H}(58 \mathrm{~B})$ & 111.0 & $\mathrm{C}(64)-\mathrm{C}(63)-\mathrm{H}(63 \mathrm{~B})$ & 110.6 \\
\hline $\mathrm{H}(58 \mathrm{~A})-\mathrm{C}(58)-\mathrm{H}(58 \mathrm{~B})$ & 109.0 & $\mathrm{O}(8)-\mathrm{C}(64)-\mathrm{C}(63)$ & $104.9(12)$ \\
\hline $\mathrm{C}(59)-\mathrm{C}(58)-\mathrm{C}(57)$ & $103.7(9)$ & $\mathrm{O}(8)-\mathrm{C}(64)-\mathrm{H}(64 \mathrm{~A})$ & 110.8 \\
\hline $\mathrm{C}(59)-\mathrm{C}(58)-\mathrm{H}(58 \mathrm{~A})$ & 111.0 & $\mathrm{O}(8)-\mathrm{C}(64)-\mathrm{H}(64 \mathrm{~B})$ & 110.8 \\
\hline $\mathrm{C}(59)-\mathrm{C}(58)-\mathrm{H}(58 \mathrm{~B})$ & 111.0 & $\mathrm{C}(63)-\mathrm{C}(64)-\mathrm{H}(64 \mathrm{~A})$ & 110.8 \\
\hline $\mathrm{C}(58)-\mathrm{C}(59)-\mathrm{H}(59 \mathrm{~A})$ & 111.1 & $\mathrm{C}(63)-\mathrm{C}(64)-\mathrm{H}(64 \mathrm{~B})$ & 110.8 \\
\hline $\mathrm{C}(58)-\mathrm{C}(59)-\mathrm{H}(59 \mathrm{~B})$ & 111.1 & $\mathrm{H}(64 \mathrm{~A})-\mathrm{C}(64)-\mathrm{H}(64 \mathrm{~B})$ & 108.8 \\
\hline H(59A)-C(59)-H(59B) & 109.0 & $\mathrm{C}\left(60^{\prime}\right)-\mathrm{O}\left(7^{\prime}\right)-\mathrm{C}\left(57^{\prime}\right)$ & $108.5(13)$ \\
\hline $\mathrm{C}(60)-\mathrm{C}(59)-\mathrm{C}(58)$ & $103.5(10)$ & $\mathrm{O}\left(7^{\prime}\right)-\mathrm{C}\left(57^{\prime}\right)-\mathrm{H}(57 \mathrm{C})$ & 110.9 \\
\hline $\mathrm{C}(60)-\mathrm{C}(59)-\mathrm{H}(59 \mathrm{~A})$ & 111.1 & $\mathrm{O}\left(7^{\prime}\right)-\mathrm{C}\left(57^{\prime}\right)-\mathrm{H}(57 \mathrm{D})$ & 110.9 \\
\hline $\mathrm{C}(60)-\mathrm{C}(59)-\mathrm{H}(59 \mathrm{~B})$ & 111.1 & $\mathrm{O}\left(7^{\prime}\right)-\mathrm{C}\left(57^{\prime}\right)-\mathrm{C}\left(58^{\prime}\right)$ & $104.5(14)$ \\
\hline $\mathrm{O}(7)-\mathrm{C}(60)-\mathrm{C}(59)$ & $101.4(14)$ & $\mathrm{H}(57 \mathrm{C})-\mathrm{C}\left(57^{\prime}\right)-\mathrm{H}(57 \mathrm{D})$ & 108.9 \\
\hline $\mathrm{O}(7)-\mathrm{C}(60)-\mathrm{H}(60 \mathrm{~A})$ & 111.5 & $\mathrm{C}\left(58^{\prime}\right)-\mathrm{C}\left(57^{\prime}\right)-\mathrm{H}(57 \mathrm{C})$ & 110.9 \\
\hline $\mathrm{O}(7)-\mathrm{C}(60)-\mathrm{H}(60 \mathrm{~B})$ & 111.5 & $\mathrm{C}\left(58^{\prime}\right)-\mathrm{C}\left(57^{\prime}\right)-\mathrm{H}(57 \mathrm{D})$ & 110.9 \\
\hline $\mathrm{C}(59)-\mathrm{C}(60)-\mathrm{H}(60 \mathrm{~A})$ & 111.5 & $\mathrm{C}\left(57^{\prime}\right)-\mathrm{C}\left(58^{\prime}\right)-\mathrm{H}(58 \mathrm{C})$ & 112.2 \\
\hline
\end{tabular}




$\begin{array}{llll}\mathrm{C}\left(57^{\prime}\right)-\mathrm{C}\left(58^{\prime}\right)-\mathrm{H}(58 \mathrm{D}) & 112.2 & \mathrm{H}(61 \mathrm{C})-\mathrm{C}\left(61^{\prime}\right)-\mathrm{H}(61 \mathrm{D}) & 108.5 \\ \mathrm{C}\left(57^{\prime}\right)-\mathrm{C}\left(58^{\prime}\right)-\mathrm{C}\left(59^{\prime}\right) & 98.0(18) & \mathrm{C}\left(62^{\prime}\right)-\mathrm{C}\left(61^{\prime}\right)-\mathrm{H}(61 \mathrm{C}) & 110.2 \\ \mathrm{H}(58 \mathrm{C})-\mathrm{C}\left(58^{\prime}\right)-\mathrm{H}(58 \mathrm{D}) & 109.8 & \mathrm{C}\left(62^{\prime}\right)-\mathrm{C}\left(61^{\prime}\right)-\mathrm{H}(61 \mathrm{D}) & 110.2 \\ \mathrm{C}\left(59^{\prime}\right)-\mathrm{C}\left(58^{\prime}\right)-\mathrm{H}(58 \mathrm{C}) & 112.2 & \mathrm{C}\left(61^{\prime}\right)-\mathrm{C}\left(62^{\prime}\right)-\mathrm{H}(62 \mathrm{C}) & 111.0 \\ \mathrm{C}\left(59^{\prime}\right)-\mathrm{C}\left(58^{\prime}\right)-\mathrm{H}(58 \mathrm{D}) & 112.2 & \mathrm{C}\left(61^{\prime}\right)-\mathrm{C}\left(62^{\prime}\right)-\mathrm{H}(62 \mathrm{D}) & 111.0 \\ \mathrm{C}\left(58^{\prime}\right)-\mathrm{C}\left(59^{\prime}\right)-\mathrm{H}(59 \mathrm{C}) & 112.1 & \mathrm{C}\left(61^{\prime}\right)-\mathrm{C}\left(62^{\prime}\right)-\mathrm{C}\left(63^{\prime}\right) & 103.6(10) \\ \mathrm{C}\left(58^{\prime}\right)-\mathrm{C}\left(59^{\prime}\right)-\mathrm{H}(59 \mathrm{D}) & 112.1 & \mathrm{H}(62 \mathrm{C})-\mathrm{C}\left(62^{\prime}\right)-\mathrm{H}(62 \mathrm{D}) & 109.0 \\ \mathrm{H}(59 \mathrm{C})-\mathrm{C}\left(59^{\prime}\right)-\mathrm{H}(59 \mathrm{D}) & 109.8 & \mathrm{C}\left(63^{\prime}\right)-\mathrm{C}\left(62^{\prime}\right)-\mathrm{H}(62 \mathrm{C}) & 111.0 \\ \mathrm{C}\left(60^{\prime}\right)-\mathrm{C}\left(59^{\prime}\right)-\mathrm{C}\left(58^{\prime}\right) & 98.1(16) & \mathrm{C}\left(63^{\prime}\right)-\mathrm{C}\left(62^{\prime}\right)-\mathrm{H}(62 \mathrm{D}) & 111.0 \\ \mathrm{C}\left(60^{\prime}\right)-\mathrm{C}\left(59^{\prime}\right)-\mathrm{H}(59 \mathrm{C}) & 112.1 & \mathrm{C}\left(62^{\prime}\right)-\mathrm{C}\left(63^{\prime}\right)-\mathrm{H}(63 \mathrm{C}) & 110.8 \\ \mathrm{C}\left(60^{\prime}\right)-\mathrm{C}\left(59^{\prime}\right)-\mathrm{H}(59 \mathrm{D}) & 112.1 & \mathrm{C}\left(62^{\prime}\right)-\mathrm{C}\left(63^{\prime}\right)-\mathrm{H}(63 \mathrm{D}) & 110.8 \\ \mathrm{O}\left(7^{\prime}\right)-\mathrm{C}\left(60^{\prime}\right)-\mathrm{C}\left(59^{\prime}\right) & 101.9(17) & \mathrm{C}\left(62^{\prime}\right)-\mathrm{C}\left(63^{\prime}\right)-\mathrm{C}\left(64^{\prime}\right) & 104.8(10) \\ \mathrm{O}\left(7^{\prime}\right)-\mathrm{C}\left(60^{\prime}\right)-\mathrm{H}(60 \mathrm{C}) & 111.4 & \mathrm{H}(63 \mathrm{C})-\mathrm{C}\left(63^{\prime}\right)-\mathrm{H}(63 \mathrm{D}) & 108.9 \\ \mathrm{O}\left(7^{\prime}\right)-\mathrm{C}\left(60^{\prime}\right)-\mathrm{H}(60 \mathrm{D}) & 111.4 & \mathrm{C}\left(64^{\prime}\right)-\mathrm{C}\left(63^{\prime}\right)-\mathrm{H}(63 \mathrm{C}) & 110.8 \\ \mathrm{C}\left(59^{\prime}\right)-\mathrm{C}\left(60^{\prime}\right)-\mathrm{H}(60 \mathrm{C}) & 111.4 & \mathrm{C}\left(64^{\prime}\right)-\mathrm{C}\left(63^{\prime}\right)-\mathrm{H}(63 \mathrm{D}) & 110.8 \\ \mathrm{C}^{\prime}\left(59^{\prime}\right)-\mathrm{C}\left(60^{\prime}\right)-\mathrm{H}(60 \mathrm{D}) & 111.4 & \mathrm{O}\left(8^{\prime}\right)-\mathrm{C}\left(64^{\prime}\right)-\mathrm{C}\left(63^{\prime}\right) & 105.3(13) \\ \mathrm{H}^{\prime}(60 \mathrm{C})-\mathrm{C}\left(60^{\prime}\right)-\mathrm{H}(60 \mathrm{D}) & 109.2 & \mathrm{O}\left(8^{\prime}\right)-\mathrm{C}\left(64^{\prime}\right)-\mathrm{H}(64 \mathrm{C}) & 110.7 \\ \mathrm{C}\left(61^{\prime}\right)-\mathrm{O}\left(8^{\prime}\right)-\mathrm{C}\left(64^{\prime}\right) & 102.5(10) & \mathrm{O}\left(8^{\prime}\right)-\mathrm{C}\left(64^{\prime}\right)-\mathrm{H}(64 \mathrm{D}) & 110.7 \\ \mathrm{O}\left(8^{\prime}\right)-\mathrm{C}\left(61^{\prime}\right)-\mathrm{H}(61 \mathrm{C}) & 110.2 & \mathrm{C}\left(63^{\prime}\right)-\mathrm{C}\left(64^{\prime}\right)-\mathrm{H}(64 \mathrm{C}) & 110.7 \\ \mathrm{O}\left(8^{\prime}\right)-\mathrm{C}\left(61^{\prime}\right)-\mathrm{H}(61 \mathrm{D}) & 110.2 & \mathrm{C}\left(63^{\prime}\right)-\mathrm{C}\left(64^{\prime}\right)-\mathrm{H}(64 \mathrm{D}) & 110.7 \\ \mathrm{O}\left(8^{\prime}\right)-\mathrm{C}\left(61^{\prime}\right)-\mathrm{C}\left(62^{\prime}\right) & 107.4(15) & \mathrm{H}(64 \mathrm{C})-\mathrm{C}\left(64^{\prime}\right)-\mathrm{H}(64 \mathrm{D}) & 108.8 \\ & & & \end{array}$


Table 4. Anisotropic displacement parameters $\left(\AA^{2} \times 10^{3}\right)$ for neipn25. The anisotropic displacement factor exponent takes the form: $-2 \pi^{2}\left[h^{2} a^{* 2} U_{11}+\ldots+2 h \mathrm{k} \mathrm{a}^{*} \mathrm{~b}^{*} \mathrm{U}_{12}\right]$

\begin{tabular}{|c|c|c|c|c|c|c|}
\hline & $\mathrm{U}_{11}$ & $\mathrm{U}_{22}$ & $\mathrm{U}_{33}$ & $\mathrm{U}_{23}$ & $\mathrm{U}_{13}$ & $\mathrm{U}_{12}$ \\
\hline $\mathrm{Fe} 1$ & $37(1)$ & $31(1)$ & $43(1)$ & $-9(1)$ & $-10(1)$ & $6(1)$ \\
\hline $\mathrm{C} 1$ & $42(1)$ & $30(1)$ & $57(2)$ & $-12(1)$ & $-12(1)$ & $8(1)$ \\
\hline $\mathrm{C} 2$ & $42(1)$ & $29(1)$ & $48(1)$ & $-5(1)$ & $-17(1)$ & $3(1)$ \\
\hline C3 & $41(1)$ & $30(1)$ & $47(1)$ & $-9(1)$ & $-16(1)$ & $4(1)$ \\
\hline $\mathrm{C} 4$ & $45(1)$ & $35(1)$ & $46(1)$ & $-12(1)$ & $-14(1)$ & $2(1)$ \\
\hline $\mathrm{C} 5$ & $51(2)$ & $38(1)$ & $60(2)$ & $-16(1)$ & $-23(1)$ & $1(1)$ \\
\hline C6 & $44(1)$ & $44(1)$ & $68(2)$ & $-15(1)$ & $-18(1)$ & $-3(1)$ \\
\hline $\mathrm{C} 7$ & $44(1)$ & $44(1)$ & $56(2)$ & $-13(1)$ & $-9(1)$ & $0(1)$ \\
\hline $\mathrm{C} 8$ & $47(1)$ & $35(1)$ & $48(1)$ & $-11(1)$ & $-16(1)$ & $1(1)$ \\
\hline C9 & $38(1)$ & $37(1)$ & $54(2)$ & $-12(1)$ & $-17(1)$ & $4(1)$ \\
\hline $\mathrm{C} 10$ & $31(1)$ & $34(1)$ & $50(1)$ & $-11(1)$ & $-9(1)$ & $2(1)$ \\
\hline C11 & $27(1)$ & $33(1)$ & $53(1)$ & $-11(1)$ & $-10(1)$ & $2(1)$ \\
\hline $\mathrm{C} 12$ & $34(1)$ & $35(1)$ & $53(2)$ & $-9(1)$ & $-9(1)$ & $2(1)$ \\
\hline $\mathrm{C} 13$ & $34(1)$ & $33(1)$ & $69(2)$ & $-10(1)$ & $-9(1)$ & $1(1)$ \\
\hline $\mathrm{C} 14$ & $32(1)$ & $36(1)$ & $83(2)$ & $-23(1)$ & $-10(1)$ & $1(1)$ \\
\hline $\mathrm{C} 15$ & $36(1)$ & $48(2)$ & $64(2)$ & $-24(1)$ & $-11(1)$ & $3(1)$ \\
\hline C16 & $33(1)$ & $39(1)$ & $53(2)$ & $-12(1)$ & $-9(1)$ & $1(1)$ \\
\hline $\mathrm{C} 17$ & $40(1)$ & $35(1)$ & $64(2)$ & $-6(1)$ & $-10(1)$ & $-2(1)$ \\
\hline $\mathrm{C} 18$ & $34(1)$ & $35(1)$ & $53(2)$ & $-14(1)$ & $-10(1)$ & $-2(1)$ \\
\hline C19 & $36(1)$ & $34(1)$ & $54(2)$ & $-12(1)$ & $-11(1)$ & $-3(1)$ \\
\hline $\mathrm{C} 20$ & $39(1)$ & $44(1)$ & $54(2)$ & $-9(1)$ & $-9(1)$ & $-1(1)$ \\
\hline $\mathrm{C} 21$ & $37(1)$ & $48(2)$ & $64(2)$ & $-15(1)$ & $-12(1)$ & $2(1)$ \\
\hline $\mathrm{C} 22$ & $44(1)$ & $41(1)$ & $66(2)$ & $-10(1)$ & $-23(1)$ & $1(1)$ \\
\hline $\mathrm{C} 23$ & $51(2)$ & $45(1)$ & $52(2)$ & $-5(1)$ & $-18(1)$ & $-15(1)$ \\
\hline $\mathrm{C} 24$ & $43(1)$ & $46(1)$ & $52(2)$ & $-14(1)$ & $-9(1)$ & $-12(1)$ \\
\hline $\mathrm{C} 25$ & $46(2)$ & $49(2)$ & $51(2)$ & $-11(2)$ & $-1(2)$ & $2(2)$ \\
\hline $\mathrm{C} 26$ & $42(3)$ & $43(2)$ & $41(2)$ & $-13(1)$ & $-8(2)$ & $2(2)$ \\
\hline $\mathrm{C} 27$ & $42(3)$ & $43(2)$ & $41(2)$ & $-9(2)$ & $-3(2)$ & $-2(2)$ \\
\hline $\mathrm{C} 28$ & $51(2)$ & $44(4)$ & $49(3)$ & $-4(2)$ & $-2(2)$ & $-3(2)$ \\
\hline $\mathrm{C} 29$ & $65(3)$ & $43(3)$ & $46(3)$ & $-9(2)$ & $-1(2)$ & $-3(3)$ \\
\hline
\end{tabular}




\begin{tabular}{|c|c|c|c|c|c|c|}
\hline $\mathrm{C} 30$ & $72(2)$ & $42(2)$ & $43(2)$ & $-5(2)$ & $-10(2)$ & $11(2)$ \\
\hline $\mathrm{C} 31$ & $60(4)$ & $57(2)$ & $48(2)$ & $-14(1)$ & $-18(3)$ & $10(2)$ \\
\hline C32 & $50(4)$ & $50(2)$ & $43(2)$ & $-14(2)$ & $-11(3)$ & $5(3)$ \\
\hline C25' & $83(8)$ & $44(5)$ & $47(5)$ & $-22(4)$ & $-14(5)$ & $13(5)$ \\
\hline C26' & $42(3)$ & $43(2)$ & $41(2)$ & $-13(1)$ & $-8(2)$ & $2(2)$ \\
\hline C27' & $42(3)$ & $43(2)$ & $41(2)$ & $-9(2)$ & $-3(2)$ & $-2(2)$ \\
\hline C28' & $51(2)$ & $44(4)$ & $49(3)$ & $-4(2)$ & $-2(2)$ & $-3(2)$ \\
\hline C29' & $65(3)$ & $43(3)$ & $46(3)$ & $-9(2)$ & $-1(2)$ & $-3(3)$ \\
\hline C30' & $72(2)$ & $42(2)$ & $43(2)$ & $-5(2)$ & $-10(2)$ & $11(2)$ \\
\hline C31' & $60(4)$ & $57(2)$ & $48(2)$ & $-14(1)$ & $-18(3)$ & $10(2)$ \\
\hline C32' & $50(4)$ & $50(2)$ & $43(2)$ & $-14(2)$ & $-11(3)$ & $5(3)$ \\
\hline $\mathrm{Br} 1$ & $46(1)$ & $45(1)$ & $55(1)$ & $-2(1)$ & $-18(1)$ & $-13(1)$ \\
\hline $\mathrm{Cl1}$ & $46(1)$ & $45(1)$ & $55(1)$ & $-2(1)$ & $-18(1)$ & $-13(1)$ \\
\hline Mg1 & $33(1)$ & $30(1)$ & $46(1)$ & $-7(1)$ & $-8(1)$ & $-3(1)$ \\
\hline $\mathrm{O} 1$ & $34(1)$ & $34(1)$ & $50(1)$ & $-9(1)$ & $-15(1)$ & $2(1)$ \\
\hline C33 & $38(1)$ & $33(1)$ & $66(2)$ & $-9(1)$ & $-19(1)$ & $4(1)$ \\
\hline C34 & $49(2)$ & $40(1)$ & $64(2)$ & $-5(1)$ & $-27(1)$ & $-2(1)$ \\
\hline C35 & $47(2)$ & $47(2)$ & $60(2)$ & $-13(1)$ & $-22(1)$ & $-2(1)$ \\
\hline C36 & $44(1)$ & $41(1)$ & $51(2)$ & $-13(1)$ & $-15(1)$ & $1(1)$ \\
\hline $\mathrm{O} 2$ & $37(1)$ & $29(1)$ & $49(1)$ & $-6(1)$ & $-5(1)$ & $0(1)$ \\
\hline C37 & $33(1)$ & $38(1)$ & $53(2)$ & $-10(1)$ & $-5(1)$ & $-3(1)$ \\
\hline C38 & $36(1)$ & $42(1)$ & $62(2)$ & $-18(1)$ & $-8(1)$ & $-1(1)$ \\
\hline C39 & $42(1)$ & $34(1)$ & $71(2)$ & $-11(1)$ & $-12(1)$ & $2(1)$ \\
\hline $\mathrm{C} 40$ & $50(2)$ & $29(1)$ & $60(2)$ & $-3(1)$ & $-6(1)$ & $0(1)$ \\
\hline $\mathrm{O} 3$ & $40(1)$ & $40(1)$ & $43(1)$ & $-8(1)$ & $-9(1)$ & $-10(1)$ \\
\hline C41 & $43(1)$ & $42(1)$ & $53(2)$ & $-7(1)$ & $-15(1)$ & $-12(1)$ \\
\hline $\mathrm{C} 42$ & $59(2)$ & $56(2)$ & $55(2)$ & $-9(1)$ & $-9(1)$ & $-26(1)$ \\
\hline $\mathrm{C} 43$ & $56(2)$ & $58(2)$ & $50(2)$ & $-1(2)$ & $-11(2)$ & $-22(2)$ \\
\hline $\mathrm{C} 44$ & $59(2)$ & $63(3)$ & $42(2)$ & $-7(1)$ & $-8(1)$ & $-26(2)$ \\
\hline C43' & $56(2)$ & $58(2)$ & $50(2)$ & $-1(2)$ & $-11(2)$ & $-22(2)$ \\
\hline C44' & $59(2)$ & $63(3)$ & $42(2)$ & $-7(1)$ & $-8(1)$ & $-26(2)$ \\
\hline $\mathrm{O} 4$ & $36(1)$ & $37(1)$ & $68(1)$ & $-20(1)$ & $-9(1)$ & $-2(1)$ \\
\hline $\mathrm{C} 45$ & $40(2)$ & $38(2)$ & $50(2)$ & $-10(1)$ & $-9(1)$ & $-2(1)$ \\
\hline C46 & $61(2)$ & $58(3)$ & $45(2)$ & $-12(2)$ & $-4(2)$ & $-18(2)$ \\
\hline $\mathrm{C}^{\prime} 5^{\prime}$ & $40(2)$ & $38(2)$ & $50(2)$ & $-10(1)$ & $-9(1)$ & $-2(1)$ \\
\hline
\end{tabular}




\begin{tabular}{|c|c|c|c|c|c|c|}
\hline C46' & $61(2)$ & $58(3)$ & $45(2)$ & $-12(2)$ & $-4(2)$ & $-18(2)$ \\
\hline C47 & $57(2)$ & $46(1)$ & $46(2)$ & $-13(1)$ & $-11(1)$ & $-10(1)$ \\
\hline $\mathrm{C} 48$ & $51(2)$ & $34(1)$ & $53(2)$ & $-11(1)$ & $-10(1)$ & $-8(1)$ \\
\hline O5 & $36(1)$ & $34(1)$ & $49(1)$ & $-4(1)$ & $-10(1)$ & $-7(1)$ \\
\hline C49 & $40(1)$ & $42(1)$ & $61(2)$ & $-14(1)$ & $-10(1)$ & $-9(1)$ \\
\hline C50 & $42(1)$ & $40(1)$ & $65(2)$ & $-12(1)$ & $-4(1)$ & $-10(1)$ \\
\hline C51 & $48(2)$ & $34(1)$ & $64(2)$ & $-6(1)$ & $2(1)$ & $-4(1)$ \\
\hline C52 & $39(1)$ & $35(1)$ & $52(2)$ & 1(1) & $-7(1)$ & $-2(1)$ \\
\hline O6 & $91(2)$ & $77(2)$ & $57(1)$ & $-9(1)$ & $-12(1)$ & $-10(1)$ \\
\hline C53 & $74(2)$ & $83(3)$ & $69(2)$ & $-20(2)$ & $-24(2)$ & $-11(2)$ \\
\hline C54 & $69(2)$ & $53(2)$ & $59(2)$ & $-10(1)$ & $-16(2)$ & $-12(2)$ \\
\hline C55 & $118(3)$ & $68(2)$ & $64(2)$ & $-20(2)$ & $-4(2)$ & $-36(2)$ \\
\hline C56 & 193(6) & $71(3)$ & $72(3)$ & $-24(2)$ & $18(3)$ & $-57(3)$ \\
\hline O7 & $103(3)$ & $113(3)$ & $89(3)$ & $-14(2)$ & $-25(2)$ & $-38(2)$ \\
\hline C57 & $179(8)$ & $51(4)$ & $86(3)$ & $-15(2)$ & $-65(4)$ & $-16(5)$ \\
\hline C58 & $132(5)$ & $74(6)$ & $68(4)$ & $-1(3)$ & $-35(3)$ & $-47(5)$ \\
\hline C59 & $88(5)$ & $69(4)$ & $69(4)$ & $-29(3)$ & $3(3)$ & $-28(3)$ \\
\hline C60 & $104(8)$ & $131(8)$ & $65(4)$ & $-24(5)$ & $-3(6)$ & $-52(6)$ \\
\hline $\mathrm{O} 8$ & $61(2)$ & $64(2)$ & $69(2)$ & $-25(2)$ & $-6(2)$ & $-8(2)$ \\
\hline C61 & $75(5)$ & $58(4)$ & $89(8)$ & $-33(4)$ & $-9(4)$ & $-8(3)$ \\
\hline C62 & $72(3)$ & $73(10)$ & $81(3)$ & $-30(5)$ & $6(2)$ & $-19(4)$ \\
\hline C63 & $67(4)$ & $55(10)$ & $78(3)$ & $-16(4)$ & $-9(5)$ & $-1(5)$ \\
\hline C64 & $72(6)$ & $75(7)$ & $82(5)$ & $-20(5)$ & $-19(4)$ & $-22(5)$ \\
\hline O7' & $103(3)$ & $113(3)$ & $89(3)$ & $-14(2)$ & $-25(2)$ & $-38(2)$ \\
\hline C57' & $179(8)$ & $51(4)$ & $86(3)$ & $-15(2)$ & $-65(4)$ & $-16(5)$ \\
\hline C58' & $132(5)$ & $74(6)$ & $68(4)$ & $-1(3)$ & $-35(3)$ & $-47(5)$ \\
\hline C59' & $88(5)$ & $69(4)$ & $69(4)$ & $-29(3)$ & $3(3)$ & $-28(3)$ \\
\hline C60' & $104(8)$ & $131(8)$ & $65(4)$ & $-24(5)$ & $-3(6)$ & $-52(6)$ \\
\hline O8' & $61(2)$ & $64(2)$ & $69(2)$ & $-25(2)$ & $-6(2)$ & $-8(2)$ \\
\hline C61' & $75(5)$ & $58(4)$ & $89(8)$ & $-33(4)$ & $-9(4)$ & $-8(3)$ \\
\hline C62' & $72(3)$ & $73(10)$ & $81(3)$ & $-30(5)$ & $6(2)$ & $-19(4)$ \\
\hline C63' & $67(4)$ & $55(10)$ & $78(3)$ & $-16(4)$ & $-9(5)$ & $-1(5)$ \\
\hline C64' & $72(6)$ & $75(7)$ & $82(5)$ & $-20(5)$ & $-19(4)$ & $-22(5)$ \\
\hline
\end{tabular}


Table 5. Hydrogen coordinates $\left(\times 10^{4}\right)$ and isotropic displacement parameters $\left(\AA^{2} \times 10^{3}\right)$ for neipn25.

\begin{tabular}{|c|c|c|c|c|}
\hline & $\mathrm{x}$ & $\mathrm{y}$ & $\mathrm{z}$ & $\mathrm{U}(\mathrm{eq})$ \\
\hline $\mathrm{H} 1 \mathrm{~A}$ & 3969 & -455 & 1387 & 54 \\
\hline H1B & 4875 & -242 & 1799 & 54 \\
\hline $\mathrm{H} 2$ & 3564 & -208 & 2675 & 50 \\
\hline $\mathrm{H} 4$ & 2324 & -921 & 1472 & 52 \\
\hline H5 & 664 & -1577 & 1657 & 59 \\
\hline H6 & -512 & -1626 & 2643 & 63 \\
\hline $\mathrm{H} 7$ & -28 & -961 & 3447 & 60 \\
\hline H8 & 1629 & -295 & 3268 & 53 \\
\hline H9A & 1139 & 2590 & 1070 & 53 \\
\hline H9B & 1064 & 1336 & 1468 & 53 \\
\hline H10 & 1202 & 1618 & 2436 & 48 \\
\hline H12 & 1269 & 4185 & 1162 & 51 \\
\hline H13 & 963 & 5890 & 1356 & 57 \\
\hline H14 & 744 & 6052 & 2433 & 60 \\
\hline H15 & 838 & 4478 & 3332 & 59 \\
\hline H16 & 1167 & 2766 & 3144 & 51 \\
\hline H17 & 4250 & 3328 & 1349 & 59 \\
\hline H18 & 3464 & 2320 & 2589 & 49 \\
\hline $\mathrm{H} 20$ & 6210 & 1370 & 1730 & 57 \\
\hline $\mathrm{H} 21$ & 7791 & 103 & 2219 & 62 \\
\hline $\mathrm{H} 22$ & 7634 & -867 & 3337 & 61 \\
\hline $\mathrm{H} 23$ & 5850 & -546 & 3967 & 59 \\
\hline $\mathrm{H} 24$ & 4267 & 708 & 3480 & 55 \\
\hline $\mathrm{H} 25 \mathrm{~A}$ & 5260 & 1896 & 434 & 78 \\
\hline $\mathrm{H} 25 \mathrm{~B}$ & 4990 & 1607 & -187 & 78 \\
\hline $\mathrm{H} 25 \mathrm{C}$ & 5136 & 701 & 500 & 78 \\
\hline $\mathrm{H} 26$ & 3181 & 1332 & 352 & 52 \\
\hline $\mathrm{H} 28$ & 4277 & 3718 & 183 & 62 \\
\hline $\mathrm{H} 29$ & 3325 & 5525 & -283 & 65 \\
\hline
\end{tabular}




\begin{tabular}{|c|c|c|c|c|}
\hline H30 & 1486 & 5921 & -643 & 70 \\
\hline H31 & 617 & 4485 & -555 & 70 \\
\hline H32 & 1532 & 2685 & -64 & 60 \\
\hline $\mathrm{H} 25 \mathrm{D}$ & 4528 & 548 & 289 & 91 \\
\hline $\mathrm{H} 25 \mathrm{E}$ & 3976 & 1486 & -318 & 91 \\
\hline $\mathrm{H} 25 \mathrm{~F}$ & 3170 & 926 & 277 & 91 \\
\hline H26' & 4677 & 2058 & 515 & 52 \\
\hline H28' & 4196 & 4058 & 332 & 62 \\
\hline H29' & 3069 & 5788 & -97 & 65 \\
\hline H30' & 1374 & 5984 & -577 & 70 \\
\hline H31' & 866 & 4416 & -623 & 70 \\
\hline H32' & 1978 & 2664 & -183 & 60 \\
\hline H33A & 3761 & 7187 & 2172 & 56 \\
\hline H33B & 3026 & 6278 & 2354 & 56 \\
\hline H34A & 4080 & 7193 & 1075 & 63 \\
\hline H34B & 2797 & 7007 & 1243 & 63 \\
\hline H35A & 3441 & 5121 & 1428 & 62 \\
\hline H35B & 4314 & 5550 & 816 & 62 \\
\hline H36A & 5106 & 4278 & 1925 & 55 \\
\hline H36B & 5768 & 5176 & 1468 & 55 \\
\hline H37A & 8491 & 4380 & 2361 & 51 \\
\hline H37B & 7647 & 4680 & 1793 & 51 \\
\hline H38A & 9139 & 2898 & 1914 & 56 \\
\hline H38B & 7852 & 2844 & 1854 & 56 \\
\hline H39A & 8923 & 2297 & 3070 & 61 \\
\hline H39B & 8262 & 1553 & 2870 & 61 \\
\hline $\mathrm{H} 40 \mathrm{~A}$ & 6498 & 2568 & 3115 & 60 \\
\hline H40B & 7172 & 2875 & 3591 & 60 \\
\hline $\mathrm{H} 41 \mathrm{~A}$ & 4395 & 3362 & 3034 & 55 \\
\hline H41B & 3389 & 4404 & 3083 & 55 \\
\hline $\mathrm{H} 42 \mathrm{~A}$ & 2643 & 3522 & 4091 & 66 \\
\hline H42B & 3180 & 2486 & 3808 & 66 \\
\hline $\mathrm{H} 42 \mathrm{C}$ & 2541 & 3203 & 3862 & 66 \\
\hline $\mathrm{H} 42 \mathrm{D}$ & 3725 & 2311 & 3985 & 66 \\
\hline $\mathrm{H} 43 \mathrm{~A}$ & 4839 & 2047 & 4333 & 66 \\
\hline
\end{tabular}




\begin{tabular}{|c|c|c|c|c|}
\hline H43B & 3888 & 2446 & 4876 & 66 \\
\hline $\mathrm{H} 44 \mathrm{~A}$ & 4272 & 4147 & 4576 & 64 \\
\hline H44B & 5533 & 3434 & 4451 & 64 \\
\hline $\mathrm{H} 43 \mathrm{C}$ & 2799 & 4006 & 4605 & 66 \\
\hline H43D & 3587 & 2833 & 4914 & 66 \\
\hline $\mathrm{H} 44 \mathrm{C}$ & 4413 & 4599 & 4488 & 64 \\
\hline H44D & 5218 & 3410 & 4540 & 64 \\
\hline $\mathrm{H} 45 \mathrm{~A}$ & 3195 & 5993 & 3717 & 53 \\
\hline H45B & 2873 & 7236 & 3281 & 53 \\
\hline $\mathrm{H} 46 \mathrm{~A}$ & 3646 & 6478 & 4586 & 66 \\
\hline H46B & 2552 & 7437 & 4344 & 66 \\
\hline $\mathrm{H} 45 \mathrm{C}$ & 4415 & 5835 & 4333 & 53 \\
\hline $\mathrm{H} 45 \mathrm{D}$ & 3390 & 5842 & 3947 & 53 \\
\hline $\mathrm{H} 46 \mathrm{C}$ & 2939 & 7120 & 4679 & 66 \\
\hline H46D & 2489 & 7642 & 3952 & 66 \\
\hline $\mathrm{H} 47 \mathrm{~A}$ & 3659 & 8666 & 3821 & 59 \\
\hline H47B & 4524 & 7902 & 4360 & 59 \\
\hline $\mathrm{H} 47 \mathrm{C}$ & 4532 & 7812 & 4376 & 59 \\
\hline H47D & 3768 & 8704 & 3832 & 59 \\
\hline $\mathrm{H} 48 \mathrm{~A}$ & 4944 & 8142 & 3036 & 55 \\
\hline H48B & 5751 & 7298 & 3580 & 55 \\
\hline $\mathrm{H} 49 \mathrm{~A}$ & 8336 & 6009 & 2670 & 57 \\
\hline H49B & 7655 & 7147 & 2805 & 57 \\
\hline H50A & 8631 & 6800 & 1546 & 59 \\
\hline H50B & 8763 & 7741 & 1839 & 59 \\
\hline H51A & 6842 & 8685 & 1693 & 63 \\
\hline H51B & 7206 & 8284 & 1036 & 63 \\
\hline H52A & 5497 & 7688 & 1842 & 55 \\
\hline H52B & 6297 & 6885 & 1438 & 55 \\
\hline H53A & 2592 & 8892 & 161 & 90 \\
\hline H53B & 1509 & 9844 & 260 & 90 \\
\hline $\mathrm{H} 54 \mathrm{~A}$ & 2300 & 9675 & -915 & 73 \\
\hline H54B & 954 & 10140 & -756 & 73 \\
\hline H55A & 831 & 8652 & -1061 & 97 \\
\hline H55B & 2061 & 7964 & -813 & 97 \\
\hline
\end{tabular}




\begin{tabular}{|c|c|c|c|c|}
\hline H56A & -62 & 8252 & -48 & 131 \\
\hline H56B & 997 & 7223 & 84 & 131 \\
\hline H57A & 1211 & 11149 & 4422 & 122 \\
\hline H57B & 2209 & 10654 & 3937 & 122 \\
\hline H58A & 3513 & 10305 & 4653 & 105 \\
\hline H58B & 2548 & 10953 & 5087 & 105 \\
\hline H59A & 3238 & 8668 & 5293 & 87 \\
\hline H59B & 2669 & 9308 & 5836 & 87 \\
\hline H60A & 1384 & 8388 & 5480 & 116 \\
\hline H60B & 832 & 9615 & 5518 & 116 \\
\hline H61A & -1708 & 7587 & 4270 & 87 \\
\hline H61B & -2065 & 6455 & 4624 & 87 \\
\hline H62A & -564 & 6698 & 3587 & 89 \\
\hline H62B & -593 & 5531 & 4097 & 89 \\
\hline H63A & 1104 & 6634 & 3932 & 83 \\
\hline H63B & 1064 & 5479 & 4449 & 83 \\
\hline H64A & 796 & 6402 & 5223 & 89 \\
\hline H64B & 363 & 7553 & 4704 & 89 \\
\hline H57C & 1360 & 11131 & 4436 & 122 \\
\hline H57D & 2349 & 10568 & 3973 & 122 \\
\hline H58C & 2953 & 10892 & 4989 & 105 \\
\hline H58D & 3561 & 9753 & 4824 & 105 \\
\hline H59C & 2593 & 9257 & 5922 & 87 \\
\hline H59D & 1423 & 10106 & 5675 & 87 \\
\hline H60C & 2577 & 8254 & 5175 & 116 \\
\hline H60D & 1288 & 8440 & 5518 & 116 \\
\hline H61C & -2174 & 7004 & 4074 & 87 \\
\hline H61D & -1836 & 6249 & 4788 & 87 \\
\hline H62C & -465 & 6353 & 3578 & 89 \\
\hline H62D & -445 & 5319 & 4210 & 89 \\
\hline H63C & 966 & 6750 & 3930 & 83 \\
\hline H63D & 989 & 5715 & 4560 & 83 \\
\hline H64C & -160 & 6721 & 5209 & 89 \\
\hline H64D & 318 & 7701 & 4691 & 89 \\
\hline
\end{tabular}


Table 6. Torsion angles $\left[{ }^{\circ}\right]$ for neipn 25 .

\begin{tabular}{|c|c|c|c|}
\hline $\mathrm{Fe} 1-\mathrm{C} 1-\mathrm{C} 2-\mathrm{C} 3$ & $105.2(2)$ & C17-C18-C19-C20 & $-4.3(4)$ \\
\hline $\mathrm{Fe} 1-\mathrm{C} 2-\mathrm{C} 3-\mathrm{C} 4$ & $74.5(3)$ & C17-C18-C19-C24 & $175.6(3)$ \\
\hline $\mathrm{Fe} 1-\mathrm{C} 2-\mathrm{C} 3-\mathrm{C} 8$ & $-105.9(2)$ & C18-C19-C20-C21 & $179.5(3)$ \\
\hline Fe1-C9-C10-C11 & $105.1(2)$ & C18-C19-C24-C23 & $-179.3(2)$ \\
\hline $\mathrm{Fe} 1-\mathrm{C} 10-\mathrm{C} 11-\mathrm{C} 12$ & $66.5(3)$ & C19-C20-C21-C22 & $0.1(5)$ \\
\hline Fe1-C10-C11-C16 & $-114.2(2)$ & C20-C19-C24-C23 & $0.6(4)$ \\
\hline Fe1-C17-C18-C19 & $105.7(2)$ & $\mathrm{C} 20-\mathrm{C} 21-\mathrm{C} 22-\mathrm{C} 23$ & $0.0(4)$ \\
\hline Fe1-C18-C19-C20 & $71.5(3)$ & C21-C22-C23-C24 & $0.2(4)$ \\
\hline Fe1-C18-C19-C24 & $-108.6(2)$ & C22-C23-C24-C19 & $-0.6(4)$ \\
\hline $\mathrm{Fe} 1-\mathrm{C} 26-\mathrm{C} 27-\mathrm{C} 28$ & $82.6(5)$ & C24-C19-C20-C21 & $-0.4(4)$ \\
\hline $\mathrm{Fe} 1-\mathrm{C} 26-\mathrm{C} 27-\mathrm{C} 32$ & $-94.0(6)$ & $\mathrm{C} 25-\mathrm{C} 26-\mathrm{C} 27-\mathrm{C} 28$ & $-43.8(7)$ \\
\hline $\mathrm{Fe} 1-\mathrm{C} 26^{\prime}-\mathrm{C} 27^{\prime}-\mathrm{C} 28^{\prime}$ & $85.0(13)$ & $\mathrm{C} 25-\mathrm{C} 26-\mathrm{C} 27-\mathrm{C} 32$ & $139.7(6)$ \\
\hline $\mathrm{Fe} 1-\mathrm{C} 26^{\prime}-\mathrm{C} 27^{\prime}-\mathrm{C} 32^{\prime}$ & $-85.5(14)$ & C26-C27-C28-C29 & $-174.9(6)$ \\
\hline $\mathrm{C} 1-\mathrm{C} 2-\mathrm{C} 3-\mathrm{C} 4$ & $-2.6(4)$ & $\mathrm{C} 26-\mathrm{C} 27-\mathrm{C} 32-\mathrm{C} 31$ & $176.0(7)$ \\
\hline $\mathrm{C} 1-\mathrm{C} 2-\mathrm{C} 3-\mathrm{C} 8$ & $177.1(2)$ & C27-C28-C29-C30 & $-1.0(5)$ \\
\hline $\mathrm{C} 2-\mathrm{C} 3-\mathrm{C} 4-\mathrm{C} 5$ & $179.5(2)$ & $\mathrm{C} 28-\mathrm{C} 27-\mathrm{C} 32-\mathrm{C} 31$ & $-0.8(3)$ \\
\hline $\mathrm{C} 2-\mathrm{C} 3-\mathrm{C} 8-\mathrm{C} 7$ & $-179.4(2)$ & C28-C29-C30-C31 & $-0.8(5)$ \\
\hline C3-C4-C5-C6 & $-0.3(4)$ & C29-C30-C31-C32 & $1.8(6)$ \\
\hline $\mathrm{C} 4-\mathrm{C} 3-\mathrm{C} 8-\mathrm{C} 7$ & $0.3(4)$ & C30-C31-C32-C27 & $-1.0(5)$ \\
\hline C4-C5-C6-C7 & $0.8(4)$ & C32-C27-C28-C29 & $1.8(4)$ \\
\hline C5-C6-C7-C8 & $-0.7(4)$ & C25'-C26'-C27'-C28' & $-149.3(12)$ \\
\hline C6-C7-C8-C3 & $0.1(4)$ & C25'-C26'-C27'-C32' & $40.2(17)$ \\
\hline C8-C3-C4-C5 & $-0.2(3)$ & C26'-C27'-C28'-C29' & $-170.1(18)$ \\
\hline C9-C10-C11-C12 & $-10.4(4)$ & C26'-C27'-C32'-C31' & $170.8(17)$ \\
\hline C9-C10-C11-C16 & $168.8(2)$ & C27'-C28'-C29'-C30' & $-0.3(6)$ \\
\hline C10-C11-C12-C13 & $179.7(2)$ & C28'-C27'-C32'-C31' & $-0.3(4)$ \\
\hline C10-C11-C16-C15 & $-179.3(2)$ & C28'-C29'-C30'-C31' & $-0.4(7)$ \\
\hline C11-C12-C13-C14 & $-0.5(4)$ & C29'-C30'-C31'-C32' & $0.8(8)$ \\
\hline C12-C11-C16-C15 & $0.0(4)$ & C30'-C31'-C32'-C27' & $-0.4(6)$ \\
\hline C12-C13-C14-C15 & $0.1(4)$ & C32'-C27'-C28'-C29' & $0.7(6)$ \\
\hline C13-C14-C15-C16 & $0.4(4)$ & Mg1-O1-C33-C34 & $157.16(18)$ \\
\hline C14-C15-C16-C11 & $-0.4(4)$ & Mg1-O1-C36-C35 & $177.84(18)$ \\
\hline C16-C11-C12-C13 & $0.4(4)$ & Mg1-O2-C37-C38 & $-175.82(16)$ \\
\hline
\end{tabular}




\begin{tabular}{|c|c|c|c|}
\hline Mg1-O2-C40-C39 & $-159.22(18)$ & C45'-C46'-C47-C48 & $26(3)$ \\
\hline Mg1-O3-C41-C42 & $-176.91(18)$ & C46'-C47-C48-O4 & $-3.3(19)$ \\
\hline Mg1-O3-C44-C43 & $-158.6(2)$ & $\mathrm{C} 48-\mathrm{O} 4-\mathrm{C} 45-\mathrm{C} 46$ & $-37.0(4)$ \\
\hline Mg1-O3-C44'-C43' & $162.1(18)$ & $\mathrm{C} 48-\mathrm{O} 4-\mathrm{C} 45^{\prime}-\mathrm{C} 46^{\prime}$ & $41.2(18)$ \\
\hline Mg1-O4-C45-C46 & $129.8(3)$ & O5-C49-C50-C51 & $37.6(3)$ \\
\hline Mg1-O4-C45'-C46' & $172.8(17)$ & C49-O5-C52-C51 & $-5.4(3)$ \\
\hline Mg1-O4-C48-C47 & $-147.90(18)$ & C49-C50-C51-C52 & $-40.1(3)$ \\
\hline Mg1-O5-C49-C50 & $162.33(16)$ & C50-C51-C52-O5 & $28.5(3)$ \\
\hline Mg1-O5-C52-C51 & $171.83(17)$ & C52-O5-C49-C50 & $-20.5(3)$ \\
\hline O1-C33-C34-C35 & $36.5(3)$ & O6-C53-C54-C55 & $-27.5(4)$ \\
\hline C33-O1-C36-C35 & $-4.9(3)$ & C53-O6-C56-C55 & $7.1(6)$ \\
\hline C33-C34-C35-C36 & $-38.7(3)$ & C53-C54-C55-C56 & $30.0(5)$ \\
\hline C34-C35-C36-O1 & 27.4(3) & C54-C55-C56-O6 & $-23.9(6)$ \\
\hline C36-O1-C33-C34 & $-20.1(3)$ & C56-O6-C53-C54 & $13.3(5)$ \\
\hline O2-C37-C38-C39 & $-42.0(2)$ & O7-C57-C58-C59 & $-7(4)$ \\
\hline C37-O2-C40-C39 & $-1.4(3)$ & C57-O7-C60-C59 & $-46(3)$ \\
\hline C37-C38-C39-C40 & $40.4(3)$ & C57-C58-C59-C60 & $-20(3)$ \\
\hline C38-C39-C40-O2 & $-24.7(3)$ & C58-C59-C60-O7 & $41(3)$ \\
\hline C40-O2-C37-C38 & 27.4(3) & C60-O7-C57-C58 & $34(4)$ \\
\hline $\mathrm{O} 3-\mathrm{C} 41-\mathrm{C} 42-\mathrm{C} 43$ & $-29.4(3)$ & O8-C61-C62-C63 & $-20(4)$ \\
\hline O3-C41-C42-C43' & $20.1(11)$ & C61-O8-C64-C63 & $-33(3)$ \\
\hline C41-O3-C44-C43 & $16.6(4)$ & C61-C62-C63-C64 & $-1(4)$ \\
\hline C41-O3-C44'-C43' & $-7(4)$ & C62-C63-C64-O8 & $21(3)$ \\
\hline C41-C42-C43-C44 & $38.6(4)$ & C64-O8-C61-C62 & $34(3)$ \\
\hline C41-C42-C43'-C44' & $-25(3)$ & O7'-C57'-C58'-C59' & $-36(5)$ \\
\hline $\mathrm{C} 42-\mathrm{C} 43-\mathrm{C} 44-\mathrm{O} 3$ & $-34.6(4)$ & C57'-O7'-C60'-C59' & $26(6)$ \\
\hline C42-C43'-C44'-O3 & $20(4)$ & C57'-C58'-C59'-C60' & $51(3)$ \\
\hline C44-O3-C41-C42 & $7.9(3)$ & C58'-C59'-C60'-O7' & $-48(4)$ \\
\hline C44'-O3-C41-C42 & $-8(2)$ & C60'-O7'-C57'-C58' & $7(7)$ \\
\hline $\mathrm{O} 4-\mathrm{C} 45-\mathrm{C} 46-\mathrm{C} 47$ & $39.1(5)$ & O8'-C61'-C62'-C63' & $24(4)$ \\
\hline O4-C45'-C46'-C47 & $-41(3)$ & C61'-O8'-C64'-C63' & $39(3)$ \\
\hline C45-O4-C48-C47 & $20.2(3)$ & C61'-C62'-C63'-C64' & $0(4)$ \\
\hline C45-C46-C47-C48 & $-26.8(5)$ & C62'-C63'-C64'-O8' & $-24(4)$ \\
\hline $\mathrm{C} 46-\mathrm{C} 47-\mathrm{C} 48-\mathrm{O} 4$ & $5.0(4)$ & C64'-O8'-C61'-C62' & $-40(3)$ \\
\hline C45'-O4-C48-C47 & $-21.2(6)$ & & \\
\hline
\end{tabular}


